\title{
De doorwerking van algemene rechtsbeginselen in de BTW : als uitgelegd door het Hof van Justitie EU
}

Citation for published version (APA):

Bomer, A. (2012). De doorwerking van algemene rechtsbeginselen in de BTW : als uitgelegd door het Hof van Justitie EU. [Doctoral Thesis, Maastricht University]. Universiteit Maastricht. https://doi.org/10.26481/dis.20120621ab

Document status and date:

Published: 01/01/2012

DOI:

10.26481/dis.20120621ab

Document Version:

Publisher's PDF, also known as Version of record

\section{Please check the document version of this publication:}

- A submitted manuscript is the version of the article upon submission and before peer-review. There can be important differences between the submitted version and the official published version of record.

People interested in the research are advised to contact the author for the final version of the publication, or visit the DOI to the publisher's website.

- The final author version and the galley proof are versions of the publication after peer review.

- The final published version features the final layout of the paper including the volume, issue and page numbers.

Link to publication

\footnotetext{
General rights rights.

- You may freely distribute the URL identifying the publication in the public portal. please follow below link for the End User Agreement:

www.umlib.nl/taverne-license

Take down policy

If you believe that this document breaches copyright please contact us at:

repository@maastrichtuniversity.nl

providing details and we will investigate your claim.
}

Copyright and moral rights for the publications made accessible in the public portal are retained by the authors and/or other copyright owners and it is a condition of accessing publications that users recognise and abide by the legal requirements associated with these

- Users may download and print one copy of any publication from the public portal for the purpose of private study or research.

- You may not further distribute the material or use it for any profit-making activity or commercial gain

If the publication is distributed under the terms of Article $25 \mathrm{fa}$ of the Dutch Copyright Act, indicated by the "Taverne" license above, 
De doorwerking van algemene rechtsbeginselen in de BTW 
Voor Maria en Anna Anfisa

Voor mijn moeder 


\title{
De doorwerking van algemene rechtsbeginselen in de BTW
}

als uitgelegd door het Hof van Justitie EU

\author{
Proefschrift
}

ter verkrijging van de graad van doctor

aan de Universiteit Maastricht,

op gezag van de Rector Magnificus, prof. mr. G.P.M.F. Mols

volgens het besluit van het College van Decanen,

in het openbaar te verdedigen

op donderdag 21 juni 2012 om 14.00 uur

door

Albert Hendrik Bomer 
Promotor:

Prof. mr. dr. A.H.R.M. Denie

Beoordelingscommissie:

Prof. dr. R.G. Prokisch (voorzitter)

Prof. dr. H.W.M. van Kesteren (Universiteit van Tilburg)

Prof. dr. R.H.C. Luja 


\section{INHOUDSOPGAVE}

1.1 Europese belasting over de toegevoegde waarde $\quad 1$

$1.2 \quad$ Hof van Justitie EU en de Europese BTW 5

1.3 Hof van Justitie EU, de Europese BTW en kritiek 8

$\begin{array}{lll}1.4 & \text { Probleemstelling } & 12\end{array}$

$\begin{array}{lll}1.5 & \text { Plan van behandeling } & 14\end{array}$

$\begin{array}{llr}1.6 & \text { Europeesrechtelijk kader en verwijzingen } & 18\end{array}$

HOOFDSTUK 2 KLASSIEKE BTW-BEGINSELEN (RECHTSKARAKTER) 21

$\begin{array}{lll}2.1 & \text { Inleiding } & 21\end{array}$

$\begin{array}{lll}2.2 & \text { Verbruiksbeginsel } & 23\end{array}$

2.3 Territorialiteit, oorsprong, bestemming 32

$\begin{array}{lll}\text { 2.3.1 Territorialiteitsbeginsel } & 32\end{array}$

2.3.2 Oorsprongslandbeginsel en bestemmingslandbeginsel 36

2.3.2.1 Achtergrond en vormgeving 36

2.3.2.2 Het overgangsregime 41

$\begin{array}{lll}2.4 & \text { Neutraliteitsbeginsel } & 43\end{array}$

$\begin{array}{lll}2.4 .1 & \text { Concurrentieverhoudingen } & 43\end{array}$

2.4.2 Oorzaken verstoring van de externe neutraliteit 46

$2.5 \quad$ Conclusies 55

$\begin{array}{lll}\text { HOOFDSTUK } 3 & \text { ALGEMENE RECHTSBEGINSELEN } & 57\end{array}$

$\begin{array}{lll}3.1 & \text { Inleiding } & 57\end{array}$

3.2 Kenmerken algemene rechtsbeginselen 58

$\begin{array}{lll}3.2 .1 & \text { Rechtsbewustzijn } & 58\end{array}$

$\begin{array}{lll}\text { 3.2.2 } & \text { Rechtsregels en rechtsbeginselen } & 63\end{array}$

3.2.3 Omschrijving van algemene rechtsbeginselen 69

$\begin{array}{lll}3.3 & \text { De werking van algemene rechtsbeginselen } & 72\end{array}$

$\begin{array}{lll}\text { 3.3.1 Beginselen van formeel recht en interpretatiebeginselen } & 72\end{array}$

3.3.2 Inperkende en verruimende effecten van de

$\begin{array}{ll}\text { 3.3.3 Interpretatietechniek van de geschreven rechtsregels } & 80\end{array}$ 
3.4 De drie algemene rechtsbeginselen in het onderzoek 83

$\begin{array}{lll}3.4 .1 & \text { Gelijkheidsbeginsel } & 83\end{array}$

3.4.1.1 Algemene aspecten gelijkheidsbeginsel 83

3.4.1.2 Europeesrechtelijke invulling van het gelijkheidsbeginsel 85

$\begin{array}{lll}3.4 .2 & \text { Evenredigheidsbeginsel } & 89\end{array}$

3.4.2.1 Algemene aspecten van het evenredigheidsbeginsel 89

3.4.2.2 Europeesrechtelijke invulling van het evenredigheidsbeginsel 89

3.4.3 Rechtszekerheids- en vertrouwensbeginsel 92

$\begin{array}{lll}\text { 3.4.3.1 Berekenbaarheid } & 92\end{array}$

3.4.3.2 Europees rechtelijk invulling van het rechtszekerheidsbeginsel $\begin{array}{ll}\text { en het vertrouwensbeginsel } & 94\end{array}$

3.4.3.3 Begrenzing nationale werking vertrouwensbeginsel 97

3.5 De klassieke BTW-beginselen en de algemene rechtsbeginselen 99

3.5.1 Waarom geen echte algemene rechtsbeginselen? 99

3.5.2 Het neutraliteitsbeginsel en de algemene rechtsbeginselen 101

$\begin{array}{lll}3.6 & \text { Conclusies } & 102\end{array}$

HOOFDSTUK 4 ALGEMENE RECHTSBEGINSELEN EN HET UNIERECHT 105

$\begin{array}{lll}4.1 & \text { Inleiding } & 105\end{array}$

$\begin{array}{lll}4.2 & \text { Autonome rechtsorde } & 105\end{array}$

4.3 Communautair rechtsbegrip dan wel autonoom begrip

4.4 Rechtsvinding door het Hof van Justitie EU 111

$\begin{array}{lll}4.4 .1 & \text { Inleiding } & 111\end{array}$

$\begin{array}{lll}\text { 4.4.2 Interpretatiemethoden } & 112\end{array}$

$\begin{array}{ll}\text { 4.4.2.1 Grammaticale interpretatiemethode } & 112\end{array}$

$\begin{array}{lll}\text { 4.4.2.2 Historische interpretatiemethode } & 114\end{array}$

$\begin{array}{lll}\text { 4.4.2.3 Rechtsvergelijkende interpretatiemethode } & 114\end{array}$

$\begin{array}{lll}\text { 4.4.2.4 Systematische interpretatiemethode } & 116\end{array}$

$\begin{array}{lll}\text { 4.4.2.5 Teleologische interpretatiemethode } & 116\end{array}$

$\begin{array}{lll}4.4 .3 & \text { Analogieargumentatie } & 117\end{array}$

$\begin{array}{lll}\text { 4.4.3.1 Inleiding } & 117\end{array}$

4.4.3.2 Analogieargumentatie en het gelijkheidsbeginsel 118

$\begin{array}{ll}\text { 4.4.3.3 Argumentatie a contrario dan wel naar analogie } & 120\end{array}$

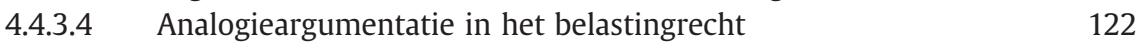

$\begin{array}{lll}\text { 4.4.3.5 Tussenconclusies } & 123\end{array}$

4.4.4 Fiscale neutraliteit, gelijkheidsbeginsel en analogieargumentatie 123

$\begin{array}{lll}\text { 4.4.4.1 Inleiding } & 123\end{array}$

$\begin{array}{lll}\text { 4.4.4.2 Fiscale neutraliteit en het gelijkheidsbeginsel } & 124\end{array}$

$\begin{array}{lll}\text { 4.4.4.3 Fiscale neutraliteit en analogieargumentatie } & 128\end{array}$

$\begin{array}{lll}\text { 4.4.4.4 Tussenconclusies } & 128\end{array}$

$\begin{array}{ll}4.5 & 129\end{array}$

$\begin{array}{ll}\text { 4.5.1 Primair Unierecht } & 129\end{array}$

$\begin{array}{ll}\text { 4.5.2 Secundair Unierecht } & 130\end{array}$

$\begin{array}{lll}\text { 4.5.2.1 Algemeen } & 130\end{array}$

$\begin{array}{ll}\text { 4.5.2.2 Verordeningen } & 131\end{array}$

$\begin{array}{lll}\text { 4.5.2.3 Richtlijnen } & 132\end{array}$ 
$\begin{array}{lll}\text { 4.5.2.4 Beschikkingen } & 135\end{array}$

$\begin{array}{ll}\text { 4.5.2.5 Ontbreekt regeling in secundair Unierecht } & 136\end{array}$

$\begin{array}{lll}4.6 & \text { Rechtstreekse werking } & 138\end{array}$

$\begin{array}{lll}4.7 & \text { Richtlijn/beginselconforme interpretatie } & 142\end{array}$

$\begin{array}{lll}4.8 & \text { Conclusies } & 147\end{array}$

HOOFDSTUK 5 EUROPEESRECHTELIJKE LEERSTUKKEN EN DE ALGEMENE RECHTSBEGINSELEN 149

$\begin{array}{lll}5.1 & \text { Inleiding } & 149\end{array}$

5.2 Maatregelen ter vereenvoudiging en voorkoming van misbruik 149

5.3 Algemeen beginsel van het verbod van misbruik van recht 152

$\begin{array}{lll}5.4 & \text { Formele rechtskracht van besluiten } & 164\end{array}$

$\begin{array}{ll}5.5 & \text { Het rechtszekerheidsbeginsel en de terugwerkende kracht } \\ \text { van regels } & 170\end{array}$

5.6 Beperking van de werking van een prejudiciële beslissing in de tijd 174

5.6.1 Algemene aspecten van de uitgestelde werking 174

$\begin{array}{lll}\text { 5.6.2 Onzekerheid over de strekking van de communautaire bepaling } & 177\end{array}$

5.6.3 De voorwaarde van het gevaar van ernstige economische verstoringen 179

5.6.4 Slotsom over de uitgestelde werking van arresten 180

$\begin{array}{lll}5.7 & \text { Conclusies } & 181\end{array}$

$\begin{array}{llr}\text { HOOFDSTUK } 6 & \text { BELASTBARE HANDELINGEN } & 183\end{array}$

$\begin{array}{lll}6.1 & \text { Inleiding } & 183\end{array}$

$\begin{array}{ll}6.2 & 185\end{array}$

$\begin{array}{llr}6.3 & \text { Fraude } & 187\end{array}$

$\begin{array}{lll}6.4 & 191\end{array}$

$\begin{array}{ll}6.5 & 195\end{array}$

$\begin{array}{lll}6.6 & \text { Conclusies } & 205\end{array}$

$\begin{array}{lll}\text { HOOFDSTUK } 7 & \text { BELASTINGPLICHT } & 207\end{array}$

$\begin{array}{lll}7.1 & \text { Inleiding } & 207\end{array}$

$\begin{array}{lll}7.2 & \text { Begin van belastingplicht } & 207\end{array}$

$\begin{array}{ll}\text { 7.2.1 Geen belaste handelingen } & 207\end{array}$

7.2.2 De fiscale neutraliteit en de vergelijkingsmethode 210

7.2.3 Startende ondernemer en vertrouwens- en rechtszekerheidsbeginsel 214

$\begin{array}{lll}7.2 .4 & \text { Conclusies } & 218\end{array}$

$\begin{array}{lll}7.3 & \text { Holdingmaatschappijen } & 219\end{array}$

$\begin{array}{lll}\text { 7.3.1 Algemeen } & 219\end{array}$

7.3.2 Sector benadering bij holdingmaatschappijen 220

7.3.3 Beleidsbepalende holding en de fiscale neutraliteit 222

$\begin{array}{lll}\text { 7.3.4 Analoge toepassing bij de startende ondernemer en niet bij } & \\ \text { de holdingmaatschappij } & 225\end{array}$

$\begin{array}{lll}\text { 7.3.5 Conclusies } & 227\end{array}$

$\begin{array}{lll}7.4 & \text { Belastingplicht van publiekrechtelijke lichamen } & 227\end{array}$ 
Inhoudsopgave

$\begin{array}{lll}7.4 .1 & \text { Inleiding } & 227\end{array}$

$\begin{array}{ll}\text { 7.4.2 Ruime werkingssfeer van de BTW } & 229\end{array}$

$\begin{array}{lll}\text { 7.4.3 Correctie op de ruime werkingssfeer } & 229\end{array}$

$\begin{array}{ll}\text { 7.4.4 Publiekrechtelijke lichamen } & 230\end{array}$

7.4.5 De werkzaamheden of handelingen die zij als overheid verrichten 233

$\begin{array}{lll}\text { 7.4.6 Concurrentievervalsing van enige betekenis } & 239\end{array}$

7.4.7 Werkzaamheden van niet onbeduidende omvang 243

7.4.8 Vrijgestelde werkzaamheden als werkzaamheden van de overheid 243

7.4.9 Publiekrechtelijke lichamen en de fiscale neutraliteit 245

HOOFDSTUK 8 RATIONALITEIT VAN DE PLAATS VAN DIENST 249

$\begin{array}{lll}8.1 & \text { Inleiding } & 249\end{array}$

8.2 Doel van de regels met betrekking tot de plaats van dienst 254

8.3 Vaste inrichting fiscaal rationeel? 260

8.4 Het begrip vaste inrichting in het DFDS-arrest 267

$\begin{array}{lll}8.4 .1 & \text { Hulporgaan } & 267\end{array}$

$\begin{array}{lll}\text { 8.4.2 Economische realiteit } & 273\end{array}$

$\begin{array}{lll}8.5 & \text { Zetel van de bedrijfsuitoefening } 274\end{array}$

8.6 Bijzondere bepaling ter voorkoming van concurrentievervalsing 277

$\begin{array}{lll}\text { 8.6.1 Achtergrond van artikel } 59 \text { bis, BTW-richtlijn } & 277\end{array}$

8.6.2 Interpretatie van 'werkelijke gebruik' en 'werkelijke exploitatie' 279

$\begin{array}{lll}8.7 & \text { Conclusies } & 282\end{array}$

$\begin{array}{lll}\text { HOOFDSTUK } 9 \text { MAATSTAF VAN HEFFING } & 285\end{array}$

$\begin{array}{lll}9.1 & \text { Inleiding } & 285\end{array}$

9.2 Minimum maatstaf van heffing 286

9.2.1 Grenzen aan het bereik van artikel 395 BTW-richtlijn 286

9.2.2 De minimummaatstaf van heffing in de BTW-richtlijn 290

$\begin{array}{lll}\text { 9.2.3 Lage verkoopprijs aan personeel (Scandic-arrest) } 292 & 292\end{array}$

9.3 Gesplitste vergoedingen en eenheid van prestatie 294

$\begin{array}{lll}\text { 9.3.1 Algemeen kader } & 294\end{array}$

9.3.2 De lijn in de jurisprudentie van het Hof van Justitie EU 295

$\begin{array}{lll}9.4 & \text { Conclusies } & 301\end{array}$

$\begin{array}{lll}\text { HOOFDSTUK } 10 \text { VRIJSTELLINGEN } & 303\end{array}$

$\begin{array}{lll}10.1 & \text { Inleiding } & 303\end{array}$

10.2 Raamwerk en achtergrond van de vrijstellingen 304

10.3 Benadering van de vrijstellingen door het Hof van Justitie EU 305

10.4 Gelijkheidsbeginsel 311

$\begin{array}{lll}10.5 & \text { Rechtszekerheidsbeginsel } & 318\end{array}$

$\begin{array}{lll}10.6 & \text { Conclusies } & 320\end{array}$

$\begin{array}{lll}10.7 & \text { Intracommunautaire leveringen } & 321\end{array}$ 
11.2 Het raamwerk van de aftrekregeling 328

11.3 De uitleg van de aftrekregeling door het Hof van Justitie EU 332

$\begin{array}{lll}11.4 & \text { Het gelijkheidsbeginsel } & 334\end{array}$

$\begin{array}{lll}11.4 .1 & \text { Inleiding } & 334\end{array}$

11.4.2 Eindverbruikers kennen geen fiscale neutraliteit 335

11.4.3 Het SKF-arrest en de gelijke behandeling van ongelijke gevallen 338

11.4.4 Teruggaven aan belastingplichtigen gevestigd in een andere lidstaat 341

11.4.5 Intracommunautaire en in de lidstaat vrijgestelde handelingen $\begin{array}{ll}\text { (Eurodental-arrest) } & 342\end{array}$

$\begin{array}{lll}11.5 & \text { Het evenredigheidsbeginsel } & 344\end{array}$

11.5.1 Beperking recht op aftrek op grond van een machtiging 344

$\begin{array}{lll}\text { 11.5.1.1 Inleiding } & 344\end{array}$

$\begin{array}{lll}\text { 11.5.1.2 } & \text { Ampafrance-arrest } & 345\end{array}$

$\begin{array}{lll}\text { 11.5.1.3 Sudholz-arrest } & 347\end{array}$

$\begin{array}{lll}\text { 11.5.1.4 Tussenconclusies } & 349\end{array}$

$\begin{array}{lll}\text { 11.5.2 Optieverzoek } & 349\end{array}$

$\begin{array}{lll}11.6 & \text { Conclusies } & 351\end{array}$

HOOFDSTUK 12 ADMINISTRATIEVE VERPLICHTINGEN IN HET BINNENLANDSVERKEER 353

$\begin{array}{lll}12.1 & \text { Algemeen kader } & 353\end{array}$

$\begin{array}{lll}12.2 & \text { Verschuldigdheid van BTW } & 356\end{array}$

12.2.1 Creditfacturen (Langhorst-arrest) 356

12.2.2 Correctie van de verschuldigdheid (Schmeink \& Strobel, Stadeco) 359

12.2.3 Overige verplichtingen (Eismann-arrest) 364

$\begin{array}{lll}\text { 12.2.4 Tijdstip van verschuldigdheid } & 366\end{array}$

$\begin{array}{lll}12.3 & \text { Het recht op aftrek van voorbelasting } & 369\end{array}$

$\begin{array}{lll}\text { 12.3.1 De factuur } & 369\end{array}$

$\begin{array}{lll}\text { 12.3.1.1 Genius-arrest } & 370\end{array}$

$\begin{array}{lll}\text { 12.3.1.2 Jeunehomme-arrest } & 372\end{array}$

$\begin{array}{lll}\text { 12.3.1.3 Minerales-arrest (SGGSEMF) } & 374\end{array}$

12.3.2 Aanvullende voorwaarden recht op aftrek voorbelasting 378

$\begin{array}{lll}\text { 12.3.2.1 Gabalfrisa-arrest } & 378\end{array}$

$\begin{array}{ll}\text { 12.3.2.2 Sosnowska-arrest } & 380\end{array}$

$\begin{array}{lll}12.4 & \text { Conclusies } & 382\end{array}$

HOOFDSTUK 13 SLOTBESCHOUWING EN CONCLUSIES 385

$\begin{array}{lll}13.1 & & 385\end{array}$

13.2 Gelijkheidsbeginsel en fiscale neutraliteit 386

$\begin{array}{lll}\text { 13.2.1 Gelijkheidsbeginsel } & 386\end{array}$

13.2.2 Fiscale neutraliteit als stelselbeginsel 388

13.2.3 Fiscale neutraliteit, analoge toepassing en de ratio van de bepaling 389

$\begin{array}{lll}13.3 & \text { Rechtszekerheids- en vertrouwensbeginsel } & 391\end{array}$ 
13.3.1 Objectieve uitleg 391

13.3.2 Geen bescherming in geval van fraude of misbruik 392

13.3.3 Rechtszekerheidsbeginsel in de uitvoeringssfeer 392

13.3.4 Rechtszekerheid en de uitleg naar doel en strekking 395

13.4 Evenredigheidsbeginsel 396

13.4.1 Algemeen rechtsbeginsel van formeel recht 396

13.4.2 Het evenredigheidsbeginsel als interpretatiebeginsel 397

$\begin{array}{lll}\text { 13.5 Relatie tussen algemene rechtsbeginselen en klassieke } & \\ \text { BTW-beginselen } & \end{array}$

$\begin{array}{ll}\text { SUMMARY } & 401\end{array}$

LIJST VAN AANGEHAALDE LITERATUUR 409

LIJST VAN AANGEHAALDE JURISPRUDENTIE $\quad 427$

$\begin{array}{ll}\text { TREFWOORDENREGISTER } & 443\end{array}$

$\begin{array}{ll}\text { CURRICULUM VITAE } & 449\end{array}$ 


\section{LIJST VAN GEBRUIKTE AFKORTINGEN}

Achtste richtlijn

A-G
AWB
AWR
B2B
B2C
BNB
BTW
BTW-richtlijn

BTW-verordening

BUA

COM

Commissie

Dertiende richtlijn

Eerste richtlijn

EEG
Richtlijn 79/1072/EEG van de Raad van 6 december 1979 betreffende de harmonisatie van de wetgevingen van der Lid-Staten inzake omzetbelasting - Regeling voor de teruggaaf van de belasting over de toegevoegde waarde aan niet in het binnenland gevestigde belastingplichtigen, Pb EG 1979 L 331/11

Advocaat-generaal

Algemene wet bestuursrecht

Algemene wet inzake Rijksbelastingen

Business-to-business

Business-to-consumer

Beslissingen inzake Belastingzaken

Belasting over de toegevoegde waarde

Richtlijn 2006/112/EG van de Raad van 28 november 2006 betreffende het gemeenschappelijk stelsel van belasting over de toegevoegde waarde, Pb EU 2006 L 347/1 Verordening 1777/2005 van de Raad van 17 oktober 2005 houdende vaststelling van maatregelen ter uitvoering van Richtlijn 77/338/EEG betreffende het gemeenschappelijk stelsel van belasting over de toegevoegde waarde, $\mathrm{Pb}$ EU 2005 L 288/1. Deze verordening is vervangen door Verordening 282/2011van de Raad van 15 maart 2011, Pb EU $2011 \mathrm{~L} 77 / 1$

Besluit uitsluiting aftrek omzetbelasting 1968

Commissiestuk

Commissie van de Europese Unie

Richtlijn 86/560/EEG van de Raad van 17 november 1986 betreffende de harmonisatie van de wetgevingen der lidstaten inzake omzetbelasting - Regeling voor de teruggaaf van de belasting over de toegevoegde waarde aan niet op het grondgebied van de Gemeenschap gevestigde belastingplichtigen, Pb EG 1986 L 326/40

Richtlijn 67/227/EEG betreffende de harmonisatie van de wetgevingen der Lid-Staten inzake omzetbelasting van 11 april 1967, Pb EG van 14 april 1967, nr. 71 Europese Economische Gemeenschap 
EG

EG-Verdrag

EU

EU-Verdrag

FED

GATT

GATS

Hof

HR

IBFD

Jur.

MBB

MvA

MvT

NTFR

OECD

$\mathrm{Pb}$ EG

$\mathrm{Pb} \mathrm{EU}$

Raad

r.o.

Stb.

TFB

Tweede richtlijn

Trb.

Uitv. besch. OB 1968

Uitv. besl. OB 1968

VAT

VEU

$\mathrm{V}-\mathrm{N}$

Voorstel voor een

Zesde richtlijn

VPB

VwEU

Wet BRV

Wet OB

Wet VpB

WFR

WTO
Europese Gemeenschap

Verdrag van Rome tot oprichting van de Europese

Economische Gemeenschap

Europese Unie

Verdrag van Maastricht betreffende de Europese Unie

Fed Fiscaal weekblad

General Agreement on Tariffs and Trade

General Agreement on Trade in Services

Hof van Justitie van de Europese Unie, Hof van Justitie van

de Europese Gemeenschappen

Hoge Raad der Nederlanden

International Bureau of Fiscal Documentation

Jurisprudentie van het Hof van Justitie van de Europese Unie

Maandblad Belasting Beschouwingen

Memorie van Antwoord

Memorie van Toelichting

Nederlands Tijdschrift voor Fiscaal Recht

Organization for Economic Co-operation and Development

Publicatieblad van de Europese gemeenschappen

Publicatieblad van de Europese Unie

Raad van de Europese Unie

Rechtsoverweging

Staatsblad van het Koninkrijk der Nederlanden

Tijdschrift voor Formeel Belastingrecht

Richtlijn 67/228/Eeg van de Raad van 11 april 1967

betreffende de harmonisatie van de wetgevingen der

lidstaten inzake omzetbelasting - structuur en wijze van

toepassing van het gemeenschappelijk stelsel van belas-

ting over de toegevoegde waarde, Pb EG 1967, blz. 1303

Tractatenblad

Uitvoeringsbeschikking omzetbelasting 1968

Uitvoeringsbesluit omzetbelasting 1968

Value added tax

Verdrag betreffende de Europese Unie (Unieverdrag)

Vakstudie-Nieuws

Voorstel voor een Zesde richtlijn van de Raad van 29 juni 1973, COM 73/950, V-n 1973, nr. 18A, blz. 753 e.v.

Vennootschapsbelasting

Verdrag betreffende de werking van de Europese Unie

(Werkingsverdrag)

Wet op de belastingen van rechtsverkeer

Wet op de omzetbelasting 1968

Wet op de vennootschapsbelasting 1969

Weekblad Fiscaal Recht

World Trade Organisation 
Lijst van gebruikte afkortingen

Zesde richtlijn

Richtlijn 77/338/EEG van de Raad van 17 mei 1977 betreffende de harmonisatie van de wetgevingen der Lid-Staten inzake omzetbelasting - Gemeenschappelijk stelsel van belasting over toegevoegde waarde: uniforme grondslag, Pb EG 1977 L 145/1 



\section{HOOFDSTUK 1}

\section{Inleiding}

\section{$1.1 \quad$ Europese belasting over de toegevoegde waarde}

De Europese Gemeenschap (thans Europese Unie) heeft vanaf haar ontstaan invloed op de heffing van belastingen. ${ }^{1}$ Ondanks het gegeven dat slechts enkele artikelen van het Werkingsverdrag (voorheen EG-Verdrag) direct betrekking hebben op de heffing van belastingen, kan gesteld worden dat de Europese Gemeenschap praktisch de gehele BTW heeft gevormd. ${ }^{2}$ Vanaf het begin van de Europese Gemeenschap heeft de vormgeving van de BTW in het licht gestaan van het streven naar éen interne markt. ${ }^{3}$ Onder het streven naar een interne markt wordt verstaan:

"De afschaffing van alle belemmeringen van het intracommunautaire handelsverkeer teneinde de nationale markten te verenigen tot één enkele markt die de omstandigheden van een binnenlandse markt zo dicht mogelijk benadert." 4

\footnotetext{
1. In deze subparagraaf gebruik ik de termen Europese Gemeenschap en Europese Unie door elkaar. Ik verduidelijk het onderscheid in paragraaf 1.6 waar ik aandacht besteed aan het Verdrag van Lissabon. 2. Zie de artikelen $110 \mathrm{t} / \mathrm{m} 112 \mathrm{VwEU}$ (voorheen $90 \mathrm{t} / \mathrm{m} 93 \mathrm{EG}$ ). Verder uiteraard de artikelen die betrekking hebben op de douanerechten, artikelen $28 \mathrm{t} / \mathrm{m} 32 \mathrm{VwEU}$ (voorheen $23 \mathrm{t} / \mathrm{m} 27 \mathrm{EG}$ ).

3. Voor het eerst werden de contouren van een gemeenschappelijke markt geschetst in het Spaak rapport. Het rapport vermeldt op blz. 13: "Doel van een gemeenschappelijke markt moet zijn de schepping van één grote ruimte met een gemeenschappelijke economische politiek, zodat een machtige eenheid van productie wordt gevormd en een voortdurende expansie mogelijk wordt gemaakt, evenals de toename van de stabiliteit, een versnelde verhoging van de levensstandaard en de ontwikkeling van de betrekkingen tussen de Lid-Staten, die erin verenigd zijn." Zie rapport van de Chefs der delegatie van de Ministers van Buitenlandse zaken, Brussel 1956. Zie voor een uitgebreide behandeling P.J.G. Kapteyn \& P. VerLoren van Themaat, Het recht van de Europese Unie en van de Europese Gemeenschappen, Deventer: Kluwer 2003, blz. 12 e.v.

4. Zie Hof 5 mei 1982, nr. 15/81, Gaston Schul I, BNB 1982/225, r.o. 33. Vanuit wordt gegaan dat de termen interne markt en gemeenschappelijke markt niet wezenlijk van elkaar verschillen. Dit blijkt uit Hof 11 juni 1991, nr. C-300/89, Commissie/Raad, Jur. 1991, blz. 2867, r.o. 14 op het gebied van de richtlijn titaandioxideafval. Zie hiervoor nader R. Barents \& L.J. Brinkhorst, Grondlijnen van Europees Recht, Deventer: Kluwer 2003, blz. 290.
} 
Het streven naar een interne markt blijkt onder meer al uit het Verdrag tot oprichting van de Europese Gemeenschap van 25 maart $1957 . .^{5}$ Zie in het bijzonder de vierde overweging in de preambule:

"Erkennende, dat de verwijdering van de bestaande hinderpalen eensgezind optreden vereist ten einde de gestadige expansie, het evenwicht in het handelsverkeer en de eerlijkheid in de mededinging te waarborgen."

Een eerste stap om dit streven gestalte te geven werd gezet met de afschaffing van de heffing van de douanerechten tussen de lidstaten. Voorafgegaan door uitvoerige studies, over onder meer systemen en economische effecten, werd vervolgens een proces van harmonisatie van de BTW opgestart. ${ }^{6}$

De Europese Gemeenschap heeft gekozen voor het systeem van heffing van belasting over de omzet met het recht op aftrek van voorbelasting. ${ }^{7}$ De voorbelasting mag onmiddellijk worden afgetrokken van de verschuldigde belasting en wel op het moment dat deze in rekening wordt gebracht. Dit moment kan voor het tijdstip van wederverkoop liggen en soms zelfs voor het moment waarop de ondernemer zijn leverancier of dienstverrichter betaalt. Het gevolg hiervan is dat in de belaste BTWsfeer de goederen belastingvrij aanwezig zijn bij de ondernemer. ${ }^{8}$

5. Trb. 1957, 74 en 91.

6. Zie Algemeen Rapport van de subgroepen A,B en C, ingesteld ter bestudering van de verschillende mogelijkheden tot harmonisatie van de omzetbelasting, Commissie van de EEG, Directoraat-generaal van de concurrentie, Directe belastingvraagstukken, januari 1962, Zie verder Neumark-rapport, Rapport van het Fiscaal en financieel Comité 1962. Voor een beschrijving van de voorgeschiedenis van het harmonisatie proces zie R.F.W. van Brederode, De bijzondere positie van de landbouw in de omzetbelasting (diss. Amsterdam UvA), Deventer: Kluwer 1993, blz. 12 t/m 24.

7. Onder voorbelasting wordt verstaan: het totaal van de BTW dat aan de belastingplichtige in rekening is gebracht door leveranciers en dienstverrichters, eventueel verhoogd met het bedrag dat aan BTW bij invoer en ter zake van intracommunautaire verwervingen is betaald.

8. Gezien dit aspect duidt Terra, in navolging van Denie, de Europese BTW aan als een consumption type belasting. Daarnaast zijn nog te onderscheiden de income type en de product type belasting. B.J.M. Terra, Sales Taxation, The case of value added tax in the European Community, Deventer-Boston: Kluwer Law and Taxation Publishers 1988, blz. 31 t/m 32. Ook Denie noemt de Europese BTW een van het consumption type, omdat het een consumptiebelasting is en de bedrijfsmiddelen in technische zin niet (voor)belast worden. A.H.R.M. Denie, De overheid in de omzetbelasting (diss. Leiden), Deventer: Kluwer 1987, blz. 30 t/m 33. Op grond van het uitgangspunt dat de belastingplichtige in beginsel direct en geheel van BTW-druk wordt ontlast, leidt volgens Van Zadelhoff tot de conclusie dat de BTW aangemerkt kan worden als een belasting over de toegevoegde waarde naar het consumptie-type. Het gegeven dat met betrekking tot incidenteel verrichte leveringen van (een gedeelte van een) gebouw of bouwterrein een uitzondering mogelijk is op het beginsel van directe aftrek doet daar volgens hem niets aan af. Zie B.G. van Zadelhoff, Onroerende goederen en belasting over de toegevoegde waarde (diss. Amsterdam UvA), Deventer: Uitgeverij FED 1992, blz. 53 t/m 56. 
De BTW is in het primaire Unierecht verankerd in een aantal artikelen, namelijk in de artikelen $110 \mathrm{t} / \mathrm{m} 112 \mathrm{VwEU}$ (voorheen $90 \mathrm{t} / \mathrm{m} 93 \mathrm{EG}$ ). ${ }^{9}$ In het secundaire Unierecht is de BTW nader uitgewerkt in een aantal richtlijnen. ${ }^{10}$ Het in de vorige alinea beschreven systeem van heffing over de toegevoegde waarde met aftrek van voorbelasting is neergelegd in de Eerste richtlijn. Artikel 2, Eerste richtlijn geeft kernachtig het systeem van heffing weer:

"Het gemeenschappelijk stelsel van belasting over de toegevoegde waarde berust op het beginsel dat van goederen en diensten een algemene verbruiksbelasting wordt geheven welke strikt evenredig is aan de prijs van goederen en diensten, zulks ongeacht het aantal transacties welke tijdens het productie- en distributieproces vóór de fase van heffing plaatsvonden. Bij elke transactie is de belasting over de toegevoegde waarde, berekend over de prijs van het goed of van de dienst volgens het tarief dat voor het goed of voor de dienst geldt, verschuldigd onder aftrek van het bedrag van de belasting over de toegevoegde waarde waarmede de onderscheidende elementen van de prijs rechtstreeks zijn belast. Het gemeenschappelijk stelsel van belasting over de toegevoegde waarde wordt toegepast tot en met de kleinhandelsfase. (...)."

De Tweede richtlijn schrijft aan de lidstaten voor hoe deze belasting er in grote lijnen uit zou moeten zien. In 1977 is de Tweede richtlijn vervangen door de veel gedetailleerder uitgewerkte Zesde richtlijn. De Zesde richtlijn geeft nadere regels over de invulling van het belastbaar feit, de maatstaf van heffing en de vrijstellingen. In diverse richtlijnen is de Zesde richtlijn verder aangevuld, bijvoorbeeld de Achtste ${ }^{11}$ en Dertiende richtlijnen met betrekking tot teruggave van BTW aan buitenlandse ondernemers en de Zevende richtlijn inzake een regeling voor gebruikte goederen. Zeer ingrijpend was de aanpassing van de Zesde richtlijn in 1993. Daarbij werden de fiscaalfysieke grenzen tussen de lidstaten afgeschaft. ${ }^{12}$ De Zesde richtlijn is met ingang van 1 januari 2007 vervangen door BTW-richtlijn 2006/112/EG. ${ }^{13}$ Met deze nieuwe richtlijn is geen inhoudelijke wijziging beoogd. Met uitzondering van de Achtste en Dertiende richtlijnen, zijn de overige relevante richtlijnen tot dan toe in de nieuwe BTW-richtlijn begrepen.

Gezien de verankering van de BTW in het Werkingsverdrag en het secundaire Unierecht, kan de ontwikkeling van de BTW niet los worden gezien van het overige Unierecht. Zoals eerder naar voren is gebracht staat de harmonisatie van de BTW op

9. Met het primaire Unierecht wordt in het algemeen gedoeld op het in het Unieverdrag en het Werkingsverdrag neergelegde regelgeving en de algemene rechtsbeginselen. Paragraaf 4.5.1 verduidelijkt het primaire Unierecht.

10. Onder secundair Unierecht verstaat men in het algemeen de besluiten die op grond van de in het primaire Unierecht (verdragen) neergelegde bevoegdheden worden genomen door de instellingen van de Unie. De voornaamste vormen van besluiten zijn verordeningen, richtlijnen, beschikkingen en aanbevelingen. Zie nader paragraaf 4.5.2.

11. Met ingang van 1 januari 2010 vervangen door richtlijn 2008/9/EG van 12 februari 2008, welke voorziet in teruggaafprocedures langs elektronische weg; zie ook artikel 171, BTW-richtlijn.

12. De overgangsregeling is neergelegd in de richtlijn van 16 december 1991, 91/680/EEG. Vervolgens zijn enkele regelingen weer aangepast door middel van aanpassingsrichtlijnen, 14 december 1992, 92/ 110/EEG en 10 april 1995, 95/7/EG.

13. BTW-richtlijn 2006/112/EG, Pb EG 2006 L 347, blz. 1. 
Europees niveau niet op zich zelf, maar is onderdeel van het streven naar Europese integratie op vele terreinen. De harmonisatie van de BTW is voor een belangrijk deel beïnvloed door het streven naar de vier vrijheden, namelijk vrij goederen-, diensten-, kapitaal- en personenverkeer. ${ }^{14}$ Volgens artikel 113 VwEU (voorheen artikel 93 EG) dienen de belastingwetgevingen op het gebied van de omzetbelasting en de andere indirecte belastingen te worden geharmoniseerd, voor zover dat noodzakelijk is voor de instelling van de interne markt. Dit blijkt ook uit de vierde overweging in de considerans van de BTW-richtlijn waar is vermeld dat:

"Het verwezenlijken van de doelstelling een interne markt in te stellen vooronderstelt dat in de lidstaten wetgevingen inzake omzetbelasting worden toegepast die de mededingingsvoorwaarden niet vervalsen en het vrije verkeer van goederen en diensten niet belemmeren. Het is derhalve noodzakelijk om door middel van een stelsel van belasting over de toegevoegde waarde (BTW) een harmonisatie van de wetgevingen inzake omzetbelasting tot stand te brengen die ten doel heeft, de factoren die de mededingingsvoorwaarden op nationaal of op communautair niveau zouden kunnen vervalsen, zoveel mogelijk uit te schakelen."

Kortom, harmonisatie van de BTW staat niet op zich zelf maar is een noodzakelijke voorwaarde om de doelstelling van de interne markt te bereiken.

Het streven naar de interne markt is niet zozeer het einddoel, maar is één van de doelstellingen waarnaar de Europese Unie streeft. Eerder lijkt het juist een middel te zijn om een scala van doelstellingen te verwezenlijken. ${ }^{15}$ De doelstellingen van de EU zijn onder meer te vinden in artikel 3, lid 3 VEU (voorheen 2 EG). Het artikel vermeldt over de doelstellingen: "De Unie brengt een interne markt tot stand. Zij zet zich in voor de duurzame ontwikkeling van
Europa, op basis van een evenwichtige economische groei en van prijsstabiliteit, een sociale
markteconomie met een groot concurrentievermogen die gericht is op volledige werkgele-
genheid en sociale vooruitgang, en van een hoog niveau van bescherming en verbetering van
de kwaliteit van het milieu. De Unie bevordert wetenschappelijke en technische vooruitgang.
De Unie bestrijdt sociale uitsluiting en discriminatie, en bevordert sociale rechtvaardigheid en
bescherming, de gelijkheid van vrouwen en mannen, de solidariteit tussen generaties en de
bescherming van de rechten van het kind. De Unie bevordert de economische, sociale en
territoriale samenhang, en de solidariteit tussen de lidstaten. De Unie eerbiedigt haar rijke
verscheidenheid van cultuur en taal en ziet toe op de instandhouding en de ontwikkeling van
het Europese culturele erfgoed."

Opvallend is dat uit de tekst van dit artikel blijkt dat de interne markt niet het enige doel is waarnaar de Europese Unie streeft. Dit alles maakt duidelijk dat de ontwikkelingen van de BTW nauw verweven is met de ontwikkeling van het Europees recht.

14. Vrij verkeer van goederen artikelen $26 \mathrm{t} / \mathrm{m} 37 \mathrm{VwEU}$, vrij verkeer van personen artikelen $45 \mathrm{t} / \mathrm{m}$ $55 \mathrm{VwEU}$, van diensten artikelen $56 \mathrm{t} / \mathrm{m} 62 \mathrm{VwEU}$ en kapitaal artikelen $63 \mathrm{t} / \mathrm{m} 66$ VwEU. Zie P.J.G. Kapteyn \& P. VerLoren van Themaat 2003, blz. 487 e.v.

15. Dit blijkt vooral uit de tekst van artikel 2 EG (de voorloper van het huidige artikel 3 VEU. Artikel 2 EG vermeldt: "De Gemeenschap heeft tot taak, door het instellen van een gemeenschappelijke markt (...) (cursief AHB)" en dan volgen een scala aan doelstellingen. 


\subsection{Hof van Justitie EU en de Europese BTW}

Een interne markt vereist dat de BTW zich in de lidstaten op een eenduidige wijze ontwikkelt. Verscheidene factoren dragen bij tot een verdergaande harmonisatie van de BTW. Een belangrijke factor is de directe werking van richtlijnen. ${ }^{16}$ Daarnaast draagt de techniek van een richtlijnconforme interpretatie bij tot 'weginterpreteren' van een 'conflict' tussen het nationale recht en de BTW-richtlijn. ${ }^{17}$ Ook kan ambtelijk overleg gebaseerd op artikel 398, BTW-richtlijn bijdragen tot een afstemming op Europees niveau van de verscheidene BTW-bepalingen. ${ }^{18}$

16. Met directe werking van richtlijnen wordt bedoeld, dat in alle gevallen waarin bepalingen inhoudelijk gezien onvoorwaardelijk en voldoende nauwkeurig lijken te zijn, particulieren gerechtigd zijn deze tegen de Staat in te roepen, hetzij wanneer deze zich onthoudt van het tijdig omzetten van de richtlijn in nationaal recht, hetzij wanneer hij de omzetting niet op een correcte wijze verricht. Zie Hof 26 februari 1986, nr. 152/84, Marshall I, Jur. 1986, blz. 723, r.o. 46. Zie verder het arrest van het Hof van 19 januari 1982, nr. 8/81, Ursula Becker, Jur. 1982, blz. 52, toegespitst op de directe werking van artikel 135, lid 1, sub b, BTW-richtlijn (voorheen artikel 13, sub d(1), Zesde richtlijn) inzake de werkzaamheden van een kredietbemiddelaar. Zie verder ook over de directe werking van richtlijnen paragraaf 4.6.

17. De nationale rechter dient bij de toepassing van nationaal recht, ongeacht of het daarbij gaat om bepalingen die dateren van eerdere of latere datum dan de richtlijn, dit recht zo veel mogelijk uit te leggen in het licht van de bewoordingen en het doel van de richtlijn, teneinde het hiermee beoogde resultaat te bereiken. Zie Hof 13 november 1990, nr. C-106/89, Marleasing, Jur. 1990, blz. I-4135. Zie verder paragraaf 4.7

18. Het BTW-Comité is een raadgevend comité waarvan de adviezen geen wettelijke status hebben. De lidstaten zijn dus niet gehouden de adviezen van het comité op te volgen en kunnen besluiten van de gemeenschappelijke interpretatie af te wijken. A-G Kokott besteedt in haar conclusie in de Levobprocedure voor het Hof aandacht aan de beperkte betekenis van beslissingen van het BTW-Comité voor de interpretatie van de BTW-richtlijn (Conclusie A-G Kokott van 12 mei 2005, arrest van het Hof 27 oktober 2005, nr. C-41/04, Levob, NTFR 2005/1497). Overigens kan raadpleging van het BTWComité voor de lidstaten wel een belangrijke procedurele verplichting zijn. Zie bijvoorbeeld artikel 177, BTW-richtlijn (voorheen artikel 17, lid 7, Zesde richtlijn) waar is bepaald dat na raadpleging van het BTW-Comité een lidstaat om conjuncturele redenen investeringsgoederen of andere goederen geheel of gedeeltelijk van de aftrekregeling kan uitsluiten. Het Hof heeft beslist in de arresten Metropol \& Stadler (8 januari 2002, nr. C-409/99, V-N 2002/8.33, NTFR 2002/05) en Stradasfalti (14 september 2006, nr. C-228/05, V-N 2006/47.15, NTFR 2006/1554) dat raadpleging een procedurele verplichting is indien gebruikt wordt gemaakt door een lidstaat van de mogelijkheid die artikel 177, BTW-richtlijn biedt. Indien geen raadpleging heeft plaatsgevonden mag geen gebruik worden gemaakt van de desbetreffende regeling. Zie ook artikel 11, BTW-richtlijn (fiscale eenheid). In dit kader is van belang dat in het Van Paassen-arrest (Hof 12 juni 1979, nrs. 181/78 en 229/78, BNB 1980/44) is beslist dat Nederland aan de vereiste raadpleging heeft voldaan wat betreft de fiscale eenheid die in artikel 7, vierde lid van onze nationale wet is te vinden. Wel is het zo dat deze beslissing van het Hof betrekking heeft op een vergelijkbare regeling die is te vinden in de Tweede richtlijn die toentertijd van kracht was. De procedurele verplichting is tevens te vinden op de volgende plaatsen in de BTW-richtlijn: artikel 27 (interne dienst), 80 (maatstaf bij gelieerde verhoudingen), 155 (bijzondere maatregelen inzake vrijstellingen), 164 (vrijstelling intracommunautair goederen verkeer), 191 (aanpassing herzieningsregeling), 199 (verleggingregeling), 238 (vereenvoudiging factuurvereisten), 281 (KO-regeling), 318 (globalisatieregeling), 352 (regeling beleggingsgoud). Gesteld kan worden dat de beslissingen van het BTW-Comité geen (dan wel beperkte) invloed hebben in de jurisprudentie van het Hof wat betreft de uitleg van bepalingen in de BTW-richtlijn. Echter als verplichte procedurele maatregel heeft de $\rightarrow$ 
Verder is een belangrijke functie weggelegd voor de nationale rechtelijke instanties. De nationale rechter kan door het stellen van prejudiciële vragen aan het Hof uitleg vragen over de BTW-regelgeving. In het Cilfit-arrest ${ }^{19}$ van 6 oktober 1982 is aangegeven welke aspecten het noodzakelijk kunnen maken dat de nationale rechter prejudiciële vragen stelt aan het Hof. In het kader van artikel 267 VwEU (voorheen artikel $234 \mathrm{EG)}$ is de nationale rechter bevoegd en in bepaalde gevallen verplicht aan het Hof een uitspraak te vragen over de uitleg van het Unierecht.

Artikel 19, lid 1 VEU (voorheen artikel 220 EG) omschrijft de taak van het Hof. Deze taak houdt in het verzekeren van de eerbiediging van het recht bij de uitleg en de toepassing van het Unierecht. Wat onder de term 'recht' dient te worden verstaan is ter exclusieve beoordeling van het Hof. ${ }^{20}$ Het 'recht' omvat meer dan het geschreven recht. Het Hof kan ook putten uit andere bronnen dan het verdragsrecht. Het open rechtsbegrip maakt het mogelijk dat aan algemene rechtsbeginselen betekenis wordt toegekend (zie verder de paragrafen 4.2 en 4.4).

De rol van het Hof raakt de kern van het Unierecht. De instellingen en de lidstaten kunnen geen inbreuk maken op de rechtsmacht van het Hof. Deze centrale rol van het Hof heeft tot gevolg dat het Hof een belangrijke motor is achter de Europese eenwording. Wat de BTW betreft speelt het Hof onmiskenbaar een belangrijke rol. Op praktisch elk onderdeel van de BTW-regelgeving heeft het Hof wel een arrest gewezen. In de begin periode van de BTW verschenen arresten op het terrein van de uitleg van het EEG-Verdrag (thans werkingsverdrag), zoals het beroemde Gaston Schul I-arrest. ${ }^{21}$ De laatste paar jaren verschijnt er nauwelijks meer een arrest van het Hof op het terrein van de BTW waarin de uitleg van het Werkingsverdrag centraal staat. Tegenwoordig ligt het accent meer op de uitleg van het secundaire Unierecht. Daar bedoel ik mee dat tegenwoordig nationale rechters in het bijzonder vragen stellen ter verduidelijking van de bepalingen die zijn te vinden in de BTW-richtlijn. Dit is anders op het

\footnotetext{
$\rightarrow$ raadplegingprocedure een stevige positie. Het gebrek aan transparantie en het ontbreken van een wettelijke status van de door het BTW-Comité uitgebrachte adviezen waren voor de Commissie aanleiding om in september 1997 een voorstel in te dienen om de status van het BTW-Comité te wijzigen (Pb EG 1997, C 278, blz. 5). Het doel van het voorstel is het verlenen van rechtskracht aan besluiten van het comité die zijn genomen, en ervoor te zorgen dat deze beslissingen officieel bekend worden gemaakt. Op dit moment is er binnen de Raad (nog) geen overeenstemming over het voorstel van de Commissie.

19. Hof 6 oktober 1982, nr. 283/81, Cilfit, Jur. 1982, blz. 3415. Zie ook P.J.G. Kapteyn \& P. VerLoren van Themaat 2003, blz. 393 e.v. over het samenspel tussen het Hof en de nationale rechter. Zie verder K.J.M. Mortelmans, R.H. van Ooik \& S. Prechal, Europees recht en de Nederlandse rechter, Deventer: Kluwer 2004, blz. 52 e.v. Zie tevens D.M. Weber, \& F.H.I.J. Davids, De acte éclairé en acte clair-leer in het belastingrecht - algemeen (deel I), TFB 2008/02 en - de praktische toepassing (deel II), TFB 2008/03. 20. Zie verder R. Barents \& L.J. Brinkhorst, Grondlijnen van Europees recht, Deventer: Kluwer 2003, blz. 246 en 247.

21. Hof 5 mei 1982, nr. 15/81, Gaston Schul I, BNB 1982/228. Deze beslissing maakt duidelijk dat bij berekening van de verschuldigde BTW bij invoer uit een andere lidstaat, rekening dient te worden gehouden met de buitenlandse BTW. Deze procedure is uit de tijd dat tussen de lidstaten nog het belastbaar feit invoer bestond.
} 
terrein van de directe belastingen zoals de vennootschapsbelasting. In de jurisprudentie van het Hof op het terrein van de directe belastingen staat vaak wel de uitleg van het Werkingsverdrag centraal. De oorzaak daarvan is te vinden in de lange afwezigheid van aandacht voor deze belastingen in het Werkingsverdrag en de beperkte harmonisatie die op het terrein van de directe belastingen heeft plaatsgevonden. $^{22}$

Indien het gaat om handhaving van rechten die belastingplichtigen rechtstreeks aan het primaire of secundaire Unierecht ontlenen, is de nationale rechter de bevoegde instantie. Belastingplichtigen kunnen niet direct bij het Hof in beroep gaan, maar zij zijn dus bij het veiligstellen van hun rechten dan wel bij de uitleg van het Unierecht in eerste instantie afhankelijk van hun nationale rechter. Duidelijk is dus dat de hoogste nationale rechter zich zorgvuldig dient te oriënteren op de stand van het Unierecht en dat daar heel wat bij komt kijken. Een onjuiste inschatting door de hoogste nationale rechter kan voor een lidstaat en belastingplichtigen gevolgen hebben. ${ }^{23}$

De Commissie kan tegen schendingen van het Unierecht door een lidstaat op grond van artikel 258 VwEU (voorheen artikel 226 EG) beroep instellen bij het Hof. ${ }^{24}$ Ook een lidstaat kan op grond van artikel 259 VwEU (voorheen artikel 227 EG) bij het Hof een procedure opstarten indien schending van het Unierecht door een andere lidstaat mogelijk aan de orde is. ${ }^{25}$ Verder voorziet artikel 260 VwEU (voorheen artikel $228 \mathrm{EG}$ ) in een speciale beroepsprocedure wegens het niet uitvoeren van arresten van het Hof. ${ }^{26}$

22. Zie daarover nader B.J.M. Terra \& P.J. Wattel, European Tax Law, Deventer: Kluwer 2008, blz. 18 e.v. 23. Uit het Köbler-arrest (Hof 30 september 2003, nr. C-224/01, BNB 2004/151, m.n.v. P.J. Wattel, NTFR 2003/2125, zie in het bijzonder r.o. 52-55) blijkt dat een lidstaat in principe ook aansprakelijk kan worden gehouden voor onjuiste beslissingen van de hoogste nationale rechter.

24. Nederland is door de Commissie een aantal keren voor het Hof gedaagd. Zie in dit kader: Hof 10 juli 1985, nr. 16/84, FED 1985/509, waarin is beslist dat de Nederlandse inruilregeling was toegestaan in afwachting van een definitieve regeling voor gebruikte goederen; Hof 26 maart 1987, nr. 235/85, FED $1987 / 341$, in dit arrest is beslist dat Nederland ten onrechte de ambtelijke werkzaamheden die door notarissen en gerechtsdeurwaarders worden uitgeoefend aanmerkte als overheidsprestaties; Hof 12 september 2000, nr. C-408/97, V-N 2000/41.19, waarin is beslist dat Nederland geen BTW hoeft te heffen over tolgelden; Hof 8 november 2001, nr. C-338/98, BNB 2002/149, NTFR 2001/1570, in deze procedure werd Nederland veroordeeld voor het toestaan van aftrek van voorbelasting op het gebied van een kilometervergoeding aan werknemers; Hof 25 maart 2010, nr. C-79/09, NTFR 2010/849, waar de regeling inzake uitlenen van personeel in bepaalde sectoren de toetsing aan de BTW-richtlijn doorstaat.

25. In de BTW is een procedure gebaseerd op artikel 259 VwEU (nog) niet aan de orde geweest. Wel kan verwacht worden dat als de beleidsconcurrentie tussen de lidstaten toeneemt, artikel 259 VwEU mogelijk een rol in het Europese belastingrecht kan gaan spelen.

26. Een voorbeeld van een dergelijke procedure op het terrein van de BTW is het arrest van 14 oktober 1992, nr. C-262/91, Commissie/Italië, Jur. 1992, blz. I-5269. In deze procedure daagde de Commissie Italië opnieuw voor het Hof omdat Italië geen uitvoering gaf aan het arrest van 24 november 1987, nr. 125/86, Jur. 1987, blz. 4669. In dit laatste arrest is Italië veroordeeld wegens het niet nakomen van haar verplichtingen om artikel 14, lid 1, sub d, Zesde richtlijn (vrijstelling bij invoer) (thans artikel 143, BTW-richtlijn) correct te implementeren. Zie verder ook Hof 19 januari 1993, nr. C-101/91, Commissie/ Italië, Jur. 1993, blz. 191. 
Vanaf de inwerkingtreding van de Tweede richtlijn zijn voor het Hof ruim 80 procedures gevoerd op grond van artikel 258 VwEU en ruim 350 prejudiciële procedures gebaseerd op artikel 267 VwEU, waarvan kan worden gesteld dat deze procedures direct betrekking hebben op de heffing van BTW. Duidelijk is dus dat het Hof een belangrijke positie inneemt bij de vorming van het Europese BTW-recht. ${ }^{27}$

\subsection{Hof van Justitie EU, de Europese BTW en kritiek}

De beslissingen van het Hof leiden regelmatig tot verrassingen. Zo is de nationale rechter geregeld genoodzaakt door een arrest van het Hof terug te komen op een ingezette lijn. De Hoge Raad besliste bijvoorbeeld in 1983 dat het onverplicht afstand doen van een huurrecht door de huurder een belaste dienst is voor de heffing van BTW. ${ }^{28}$ Ook al werd de onroerende zaak vrijgesteld van BTW gehuurd. De beslissing van de Hoge Raad had een stroom van jurisprudentie tot gevolg, waarin telkens de vraag aan de orde was of de huurder 'vrijwillig' zijn medewerking verleende aan het afstand doen van het huurrecht. ${ }^{29}$

Op 15 december 1993 zorgde het Hof voor een verrassende wending door te kiezen voor een mogelijkheid die in de Nederlandse jurisprudentie en literatuur niet was onderkend. ${ }^{30}$ Het Hof besliste dat indien de huurder afstand doet van zijn huurrecht en de onroerende zaak weder ter beschikking stelt aan degene die het aan hem heeft verhuurd, een dergelijke omstandigheid dan valt onder het begrip 'verhuur van onroerende goederen' waarvoor ingevolge artikel 135, lid 1, sub 1, BTW-richtlijn (voorheen artikel 13B, sub b, Zesde richtlijn) een vrijstelling geldt. Het Hof voegt daar aan toe, dat artikel 135, lid 1, sub 1, BTW-richtlijn de lidstaten niet de bevoegdheid verleent om het bedrag dat de ene partij aan de andere partij betaalt te belasten, wanneer de krachtens de huurovereenkomst betaalde huurbedragen waren vrijgesteld van BTW-heffing. Uit het arrest van het Hof kan de conclusie worden getrokken, dat indien een transactie binnen de reikwijdte van een vrijstelling valt (zoals de verhuur van een onroerende zaak), zulks evenzeer geldt voor een verandering in de contractuele betrekkingen tussen partijen, zoals de beëindiging

27. Zie voor nadere gegevens over de verscheidene procedures voor het Hof het Jaarverslag van het Hof. Dit verslag is te vinden op de site van het Hof: www.curia.europa.eu.

28. HR 5 januari 1983, nr. 20 941, BNB 1983/104. In zijn conclusie bij dit arrest concludeerde A-G Van Soest dat het noodzakelijk was om prejudiciële vragen voor te leggen aan het Hof. Gezien het vervolg ruim tien jaar later, is achteraf te constateren dat deze mogelijkheid te snel terzijde is gelegd.

29. Hof Amsterdam 12 november 1986, nr. 4565/86, BNB 1988/84; Hof Leeuwarden 16 januari 1987, nr. 1995/82, BNB 1988/64; Hof Amsterdam 16 juni 1987, nr. 4565/86, BNB 1989/93; HR 5 september 1990, nr. 26 721, BNB 1990/305; HR 19 december 1990, nr. 26 144, BNB 1991/40; HR 19 december 1990, nr. 26 764, BNB 1991/41; Hof 's-Gravenhage 27 maart 1991, nr. 638/90, V-N 1991, blz. 2332.

30. Hof 15 december 1993, nr. C-63/92, Lubbock Fine \& Co, FED 1994/155 en ruim 5 jaar later gepubliceerd in BNB 1999/193. 
van de verhuur tegen een vergoeding. Kortom, de afkoopsom die wordt betaald om het huurcontract te beëindigen, is vrijgesteld van BTW heffing indien de verhuur ook was vrijgesteld. ${ }^{31}$ In de benadering van het Hof is de eerder weergegeven leer van de Hoge Raad in het geheel niet te herkennen.

Ook het antwoord op de vraag of een directeur-grootaandeelhouder die in dienst is van zijn vennootschap belastingplichtig is, blijkt aan de nodige wendingen onderhevig te zijn. Het begon met het arrest van de Hoge Raad van 26 april 2002. ${ }^{32}$ In dit arrest besliste de Hoge Raad, onder verwijzing naar het Asscher-arrest, ${ }^{33}$ dat een directeur-grootaandeelhouder belastingplichtig is voor de BTW. Dit was voor de uitvoeringspraktijk een verrassing. Vele directeuren-grootaandeelhouder werden dan ook vervolgens door de Belastingdienst geregistreerd als afzonderlijke belastingplichtigen dan wel opgenomen in een fiscale eenheid. Het Hof besliste echter in het Van der Steen-arrest, dat een directeur-grootaandeelhouder niet zelfstandig is voor de BTW en dan ook niet kan worden aangemerkt als belastingplichtige. ${ }^{34}$ Het gevolg van het Van der Steen-arrest was dat de directeuren-grootaandeelhouders door de Belastingdienst ten onrechte waren aangemerkt als belastingplichtigen. Dit was gebeurd op grond van het hierboven genoemde, zo als later bleek, onjuiste arrest van de Hoge Raad. Duidelijk is dan ook dat een onjuiste inschatting van het Europees BTW-recht grote gevolgen kan hebben voor de praktijk. ${ }^{35}$

Niet alleen de nationale rechter kan soms door het Hof worden geconfronteerd met een verrassend arrest. Ook de wetgever deelt dit lot regelmatig. Een voorbeeld ${ }^{36}$ daarvan is het arrest Charles-Tijmens. ${ }^{37}$ In dit arrest is de Nederlandse regelgeving op het terrein van het recht op aftrek van voorbelasting voor een deel in strijd

31. Op 26 augustus 1998 heeft de HR (nr. 33.690, V-N 1998/46.26) beslist dat uit het Lubbock Finearrest de conclusie kan worden getrokken dat indien partijen hebben geopteerd voor belaste verhuur, tevens de afkoopsom ter ontbinding van de verhuurovereenkomst is belast met BTW. Simons heeft kritiek op deze invulling. Hij is van menig dat bij het afstand doen van een huurrecht geen sprake is van een prestatie. Zie Simons, Foute rechtsontwikkeling van de prestatie in de omzetbelasting, WFR 1999/743. Zie verder ook paragraaf 10.5 over het rechtszekerheidsbeginsel en de vrijstellingen.

32. HR 26 april 2002, nr. 35 775, NTFR 2002/630.

33. Hof 27 juni 1996, nr. C-107/94, Asscher, Jur. 1996, blz. I-3089

34. Ik ga in dit verband niet op het arrest in, noch op de mogelijk relevante verschillen in betekenis tussen het begrip zelfstandig als beslist en dit begrip omschreven in de vraagstelling van het Hof Amsterdam. Zie nader A.H.R.M. Denie, Moet de directeur-grootaandeelhouder, zonder BTW-status in de EU, managen? in: DGA en Fiscus: de stand van zaken, Maastrichtse fiscale symposia, nr. 18, Deventer: Kluwer 2009, blz. 3 t/m 18.

35. Zie voor een aantal van deze gevolgen het Besluit van 21 december 2007, nr. CPP 2007/3160, NTFR $2008 / 84$.

36. Ander voorbeeld is de te beperkte formulering in de Wet OB van de medische vrijstelling (zie Hof 27 april 2006, nr. 443/04 en C-444/04, Solleveld \& Van den Hout-van Eijnsbergen, BNB 2006/256); ander voorbeeld: de heffing van invoer bleek bij particulieren niet ongeclausuleerd plaats te kunnen vinden (Hof 5 mei 1982, nr. 15/81, Gaston Schul I, BNB 1982/228).

37. Hof 14 juli 2005, C-434/03, Charles-Tijmens, BNB 2005/284, V-N 2005/35.18. Zie voor een kritische beschouwing over het arrest: J.J.M. Lamers, Etikettering, aftrek en heffing volgens Johan Cruijff, WFR 2006/159. 
verklaard met de BTW-richtlijn. ${ }^{38}$ Op het moment van verschijnen van onze Wet op de omzetbelasting 1968 was dit niet te verwachten.

In de literatuur is regelmatig kritiek te vinden op arresten van het Hof. Deze kritiek is vaak gericht op het ontbreken van uitgangspunten/beginselen. Ik zal enkele pregnante voorbeelden geven. Het eerste voorbeeld betreft Simons over het Hong Kongarrest van het Hof van 1 april 1982. ${ }^{39}$ In deze procedure besliste het Hof, dat geen sprake is van belastingplicht indien een organisatie uitsluitend om niet diensten verricht. Simons meent dat deze beslissing in wezen fout is. ${ }^{40}$ Volgens hem heeft het Hof in deze procedure te veel gekeken naar de letterlijke tekst van de BTW-richtlijn en heeft de maatschappelijke werkelijkheid te weinig aandacht gekregen.

Ook het beroemde Tolsma-arrest ${ }^{41}$ is in de literatuur omstreden. ${ }^{42}$ Het Hof besliste in deze procedure dat een orgeldraaier die langs de openbare weg muziek ten gehore brengt buiten de BTW-heffing valt omdat hij geen prestatie verricht onder bezwarende titel. Van Hilten vraagt zich af of het Hof met deze beslissing niet te weinig aandacht heeft geschonken aan doel en strekking van de BTW en te veel heeft geleund op pragmatische overwegingen. ${ }^{43}$ Simons is van mening dat het Hof met deze beslissing de economische (maatschappelijke) benadering geweld aan doet. ${ }^{44}$ De door het Hof ingezette lijn verstoort volgens hem de neutraliteit, hetgeen een aanpassing van de BTW-richtlijn noodzakelijk kan maken. Verder is Simons van mening dat het arrest in strijd is met het idee van een verbruiksbelasting zoals die in de eerste richtlijn expliciet en meer impliciet in de Zesde is neergelegd. ${ }^{45}$ Bijl constateert in zijn aantekening bij het arrest dat met de beslissing van het Hof afbreuk wordt gedaan aan het karakter van de omzetbelasting als bestedingsbelasting. ${ }^{46}$ Bijl

38. Zie verder over deze problematiek paragraaf 6.5 .

39. Hof 1 april 1982, nr. 89/81, Hong Kong Trade Development Council, BNB 1982/311, FED 1983/25. 40. A.L.C. Simons, Terug naar de basis van de BTW: het maatschappelijk verkeer!, WFR 1994/5. Zie ook A.L.C. Simons, De nieuwe rechtstheorie 'getriggerd' door BTW constructies, WFR 95/469.

41. Hof 3 maart 1994, nr. C-16/93, Tolsma, BNB 1994/271, V-N 1994/1069, pt. 25, FED 1994/348.

42. Zie voor een beschouwing voorafgaand aan het arrest, A.H.R.M. Denie, Minder muziek bij het jubileum van de BTW?, WFR 1994/27. In dit artikel werd de lijn van het Hof al aangegeven. Zie tevens W.A.P. Nieuwenhuizen, Tolsma en het gelijk van het Hof van Justitie, WFR 1995/252. Nieuwenhuizen is van mening dat het Tolsma-arrest niet is te zien als een inbreuk op de bestedingsgedachte. Volgens Nieuwenhuizen kan men geen besteding belasten indien men zelf niet bewust is van het feit dat men een prestatie in ontvangst neemt tegenover de eigen besteding.

43. M.E. van Hilten, Het bakje van de orgelman, BTW-Brief 1994, nr. 3, blz. 2. Zie ook het afscheidscollege van J. Reugebrink, De zomer was groots, WFR 1995/1792. Reugebrink typeert deze uitspraak als een onweersbui. Immers, het normatieve van de omzetbelasting verdwijnt met deze uitspaak achter de wolken: wat is in de portemonnee uiteindelijk het verschil tussen de besteding voor een CD met orgelmuziek en de gulden die in het bakje van de orgelman verdwijnt, vraagt Reugebrink zich af. 44. A.L.C. Simons, Neutrality in VAT and the Organ-Grinder, EC Tax Review 1994/2, blz. 44.

45. A.L.C. Simons, Open brief aan prof. mr. J. Reugebrink, WFR 1995/1587.

46. Noot bij het Tolsma-arrest in FED 1994/348. 
wil niet zo ver gaan door de benadering in het arrest als te formalistisch te bestempelen. Men kan immers ook zeggen, dat in de Zesde-richtlijn kennelijk de gedachte van een bestedingsbelasting niet op de juiste wijze vorm heeft gekregen. Wanneer de lidstaten werkelijk een algemene bestedingsbelasting wensen, ligt volgens Bijl een aanpassing van de BTW-richtlijn meer voor de hand dan kritiek op het onderhavige arrest van het Hof.

Het Bulthuis-arrest van 11 augustus 1995 over de vrijstelling van heffing van BTW in geval van de exploitatie van een kinderdagverblijf is een ander voorbeeld waarin men de kritiek niet onder stoelen of banken stak. ${ }^{47}$ Het Gerechtshof Amsterdam stelde een prejudiciële vraag over de uitleg van artikel 132, lid 1, sub g, BTW-richtlijn (voorheen artikel 13A, lid 1, sub g, Zesde richtlijn). De vraag spitste zich toe op de precieze invulling van de voorwaarde dat niet 'systematisch het maken van winst' mag worden beoogd om onder de vrijstelling te vallen. Het Hof kwam aan deze vraag echter niet toe. De toepassing van de vrijstelling struikelde al in een eerder stadium. Het Hof besliste dat Bulthuis-Griffioen niet kan worden aangemerkt als een 'instelling'. Onder 'instellingen' moet volgens het Hof worden verstaan rechtspersonen. Natuurlijke personen kunnen niet worden aangemerkt als een instelling in de zin van de vrijstelling. Van Hilten is van mening dat het Hof met deze beslissing de neutraliteit enigszins uit het oog heeft verloren. ${ }^{48}$ Het enkele feit dat iemand geen rechtspersoon is staat volgens haar ten onrechte de toepassing van de vrijstelling in de weg. Zij bespeurt de laatste jaren een proces waarbij de neutraliteit van de heffing van BTW naar de achtergrond verschuift ten gunste van een zeker pragmatisme. Ook de redactie van Vakstudie Nieuws uit kritiek op de magere plaats van het neutraliteitsbeginsel bij de uitleg van het begrip 'instelling. ${ }^{49}$ Verder heeft ook de Staatssecretaris moeite met de beperkte uitleg die het Hof toekent aan de vrijstelling voor kinderopvang. In enkele Besluiten heeft hij geprobeerd de toepassing van de vrijstelling veilig te stellen. ${ }^{50}$ De beperkte uitleg van het begrip 'instellingen' heeft overigens niet lang geduurd. In het Gregg-arrest ${ }^{51}$ van 7 september 1999 besliste het Hof dat de vrijstelling niet beperkt is tot natuurlijke personen.

“(...), dat met de termen 'inrichting' en 'organisaties' niet alleen rechtspersonen worden bedoeld, strookt met name met het beginsel van de fiscale neutraliteit dat inherent is aan het gemeenschappelijk BTW-stelsel, en dient te gelden bij de toepassing van de vrijstellingen van artikel 13 van de Zesde richtlijn (...)." (r.o. 19)

Het Hof is dus teruggekomen op wat algemeen in de literatuur als een foute lijn wordt gezien.

47. Hof 11 augustus 1995, nr. C-453/93, Bulthuis-Griffioen, V-N 1995/2932, pt. 32, FED 1995/703.

48. M.E. van Hilten, Neutraliteit anno nu, WFR 1995/1579.

49. V-N 1995/2932, pt. 32. Zie verder ook U.E. Tromp, Hof van Justitie over kinderopvang, BTW-Brief 1995/10, blz. 7. Tromp is van mening dat zeker concurrentieverstoring zal optreden indien ondernemers/natuurlijke personen niet onder de vrijstelling vallen.

50. Besluit van 16 februari 1995, nr. VB 95/634 (V-N 1995/867, pt. 29), Besluit van 7 november 1998, VB 98/2467, V-N 1998/58.24.

51. Hof 7 september 1999, nr. C-216/97, Gregg, BNB 1999/395, V-N 1999/47.21. 
Verder kunnen de serie arresten van het Hof met betrekking tot het houden van aandelen, obligaties en depots niet op veel bijval rekenen. ${ }^{52}$ Reugebrink en Van Hilten zijn van mening dat door deze jurisprudentie de behandeling van aandelenbezit en andere 'beleggingen' door ondernemers die overigens gewoon belastbare prestaties verrichten, er niet eenvoudiger op wordt. ${ }^{53}$ Verder menen zij dat het houden van participaties, bankrekeningen enz. BTW schoon zou moeten kunnen geschieden. In een verbruiksbelasting hoort daar volgens hen geen BTW op te drukken. Beelen merkt over het SKF-arrest ${ }^{54}$ op:

"Om een aantal belangrijke uitgangspunten van de BTW niet al te veel geweld aan te doen moet het hof zich daarvoor in nogal wat bochten wringen. Misschien moet daarbij wel geconstateerd worden dat het Hof uit de bocht is gevlogen." ${ }^{35}$

In algemene zin geeft Reugebrink aan, dat naar zijn mening het één en al pragmatisme is wat de klok slaat, wanneer men de jurisprudentie van het Hof beziet. ${ }^{56}$

Tot zover de verrassingen die de rechtspraak van het Hof voor ons hoogste rechtscollege en onze wetgever soms in petto heeft en de soms niet mis te verstane kritiek in de literatuur. ${ }^{57}$ Deze kritiek houdt vaak in dat het Hof het neutraliteitsbeginsel geweld aan doet en onvoldoende rekening houdt met het (rechts)karakter van een indirecte algemene verbruiksbelasting.

\section{$1.4 \quad$ Probleemstelling}

Uit de in de vorige paragraaf behandelde literatuur blijkt een zekere spanning tussen enerzijds de ervaringen in de Nederlandse rechtspraktijk en anderzijds de

52. Zie bijvoorbeeld de volgende arresten respectievelijk kritieken: Hof 20 juni 1991, nr. C-60/90, Polysar, V-N 1991/2140, pt. 35, FED 1991/633 (inzake het houden van aandelen; Hof 6 april 1995, nr. C4/94, BLP, V-N 1995/3030, pt. 27, FED 1995/495 (inzake de verkoop van een deelneming); Hof 20 juni 1996, nr. C-155/94, Wellcome Trust, V-N 1997/1034, pt. 17, FED 1996/577 (inzake het beheer van vermogen van een charitatieve trust); Hof 11 juli 1996, nr. C-306/94, Régie Dauphinoise, BNB 1997/38, (inzake deposito's); Hof 6 februari 1997, nr. C-80/95, Harnas \& Helm CV (inzake het houden van obligaties), BNB 1997/386, V-N 1997/1031, FED 1997/158; zie verder W.A.P. Nieuwenhuizen, De Régie van de BTW, WFR 1997/54; zie tevens redactie V-N bij het Securenta-arrest van 13 maart 2008, nr. C437/06, V-N 2008/14.20 waar opgemerkt wordt dat de door het Hof gehanteerde beginselen eigenaardig zijn en verwarring in de hand kunnen werken.

53. J. Reugebrink \& M.E. van Hilten, Omzetbelasting, Deventer: Kluwer 1997, blz. 87 en 88 . Zie tevens M.E. van Hilten \& H.W.M. van Kesteren, Omzetbelasting, Deventer: Kluwer 2007, blz. 244.

54. Hof 29 oktober 2009, nr. C-29/08, AB SKF, V-N 2009/56.13, NTFR 2009/2421. Deze procedure gaat over het recht op aftrek van voorbelasting bij een aandelentransactie.

55. S.T.M. Beelen, Aftrek van BTW als (belaste) omzet ontbreekt (diss. Rotterdam), Deventer: Kluwer 2010, blz. 152.

56. J. Reugebrink, Een dubbel jubileum van de omzetbelasting, WFR 1994/3.

57. Zonder uitputtend te zijn verwijs ik ook naar: J.J.M. Lamers, Etikettering, aftrek en heffing volgens Johan Cruijff, WFR 2006/159, waar hij kritiek uit op het leerstuk keuzevermogen; J.J.M. Lamers, Omtrent onttrekkingen, NTFR Beschouwingen 2009/39, hij noemt het beleid van het Hof incidentenpolitiek; M.E. van Hilten, Over de neutraliteit van de omzetbelasting en het hellend vlak van de uitzonderingen (oratie Amsterdam VU), Deventer: Kluwer 2010. 
verwachtingen en resultaten van de jurisprudentie van het Hof. Deze spanning kan naar men mag veronderstellen te maken hebben met cultuur, nationale rechtsopvattingen of wellicht met de eigenheid van het Europees recht. In elk geval is een mate van onbegrip te bespeuren. Overzien wij voorgaande verrassingen die de rechtspraak van het Hof heeft voor onze nationale rechtspraak en regelgeving, en bezien wij de vaak weinig verheulde kritiek in de literatuur, dan is de veronderstelling niet ongerechtvaardigd dat de Nederlandse rechtspraktijk zich door andere uitgangspunten of beginselen laat leiden dan het Hof. Mede naar aanleiding van de gesignaleerde discrepantie rijst de vraag: door welke beginselen laat het Hof zich leiden? De vraag heeft, na 40 jaar Europese ervaring op dit rechtsgebied ook zelfstandige betekenis. Kennen wij de beginselen, althans kennen wij deze voldoende binnen hun toepassingsbereik om er in de rechtspraktijk mee te werken, met name in gevallen waarin de richtlijnteksten om interpretatie vragen en om de feitelijke maatschappelijke veranderingen binnen de richtlijn een plaats te geven? Meer dan oppervlakkig wetend dat het Hof zich van rechtsbeginselen bedient, is het zinnig om deze bloot te leggen en de werking ervan te leren kennen. Of, zoals Scholten het in algemene zin formuleerde: ${ }^{58}$

"Het is een der voornaamste functies der rechtswetenschap het rechtsbeginsel in het positieve recht op te sporen."

Zie hier het centrale thema van deze studie. Daarin beperk ik mij tot de rechtspraak van het Hof op, in het bijzonder, het richtlijnenrecht op het gebied van de BTW.

Uit de jurisprudentie van het Hof blijkt dat er een autonome rechtsorde van de Europese Unie is. ${ }^{59}$ Deze rechtsorde is gebaseerd op een aantal rechtsbeginselen, die evenals het Werkingsverdrag en de richtlijnen, behoren tot het Unierecht. Uit deze beginselen zijn vervolgens maatstaven af te leiden waaraan het optreden van de nationale overheden en de gemeenschapsinstellingen van de Europese Unie moeten voldoen wanneer zij verdragsregels en richtlijnen uitvoeren. ${ }^{60}$ Gezien het gegeven dat de BTW is verankerd in het Unierecht, werken de rechtsbeginselen door in de rechtspraktijk van de BTW. ${ }^{61}$

Zoals uit de vorige paragraaf blijkt, benadert men de BTW vaker vanuit de voor deze belasting, min of meer, geldende of noodzakelijke beginselen, uitgangspunten of, zoals Denie het formuleert 'grondslagen'. ${ }^{62}$ Men denkt bijvoorbeeld aan de vraag van het rechtskarakter van de BTW, de meer aan de heffing geëigende neutraliteit en het bestemmingslandbeginsel (zie hoofdstuk 2, inzake 'klassieke BTW-beginselen').

58. P. Scholten, Asser-Scholten (Algemeen deel), Zwolle: E.E.J. Tjeenk Willink 1974, blz. 63.

59. Hof 5 februari 1963, nr. 26/62, Van Gend en Loos, Jur. 1963, blz. 3. Zie verder paragraaf 4.2.

60. Zie T. Koopmans, Rechtsbeginselen in het Europees Gemeenschapsrecht, Ars Aequi 1991, blz. 927 e.v. 61. De hoofdstukken 3 en 4 gaan uitgebreid in op deze rechtsbeginselen en zal tevens het begrip nader worden omschreven. Vooralsnog doel ik op rechtsbeginselen in de breedste zin van het woord. 62. Denie 1987, blz. 2 en 8. 
Uiteraard geven genoemde grondslagen vorm en inhoud aan de regels en beïnvloeden zoals nader blijkt soms betwist - het verbruiksbeginsel en meer dominant het neutraliteitsbeginsel, de rechtspraak. Ook de literatuur - de meeste dissertaties in Nederland op het terrein van de BTW besteden daar in mindere of bepaald meerdere mate aandacht aan - behandelt deze grondslagen, of zo men wil 'beginselen' van de BTW. Maar met een verwijzing daarnaar, zijn wij er bepaald niet als wij de vraag stellen of het BTW-recht mede door beginselen wordt 'aangestuurd', zo ja, door welke en wat hun werking en dus ook invloed daarvan is. Over welke beginselen praten wij, wetend dat er 'grote' rechtsbeginselen zijn de algemene rechtsbeginselen - en in elk geval wetend, dat wij deze ook tegenkomen in de rechtspraak van het Hof? Moeten genoemde 'beginselen' van de BTW niet onderscheiden worden van de algemene rechtsbeginselen? Denk bijvoorbeeld aan het maken van onderscheid of het onderkennen van overlapping tussen het neutraliteitsbeginsel en het 'grote' gelijkheidsbeginsel. Al bij oppervlakkig kennisnemen van de rechtspraak van het Hof op het BTW-terrein kan men vaststellen, en gedurende het onderzoek is dat ook gebleken, dat naast het gelijkheidsbeginsel ook het rechtszekerheidsbeginsel en het evenredigheidsbeginsel een wat de toepassing van beginselen betreft, dominante rol spelen. ${ }^{63}$ Het onderzoek richt zich daarom bepaaldelijk op deze beginselen, dat wil zeggen, op het situeren - het inventariseren van de plaatsen waar zij een rol spelen - het laten zien van de werking ervan ter bestemde plaatse, en zo mogelijk vergelijken van de werking van deze beginselen onderling dan wel in verhouding tot andere aspecten van de uitleg van het recht, hetgeen uiteindelijk kan uitmonden in een analyse van de doorwerking van de - Europese Unie bindende - algemene rechtsbeginselen in het recht van de BTW als uitgelegd door het Hof.

\subsection{Plan van behandeling}

De vorenstaande vragen naar de toepassing van beginselen, welke beginselen en hun onderscheidende werking op onderscheiden plaatsen brengt mij tot de navolgende opbouw van het onderzoek, waarin, zoals blijkt, subvragen en nadere ordeningen begrepen zijn.

In de eerste plaats geef ik in hoofdstuk 2 een beschrijving van beginselen - naar de onderzochte literatuur algemeen aanvaard - eigen zijn aan de BTW. Zonder de BTW eigen beginselen achter de concepten, wetsopbouw en wetsbegrippen functioneert de BTW niet. Deze beginselen worden door mij aangeduid als klassieke BTWbeginselen (rechtskarakter). Wij spreken dan over het verbruiksbeginsel (paragraaf 2.2), het neutraliteitsbeginsel (paragraaf 2.4), en het beginsel van territorialiteit (paragraaf 2.3.1), bestemming of oorsprong (paragraaf 2.3.2).

Om inzichtelijk te krijgen en te ordenen wat wij onder ons onderwerp algemene rechtsbeginselen moeten of kunnen verstaan en de plaats aan te geven waarin deze

63. Zie ook S. Prechal \& T. Heukels, Algemene beginselen in het Nederlandse recht en het Europees recht: rechtsvergelijking en interactie, SEW 1986 mei, blz. 287. 
beginselen hun werking hebben, heb ik een voor dit onderzoek hanteerbare definitie van algemene rechtsbeginselen uitgewerkt (paragraaf 3.2.3).

De algemene rechtsbeginselen die in dit onderzoek aan de orde zijn betreffen het gelijkheidsbeginsel, het evenredigheidsbeginsel en het rechtszekerheidsbeginsel. Bij het bespreken van de rol en de toepassing van deze 'grote' beginselen is het interessant en nuttig te onderscheiden tussen het materiële rechtsterrein en het formele rechtsterrein (paragraaf 3.3.1). Op het gebied van de inhoud van regels die de belastingplicht, het belastbaar feit, de aftrek van voorbelasting, enz., enz., bepalen, het gebied dat men in het algemeen het materiële recht noemt, werken de algemene rechtsbeginselen als interpretatiebeginsel, als ware het 'interpretatieregels' bij de uitleg door het Hof van het richtlijnenrecht. Bij nagenoeg alle kernpunten van het materiële recht spelen de 'grote' algemene rechtsbeginselen op deze wijze een rol (hoofdstukken $6 \mathrm{t} / \mathrm{m} \mathrm{12}$ ). Dezelfde beginselen opereren ook op het terrein van de formele rechtsverhoudingen tussen overheid en particulier, als norm waaraan het overheidsoptreden moet voldoen. Hoofdstuk 5 heeft daarop in het bijzonder betrekking en in paragraaf 7.2 speelt het een rol bij de startende ondernemer. De algemene rechtsbeginselen vervullen die rol dan naast, kortst gezegd, andere beginselen van behoorlijk bestuur, die overigens in dit onderzoek uiteraard niet aan de orde komen. Dit alles leidt in paragraaf 3.3.1 tot het onderscheid in algemene rechtsbeginselen als interpretatiebeginsel en als beginsel van formeel recht.

Omdat de vragen voorliggen of, waar en in welke mate algemene rechtsbeginselen voor de BTW-regelgeving van betekenis zijn, is het van belang de inperkende en verruimende effecten van de algemene rechtsbeginselen te onderkennen (paragraaf 3.3.2). De uitkomst van het interpretatieproces kan zijn dat de rechter een uitleg aan een BTW-regel geeft die voor de rechtspraktijk nieuw is. Paragraaf 3.3.2 gaat hier nader op in voor zowel de algemene rechtsbeginselen van formeel recht en als interpretatiebeginsel. In paragraaf 3.3 verduidelijk ik de werking van de algemene rechtsbeginselen aan de hand van verscheidene indelingen. ${ }^{64}$

Na de kenmerken (paragraaf 3.2) en de werking (paragraaf 3.3) van de algemene rechtsbeginselen uiteen te hebben gezet, ga ik nader in op de drie algemene

64. Zie bijvoorbeeld de oratie van R.F.W. van Brederode, Ethiek van het omzetbelastingrecht, Deventer: Kluwer 1996. Hij maakt op blz. 15 de volgende indeling van de belastingbeginselen in de BTW:

“1 Immanente beginselen, daaronder verstaat hij beginselen die rechtstreeks uit het heffingssysteem van de belasting volgen, bijvoorbeeld oorsprongsland, bestemmingslandbeginsel en het neutraliteitsbeginsel.

2. Additionele beginselen, daaronder verstaat hij beginselen die niet inherent zijn aan het heffingssysteem maar die door de wetgever in de regelgeving zijn gebracht in aanvulling of in afwijking van de immanente beginselen, bijvoorbeeld het verlaagde tarief kan gezien worden als een uitvloeisel van het herverdelingsbeginsel.

3. Flankerende beginselen, daaronder verstaat hij beginselen die niet expliciet of impliciet in de belastingwet zijn opgenomen, maar wel op belastingen van toepassing zijn als bron van rechtsbescherming, bijvoorbeeld regels van internationaal en Europees recht inzake de mensenrechten, zoals neergelegd in bijvoorbeeld het IVBPR en de ECRM." 
rechtsbeginselen van het onderzoek. Met name de Europees rechtelijke invulling van het algemene gelijkheidsbeginsel (paragraaf 3.4.1), evenredigheidsbeginsel (paragraaf 3.4.2) en het rechtszekerheidsbeginsel (paragraaf 3.4.3) staat centraal. Ook zal ik onderzoeken of de eerdergenoemde klassieke BTW-beginselen zijn aan te merken als algemene rechtsbeginselen (paragraaf 3.5).

Van belang is dat de algemene rechtsbeginselen in de Europese rechtsorde zijn verankerd, zodat het in het kader van mijn onderzoek vereist is om aandacht te schenken aan de relevante kenmerken van die rechtsorde. In hoofdstuk 4 komt de invloed van het Europees recht met betrekking tot de eerder genoemde algemene rechtsbeginselen aan bod. Tevens beschrijft hoofdstuk 4 de koppeling tussen het autonome Unierecht en de nationale omzetbelastingregelgeving/jurisprudentie. De koppeling vindt plaats door rechtstreekse werking van richtlijnen (paragraaf 4.6) en richtlijn/beginselconforme interpretatie (paragraaf 4.7). Deze koppeling heeft tot gevolg dat de rechtsbeginselen voor de nationale praktijk van belang zijn. Ook schenkt dit hoofdstuk aandacht aan de techniek van rechtsvinding die het Hof toepast. Aandacht hiervoor is noodzakelijk gezien het gegeven dat algemene rechtsbeginselen nauw verweven zijn met de rechtsvinding. ${ }^{65}$ Het Hof gebruikt de algemene rechtsbeginselen om de BTW-regels uit te leggen. Aan bod komen onder meer de interpretatiemethoden (paragraaf 4.4.2) en de analogieargumentatie (paragraaf 4.4.3). Denkbaar is dat de rechter een bepaling uitlegt in het nadeel van belanghebbende. Deze uitleg kan op gespannen voet staan met de verwachte uitkomsten van de tekst van de bepaling en het rechtszekerheidsbeginsel en komt aan de orde in de paragrafen 4.4.3.4 (analogieargumentatie in het belastingrecht) en 5.3 (misbruik van recht). Tevens komt aan de orde de wijze waarop het gelijkheidsbeginsel, fiscale neutraliteit en de analogieargumentatie zich tot elkaar verhouden en welke aspecten zij gemeenschappelijk hebben (paragraaf 4.4.4). Hetgeen hoofdstuk 4 behandelt, dient ter ondersteuning van een volledig begrip van het BTW-recht.

De hoofdstukken 4 en 5 benaderen de algemene rechtsbeginselen vanuit Europees rechtelijk perspectief. Kort weergegeven besteedt hoofdstuk 4 aandacht aan de positie/rol van de algemene rechtsbeginselen in het Europese recht en hoofdstuk 5 gaat in op enkele voor de BTW relevante leerstukken in het Europees recht die zonder enige twijfel zijn vormgegeven onder invloed van de algemene rechtsbeginselen. De hoofdstukken 4 en 5 helpen de kernpunten van het BTW-recht een belangrijke setting te geven.

Hoofdstuk 5 besteedt in het bijzonder aandacht aan de algemene rechtsbeginselen van formeel recht. In de hoofdstukken $6 \mathrm{t} / \mathrm{m} 12$ zal het accent liggen op de algemene rechtsbeginselen als interpretatiebeginsel. Uiteraard in beide gevallen toegespitst op de BTW.

65. De vraag wanneer interpretatie rechtsvorming is, komt neer op de vraag waar de grens ligt tussen interpretatie en rechtsvorming. Het antwoord op deze vraag valt buiten mijn onderzoek en ik verwijs dan ook voor de geïnteresseerde lezer naar de noten in paragraaf 3.3.2. 
Na de klassieke BTW-beginselen (hoofdstuk 2) en de algemene rechtsbeginselen (hoofdstuk 3) te hebben beschreven, de Europeesrechtelijke setting te hebben behandeld (hoofdstuk 4) en enkele bijzondere leerstukken die zijn vormgegeven onder invloed van de algemene rechtsbeginselen te hebben besproken (hoofdstuk 5), kom ik toe aan de behandeling van de BTW jurisprudentie van het Hof. Vanaf de inwerkingtreding van de Tweede richtlijn zijn voor het Hof ruim 80 procedures gevoerd op grond van artikel 258 VwEU en ruim 350 prejudiciële procedures gebaseerd op artikel 267 VwEU, waarvan kan worden gesteld dat deze procedures direct betrekking hebben op de Heffing van BTW. De ruim 430 procedures zijn door mij onderzocht (hoofdstukken $6 \mathrm{t} / \mathrm{m} \mathrm{12}$ ) op welke wijze de drie eerder genoemde algemene rechtsbeginselen richting geven aan de jurisprudentie op het terrein van de BTW.

In hoofdstukken $6 \mathrm{t} / \mathrm{m} 12$ onderzoek ik de toepassing van algemene rechtsbeginselen aan de hand van de kernpunten van de BTW-regels. In hoofdstuk 6 staan centraal de randvoorwaarden die de algemene rechtsbeginselen stellen aan de belastbare handelingen. In hoofdstuk 7 wordt deze exercitie uitgevoerd voor de belastingplicht. En de exercitie herhaalt zich in hoofdstuk 8 voor de toewijzing van de heffing over diensten aan de lidstaten, hoofdstuk 9 voor de maatstaf van heffing, hoofdstuk 10 voor de vrijstellingen, hoofdstuk 11 voor het recht op aftrek van voorbelasting en in hoofdstuk 12 ten slotte voor de verplichtingen in het binnenlandse verkeer.

Het materiaal in de hoofdstukken $2 \mathrm{t} / \mathrm{m} 4$ is te beschouwen als het noodzakelijke theoretische kader voor de hoofdstukken $5 \mathrm{t} / \mathrm{m} \mathrm{12}$. De bevindingen uit de hoofdstukken $2 \mathrm{t} / \mathrm{m} 4$ vormen de bouwstenen waar het podium van hoofdstukken $5 \mathrm{t} / \mathrm{m} 12$ op rust. In feite worden in hoofdstuk $2 \mathrm{t} / \mathrm{m} 4$ de (algemene) beginselen in abstracte vorm bestudeerd. Maar daarnaast is vereist dat in de hoofdstukken $5 \mathrm{t} / \mathrm{m} 12$ het resultaat in concrete situaties wordt bestudeerd. Willen algemene rechtsbeginselen namelijk bruikbaar zijn, dan is het bestuderen van algemene rechtsbeginselen het bestuderen van uitkomsten.

Hoofdstuk 13 sluit af met een slotbeschouwing en conclusies. Dit hoofdstuk ordent het materiaal uit de voorafgaande hoofdstukken om zo inzichtelijk te maken de wijze waarop de algemene rechtsbeginselen het BTW-recht beïnvloeden. Voorst zal blijken dat er een relatie bestaat tussen de klassieke BTW-beginselen en de algemene rechtsbeginselen (paragraaf 13.5). Ik sluit in hoofdstuk 14 af met een samenvatting.

Dit onderzoek besteedt geen aandacht aan het binnenkomen van goederen van buiten de Europese Unie en de heffing die ter zake daarvan plaatsvindt (invoer). Tevens laat ik buiten beschouwing het van belasting ontdoen van goederen in het kader van uitvoer naar derde landen (nultarief). De reden daarvan is gelegen in het eigen karakter van dit onderwerp en de verwevenheid met de douaneproblematiek.

Het onderzoek is afgesloten op 1 januari 2012. In een enkel geval is nog jurisprudentie van een latere datum verwerkt. 


\subsection{Europeesrechtelijk kader en verwijzingen}

Het Verdrag van Lissabon is op 13 december 2007 door de vertegenwoordigers van de lidstaten ondertekend en op 1 december 2009 in werking getreden nadat het door alle lidstaten was geratificeerd. ${ }^{66}$ Het Verdrag van Lissabon bevat een aantal amendementen op de Verdragen van Rome (EG-Verdrag) en Maastricht (EU-Verdrag) uit respectievelijk 1957 en $1992 .{ }^{67}$ Het EG-Verdrag staat vanaf de inwerkingtreding van het Verdrag van Lissabon bekend als het Verdrag betreffende de Werking van de Europese Unie, kortweg Werkingsverdrag (VwEU). Het EU-Verdrag staat vanaf die datum bekend als Verdrag betreffende de Europese Unie, kortweg Unieverdrag (VEU). Het Verdrag van Lissabon heeft diverse wijzigingen tot gevolg, onder meer het opgeven van de driepijlerstructuur en als gevolg daarvan het verdwijnen van de Europese Gemeenschap. Een belangrijke wijziging is verder dat de rechtsprekende instelling van de Unie sedert 1 december 2009 Hof van Justitie van de Europese Unie heet. ${ }^{68}$ De wijzigingen die het Verdrag van Lissabon tot gevolg heeft gehad laat ik in mijn onderzoek onbesproken. Op deze plaats is van belang te vermelden dat ik zo veel als mogelijk zal verwijzen naar de artikelen in het Werkingsverdrag dan wel Unieverdrag. Veelal betreft het een vernummering van bepalingen zonder inhoudelijke wijzigingen. Lastig kan dit zijn bij het lezen van de al wat oudere arresten van het Hof. Zo verwijst het nog te behandelen Gaston Schul I-arrest naar artikel 95 EEG-Verdrag. Dit is na het Verdrag van Amsterdam vernummerd tot artikel 90 van het EG-Verdrag en is dan nu vanaf 1 december 2009 artikel 110 VwEU. Ik zal - gezien het verdwijnen van de Europese Gemeenschap - zo veel als mogelijk verwijzen naar het Unierecht. Op een enkele plaats komen - omwille van de leesbaarheid - nog termen voor als (autonoom begrip van) gemeenschapsrecht en Europese Gemeenschap. Dit heeft voor dit onderzoek geen onderscheidende betekenis.

Op 1 januari 2006 is de Zesde richtlijn vervangen door de BTW-richtlijn. Uit de considerans van de BTW-richtlijn blijkt dat met deze vervanging geen inhoudelijke wijziging is beoogd. ${ }^{69}$ Ik verwijs zo veel als mogelijk naar de artikelen in de BTWrichtlijn. ${ }^{70}$ In aanhalingen van de jurisprudentie van het Hof komen echter verwijzingen voor naar artikelen uit de Zesde richtlijn. Bij de behandeling van de regels

66. Verdrag van Lissabon tot wijziging van het Verdrag betreffende de Europese Unie en het Verdrag tot oprichting van de Europese Gemeenschap, Pb EU 2007 C 306/01.

67. Geconsolideerde versie van het Verdrag betreffende de Europese Unie en het Verdrag betreffende de werking van de Europese Unie, Pb EU 2008 C 115/01.

68. Artikel 19, VEU. Ik hanteer de afkorting Hof zowel voor de periode waarin het Hof van Justitie van de Europese Gemeenschappen het recht uitlegde als voor de periode daarna.

69. De derde overweging in de Considerans bij de BTW-richtlijn geeft aan: "Een heldere en rationele presentatie van de bepalingen, overeenkomstig het beginsel van betere regelgeving, vergt dat de structuur en de formulering van de richtlijn worden herschikt, waarbij evenwel in principe geen materiële wijzigingen in de bestaande wetgeving worden aangebracht. Niettemin moet een gering aantal materiële wijzigingen die inherent zijn aan de herschikkingsexercitie, in de tekst worden aangebracht. De wijzigingen in kwestie zijn limitatief vermeld in de bepalingen betreffende omzetting en inwerkingtreding." 70. Artikel 411, lid 2, BTW-richtlijn bepaalt dat verwijzingen naar de Zesde richtlijn gelden als verwijzingen naar de BTW-richtlijn. Zie tevens Hof 12 mei 2011, nr. C-107/10, Enel, V-N 2011/27.6, NTFR 2011/1274, r.o. 25 en 26. 
inzake de plaats van dienst in hoofdstuk 8 verwijs ik wel naar de artikelen in de Zesde richtlijn. De regels met betrekking tot de plaats van dienst zijn per 1 januari 2010 ingrijpend veranderd. De jurisprudentie van het Hof die ik behandel is echter (bijna geheel) van voor deze datum. Dat neemt niet weg dat deze jurisprudentie zoals zal blijken - wel degelijk relevant is voor de uitleg van de huidige regelgeving.

Ik zal zo veel als mogelijk aansluiten bij de begrippen die gebruikelijk zijn in de BTW-richtlijn. Zo zal ik bijvoorbeeld de terminologie 'onroerend goed' gebruiken in plaats van de term 'onroerende zaken' welke in onze nationale Wet OB voorkomt.

Het onderzoek beweegt zich op het Europeesrechtelijke niveau, de jurisprudentie en de rechtsprekende rol van het Hof. Daar gaat het in dit onderzoek om. Slechts sporadisch besteed ik aandacht aan de nationale jurisprudentie. De reden daarvoor is dat mijn onderzoek zich beweegt op het Europees(rechtelijk) niveau, de jurisprudentie en dus de rechtsvormende rol van het Hof.

Ter gelegenheid van de inventarisatie van deze rechtspraak kwamen tegelijkertijd de onderwerpen en dus ook tegelijkertijd de hoofdstukken 4 en 5 tot stand. Een aardig bijproduct, zo constateer ik, is de vaststelling dat men thans, na 40 jaar BTW in Europa, het Unierecht voor een buitengewoon groot deel kan behandelen aan de hand van enkel de BTW-jurisprudentie. 



\section{HOOFDSTUK 2}

\section{Klassieke BTW-beginselen (rechtskarakter)}

\section{$2.1 \quad$ Inleiding}

De literatuur brengt geregeld de beginselen van de BTW ter sprake. Het gaat daarbij in het bijzonder om het bestemmingslandbeginsel, in tegenstelling daartoe, het oorsprongslandbeginsel en het neutraliteitsbeginsel (zie paragrafen 2.3 en 2.4). In de literatuur worden deze beginselen door een keur aan schrijvers uitgebreid behandeld. Ik duid hen aan met klassieke BTW-beginselen. De term 'klassiek' heeft in deze context een dubbele betekenis. Ten eerste bedoel ik daarmee dat aan het desbetreffende beginsel blijvend gezag wordt toegekend (de literatuur neemt deze beginselen als uitgangspunt). Ten tweede begrijp ik 'klassiek' in de zin van traditioneel. Met traditioneel bedoel ik dat deze beginselen al van oudsher een rol spelen bij de beschrijving van de BTW en haar rechtsvoorgangers, zoals de omzetbelasting volgens een cumulatief systeem.

De verschijningsvorm van de klassieke BTW-beginselen is niet in alle gevallen beperkt tot de BTW. Ook in andere delen van het (belasting)recht kunnen zij zich doen gelden. ${ }^{1}$ In die zin is de term BTW tussen 'klassiek' en 'beginsel' misleidend. Het is dus niet zo dat als de BTW als vorm van belasting niet zou bestaan, de in dit hoofdstuk beschreven uitgangspunten volledig onbekend zouden zijn. Wel is het omgekeerde het geval. Indien de beginselen niet zouden bestaan, is de BTW in zijn huidige verschijningsvorm niet goed denkbaar. Het betreft dus beginselen die voor een belangrijk deel de vormgeving van de BTW als indirecte belasting bepalen. Ik kies ervoor de in dit hoofdstuk beschreven beginselen enkel in het BTW-recht te onderzoeken.

De klassieke BTW-beginselen worden regelmatig gebruikt om de jurisprudentie van het Hof en onze nationale rechters te beoordelen. De desbetreffende beginselen

\footnotetext{
1. Zie in dit kader de analyse van Cnossen van de betekenis van het neutraliteitsbeginsel in de BTW en VPB, S. Cnossen, Om de toekomst van de vennootschapsbelasting in de Europese Unie, WFR 1996/871. Denie meent dat bestemmingslandbeginsel en oorsprongslandbeginsel dezelfde thema's zijn als woonplaats- en bronlandbeginsel in de IB/VPB. A.H.R.M. Denie, De overheid in de omzetbelasting (diss. Leiden), Deventer: Kluwer 1987, blz. 47 t/m 49, zie in het bijzonder zijn analyse in noot 159. Vgl. de diverse bijdragen in de bundel van het IBFD, M. Lang, P. Melz, E, Kristoffersson, Value Added Tax and Direct Taxation, Similarities and Differences, Amsterdam: IBFD 2009.
} 
fungeren dan als norm waaraan uitspraken, beslissingen en andere rechtstoepassingen worden getoetst. ${ }^{2}$ Bij het bestuderen van de klassieke BTW-beginselen komen de volgende vragen op. Welke klassieke BTW-beginselen beschrijft de literatuur? Zijn dit 'echte' rechtsbeginselen? En zijn deze bruikbaar bij het zoeken naar het recht? Deze vragen komen hierna op verschillende plaatsen aan de orde. De vraag of het hier om 'echte' rechtsbeginselen gaat komt in paragraaf 3.5 aan de orde, terwijl in de hoofdstukken $6 \mathrm{t} / \mathrm{m} 13$ telkens de kracht van de klassieke BTW-beginselen passeert. Deze hoofdstukken onderzoeken namelijk de jurisprudentie van het Hof op het terrein van een aantal BTW-thema's. Dit hoofdstuk inventariseert de belangrijkste klassieke BTW-beginselen.

De klassieke beginselen die regelmatig in de literatuur opduiken in combinatie met de BTW zijn: het territorialiteitsbeginsel, oorsprongslandbeginsel, bestemmingslandbeginsel en het neutraliteitsbeginsel. ${ }^{3}$ Bij het uitspreken van waardeoordelen over de jurisprudentie van het Hof wordt echter niet alleen teruggegrepen naar deze klassieke BTW-beginselen. Ook wordt regelmatig getoetst aan het rechtskarakter van de BTW. De eerder geformuleerde vragen met betrekking tot de klassieke BTWbeginselen kunnen ook worden gesteld bij het in stelling brengen van het rechtskarakter van de BTW als norm waaraan men de rechtstoepassing toetst. Het rechtskarakter van de BTW is dan ook te zien als een klassiek BTW-beginsel. Het is klaarblijkelijk daarom dat men in de literatuur en in mindere mate in de rechtspraak dit uitgangspunt, dan wel kerndoel van de heffing, als een centraal punt van heffing bovenaan zet en soms ook het woord beginsel hanteert. Het betreft dan uiteraard een beginsel dat beperkt is tot het veld van de BTW. Indien de term beginsel voorkomt in combinatie met de term rechtskarakter, dan bedoel ik daarmee niet dat het een universeel uitgangspunt betreft (dit in tegenstelling tot bijvoorbeeld het non-discriminatiebeginsel), maar wordt de term beginsel gebruikt in de betekenis van een grondstelling voor de BTW.

Paragraaf 2 beschrijft de belangrijkste aspecten van het rechtskarakter. In paragraaf 3 komen het territorialiteitsbeginsel, oorsprongslandbeginsel en het bestemmingslandbeginsel aan de orde als onderdelen van de problematiek van juridisch dubbele belastingheffing. Paragraaf 4 behandelt het neutraliteitsbeginsel. Tevens vermeldt deze paragraaf een aantal belangrijke oorzaken van verstoringen van de neutraliteit. Daarbij besteed ik vooral aandacht aan verstoringen van de concurrentieverhoudingen bij grensoverschrijdende transacties.

2. Zie bijvoorbeeld A.J. van Doesum, Contractuele samenwerkingsverbanden in de BTW (diss. Tilburg) 2009. De auteur onderzoekt in hoeverre de transacties, die bij contractuele samenwerkingsverbanden kunnen worden onderkend, naar wenselijk recht belastbaar zouden moeten zijn. Daarbij maakt hij gebruik van een toetsingskader dat is gebaseerd op de wezenlijke kenmerken van het BTW-stelsel (blz. 27 e.v.). Zie tevens M.M.W.D. Merkx, De woon- en vestigingsplaats in de btw (diss. Tilburg) 2011. Merkx gaat in haar onderzoek onder meer na hoe de vestigingsplaatsvormen dienen te worden ingevuld zodat zij in overeenstemming zijn met het rechtskarakter van de omzetbelasting.

3. Deze opsomming is niet uitputtend. Overige beginselen, zoals het draagkrachtbeginsel (herverdelingsbeginsel) laat ik in dit hoofdstuk buiten beschouwing. 
Concluderend stel ik vast dat het bestemmingslandbeginsel, oorsprongslandbeginsel en de neutraliteit vorm en betekenis geven aan het rechtskarakter van de BTW. ${ }^{4} \mathrm{Zij}$ zijn echter zo cruciaal dat ik deze in aparte paragrafen beschrijf. Welbeschouwd gaat geheel hoofdstuk 2 dan ook over het rechtskarakter van de BTW. Wel is het zo dat het verbruiksbeginsel zoals is beschreven in paragraaf 2 enkel voor de BTW geldt. De overige in dit hoofdstuk beschreven beginselen kunnen ook gelden voor andere belastingen. ${ }^{5}$

Het hoofdstuk sluit af met een conclusie.

\section{Verbruiksbeginsel}

In diverse rechtsbronnen, te beginnen met de Eerste richtlijn, zijn verwijzingen te vinden naar het rechtskarakter van de BTW. ${ }^{6}$ Artikel 2, Eerste richtlijn bespreekt niet slechts het systeem van heffing op hoofdlijnen (zie paragraaf 1.1), maar geeft ook

4. A.H.R.M. Denie 1987, onder meer blz. 41, is van mening dat het neutraliteitsbeginsel een onderdeel is van het rechtskarakter. Zie ook voor een ruimer verband, A.H.R.M. Denie 1987, blz. 57 waar hij stelt dat de kernpunten van de wet (belastbaar feit, het tenietdoen daarvan door vooraftrek, de maatstaf en de belastingplichtige) worden gevormd door rechtskarakter, neutraliteit en indirecte vorm (en niet algemene karakter, draagkracht- en bestemmingslandbeginsel).

5. Zie bijvoorbeeld A.H.R.M. Denie 1987, blz. 57: "Drie grondslagen van de belasting, te weten het algemene karakter, het bestemmingslandbeginsel als criterium ter voorkoming van dubbele belasting en het draagkrachtbeginsel zijn niet specifiek voor de omzetbelasting; zij gelden in het algemeen de grote rijksbelastingen op inkomen, vermogen en bestedingen. Zij zijn terug te voeren op algemene rechtsbeginselen (...)."

6. Voordat ik het rechtskarakter beschrijf van de BTW is het allereerst van belang om na te gaan wat wordt bedoeld met de term 'rechtskarakter'. Of beter geformuleerd, wat men in de literatuur met dit begrip wil beschrijven. Alleen dan is duidelijk in welke context de diverse in de literatuur voorkomende kwalificaties van de BTW geplaatst moeten worden. De term rechtskarakter komt regelmatig voor in de literatuur, echter zelden geeft de gebruiker aan wat precies met de term wordt bedoeld. Slechts enkele schrijvers hebben een poging gewaagd de term rechtskarakter te definiëren. Zie bijvoorbeeld B.J.M. Terra, Omzetbelasting bij grensoverschrijdend verkeer (diss. Leiden), Deventer: FED 1984, blz. 25. Hij verstaat onder de term rechtskarakter: "de aard van de belasting waaraan zonder meer juridische gevolgen (behoren te) zijn verbonden." Voorbeelden van de juridische gevolgen die volgens Terra aan dit karakter (behoren te) zijn verbonden, zijn onder meer het feit dat de belasting niet geheven wordt als een directe productiebelasting en de toepassing van het bestemmingslandbeginsel. Zie verder A.H.R.M. Denie, Tussen toen en toekomst, WFR 1995/1569. Hij verstaat onder rechtskarakter het antwoord op de vraag wie en wat men wil belasten. Zie ook A.H.R.M. Denie 1987, blz. 14. Zie in dit verband tevens H.W.M. Van Kesteren, Fiscale rechtswil (diss. Leiden), Arnhem: Gouda Quint 1994, blz. 57. Hij is van mening dat het begrip rechtskarakter synoniem is met de oorspronkelijke doelstellingen die aan een wet ten grondslag liggen en dat derhalve de wijze waarop een belasting wordt geheven geen component behoort te zijn/is van het begrip rechtskarakter (van een belastingwet). Het is een leidraad die reeds vanaf het embryonale stadium van de wet onveranderd als norm dient te gelden en niet welk subject of object uiteindelijk door de wet wordt belast. Zie verder G.J. van Norden, Het concern in de BTW (diss. Tilburg), Deventer: Kluwer 2007, blz. 19 en 20 over het onderscheid tussen 'rechtsgrond', 'rechtsgrondslag' en 'rechtskarakter'. Zie tevens M.M.W.D. Merkx, De woon- en vestigingsplaats in de btw (diss. Tilburg) 2011, blz. 22 t/m 29. Ik gebruik de term rechtskarakter om aan te geven wie en wat de BTW-richtlijn belast; de ultieme lijn tot waar de BTWheffing kan gaan. 
aan, dat de BTW berust op het beginsel dat van goederen en diensten een algemene verbruiksbelasting wordt geheven. ${ }^{7}$

Het Hof put in een aantal arresten uit het rechtskarakter van de BTW bij het beantwoorden van prejudiciële vragen. In het Hong Kong-arrest ${ }^{8}$ ging het om de vraag of een organisatie die regelmatig diensten verricht, echter uitsluitend om niet, is aan te merken als belastingplichtige in de zin van artikel 4, Tweede richtlijn. Het Hof overweegt bij de beantwoording van deze vraag, dat men de relevante kenmerken van het gemeenschappelijke stelsel moet zoeken in het licht van de doelstellingen van het stelsel (r.o. 5). Daarbij betrekt het Hof genoemd artikel 2, Eerste richtlijn en concludeert het dat - en dat geldt dus ook voor de Hong Kongorganisatie - de voorbelasting niet meer aftrekbaar is:

“(...) zodra men aan het eind van de transactieketen is gekomen. De belasting wordt dus geheven van de eindverbruiker, die het bedrag ervan niet op anderen kan afwentelen, daar er geen verdere transactie tegen een bepaalde prijs meer is." (r.o. 9)

Het Hof overweegt vervolgens, dat degene die presteert zonder een tegenprestatie te bedingen gelijk is te stellen met een eindverbruiker, daar de productie- en distributieketen bij hem ophoudt.

Het Hof trekt dus de conclusie dat de BTW naar haar aard een belasting is die de eindverbruiker van goederen en diensten probeert te treffen. Tevens geeft het Hof een definitie van eindverbruiker. Eindverbruiker is degene die de aan haar in rekening gebrachte BTW niet op anderen kan afwentelen. Dit is het geval als transacties worden verricht zonder een tegenprestatie te bedingen.

Een ondernemer die vrijgestelde prestaties verricht is volgens mij ook te beschouwen als een eindverbruiker gezien het gegeven dat deze de BTW niet in rekening kan brengen ${ }^{9}$ aan zijn afnemers. ${ }^{10}$

7. Artikel 2, Eerste richtlijn bepaalt: "Het gemeenschappelijk stelsel van belasting over de toegevoegde waarde berust op het beginsel dat van goederen en diensten een algemene verbruiksbelasting wordt geheven welke strikt evenredig is aan de prijs van goederen en diensten, zulks ongeacht het aantal transacties welke tijdens het productie- en distributieproces vóór de fase van heffing plaatsvonden. Bij elke transactie is de belasting over de toegevoegde waarde, berekend over de prijs van het goed of van de dienst volgens het tarief dat voor het goed of voor de dienst geldt, verschuldigd onder aftrek van het bedrag van de belasting over de toegevoegde waarde waarmede de onderscheidende elementen van de prijs rechtstreeks zijn belast. Het gemeenschappelijk stelsel van belasting over de toegevoegde waarde wordt toegepast tot en met de kleinhandelsfase. (...)."

8. Hof 1 april 1982, nr. 89/81, Hong Kong Trade Development Council, FED 1983/25.

9. Uiteraard kan de BTW wel - voor zover de prijselasticiteit het toelaat - verdisconteerd zijn in de marktprijs.

10. Dit blijkt ook uit het Kögáz-arrest. Het Hof besliste in deze procedure dat de Hongaarse gemeentelijke belasting HIPA niet over de wezenlijke kenmerken van de BTW beschikt. Het arrest verduidelijkt tevens dat het systeem van recht op aftrek van voorbelasting tot gevolg heeft dat de eindverbruiker wordt belast. Hof 11 oktober 2007, nrs. C-283/06 en C-312/06, Kögáz e.a., V-N 2007/48.18, r.o. 51. 
Ook het Mohr-arrest ${ }^{11}$ brengt het rechtskarakter van de BTW in het geding. In deze procedure is de vraag aan de orde of een subsidie die een landbouwproducent ontvangt, op grond van EG-regelgeving indien hij zijn melkproductie beëindigt, onderworpen is aan de BTW. Het Hof verwijst ook in deze procedure naar artikel 2, Eerste richtlijn en overweegt dat de BTW een algemene verbruiksbelasting is op goederen en diensten. Het gaat in de BTW dus om verbruik. In deze procedure komt het Hof tot de conclusie dat geen sprake is van verbruik en dat de desbetreffende subsidie niet onderworpen is aan de BTW. Het Hof is van mening dat de Unie geen goederen of diensten verwerft voor eigen gebruik door de landbouwer de subsidie te geven, maar zij handelde in het algemeen belang, te weten het bevorderen van de goede werking van de communautaire markt voor melk (r.o. 21). Het Hof overweegt vervolgens:

“Zo gezien, levert de verbintenis van de landbouwer om zijn melkproductie te beëindigen noch de gemeenschap noch de bevoegde nationale autoriteiten een voordeel op waardoor zij als verbruikers van een dienst kunnen worden aangemerkt. De betrokken verbintenis is derhalve geen dienst in de zin van artikel 6, lid 1 van de richtlijn." (r.o. 22)

In het Landboden-arrest ${ }^{12}$ is wederom de vraag aan de orde of een subsidie, toegekend in ruil voor de vermindering van de jaarlijkse aardappelproductie, een belaste dienst is voor de heffing van de BTW. De Duitse regering benadrukte in deze procedure dat het karakter van de BTW - een algemene verbruiksbelasting op goederen en diensten - geen criterium kan zijn bij de beantwoording van de vraag, of sprake is van een dienst. Daartoe zou enkel mogen worden uitgegaan van de bewoordingen van artikel 6, Zesde richtlijn (thans artikel $24 \mathrm{t} / \mathrm{m} \mathrm{29}$, BTW-richtlijn). Het Hof herhaalt dat een verbintenis slechts onder het gemeenschappelijk BTWstelsel valt indien sprake is van verbruik. Volgens het Hof is geen sprake van verbruik, aangezien de door de landbouwproducent aangegane verbintenis tot vermindering van zijn productie noch de bevoegde nationale autoriteiten noch identificeerbare andere personen een voordeel oplevert waardoor zij als verbruikers van een dienst zijn te beschouwen. ${ }^{13}$

Niet het rechtskarakter, zoals als notie bekend is in de literatuur, maar het 'karakter van omzetbelasting' komt aan de orde in artikel 401, BTW-richtlijn (voorheen artikel 33, Zesde richtlijn). ${ }^{14}$ Artikel 401, BTW-richtlijn bepaalt onder meer, dat onverminderd andere communautaire bepalingen de BTW-richtlijn geen beletsel vormt voor de handhaving of invoering van belastingen op verzekeringsovereenkomsten en op spelen en weddenschappen, alsmede accijnzen, registratierechten en,

11. Hof 29 februari 1996, nr. C-215/94, J. Mohr, BNB 1997/32.

12. Hof 18 december 1997, nr. C-384/95, Landboden-Agrardiensten GmBH, V-N 1998/5.17, FED 1998/141. 13. Zie nader R.N.G. van der Paardt, Subsidies en BTW in de Europese Unie (diss. Groningen), Deventer: Kluwer 2000, blz. 83 t/m 93 en blz. 119 en 120.

14. Artikel 401, BTW-richtlijn verwijst niet naar het 'rechtskarakter' van de BTW maar gebruikt de term 'karakter'. Eerder is door mij aangegeven dat ik doel met de term rechtskarakter op wie en wat de BTW-richtlijn belast; de ultieme lijn tot waar de BTW-heffing kan gaan. Deze aspecten komen in de jurisprudentie op het terrein van artikel 401, BTW-richtlijn aan de orde. 
meer in het algemeen, van alle belastingen die niet het karakter van omzetbelasting bezitten, mits deze belastingen in het verkeer tussen de lidstaten geen aanleiding geven tot formaliteiten in verband met het overschrijden van een grens. Kortom, artikel 401, BTW-richtlijn verbiedt de invoering van een belasting met de kenmerken van een BTW.

Of een nationale belasting in strijd is met artikel 401, BTW-richtlijn gaat het Hof na door de nationale belasting te toetsen aan het karakter van de BTW. ${ }^{15}$ In het Caredaarrest ${ }^{16}$ staat centraal de vraag of een belastingheffing op de exploitatie van speelautomaten het karakter van een omzetbelasting heeft.

\section{Het Hof overweegt:}

“(...) de BTW is algemeen van toepassing op transacties betreffende goederen en diensten; zij is evenredig aan de prijs van die goederen en diensten, ongeacht het aantal transacties dat heeft plaatsgevonden; zij wordt geïnd in elk stadium van het productie- en distributieproces; zij wordt, tenslotte, geheven over de toegevoegde waarde van de goederen en diensten, doordat de over een transactie verschuldigde belasting wordt berekend na aftrek van die welke in de voorgaande stadia is betaald (...)". (r.o. 14)

Het Hof introduceert, na deze beschrijving van het systeem, in de volgende overweging van het Careda-arrest in volle glorie de verbruiker: ${ }^{17}$

“(...) dat de betrokken heffing, wil zij het karakter van omzetbelasting bezitten in de zin van artikel 33 van de richtlijn, op de verbruiker moet worden afgewenteld." (r.o. 15)

Bij de beoordeling van de afwenteling van de BTW op de verbruiker is niet van belang of de nationale wet bepaalt dat de betrokken heffing wordt afgewenteld, maar moet worden gekeken naar de voornaamste kenmerken. ${ }^{18}$

15. Artikel 401, BTW-richtlijn vermeldt de term 'karakter'. Het Hof heeft onder meer in het Banca Popolare-arrest beslist dat toetsing dient plaats te vinden aan 'de wezenlijke kenmerken van de BTW'. Hof 3 oktober 2006, nr. C-475/03, Banca Popolare, V-N 2006/52.20, NTFR 2006/1578, r.o. 26 en 28. Bij de beoordeling of een nationale heffing het karakter van een BTW heeft kijkt het Hof niet alleen of de belasting uiteindelijk wordt gedragen door een eindverbruiker. Uit de jurisprudentie op het terrein van artikel 401, BTW-richtlijn blijkt dat ook van belang is - kort weergegeven - de algemeenheid van de belasting, evenredigheid aan de prijs, geheven in elke fase van het voortbrengingsproces en heffing over de toegevoegde waarde. Zie nader over deze jurisprudentie A.H.R.M. Denie, De kansspelbelasting op speelautomaten EU-bestendig?, MBB 2008, nr.7/8.

16. Hof 26 juni 1997, gevoegde zaken nrs. C-370/95, C-371/95 en C-372/95, Careda Sa, Femara, Facomare, V-N 1997/3631, pt. 45.

17. Zie ook Hof 11 oktober 2007, nrs. C-283/06 en C-312/06, Kögáz, V-N 2007/48.18, r.o. 50. In deze procedure is beslist dat de Hongaarse gemeentelijke belasting HIPA niet voldoet aan de wezenlijke kenmerken van de BTW.

18. Het Hof had al in gelijke zin beslist in het arrest van 3 maart 1988 (nr. 252/86, G. Bergandi, Jur. 1988, blz. 1343). Vooral in r.o. 8 had het Hof al verduidelijkt dat de BTW, gelet op haar voornaamste kenmerken, uiteindelijk door de eindverbruiker wordt gedragen. Zie ook het arrest van 3 oktober 2006, nr. C-475/03, Banca Popolare, V-N 2006/52.20, NTFR 2006/1578, r.o. 32 en 35. 
Het Hof positioneert ook in het Gibbs-arrest ${ }^{19}$ de eindverbruiker stevig in het BTWstelsel:

"Het basisbeginsel van het BTW-stelsel is dat enkel de eindverbruiker wordt belast (...)." (r.o. 19)

Uit de arresten zijn een aantal conclusies te trekken. Ten eerste blijkt uit het Mohrarrest en het Landboden-arrest dat het in de BTW gaat om het belasten van 'verbruik' van goederen en diensten. Ten tweede dat bij de beoordeling van de vraag of verbruik plaatsvindt, deze vraag moet worden beantwoord vanuit de positie van de afnemer. De afnemer moet een voordeel hebben ontvangen, dit voordeel kan zijn in de vorm van goederen of diensten. ${ }^{20}$ Uit de bovenstaande arresten van het Hof kan dan ook de conclusie worden getrokken dat de BTW een algemene verbruiksbelasting is. Uiteindelijk moet de BTW drukken op de eindverbruiker, oftewel degene die de belasting niet verder kan afwentelen daar deze geen transacties verricht die aan BTW-heffing zijn onderworpen.

Diverse schrijvers hebben zich gebogen over het rechtskarakter van de BTW. Denie verwijst naar het klassieke schoolvoorbeeld van een fles melk die de consument na betaling uit zijn handen laat vallen. ${ }^{21}$ Verbruik volgens de letterlijke betekenis heeft nog niet plaatsgevonden, zodat een verbruiksbelasting de bij aankoop betaalde belasting dient terug te geven. Door verscheidene schrijvers wordt de BTW dan ook getypeerd als een bestedingsbelasting in plaats van een verbruiksbelasting. Het onderscheid is volgens Denie, dat bij een bestedingsbelasting de besteding in financiële, geldelijke zin des woords het object van de belasting is. ${ }^{22}$ Het object van een verbruiksbelasting is het verbruik of het genot van de goederen en diensten. Denie relativeert de normatieve betekenis van de term 'verbruiksbelasting'. Hij meent dat:

19. Hof 24 oktober 1996, nr. C-317/94, Elida Gibbs Ltd, V-N 1996/4573, pt. 25. In het Gibbs-arrest is beslist dat kortingsbonnen en geld terug bonnen de maatstaf van heffing verlagen bij de fabrikant. Zie ook Hof 11 oktober 2007, nrs. C-283/06 en C-312/06, Kögaz, V-N 2007/48.18, en dan in het bijzonder r.o. 51. In deze procedure is beslist dat de Hongaarse gemeentelijke bedrijfsbelasting niet het karakter van BTW heeft.

20. De redactie van Vakstudie Nieuws (V-N, 2 mei 1996, blz. 1651) vindt de redenering van het Hof in het Mohr-arrest van 29 februari 1996 niet overtuigend. Zij ziet niet in waarom de medewerking van de landbouwer van de beperking van de melkproductie de gemeenschap geen voordeel oplevert. Het criterium van het algemeen belang acht zij een niet voldoende onderscheidend criterium. Tenslotte handelt de overheid uiteindelijk altijd met het oog op het algemeen belang. Ook in het Landbodenarrest van 18 december 1997 is volgens de redactie van Vakstudie Nieuws (V-N 22 januari 1998, blz. 527) geen goed hanteerbaar criterium voor de praktijk te vinden. De ingezette lijn van het verbruik geeft wel een richting aan, maar is volgens de redactie van Vakstudie Nieuws lastig in te vullen. Het is in ieder geval belangrijk om vast te stellen of identificeerbare personen voordeel verkrijgen.

21. A.H.R.M. Denie 1987, blz. 16.

22. A.H.R.M. Denie 1987, blz. 16. 
"Uit het systeem van richtlijn en wet vloeit in elk geval voort dat de omzetbelasting een consumptiebelasting is, dat wil zeggen alleen een belasting op de afnemer, en - indien dit rechtskarakter van de Wet op de omzetbelasting 1968 preciezer geduid moet worden - dan heeft het naar systeem en de daarbij passende maatstaf van heffing de strekking een bestedingsbelasting te zijn."23

En hij vervolgt:

"In de verbruiksbelasting staat, zo niet de grondslag van het gebruik of genot, de prestatie van de ondernemer voorop, in de bestedingsbelasting de (ontvangen) betaling." 24

Denie typeert het rechtskarakter van de omzetbelasting als een algemene indirecte belasting op particuliere bestedingen. ${ }^{25}$ In praktisch gelijke zin Van Brederode die de BTW typeert als een in beginsel algemene bestedingsbelasting, dat wil zeggen een belasting die via de bestedingen beoogt de consumptie te treffen. ${ }^{26}$ De indirecte wijze van heffen doet daar volgens hem niets aan af. Waar in de omzetbelasting wordt aangegrepen bij het verbruik/genot, geschiedt dat volgens hem slechts met betrekking tot de aftrek van voorbelasting en de herzieningsregels voor investeringsgoederen. ${ }^{27}$

Reugebrink memoreert in zijn afscheidscollege dat het rechtskarakter van de BTW in de Europese richtlijnen wordt omschreven als een algemene verbruiksbelasting. ${ }^{28}$ Maar - vraagt hij zich af - wat is een algemene verbruiksbelasting? Of is de BTW wel een algemene verbruiksbelasting? Reugebrink meent dat de BTW het beste kan worden getypeerd als een algemene bestedingsbelasting. In het geval namelijk dat wel een besteding heeft plaatsgevonden, maar geen verbruik (bijvoorbeeld in geval van verlies of teniet gaan voor daadwerkelijke consumptie), dan is in de wet niet voorzien in een teruggaafregeling. Het gaat in de BTW dus niet zozeer om verbruik als wel om de besteding. Hij definieert een verbruiksbelasting als een belasting die de consumptie beoogt te belasten en dat doet door de besteding als maatstaf van die consumptie te hanteren. ${ }^{29}$

23. A.H.R.M. Denie 1987, blz. 35

24. A.H.R.M. Denie 1987, blz. 35.

25. A.H.R.M. Denie 1987, blz. 40 en 41. Zie ook A.H.R.M. Denie, Tussen toen en toekomst, WFR 1995 1569.

26. R.F.W. van Brederode, De scheidslijn tussen consumptie en productie in de BTW, WFR 1998/1577. Van der Paardt kenmerkt de BTW als een bestedingsbelasting die beoogt het consumptieve verbruik te belasten, R.N.G. van der Paardt 2000, blz. 58.

27. R.F.W. van Brederode, De bijzondere positie van de landbouw in de omzetbelasting (diss. Amsterdam UvA), Deventer: Kluwer 1993, blz. 273. Zie ook Denie 1987, blz. 350. Vgl. J.T. Sanders, Le droit de rêver (diss. Groningen), Amersfoort: Sdu Uitgevers 2011, blz. 54 en 55.

28. Afscheidscollege van J. Reugebrink, De zomer was groots, WFR 1995/1792.

29. J. Reugebrink \& M.E. van Hilten, Omzetbelasting, Deventer: Kluwer 1997, blz. 8. 
Indien er een scherp onderscheid bestaat tussen een verbruiksbelasting en een bestedingsbelasting kan dat een effect hebben op de materiële uitwerking van de BTW. Volgens Denie:

“(...) zal het gelijkheidsbeginsel zich in een verbruiksbelasting laten leiden door vergelijkbaar gebruik of genot. Daarom tendeert de verbruiksbelasting naar een objectieve maatstaf van heffing. In een bestedingsbelasting zal gekeken worden naar dezelfde prijzen, (vergelijkbare kosten en bestedingen). Daarom tendeert een bestedingsbelasting naar een subjectieve maatstaf van heffing." ${ }^{30}$

Verscheidene schrijvers relativeren het onderscheid tussen een verbruiksbelasting en een bestedingsbelasting. Ploeger is van mening dat in de Wet op de omzetbelasting 1968 sprake is van een regeling van een belasting die naar haar wezen een algemene verbruiksbelasting is en die in haar vormgeving - in haar technisch stelsel - uitgaat van een heffing bij personen die juist niet de verbruikers van goederen en diensten zijn. ${ }^{31}$ De wetgever gaat ervan uit dat overal waar omzetbelasting definitief wordt geheven verbruik aanwezig is. Vervolgens concludeert Ploeger dat "de man die geen aftrekrecht heeft is de verbruiker." 32 Volgens mij blijkt de juistheid van deze visie onder meer uit het in het begin van deze paragraaf behandelde Hong Kong-arrest. In dit arrest heeft het Hof beslist dat de BTW behoort te drukken op de eindverbruiker. Vervolgens geeft het Hof aan dat de eindverbruiker degene is die de BTW niet kan afwentelen.

Van Hilten relativeert het onderscheid tussen 'verbruik' en 'besteding' door erop te wijzen dat niet uit het oog mag worden verloren dat de besteding de maatstaf is van de consumptie en dat het de consumptie is die, zij het in de gedaante van de consumptieve besteding, in de heffing moet worden betrokken. ${ }^{33}$ Van Hilten is van mening dat tussen de verschillende uitgangspunten niet een zodanig groot verschil bestaat als op het eerste gezicht lijkt. Om dat aan te tonen gaat zij dieper in op het begrip consumptie. Van Hilten meent:

"Samenvattend kan worden gesteld dat een algemene verbruiksbelasting, (...), in beginsel een belasting op consumptie is. Het begrip 'consumptie' in de verbruiksbelasting kan echter niet zonder meer gelijk worden gesteld aan het economische begrip. Dit wordt veroorzaakt door de maatstaf die voor de consumptie wordt gehanteerd, namelijk de besteding, en door de indirecte wijze waarop de belasting wordt geheven. In tweeërlei opzicht verschilt het verbruikstechnische begrip consumptie van het economische begrip. Ten eerste is het begrip enger in die zin dat zonder besteding niet aan consumptie in belastingtechnische zin kan worden toegekomen en in de tweede plaats kan bij de belastingheffing geen rekening worden gehouden met een over een zekere periode gespreide consumptie. Het belastingtechnische begrip 'consumptie' kan dan ook vrijwel gelijk worden gesteld aan het begrip 'besteding', zij het dat uit enige voorzieningen in de huidige Europese regelgeving kan

30. Denie 1987, blz. 16.

31. L.F. Ploeger, Het verbruik in de omzetbelasting (I), WFR 1972/969

32. L.F. Ploeger, Het verbruik in de omzetbelasting (II), WFR 1972/989. Ploeger komt tot deze conclusie na een analyse van de bedoeling van de wetgever.

33. M.E. van Hilten, Bancaire en financiële prestaties in de Europese BTW (diss. Leiden), Deventer: Kluwer 1992, blz. 16. Deze benadering wordt gedeeld door Van Kesteren. Ook hij is van mening dat de BTW een algemene verbruiksbelasting is die in beginsel een belasting op consumptie is. H.W.M. van Kesteren 1994, blz. 69 t/m 73. Zie verder G.J. van Norden 2007, blz. 25 t/m 29. 
worden afgeleid dat in essentie het economische consumptiebegrip het object van de belasting is. Dit kan bijvoorbeeld worden opgemaakt uit de bepaling dat ook particulieren bij invoer van goederen belasting verschuldigd zijn, terwijl zij hun besteding elders hebben gedaan en uit de omstandigheid dat bij invoer door deze personen geen rekening wordt gehouden met de nog op het ingevoerde goed drukkende omzetbelasting." ${ }^{4}$

Van Hilten komt dus tot de conclusie dat het begrip 'consumptie' in een verbruiksbelasting niet zonder meer gelijk kan worden gesteld aan het economische begrip consumptie. Dat neemt niet weg dat er volgens mij ook sterk economisch getinte elementen zijn te vinden in de termen 'consumptie' en 'verbruik'.

Uit de aangehaalde arresten van het Hof kan men niet afleiden wat men meer exact onder eindverbruiker, of verbruik moet verstaan. Het Hof geeft een summiere omschrijving. Uit het Mohr-arrest (r.o. 22) en het Landboden-arrest kan, zoals eerder in deze paragraaf is aangegeven, in ieder geval de conclusie worden getrokken dat de verbruiker degene is die het voordeel van de prestatie heeft. Kennelijk doelt het Hof niet op de letterlijke betekenis van het woord 'verbruik' in de zin van consumptie, maar meer op een economisch getinte invulling in de betekenis van het genieten van een voordeel (voordeel genieten = verbruiken). Het gebruik van de term 'voordeel' doet sterk een economische invulling van de term 'verbruik' vermoeden. Echter het Hof lijkt consumptie/verbruik beperkter te definiëren dan de economische wetenschap. Bijvoorbeeld de vernietiging van goederen wordt in de economische wetenschap als consumptie beschouwd. ${ }^{35}$ De vernietiging van de oogst door een boer is dus volgens de economische wetenschap te beschouwen als consumptie. Echter niet volgens het eerder gegeven criterium zoals is geformuleerd door het Hof in het Mohr-arrest en het Landboden-arrest. Er is immers geen afnemer te identificeren die een voordeel geniet in de vorm van goederen of diensten. Indien het echter wel overwogen gebeurt, kan de vernietiging gericht zijn op het creëren van tekorten op een bepaalde markt waardoor de prijs wordt opgedreven. Is er dan volgens het Hof wel onder omstandigheden sprake van verbruik? Of betekent 'verbruik' dat er een markt voor moet bestaan ${ }^{36}$ De vraag is dan ook of een (beperkte) economische invulling van het verbruikscriterium in de praktijk goed hanteerbaar is.

Uit de jurisprudentie van het Hof blijkt dus dat het rechtskarakter van de BTW als volgt is te beschrijven. In de BTW gaat het om het belasten van verbruik en verbruik is gelijk aan het genieten van voordeel. De BTW probeert de eindverbruiker te treffen en de eindverbruiker is gelijk aan degene die de BTW niet kan afwentelen. Kortom, de BTW beoogt uiteindelijk te belasten degene die het voordeel geniet van een prestatie en geen aftrekrecht heeft. Het gegeven dat gebruik wordt gemaakt van een

34. M.E. van Hilten 1992, blz. 18. Zie ook M.E. van Hilten, Over recht en onrecht, WFR 1997/1011, Verslag seminar ter afscheid van Simons bij de postdoctorale opleiding Europese Fiscale Studies. In deze publicatie schaart zij zichzelf onder diegene die de BTW beschouwen als een belasting met als doel het belasten van het werkelijke particuliere verbruik. Zij brengt naar voren dat het Hof al in het Gaston Schul I-arrest, de BTW als verbruiksbelasting aanmerkt. In dit arrest erkent het Hof namelijk dat de BTW 'schuil gaat' in gebruikte goederen. Zie Hof 5 mei 1982, nr. 15/81, Gaston Schul I, BNB 1982/225.

35. In de zin van tegenhanger van investeringen.

36. Zie nader R.N.G. van der Paardt 2000, blz. 77 e.v. voor een uitgebreide analyse van dit aspect. 
indirecte wijze van heffen en dat uit oogpunt van doelmatigheid wordt aangeknoopt bij de bestedingen, doet daar volgens mij niets aan af. Wat het Hof precies verstaat onder 'het genieten van voordeel' is nog niet volledig duidelijk. Te verwachten is dan ook dat dit element in de praktijk tot de nodige discussies aanleiding zal geven. ${ }^{37}$

Diverse Amerikaanse schrijvers staan uitgebreid stil bij de kenmerken van een belasting op consumptie. In het bijzonder vergelijken zij een belasting op consumptie met een belasting op inkomen. De Amerikaanse literatuur ziet als het belangrijkste kenmerk van een consumptiebelasting het ongemoeid laten van sparen bij alle belastingplichtigen. ${ }^{38}$ Utz geeft aan dat in de literatuur dit gegeven als één van de belangrijkste pluspunten wordt beschouwd van een consumptiebelasting. Ook is van betekenis het gegeven dat een consumptiebelasting als voordeel heeft het ontbreken van een tijdselement. Consumptie van een maaltijd nu heeft evenveel genot/plezier tot gevolg als consumptie van een identieke maaltijd morgen. In ieder geval maakt de economische wetenschap dat onderscheid niet. In de structuur van een consumptiebelasting hoeft dan ook geen rekening te worden gehouden met het tijdselement. Dit in tegenstelling tot een belasting op inkomen.

In de Amerikaanse literatuur komt naar voren dat de behandeling van charitatieve bijdragen, legaten en het deelnemen aan weddenschappen problematisch is in een consumptiebelasting. Volgens Utz bevatten namelijk deze bijdragen volgens de economische wetenschap zowel elementen van sparen als van consumptie. ${ }^{39}$ Een donatie wil niet zeggen dat de donateur niet op één of andere wijze wordt gecompenseerd. Deze problematiek is uiteindelijk weer terug te voeren op de definitie van het begrip consumptie. Kortom, de onduidelijkheid van het begrip 'consumptie' in een consumptiebelasting speelt niet alleen in het Europees belastingrecht.

In deze paragraaf zijn verscheidene procedures behandeld waarbij het erop aankomt de ultieme lijn te vinden tot waar de heffing kan gaan. Het Hof grijpt terug op wat het kennelijk als basisprincipe, als leidraad achter de richtlijn ziet, zonder dat de considerans daar expliciet melding van maakt. Daartoe gebruikt het Hof, kort aangehaald, de bewoordingen:

- Eindgebruiker, die (...) niet op anderen kan afwentelen (Hong Kong-arrest).

- Levert de verbintenis (...) voordeel op waardoor zij als verbruiker van een dienst kan worden aangemerkt (Mohr-arrest).

37. Het arrest van 26 augustus 1998 (33 625, BNB 1999/50 m.n.v. Finkensieper) laat goed zien hoe moeilijk het kan zijn of de afnemer een product verkrijgt en dan ook verbruikt in de zin van het Mohrarrest. Het Gerechtshof Amsterdam concludeerde dat de stichting die een innovatiesubsidie van het Ministerie van Onderwijs en wetenschappen voor een ICT-innovatieproject doorgaf aan een dochtervennootschap, die een computernetwerk van universiteiten exploiteerde, in casu een product verkreeg. Op grond van de feiten komt de HR tot een totaal tegengestelde conclusie. De HR oordeelde dat noch de stichting noch de overheid een voordeel heeft gehad met het subsidiëren van de activiteiten. Een belastbare dienst was dan ook niet aanwezig.

38. S.G. Utz, Tax Policy, An Introduction and Survey of the Principal Debates, St Paul: West Publishing Co 1993, blz. 136.

39. S.G. Utz 1993, blz. 114 t/m 116 en blz. 138 t/m 142 over het consumptiebegrip. 
- Algemene verbruiksbelasting (...) op goederen en diensten (artikel 2, Eerste richtlijn; Mohr-arrest).

- Heffing (...) karakter van omzetbelasting (...) op de verbruiker moet worden afgewenteld (bij de uitleg van artikel 401, BTW-richtlijn; Careda-arrest).

- Het basisbeginsel van het BTW-stelsel is dat enkel de eindverbruiker wordt belast (Gibbs-arrest).

Men kan derhalve stellen, dat het Hof geregeld terugvalt op wat men in de literatuur het rechtskarakter van de BTW noemt om de grenzen van de heffing af te bakenen. In het vervolg van mijn onderzoek zal ik de term 'verbruiksbeginsel' gebruiken als ik doel op het rechtskarakter van de BTW. Daarbij mag uiteraard niet uit het oog worden verloren, zoals ik eerder heb aangegeven, dat het rechtskarakter volgens verscheidene schrijvers ruimer is dan enkel het verbruiksbeginsel. De term 'beginsel' gebruik ik in deze context omdat paragraaf 1.3 verwijst naar diverse schrijvers die het verbruiksbeginsel hanteren als norm waaraan dient te worden getoetst. Kennelijk vormt het verbruiksbeginsel dan een fundamenteel kader voor de BTW. Paragraaf 3.5.1 verduidelijkt dat het verbruiksbeginsel geen algemeen rechtsbeginsel is. In deze paragraaf is afdoende aangetoond dat het verbruiksbeginsel rechtens richtinggevend is in de jurisprudentie van het Hof. In de hoofdstukken $6 \mathrm{t} / \mathrm{m} 12$ zal blijken dat het verbruiksbeginsel belangrijk is, echter bepaald niet in alle gevallen richting geeft aan de uitleg van de BTW-regels. In hoofdstuk 13 zal naar voren komen dat het verbruiksbeginsel verweven kan zijn met de fiscale neutraliteit.

\subsection{Territorialiteit, oorsprong, bestemming}

\subsubsection{Territorialiteitsbeginsel}

Het oorsprongsland- en bestemmingslandbeginsel wijzen de heffingsbevoegdheid toe aan een land. Uitgangspunt is echter het territorialiteitsbeginsel. Algemeen is aanvaard dat een land de bevoegdheid heeft belasting te heffen over belastbare feiten die plaatsvinden op zijn grondgebied. ${ }^{40}$ Daniëls gebruikt in dit kader de term interne belastingsoevereiniteit. ${ }^{41}$ Hij doelt daarbij op de bevoegdheid van een staat om zijn belastingwetten in te richten op basis van de nationale wensen ten aanzien van economische doelmatigheid en rechtvaardigheid. Daniëls brengt naar voren dat

40. Zie P.H. Kooijmans, Internationaal publiekrecht, Deventer: Kluwer 2008, blz. 26 en 43. Kooijmans omschrijft de staat als een: 'territoriaal bepaalde gezagseenheid'. Dat betekent dat de staat op zijn territoir de exclusieve bevoegdheid heeft gezag uit te oefenen door het stellen, doorvoeren en afdwingen (handhaven) van regels. Hij noemt dit de jurisdictie van de staat die een attribuut is van de soevereiniteit. Zie ook - toegespitst op de BTW - H.G. Ruppe, General Report, Cahier de droit fiscal international, XXXVII Congres, Deventer: Kluwer 1983, blz. 142 en 143. Ruppe concludeert uit diverse deelrapportages dat het territorialiteitsbeginsel door praktisch alle rapporterende landen is aanvaard als uitgangspunt op het terrein van de belastingen op de verkoop van goederen en het verrichten van diensten. Zie tevens M.M.W.D. Merkx, De woon- en vestigingsplaats in de btw (diss. Tilburg 2011), in het bijzonder blz. 50 waar zij de soevereiniteitstheorie behandelt.

41. A.H.M. Daniëls, Soevereine zaken (oratie Maastricht), Deventer: Kluwer 1998, blz. 6 en 7. 
de interne belastingsoevereiniteit onder druk staat. Het wordt steeds moeilijker om als staat het eigen belastingstelsel te handhaven. ${ }^{42}$

Artikel 52 VEU (voorheen 299, lid 1 EG) is het startpunt ter bepaling van de ruimtelijke werkingssfeer van de BTW. Het artikel bepaalt dat het Unierecht van toepassing is op de daarin genoemde staten als partij van de verdragen. Daarmee staat in ieder geval vast dat het Unierecht de partijen bindt met betrekking tot het gehele territorium, met inbegrip van de niet-Europese delen voor zover het Werkingsverdrag zelf daarop niet een uitzondering toelaat of bijzondere regels stelt. ${ }^{43}$ De BTW-richtlijn vult het uitgangspunt zoals is neergelegd in het Unieverdrag en het Werkingsverdrag nader in. In de BTW-richtlijn is in de artikelen 2 en $5 \mathrm{t} / \mathrm{m} 8$ het territorialiteitsbeginsel terug te vinden. In artikel 2, BTW-richtlijn is namelijk onder meer bepaald, dat aan de BTW zijn onderworpen de belastbare prestaties die in het binnenland worden verricht. De artikelen $5 \mathrm{t} / \mathrm{m} \mathrm{8}$, BTW-richtlijn duiden het geografisch toepassingsgebied nader aan. ${ }^{44}$ Artikel 6 , BTW-richtlijn vermeldt dat bepaalde gebieden niet behoren tot het gebied waar de BTW-richtlijn geldt. Het territorium waar de Europese BTW-regelgeving geldt, is dus beperkter dan het gebied waar het Unieverdrag op van toepassing is.

Uit het bovenstaande blijkt dat het secundaire Unierecht (in dit geval de BTWrichtlijn) op een beperkter territorium van toepassing is dan het primaire Unierecht (Unieverdrag en het Werkingsverdrag). Het kan echter niet zo zijn dat secundaire Unierecht de werking van het primaire Unierecht beperkt. De werking van het Unieverdrag en het Werkingsverdrag blijft dan ook van toepassing op het gehele gebied zoals is vastgelegd in artikel 52 VEU, tenzij uiteraard het Unieverdrag zelf daarop uitzonderingen toelaat of bijzondere regels stelt. ${ }^{45}$ Op deze plaats is van belang de constatering dat de door mij onderzochte algemene rechtsbeginselen

42. Kooijmans vermeldt dat de territoriale jurisdictie van een staat in beginsel alomvattend is, doch er worden door het internationale recht uitzonderingen op gemaakt. Kooijmans behandelt beperkingen van regeldoorvoerende en regelhandhavende bevoegdheid. P.H. Kooijmans 2008, blz. 43 en 44.

43. Zie de nadere uitwerking in het Werkingsverdrag in de artikelen 349 en 355 VwEU. Zie tevens nader P.J.G. Kapteyn \& P. VerLoren van Themaat, Het recht van de Europese Unie en van de Europese Gemeenschappen, Deventer: Kluwer 2003, blz. 65 e.v.

44. Niet alleen in de artikelen $5 \mathrm{t} / \mathrm{m} \mathrm{8}$, BTW-richtlijn is een nadere invulling gegeven aan het geografisch toepassingsgebied van de BTW-richtlijn. Het op artikel 398, BTW-richtlijn (voorheen artikel 29, Zesde richtlijn) gebaseerde Raadgevend Comité heeft in diverse beslissingen een nadere invulling gegeven aan het geografisch toepassingsgebied voor de BTW. Zie ook B.G. van Zadelhoff, Onroerende goederen en belasting over toegevoegde waarde (diss. Amsterdam), Deventer: FED 1992, blz. 102 e.v. Onder de nu vigerende BTW-richtlijn zullen dergelijke beslissingen gebaseerd zijn op artikel 8, BTW-richtlijn.

45. Het zogenoemde Eerste Verslag van de Commissie aan de Raad (COM(83) 426 def.) geeft summier aan hoe de verhouding ligt tussen het Werkingsverdrag en de BTW-richtlijn. De inleiding van het Eerste Verslag vermeldt: “De toepassing van de richtlijn 'qua gebied' is minder moeilijk gebleken dan de toepassing ervan 'in de tijd', doordat voor het toepassingsgebied van de Zesde richtlijn, zoals omschreven in artikel 3 (thans artikelen $5 \mathrm{t} / \mathrm{m} \mathrm{8}$, BTW-richtlijn), is uitgegaan van artikel 227 van het Verdrag (thans artikel 52 VEU en 349 en 355 VwEU). Dit betekent dat eventuele moeilijkheden hun oorsprong vinden in de interpretatie van artikel 227 en niet in die van de richtlijn zelf. De uitsluiting $\rightarrow$ 
behoren tot het primaire Unierecht (zie paragraaf 4.5.1) en zich dan ook laten gelden in een ruimer territorium dan de regelgeving zoals deze is te vinden in de BTWrichtlijn.

De vraag doet zich voor, wat de rol is van het territorialiteitsbeginsel voor de werking van de BTW-richtlijn. In het verslag van 23 november 1994 over de werking van de BTW-overgangsregeling brengt de Commissie naar voren dat het territorialiteitsbeginsel centraal dient te staan bij de uitwerking door een lidstaat van facultatieve bepalingen. Punt 28 van het verslag merkt op:

"Iedere lidstaat moet inderdaad de mogelijkheid hebben zijn bevoegdheid inzake belastingheffing uit te oefenen, ongeacht de feiten die zich hebben voorgedaan in een ander land (andere lidstaat of een derde land). In het kader van een gemeenschappelijk stelsel van belastingheffing voor alle lidstaten, steunt de eerbiediging van dit principe integraal op de regels van territorialiteit van de handelingen. De plaats van belastingheffing verkrijgt aldus een kapitaal belang, dat nog wordt verhoogd door het feit dat aan de lidstaten opties worden geboden die hun toelaten af te wijken van de gemeenschappelijke regels van heffing (uitgaven waarvoor geen recht op aftrek bestaat; facultatieve vrijstellingen; enz.)."46

Uit het bovenstaande citaat is de gevolgtrekking te maken dat de Commissie een zeer ruime werking toekent aan het territorialiteitsbeginsel. Met feiten die zich in een andere lidstaat hebben voorgedaan hoeft geen rekening te worden gehouden. Zodra sprake is van een facultatieve bepaling in de BTW-richtlijn, dan is volgens de Commissie een lidstaat volledig vrij bij de invulling daarvan. Eerst zal ik nagaan of het Hof ook een dergelijke ruime invulling aan het territorialiteitsbeginsel geeft.

In een aantal arresten van het Hof is het territorialiteitsbeginsel aan de orde geweest. In het Berkholz-arrest ${ }^{47}$ van 4 juli 1995 overweegt het Hof:

“(...) de bevoegdheid van de Lid-Staten om belasting te heffen over diensten die buiten hun territoriaal soevereiniteitsgebied worden verricht aan boord van zeeschepen die onder hun jurisdictie vallen, (wordt) door artikel 9 niet beperkt. In tegenstelling tot de door de verzoeker in het hoofdgeding verdedigde en door de Commissie gesteunde opvatting voorziet de richtlijn dus in het geheel niet in belastingvrijdom voor diensten die worden verricht op volle zee of, algemener gezegd, buiten het territoriale gebied van de Lid-Staat

$\rightarrow$ van de Franse overzeese departementen van het toepassingsgebied van de richtlijn is een kenmerkend voorbeeld van deze situatie: zich baserend op een bepaalde interpretatie van artikel 227 van het Verdrag waren Raad en de Commissie van mening dat deze departementen van rechtswege van het toepassingsgebied van de richtlijn waren uitgesloten en dat het derhalve niet nodig was hen te vermelden in lid 2 van artikel 3 van de Zesde richtlijn. Eerst nadat het arrest van het Hof van Justitie van de Europese Gemeenschappen in een zaak van fiscale aard een andere interpretatie van artikel 227 werd gegeven moest de Raad de Elfde richtlijn van 26 maart 1980 (PB nr. L 90 van 3 april 1980) aannemen, waarbij de overzeese departementen werden toegevoegd aan lid 2 van artikel 3 van de Zesde richtlijn als gebieden die zijn uitgesloten van de toepassing van het gemeenschappelijk BTWstelsel. (toevoegingen: AHB)" Hieruit blijkt dat ook volgens de Commissie artikel 52 VEU het uitgangspunt is.

46. COM (94) 515 def.

47. Hof 4 juli 1998, nr. 168/84, G. Berkholz, Jur. 1985, blz. 2251. In deze procedure besliste het Hof dat speelautomaten aan boord van een schip geen vaste inrichting vormen. 
onder wiens jurisdictie het schip valt, en zulks ongeacht of de betrokken diensten moeten worden geacht te zijn verricht in de zetel van de dienstverrichter dan wel in een andere vaste inrichting. (toevoegvoeging: AHB)" (r.o. 16)

In de zaak Trans Tirreno Express ${ }^{48}$ is de bovenstaande lijn door het Hof voortgezet. Belanghebbende vervoerde passagiers tussen twee op Italiaans grondgebied gelegen punten, echter een gedeelte van het vervoer vond plaats over een traject gelegen in internationale wateren. De vraag was aan de orde of ingevolge artikel 9, lid 2, sub b, Zesde richtlijn BTW kan worden geheven met betrekking tot het vervoer dat plaatsvond in internationale wateren. Het Hof overweegt dat de vervoersdienst geen bevoegdheidsconflict tot gevolg had indien geen plaats wordt aangedaan die onder de nationale soevereiniteit van een andere lidstaat valt (r.o. 18). ${ }^{49}$ Vervolgens overweegt het Hof met verwijzing naar de toen geldende Zesde richtlijn:

"Met betrekking tot dergelijke vervoersdiensten die als louter binnenlandse vervoersdiensten kunnen worden aangemerkt, dient de geografische werkingssfeer van de BTW te worden afgebakend met inachtneming van de basisregels van de artikelen 2 en 3 van de richtlijn, en niet van artikel 9." (r.o. 19)

Kortom, indien geen heffingsconflict tussen twee lidstaten optreedt, is artikel 9, BTW-richtlijn (thans de artikelen $43 \mathrm{t} / \mathrm{m} 59$ ter, BTW-richtlijn) niet aan de orde. ${ }^{50}$ Het Hof kwam tot de conclusie dat de artikelen 2 en $5 \mathrm{t} / \mathrm{m} \mathrm{8}$, BTW-richtlijn van toepassing zijn op het nationale grondgebied van de desbetreffende lidstaat, echter de richtlijn beperkt de vrijheid van de lidstaten niet om het toepassingsgebied uit te breiden tot buiten hun grondgebied, mits geen inbreuk wordt gemaakt op de bevoegdheden van andere lidstaten. Let wel, artikel 9, Zesde richtlijn verzet zich niet tegen BTW-heffing, echter het Hof sprak zich niet uit over het bestaan van een verplichting om in dergelijke situaties als lidstaat BTW te heffen. De vraag of een lidstaat deze verplichting heeft, is uiteraard van belang voor de eigen middelen van de EU. ${ }^{51}$

In de inbreukprocedure tegen Frankrijk is de vraag aan de orde of de lidstaten verplicht zijn BTW te heffen over vervoersdiensten verricht tussen twee plaatsen gelegen op het nationale grondgebied, waarbij het vervoer gedeeltelijk plaatsvindt

48. Hof 23 januari 1986, nr. 283/84, Trans Tirreno Express Spa, Jur. 1986, blz. 231.

49. Vgl. Hof 15 september 2005, nr. C-58/04, A. Köhler, V-N 2005/47.24. Verkopen op een cruiseschip niet belast met BTW indien een tussenstop wordt gemaakt buiten de Europese Unie. Zie vooral r.o. 24 $\mathrm{t} / \mathrm{m}$ 26. De fiscale behandeling van de levering van goederen valt in dat geval onder de fiscale bevoegdheid van de staat waar de tussenstop plaatsvindt.

50. Het Hof overweegt in gelijke zin in het arrest van 6 november 1997, nr. C-116/96, Reisbüro Binder GmbH, V-N 1998/4.13. In r.o. 12 overweegt het Hof met betrekking tot lid 1 en lid 2 van artikel 9, Zesde richtlijn: “(...) Het doel van deze bepalingen is met name, bevoegdheidsconflicten tussen de lid-Staten die tot dubbele belasting kunnen leiden, te voorkomen." Hoofdstuk 8 gaat uitgebreid in op deze jurisprudentie.

51. Zie voor een uitgebreide beschouwing over de regelgeving met betrekking tot de eigenmiddelen: A. van Dongen, De harmonisatie van de BTW (diss. Tilburg), Amersfoort: Sdu Uitgevers 2007, blz. 191. 
in internationale wateren. ${ }^{52}$ Het Hof besliste dat de lidstaten deze verplichting niet hebben. ${ }^{53}$ De lidstaten zijn dan ook niet verplicht in de berekeningsgrondslag voor de eigen middelen rekening te houden met deze omzetten.

Uit de bovenstaande arresten zijn de volgende conclusies te trekken met betrekking tot de kracht van het territorialiteitsbeginsel. Ten eerste is de in de BTW-richtlijn neergelegde regeling dwingend van toepassing op het gehele nationale grondgebied van de lidstaten. Ten tweede zijn in beginsel de basisregels van artikel 2 en $5 \mathrm{t} / \mathrm{m} 8$, BTW-richtlijn van toepassing. Slechts in geval van een heffingsconflict met een andere lidstaat zijn de artikelen $43 \mathrm{t} / \mathrm{m} 59$ ter, BTW-richtlijn aan de orde. Ten derde hebben de lidstaten de bevoegdheid (niet de verplichting) het toepassingsgebied van hun belastingwetgeving uit te breiden tot buiten hun grondgebied. Hierbij geldt de voorwaarde dat geen inbreuk mag worden gemaakt op de bevoegdheden van andere lidstaten. Kennelijk is op het moment van botsing van heffingsbevoegdheden de kracht van het territorialiteitsbeginsel teniet gedaan. Of anders geformuleerd, is het gedaan met de voorrang van het territorialiteitsbeginsel en komen de artikelen $43 \mathrm{t} / \mathrm{m}$ 59 ter, BTW-richtlijn met een fiscaal rationele oplossing (zie uitgebreid hoofdstuk 8). Het lijkt mij dat het Hof een ruime werking toekent van het territorialiteitsbeginsel. Echter niet zo ruim als de Commissie van mening is in het eerder aangehaalde citaat. Bij een heffingsconflict is in ieder geval de grens bereikt.

In paragraaf 2.4.2 zal blijken dat het manipuleren van het territorialiteitsbeginsel tot gevolg kan hebben dat de externe neutraliteit wordt verstoord.

\subsubsection{Oorsprongslandbeginsel en bestemmingslandbeginsel}

\subsubsection{Achtergrond en vormgeving}

Het territorialiteitsbeginsel bepaalt niet altijd het antwoord op de vraag in welke lidstaat een prestatie belast is. ${ }^{54}$ Sterker nog, uit de jurisprudentie die in de vorige paragraaf is behandeld, blijkt dat in geval van een heffingsconflict tussen lidstaten het territorialiteitsbeginsel per definitie heeft afgedaan. Dubbele dan wel niet-heffing van belasting is dan ook niet te voorkomen indien het territorialiteitsbeginsel het uitgangspunt is. Dit onderzoek doelt met de terminologie 'dubbele belastingheffing' niet op de strekking die dit begrip meestal heeft in de vakliteratuur. ${ }^{55}$ Dikwijls beperkt

52. Hof 13 maart 1990, nr. C-30/89, Commissie/Frankrijk, Jur. 1990, blz. 691. Zie nader Hof 29 maart 2007, nr. C-111/05, Aktiebolaget NN, V-N 2007/18.22. De levering en plaatsing van een glasvezelkabel die twee lidstaten met elkaar verbindt is niet aan de heffing van BTW onderworpen voor het deel van de handeling, dat plaatsvindt buiten de twaalfmijlszone.

53. Zie in dit kader ook Hof 23 mei 1996, nr. C-331/94, Commissie/Griekenland, Jur. 1996, blz. I-2675, r.o. 10. In deze procedure besliste het Hof dat het niet heffen van BTW door Griekenland op een nationaal traject voor cruises in strijd is met de BTW-richtlijn.

54. B.G. van Zadelhoff 1992, blz. 58 is van mening dat het territorialiteitsbeginsel van beperkte betekenis is.

55. Zie C. van Raad, Cursus belastingrecht (internationaal belastingrecht), Deventer: Kluwer (losbladig), onderdelen 0.1 en 1.2 . 
deze definitie zich tot dezelfde belastingplichtige met betrekking tot de heffing van een vergelijkbare belasting, ten aanzien van hetzelfde belastbare feit, over dezelfde periode, in meerdere staten. Deze problematiek valt buiten mijn onderzoek. Dit onderzoek doelt met de termen 'internationale dubbele belastingheffing' op een situatie waarin een internatonale transactie meerdere keren is onderworpen aan de BTW, onafhankelijk van de vraag of het dezelfde belastingplichtige betreft. ${ }^{56}$ Internationale dubbele belastingheffing op goederen en diensten heeft dan ook betrekking op hetzelfde object en niet noodzakelijkerwijs op hetzelfde subject (belastingplichtige) ${ }^{57}$ Dubbele belastingheffing is te onderscheiden in juridische dubbele belastingheffing en economische dubbele belastingheffing. Met juridische dubbele belastingheffing wordt bedoeld, dat verscheidene staten een transactie aan een vergelijkbare belasting onderwerpen. Met economische dubbele belastingheffing wordt bedoeld dat op een bepaalde transactie belasting drukt zonder recht op aftrek van voorbelasting, zoals bij sommige vrijstellingen. Tenzij anders aangegeven, ga ik uit van juridische dubbele belastingheffing indien ik het heb over dubbele belastingheffing.

Bij de toewijzing van een heffingsbevoegdheid aan een lidstaat kan het oorsprongslandbeginsel dan wel het bestemmingslandbeginsel een rol spelen. ${ }^{58}$ De term oorsprongslandbeginsel geeft aan dat de BTW wordt geheven in het land van productie van de goederen dan wel de diensten worden verricht. Het bestemmingslandbeginsel heeft tot gevolg dat de heffing van BTW plaatsvindt in het land van verbruik van het geleverde goed of verrichte dienst. De desbetreffende beginselen kunnen worden gebruikt om de heffingsbevoegdheid toe te kennen aan een bepaalde lidstaat.

Toepassing van het oorsprongslandbeginsel heeft een belangrijk nadelig effect. Volgens dit beginsel ondervindt de productie voor de export de binnenlandse belastingdruk. En bij import geldt het omgekeerde. Het gevolg hiervan is immers dat de BTW druk op geïmporteerde goederen niet noodzakelijkerwijs gelijk is aan die op de in het binnenland geproduceerde goederen. Het land van oorsprong bepaalt namelijk de BTW-druk. De literatuur ziet dit effect als een belangrijk nadeel van het oorsprongslandbeginsel. ${ }^{59}$

56. Zie nader B.J.M. Terra, De plaats van de prestatie (oratie Amsterdam UvA), Deventer: Kluwer 1989, blz. 7. Zie ook H.G. Ruppe 1983, blz. 114, 144 en 145.

57. Men kan ook aanknopen bij het onderscheid objectieve en subjectieve belastingen. Zie voor het verschil in kenmerken H.W.M. van Kesteren, Fiscale Rechtswil (diss. Leiden), Arnhem: Gouda Quint 1994, blz. 63.

58. In de literatuur zijn ook andere uitgangspunten te vinden, zoals het baatbeginsel. Zie voor een uitgebreide behandeling, M.M.W.D. Merkx, De woon- en vestigingsplaats in de btw (diss. Tilburg) 2011, blz. 51 e.v.

59. Zie M.A. van Hilten, Bancaire en financiële prestaties in de Europese BTW (diss. Leiden), Deventer: Kluwer 1992, blz. 207. Zij meent dat deze omstandigheid het oorsprongslandbeginsel ongeschikt maakt voor een verbruiksbelasting zoals de omzetbelasting is. 
Het bestemmingslandbeginsel past beter bij een verbruiksbelasting. ${ }^{60}$ De BTW wordt dan geheven in het land van verbruik. Het bestemmingslandbeginsel past dan ook beter bij het rechtskarakter van de BTW zoals dat in paragraaf 2.2 is beschreven. Verder kan bij de grensoverschrijdingen door compenserende heffingen dan wel teruggaven de neutraliteit beter worden bereikt dan bij hantering van het oorsprongslandbeginsel. ${ }^{61}$ Een nadeel daarbij is wel dat administratieve dan wel fysieke grenzen noodzakelijk zijn.

Het bestemmingslandbeginsel is terug te vinden in de Wereldovereenkomst voor Tarieven en Handel GATT (General Agreement on Tariffs and Trade 1947). ${ }^{62}$ De artikelen 110 en 111, VwEU (voorheen 90 en 91, EG) zijn in overeenstemming met de uitgangspunten zoals deze zijn te vinden in de GATT. Deze artikelen bepalen namelijk, in het kort weergegeven, dat de lidstaten geen hogere binnenlandse belastingen mogen heffen op producten uit andere lidstaten. Tevens mag bij uitvoer van producten naar het grondgebied van een andere lidstaat de teruggave van binnenlandse belastingen niet het bedrag overschrijden dat daarop is geheven.

Vanaf 1 januari 1995 is de GATT vervangen door de Wereldhandelsorganisatie WTO (World Trade Organisation). De plaats van het bestemmingslandbeginsel heeft geen wezenlijke verandering ondergaan ten opzichte van de GATT. ${ }^{63}$ Wel zijn drie andere veranderingen geïntroduceerd. Het eerste is dat het materiële recht van de WTO aanzienlijk meer omvat dan de GATT. De GATT-bepalingen zijn bij de oprichting van de WTO aangepast en worden nu GATT 1994 genoemd. Deze bepalingen hebben betrekking op goederen. De WTO heeft echter ook betrekking op het internationale dienstenverkeer en kent verder bepalingen die betrekking hebben op handelsgerelateerde aspecten van intellectuele eigendomsrechten. Deze uitbouw van het materiële recht is na de totstandkoming van de WTO doorgegaan en omvat inmiddels ook akkoorden over liberalisatie van telecommunicatiediensten, financiële diensten en informatietechnologie. ${ }^{64}$

De tweede verandering is dat de WTO rechtspersoonlijkheid heeft gekregen. Dit maakt de oprichting mogelijk van een administratief apparaat dat vergelijkbaar is met andere internationale organisaties.

60. Zie ook Terra 1989, blz. 10 en 11 voor een analyse van het baatbeginsel en het belasten van verbruik. 61. Rapport van de commissie ter bestudering van de BTW-heffing ten aanzien van grensoverschrijdende goederenbewegingen binnen de EU, Geschriften van de Vereniging voor Belastingwetenschap, no. 202, blz. 24 t/m 27.

62. Zie artikel III, paragraaf 2, artikel XVI. Zie ook Koopmans, Geschriften van de Vereniging voor belastingwetenschap, no. 186, blz. 7: "De definitie van douane-unie is ouder dan de gemeenschap. Men vindt hem in de GATT-verdrag, dat al bestond en in werking was toen de EEG-onderhandelingen plaatsvonden in de jaren vijftig."

63. Artikel XXIV GATT 1994.

64. P.H. Kooijmans 2008, blz. 207 en 208. 
De derde wijziging is van wezenlijk belang. Namelijk de introductie van een procedure om geschillen tussen de diverse handelslanden te beslechten. Een dergelijke mogelijkheid bestond al in een zwakke vorm onder de GATT. In de WTO is dit echter belangrijk uitgebreid. ${ }^{65}$ De vraag doet zich nu voor op welke wijze in deze jurisprudentie van de WTO algemene rechtsbeginselen zijn te ontdekken, zoals het gelijkheidsbeginsel en hoe deze jurisprudentie van de WTO zich verhoudt tot de jurisprudentie van het Hof. ${ }^{66}$ Ondanks het feit dat diverse beslissingen van de WTO de nodige stof hebben doen opwaaien laat ik het in mijn onderzoek buiten beschouwing. ${ }^{67}$ De reden daarvoor is dat mijn onderzoek zich beweegt op het Europees (rechtelijke) niveau, de jurisprudentie en dus de rechtsvormende rol van het Hof. In dit kader is het van belang om te constateren dat het Hof heeft aangegeven, dat de WTO-overeenkomsten gezien hun aard en opzet, in beginsel niet tot de normen behoren waaraan het Hof de wettigheid van handelingen van de instellingen van de Europese Unie kan toetsen. ${ }^{68}$ Dit is anders als de Europese Unie uitvoering heeft willen geven aan een in het kader van de WTO aangegane bijzondere verplichting of indien de gemeenschapshandeling uitdrukkelijk naar specifieke bepalingen van de WTO-overeenkomsten verwijst. Het is vaste rechtspraak met betrekking tot de invloed die een internationale overeenkomst kan uitoefenen op de uitlegging van een bepaling van afgeleid Unierecht, dat de door de Europese Unie gesloten internationale overeenkomsten van hogere rang zijn dan de bepalingen van afgeleid Unierecht. Het afgeleid Unierecht moet dan ook zo veel als mogelijk in overeenstemming met dergelijke internationale overeenkomsten worden uitgelegd. ${ }^{69}$

65. Indien een geschil ontstaat tussen WTO leden en het geschil kan niet worden opgelost door middel van overleg, dan wordt een zogenoemd Panel ingesteld. Dit Panel wordt op ad-hocbasis samengesteld uit een lijst van onafhankelijke deskundigen en bestaat uit drie personen. Indien een partij het niet eens is met een beslissing van een Panel (in de vorm van een Panelrapport), dan kan in hoger beroep worden gegaan bij een Appellate Body. Dit orgaan heeft een vaste samenstelling en bestaat uit zeven onafhankelijke leden. Op de uitvoering van beslissingen van Panels (dan wel het Appellate Body) wordt strikt toegezien en indien de uitvoering tekort schiet kunnen sancties worden opgelegd. Zie P.H. Kooijmans 2008, blz. 2008 en 2009. Zie verder voor een uitgebreide bespreking J.H. Jackson, The World Trade Organisation, Constitution and Jurisprudence, London: The Royal Institute of International Affairs 1999. Vooral hoofdstuk 4.

66. Zie in dit kader R. Korf, The General Agreement on Trade in Services and Its Impact on European Taxation, in: M. Lang, P. Melz, E. Kristoffersson (red.), Value Added Tax and Direct Taxation, Similarities and Differences, Amsterdam: IBFD 2009, blz. 1197-1229.

67. Voor een overzicht van de jurisprudentie zie de site www.wto.org van de WTO. Jackson is van mening dat diverse landen de impact van het WTO verdrag en de diverse uitgebreide bijlagen niet beseffen, dit geldt volgens hem ook voor een aantal van de machtigste handelsnaties, J.H. Jackson 1999, blz. 1 en 2.

68. Hof 23 november 1999, nr. C-149/96, Portugal/Raad, Jur. 1999, blz. I-8395, r.o. 47 t/m 49. Zie ook Hof 9 september 2008, nrs. C-120/06p en C-121/06p, FIAMM en Fedon, en de bij dit arrest lezenswaardige scherpe annotatie van J.H. Jans \& N. Lavranos, SEW 2009/150.

69. Een voorbeeld van een dergelijk effect op het terrein van de BTW is te vinden in het RLP-arrest, Hof 7 juni 2007, nr. C-335/05, V-N 2007/28.20. Het Hof gaat in het RLP-arrest nader in op de mogelijke voorwaarde van wederkerigheid bij BTW teruggaaf aan niet EU-ondernemers zoals die kan worden gelezen in artikel 2, lid 2, Dertiende richtlijn. In de desbetreffende procedure is beslist dat het voor Duitsland niet mogelijk is om de voorwaarde van wederkerigheid te stellen op grond van de verplichting die is te vinden in artikel II, lid 1, GATS (General Agreement on Trade in Services). 
In WTO en VwEU treffen wij dus als uitgangspunt het bestemmingslandbeginsel aan. Ook de OECD heeft als uitgangspunt - althans bij het belasten van diensten en de overdracht van onlichamelijke zaken - dat dient te worden aangesloten bij het land van consumptie. ${ }^{70}$ De discussie binnen de Europese Unie over de vraag of gekozen moet worden voor het bestemmings- dan wel oorsprongslandbeginsel heeft alleen betrekking op de handel tussen de lidstaten. Voor goederentransacties met derde landen is de keuze voor het bestemmingslandbeginsel buiten elke discussie.

Om de BTW-heffing volgens het bestemmingsland te laten verlopen kan men verschillende technieken toepassen:

- Toepassen van een vrijstelling met daaraan gekoppeld een recht op aftrek van voorbelasting op transacties waarbij de goederen het territorium verlaten (artikel 138, lid 1, BTW-richtlijn) (in de Wet OB aangeduid als een nultarief). Daar staat dan een heffing in het land van import tegenover.

- Bepalen dat het belastbaar feit plaatsvindt in de staat waar de afnemer is gevestigd (bijvoorbeeld artikel 44, BTW-richtlijn). Eventueel kan tevens de verschuldigdheid van de BTW worden verlegd naar de afnemer (bijvoorbeeld artikel 196, BTW-richtlijn).

- Voor de heffing van BTW het toepassingsgebied inperken. Op deze wijze geldt BTW-vrijdom in het desbetreffende gebied. Indien goederen die in een dergelijk gebied worden aangeschaft is een eventuele BTW-heffing een aangelegenheid van de Staat van bestemming (zie verder paragraaf 2.4.2).

De uitwerking van het bestemmingsland- en oorsprongslandbeginsel is nog te verduidelijken door enkele kenmerkende toepassingen van deze beginselen in een tabel weer te geven:

\begin{tabular}{|l|l|l|}
\cline { 2 - 3 } \multicolumn{1}{c|}{} & Oorsprong & Bestemming \\
\hline A. Tarief van toepassing & Land van 'export' & Land van 'import' \\
\hline B. Recht op belastingopbrengst & Land van 'export' & Land van 'import' \\
\hline C. Land waar de BTW heffing plaatsvindt & Land van 'export' & Land van 'import' \\
\hline
\end{tabular}

Een volledige toepassing van het oorsprongslandbeginsel betekent dat de elementen $A$, B en C alle drie toevallen aan het land van 'export' van het goed of de dienst. In geval van toepassing van het bestemmingslandbeginsel zijn de criteria $A$, B en C gekoppeld aan het land van 'import'. Dit wil niet zeggen dat de kenmerkende toepassingen altijd in een ideaal-schema als hier moeten vallen. Voor de praktijk is het denkbaar dat wetgevers - zo ook gezamenlijk in de EU - naar belang en beleid daarin muteren. Denkbaar is een systeem waarbij het tarief $(A)$ en de heffing $(C)$ volgens het land van 'import' plaatsvinden, terwijl de belastingopbrengst (B) door

70. OECD International VAT/GST Guidelines on the application of VAT/GST to the international trade in services and intangibles for public consultation, 1 February to 30 june 2010, Working Party No. 9 on Consumption Taxes OECD, blz. 6 e.v. 
middel van een verrekening tussen de lidstaten toekomt aan het land van 'export'. Er is dan sprake van een beperkte toepassing van het bestemmingslandbeginsel. ${ }^{71}$

\subsubsection{Het overgangsregime}

In artikel 14 EG was bepaald dat met ingang van 1 januari 1993 een interne markt moet zijn gerealiseerd. Het desbetreffende artikel werd algemeen gezien als een inspanningsverplichting van de lidstaten en niet als een resultaatverplichting. ${ }^{72}$ Het feit dat de datum van 1 januari 1993, waarop volgens artikel 14 EG de interne markt moest zijn gerealiseerd, niet volledig op alle onderdelen is gehaald bleef dan ook zonder gevolgen. Artikel 14 EG is per 1 december 2009 op grond van het Verdrag van Lissabon vervangen door artikel 26 VwEU. Deze bepaling noemt echter geen datum meer waarop de interne markt moet zijn gerealiseerd.

Tot 1 januari 1993 werden de fiscale grenzen tussen de lidstaten verwezenlijkt door de toepassing van een nultarief bij uitvoer en heffing van BTW bij invoer. In augustus 1987 publiceerde de Commissie voorstellen ter opheffing van de fiscale grenzen tussen de lidstaten. ${ }^{73}$ De Commissie stelde voor om bij een goederenlevering aan een ondernemer gevestigd in een andere lidstaat BTW in rekening zou moeten worden gebracht. Op deze wijze zouden binnenlandse leveringen en intracommunautaire transacties gelijk worden behandeld. Oorspronkelijk was het voorstel om de aftrek van de in het buitenland in rekening gebrachte BTW niet anders te behandelen dan de in het binnenland in rekening gebrachte BTW. Dat wil zeggen dat een in Nederland gevestigde ondernemer eventueel Italiaanse BTW op zijn aangifte in aftrek zou kunnen brengen. De Nederlandse Belastingdienst zou dan BTW teruggeven die in Italië in de schatkist was gevloeid. Om te bereiken dat de belastingopbrengst toevloeit aan de lidstaat van bestemming/verbruik werd een verrekeningsstelsel voorgesteld. Elke lidstaat zou periodiek moeten berekenen welk bedrag aan BTW ter zake van intracommunautaire leveringen hij per saldo te vorderen heeft van de andere lidstaten, dan wel verschuldigd is aan andere lidstaten. Het saldo zou vervolgens via één centrale rekening tussen de lidstaten worden verrekend. Op deze wijze komt de belastingopbrengst ten goede aan de lidstaat van consumptie.

De Raad van ministers aanvaardde de voorstellen van de Commissie niet. Men uitte bezwaren tegen de omvangrijke geldstromen tussen de lidstaten en men vreesde een gebrek aan controle. Wel vond men een compromis in de vorm van een overgangsregeling. Deze overgangsregeling is na de beoogde einddatum van 31 december 1996

71. Zie voor een meer gedetailleerde beschouwing en voor een verdere nuancering met betrekking tot het oorsprongslandbeginsel en het bestemmingslandbeginsel: Ken Messere, Consumption Tax Rules, International Bureau of Fiscal Documentation, Bulletin December 1994, blz. 665 e.v.

72. Zie R. Barents en L.J. Brinkhorst, Grondlijnen van Europees Recht, Deventer: Kluwer 2003, blz. 289 en 290.

73. Deze voorstellen zijn gepubliceerd in COM (87) 320 t/m 328. De voorstellen worden beschreven door D.B. Bijl, Derde-generatie-BTW, WFR 1988/183 en door H.A. Kogels, BTW zonder grenzen (II), MBB, januari 1988, blz. 5. 
van kracht gebleven en blijft ook van kracht totdat de definitieve regeling is ingevoerd. ${ }^{74}$ Per 1 januari 2007 is de Zesde richtlijn vervangen door de BTW-richtlijn en is de overgangsregeling in de BTW-richtlijn opgenomen.

De regeling houdt in dat de formaliteiten en controles aan de (doorgaans) fysieke binnengrenzen zijn vervallen en dat de controle voor een belangrijk deel is verschoven naar de administratie van belastingplichtigen. En in plaats van invoer is het belastbaar feit thans de intracommunautaire verwerving, te verantwoorden op de binnenlandse aangiften. De intracommunautaire levering is, evenals voorheen de 'exportlevering', belast tegen het nultarief. Voorwaarden zijn dat de goederen aantoonbaar naar een andere lidstaat zijn vervoerd en bestemd voor een verwervende ondernemer, die in het land van verwerving is geregistreerd. Van belang in het kader van dit hoofdstuk is de constatering dat onder de overgangsregeling het bestemmingslandbeginsel in principe is gehandhaafd voor ondernemers. De goederen verlaten belastingschoon de 'exportlidstaat' en komen via het belastbaar feit verwerving in de 'importlidstaat' onder de belastingheffing van het verbruikersland. Het belastbaar feit invoer is er enkel nog bij binnenkomst van goederen uit derdelanden. Voor particulieren is in beginsel het oorsprongslandbeginsel van toepassing. ${ }^{75}$ Op in een andere lidstaat gekochte goederen en diensten drukt de BTW van die lidstaat. De Parijzenaar koopt in Utrecht artikelen met Nederlandse BTW en keert met die Nederlandse BTW-druk huiswaarts; zonder dat de grenspassage relevant is. Invoer aldaar bestaat niet meer en eigenlijk vormt dit wel de grootste verandering die de overgangsregeling ons bezorgde.

Op 11 juli 1996 heeft de Commissie opnieuw voorstellen gedaan om over te gaan op een systeem van heffing in het land van oorsprong. ${ }^{76}$ De Commissie heeft voorgesteld om bij de verrekening tussen de lidstaten de statistieken betreffende de BTWplichtige consumptie tot uitgangspunt te nemen. Of deze voorstellen de bestaande reserves van de lidstaten zullen wegnemen is te betwijfelen. ${ }^{77}$

Verder is van belang dat de opdracht voor een definitieve regeling is vastgelegd in artikel 402, BTW-richtlijn. In dit artikel staat onder meer:

“(...) de belastingheffing in het handelsverkeer tussen de lidstaten is een overgangsregeling en zal worden vervangen door een definitieve regeling, in beginsel gebaseerd op belastingheffing in de lidstaat van oorsprong van de goederenleveringen en de diensten."

74. De overgangsregeling is te vinden in richtlijn nr. 91/680 van 16 december 1991, Pb 1991 L 376 en richtlijn 92/111 van 16 december 1992, Pb 1992 L 384.

75. Zie voor een inbreuk op dit beginsel de regeling voor afstandverkopen (artikel 33, BTW-richtlijn) 76. Een gemeenschappelijk BTW-stelsel, Een programma voor de interne markt, COM (96) 328 def. Zie ook de mededeling aan de Raad en het Europees Parlement van 7 juni 2000 getiteld: 'Strategie ter verbetering van de werking van het BTW-stelsel in het kader van de interne markt', COM (2000) 348 def. 77. Zie voor enkele bespiegelingen over toekomstige scenario's, A. van Dongen, De harmonisatie van de BTW (diss. Tilburg), Amersfoort: Sdu Uitgevers 2007, blz. 219 en 220 
Het lijkt er dus op dat is gekozen voor een definitief BTW-systeem waarbij de heffing plaatsvindt volgens het oorsprongslandbeginsel. ${ }^{78}$ Indien ooit de lidstaten van de Europese Unie als één belastingterritorium worden gezien is de keuze tussen bestemmingslandbeginsel dan wel oorsprongslandbeginsel irrelevant. $\mathrm{Er}$ is dan immers slechts één buitengrens. Echter zolang deze vergaande vorm van integratie niet is verwezenlijkt, blijft er een weerkerende spanning bestaan tussen de toepassing van hetzij het oorsprongslandbeginsel, hetzij het bestemmingslandbeginsel.

\section{$2.4 \quad$ Neutraliteitsbeginsel}

\subsubsection{Concurrentieverhoudingen}

Neutraliteit betekent dat de heffing van BTW geen invloed heeft op de concurrentieverhoudingen en de allocatie van productiemiddelen. ${ }^{79}$ De Europese BTW is gebaseerd op dit uitgangspunt. Artikel 2, Eerste richtlijn bepaalt dat de BTW berust op het beginsel dat van goederen en diensten een algemene verbruiksbelasting wordt geheven: ${ }^{80}$

“(...) welke strikt evenredig is aan de prijs van goederen en diensten, zulks ongeacht het aantal transacties welke tijdens het productie- en distributieproces vóór de fase van heffing plaatsvonden. (...)"

Oftewel, de BTW-druk voor de consument blijft gelijk ongeacht de weg die het product aflegt voordat de eindverbruiker het verbruikt. Deze benadering gaat ervan uit dat de BTW de prijsverhoudingen zo min mogelijk beïnvloedt. ${ }^{81}$ In deze

78. Zie echter Geschriften van de Vereniging voor Belastingwetenschap, No. 202, Europese BTW-heffing, Rapport van de commissie ter bestudering van de BTW-heffing ten aanzien van grensoverschrijdende goederenbewegingen binnen de EU. Volgens blz. 33 van dit rapport laat de tekst van artikel 28terdecies van de Zesde richtlijn (huidig artikel 402, BTW-richtlijn) meerdere opties open: “(...) er zou uiteindelijk sprake kunnen zijn van een systeem van heffing in het land van oorsprong (of liever: in het land van herkomst), waarbij het bestemmingslandbeginsel gehandhaafd wordt, of waaruit voor de lidstaten een nationale BTW-opbrengst voortvloeit die in meerdere of mindere mate overeenkomt met die welke verkregen zou worden bij handhaving van het bestemmingslandbeginsel."

79. Zie bijvoorbeeld A.H.R.M. Denie 1987, blz. 41: "Uit het rechtskarakter van de omzetbelasting vloeit het neutraliteitsbeginsel voort. De concurrentieverhoudingen van de belastingplichtigen dienen in beginsel niet ten gevolge van de belasting verstoord te worden (concurrentieneutraliteit), de belasting hoort op de particulieren afgewenteld te worden."

80. Eerste richtlijn, 67/227/EEG, vastgesteld op 11 april 1967 en afgekondigd in het Pb EG van 14 april 1967, nr. 71

81. Het aspect is ook opgenomen in de $7^{\mathrm{e}}$ overweging van de BTW-richtlijn. "Het gemeenschappelijke BTW-stelsel moet - zelfs indien de tarieven en vrijstellingen niet volledig worden geharmoniseerd uiteindelijk mededingingsneutraal zijn in die zin dat op het grondgebied van elke lidstaat op soortgelijke goederen en diensten dezelfde belastingdruk rust, ongeacht de lengte van de productieen distributieketen." Zie ook M.E. van Hilten, Over de neutraliteit van de omzetbelasting en het hellend vlak van de uitzonderingen (oratie Amsterdam VU), Deventer: Kluwer 2010, en dan in het bijzonder paragraaf 2 . 
betekenis kan het beginsel van de neutraliteit gezien worden als een stelselbeginsel. In de literatuur onderscheidt men wel tussen interne ${ }^{82}$ en externe neutraliteit, de eerste op het binnenlandse handelsverkeer, de tweede op het niet beïnvloeden van de concurrentieverhoudingen in het grensoverschrijdende handelsverkeer. ${ }^{83}$ Het waarborgen van de externe neutraliteit is mogelijk met behulp van compenserende heffingen op het leveren van goederen en diensten die worden verricht door ondernemers gevestigd buiten de binnenmarkt aan afnemers die in het binnenland zijn gevestigd. Daarnaast wordt door teruggaven van voorbelasting bereikt dat goederen en diensten BTW-vrij de afzetmarkten buiten de binnenmarkt bereiken. Reugebrink brengt naar voren dat de neutraliteit van de omzetbelasting een relatieve aangelegenheid is. ${ }^{84}$ Niet alleen omdat zij zelden is te bereiken, maar ook omdat zij slechts kan worden beschouwd met betrekking tot bepaalde aangewezen verhoudingen. Indien de neutraliteit ten aanzien van bepaalde verhoudingen wordt nagestreefd, kan het resultaat zijn dat met betrekking tot andere verhoudingen verstoringen ontstaan.

Bij grensoverschrijdende goederentransacties tussen belastingplichtigen wordt de externe neutraliteit bereikt door de goederen belastingvrij de grens te laten passeren. Bij prestaties verricht in het binnenland is het van belang dat de BTW uiteindelijk afgewenteld kan worden op de eindverbruiker om zo de interne neutraliteit te bereiken. Als ondernemers slagen in de afwenteling van de BTW worden de concurrentieverhoudingen niet beïnvloed. De aandacht in de BTW gaat dus uit naar het effect van de belastingdruk op de prijsverhoudingen van goederen en diensten. De mate waarin de BTW kan worden doorberekend aan de eindverbruiker is afhankelijk van de prijselasticiteit van de gevraagde hoeveelheid. ${ }^{85}$ Indien vraaguitval optreedt bij een volledige doorberekening van de BTW aan een eindverbruiker, zal de ondernemer een deel (zo niet geheel) van de BTW voor zijn rekening moeten nemen. Uiteraard kan het ook zo zijn dat een eventuele BTW verlaging niet wordt doorberekend aan de eindverbruikers. De ondernemer kan dan de BTW verlaging toevoegen aan zijn winst. $^{86}$

82. Zie J. Reugebrink \& M.E. van Hilten 1997 blz. 22 en 23. Reugebrink en Van Hilten zijn van mening dat het niet zo is dat de BTW de concurrentieverhoudingen nimmer mag verstoren. Neutraliteit is een relatieve aangelegenheid. Maatregelen die de afwentelingsmogelijkheid van de BTW op de consument verkleinen, uit oogpunt van een rechtvaardiger belastingheffing, kunnen aanvaardbaar zijn. Waar het om gaat is dat degelijke maatregelen bewust en openlijk worden getroffen.

83. J. Reugebrink \& M.E. van Hilten 1997, blz. 25 en J. Reugebrink, Enige beschouwingen over de neutraliteit van de omzetbelasting. Zie ook B.J.M. Terra, Omzetbelasting bij grensoverschrijdend verkeer, Deventer: FED 1984, blz. 32 t/m 37 waar interne en externe neutraliteit naast elkaar worden geplaatst. 84. J. Reugebrink, Enkele beschouwingen over de neutraliteit van de omzetbelasting (openbare les Leiden), Deventer: Kluwer 1965, blz. 4.

85. De prijselasticiteit van de gevraagde hoeveelheid geeft de relatieve (procentuele) verandering van de gevraagde hoeveelheid aan als gevolg van een relatieve (procentuele) prijsverandering van dat goed of dienst.

86. Zie de maatregelen ter stimulering van arbeidsintensieve diensten, artikelen $106 \mathrm{t} / \mathrm{m} \mathrm{108,} \mathrm{BTW-}$ richtlijn. Zie ook de Kamervragen en de antwoorden daarop van de Staatsecretaris over het niet (volledig) doorberekenen van tariefverlaging door kappers, Persbericht Ministerie van Financiën 2 februari 2000 en de brief van de Staatsecretaris aan de Tweede Kamer van 31 maart 2000. 
Belastingconcurrentie tussen de lidstaten is voorkomen als consumptiekeuzes van consumenten door de BTW-heffing niet worden beïnvloed. Met belastingconcurrentie wordt in dit kader bedoeld de concurrentieslag tussen de lidstaten om door middel van gunstige belastingmaatregelen buitenlandse investeerders aan te trekken. ${ }^{87}$ De belastingconcurrentie kan er toe leiden dat er in een bepaalde lidstaat te weinig collectieve goederen worden geproduceerd en dat een verdelingspolitiek op nationaal niveau alleen gefinancierd kan worden door belasting te heffen op immobiele factoren. ${ }^{88}$ De BTW beïnvloedt de belastingconcurrentie tussen de lidstaten in beginsel niet. Wel is vereist dat de tarieven tussen de lidstaten niet te veel van elkaar verschillen voor vergelijkbare goederen, omdat anders wel degelijk de keuzes van de consumenten worden beïnvloed. Het gevolg kan zijn dat consumenten hun bestedingen verleggen naar een lidstaat met een lagere BTW druk. In het bijzonder in grensstreken kan deze problematiek een rol spelen. ${ }^{89}$

Het feit, dat tot nu toe in het bovenstaande vooral de nadruk is gelegd op de neutraliteit ten aanzien van bepaalde economische verhoudingen tussen ondernemers wil niet zeggen, dat het vraagstuk zich niet leent voor een juridische benadering. ${ }^{90}$ Terra meent dat de neutraliteit onderdeel uitmaakt van het leerstuk vermijding van dubbele belastingheffing en geeft vervolgens een meer juridische en Europees rechtelijke dimensie aan het leerstuk. ${ }^{91}$ Vanuit dit perspectief bespreekt Terra de problematiek rond de plaats van de prestatie. Volgens Terra spelen een aantal beginselen een rol, namelijk het territorialiteitsbeginsel en het bestemmingslandbeginsel. Het bestemmingslandbeginsel is weer gebaseerd op het baatbeginsel. ${ }^{92}$ Volgens Terra echter is het gelijkheidsbeginsel het overheersende beginsel om dubbele belastingheffing te vermijden in de Europese BTW. Binnen de BTW krijgt het gelijkheidsbeginsel een Europese dimensie. De BTW is in elke lidstaat een

87. R.H.M.J. Offermanns gaat nader in op verschillende onderverdelingen van het begrip 'concurrrentieverschillen'. Hij gaat onder meer in op globale en specifieke concurrentieverschillen tussen de lidstaten. Zie R.H.M.J. Offermanns, Het ondernemerbegrip in Europees perspectief (diss. Tilburg) 1996, blz. $284 \mathrm{t} / \mathrm{m} 286$.

88. Zie A.H.M. Daniëls, Soevereine zaken (oratie: Maastricht), Deventer: Kluwer 1998, met name blz. 14 en 15 waar hij verduidelijkt waar belastingconcurrentie toe kan leiden volgens de economische speltheorie.

89. Ook op het terrein van nieuwe vervoermiddelen kunnen tariefverschillen een rol spelen. Zie Hof 18 november 2010 (nr. C-84/09, X, V-N 2010/62.20, NTFR 2010/2841) over het omzeilen van de regeling voor nieuwe vervoermiddelen.

90. J. Reugebrink 1965, blz. 4 en 5. Zie tevens A.J van Doesum 2009, blz. 32 e.v. waar hij aangeeft dat het neutraliteitsbeginsel tevens (naast een economische dimensie) een bijzondere verschijningsvorm is van het gelijkheidsbeginsel. Zie ook B. Terra \& J. Kajus, A Guide to the European VAT Directives, Volume 1, Introduction to European VAT and other Indirect Taxes 2006, blz. 418-422. Zij verduidelijken dat de neutraliteit van de BTW een complex vraagstuk is, met een juridische dimensie om een nietdiscriminerende behandeling voor de wet te waarborgen, een economische dimensie om de keuze van de productiemiddelen te optimaliseren, en een derde, de mededinging betreffende dimensie om de markt niet te verstoren.

91. B.J.M. Terra 1989, blz. 5.

92. Zie voor een verdere analyse van het baatbeginsel in relatie tot het bestemmingslandbeginsel B.J.M. Terra 1989, blz. 10 en 11. 
nationale belasting gebaseerd op het territorialiteitsbeginsel, bestemmingslandbeginsel en het gelijkheidsbeginsel op nationaal niveau. Maar dit neemt niet weg dat de BTW op de eerste plaats een Europese belasting is. Dit betekent volgens Terra, dat indien het territorialiteitsbeginsel of het bestemmingslandbeginsel op nationaal niveau tot belastingheffing leiden, de gelijkheid tussen Europese belastingplichtigen bepalend dient te zijn of een transactie (nogmaals) kan worden belast. ${ }^{93}$

In deze paragraaf is de definitie van het begrip neutraliteit vanuit economisch perspectief behandeld (stelselbeginsel). Paragraaf 3.4.1 komt terug op de nadere precisering van de betekenis van het neutraliteitsbeginsel vanuit (Europees) juridisch perspectief. In paragraaf 4.4.4 komt aan de orde de wijze waarop de begrippen neutraliteit, gelijkheidsbeginsel en analoge toepassing van de regelgeving zich tot elkaar verhouden. De hoofdstukken $5 \mathrm{t} / \mathrm{m} 12$ zullen ter bestemde plaatse de betekenis van het neutraliteitsbeginsel in de jurisprudentie nader onderzoeken, om vervolgens in hoofdstuk 13 te verhelderen de relatie tussen de neutraliteit en het rechtskarakter van de BTW.

\subsubsection{Oorzaken verstoring van de externe neutraliteit}

Bij belastingherzieningen binnen de Europese Unie vormt het handhaven van de externe neutraliteit een belangrijk uitgangspunt. Een belastingsysteem dat als effect heeft dat de externe neutraliteit wordt verstoord brengt hoge economische kosten met zich mee. Deze kosten worden veroorzaakt doordat een dergelijk systeem een logische en efficiënte lokalisering van economische activiteiten verstoort. ${ }^{94}$ Externe neutraliteit is één van de maatstaven die van belang is bij het bepalen of een belastingsysteem goed dan wel slecht functioneert. ${ }^{95}$

Perfecte externe neutraliteit kan haaks staan op andere belangrijke doelstellingen, zoals het handhaven van nationale controle op het belastingsysteem, aangezien de externe neutraliteit nu eenmaal om uitvoeringshandelingen vraagt bij het binnenkomen of verlaten van goederen en diensten aan de nationale grenzen. ${ }^{96}$ In dit kader

93. B.J.M. Terra 1989, blz. 12.

94. De OECD kwam in 2006 tot de conclusie dat tekortkomingen in BTW-systemen de economische groei belemmeren. In OECD verband zijn dan ook de volgende beginselen geformuleerd waar een BTW-systeem aan zou moeten voldoen: neutraliteit, efficiëntie, zekerheid en eenvoud, effectiviteit, redelijkheid en flexibiliteit. Zie Centre For Tax Policy and Administration (CPTA) of the OECD, Application of Consumption Taxes to Internationally Traded Services and Intanglibles - Principles, www.uscib.org/docs/principles.pdf. Zie ook over deze problematiek in OESO verband H.A. Kogels, Modernisering van de BTW, MBB 2008/03.

95. Voor een analyse van de externe neutraliteit in de VPB, zie S. Cnossen, Om de toekomst van de vennootschapsbelasting in de Europese Unie, WFR 1996/871.

96. Voor een verdere relativering van het neutraliteitsbeginsel in algemene zin, zie A.H.R.M. Denie 1987, blz. 45: “De indirecte vorm, de vrijstellingen in het systeem en het draagkrachtbeginsel doen het neutraliteitsbeginsel minder uit de verf komen dan wanneer het neutraliteitsbeginsel de alleenzeggenschap zou hebben. Het neemt niet weg dat er geen omzetbelasting is geweest welke binnen haar bestek zo zuiver als de huidige het neutraliteitsprincipe uitwerkt." 
dringt het subsidiariteitsbeginsel zoals is te vinden in artikel 5 VEU (voorheen 5 EG) zich op de voorgrond. Lid 3 van artikel 5 VEU luidt:

"Krachtens het subsidiariteitsbeginsel treedt de Unie op de gebieden die niet onder haar exclusieve bevoegdheid vallen, slechts op indien en voor zover de doelstellingen van het overwogen optreden niet voldoende door de lidstaten centraal, regionaal of lokaal niveau kunnen worden verwezenlijkt, maar vanwege de omvang of de gevolgen van het overwogen optreden beter door de Unie kunnen worden bereikt. (...)"

Tussen externe neutraliteit en het subsidiariteitsbeginsel bestaat een balans. Denkbaar zijn situaties waarbij het noodzakelijk kan zijn om genoegen te nemen met een lagere graad van externe neutraliteit. ${ }^{97}$ Daarbij komt direct de vraag op wat de betekenis is van het subsidiariteitsbeginsel voor het recht en dan in het bijzonder voor de uitleg van de BTW-regelgeving. Diverse schrijvers zijn van mening dat we te maken hebben met een politiek beginsel. ${ }^{98}$ Zoals in de vervolghoofdstukken blijkt, is het subsidiariteitsbeginsel van beperkte betekenis voor de uitleg van de BTW-regels, maar laat het aan dit beginsel grenzende evenredigheidsbeginsel zich wel degelijk gelden. Wel zal duidelijk zijn dat het formuleren van nationale regels zonder Europees rechtelijke basis de neutraliteit kan verstoren. Afweging tussen het formuleren van regels op Europees niveau dan wel op nationaal niveau vormt bij de regelgeving van belastingen op inkomen en winst een serieuzer probleem dan bij een consumptiebelasting. Zoals in de vorige paragraaf naar voren is gebracht speelt belastingconcurrentie bij consumptiebelastingen een beperkte rol in vergelijking met belastingen op inkomen en winst. ${ }^{99}$ In dit kader is van belang de constatering dat de toepassing van het subsidiariteitsbeginsel tot gevolg kan hebben dat genoegen moet worden genomen met een lagere graad aan externe neutraliteit. De conclusie dat een belastingsysteem goed functioneert als de externe neutraliteit perfect is, kan dan ook niet zonder meer worden getrokken. Het subsidiariteitsbeginsel kan een dergelijke verstoring rechtvaardigen. In de jurisprudentie van het

97. Zie voor een beschouwing over de vraag op welke wijze het neutraliteitsbeginsel zich verhoudt tot het subsidiariteitsbeginsel, Stephen Smith, Subsidiarity and Neutrality in European tax Policy: Economic Considerations, in: de EFS uitgave Neutrality and subsidiarity in taxation, Stephen Smith \& René Barents, London/The Hague/Boston: Kluwer Law Internatinal 1996. Vooral de voorbeelden op blz. 8 e.v. en blz. 24

98. R. Barentz stelt: "The subsidiarity principle is nothing more than a political slogan. In legal terms this principle could be qualified as a pollution of Community Law. Because of its inherent vagueness it can be used in favor of or against any Community action, depending on the attitude onetakes vis-á-vis the integretation process and he continuous transfer of sovereignty that this process implies. (...) It would seem, therefore, that the principle of subsidiarity is too vague to have any operational significance in the field of Community litigation." R. Barents, The Priciple of Subsidiarity and the Court of Justice, in: de EFS uitgave Neutrality and Subsidiarity in Taxation, London/The Hague/Boston: Kluwer Law International 1996. Zie verder ook P.J.G. Kapteyn \& P. VerLoren van Themaat 2003, blz. 117 waar zij stellen dat het een duidelijk politiek beginsel is.

99. In de BTW is de discussie echter niet geheel afwezig. Zie bijvoorbeeld de discussie rond de ruime toepassing van de vrijstelling van het beheer van gemeenschappelijke beleggingsfondsen (artikel 135, lid 1, sub g, BTW-richtlijn) in Luxemburg, Ierland en België. Deze landen stellen ingehuurd vermogensbeheer vrij, in tegenstelling tot Nederland. De in Nederland gevestigde pensioenfondsen pleiten dan ook voor een gelijke toepassing in Nederland, zie Financieel Dagblad van 3 september 2007. 
Hof op het terrein van de BTW is een dergelijke afweging (nog) niet expliciet aan de orde geweest.

Een situatie van niet-heffing van BTW is even ernstig is als een situatie van dubbele heffing. Beide situaties verstoren de concurrentieverhoudingen en duperen belanghebbenden.

Het vervolg van deze paragraaf schetst een aantal situaties waarbij de externe neutraliteit wordt verstoord. Deze opsomming is niet uitputtend. Enkele situaties zullen terugkeren bij de behandeling van de jurisprudentie in de hoofdstukken $6 \mathrm{t} / \mathrm{m} 12$.

Hierna bespreek ik, gedeeltelijk aan Ruppe ontleende, verstoringen van de externe neutraliteit: ${ }^{100}$

1. Een beperkt territorium waar de BTW-regelgeving geldt

Zoals in paragraaf 2.3.1 naar voren is gebracht, bestrijkt het territorium waar het recht om BTW te heffen geldt, niet de volledige Europese Unie. Het beperken van het geografisch toepassingsgebied waarbinnen de BTW-regelgeving van toepassing is, leent zich om bepaalde economische doelstellingen te verwezenlijken, zoals de stimulering van het toerisme in een gebied. Kennelijk wordt verwacht dat dergelijke inperkingen van het geografisch toepassingsgebied van de BTWheffing geen belangrijke invloed heeft op de concurrentieverhoudingen, dan wel de verstoring wordt uit politieke overwegingen getolereerd. ${ }^{101}$

Het territorium speelt in verschillende bepalingen van de BTW-richtlijn een rol. Bijvoorbeeld in de artikelen 2, 9, lid 2 en 71, BTW-richtlijn. Verder in de bepalingen van de plaats van dienst; bijvoorbeeld artikel 59, BTW-richtlijn regelt dat bepaalde diensten verricht aan niet-belastingplichtige afnemers die gevestigd zijn buiten de Europese Unie niet belast zijn. Verder kent artikel 169, sub c, BTWrichtlijn een recht op aftrek van voorbelasting toe indien bepaalde financiële prestaties worden verricht aan afnemers die gevestigd zijn buiten de Europese Unie of wanneer de handelingen rechtstreeks samenhangen met goederen die bestemd zijn om te worden uitgevoerd uit de Europese Unie. Ook indien een buitenlandse ondernemer een verzoek om teruggave doet van in rekening gebrachte omzetbelasting maakt het uit of hij binnen, dan wel buiten de Europese Unie is gevestigd. De Dertiende richtlijn is namelijk van toepassing als hij is

100. H.G. Ruppe 1983, blz. 121 e.v. Zie verder ook de consultation paper van 5 januari 2007 van de Commissie. In het desbetreffende document worden enkele verstoringen geschetst en mechanisme om verstoringen ten gevolge van dubbele belastingheffing op te lossen.

101. Zie het onderzoek van de Europese Rekenkamer. Dit onderzoek was erop gericht om na te gaan voor welke gebieden of in welke situaties een bijzondere regeling geldt die een belangrijke financiële uitwerking heeft op de traditionele eigen middelen van de Gemeenschap. Rekenkamer, Speciaal verslag, nr. 2/93 over het douanegebied van de Gemeenschap en daarmee verband houdende regelingen van het handelsverkeer vergezeld van de antwoorden van de Commissie, $\mathrm{Pb}$ C 347/1. 
gevestigd buiten de Europese Unie. ${ }^{102}$ Op deze plaats volsta ik met de vaststelling dat de beperking van het territorium gevolgen kan hebben voor de externe neutraliteit.

2. Verschillende definities van het leveringsbegrip en de plaats van levering Indien het leveringsbegrip van artikel 14, lid 1, BTW-richtlijn in de verscheidene lidstaten niet op dezelfde wijze is gedefinieerd, kan er dubbele heffing dan wel niet-heffing ontstaan bij grensoverschrijdende transacties. Denkbaar zijn dan situaties waarbij de ene lidstaat uitgaat van een levering van een goed terwijl de andere lidstaat de transactie als een dienst duidt. ${ }^{103}$ Gezien het gegeven dat de plaatsbepaling van leveringen in de BTW-richtlijn (artikel 31) door een andere regelgeving wordt bepaald dan bij diensten (artikel 43 e.v.) is een verstoring van de externe neutraliteit niet uit te sluiten.

Het Hof heeft in het Forwarding Enterprise Safe-arrest ${ }^{104}$ gekozen voor een economische invulling van het leveringsbegrip. Deze benadering is volstrekt logisch. Een definitie van het begrip levering waarbij het civiele recht het uitgangspunt zou vormen, werkt ongetwijfeld verstorend in geval van grensoverschrijdende transacties, gezien de beperkte harmonisatie van het civiele recht. Door op basis van een economisch uitgangspunt het leveringsbegrip in te vullen, voorkomt het Hof voor een dergelijke verstoring. Verstoringen van de externe neutraliteit zijn echter niet geheel te voorkomen. ${ }^{105}$

3. Toepassen van verschillende uitgangspunten bij de bepaling van de plaats van dienst De heffing van BTW bij grensoverschrijdende diensten kan plaatsvinden volgens de volgende criteria:

- Vestigingsplaats van de dienstverrichter

De dienst is daar verricht waar de dienstverrichter is gevestigd. ${ }^{106}$ Toepassing van dit uitgangspunt komt in feite neer op toepassing van het oorsprongslandbeginsel.

102. De Achtste richtlijn is ingetrokken en vervangen door de richtlijn van 12 februari 2008 2008/9/EG, $\mathrm{Pb} 20$ februari 2008, L 44/23. De nieuwe richtlijn is van kracht vanaf 1 januari 2010 en introduceert een elektronische procedure van teruggave die sneller zal zijn dan het systeem gebaseerd op de Achtste richtlijn. Dit heeft als gevolg dat het aangestipte probleem per 1 januari 2010 anders is komen te liggen tussen lidstaten dan in de verhouding met derde landen.

103. Zie bijvoorbeeld Hof 22 december 2010, nr. C-277/09, RBSD, V-N 2011/82, NTFR 2011/82. Paragraaf 8.2 behandelt het arrest nader.

104. Hof 8 februari 1990, nr. C-320/88, Forwarding Enterprise Safe, Jur. 1990, blz. I-285. Het Hof besliste dat als levering van een goed in de zin van artikel 14, lid 1, BTW-richtlijn moet worden beschouwd de overdracht van de macht om als eigenaar over een lichamelijke zaak te beschikken, ook indien geen juridische eigendomsoverdracht plaatsvindt. Zie ook voor een analyse van het begrip levering naar aanleiding van recente jurisprudentie van de HR inzake roerende zaakconstructies, J.T. Sanders, Zijn we Safe?, Btw-Brief nr. 4 2008, blz. 3.

105. Zie voor voorbeelden de consultation paper van de Commissie van 5 januari 2007. Als voorbeeld wordt genoemd het verschil in uitleg door de lidstaten van leasing (levering dan wel dienst). 106. Zie M.M.W.D. Merkx, De woon- en vestigingsplaats in de btw (diss. Tilburg) 2011. 
- Plaats waar de activiteit wordt verricht

Het kan moeilijk zijn om een dienst te belasten op de plaats waar deze wordt verricht. En wel in een tweetal opzichten. A) Controletechnisch moet een lidstaat die heffingsbevoegd is, kunnen signaleren dat binnen haar jurisdictie een dienst wordt verricht (bij circussen kan men bijvoorbeeld met circus en al vertrokken zijn voordat de BTW-heffing is geëffectueerd). B) Gezien de aard van sommige diensten kan het lastig zijn om eenduidig vast te stellen waar de dienst precies wordt verricht. ${ }^{107}$

- $\quad$ Plaats waar de afnemer van de dienst is gevestigd Indien men aanknoopt bij de vestigingsplaats van de afnemer kunnen zich ook verscheidene problemen voordoen. Bijvoorbeeld indien de afnemer een niet-ondernemer is. Het is niet eenvoudig om vast te stellen dat een nietondernemer een dienst afneemt. Verder is het niet altijd even eenduidig te bepalen wie de dienst daadwerkelijk afneemt. Indien de afnemer verbruikt in het land van vestiging komt dit uitgangspunt neer op toepassing van het bestemmingslandbeginsel.

- Plaats van verbruik van de dienst

Dit criterium is volledig in lijn met het bestemmingslandbeginsel. Het kan echter in een aantal gevallen moeilijk zijn om vast te stellen waar het verbruik van een dienst plaatsvindt. Ten eerste moet dan duidelijk zijn wat onder 'verbruik' dient te worden verstaan en ten tweede moet de lidstaat waar het verbruik plaatsvindt in staat zijn om het verbruik te constateren.

De BTW-richtlijn lost de plaatsbepaling van diensten op in de artikelen $43 \mathrm{t} / \mathrm{m} 59$ ter. Dit wordt bereikt door voor diensten binnen de Europese Unie een sluitend systeem te geven. Dat neemt niet weg dat in geval van transacties met derde landen verstoringen kunnen optreden. Indien namelijk in de betrokken landen bij de heffing wordt uitgegaan van een verschillend beginsel (oorsprongs- dan wel bestemmingslandbeginsel) kan de externe neutraliteit worden verstoord.

Verder is het de vraag of deze problematiek binnen de EU voldoende is opgelost. De artikelen $43 \mathrm{t} / \mathrm{m} 59$ ter, BTW-richtlijn hebben als functie het toewijzen van heffingsbevoegdheid aan een bepaalde lidstaat. In dit opzicht is een parallel te trekken met de verdragen ter voorkoming van dubbele belastingheffing bij de directe belastingen. De genoemde artikelen in de BTW-richtlijn zouden de toewijzing van heffing op een volledige wijze moeten regelen. In de praktijk blijken echter allerlei verstoringen op te treden. Door bijvoorbeeld een verschillende uitleg van de begrippen in de BTWregels kunnen de concurrentieverhoudingen worden verstoord. ${ }^{108}$ Paragraaf 4.3 (communautair rechtsbegrip dan wel autonoom begrip van gemeenschapsrecht)

107. Zie bijvoorbeeld het RAL-arrest. Het Hof besliste dat de exploitatie van speelautomaten als vermakelijkheidsactiviteit belast is daar waar de activiteit materieel wordt verricht (d.w.z. het gebruiken van de speelautomaten), Hof 12 mei 2005, nr. C-452/03, V-N 2005/32.26, NTFR 2005/728. 108. Zie A.H. Bomer \& H.W.M. van Kesteren, De houdstermaatschappij: geknipt voor de BTW, WFR 1999/6329, blz. 264. Toegespitst op de uitleg van de begrippen 'belastingplichtige' en 'verbruik' en de doorwerking van deze uitleg op artikel 59 ter, BTW-richtlijn. 
en hoofdstuk 8 (De rationaliteit van de plaats van dienst) werken deze problematiek nader uit.

De regels die de diensten aan de ene of de andere lidstaat toewijzen zijn per 1 januari 2010 veranderd. ${ }^{109}$ Wanneer de afnemer van de dienst een ondernemer is komt de nieuwe regelgeving in hoofdlijnen neer op het lokaliseren van de plaats van de dienst daar waar de afnemer is gevestigd. In geval van diensten verricht aan nietbelastingplichtigen blijft de plaats van de dienst veelal de lidstaat waar de dienstverrichter is gevestigd. ${ }^{110}$

4. Verschillende behandeling van binnenlandse en buitenlandse belastingplichtigen Voor de externe neutraliteit tussen de lidstaten is het van fundamenteel belang dat in het buitenland gevestigde belastingplichtigen op dezelfde wijze worden behandeld als in het binnenland gevestigde belastingplichtigen. De gelijkheid moet zowel in het materiële recht als in het formele recht zijn doorgevoerd. Binnen de Europese Unie is dit op grond van het Werkingsverdrag vanzelfsprekend. Dat neemt niet weg dat sommige lidstaten in het buitenland gevestigde belastingplichtigen regelmatig discrimineren door het stellen van formele eisen. ${ }^{111}$ Voor het bereiken van externe neutraliteit is het van belang dat de gelijkheid zowel wordt doorgevoerd bij het belasten van de output, als bij het teruggeven van voorbelasting. Zoals in hoofdstuk 12 zal blijken, is dit een aspect dat geregeld tot procedures heeft geleid.

A. Output buitenlandse ondernemingen

Praktische en BTW technische problemen duiken op in de situatie dat een in een bepaalde lidstaat gevestigde ondernemer in twee of meer lidstaten omzet genereert. Ten eerste kan BTW-heffing plaatsvinden door aan te knopen bij het bestaan van een vaste inrichting. ${ }^{112}$ Ten tweede kan men de ondernemer in het

109. Richtlijn 2008/8/EG van 12 februari 2008, Pb EU van 20 februari 2008, L 44/11.

110. Zie voor een beschrijving van de nieuwe regelgeving A.J. van Doesum, H.W.M. van Kesteren, G.J. van Norden en I.H.T. Reiniers, De nieuwe regels voor de plats van dienst in de BTW, WFR 2008/279. Zie verder M.E. van Hilten \& J.B.J. Boender, BTW-pakket 2010, Plaats van dienst, teruggaaf en antifraude-maatregelen in de btw vanaf 2010, Deventer: Kluwer 2010. Zie tevens M.M.W.D. Merkx, De woon- en vestigingsplaats in de btw (diss. Tilburg) 2011.

111. Zie bijvoorbeeld Hof 11 juni 1998, nr. C-361/96, Minerales, V-N 1998/39.42. De Duitse Belastingdienst eiste van het in Frankrijk gevestigde Minerales de originele factuur bij een verzoek om teruggaaf op grond van de Achtste richtlijn. Een dergelijke eis wordt niet gesteld aan in Duitsland gevestigde belastingplichtige die voorbelasting terugvragen. Het Hof haalde een streep door dit onderscheid ten gunste van Minerales. Zie voor een bespreking van het arrest paragraaf 12.3.1.3.

112. Waarbij het overigens door de belastingadministratie wel mogelijk moet zijn om tot vaststelling van een vaste inrichting over te gaan. Zie Pasquale Pistone, Fixed establishment and permanent establishment, VAT Monitor 1999, May/June, blz. 101. Gezien de jurisprudentie van het Hof op het terrein van het begrip vaste inrichting is de schrijver van mening dat de lidstaten toe moeten naar een nieuw concept. Dit is vereist gezien de globalisering van de economie en de technologische ontwikkelingen. Pistone pleit voor een snellere vaststelling van een vaste inrichting gezien de veronderstelling dat dan meer recht wordt gedaan aan het bestemmingslandbeginsel. Pistone pleit tevens voor overleg op dit punt tussen specialisten op het terrein van de directe belastingen en de BTW. Zie verder de paragrafen 8.3 en 8.4 
land van omzet als in het binnenland gevestigde belastingplichtige registreren. Verder kan belastingheffing worden verzekerd door te eisen dat gebruik wordt gemaakt van een zogenoemde fiscaal vertegenwoordiger. ${ }^{113}$ Ook kan de BTWheffing plaatsvinden door het belastbaar feit toe te wijzen aan de lidstaat waar de afnemer is gevestigd. Eventueel kan daaraan gekoppeld de verschuldigdheid van de belasting worden verlegd naar de lidstaat van de afnemer. ${ }^{114}$

B. Recht op aftrek voorbelasting buitenlandse ondernemingen

De teruggave van voorbelasting aan belastingplichtigen die in een ander land zijn gevestigd is geregeld in de Achtste (tot 1 januari 2010) en Dertiende richtlijn. Binnen de Europese Unie loopt echter de implementatie van deze richtlijnen uiteen. In een aantal lidstaten gelden beperkingen wat betreft het minimum bedrag van de teruggave en/of de tijdsperiode waarin het verzoek van de teruggave moet zijn ingediend. ${ }^{115}$ Verder eisen een aantal landen (bijvoorbeeld Duitsland) wederkerigheid. ${ }^{116}$ Dat wil zeggen dat alleen BTW wordt teruggeven aan de in het buitenland gevestigde ondernemer, indien de Staat waar hij is gevestigd ook een dergelijke teruggaaf regeling kent voor belastingen die vergelijkbaar zijn met de Europese BTW. De uiteenlopende implementaties van de Achtste en Dertiende richtlijn komen uiteraard de gewenste externe neutraliteit niet ten goede.

Te verwachten is dat de nieuwe richtlijn die de Achtste richtlijn heeft vervangen deze verstoring zal verkleinen. De nieuwe richtlijn is van kracht vanaf 1 januari 2010 en introduceert een elektronische procedure van teruggave voor belasting plichtigen die in een andere lidstaat zijn gevestigd dan de lidstaat van teruggaaf. Deze elektronische procedure zal sneller zijn dan het systeem dat is gebaseerd op de Achtste richtlijn. ${ }^{117}$

Niet alleen een verschillende implementatie kan een verstorende invloed hebben op de concurrentieverhoudingen. Ook de uitleg van de regelgeving tussen de lidstaten kan de concurrentieverhoudingen beïnvloeden. Indien in de praktijk

113. Artikel 24d van het Uitv. besl. OB 1968 stelt het gebruik van een fiscaal vertegenwoordiger met algemene vergunning verplicht in geval van verkoop op afstand (in de zin van artikel 5a Wet OB).

114. Dit kan aan de orde zijn indien een in Nederland gevestigde ondernemer een dienst afneemt van een ondernemer die is gevestigd in het buitenland. Op grond van artikel 6 Wet OB zou de in het buitenland gevestigde ondernemer in Nederland BTW op aangifte moeten voldoen. Echter, artikel 12, derde lid van de Wet OB verlegt de verschuldigdheid van de BTW naar zijn afnemer in Nederland. 115. Nederland gaat als één van de weinige landen in de Europese Unie uit van een periode van vijf jaar. Dit is gebaseerd op het Voorschrift inzake het ambtshalve verlenen van verminderingen en teruggaven (Besluit van 25 maart 1991, nr. DB 89/735, zoals dit laatstelijk is gewijzigd bij het besluit van 3 juni 1996, nr. AFZ 96/1125M). Het merendeel van lidstaten gaan uit van een periode van één jaar waarbinnen het verzoek moet zijn ingediend.

116. Hof 7 juni 2007, nr. C-335/05, RLP, V-N 2007/28.20. Het Hof gaat nader in op de mogelijke voorwaarde van wederkerigheid bij BTW teruggaaf aan niet EU-ondernemers zoals die kan worden gelezen in artikel 2, lid 2, Dertiende richtlijn. In de desbetreffende procedure is beslist dat het voor Duitsland niet mogelijk is om de voorwaarde van wederkerigheid te stellen op grond van de verplichting die is te vinden in artikel II, lid 1, GATS (General Agreement on Trade in Services). 117. De Achtste richtlijn is ingetrokken en vervangen door de richtlijn van 12 februari 2008 2008/9/EG, $\mathrm{Pb} 20$ februari 2008, L 44/23. 
niet in alle lidstaten een zelfde wijze van teruggaaf kennen - zoals de teruggaaf naar rato van belaste en vrijgestelde omzetten - dan leidt dat tot verstoring van de concurrentieverhoudingen. ${ }^{118}$

\section{Verschillende tarieven in de lidstaten voor vergelijkbare producten}

Gegeven bepaalde minima hanteren de lidstaten verschillende tarieven. ${ }^{119}$ Het gevaar dat de tariefverschillen tussen de lidstaten leidt tot verstoringen van de concurrentieverhoudingen tussen ondernemers is toegenomen met het verdwijnen van de fiscale grenzen. ${ }^{120}$ Dat geldt voornamelijk voor ondernemers die presteren aan particulieren. Particulieren hebben namelijk vanaf 1 januari 1993 vooral te maken met het tarief dat geldt in de lidstaat waar zij hun aankopen doen. Recent heeft de discussie over de tarieven een nieuwe variant gekregen, namelijk de vraag op welke wijze belastingvrije aankopen (en/of tariefvoordelen) via internet de concurrentieverhoudingen beïnvloeden. Uit onderzoek blijkt dat deze technische ontwikkelingen de vraag naar producten aanzienlijk kunnen beïnvloeden. ${ }^{121}$ Op een aantal plaatsen in de regelgeving zijn maatregelen te

118. Zie Hof 13 juli 2000, nr. C-136/99, Monte Dei Paschi di Siena, V-N 2000/50.22, FED 2000/615. Het Hof besliste dat een buitenlandse bank aftrekgerechtigd is op basis van pro-rata in de lidstaat van vestiging, maar er moet wel rekening worden gehouden of de desbetreffende handelingen in de lidstaat van teruggaaf wel recht op aftrek geven.

119. Richtlijn 92/77/EEG, Pb EG 31 oktober 1992. Deze richtlijn is opgegaan in de BTW-richtlijn. De tarieven (en de diverse goedkeuringen aan verscheidene lidstaten) is te vinden in de artikelen $96 \mathrm{t} / \mathrm{m}$ 130, BTW-richtlijn. In beginsel mogen drie tarieven worden gehanteerd. Namelijk één algemeen tarief van minimaal $15 \%$ en één of twee verlaagde tarieven van minimaal 5\%. Deze verlaagde tarieven mogen uitsluitend worden toegepast op bepaalde goederen en diensten. Echter op deze uitgangspunten zijn in de eerder genoemde artikelen van de BTW-richtlijn een scala aan uitzonderingen te vinden.

120. Uit de Considerans bij de Eerste richtlijn blijkt dat in het begin vooral de harmonisatie gericht was op het introduceren van de BTW en het gelijktijdig afschaffen van het cumulatieve cascadestelsel in de diverse lidstaten. Zolang de fiscale grenzen tussen de lidstaten niet waren opgeheven hoefde ook de tarieven niet te worden geharmoniseerd. Zie meer uitgebreid A. van Dongen 2007, blz. 78, 90 e.v.

121. Zie het onderzoek van de Universiteit van Chicago naar het effect op de vraag naar goederen indien de elektronische handel op dezelfde wijze zou worden belast met een consumptiebelasting als de niet elektronische handel. Uit analyse bleek dat 20\% van de internetgebruikers in de Verenigde Staten recentelijk een aankoop had gedaan via internet met een gemiddelde waarde van 300 dollar. Uit het onderzoek bleek dat de consumenten eerder geneigd waren goederen via internet te kopen indien de belasting in de staat waar zij woonden hoger was. In grote stedelijke gebieden was dit effect het duidelijkst. Elke procent verhoging van verkoopbelasting vergrootte de kans dat de internetgebruikers een elektronische aankoop deden met 2.9\%. In metropolen als New York en Los Angeles waar de belasting op verkopen hoger is dan waar ook in de Verenigde Staten, vergrootte elke procent verhoging van de consumptiebelasting de kans op een elektronische aankoop met $8 \%$, terwijl het bestede bedrag $11,7 \%$ hoger werd. Uit het onderzoek bleek ook dat deze verhogingen niet het gevolg konden zijn van een hogere graad van informatietechnologische kennis en ervaring. Ten slotte bleek uit het onderzoek dat de handel op internet met $23 \%$ zou dalen als de overheid de elektronische aankopen een belasting van $5 \%$ zou opleggen. Als de thans geldende consumptiebelasting in alle Amerikaanse staten zou gaan gelden voor de handel op internet zou het aantal onlinekopers $24 \%$ kleiner worden en zouden de verkoopcijfers met maar liefs 30\% dalen. Zie voor de onderzoeksresultaten verder Harvard Business Review, augustus 1999. Uiteraard moet bij de interpretatie van deze onderzoek gegevens in de $\rightarrow$ 
vinden om concurrentieverstoringen ten gevolge van tariefverschillen tegen te gaan. Zie bijvoorbeeld de bijzondere regeling voor afstandverkopen. ${ }^{122}$

6. Bepalingen in de BTW-richtlijn die de lidstaten vrijheid geven om zelf nader in te vullen De lidstaten hebben op grond van de BTW-richtlijn de keuze om bepaalde regelingen al dan niet te implementeren (onder meer de zogenoemde kan-bepalingen). Zo zijn de lidstaten niet verplicht om op grond van artikel 11, BTW-richtlijn het fenomeen fiscale eenheid in hun regelgeving te implementeren. ${ }^{123}$

Een aantal oorzaken van verstoring van de externe neutraliteit zijn hierboven aangestipt. Deze inventarisatie pretendeert niet uitputtend te zijn. ${ }^{124}$ Zoals ik in het begin van deze paragraaf naar voren bracht, is de mate van externe neutraliteit een van de maatstaven aan de hand waarvan men de vraag kan beoordelen of een belastingsysteem goed functioneert. Het Hof 'lost' in een aantal arresten verstoringen van de externe neutraliteit op (zie onder meer hoofdstuk 8 en paragraaf 12.3.1.3). In mijn onderzoek gaat het erom helder te krijgen wat de rol van algemene rechtsbeginselen is in het probleemveld van de externe neutraliteit. Zoals in de vervolghoofdstukken zal blijken, laten de algemene rechtsbeginselen zich bij bepaalde vormen van verstoring van de externe neutraliteit krachtig gelden.

Uit de bovenstaande, beperkte, inventarisatie blijkt dat de verstoringen voor een deel zijn terug te voeren tot een verschillende uitleg van de BTW-regels door de lidstaten, dan wel door een beperkte harmonisatie van de BTW-regelgeving op Europees niveau. ${ }^{125}$

$\rightarrow$ beschouwing worden betrokken dat in de Verenigde Staten in het geheel geen consumptiebelasting wordt geheven inzake aankopen via internet. Duidelijk is echter dat belastingvrijdom dan we tariefverschillen de concurrentieverhoudingen beïnvloeden en dat nieuwe technische ontwikkelingen het voor de consument eenvoudiger maken om deze mogelijkheden te benutten.

122. Het gaat om situaties dat een particulier of daarmee gelijkgestelde goederen bestelt bij een ondernemer in een andere lidstaat die de goederen bij hem bezorgt of laat bezorgen (bijvoorbeeld postorderverkopen) In een dergelijk geval wordt de levering gesitueerd in de lidstaat waar de afnemer is gevestigd. Met als gevolg dat het tarief van de lidstaat van de afnemer van toepassing is. Voor de voorwaarden van de regeling zie de artikelen 33 en 34, BTW-richtlijn.

123. Andere voorbeelden zijn: artikel 59 bis, BTW-richtlijn ter bepaling van de plaats van dienst, de interne dienst zoals is neergelegd in artikel 27, BTW-richtlijn, de overgangsregeling met betrekking tot bepaalde vrijstellingen en verlaagde tarieven van de artikelen $109 \mathrm{t} / \mathrm{m}$ 130, BTW-richtlijn en in een iets andere vorm de mogelijkheid die artikel 80, BTW-richtlijn biedt aan de lidstaten om maatregelen inzake fraude en misbruik te nemen. In de hoofdstukken $5 \mathrm{t} / \mathrm{m} 12$ behandel ik verscheidene voorbeelden van deze regelingen en zet ik deze af tegen de werking van de algemene rechtsbeginselen. Zie ook R.H.M.J. Offermans, Het ondernemersbegrip in Europees perspectief (diss. Tilburg), blz. 291 en 292. Hij is van mening dat de diverse kan-bepalingen concurrentievervalsing tot gevolg hebben.

124. Zie ook Van Kesteren \& Soltysik, Misbruik en de onvoltooide harmonisatie, WFR 2007/481. Alhoewel in dit artikel de nadruk ligt op misbruik situaties, komt ook naar voren de gevolgen van zogenoemde kan-bepalingen, overgangsregelingen, niet of onjuiste implementatie en interpretatieverschillen tussen de lidstaten.

125. Zie voor een uitgebreide analyse A. van Dongen, De harmonisatie van de BTW (diss. Tilburg), Amersfoort: Sdu Uitgevers 2007. 


\section{$2.5 \quad$ Conclusies}

In dit hoofdstuk zijn klassieke BTW-beginselen beschreven, namelijk het verbruiksbeginsel, territorialiteitsbeginsel, bestemmingslandbeginsel, oorsprongslandbeginsel, en het neutraliteitsbeginsel.

Het verbruiksbeginsel verwijst naar het rechtskarakter van de BTW. In paragraaf 2.2 heb ik enkele arresten van het Hof geanalyseerd waarin het rechtskarakter van de BTW speelt, zonder dat het Hof overigens dit woord gebruikt. Uit deze jurisprudentie is de gevolgtrekking te maken, dat het in de BTW gaat om het belasten van verbruik. Verbruik is gelijk te stellen aan het genieten van voordeel. Wat precies onder 'voordeel genieten' is te verstaan is niet geheel duidelijk. Wel is duidelijk, dat 'verbruik' beperkter wordt uitgelegd dan het begrip 'consumptie' in de economische wetenschap. Ook heeft het Hof aangegeven, dat de BTW beoogt om uiteindelijk de eindverbruiker te belasten. Eindverbruiker is degene die de aan haar in rekening gebrachte BTW niet op anderen kan afwentelen. In paragraaf 2.2 zijn een aantal arresten beschreven waarin het Hof bij de uitleg van de BTW-richtlijn - naar wat ik noem - het verbruiksbeginsel toepast.

De Commissie kent in beginsel een ruime werking toe aan het territorialiteitsbeginsel. $\mathrm{Zij}$ is van mening dat elke lidstaat de mogelijkheid moet hebben om zijn bevoegdheid om belasting te kunnen heffen uit te oefenen (toegespitst op de invulling van de zogenoemde kan-bepalingen in de BTW-richtlijn). De Commissie is van mening dat met feiten die zich in een andere lidstaat hebben voorgedaan geen rekening hoeft te worden gehouden. Uit de jurisprudentie van het Hof blijkt dat deze zienswijze moet worden genuanceerd. De lijn in deze jurisprudentie is als volgt samen te vatten. Ten eerste is de in de BTW-richtlijn neergelegde regeling dwingend van toepassing op het gehele nationale grondgebied van de lidstaten. Ten tweede zijn daarbij de basisregels van artikel 2 en $5 \mathrm{t} / \mathrm{m} \mathrm{8}$, BTW-richtlijn wat betreft het geografisch toepassingsgebied in beginsel van toepassing. Ten derde hebben de lidstaten de bevoegdheid het toepassingsgebied van hun BTW-wetgeving uit te breiden tot buiten hun grondgebied. Het territorialiteitsbeginsel vormt geen belemmering om buiten het eigen territoir belasting te heffen indien men geen inbreuk maakt op de heffingsbevoegdheid van andere lidstaten. Slechts in geval van een heffingsconflict met een andere lidstaat zijn de artikelen $43 \mathrm{t} / \mathrm{m} 59$ ter, BTW-richtlijn van toepassing. In hoofdstuk 8 onderzoek ik of het Hof algemene rechtsbeginselen erkent, die krachtig genoeg zijn om de werking van het territorialiteitsbeginsel verder in te perken.

Met het oorsprongslandbeginsel bedoelt men in het algemeen, dat de BTW wordt geheven in het land van productie van de goederen dan wel de diensten worden verricht. Het bestemmingslandbeginsel heeft daarentegen tot gevolg dat de heffing van BTW plaatsvindt in het land van verbruik van het geleverde goed of verrichte dienst. Deze beginselen kunnen worden gebruikt om de heffingsbevoegdheid toe te wijzen aan een bepaalde lidstaat. In paragraaf 2.3.2.1 is erop gewezen dat men bij de uitwerking niet altijd kiest voor een scherp onderscheid tussen het oorsprongslandbeginsel en het bestemmingslandbeginsel. Denkbaar is een toepassing van een mix van kenmerken van beide beginselen. 
Met het neutraliteitsbeginsel bedoelt men dat de heffing van BTW de concurrentieverhoudingen niet beïnvloedt. Paragraaf 2.4.1 verduidelijkt zowel de interne als de externe neutraliteit. Externe neutraliteit vereist een substantiële graad van belastingharmonisatie. Er bestaat een complexe balans tussen het neutraliteitsbeginsel en het subsidiariteitsbeginsel. Subsidiariteit kan vereisen dat een tolereerbaar niveau van verstoring van de externe neutraliteit wordt geaccepteerd.

Paragraaf 2.4 .2 beschrijft een aantal oorzaken van verstoring van de externe neutraliteit:

1. Een beperkt territorium waar de BTW-regelgeving geldt.

2. Verschillende definities van het leveringsbegrip dan wel de plaats van de levering.

3. Toepassing van verschillende uitgangspunten bij de bepaling van de plaats van dienst.

4. Verschillende behandeling van binnenlandse en buitenlandse belastingplichtigen.

5. Verschillende tarieven in de lidstaten voor vergelijkbare producten.

6. De BTW-richtlijn bevat bepalingen die de lidstaten een zekere vrijheid geven bij de invulling van de regelgeving.

Het gaat, zoals gezegd, niet om een uitputtende opsomming van de oorzaken van verstoring van de externe neutraliteit. Het betreft het verduidelijken van de rol van de algemene rechtsbeginselen in het probleemveld van de externe neutraliteit.

In dit hoofdstuk beschrijf ik de klassieke BTW-beginselen in aparte paragrafen. Dit zou de indruk kunnen wekken dat zij een onafhankelijk leven kunnen leiden. Niets is minder waar. Klassieke BTW-beginselen zijn nauw met elkaar verweven. Denie is van mening:

"De eisen van algemeenheid en gelijkheid, welke met het rechtskarakter en de neutraliteit van de belasting samenhangen, hebben als vanzelf ook betrekking op het bestemmingslandbeginsel; een Engels rijwiel komt hier te lande eenzelfde belastingdruk toe als een Nederlands fabricaat." ${ }^{126}$

Denie concludeert dan ook dat, indien men in de oplossing van problemen het rechtskarakter van de omzetbelasting aan de orde stelt, men tevens het algemene karakter ter sprake brengt, inclusief dat der gelijkheid voor de wet, alsmede dat der gelijkheid van belastingdruk. ${ }^{127}$ Kortom, de klassieke BTW-beginselen laten zich zelden geïsoleerd van de algemene rechtsbeginselen gelden. In de slotbeschouwing van hoofdstuk 13 zal ook blijken dat er een relatie is met de algemene rechtsbeginselen.

In de hoofdstukken 1 en 2 komt regelmatig de term (algemene) rechtsbeginselen voor. Dit mede ter onderscheiding van de klassieke BTW-beginselen. Voordat ik toekom aan een verdere inventarisatie, ordening, behandeling en analyse van de beginselen in de rechtspraak van het Hof, zal ik in hoofdstuk 3 eerst aangeven wat onder algemene rechtsbeginselen wordt verstaan. Daarbij verduidelijk ik tevens waarom de klassieke BTW-beginselen geen echte algemene rechtsbeginselen zijn.

126. Denie 1987, blz. 13.

127. Denie 1987, blz. 13 en 14. 


\section{HOOFDSTUK 3}

\section{Algemene rechtsbeginselen}

Het onderzoek betreft rechtsbeginselen, in het bijzonder een drietal rechtsbeginselen (zie paragraaf 1.4), en de doorwerking daarvan in het materiële recht van de BTW. Wat verstaat men onder rechtsbeginselen? Hoe kunnen wij de rechtsbeginselen en hun werking herkennen in de rechtspraak van het Hof?

Zoals in het vervolg van dit hoofdstuk zal blijken, zijn rechtsbeginselen abstract van aard, hebben zij een ethische dimensie en zij kennen dus vage contouren. Deze aspecten dragen er toe bij dat men soms van mening verschilt over de reikwijdte van het functioneren van de rechtsbeginselen. Dit onderstreept het belang om bij het begrip en functie ervan stil te staan.

In paragraaf 3.2 geef ik vooreerst aan op welke wijze algemene rechtsbeginselen zijn verbonden met het zogenoemde rechtsbewustzijn. In dit kader bespreek ik tevens de beperkingen die een beroep op algemene rechtsbeginselen ter ondersteuning van een bepaalde stelling met zich meebrengen. Ik zal bovendien verduidelijken op welke wijze algemene rechtsbeginselen ontstaan en wat het onderscheid is met rechtsregels. Ook volgt een beschrijving van de karakteristieken van het rechtsbeginsel en zijn werking in het recht. Paragraaf 3.2.3 geeft een omschrijving van algemene rechtsbeginselen die ik verder in mijn onderzoek als afbakening en uitgangspunt zal gebruiken.

In paragraaf $3.3 \mathrm{komt}$ nader de werking van algemene rechtsbeginselen aan de orde. Ik maak een onderscheid tussen algemene rechtsbeginselen 'van formeel recht' en 'interpretatiebeginselen' (paragraaf 3.3.1). Tevens komt aan de orde dat de algemene rechtsbeginselen een inperkend en verruimend effect kunnen hebben op de BTWregelgeving (paragraaf 3.3.2). Verder verduidelijk ik dat toepassing van een algemeen rechtsbeginsel door de rechter neer kan komen op de toepassing van een methode van rechtsvinding (paragraaf 3.3.3).

Paragraaf 3.4 gaat nader in op de drie algemene rechtsbeginselen. Aangegeven wordt waarom men het gelijkheidsbeginsel, het rechtszekerheidsbeginsel en het evenredigheidsbeginsel als algemene rechtsbeginselen kan zien. Tevens beschrijf ik 
daarbij de belangrijkste karakteristieken. Verder komt aan de orde de verhouding van de beginselen in het nationale recht tot het Unierecht. Centraal in paragraaf 3.4 staan echter de algemene lijnen zoals deze in het Europees recht zijn te vinden.

In paragraaf 3.5 geef ik aan waarom de klassieke BTW-beginselen zoals beschreven in hoofdstuk 2 niet als algemene rechtsbeginselen zijn aan te merken. Het neutraliteitsbeginsel is, zo zal daar ook blijken, echter in zijn uitwerking meervoudig van aard. Het neutraliteitsbeginsel draagt namelijk elementen die het gemeen heeft met het gelijkheidsbeginsel. Het kan dus in arresten van het Hof voorkomen dat de term 'neutraliteitsbeginsel' wordt gebruikt, terwijl zich in feite het gelijkheidsbeginsel doet gelden. Daar staat tegenover dat het Hof ook regelmatig verwijst naar het neutraliteitsbeginsel, terwijl duidelijk is, dat daar niet het gelijkheidsbeginsel mee wordt bedoeld.

Het hoofdstuk sluit ik af met een conclusie. Deze bevat het materiaal waarmee in de volgende hoofdstukken verder wordt gewerkt.

\subsection{Kenmerken algemene rechtsbeginselen}

\subsubsection{Rechtsbewustzijn}

In het rechtsbewustzijn van een samenleving is een stelsel van normen en waarden te onderkennen en uiteraard leven er verschillende ideeën over rechtvaardigheid. Met rechtsbewustzijn wordt dan bedoeld het in ieder mens levend bewustzijn van wat recht is of behoort te zijn. Scholten merkt onder meer het volgende op over het rechtsbewustzijn:

"Met de term rechtsbewustzijn meent men dan niet het rechtsoordeel over enig concreet geval, doch het in ieder mens levend bewustzijn van wat recht is of behoort te zijn, een bepaalde categorie van ons geestesleven, waardoor wij met onmiddellijk evidentie los van positieve instellingen scheiding maken tussen recht en onrecht, gelijk we doen tussen waar en onwaar, goed en kwaad, schoon en lelijk. Dit rechtsbewustzijn is (...), de bron van alle recht."1

De term verder duidend merkt Scholten op:

"De term rechtsbewustzijn is dubbelzinnig. Hij duidt ten eerste een categorie van het individuele geestesleven aan, doch dient tegelijk om het gemeenschappelijke in oordelen in een bepaalde kring aan te wijzen."

Vervolgens relativeert Scholten de functie van het rechtsbewustzijn voor het recht en de rechtsvinding in het bijzonder. Scholten is van mening dat de inhoud van dat

1. P. Scholten, Asser-Scholten (Algemeen Deel) 1974, blz. 124.

2. P. Scholten 1974, blz. 126. 
rechtsbewustzijn niet het recht is. ${ }^{3}$ Gezien het gegeven dat het bestaan van zulk een algemene inhoud van het rechtsbewustzijn van een volk niet is aan te tonen. Wat met de term 'rechtsbewustzijn' wordt aanduid is niet meer dan een vage voorstelling van wat recht behoort te zijn.

Zoals hierboven is aangegeven, moet de rol van het rechtsbewustzijn in de concrete toepassing van het recht worden gerelativeerd. Dat neemt niet weg dat in een samenleving een stelsel van normen en waarden kan worden onderkend en dat er verscheidene ideeën leven over rechtvaardigheid. Deze normen en waarden (beginselen) die leven in een samenleving kunnen op een bepaald moment een bindend karakter krijgen; dat kan doordat zij opgenomen worden in een wet of verdrag, of omdat de rechter deze gaat gebruiken om leemtes in de regelgeving op te vullen. Storme merkt over het ontstaan van algemene rechtsbeginselen op:

"Deze groeien spontaan, omdat zij aangevoeld worden door velen; zij worden bovendien gestimuleerd door die enkelingen, die in staat zijn om ze bewust en rationeel uit te drukken; (...)."4

De rechter legt de algemeen geldende beginselen open. Hij ontdekt, en (her)formuleert. De rechter creëert niet. De beginselen zijn al algemeen aanwezig in de samenleving. De rechter past ze slechts toe in een concreet geschil. Of zoals Storme het, in iets andere zin, weergeeft:

"Algemene rechtsbeginselen worden op een bepaald ogenblik tot 'rechtsvormers' geformuleerd en tot norm verheven. Zij bevinden zich meestal aan het einde van een (lange) ontwikkeling, zodat deze beginselen voor de burgers voordien reeds herkenbaar en erkenbaar waren. Zijn onderhuids reeds aanwezig. Zij kennen een graduele intensiteit: sommige al zo ver, andere op weg, weer andere zullen de status nooit bereiken." 5

De vorming van recht is waardering en afweging van goed en kwaad, het toepassen van recht en het hanteren van logische figuren. De ordening schept óf nieuw recht, dan is sprake van rechtsvorming óf zij doet dat niet en past het bestaande toe. ${ }^{6}$ Zoals hierboven aangegeven leven de rechtsbeginselen in het rechtsbewustzijn van een samenleving en worden zij ontdekt en geconcretiseerd door de rechter.

Met de algemene rechtsbeginselen staan wij dus aan de grenzen van het recht. Tot waar zijn gedragsregels nog 'moraal'? En hoe werkt de moraal in op het 'recht'? Deze vragen zijn verweven met de algemene rechtsbeginselen, maar vallen buiten mijn onderzoek.

3. P. Scholten 1974, blz. 126.

4. M. Storme, Algemene beginselen van behoorlijke procesvoering, in: M. van Hoecke (red.) Algemene rechtsbeginselen, Antwerpen: Kluwer rechtswetenschappen 1991, blz. 168.

5. M. Storme 1991, blz. 172 en 173.

6. P. Scholten 1974, blz. 7. 
Indien een rechter overgaat tot het toepassen van een algemeen rechtsbeginsel (formuleren) wordt dit door de samenleving niet als vreemd ervaren. ${ }^{7}$ De algemene rechtsbeginselen vloeien dan ook soepel de jurisprudentie binnen. Sterker nog, mogelijk worden de algemene rechtsbeginselen niet als zodanig herkend, gezien hun verwevenheid met de in een samenleving heersende opvattingen over rechtvaardigheid. ${ }^{8}$ Ze worden al als onderdeel van het recht ervaren. De rechter kan dan ook in de meest ideale vorm de algemene rechtsbeginselen praktisch onmerkbaar gebruiken om leemtes in de regelgeving op te vullen. De samenleving ervaart namelijk geen leemte.

Duidelijk is ook dat juridische beslissingen als rechtvaardiger worden ervaren indien zij voldoen aan normen/beginselen die zijn gevestigd in een maatschappij. ${ }^{9}$

Zoals in het begin van deze paragraaf aangegeven, ontstaan algemene rechtsbeginselen in het rechtsbewustzijn van een samenleving. Zij worden ontdekt en blootgelegd. Op een gegeven moment zijn zij dusdanig helder dat zij zich lenen voor concrete toepassing. Er bestaat dus als het ware een embryonale fase. Een fase voordat zij concreet genoeg zijn om de status van algemeen rechtsbeginsel te verkrijgen. In deze fase ligt volgens mij één van de belangrijkste beperkingen en gevaren van algemene rechtsbeginselen (in wording). Wat door sommige aangezien zou kunnen worden voor uitgangspunten die leven in het rechtsbewustzijn, is echter voor een ander omstreden of leidt tot tegenovergestelde conclusies. De koppeling tussen het rechtsbewustzijn en de algemene rechtsbeginselen komt mij dan ook als discutabel voor. Een voorbeeld hiervan in de BTW-literatuur is volgens mij de rechtstheorie van Simons.

Uitgangspunt van de door Simons beschreven rechtstheorie is het onderscheid tussen recht en onrecht. Dit onderscheid wordt door hem mathematisch weergegeven als: Recht $\neq$ Onrecht. ${ }^{10}$ Het recht kan dan alles zijn, als het maar geen onrecht is. Simons schrijft over het onderscheid:

7. Soetaert is van mening dat: "De inhoud van een algemeen rechtsbeginsel zal, dunkt me, nooit gehee nieuw zijn”, blz. 93 en hij vervolgt: “Het 'scheppen' van algemene rechtsbeginselen komt aldus meestal neer op het inpassen van regels uit andere rechtstakken, andere rechtssystemen, of ook direct uit de 'moraal', (...)". R. Soetaert, Algemene rechtsbeginselen in Cassatie, in: M. van Hoecke (red.), Algemene rechtsbeginselen, Antwerpen: Kluwer rechtswetenschappen 1991, blz. 94.

8. Van Orshoven schrijft in dit kader dat men in een bepaalde maatschappij niet anders kan dan vaststellen dat algemene rechtsbeginselen bestaan. De scheppende kracht van algemene rechtsbeginselen is derhalve terug te voeren op een in de maatschappij algemeen gedeelde rechtsovertuiging. P. van Orshoven, Non scripta, sed nata lex - Over het begrip en de plaats in de normenhiërarchie van de algemene rechtsbeginselen, in: M. van Hoecke (red.), Algemene rechtsbeginselen, Antwerpen: Kluwer rechtswetenschappen 1991, blz. 73.

9. R. Dworkin, Taking Rights Seriously, London: Duckworth 1994, blz. 5. Daar kan dan weer tegenin worden gebracht de vraag: wat zijn dan de gevestigde normen in een bepaalde maatschappij. Volgens Dworkin moeten rechtelijke beslissingen blootleggen de aard van de morele argumenten, om op deze wijze de rechtvaardigheid van een beslissing te verduidelijken.

10. A.L.C. Simons, De nieuwe rechtstheorie 'getriggerd' door BTW-constructies, WFR 1995/6144, blz. 470 . 
"Het recht kan echter nooit zijn grenzen overschrijden; grenzen die a.h.w. door het onrecht worden bepaald en, aangezien de mens onrecht onderkent, in de menselijke natuur zijn verankerd. Onze werkelijke rechtsbeginselen nu houden zich bezig met die grenzen. Rechtsbeginselen, soms ook genoemd algemene leerstukken, elk op hun gebied, leren ons de grenzen van het onrecht niet te overschrijden."11

Volgens Simons behoort er rechtsfilosofisch geen onderscheid te zijn tussen het juridische en het maatschappelijke, omdat het recht immers een onderdeel is van en dienstbaar is aan de maatschappij waarvoor het is geschapen. ${ }^{12}$ In zijn rechtstheorie heeft Simons in het bijzonder het begrip 'maatschappelijk verkeer' op het oog als leidend beginsel in het recht. Simons schrijft in deze context:

"Die principes (bedoeld wordt onder meer het maatschappelijke verkeer: toevoeging AHB) berusten echter op algemene beginselen in het recht, zodat ook op andere wetgeving die principes hun invloed kunnen gaan uitoefenen." 13

Dat Simons een zeer ruime werking toekent aan het beginsel 'maatschappelijk verkeer' blijkt onder meer uit het volgende:

"De argumenten in mijn verhaal leiden ertoe dat in één klap heel die santenkraam van juridische spinsels van de tafel kan worden geveegd en er een ander maatschappelijk beeld van BTW-heffing voor in de plaats kan worden gezet. Een heffing die in al zijn vezels dat maatschappelijke in zich moet hebben. De interpretatie van die wetgeving kan dan ook plaatsvinden door in elk geval bij elke beslissing weer terug te koppelen naar dat maatschappelijke gevoelen." ${ }^{14}$

De rechtstheorie heeft de volgende consequenties volgens Simons:

“(...)

- De rechtvaardigheid - in de zin van geen onrecht - is van een hogere orde dan de doelmatigheid.

- Rechtsbeginselen beheersen eigenlijk het hele juridische leven; zij stellen grenzen aan contracten tussen mensen en aan wetgeving.

- Rechters krijgen daardoor meer macht; een beoordeling per individu vindt dan ook steeds meer plaats." ${ }^{15}$

11. A.L.C. Simons 1995, blz. 470.

12. A.L.C. Simons, Terug naar de basis van de BTW: het maatschappelijk verkeer!, WFR 1994/6086, blz. 10. 13. A.L.C. Simons 1994, blz. 12. Toegespitst op de uitleg van de BTW-regelgeving schrijft Simons (blz. 11): "De oplossing daarvoor ligt in het zuiver toepassen van het begrip 'in het maatschappelijk verkeer'; het enige goede criterium voor de toepassing van een algemene verbruiksbelasting als een belasting op de gehele maatschappij."

14. A.L.C. Simons 1994, blz. 14

15. A.L.C. Simons 1995, blz. 472. 
Het element 'maatschappelijk verkeer' berust kennelijk volgens Simons op een algemeen beginsel waar veel van kan worden verwacht. Zelfs zoveel dat:

"Een goede rechter kan, als hij de feiten en omstandigheden kent, ook zonder wetteksten een rechtvaardig oordeel vellen."16

Het beginsel is uiteindelijk gebaseerd op wat in de samenleving als recht wordt ervaren. Simons past het uitgangspunt onder meer toe op de jurisprudentie met betrekking tot de BTW-constructies. Simons is van mening dat:

“Met betrekking tot de BTW-constructies is HR BNB 1994/71, inzake de BTW-druk op een gemeentehuis een goed voorbeeld hoe de rechtsvinding fout kan gaan. Er waren voldoende aspecten om, indien de Hoge Raad als rechter gewoon hun rechtsgevoel hadden laten werken, die constructie om zeep te helpen." ${ }^{17}$

Het door Simons geschetste theoretisch kader is gebaseerd op in de maatschappij levende beginselen, normen, waarden op het terrein van rechtvaardigheid. Uiteindelijk leidt dat volgens hem tot een afwijzing van de jurisprudentie op het terrein van de BTW-constructies.

Hoe discutabel een dergelijk uitgangspunt is, blijkt onder meer uit het feit dat andere schrijvers bij het tot uitgangspunt nemen van de ethiek tot een ander resultaat komen. Van Brederode schrijft in deze context:

"Het is daarom een zedelijke plicht voor de overheid de belastingwetgeving helder vorm te geven en in te richten conform de immanente beginselen van de desbetreffende heffing. Waar de overheid dit nalaat, steken belastingbesparende constructies onherroepelijk de kop op. Zoals hiervoor is betoogd, zijn vrijstellingen zonder recht op vooraftrek strijdig met het rechtskarakter, de immanente beginselen van de BTW. Het is dan ook niet verwonderlijk dat juist in de vrijgestelde sfeer de meeste constructies blijken te worden toegepast. Waar onrechtvaardigheden zich voordoen, herstelt de praktijk op de een of andere wijze de ethische balans." 18

16. A.L.C. Simons 1995, blz. 474. In dezelfde strekking de noot van A.L.C. Simons in BNB 2000/267. In deze noot blijkt dat Simons de rechter Tie op het oog heeft uit de detectiveliteratuur. Of Simons daarbij alle facetten van het fenomeen Tie op het oog heeft betwijfel ik echter. Het was een van de voornaamste principes van het Chinese recht dat niemand kon worden veroordeeld indien hij zijn misdaad niet bekende. Om te verhinderen dat doortrapte misdadigers hun schuld bleven ontkennen, zelfs wanneer deze onomstotelijk was vastgesteld, kende het Chinese recht de ondervraging op de pijnbank. Wat rechter Tie dan ook in diverse detectiveverhalen door de gerechtsdienaren laat doen. De rechter moest echter voorzichtig zijn bij de toepassing van marteling, want mocht de verdachte later onschuldig blijken te zijn, dan stond hij zelf aan zware disciplinaire straffen bloot. Stierf de verdachte als gevolg van de pijniging, dan wachtte de rechter zelf de doodstraf. Zie over de rechtspraktijk in de tijd dat rechter Tie leefde, R. van Gulik, Klokken van Kao-Yang, Amsterdam: De Boekerij 2005, nawoord op blz. 268.

17. A.L.C. Simons 1995, blz. 474

18. R.F.W. van Brederode, Ethiek van het omzetbelastingrecht (oratie Rotterdam), Deventer: Kluwer 1996, blz. 26 
Indien het rechtvaardigheidsgevoel zoals dat leeft in het rechtsbewustzijn tot uitgangspunt wordt genomen brengt ons dat niet veel verder. Zoals Scholten (zie eerder in deze paragraaf) al naar voren heeft gebracht is een dergelijk collectief gevoel van wat onder rechtvaardigheid dient te worden verstaan niet aan te tonen. Wat de één zonneklaar als 'recht' ervaart, wordt door de ander als een te bestrijden 'onrecht' gezien. ${ }^{19}$ Het is dan ook discutabel om dergelijke vage criteria als uitgangspunt te nemen. Het betreft dan al snel een vage voorstelling van wat recht behoort te zijn. In het gunstigste geval zijn dergelijke uitgangspunten te zien als algemene rechtsbeginselen in ontwikkeling. Nog niet voldoende gerijpt voor concrete toepassing. Waarschijnlijk dat zij het nooit tot een krachtig algemeen rechtsbeginsel zullen brengen. En heel misschien dat een enkeling het embryonale stadium weet te verlaten en zich laat gelden als een belangrijke richtingaanwijzer. Ik heb het dan verder ook over beginselen die concreet zijn en het stadium van een discutabele vaagheid te boven zijn. Op deze plaats kan dan ook verwezen worden naar Soetaert, die naar voren brengt:

"Een beroep op een algemeen rechtsbeginsel vergt veel inzicht, ruime kennis van het recht en een dosis moed. Maar ook voorzichtigheid is gewenst. (...) Men zwaaie niet met algemene rechtsbeginselen eer men de mogelijkheid van de toepasselijke wetsbepaling heeft uitgetest." 20

\subsubsection{Rechtsregels en rechtsbeginselen}

De literatuur over algemene rechtsbeginselen besteedt veel aandacht aan het onderscheid tussen rechtsregels en algemene rechtsbeginselen. Voor een goed begrip van algemene rechtsbeginselen is het noodzakelijk om bij dit verschil stil te staan. $^{21}$

Zoals hierna zal blijken is het juridisch spraakgebruik rond rechtsregels en rechtsbeginselen niet eenduidig. Het uitgangspunt dat beginselen verwijzen naar een wat

19. Zie J. Rawls, Een theorie van rechtvaardigheid, Rotterdam: Lemniscaat 2006, blz. 364 t/m 369 . Rawls komt na een analyse tot de conclusie dat wij in een nagenoeg rechtvaardige situatie normaal gesproken een plicht hebben om onrechtvaardige wetten na te leven krachtens onze plicht om een rechtvaardige constitutie te steunen. Met het oog hierop hebben wij, volgens Rawls, een natuurlijke burgerplicht niet de tekorten van maatschappelijke ordeningen aan te voeren als een al te gemakkelijk excuus om ze niet na te leven, en niet onvermijdelijke mazen in de regels te benutten om onze belangen te bevorderen. De burgerplicht legt een gepaste aanvaarding van de onvolkomenheden van instituties op, en een bepaalde beteugeling van het gebruik ervan in ons eigen voordeel. Zonder erkenning van deze plicht zullen wederzijds trouw en zekerheid gemakkelijk afbrokkelen. Rawls stelt daarbij wel voorop dat ze niet bepaalde grenzen van onrechtvaardigheid overschrijden. Zie ook over het naleven van onbillijke belastingheffing in de context van de ideeën van Hobbes, J.L.M. Gribnau, Soevereiniteit en legitimiteit: grenzen aan (fiscale) regelgeving (oratie Leiden), Amersfoort: Sdu Uitgevers 2009, blz. 46 e.v.

20. R. Soetaert 1991, blz. 94.

21. Of zoals Gijssels het stelt: “De kernvraag is het verschil tussen een beginsel en een regel." J. Gijssels, Rechtsbeginselen zijn nog geen recht, in: M. van Hoecke (red.), Algemene rechtsbeginselen, Antwerpen: Kluwer rechtswetenschappen 1991, blz. 38. 
vager ideaal en regels naar een concreet gedragsvoorschrift geeft het spraakgebruik waarschijnlijk nog het beste weer.

Volgens Dworkin bestaat er een scherp onderscheid tussen rechtsbeginselen en rechtsregels. ${ }^{22}$ Beide geven een wettige verplichting van hoe gehandeld moet worden in een bepaalde situatie, echter zij verschillen in het karakter van de richting die zij aangeven. Als de rechtsregel is vastgelegd, zijn er twee mogelijkheden. Of de rechtsregel is toepasbaar of niet toepasbaar en in het laatste geval draagt de rechtsregel niet bij tot de beslissing. ${ }^{23}$ Rechtsregels zijn dus op een alles of niets manier toepasbaar. Volgens Dworkin dwingen de rechtsbeginselen niet tot een bepaalde beslissing. Zij geven eerder een richting aan om een bepaalde beslissing te onderbouwen. ${ }^{24}$ Indien de beslissing de andere kant uitvalt wil dat nog niet zeggen dat de algemene rechtsbeginselen daarmee geen 'echte' algemene rechtsbeginselen zijn. Onder andere condities kunnen deze algemene rechtsbeginselen namelijk wel degelijk krachtig genoeg zijn om een beslissing in een bepaalde richting te forceren. ${ }^{25}$

De algemene rechtsbeginselen liggen vaak ook dieper dan de rechtsregels. ${ }^{26}$ Voordat zij toegepast kunnen worden moeten zij eerst worden geconcretiseerd. ${ }^{27}$ Dit in tegenstelling tot de rechtsregels. Deze laatste zijn al concreet en dus al of niet toepasbaar op een bepaald feitencomplex. ${ }^{28}$

22. R. Dworkin 1994, blz. 24.

23. In gelijke zin Happé: "Rechtsregels zijn op een alles-of-niets manier toepasbaar. Zij gelden in een bepaalde situatie of niet. Rechtsbeginselen dwingen niet tot een bepaalde beslissing. Een in een bepaald geval relevant rechtsbeginsel verschaft een reden voor een beslissing in een bepaalde richting", R.H. Happé, Drie beginselen van fiscale rechtsbescherming (diss. Leiden), Deventer: Kluwer 1996, blz. 78

24. R. Dworkin 1994, blz. 26

25. Voor een kritische beschouwing over het door Dworkin geconstateerde scherpe onderscheid tussen rechtsregels en algemene rechtsbeginselen, zie A. Soeteman, Hercules aan het werk. Over de rol van rechtsbeginselen in het recht. Ars Aequi 1991, blz. 744.

26. R. Soetaert 1991, blz. 83 stelt bij het omschrijven van het algemeen rechtsbeginsel vast dat: “(...) een 'beginsel' ligt uiteraard dieper dan een regel en zal, als het deugdelijk is, talrijke specifieke regels respectievelijk een geheel daarvan funderen."

27. P. Scholten 1974, blz. 62 en 63 omschrijft het als volgt: "Een rechtsbeginsel is niet een rechtsregel. Was het regel, dan zou die zo algemeen zijn, dat hij óf niets óf veel te veel zeide. Directe toepassing door subsumptie van een geval onder een beginsel is niet mogelijk, daartoe moet eerst door een meer concrete inhoud de regel worden gevormd. Bij die vorming botst beginsel tegen beginsel: het ene zal in deze, het andere in die richting dringen. Het beginsel is dus niet recht, doch geen recht is te begrijpen zonder die beginselen. Het zijn tendensen, welke ons zedelijk oordeel aan het recht stelt, algemeenheden, met al de betrekkelijkheid, die dat meebrengt, maar die toch niet te missen zijn. In het beginsel raken wij het zedelijk element in het recht, gelijk in de grondvorm het logische."

28. R. Dworkin 1994, blz. 24 en M. van Hoecke, De algemene rechtsbeginselen als rechtsbron: een inleiding, in: M. van Hoecke (red.), Algemene rechtsbeginselen, Antwerpen: Kluwer rechtswetenschappen 1991, blz. 7 waar deze laatste schrijver het onderscheid toelicht met voorbeelden uit de Belgische jurisprudentie. 
Een ander onderscheid tussen zuivere rechtsregels en algemene rechtsbeginselen is dat rechtsregels niet tegengesteld kunnen zijn. Anders zou namelijk het rechtssysteem inconsequent zijn. Algemene rechtsbeginselen kunnen echter wel degelijk tegengesteld zijn. Indien de algemene rechtsbeginselen botsen, moet de rechter het relatieve gewicht in aanmerking nemen en tegen elkaar afwegen. Het rechtsbeginsel met het meeste gewicht geeft dan de doorslag. Gesteld zou zelfs kunnen worden, dat het gegeven dat zij tegengesteld kunnen zijn de rechtsbeginselen in evenwicht houdt. Nieuwenhuis verwoordt het als volgt:

“(...) de rechtsbeginselen vormen onderling een systeem van 'checks and balances'. Beginselen wijzen vaak in tegengestelde richting. Wat voor rechtsregels een vloek zou zijn, is hier een zegen. Doordat zij in tegengestelde richting wijzen houden zij elkaar in toom en zodoende in evenwicht." 29

Nieuwenhuis gaat dieper in op de relatie tussen rechtsbeginselen en rechtsregels. Hij onderscheidt, naargelang de afhankelijkheid van de handeling ten opzichte van de regels, twee categorieën. ${ }^{30}$ Regels die los van die regels al mogelijke handelingen verbieden (bijvoorbeeld links rijden) of juist gebieden (bijvoorbeeld rechts rijden), en regels die een bepaalde handeling eerst mogelijk maken (bijvoorbeeld de schaakregels die een schaakspel mogelijk maken). Regels van het eerste typen noemen we obligatoir, regels van het tweede typen duidt hij aan als constitutieve regels. De constitutieve regels vormen een gesloten systeem. De schaakregels blijven hetzelfde. De rechtsregels echter zijn volgens Nieuwenhuis een open systeem. ${ }^{31}$ Ook Scholten typeert het recht als een open systeem. ${ }^{32}$ Hij brengt naar voren dat het recht nooit 'af' is. Het verandert dagelijks. Niet alleen de wetgeving verandert door de bewuste schepping van nieuw recht. Het recht verandert ook door de toepassing. Het is niet een statisch maar een dynamisch systeem. Scholten brengt ook naar voren, dat het rechtssysteem daarom een 'open systeem' is, omdat de beslissingen niet slechts de output van een regelsysteem vormen, maar tevens via en 'feedback' mechanisme dat regelsysteem weer beïnvloeden. Het recht heeft dus een open karakter. Anders geformuleerd: rechtsnormen hebben een open karakter. ${ }^{33}$ De rechtsnormen zijn naar hun aard voorgekleurd. Voorgekleurd door de materiële rechtsbeginselen die de rechtsnormen beheersen. Deze beginselen worden, zoals eerder naar voren is gebracht, bepaald door de waarden en normen die gelden in de samenleving.

29. J.H. Nieuwenhuis, Drie beginselen van contractenrecht (diss. Leiden), Deventer: Kluwer 1979, blz. 4. Hij ligt zijn stelling toe met een voorbeeld op het terrein van de regeling van de overdracht van een roerende zaak.

30. J.H. Nieuwenhuis 1979, blz. 10, meer specifiek in relatie tot de regels van het contractenrecht.

31. J.H. Nieuwenhuis 1979, blz. 38 en 39.

32. P. Scholten 1974, blz. 75 t/m 77.

33. J.H. Nieuwenhuis 1979, blz. 21. Dat de rechtsnormen een 'open' karakter hebben, wil nog niet betekenen dat zij blanco zijn. 
Gesteld zou kunnen worden dat de rechtsbeginselen de rechtsregels sturen. Of zoals Nieuwenhuis het formuleert:

"De rechtsbeslissing vervult in het proces van de rechtsverwerkelijking een autonome rol en is niet louter een afgeleide van een rechtsregel. Maar dit is slechts één kant van de médaille. De verwerkelijking van het recht voltrekt zich in drie fasen: beginsel, regel, beslissing. (...) Niet alleen naar de kant van de beslissing, maar ook naar de kant van de rechtsbeginselen dragen de rechtsregels een 'open' karakter. Met name om deze 'openheid' gaat het (...): de open verbinding tussen rechtsbeginselen en rechtsregels. Wisselwerking ook tussen rechtsbeginselen en rechtsregels. De rechtsbeginselen leveren aan de ene kant het materiaal voor de interpretatie van rechtsregels, maar verkrijgen omgekeerd pas een herkenbaar profiel in en door de confrontatie met die regels." ${ }^{34}$

En Nieuwenhuis vervolgt over de relatie tussen rechtsbeginselen en rechtsregels:

"Het betrekkelijk globale karakter van rechtsbeginselen (bijvoorbeeld:

gerechtvaardigd vertrouwen verdient bescherming) maakt het mogelijk dat zij de tand des tijds doorstaan. Via een aangepaste invulling kunnen zij veranderingen in de maatschappelijke verhoudingen en in het vigerende waardepatroon opvangen en doorgeven aan het positieve recht."35

Kortom, de algemene rechtsbeginselen sturen en geven invulling aan de rechtsregels.

Niet alleen in de jurisprudentie duiken algemene rechtsbeginselen op. Ook in wetten en verdragen zijn zij te herkennen. Verscheidene schrijvers verdedigen dat algemene rechtsbeginselen geen onderdeel uitmaken van het recht en dat zij dan ook kennelijk niet zijn terug te vinden in wetten en verdragen. ${ }^{36}$ Op het moment dat een bepaalde

34. J.H. Nieuwenhuis 1979, blz. 39.

35. J.H. Nieuwenhuis 1979, blz. 42

36. Zo meent J. Gijssels 1991, blz. 46: “(...), dat de wetgever wel degelijk een beroep doet op beginselen van ethische of andere extra-juridische aard om recht te scheppen. Tegelijk illustreren zij de functie van de wetgever in het hanteren van beginselen. De beginselen recipieert hij niet zomaar in het recht, maar hij beperkt, verfijnt en nuanceert ze ten aanzien van bepaalde subjecten, materies, verhoudingen en situaties. Daarmee is ten overvloede aangetoond dat de beginselen op een ander niveau liggen dan het recht, dat zij geen recht zijn, maar door een uitdrukkelijke wils-akt van een rechtsvormer (hier de wetgever) geactualiseerd worden tot recht (hier rechtsnorm) met een vrij concrete draagwijdte. Niemand zal zeggen dat de wetgever recht vindt zoals men dat van de rechter zegt. De wetgever vormt recht. Wanneer hij zich, bij het vastleggen van rechtsregels, laat inspireren door in de samenleving gangbare of ontluikende ideeën en normen, dan maakt hij recht van wat geen recht is. Maar hij creëert het beginsel niet, wel een rechtsnorm." Gijssels meent dus zelfs dat de algemene rechtsbeginselen geen onderdeel zijn van het recht. Ook Debaedts is kennelijk van mening dat de algemene rechtsbeginselen ongeschreven zijn. Deze schrijver ziet twee opgaven voor algemene rechtsbeginselen, toegespitst op het administratief recht. Ten eerste te bereiken dat de discretionaire macht van de administratie binnen de perken blijft van wat algemeen als rechtmatig wordt aangevoeld. Ten tweede dienen algemene rechtsbeginselen om de wet te interpreteren. Deze problematiek heeft in hoofdzaak betrekking op het ongeschreven karakter van de algemene rechtsbeginselen. Zie, F. Debaedts, De algemene rechtsbeginselen in het administratief recht, in: M. van Hoecke (red.), Algemene rechtsbeginselen, Antwerpen: Kluwer rechtswetenschappen 1991, blz. 268. 
norm wordt opgenomen in een wet of verdrag is het geen algemeen rechtsbeginsel meer. Niet goed valt echter in te zien, dat als eenmaal een bepaalde fundamentele norm wordt opgenomen in regelgeving, deze norm geen algemeen rechtsbeginsel zou kunnen zijn. ${ }^{37}$ Wel is duidelijk dat na codificatie algemene rechtsbeginselen duidelijker en dwingender zijn geworden. ${ }^{38}$

Niet alleen de rechter ontdekt en formuleert de algemene rechtsbeginselen. Ook de wetgever kan dus een rol spelen in het ontdekken en weergeven. Verschillende normgevers en verschijningsvormen laten zich dan ook gelden. Soetaert brengt in deze context naar voren:

"Dat algemene rechtsbeginselen 'min of meer impliciet aanwezig zijn', sluit allereerst in dat ze zowel geschreven kunnen zijn, als door interpretatie leesbaar gemaakt. Maar ook stuit men op wetboeken, verdragen of wetten waarin zodanige beginselen worden uitgedrukt, of een enkele keer aan de rechter opdracht wordt gegeven ze vast te stellen. Vandaar dat van verschijningsvormen mag worden gesproken. Algemene rechtsbeginselen kunnen iedere dag in een wet of een verdrag worden opgenomen en houden daarmee niet op beginselen te zijn, met al hun kenmerken van algemeenheid en vaagheid, voor de rechtstakken waarvoor de wet of het verdrag moet gelden." ${ }^{39}$

Kortom, algemene rechtsbeginselen kunnen expliciet zijn opgenomen in wetten en verdragen, dan wel ongeschreven zijn.

Het meest intrigerend zijn de algemene rechtsbeginselen die niet in de regelgeving zijn neergelegd, maar door de rechter worden blootgelegd. De rechter formuleert in dit proces het algemene rechtsbeginsel. In paragraaf 3.2.1. is naar voren gebracht dat niet elke voorstelling die leeft in het rechtsbewustzijn van de samenleving het tot een algemeen rechtsbeginsel brengt. Zij blijven in het ontwikkelingsproces steken. Dit kan komen doordat zij niet sterk genoeg zijn of omdat zij niet te pakken zijn in de taal. De semantiek schiet tekort om het rechtsbeginsel, dat kennelijk leeft in het rechtsbewustzijn, te formuleren.

37. In dit kader brengt Gribnau naar voren dat het onderscheid tussen rechtsregels en rechtsbeginselen niet geheel hetzelfde is als dat tussen geschreven en ongeschreven recht. Hij verduidelijkt dit met het beginsel redelijkheid en billijkheid dat is gecodificeerd in het BW en dan ook geschreven recht is geworden. Maar de redelijkheid en billijkheid is niet op gedetailleerde wijze in direct toepasbare regels uitgewerkt. Zij blijft dus een zeer algemeen geschreven norm. Hoewel geschreven blijft dus het normatieve karakter van rechtsbeginselen overheersen. Volgens Gribnau gaat het in dit geval om de tegenstelling tussen door het bevoegd orgaan uitgevaardigde normen en normen die hun oorsprong vinden in de aanvaarding en erkenning door de samenleving en het juridisch forum. J.L.M. Gribnau, Rechtsbetrekking en rechtsbeginselen in het belastingrecht (diss. Rotterdam), Rotterdam: Sanders Instituut \& Gouda Quint 1998, blz. 60.

38. Volgens Vanistendael zijn algemene rechtsbeginselen niet per definitie ongeschreven recht. Wel is deze schrijver van mening dat in de wet, verdrag en rechtspraak neergelegde algemene rechtsbeginselen een grotere legitimatie hebben. F. Vanistendael, Algemene rechtsbeginselen in het belastingrecht, in: M. van Hoecke (red.), Algemene rechtsbeginselen, Antwerpen: Kluwer rechtswetenschappen 1991, blz. 226.

39. R. Soetaert 1991, blz. 83 en 84 . 
Op deze plaats is van belang de constatering dat algemene rechtsbeginselen bij het nemen van een beslissing niet allen dezelfde richting uitwijzen. ${ }^{40}$ Ook is van belang de constatering dat de algemene rechtsbeginselen nooit 'af' zijn maar deel uit maken van een 'dynamisch' systeem. De dynamiek van het recht wordt vergroot doordat de algemene rechtsbeginselen kleur en sturing geven aan de rechtsregels.

Zoals eerder in deze paragraaf naar voren is gebracht kunnen de algemene rechtsbeginselen, in tegenstelling tot de rechtsregels, met elkaar botsen. De rechter moet dan aangeven welk algemeen rechtsbeginsel zich het krachtigst laat gelden. De rechter geeft dan de voorrang van het ene beginsel boven het andere beginsel. In feite wordt op dat moment een regel gecreëerd voor vergelijkbare gevallen. Het resultaat is een voorrangsregel. Happé omschrijft voorrangsregels als:

"Een voorrangsregel is een norm aan de hand waarvan in een geval van botsing van beginselen kan worden uitgemaakt welk beginsel het meeste gewicht in de schaal legt c.q. de voorrang heeft." 41

Volgens deze omschrijving van voorrangregels zijn zij van hetzelfde karakter als 'gewone' rechtsregels. Zij hebben dan een alles of niets karakter. ${ }^{42}$ Het scherpe onderscheid tussen rechtsregels en algemene rechtsbeginselen mag dan op dit punt worden genuanceerd. Ook algemene rechtsbeginselen kunnen onder bepaalde omstandigheden dwingend zijn.

40. Bijna een halve eeuw voor het verschijnen van het eerder aangehaalde boek van Dworkin, heeft Scholten zijn boek geschreven over de rol van rechtsbeginselen. Een boek dat sterk doet denken aan het boek van Dworkin. Sterker nog, dat op sommige terreinen de theorie van Dworkin lijkt uit te breiden. Beide schrijvers wijzen erop dat beginselen geen 'alles of niets' karakter hebben. Beide wijzen er ook op dat de algemene rechtsbeginselen binnen het recht hun gelding hebben. Anders dan Dworkin makt Scholten echter een belangrijk onderscheid tussen de diverse soorten beginselen. Scholten herkent beginselen met een sterk regelachtig karakter. Daarnaast herkent hij ook beginselen met een algemenere strekkingen en ook een meer morele lading hebben. Door verschil te maken tussen de diverse soorten beginselen, kan Scholten ook aangeven welk beginsel het zwaarst moet wegen bij een botsing van beginselen. Het algemene beginsel gaat dan voor het specifieke. Het meest 'evidente' beginsel voor een minder 'evident' beginsel. Wat 'evident' is, is gebaseerd op een zedelijk oordeel volgens Scholten. Zie in dit kader ook K. Rozemond, Vierentwintig varianten van de one right answer thesis, blz. 65, in: E.T Feteris, H. Kloosterhuis, H.J. Plug, J.A. Pontier, (red.), Met Recht en Reden, Bijdragen aan het Derde Symposium Juridische Argumentatie Rotterdam 18 juni 1999, Nijmegen: Ars Aequi Libri 2000. Deze schrijver gaat in op de one right answer thesis van Dworkin en vergelijkt deze ook met de theorieën van Scholten.

41. R.H. Happé 1996, blz. 79 en 80. Volgens Happé zijn de voorrangregels dus het resultaat van de afweging van de relevante rechtsbeginselen. Volgens hem impliceert elke toepassing van rechtsregels, ook van voorrangregels tevens de afweging van rechtsbeginselen.

42. Dit hoeft volgens Happé niet het open karakter van het rechtssysteem te blokkeren. Doorgaans overheerst het gesloten karakter gezien de suprematie van de wet en de rechtszekerheid. Het open karakter manifesteert zich als de rechter in geval van een 'hard case' de afweging van de rechtsbeginselen aan de orde stelt en ertoe overgaat het tot dan toe aanvaarde evenwicht van de beginselen te vervangen door een ander evenwicht. Het recht kenmerkt zich dan door een voortdurende beweging van gesloten systeem naar een open systeem en vervolgens weer terug naar een gesloten systeem. Zie R.H. Happé 1996, blz. 81 


\subsubsection{Omschrijving van algemene rechtsbeginselen}

$\mathrm{Nu}$ in de vorige paragrafen de invloed van het rechtsbewustzijn op de algemene rechtsbeginselen is behandeld en de relatie tussen algemene rechtsbeginselen en de rechtsregels aan de orde is geweest, zal deze paragraaf een omschrijving geven van algemene rechtsbeginselen.

Zoals eerder naar voren is gebracht, hebben algemene rechtsbeginselen een morele lading en zijn zij verbonden met de in een samenleving heersende ideeën over rechtvaardigheid. Het is juist dit abstracte karakter van algemene rechtsbeginselen dat de afbakening van het fenomeen bemoeilijkt. ${ }^{43}$ Het aangeven van een 'juist' begrip van wat een algemeen rechtsbeginsel is beschouw ik niet als mijn taak. Wel zal ik in deze paragraaf een aantal omschrijvingen naar voren brengen uit de rechtstheoretische literatuur. Vervolgens zal een omschrijving van algemene rechtsbeginselen worden gegeven die ik verder in mijn onderzoek als afbakening en uitgangspunt zal gebruiken.

In de eerste plaats vereist de toevoeging 'algemeen' aan de term 'beginsel' een nadere verduidelijking. De toevoeging van het woord 'algemeen' kan verschillende betekenissen hebben. Zo kan worden bedoeld dat de werking van het beginsel niet beperkt is tot één bepaalde rechtstak óf één bepaald deel van het recht, maar zich doet gelden door het gehele recht. Of het nu het belastingrecht of het civiele recht is, het betreffende beginsel is aanwezig in de gehele rechtsorde. ${ }^{44}$

43. Moons geeft het definitieprobleem als volgt aan: "Het is precies omdat rechtsbeginselen te maken hebben met ethische begrippen, met diep verankerde menselijke waarden die boven een bepaalde staatsvorm leven, dat het zo moeilijk is om er een degelijke en volledige omschrijving van te geven. Het is alsof je een definitie zou moeten geven van wat liefde, vriendschap, rechtvaardigheid, gelijkheid, solidariteit... nu precies zijn. Iedereen voelt het wel aan (misschien op een verschillende manier) maar vindt niet direct de adequate terminologie om voornoemde begrippen precies te omschrijven." D. Moons, De toepassing van algemene rechtsbeginselen in het strafrecht in de verschillende fasen van de rechtspleging, waarbij de nadruk wordt gelegd op het vooronderzoek, in: M. van Hoecke (red.), Algemene rechtsbeginselen, Antwerpen: Kluwer rechtswetenschappen 1991, blz. 200.

44. Soetaert brengt in dit kader naar voren: "Met 'algemeen' lijkt mij daarbij niet meer gezegd, dan dat, bij een veelheid van beginselen, aan de meest algemene wordt gedacht. Het gebruik van de kwalificatie 'algemeen' kan overbodig zijn, als men die al in de term 'beginsel' aanwezig acht. Maar vaak wordt met 'algemeen' bedoeld dat het beginsel een bepaalde rechtstak te buiten gaat (...) of dat het aan verschillende rechtssystemen gemeen is (...)." R. Soetaert 1991, blz. 83.

Van Orshoven formuleert het als volgt: "Algemene rechtsbeginselen zijn niet algemeen in de zin dat zij algemeen zouden gelden in tijd en ruimte. Integendeel, zij zijn daaraan gebonden, d.i. beperkt tot en bepaalde rechtsorde, die zowel territoriaal als temporeel omschreven is. Zij ontwikkelen zich trouwens met die rechtsorde: op een bepaald ogenblik was er geen sprake van, gaandeweg werd vastgesteld dat men niet zonder kon. Door de maatschappij zelf wordt óók een wetgevende functie uitgeoefend, wat een fraaie variante is van de rechtstreekse democratie. Toch zijn de algemene rechtsbeginselen 'algemeen', maar dan in die zin dat zij een (zeer) ruime werkingssfeer hebben, zij het binnen dezelfde rechtsorde, ten aanzien van particulieren, rechters of bestuurders, naargelang van het geval. Daaruit vloeit voort dat ze abstract geformuleerd en meteen vaag zijn, zodat zij nadere concretisering behoeven, wat bij uitstek in de rechtspraak geschiedt." P. van Orshoven 1991, blz. 74. 
Ook kan met de toevoeging van het woord 'algemeen' worden bedoeld dat het bestaan van het een beginsel algemeen aanvaard is. De inhoud en kracht van het beginsel zijn dan onbetwist en gebaseerd op een algemene consensus. ${ }^{45}$ Er kan van worden uitgegaan dat de herkomst en de kracht van algemene rechtsbeginselen liggen in de algemene aanvaarding. Dworkin formuleert het als volgt:

"The origin of $(\ldots)$ legal principles lies not in a particular decision of some legislature or court, but in a sense of appropriateness developed in the profession and the public over time. Their continued power depends upon this sense of appropriateness being sustained." 46

Algemene aanvaarding is dan ook een belangrijk element.

Voor het vervolg van het onderzoek is het van belang te vermelden dat het gelijkheidsbeginsel, het evenredigheidsbeginsel en het rechtszekerheidsbeginsel zich in het gehele recht, dus inclusief het belastingrecht, laten gelden. Verder zijn zij universeel, onbetwist en diep verankerd in wat men het rechtsbewustzijn noemt.

Zoals de toevoeging 'algemeen' heeft ook de term '(rechts)beginsel' verschillende betekenissen. ${ }^{47}$ In de literatuur over rechtsbeginselen zijn onder meer de volgende zeer abstracte omschrijvingen te vinden van het fenomeen (algemene) rechtsbeginsel:

- Van Hoecke: "Algemene rechtsbeginselen vormen dus het kader, de ruggengraat van het recht, een achtergrond tegen de welk de wetgeving begrepen en geïnterpreteerd kan worden en waardoor leemten of andere toepassingsproblemen van de wetgeving kunnen worden opgelost."48

- Gijssels: “'Rechtsbepalende principes' zou beter tot uitdrukking brengen wat bedoeld wordt. (...) wegens het gevestigde gebruik zullen we het bij het woord rechtsbeginsel laten, hopend dat de betekenis ervan geleidelijk beter wordt begrepen. Met name beginselen uit de ideële of morele sfeer die in het recht erkend zijn als juridisch geldend in de door rechtsvormers aangewezen aangelegenheden en gevallen." 49

- Storme: “Etymologisch betekent beginsel 'begin' én 'grondslag' (princeps, principium): oorsprong, oorzaak, aanvang." ${ }^{50}$ Ondanks deze betekenis meent Storme dat, hoe paradoxaal ook, de beginselen juist aan het eindpunt van een lange rechtsgeschiedenis opduiken.

45. Ook Storme herkent diverse dimensies in de toevoeging 'algemeen', namelijk in de tijd (het is een beginsel van alle tijden), in de ruimte (in de zin van wereldwijd aanvaard), dat het specifieke regels overschrijdt (gehele recht toepasbaar) en dat het gebaseerd is op een algemene consensus. M. Storme 1991, blz. 163 en 164

46. R. Dworkin 1994, blz. 40. Zie ook J.H. Nieuwenhuis 1979, blz. 40

47. Van Dale, Groot Woordenboek der Nederlandse Taal 1992, vermeldt bij 'Beginsel': 1. Aanvang. 2. De grondslagen. 3. Datgene waarvan iets uitgaat, waarop het berust. 4. Grondstelling van een systeem of theorie. 5. Stelling, overtuiging waarnaar iemand handelt, m.n. op het gebied van godsdienst, zedelijkheid en staatskunde.

48. M. van Hoecke 1991, blz. 5.

49. J. Gijssels 1991, blz. 43.

50. M. Storme 1991, blz. 162. 
- Scholten: "Het rechtsbeginsel is dus een uitspraak omtrent positief recht, die onmiddellijk evident is. We vinden het in het positieve recht, in het systeem van regels, beslissingen en instellingen in zijn geheel, doch het wijst boven het positieve uit naar het zedelijk oordeel, de scheiding van goed en kwaad, waarin het recht is gegrondvest." ${ }^{51}$

- Dworkin: "(...) a standard that is to be observed, not because it will advance or secure an economic, political, or social situation deemed desirable, but because it is a requirement of justice or fairness or some other dimension of morality." 52

In de literatuur zijn de volgende meer concrete omschrijvingen te vinden van algemene rechtsbeginselen:

- Soetaert: “(...) fundamentele normen (dus regels), die in een of meer rechtssystemen, respectievelijk rechtstakken min of meer impliciet aanwezig zijn, daarin door de rechtsleer, maar vooral door de rechtspraak worden 'gevonden' en naar de (onbetwistbaar geachte) noden en verwachtingen van de maatschappij (opnieuw) worden geformuleerd." ${ }^{23}$

- Van Orshoven: “(...) gedragsregels die op een bepaald ogenblik wezenlijk worden geacht voor een bepaalde samenleving en daarom rechtsregels (moeten) zijn, kortom, als vanzelfsprekend beschouwde, noodzakelijk gedragsregels (...) zonder welke het rechtssysteem staat of valt, en die er derhalve wezenselementen of grondslagen van uitmaken." 54

Zo te oordelen blijft een afbakening van de betekenis van het begrip algemene rechtsbeginselen altijd iets vaags houden. De algemene rechtsbeginselen vormen geen afgebakend stuk recht. Niet alleen is een exacte omschrijving uiterst moeilijk, ook is het niet mogelijk een uitputtende opsomming te geven van de algemene rechtsbeginselen die zijn ontdekt en zich laten gelden in het recht. Gezien de veranderingen waar het recht aan onderhevig is, veranderen ook de algemene rechtsbeginselen en hun verschijningsvormen. Een strakke afbakening zou geen recht doen aan de beweeglijkheid van het fenomeen.

Ondanks de bovenstaande beperkingen en gevaren, lijkt mij de volgende omschrijving in het kader van mijn onderzoek te verdedigen. In deze omschrijving zijn de zienswijzen van de bovenstaande schrijvers verwerkt.

Algemene rechtsbeginselen zijn: grondslagen die onmiddellijk evident zijn en algemeen in het recht worden erkend als juridisch geldend.

51. P. Scholten 1974, blz. 64 en 65.

52. R. Dworkin 1977, blz. 22.

53. Met min of meer impliciet bedoelt Soetaert dat ze zowel ongeschreven als geschreven kunnen zijn, als door interpretatie leesbaar gemaakt. Soetaert spreekt in dit kader dan ook van 'verschijningsvormen'. R. Soetaert 1991, onder meer op blz. 84.

54. P. van Orshoven 1991, blz. 73. 
De bovenstaande omschrijving laat in het midden of het om rechtsbeginselen moet gaan die zijn neergelegd in wetten en verdragen, dan wel dat het rechtsbeginselen moeten zijn die door de rechter worden blootgelegd en geformuleerd. Beide zijn mogelijk zoals eerder is aangegeven. In de hierboven gegeven omschrijving is tevens opgenomen dat de algemene rechtsbeginselen 'onmiddellijk evident zijn' en 'algemeen in het recht worden erkend'. Dat betekent dat zij een zodanig gewicht hebben dat zij zelf regels kunnen (gaan) vormen (zie slot paragraaf 3.2.1), dan wel bestaande (BTW-)regelgeving in de uitleg dwingend kunnen beïnvloeden. Op deze aspecten kom ik uitvoerig terug in de paragraaf 3.3. Het gaat om algemene rechtsbeginselen die onmiddellijk evident zijn en dan ook een onbetwistbare invloed hebben op de uitleg van de BTW-regelgeving. Vage abstract geformuleerde rechtsbeginselen lopen het risico in hun bestaan betwist te worden en zijn dan ook (nog) niet goed bruikbaar als richtingaanwijzers. Gezien de eerder in deze paragraaf aangehaalde schrijvers, wil dat niet zeggen dat dergelijke vage uitgangspunten geen algemene rechtsbeginselen kunnen zijn volgens de literatuur. Zij voldoen echter niet aan mijn gekozen omschrijving.

In paragraaf 3.3.1 deel ik de algemene rechtsbeginselen in in twee categorieën, 'beginselen van formeel recht' en 'interpretatiebeginselen'; onder beide categorieën heb ik het oog op het gelijkheidsbeginsel, het evenredigheidsbeginsel en het rechtszekerheidsbeginsel, zie paragraaf 3.4 en zij zijn uiteraard onder mijn omschrijving te brengen.

\subsection{De werking van algemene rechtsbeginselen}

\subsubsection{Beginselen van formeel recht en interpretatiebeginselen}

Hierna vraag ik aandacht naar toepassingsvelden waarop de algemene rechtsbeginselen hun werking doen gevoelen. Aandacht daarvoor is naar ik meen daarom geboden omdat men in de rechtspraktijk bijvoorbeeld bij de hantering van het woord gelijkheidsbeginsel min of meer onwillekeurig de focus richt op de toepassing van dit beginsel in de bestuursrechtelijke sfeer. Dat is niet geheel toevallig, want bij oppervlakkige kennisneming van de rechtspraak in 'jurisprudentiebladen' als BNB en V-N ziet men sinds de 'doorbraak-arresten'55 van 12 april 1978 en 6 juni 1979 een enorme belangstelling voor een beroep op bijvoorbeeld het vertrouwens- en het gelijkheidsbeginsel, alsmede de toepassing ervan door de rechter. En wie is inmiddels niet bekend met - populair geformuleerd - de 50+ die de Hoge Raad hanteert om het gelijkheidsbeginsel zijn werking in de praktijk te geven. ${ }^{56}$ Het terrein waar

55. HR 12 april 1978, nr. 18 452, BNB 1978/135, HR 12 april 1978, nr. 18 464, BNB 1978/136, HR 12 april 1978, nr. 18 495, BNB 1978/137 en HR 6 juni 1979, nr. 19 290, BNB 1979/211. In de arresten uit 1978 is beslist dat als de belastingadministratie een gedragslijn in een beleidsregel heeft neergelegd, dat dan het vertrouwensbeginsel zwaarder weegt dan het legaliteitsbeginsel. In het arrest uit 1979 is beslist dat de Belastingdienst aannemelijk moet maken dat er een redelijke grond is de belastingplichtige anders te behandelen dan andere belastingplichtigen.

56. HR 17 juni 1992, nr. 26 777, BNB 1992/294 en HR 17 juni 1992, nr. 27 048, BNB 1992/295. Zie nader Happé 1996, blz. 328 e.v. 
wij over spreken is dat van het bestuursrecht, meer precies gezegd, het formeel bestuursrecht, en dit laatste inclusief het bestuursprocesrecht. Wij hebben hier waar het om belastingrecht gaat - het oog op regels met betrekking tot de wijze waarop de belastingschuld wordt vastgesteld (en geïnd), en dus ook over de relatie overheid - particulier. En op dit terrein kom je dus ook te spreken over de algemene rechtsbeginselen die deze verhouding mede kunnen beheersen. Ik zou hier - in het voetspoor van de term 'algemene beginselen van behoorlijk bestuur' - ook kunnen spreken van 'algemene beginselen van formeel (belasting)recht'. Ik heb dus het toepassingsveld van de algemene beginselen op het oog.

Ik breng een en ander expliciet naar voren, omdat ik hiermee een categorisering voorsta die hanteerbaar is bij de ordening van het onderzoeksveld en tevens een bijdrage wil leveren aan het voorkomen van eventuele verwarring in terminologie die men tegenkomt in de Europeesrechtelijke literatuur over de werking van de algemene rechtsbeginselen op verschillend terrein. Ik licht dit toe. Deze literatuur ${ }^{57}$ maakt een onderscheid tussen:

- algemene rechtsbeginselen als 'regel van materieel recht'; en

- algemene rechtsbeginselen als 'interpretatieregel'.

Bij de eerstgenoemde duiding - beginsel als regel van materieel recht - heeft men het oog op de relatie overheid - particulier. Maar het veld reikt bij deze schrijvers verder dan enkel deze relatie. Het gaat hen tevens om rechtsbeginselen waaraan regelgevers moeten voldoen. ${ }^{58}$ In deze rol fungeren beginselen als toetsingsgrond van Unie-wetgeving en bestuur. Daarnaast krijgen de communautaire algemene rechtsbeginselen in toenemende mate de functie van toetsingsmaatstaf voor het optreden van de lidstaten. ${ }^{59}$ Wanneer ik voor de gedachtebepaling abstraheer van de gerichtheid van de werking van de algemene rechtsbeginselen op het veld van de regelgever, dan heb ik het enkel over de gerichtheid van de werking van de beginselen op het terrein van het bestuur, het terrein dat ik hiervoor verbreedde tot de term 'algemene beginselen van formeel (belasting)recht'. ${ }^{60}$ Anders geformuleerd, waar genoemde literatuur het woord 'materieel recht' hanteert, geef ik er de

57. Zie toegespitst op het rechtszekerheidsbeginsel, J.H. Jans e.a. 2002, blz. 208. Zie tevens T. Tridimas, The General Principles of EU Law, Oxford: University Press 2006, blz. 29 t/m 31

58. T. Tridimas 2006, blz. 29 e.v.

59. J.H. Jans e.a. 2002, blz. 159 en 160. Zij zijn van mening dat aan de communautaire algemene rechtsbeginselen in principe alleen getoetst kan worden in het kader van een toetsing aan een andere (geschreven) communautaire bepaling. Prechal en Heukels menen dat de doorwerking van de communautaire rechtsbeginselen in de nationale rechtsorde vooral een belangrijke rol speelt bij de verzekering van de draagwijdte en de doeltreffendheid van het positieve Unierecht. Zij menen dat naar hun aard de algemene rechtsbeginselen zich niet lijken te lenen voor rechtstreekse werking. S. Prechal \& T. Heukels, Algemene beginselen in het Nederlands recht en het Europees recht: rechtsvergelijking en interactie, SEW 1986, blz. 313.

60. Ik zie dus af van nadere duiding en interpretatie van de woorden en indeling bij deze schrijvers omdat het voor mij er thans enkel om gaat voldoende onderscheidende categorieën te maken (geïnspireerd op genoemde indeling). 
voorkeur aan om binnen ons onderwerp te spreken van 'formeel recht'. De volgende indeling ontstaat dan:

- algemene rechtsbeginselen als regel van formeel (belasting)recht; en

- algemene rechtsbeginselen als 'interpretatieregel'.

Hoofdstuk 5 schenkt in het bijzonder aandacht aan de algemene rechtsbeginselen in de betekenis van 'regel van formeel recht'. Aan de orde komen de onderwerpen: de formele rechtskracht van besluiten, terugwerkende kracht van regelgeving en de uitgestelde werking van arresten. Centraal staan leerstukken die in de jurisprudentie zijn ontwikkeld en waaraan de uitvoerder zich dient te houden. Voor zover ik daarbij tevens het oog heb op de functie van de beginselen als maatstaf voor het handelen van de lidstaten - waar lidstaten zich bij implementatie van de richtlijn aan hebben te houden - neem ik dit mee als veld waarop de beginselen van formeel (belasting) recht hebben te werken. In het Unierecht kan het ook gaan om de 'gezagsrelatie' tussen Uniewetgever en de lidstaat als implementator. Ten opzichte van ons nationale rechtsgebied waar de beginselen van behoorlijk bestuur dominant zijn, is het daarom zelfs wellicht beter te spreken van algemene rechtsbeginselen als regel van Europees formeel (belasting)recht. Voor de goede orde zij opgemerkt dat indien de beginselen van behoorlijk bestuur onderwerp van deze studie zouden zijn geweest, deze uiteraard 'als beginselen van formeel recht' een plaats in hoofdstuk 5 zouden hebben gekregen.

De werking van de algemene rechtsbeginselen als 'interpretatieregel' komt uiteraard terug op het hele veld van het materiële, inhoudelijke, (belasting)recht, zoals dit een plaats heeft gekregen in de BTW-richtlijn (wie en wat is belast en waarover, enz.). De hoofdstukken $6 \mathrm{t} / \mathrm{m} 12$ schenken voornamelijk aandacht aan de algemene rechtsbeginselen, behulpzaam bij de interpretatie van het secundaire BTW-recht. De algemene rechtsbeginselen fungeren dan, zoals genoemde schrijvers stellen, als interpretatieregel. ${ }^{61}$ Het Hof heeft beslist dat, zoals paragraaf 4.5.1 naar voren brengt, het secundaire Unierecht zo veel als mogelijk conform het primaire Unierecht en de algemene rechtsbeginselen dient te worden uitgelegd.

Hiervoor sprak ik over algemeen beginsel als 'regel' van formeel (belasting)recht en als interpretatieregel. Het spreekt van zelf dat hiermee niet bedoeld is de discussie over het verschil tussen beginselen en regels over te doen (zie paragraaf 3.2.2). Waar het om gaat is enkel de werking van de toepassing van het algemeen rechtsbeginsel; het opereert als regel, als ware het een regel. Duidt men niet daarop maar op het beginsel als zodanig en de toepassing daarvan, dan kan men beter spreken van:

- algemeen rechtsbeginsel van formeel recht; en

- algemeen rechtsbeginsel als interpretatiebeginsel.

Voor mij is deze indeling verder ordenend. 
In de paragrafen 5.2, 5.4, 5.5, 5.6 komen de algemene rechtsbeginselen als beginsel van formeel recht aan de orde en in paragraaf 5.3 komt als een bijzonderheid misbruik van recht als interpretatiebeginsel aan de orde.

\subsubsection{Inperkende en verruimende effecten van de algemene rechtsbeginselen}

Omdat de vragen voorliggen of, waar en in welke mate algemene rechtsbeginselen voor de BTW-regelgeving van betekenis zijn, is het van belang de inperkende en verruimende effecten van de algemene rechtsbeginselen te onderkennen. Daar bedoel ik mee dat de rechter een uitleg aan een BTW-regel kan geven die tot gevolg heeft dat een bepaalde gunstige regel voor een belastingplichtige geldt, bijvoorbeeld het aftrekrecht of een vrijstelling. Het kan dan zo zijn dat de BTW-regel ruimer wordt uitgelegd dan dat voorheen gangbaar was in de rechtspraktijk. Het kan ook zijn dat de rechter een bepaalde verplichting of last die vervat is in een BTW-regel niet van toepassing verklaart voor een belastingplichtige (bijvoorbeeld een bepaalde administratieve verplichting). Dit kan dan betekenen dat een BTW-regel beperkter wordt uitgelegd dan dat voorheen gangbaar was in de rechtspraktijk. In deze betekenissen wil ik de begrippen 'verruimen' en 'beperken' van een BTW-regel begrijpen. ${ }^{62}$ Daarnaast is denkbaar dat de rechter een last-bepaling ruimer uitlegt, of dat een gunstige bepaling een belastingplichtige wordt onthouden. Deze twee gevallen kunnen op gespannen voet staan met de verwachte uitkomsten van de

62. De uitkomst van het interpretatieproces kan zijn dat de rechter een uitleg aan een BTW-regel geeft die voor de rechtspraktijk nieuw is en deze uitleg kan zijn dat een BTW-regel voor een persoon van toepassing is of juist niet. De rechter kan algemene rechtsbeginselen gebruiken om het materiële recht uit te leggen. Of om het materiële recht te vinden. Daarbij wil ik dan in het midden laten of het materiële recht altijd al een dergelijke betekenis had. De rechter heeft het recht dan ontdekt met behulp van een algemeen rechtsbeginsel en de rechter fungeert dan als het ware als een ontdekkingsreiziger. Of dat men moet constateren dat de rechter nieuw recht schept. Gijssels besteedt uitgebreid aandacht aan de rol van de rechter bij het proces dat tot erkenning van rechtsbeginselen leidt, J. Gijsels, Is sprake van rechtsvorming of van rechtsvinding? Creatie of formulering? 1991, blz. 43 $\mathrm{t} / \mathrm{m}$ blz. 52. De rechter vernieuwt dan het recht met behulp van een algemeen rechtsbeginsel en de rechter fungeert dan als de schepper van recht. Er wordt als het ware een nog niet ontdekte betekenis blootgelegd door de rechter. Of men zou zelfs kunnen stellen dat de algemene rechtsbeginselen leemtes in de regelgeving opvullen. In de meest ideale vorm gebeurt dit op een wijze die nauwelijks opvalt. De rechter verwijst dan in de uitspraak niet expliciet naar een algemeen rechtsbeginsel ter onderbouwing van het rechtsoordeel. Nieuwenhuis merkt in dit kader op dat: "de beginselen beïnvloeden niet slechts het systeem van het positief recht, zij scheppen ook in veel gevallen een systeem. Een systeem dat er zonder die beginselen niet zou zijn. (...) de beginselen fungeren (...) als systeembouwers." J.H. Nieuwenhuis 1979, blz. 4. Zie in dit kader ook hetgeen in paragraaf 3.2.2 is geschreven over het 'open' systeem van het recht. Storme schrijft, toegespitst op het recht op verdediging, dat: “(...) de aldus geformuleerde algemene beginselen op hun beurt generatief, d.w.z. dat zij niet alleen tot naleving dwingen, maar bovendien een vernieuwende rechtsontwikkeling stimuleren en tot verdere nuancering, verfijning en uitsplitsing aanleiding geven." M. Storme 1991, blz. 171. De vraag wanneer interpretatie rechtsvorming is, komt neer op de vraag wanneer door interpretatie het geldend recht wordt veranderd. Het antwoord op de vraag waar de grens ligt tussen interpretatie en rechtsvorming valt buiten het kader van mijn onderzoek. Voor de geïnteresseerde lezer zie verder: F.T. Groenwegen, Wetsinterpretatie en rechtsvorming (diss. Amsterdam UvA), Boom Juridische Uitgevers 2006, blz. 39 e.v. 
tekst en het rechtszekerheidsbeginsel en komen aan de orde in paragraaf 4.4.3.4 (analogieargumentatie in het belastingrecht) en paragraaf 5.3 (misbruik van recht). Ik laat deze hier buiten beschouwing.

De verruimende en inperkende werking kunnen zich zowel voordoen bij de algemene rechtsbeginselen van formeel recht, als in het toepassingsveld van interpretatiebeginsel. Schematisch zijn dan vier categorieën te onderscheiden.

Inperkend Uitbreidend

\begin{tabular}{|l|l|l|}
\hline $\begin{array}{l}\text { Algemene rechtsbeginselen van } \\
\text { formeel recht }\end{array}$ & I & II \\
\hline \multicolumn{2}{|c|}{ Inperkend } & Uitbreidend \\
\hline $\begin{array}{l}\text { Algemene rechtsbeginselen als } \\
\text { interpretatiebeginsel }\end{array}$ & III & IV \\
\hline
\end{tabular}

Ik zal kort iedere categorie beschrijven.

I. Algemene rechtsbeginselen van formeel recht: inperkend In deze categorie laten de algemene rechtsbeginselen zich gelden in de relatie overheid - particulier. Het zal dan gaan om een toepassing van een algemeen rechtsbeginsel met als effect dat op een belastingplichtige de BTW-regel voor (een deel) van een periode niet van toepassing is. De algemene rechtsbeginselen beschermen dan de burger in een bepaalde situatie tegen het handelen van de overheid. Een voorbeeld hiervan is de werking van het vertrouwensbeginsel. Indien de overheid bij een belastingplichtige vertrouwen heeft gewekt met betrekking tot de fiscale gevolgen van een bepaald feitencomplex, dan moet dat vertrouwen worden gehonoreerd. Een voorbeeld hiervan is te vinden in het arrest van de Hoge Raad van 18 september $1991 .{ }^{63}$ Het arrest heeft betrekking op een boekenclub dat een cadeau verstrekte aan degene die een nieuw lid aanbracht. De boekenclub berekende geen BTW inzake de verstrekking van het cadeau. Zowel het Gerechtshof als later de Hoge Raad waren van mening dat wel degelijk BTW verschuldigd was. Belanghebbende bracht echter naar voren dat

63. HR 18 september 1991, nr. 27 127, BNB 1992/182. In het bijzonder r.o. 3.5: “(...) dat voor een in rechte te beschermen vertrouwen in gevallen als het onderhavige niet vereist is dat de aangelegenheid bij een boekenonderzoek door de belastingadministratie daadwerkelijk op zijn fiscale merites is beoordeeld, doch dat voldoende is dat de belastingplichtige in de gegeven omstandigheden mocht aannemen dat zulks het geval was. Dit zal zich in het algemeen voordoen, indien de betrokken aangelegenheid verhoudingsgewijs van zodanig belang is dat zij niet aan de aandacht van de met de controle belaste ambtenaren kan zijn ontsnapt, en bovendien de gevolgen van de belastingheffing van dien aard zijn dat het voor de hand ligt om kritische opmerkingen te maken, zo niet tot naheffing over te gaan. Alsdan zal de inspecteur, door niettemin generlei opmerkingen te maken en naheffing achterwege te laten, in het algemeen het gerechtvaardigde vertrouwen wekken dat de wijze waarop deze de betrokken aangelegenheid in fiscaal opzicht heeft behandeld zijn goedkeuring kan wegdragen." Zie voor een uitgebreide behandeling van deze werking van het vertrouwensbeginsel, R.H. Happé 1996, blz. 109 t/m 286. Zie verder ook paragraaf 3.2.2. 
sprake was van gewekt vertrouwen. Op grond van een eerdere controle was de inspecteur op de hoogte van de handelwijze van belastingplichtige. Kennelijk vond hij het toen echter niet nodig om een naheffingsaanslag op te leggen of om opmerkingen te maken. Deze verdedigingslinie van de boekenclub hield stand. De Hoge Raad gaf aan dat voldoende is, dat de belastingplichtige mag aannemen dat het desbetreffende facet door de Belastingdienst is beoordeeld en geen aanleiding gaf tot correcties of het maken van kritische opmerkingen. Cruciaal is dus dat de belastingplichtige in redelijkheid de indruk heeft kunnen krijgen dat hij juist heeft gehandeld. In deze procedure zou een correcte uitwerking van enkel de BTW regels tot gevolg hebben dat BTW zou moeten worden nageheven. ${ }^{64}$ Het vertrouwensbeginsel blokkeert echter deze uitwerking. ${ }^{65}$

II. Algemene rechtsbeginselen van formeel recht: uitbreidend

Ook in deze categorie gaat het om de toepassing van een algemeen rechtsbeginsel in de relatie overheid - particulier. De toepassing van een algemeen rechtsbeginsel heeft dan als resultaat dat de BTW-regel ook geldt voor de belastingplichtige die zich erop beroept. Een voorbeeld van een dergelijke toepassing van een algemeen rechtsbeginsel is te vinden in het arrest van de Hoge Raad ${ }^{66}$ van 17 juni 1992 waarin is beslist dat het gelijkheidsbeginsel tot effect heeft dat als - kort weergegeven - er in de meerderheid van gevallen sprake is geweest van een wetsafwijking, dan moet een juiste wetstoepassing wijken voor de werking van het gelijkheidsbeginsel. Op grond van deze meerderheidsregel kan dan een BTW-regel van toepassing zijn waar een juiste wetstoepassing een ander resultaat zou opleveren. ${ }^{67}$

III. Algemene rechtsbeginselen als interpretatiebeginsel: inperkend In deze categorie valt de uitleg van een BTW-regel met behulp van een algemeen rechtsbeginsel. Het zal dan gaan om het wegnemen van een lastbepaling. Gedacht

64. Bij de behandeling van het doorbraakarrest (HR 12 april 1978, 18 452, BNB 1978/135) op het gebied van de leer van het opgewekt vertrouwen, merkt Happé (1996, blz. 82) op: “De Hoge Raad zet hier twee beginselen tegenover elkaar: het legaliteitsbeginsel, dat hij omschrijft als de strikte toepassing van de wet, waaruit de belastingschuld voortvloeit, en het vertrouwensbeginsel, dat inhoudt dat de belastingadministratie door haar opgewekte verwachtingen honoreert. Het conflict dat in het onderhavige geval is ontstaan moet worden opgelost door de weging van het gewicht van beide beginselen." Zie voor een uitgebreide behandeling R. H. Happé 1996, blz. 81 t/m 83 .

65. Prechal en Heukels veronderstellen dat een dergelijke uitwerking het gevolg is van een afweging tussen de zwaarte van de schending van het algemene rechtsbeginsel enerzijds en het gewicht van de wettelijke bepaling, die eventueel buiten toepassing zou dienen te blijven anderzijds. In de praktijk gaat het in de relatie burger - overheid meestal om het vertrouwensbeginsel en het gelijkheidsbeginsel. Bij twijfel geniet volgens deze schrijvers de wetsconforme interpretatie voorrang. S. Prechal \& T. Heukels, Algemene beginselen in het Nederlandse recht en het Europese recht: rechtsvergelijking en interactie, Nederlands rapport ten behoeve van het FIDE-congres 1986 weergegeven in SEW 5 (1986) mei, blz. 292.

66. HR 17 juni 1992, nr. 26 777, BNB1992/294 en HR 17 juni 1992, nr. 27 048, BNB 1992/295. Zie nader Happé 1996, blz. 328 e.v.

67. Zie J.H. Gerards, Rechtelijke toetsing aan het gelijkheidsbeginsel (diss. Maastricht), Den Haag: Sdu Uitgevers 2002, blz. 550 en 551. 
kan dan worden aan bijvoorbeeld een minder strakke uitleg van een administratieve verplichting. Een voorbeeld hiervan is te vinden in het Minerales-arrest, ${ }^{68}$ waarin is beslist dat een lidstaat niet kan eisen van een in andere lidstaat gevestigde belastingplichtige, die een verzoek om teruggaaf doet op grond van de Achtste richtlijn, dat deze een originele factuur indient om het teruggaafverzoek te onderbouwen. ${ }^{69}$ Artikel 3, sub a, Achtste Richtlijn eist echter ondubbelzinnig een originele factuur om in aanmerking te komen voor een teruggaaf. Toch komt het Hof op grond van de algemene rechtsbeginselen tot een andere uitleg van de BTWregel. Paragraaf 12.3.1.3 behandelt deze procedure uitgebreid.

\section{Algemene rechtsbeginselen als interpretatiebeginsel: uitbreidend}

Ook in deze categorie gaat het om de uitleg van een BTW-regel met behulp van een algemeen rechtsbeginsel. Het komt dan neer op het toekennen van een bepaalde faciliteit. Een voorbeeld hiervan is het in de paragrafen 1.3 en 4.4.2.1 behandelde Gregg-arrest. ${ }^{70}$ In deze procedure besliste het Hof - kort weergegeven - dat een natuurlijk persoon in aanmerking komt voor de vrijstelling in artikel 132, lid 1, sub g, BTW-richtlijn (instellingen van sociale aard). In een eerdere procedure had het Hof echter beslist dat een natuurlijk persoon niet onder de term 'instellingen' valt die in de tekst van de vrijstellingsbepaling is te vinden. ${ }^{71}$ In de Gregg procedure komt het Hof tot een andere uitkomst. In dit laatste arrest geeft het Hof namelijk aan dat de fiscale neutraliteit vereist een gelijke behandeling tussen natuurlijke personen en rechtspersonen.

Het bovenstaande kan als volgt samenvattend worden weergegeven:

\begin{tabular}{|c|c|c|}
\hline & Inperkend & Uitbreidend \\
\hline \multirow[t]{2}{*}{$\begin{array}{l}\text { Algemene rechtsbeginselen van } \\
\text { formeel recht }\end{array}$} & $\begin{array}{l}\text { I Last-bepaling niet van toe- } \\
\text { passing op mij of mijn groep }\end{array}$ & $\begin{array}{l}\text { II Gunst-bepaling geldt ook } \\
\text { voor mij of mijn groep }\end{array}$ \\
\hline & Inperkend & Uitbreidend \\
\hline $\begin{array}{l}\text { Algemene rechtsbeginselen als } \\
\text { interpretatiebeginsel }\end{array}$ & III Wegnemen last-bepaling & $\begin{array}{l}\text { IV Verkrijgen van een gunst- } \\
\text { bepaling }\end{array}$ \\
\hline
\end{tabular}

De toepassing van de algemene rechtsbeginselen als interpretatiebeginsel dan wel als beginsel van formeel recht kent een verschil. De toepassing van een algemeen rechtsbeginsel als interpretatiebeginsel heeft een algemene gelding. In die zin dat de hele BTW-regel ter toetsing staat. Gaat het daarentegen om een algemeen beginsel

68. Hof 11 juni 1998, C-361/96, Minerales, V-N 1998/39.42.

69. Per 1 januari 2010 is de Achtste richtlijn vervangen door richtlijn 2008/9/EG. Belastingplichtigen kunnen de 'buitenlandse BTW' vanaf die datum centraal terugvragen bij de Belastingdienst van de lidstaat waar zij hun zetel van bedrijfsuitoefening hebben. De Achtste richtlijn-procedure is dus komen te vervallen.

70. Hof 7 september 1999, nr. C-216/97, Gregg, BNB 1999/395, V-N 1999/47.21. In deze procedure ging het om de uitleg van de term 'instelling'.

71. Zie Hof 11 augustus 1995, nr. C-453/93, Bulthuis-Griffioen, V-N 1995/2932, pt. 32, FED 1995/703. Zie nader over deze bijstelling in de jurisprudentie de paragrafen 1.3 en 4.4.2.1. 
van formeel recht dan is de toepassing met name gericht op een op zich zelfstaand geval.

Hierboven heb ik de twee toepassingsvelden waar de algemene rechtsbeginselen werken als beginsel van formeel recht toegelicht met voorbeelden uit onze nationale jurisprudentie (I en II). Paragraaf 3.4.3.3 brengt naar voren dat het Hof ruimte geeft voor het ontwikkelen van een nationale invulling van de algemene rechtsbeginselen, mits de doorwerking van het Europees recht niet wordt uitgehold. Ik ga op de verhouding tussen een nationale invulling van de algemene rechtsbeginselen en een Europees rechtelijke op deze plaats niet nader in. Van belang is de constatering dat deze velden niet hoeven samen te vallen en dat een splitsing in het schema op zijn plaats is. ${ }^{72}$

\begin{tabular}{|l|l|l|}
\multicolumn{2}{c}{ Inperkend } & \multicolumn{2}{l|}{ Uitbreidend } \\
\hline $\begin{array}{l}\text { Algemene rechtsbeginselen van } \\
\text { formeel recht }\end{array}$ & Ia Nationaal recht & Ila Nationaal recht \\
\cline { 2 - 3 } & Ib Europees recht & IIb Europees recht \\
\hline
\end{tabular}

\begin{tabular}{|l|l|l|}
\multicolumn{2}{c}{ Inperkend } & Uitbreidend \\
\hline $\begin{array}{l}\text { Algemene rechtsbeginselen als } \\
\text { interpretatiebeginsel }\end{array}$ & $\begin{array}{l}\text { III Geharmoniseerd } \\
\text { BTW-recht }\end{array}$ & $\begin{array}{l}\text { IV Geharmoniseerd } \\
\text { BTW-recht }\end{array}$ \\
\hline
\end{tabular}

Het schema maakt geen onderscheid tussen de werking van de algemene rechtsbeginselen als interpretatiebeginsel op het niveau van nationaal recht dan wel op het niveau van Europees recht. Paragraaf 4.7 zal behandelen dat de nationale rechter de verplichting heeft om de Wet OB conform de BTW-richtlijn en de Europese algemene rechtsbeginselen uit te leggen (beginselconforme interpretatie). Dat betekent dat op dit toepassingsterrein geen onderscheid bestaat.

De hierboven gegeven voorbeelden in de categorieën I en II hebben beide betrekking op Ia en IIa, namelijk een nationale toepassing van een algemeen rechtsbeginsel van formeel recht. In categorie I is een nationale uitwerking te vinden van het vertrouwensbeginsel en in categorie II van het gelijkheidsbeginsel. De nationale toepassing van de algemene rechtsbeginselen van formeel recht (Ia en IIa) valt buiten het kader van mijn onderzoek.

In hoofdstuk 5 zal met name de toepassing van de algemene rechtsbeginselen van formeel recht aan de orde komen voor zover deze zich laten gelden in de BTW jurisprudentie van het Hof (in het schema Ib en IIb). De hoofdstukken 6 t/m 12 gaan nader in op de algemene rechtsbeginselen als interpretatiebeginsel (III en IV). Het ‘beperken' en ‘verruimen' van een BTW-regel in het nadeel van belanghebbende heb

72. Van Hilten meent dat belastingplichtigen minder bescherming aan het communautaire vertrouwensbeginsel kunnen ontlenen dan aan het vertrouwensbeginsel zoals dat door de HR is ingevuld. De plaats van het vertrouwensbeginsel in het Unierecht komt in paragraaf 3.4.3.3 aan bod. M.E. van Hilten, De Europese Dimensie van door de fiscus opgewekt vertrouwen in de BTW en het douanerecht (oratie Leiden), Leiden: Rijks Universiteit Leiden 1998. 
$\mathrm{ik}$ - zoals eerder is vermeld - niet meegenomen in het schema maar komt aan bod in de paragrafen 4.4.3.4 (analogieargumentatie in het belastingrecht) en paragraaf 5.3 (misbruik van recht).

\subsubsection{Interpretatietechniek van de geschreven rechtsregels}

In paragraaf 3.2.1 is verduidelijkt dat een relatie bestaat tussen het rechtsbewustzijn en de algemene rechtsbeginselen. Tevens is daar naar voren gebracht dat vooral in het ontwikkelingsproces van algemene rechtsbeginselen de beperkingen van het fenomeen zijn te vinden. Wat bij nog niet algemeen aanvaarde beginselen (in wording) voor de één zonneklaar een algemeen rechtsbeginsel is en dan ook sturend zou moeten zijn, wordt door de ander betwist. In paragraaf 3.2.3 is een dusdanige omschrijving gegeven van algemene rechtsbeginselen dat deze zwakke varianten van algemene rechtsbeginselen voor ons doel terzijde kunnen worden geschoven. Zoals aangegeven kan er volgens mij pas van een algemeen rechtsbeginsel worden gesproken indien het bestaan onbetwist is en algemeen aanvaard is in een bepaalde rechtsorde. Zoals in de paragrafen die volgen, zal blijken, voldoen de drie algemene rechtsbeginselen aan deze voorwaarden.

Indien wij te maken hebben met volwaardige algemene rechtsbeginselen doet zich de vraag voor onder welke omstandigheden deze rechtsbeginselen sterk genoeg zijn om een dwingende kracht uit te oefenen op de invulling van de regelgeving en die van de BTW dan in het bijzonder. Onder welke omstandigheden roept een rechter de hulp in van algemene rechtsbeginselen? Wanneer schieten zij te kort? Wij zijn dan aangeland op het weerbarstige terrein van de rechtsvinding. Ondanks het gegeven dat de techniek van het interpreteren op zichzelf en in de breedte buiten mijn onderzoek valt, wil ik toch, ter afbakening van de problematiek, enige aspecten belichten (zie ook paragraaf 4.4).

Rechtsbronnen spelen een belangrijke rol bij de rechtsvinding. In het algemeen worden de wet, verdrag, gewoonte en de rechtspraak aangeduid als de (formele) rechtsbronnen. ${ }^{73}$ De algemene rechtsbeginselen worden dan als aanvullende rechtsbronnen gekwalificeerd. Zij zijn geen formele rechtsbron. De oorsprong van de algemene rechtsbeginselen ligt namelijk niet bij een bevoegd orgaan. Zij worden opgespoord door middel van een analyse van het rechtsstelsel. Een formele identificatie is niet vereist, wel een inhoudelijke analyse. Gesteld zou kunnen worden dat de algemene rechtsbeginselen een voedingsbodem zijn voor de formele rechtsbronnen.

73. Voor een uitgebreide analyse van de verhouding tussen de diverse rechtsbronnen, zie J.L.M Gribnau 1998, paragraaf 4.8. Zie in dit kader ook J.L.M. Gribnau, des Pudels Kern? Rechtsbeginselen als fundamentele rechtsbron, blz. 197, in: E.T Feteris, H. Kloosterhuis, H.J. Plug, J.A. Pontier, (red.), Met Recht en Reden, Bijdragen aan het Derde Symposium Juridische Argumentatie Rotterdam 18 juni 1999, Nijmegen: Ars Aequi Libri 2000. Gribnau geeft in deze laatste publicatie onder meer aan dat de rechtsbeginselen aangemerkt kunnen worden als fundamentele rechtsbron. Het betreft de normatieve oorsprong van alle recht. De rechtsvorming is dan ook gebonden aan rechtsbeginselen. Ook Kooijmans noemt de algemene rechtsbeginselen als één van de bronnen van het internationaal publiekrecht. P.H. Kooijmans, Internationaal publiekrecht, Deventer: Kluwer 2008, blz. 15 en 16. 
Als zodanig zijn zij dan mede richtinggevend bij de interpretatie van de geschreven rechtsregels. Mijn onderzoek spitst zich onder meer toe op de omstandigheden waaronder de algemene rechtsbeginselen zich laten gelden bij de uitleg van de geschreven BTW-regels.

Volgens Dworkin zijn rechters verplicht algemene rechtsbeginselen in hun beschouwing te betrekken. Ter onderbouwing van deze zienswijze verwijst hij naar de tweeledige functie van algemene rechtsbeginselen. ${ }^{74}$ De eerste functie is dat algemene rechtsbeginselen een rechtvaardiging kunnen geven om van rechtsregels af te wijken. Een voorbeeld daarvan zagen wij in paragraaf 3.3.2, waar het arrest van de Hoge Raad van 18 september 1991 is behandeld over de toepassing van het vertrouwensbeginsel. De tweede functie is dat sommige algemene rechtsbeginselen redenen vormen om juist niet van de rechtsregels af te wijken. Kortom, de algemene rechtsbeginselen sturen de interpretatie van de rechtsregels.

Het proces van rechtsvinding kan gezien worden als een zoektocht naar de achterliggende beginselen van de regelgeving. Een dergelijke opvatting is verwoord door Scholten. Scholten onderscheidt diverse interpretatiemethoden. ${ }^{75}$ Het is volgens hem, dat juist bij de analogische interpretatiemethode en bij de rechtsverfijning de algemene rechtsbeginselen een belangrijke rol spelen. ${ }^{76}$ In de analogie wordt een geval dat niet gedekt wordt door een regel, vergeleken met een geval dat wel onder het bereik van een regel valt. In geval van analogie worden de ogenschijnlijke verschillen als niet relevant terzijde geschoven. De rechtvaardiging van deze methode ligt dan in de veronderstelling van een algemene ongeschreven regel. Scholten gebruikt in dit verband de term 'algemene grondslag', oftewel ratio legis: de reden of zin van de wet. Deze algemene grondslagen zijn dan in de visie van Scholten beginselen (paragraaf 4.4.3.2 besteedt aandacht aan de relatie tussen het gelijkheidsbeginsel en de analogieredenering; paragraaf 4.4.3.4 gaat in op de analogieredenering in het belastingrecht).

In paragraaf 3.3.2 is toegelicht dat de algemene rechtsbeginselen de toepassing van de BTW-regelgeving kunnen inperken dan wel verruimen. Een ander onderscheid met betrekking tot de werking van algemene beginselen treft men aan bij Mertens de Wilmars. Zo maakt Mertens de Wilmars een onderscheid tussen 'echte' en 'onechte' algemene beginselen van het recht. ${ }^{77}$ De echte algemene rechtsbeginselen verwijzen naar de gevallen waar men te maken heeft met een door het Hof erkend

74. Zoals in paragraaf 3.2.2 gaat Dworkin uit van een scherp onderscheid tussen rechtsregels en algemene rechtsbeginselen. De term algemene rechtsbeginselen is dan ook ruimer in de zienswijze van Dworkin dan de omschrijving die in paragraaf 3.2.3 is gegeven.

75. P. Scholten 1974, blz. 60 t/m blz. 66.

76. Zie in dit kader ook over het toepassen van recht in concrete situaties gekoppeld aan de theorie van Scholten, A. Muntjewerff, ROSA een model gebaseerd computerprogramma voor het (leren) oplossen van juridische casus. In: E. Lissenberg, P.W. Brouwer, F. Jacobs, E. Poortinga, De actualiteit van Paul Scholten, Nijmegen: Ars Aequi Libri 1996, blz. 91 e.v.

77. J. Mertens de Wilmars, Algemene rechtsbeginselen in het Europees recht, in: M. van Hoecke (red.), Algemene rechtsbeginselen, Antwerpen: Kluwer rechtswetenschappen 1991, blz. 277 e.v. 
algemeen beginsel van het recht eigen aan de communautaire rechtsorde. De echte algemene rechtsbeginselen vereenzelvigen zich, volgens Mertens de Wilmars, met het begrip rechtsregel en vertonen dezelfde kenmerken als de bepalingen van de verdragen of de verordeningen, namelijk het primaat ten aanzien van het nationale recht in geval van een eventuele concurrerende toepassing. ${ }^{78}$ Het zijn dan sterk normatieve rechtsbeginselen: zij zijn geen rechtsbron maar recht tout court. De onechte algemene rechtsbeginselen zijn eerder te zien als een door het Hof toegepaste methode van rechtsvinding. De onechte rechtsbeginselen zijn dan te herkennen door het gebruik van uitdrukkingen zoals 'algemene beginselen van het recht' vooral met de toevoeging 'die gemeen zijn aan de rechtsstelsels der Lidstaten'. Volgens Mertens de Wilmars is de verwijzing naar 'algemene rechtsbeginselen' in een dergelijke situatie onjuist. Het gaat in dergelijke gevallen om een comparatieve methode van rechtsvinding. ${ }^{79}$

De algemene rechtsbeginselen kunnen dan voor hun functie worden onderscheiden tussen algemene rechtsbeginselen die als interpretatie-instrument voor rechtsregels fungeren dan wel algemene rechtsbeginselen die zelf positiefrechtelijke regels vormen (zie paragraaf 3.3.1 over het onderscheid tussen algemene rechtsbeginselen van formeel recht en als interpretatiebeginsel). In het vervolg van mijn onderzoek zal blijken dat het gelijkheidsbeginsel, het evenredigheidsbeginsel en het rechtszekerheidsbeginsel zowel als 'echt' rechtsbeginsel kunnen opduiken, terwijl onder andere condities het desbetreffende algemene rechtsbeginsel fungeert als interpretatie-instrument. De in de vorige alinea geschetste benadering door Mertens de Wilmars, maakt duidelijk dat het vereist is voor mijn onderzoek om in paragraaf 4.4.2 aandacht te schenken aan de karakteristieke interpretatietechnieken die het Hof toepast. Indien deze technieken namelijk duidelijk zijn, blijkt vervolgens uit de toepassing de kracht van de algemene rechtsbeginselen.

De rol die algemene rechtsbeginselen spelen bij het forceren van een rechtelijke beslissing is niet altijd even duidelijk. Dit wordt veroorzaakt doordat regelmatig algemene rechtsbeginselen met elkaar botsen. De vraag doet zich dan voor of er een methode denkbaar is die aangeeft welk beginsel dan voorrang krijgt. Zijn er rationaliteitvereisten die voorschrijven hoe dergelijke conflicterende beginselen toegepast moeten worden, of is de uiteindelijke beslissing niet meer dan een keuze waar redelijke mensen over van mening kunnen verschillen. Burg verdedigt in dit kader het optimaliseringvereiste als één van de rationaliteitvereisten die van

78. J. Mertens de Wilmars 1991, blz. 281 en 282. Hij heeft in dit kader onder meer op het oog het proportionaliteitsbeginsel en vertrouwensbeginsel.

79. Lenaerts en Van Nuffel maken onderscheid in administratieve rechtsbeginselen en rechtsbeginselen van constitutionele aard. De administratieve rechtsbeginselen zijn aanvullend van aard en enkel van toepassing op de uitvoering van Unierecht. Zij geven richting aan de administratie in geval van onduidelijkheid of leemten in de toe te passen communautaire wetgeving. De rechtsbeginselen van constitutionele aard moeten daarentegen door de gemeenschapsinstellingen ook bij de uitvaardiging van wetgevende normen worden geëerbiedigd. K. Lenaerts \& P. van Nuffel, Europees recht in hoofdlijnen, Antwerpen-Apeldoorn: Maklu Uitgevers 1999, blz. 645 en blz. 646. 
toepassing zijn op conflicterende beginselen. ${ }^{80}$ Het optimaliseringvereiste houdt volgens haar in: het vermogen van een beginsel om beslissingen die mogelijk zijn in een gegeven geval te rangschikken volgens de mate waarin het beginsel wordt gerealiseerd. Het kan dan mogelijk zijn om een beslissing te nemen die meerdere beginselen in een bepaalde mate realiseert. Dit houdt volgens haar in, dat de botsing tussen beginselen niet op een zwart - wit manier hoeft te worden opgelost in de zin dat één van de beginselen volledig wordt gerealiseerd en de andere helemaal niet. De uiteindelijke beslissing geeft dan uitdrukking aan het feit dat er meer relevante overwegingen zijn die ieder een bepaald gewicht in de schaal leggen.

In het vervolg van het onderzoek zal blijken, dat het inderdaad mogelijk is dat een beslissing meerdere algemene rechtsbeginselen in een bepaalde mate realiseert en dat het zelfs voorkomt dat een algemeen rechtsbeginsel steun vindt bij een klassiek BTWbeginsel (rechtskarakter) (paragraaf 4.4.4 en hoofdstuk 13). Het is dus zeker niet zo dat in alle gevallen de algemene rechtsbeginselen botsen dan wel elkaar uitsluiten.

\subsection{De drie algemene rechtsbeginselen in het onderzoek}

\subsubsection{Gelijkheidsbeginsel}

\subsubsection{Algemene aspecten gelijkheidsbeginsel}

Het gelijkheidsbeginsel heeft als algemeen rechtsbeginsel een lange geschiedenis. $\mathrm{Al}$ in de werken van Aristoteles is een omschrijving te vinden. Sterker nog, een omschrijving die diverse millennia later nog steeds in de literatuur als uitgangspunt is te vinden. ${ }^{81}$ Gelijkheid naar evenredigheid in wetgeving en bestuur wil volgens Aristoteles zeggen:

"Gelijke gevallen moeten gelijk worden behandeld en ongelijke gevallen ongelijk, naar mate van hun ongelijkheid." 82

Dat de omschrijving van Aristoteles nog steeds als uitgangspunt wordt genomen, wil niet zeggen dat deze geheel kritiekloos wordt aanvaard. Algemeen is aanvaard dat mensen gelijke rechten hebben, en dat rechtvaardigheid gelijke rechten impliceert. ${ }^{83}$

80. E. Burg, Rationaliteit in de toepassing van conflicterende beginselen: het optimaliseringsvereiste, blz. 55, in: E.T Feteris, H. Kloosterhuis, H.J. Plug, J.A. Pontier (red.), Met Recht en Reden, Bijdragen aan het Derde Symposium Juridische Argumentatie Rotterdam 18 juni 1999, Nijmegen: Ars Aequi Libri 2000.

81. J.H. Nieuwenhuis 1997, blz. 55 stelt dat het debat over rechtvaardigheid is opgesteld door Aristoteles en sindsdien nimmer is gewijzigd.

82. Dit is de gebruikelijke formulering van de zienswijze van Aristoteles, zie bijvoorbeeld J.H. Gerards, Rechtelijke toetsing aan het gelijkheidsbeginsel (diss. Maastricht), Nijmegen: Sdu Uitgevers 2002, blz. 9. Gerards duidt deze definitie aan als de aristotelische formule. Zij wijst er echter terecht op dat ook al is deze aristotelische formule de gebruikelijke weergave van de visie van Aristoteles, het niet een letterlijk citaat is uit zijn werken. Aristoteles geeft het complexer weer. Zie bijvoorbeeld Aristoteles, Ethica Nicomachea, Groningen: Historische Uitgeverij 1999, blz. 151 t/m 153 (1131 a10 t/m 1132 b20).

83. Overigens is de invulling van het gelijkheidsbeginsel volgens Aristoteles om meerdere redenen nogal relatief. Zo meende hij dat vrouwen en slaven (die waren gerekruteerd uit vreemde volken) niet gelijkelijk deelnamen aan de rede in vergelijking met de vrije Griekse man en dan ook inferieur waren. 
Aristoteles daarentegen meent dat rechtvaardigheid niet gelijkheid inhoudt, maar de juiste verhouding, die in sommige gevallen neerkomt op gelijkheid. ${ }^{84}$ Volgens Russell gaat Aristoteles voorbij aan de moeilijkheid die 'gelijkheid naar evenredigheid' oplevert. Als deze werkelijk rechtvaardig wil zijn moet zij worden afgemeten naar deugdzaamheid. Dit is meestal een kwestie van partij instelling en in de praktijk dan ook meestal bepaalt door het inkomen. Volgens Russel is alle maatschappelijke ongelijkheid op den duur ongelijkheid in inkomen. Dat pleit mede voor de democratie: elke poging tot 'rechtvaardigheid naar evenredigheid', gebaseerd op enige andere verdienste dan rijkdom, is volgens Russel tot mislukken gedoemd. Volgens Russell is:

“Elke vorm van 'rechtvaardigheid' die niet is gebaseerd op absolute gelijkheid zal in de praktijk neerkomen op de beloning van iets anders dan de deugd, en moet daarom worden afgewezen." 85

De hierboven weergegeven politiek filosofische discussie laat ik voor wat zij is. Wel is het zo dat als het gelijkheidsbeginsel verlangt dat gelijke gevallen gelijk worden behandeld, en ongelijke gevallen ongelijk in de mate dat zij ongelijk zijn, het een begrip is dat geen richting tot een uitkomst aangeeft. ${ }^{86}$ Daarbij staat namelijk nog niet vast wie als gelijke en wie als ongelijke beschouwd moeten worden. ${ }^{87}$ Verder geeft de formele gelijkheid niet aan op welke wijze de gelijke en de ongelijke behandeld moeten worden. ${ }^{88}$ De abstracte duiding van het gelijkheidsbeginsel dient dus geconcretiseerd te worden voordat zij geschikt is voor de toepassing in het recht en voor ons, in het BTW-recht in het bijzonder (zie ook paragraaf 4.4.3.2 over het gelijkheidsbeginsel en de analogieredenering).

84. Aristoteles, Ethica Nicomachea, Groningen: Historische Uitgeverij 1999, blz. 151 t/m 153 (1131 a10 t/m 1132 b20).

85. Bertrand Russell, Geschiedenis van de westerse filosofie, Katwijk: Servire Uitgevers 1997, blz. 218 86. A-G Sharpton gaat in haar conclusie van 22 mei 2008 uitgebreid in op dit aspect. De aristotelische formule biedt volgens haar geen antwoord op de vraag welke aspecten relevant zijn voor de toepassing van het gelijkheidsbeginsel, en welke niet. Zie ook haar historische bespiegeling over het gelijkheidsbeginsel. A-G Sharpton, 22 mei 2008, nr. C-427/06, Bartsch, pt. 44 e.v. toegespitst op een algemeen beginsel van non-discriminatie op grond van leeftijd. Gribnau meent dat de abstracte formele gelijkheid betekenis krijgt op basis van maatschappelijke en politieke opvattingen omtrent gelijkheid. Zie J.L.M. Gribnau, Perspectieven op het gelijkheidsbeginsel, WFR 2000/6391, blz. 902.

87. Het is bijna onvermijdbaar om bij de opzet van regelgeving niet te differentiëren. De Wet op de inkomstenbelasting 2001 maakt onderscheid tussen mensen met een hoog en een laag inkomen, de verkeerswetgeving maakt onderscheid tussen automobilisten en fietsers en de kieswet maakt onderscheid tussen mensen boven en onder de achttien jaar. Gelijkheid in absolute zin is dan ook praktisch onmogelijk. Het gaat dan ook niet om gelijkheid als zodanig, maar om de gelijke uitkomst van de behandeling. Dat betekent dat indien gevallen ongelijk zijn er gedifferentieerd moet worden om zo gelijke behandeling op een hoger niveau te realiseren. Zie voor een verdere uitwerking T. Loenen, Rechtstheorie, Het gelijkheidsbeginsel, Nijmegen: Ars Aequi Libri 1998, blz. 11 en 12.

88. Zie ook T. Loenen 1998, blz. 25 waar zij uitwerkt dat een ongelijke behandeling onder omstandigheden juist 'echte' gelijkheid kan bevorderen. 


\subsubsection{Europeesrechtelijke invulling van het gelijkheidsbeginsel}

Concretiseringen van het gelijkheidsbeginsel vinden in het Werkingsverdrag op ruime schaal plaats. Tevens heeft het Hof met betrekking tot het gelijkheidsbeginsel een omvangrijke jurisprudentie het licht doen zien. Indien men de toepassing van het gelijkheidsbeginsel toespitst op de BTW-regelgeving, is het in de eerste plaats van belang om de in hoofdstuk 1 getrokken conclusie in dit kader te betrekken, namelijk dat de ontwikkeling van de gemeenschappelijke BTW een uitvloeisel is van het streven naar een hoger doel. En dat hoger doel is gelegen in de totstandkoming van één interne markt. Het gelijkheidsbeginsel in Europees perspectief is dan ook verbonden met het streven naar één interne markt.

Voor een goede werking van één interne markt is vereist dat sprake is van een gelijke behandeling tussen de eigen ingezetenen en die van de andere lidstaten. De kracht achter de ontwikkeling van het gelijkheidsbeginsel is dan ook, zoals eerder naar voren is gebracht, het streven naar één interne markt. In paragraaf 2.4 is al behandeld dat het gelijkheidsbeginsel een uitgangspunt vormt met een sterk economisch getinte component.

Het gelijkheidsbeginsel wordt ook wel op één lijn geplaatst met het discriminatieverbod. ${ }^{89}$ Van belang in dit kader is dat het Ruckdeschel-arrest ${ }^{90}$ heeft verduidelijkt dat bij de toepassing van artikel 40, lid 3, tweede alinea EG-Verdrag (thans artikel 40, lid 2 VwEU):

“(...) het in genoemd artikel vervatte discriminatieverbod slechts een bijzondere uitdrukking is van het algemene gelijkheidsbeginsel, dat een der grondprincipes van het gemeenschapsrecht is (en) dat krachtens dit beginsel gelijke omstandigheden niet verschillend mogen worden behandeld, tenzij dat verschil objectief ware gerechtvaardigd."

In het vervolg ken ik geen verschil in betekenis toe aan de termen 'gelijkheidsbeginsel' en 'discriminatieverbod'.

Het gelijkheidsbeginsel is in het Werkingsverdrag onder meer terug te vinden in:

- Artikel 8 VwEU: gelijkheid van mannen en vrouwen.

- Artikel 18 VwEU: Gelijkheid nationaliteit.

- Artikel 19 VwEU: Gelijkheid van geslacht, ras, godsdienst, enz.

- Artikel 34 VwEU: Verbod op kwantitatieve invoerbeperkingen tussen de lidstaten.

- Artikel 35 VwEU: Verbod op kwantitatieve uitvoerbeperkingen tussen de lidstaten.

89. Anders Loenen. Zij beschouwt het discriminatieverbod als een species van het genus gelijkheidsbeginsel. Zie T. Loenen 1998, blz. 15 en voor een uitwerking blz. 52 t/m 53.

90. Hof 19 oktober 1977, nrs. 117/76 en 16/77, Ruckdeschel e.a., Jur. 1977, blz. 1753, in het bijzonder r.o. 7. Zie ook T. Tridimas, The General Priciples of EU Law, Oxford: Oxford University Press 2006, blz. 64. Tridimas brengt naar voren dat in de jurisprudentie van het Hof geen onderscheid is te ontdekken tussen de termen 'gelijkheidsbeginsel' en 'non-discriminatiebeginsel'. 
- Artikel 45 VwEU: Vrij verkeer werknemers.

- Artikel 49 VwEU: Vrijheid van vestiging.

- Artikel 57 VwEU: Uitoefening van diensten.

- Artikel 107 VwEU: Verbod op discriminerende steunmaatregelen.

- Artikel 110 VwEU: Geen hogere belasting op producten uit andere lidstaten.

- Artikel 111 VwEU: Geen hogere teruggaaf van belasting op producten dan is geheven.

- Artikel 157 VwEU: Gelijke beloning van mannelijke en vrouwelijke werknemers.

Artikel $18 \mathrm{VwEU}$ is een algemeen verbod van discriminatie op grond van nationaliteit. Deze bepaling kan slechts autonoom toepassing vinden in gevallen waarin het Unierecht wel geldt, maar waarvoor het Werkingsverdrag niet in bijzondere discriminatieverboden voorziet. ${ }^{91}$

In de eerste jaren na de Tweede en Zesde richtlijn verscheen op het terrein van de BTW jurisprudentie warin de artikelen 110 en 111 VwEU een rol speelden. ${ }^{92}$ Door de vergaande harmonisatie van de BTW is dat het laatste paar jaar nauwelijks meer aan de orde. ${ }^{93}$ Dat neemt niet weg dat het gelijkheidsbeginsel regelmatig in volle glorie in de BTW-rechtspraak aan de orde is.

Elk van de hierboven genoemde verboden tot discriminatie is te zien als een uitvloeisel van het gelijkheidsbeginsel dat een fundamentele norm is binnen het Unierecht. Het beginsel vereist een gelijke behandeling van gelijke gevallen tenzij de verschillende behandeling een objectief rechtvaardig doel dient. ${ }^{94}$

Bij de beoordeling van de vraag of het gelijkheidsbeginsel is geschonden moeten twee vragen worden beantwoord. Ten eerste of de situaties inderdaad gelijk zijn en

91. Hof 8 maart 2001, nr. C-397/98 en C-410/98, Metallgesellschaft e.a., Jur. 2001, blz. I-1727, r.o. 38 en 39; Hof 17 januari 2008, nr. C-105/07, Lammers \& Van Cleeff, Jur. 2008, blz. I-173, r.o. 14.

92. Zie bijvoorbeeld Hof 5 mei 1982, nr. 15/81, Gaston Schul I, BNB 1982/225. Het Hof besliste dat bij de berekening van de BTW bij invoer rekening dient te worden gehouden met de buitenlandse BTW. Dit gezien artikel 95 EG-Verdrag (thans artikel 110 VwEU).

93. Een recente uitzondering hierop is het arrest Schmelz (26 oktober 2010, nr. C-97/09, V-N 2010/ 58.20, NTFR 2010/2576). In deze procedure ligt de vraag voor of de zogenoemde kleine ondernemersregeling in overeenstemming is met de artikelen 18 VwEU, 43 EG en 49 EG, voor zover de lidstaten deze faciliteit toepassen op belastingplichtigen op hun grondgebied gevestigd, maar de mogelijkheid uitsluiten voor in andere lidstaten gevestigde kleine ondernemers. Het Hof ziet een rechtvaardiging in de beperking gezien de noodzaak om de doeltreffendheid van de fiscale controles te waarborgen. Hierbij speelt een rol dat internationale gegevensuitwisseling tussen de lidstaten niet mogelijk is, omdat geen gegevensuitwisseling plaatsvindt inzake de kleine ondernemers nu zij gezien hun geringe omzetten onder de uitwisselingsgrens blijven.

94. Hof 19 oktober 1977, nrs. 117/76 en 16/77, Ruckdeschel e.a., Jur. 1977, blz. 1753, r.o. 7 en Hof 19 oktober 1977, nrs. 124/76 en 20/77 Moulins Pont-à-Mousson e.a., Jur. 1977, blz. 1795, r.o. 16 en 17 en Hof 25 november 1986, nrs. 201/85 en 202/85, M. Klensch e.a., Jur. 1986, blz. 3477. 
ten tweede of voor een ongelijke behandeling een objectieve rechtvaardiging is aan te wijzen. Uit deze dubbele toets blijkt dat het gelijkheidsbeginsel verweven is met het evenredigheidsbeginsel. Een ongelijke behandeling is alleen te rechtvaardigen indien het evenredigheidsbeginsel niet is geschonden. Oftewel, inden een slachtoffer van ongelijke behandeling kan aantonen dat de doelstelling van het overheidsorgaan ook kan worden bereikt door middel van een maatregel die niet het gelijkheidsbeginsel schendt, kan met succes een beroep worden gedaan op het gelijkheidsbeginsel. Uit dit samenspel tussen het gelijkheidsbeginsel en het evenredigheidsbeginsel blijkt dat de evenredigheidstoets vaak in de gelijkheidstoets is verwerkt. ${ }^{95}$

Bij de toetsing aan het gelijkheidsbeginsel gaat het niet zozeer om identieke gevallen, maar om 'gelijke dan wel naar essentie op één lijn te stellen' gevallen. De eisen van het gelijkheidsbeginsel zoals deze door het Hof zijn ingevuld, kan als volgt worden omschreven:

- gelijke gevallen worden niet verschillend behandeld; en

- ongelijke gevallen worden niet gelijk behandeld. ${ }^{96}$

Het Hof formuleert het in het Puffer-arrest ${ }^{97}$ als volgt:

“(...) het vaste rechtspraak dat het algemeen gemeenschapsrechtelijk gelijkheidsbeginsel wordt geschonden wanneer verschillende regels worden toegepast op vergelijkbare situaties of wanneer dezelfde regel wordt toegepast op verschillende situaties." (r.o. 52)

Zoals eerder naar voren is gebracht, impliceert een gelijke behandeling van verschillende gevallen c.q. verschillende behandeling van gelijke gevallen niet altijd een schending van het gelijkheidsbeginsel. De verschillende c.q. gelijke behandeling kan namelijk objectief gerechtvaardigd zijn. ${ }^{98}$ Prechal en Heukels brengen naar voren dat het Hof niet altijd even consequent te werk gaat bij de toetsing aan het

95. Zie nader over de complexe relatie tussen deze twee algemene rechtsbeginselen toegespitst op de vrijheid van het goederen verkeer T. Tridimas 2006, blz. 196 t/m 199.

96. S. Prechal \& T. Heukels 1986, blz. 305.

97. Hof 23 april 2009, nr. C-460/07, Sandra Puffer, V-N 2009/25.17, NTFR 2009/1030. Zie ook de conclusie van A-G Sharpton bij het Puffer-arrest en dan in het bijzonder pt. 59, e.v. (conclusie van 11 december 2008, V-N 2009/5.22). In identieke zin Hof 7 mei 1998, nr. C-390/96, Lease Plan Luxembourg, V-N 1998/57.19, r.o. 34; HvJ 14 februari 1995, nr. C-279/93, Schumacker, Jur. 1995, blz. I-225, r.o. 30 .

98. A-G Sharpton meent dat de reden daarvoor in wezen is dat het verschil tussen (aanvaardbare) verschillen in behandeling en (onaanvaardbare) discriminatie niet daarin ligt, dat mensen verschillend worden behandeld, maar in de vraag of de samenleving de criteria waarvan de toepassing in een verschil in behandeling resulteert, als gerechtvaardigd aanvaardt, dan wel of zij daarentegen als willekeurig worden beschouwd. Volgens haar is gedetailleerde wetgeving nodig om de toepassing van bepaalde criteria in bepaalde omstandigheden als aanvaardbaar of onaanvaardbaar te kwalificeren en om bindende rechtsgevolgen toe te kennen aan die kwalificatie. Volgens haar wordt wat gerechtvaardigd is om een bepaald onderscheid te maken bepaald door de visie van een samenleving in een bepaalde tijd en plaats. A-G Sharpton, 22 mei 2008, nr. C-427/06, Bartsch, pt. 56. Zie ook T. Tridimas 2006, blz. $83 \mathrm{t} / \mathrm{m}$ 94. Tridimas werkt enkele voorbeelden uit van objectieve rechtvaardigingsgronden die te vinden zijn in de jurisprudentie op het terrein van de landbouwproducten. 
gelijkheidsbeginsel. ${ }^{99}$ De ene keer beperkt het Hof zich tot een onderzoek naar de vergelijkbaarheid. Indien de gevallen niet vergelijkbaar blijken te zijn, is er ook geen sprake van discriminatie. ${ }^{100}$ In andere zaken onderzocht het Hof of er wellicht sprake is van een objectieve rechtvaardiging. ${ }^{101}$ In het kader van deze toetsing aan de rechtvaardigheid wordt soms ook nog een toetsing aan het evenredigheidsbeginsel toegepast. ${ }^{102}$

Het gelijkheidsbeginsel verbiedt ook indirecte discriminatie. ${ }^{103}$ Met indirecte discriminatie wordt bijvoorbeeld bedoeld een situatie waarbij bepaalde eisen worden gesteld waaraan in de praktijk door één bepaalde groep makkelijker kan worden voldaan dan door een andere in essentie gelijke groep. ${ }^{104}$ Verder is van belang, zoals eerder naar voren is gebracht, dat het gelijkheidsbeginsel ook kan verhinderen een gelijke behandeling van ongelijke gevallen. ${ }^{105}$

Het gelijkheidsbeginsel is een algemeen rechtsbeginsel. Het is een algemeen aanvaard uitgangspunt dat berust op een in het rechtsbewustzijn levende voorstelling van rechtvaardigheid. ${ }^{106}$ Duidelijk is ook dat het een algemeen rechtsbeginsel is met een zeker gewicht en waaruit concrete regels zijn af te leiden. Dit blijkt uit de in deze paragraaf aangehaalde jurisprudentie van het Hof. Wel is duidelijk dat het een algemeen rechtsbeginsel is dat verder geconcretiseerd moet worden wil het praktisch bruikbaar zijn. Met name moet geconcretiseerd worden wat '(on)gelijke gevallen' zijn (zie ook paragraaf 4.4 .3 over het gelijkheidsbeginsel en de analogieredenering). En wanneer een (on)gelijke behandeling op objectieve gronden te rechtvaardigen is. Tevens moet verder worden verduidelijkt op welke wijze de toetsing aan het evenredigheidsbeginsel is verwerkt binnen een toetsing aan het gelijkheidsbeginsel. In de vervolghoofdstukken zal dit nader worden onderzocht.

99. S. Prechal \& T. Heukels 1986, blz. 305.

100. Hof 25 oktober 1978, nr. 125/77, KSH, Jur. 1978, blz. 1991, r.o. 28 t/m 31.

101. Soms komt deze toetsing nadat de vergelijkbaarheid is onderzocht (vergelijk het eerder genoemde Ruckdeschel-arrest), soms blijft ook de vergelijkbaarheidtoets achterwege.

102. Hof 5 juli 1977, nr. 114/76, Bela Mühle, Jur. 1977, blz. 1211, r.o. 7.

103. Hof 12 februari 1974, nr. 152/73, Sotgiu, Jur. 1974, blz. 153, r.o. 11. Zie ook Hof 16 februari 1978, nr. 61/77, Commissie/Ierland, Jur. 1978, blz. 417, r.o. 78.

104. A. Arnull, The General Principle of EEC Law and the Individual, New York: St. Martin's Press 1990, blz. 3. Verder blz. 38 waar dit beginsel wordt uitgewerkt in relatie tot het vrij personenverkeer. 105. Hof 17 juli 1963, nr. 13/63, Commissie/Italië, Jur. 1963, blz. 351.

106. Uit onderzoek blijkt dat de mens weerstand heeft tegen een ongelijke verdeling. Niet uit efficiency overwegingen maar op emotionele gronden. Emotie wint het bij een verdelingsvraagstuk van een zakelijke rekensom. Het gelijkheidsbeginsel appelleert aan een sterke emotie gebaseerd op de wens naar rechtvaardigheid. Zie voor een onderzoek naar dit aspect, M. Hsu, C. Anen, SR. Quartz, The Right and the Good: Distributive Justice and Neural Encoding of Equity and Effinciency, Science 23 May 2008, Vol. 320, no. 5879, p. 1092-1095. In paragraaf 3.2.1 is naar voren gebracht dat het lastig is om aan te geven wat te verstaan is onder het rechtsbewustzijn van een volk. Wat betreft het gelijkheidsbeginsel is echter steun te vinden in het aangehaalde onderzoek in de psychologische wetenschap. 


\subsubsection{Evenredigheidsbeginsel}

\subsubsection{Algemene aspecten van het evenredigheidsbeginsel}

Het evenredigheidsbeginsel is evenals het gelijkheidsbeginsel nauw verbonden met de rechtvaardigheidsgedachte. Het is een beginsel met een lange bestaansgeschiedenis. In de vorige paragraaf is naar voren gebracht dat het evenredigheidsbeginsel al is te vinden bij Aristoteles. Verder is te constateren dat het een algemeen rechtsbeginsel is dat, evenals als het gelijkheidsbeginsel, universeel is in meerdere opzichten. Het is niet alleen in het Nederlands rechtstelsel te vinden maar ook in de rechtsstelsels die van kracht zijn in de gehele westerse wereld. Het is verder universeel omdat de kracht ervan zich in alle rechtstakken doet gelden en bepaald niet alleen in bijvoorbeeld het belastingrecht. ${ }^{107}$ In alle rechtsgebieden wordt het evenredigheidsbeginsel expliciet als maatstaf voor rechtvaardigheid gehanteerd. Kortom, het is een zuiver algemeen rechtsbeginsel dat voldoet aan de gegeven omschrijving van het begrip in paragraaf 3.2.3.

Met de term 'evenredigheid' wordt in het algemeen bedoeld: onderling gelijke verhouding, juiste proportie. Ook wel: de hoedanigheid van goede verhoudingen te bezitten. ${ }^{108}$ In zijn administratiefrechtelijke functioneren is het evenredigheidsbeginsel onder meer te vinden in artikel 3:4, lid 2 van de AWB.

"De voor een of meer belanghebbenden nadelige gevolgen van een besluit mogen niet onevenredig zijn in verhouding tot de met het besluit te dienen doelen."

Uit deze bepaling blijkt een afweging tussen het beoogde doel en de middelen die gebruikt worden om het desbetreffende doel te bereiken. Met een kanon op een mug schieten is duidelijk niet de bedoeling. Echter, de vraag die dan opkomt is: wanneer sprake is van een onevenredigheid tussen doel en middel? De vraag in het kader van het onderzoek is echter op welke wijze het Hof invulling geeft aan (on)evenredigheid en dan in het bijzonder toegespitst op de uitleg van de BTW-regelgeving. In de volgende subparagraaf bespreek ik het evenredigheidsbeginsel nader en zet het daarbij vooreerst in een breder perspectief.

\subsubsection{Europeesrechtelijke invulling van het evenredigheidsbeginsel}

Het evenredigheidsbeginsel is door het Hof in het Fédéchar-arrest ${ }^{109}$ aangeduid als "een algemeen geaccepteerd rechtsbeginsel". Het Hof heeft verduidelijkt dat het gebruik van bepaalde termen in het Werkingsverdrag geïnterpreteerd kunnen worden als een verwijzing naar het evenredigheidsbeginsel. Het gaat dan om de

107. Het evenredigheidsbeginsel is verdisconteerd in allerlei juridische leerstukken. Zie voor een uitwerking De Moor-van Vugt, Maten en gewichten, Het evenredigheidsbeginsel in Europees perspectief (diss. Tilburg), Zwolle: W.E.J. Tjeenk Willink 1995, onder meer blz. 8, 9 en 10.

108. Van Dale, Groot Woordenboek der Nederlandse Taal 1992.

109. Hof 29 november 1956, nr. 8/55, Belgische Steenkool Federatie (Fédéchar), Jur. 1956, blz. 211. Zie meer uitgebreid over de ontwikkeling van het evenredigheidsbeginsel in de jurisprudentie van het Hof, A. de Moor-van Vught 1995, blz. 66 t/m 68. 
woorden 'gerechtvaardigd' en 'noodzakelijk' in diverse artikelen van het Werkingsverdrag. ${ }^{110}$ Een voorbeeld hiervan is te vinden in artikel 36 VwEU (voorheen 30 EG). Het artikel vermeldt een aantal gronden die een rechtvaardiging kunnen zijn om inbreuk te maken op het in de artikelen 34 en $35 \mathrm{VwEU}$ (voorheen artikelen 28 en $29 \mathrm{EG}$ ) genoemde verbod op in- en uitvoer beperkingen. ${ }^{111}$ Bij de toetsing van artikel 36 VwEU hanteert het Hof het evenredigheidsbeginsel. In de vorige paragraaf is vermeld dat de artikelen 34 en 35 VwEU te zien zijn als een uitdrukking van het gelijkheidsbeginsel. Hieruit blijkt dus wederom de verwevenheid van het evenredigheidsbeginsel met het gelijkheidsbeginsel.

Artikel 36 VwEU als één van de voorbeelden van inbedding van het beginsel nu daargelaten, door artikel 5, lid 4 VEU (voorheen artikel 5, derde alinea EG) is het evenredigheidsbeginsel gecodificeerd en heeft het een duidelijke en onomstreden plaats gekregen. Het zinsdeel luidt:

"Krachtens het evenredigheidsbeginsel gaan de inhoud en de vorm van het optreden van de Unie niet verder dan wat nodig is om de doelstellingen van de Verdragen te verwezenlijken. $(\ldots) "$

Het evenredigheidsbeginsel vormt een aanvulling op het in lid 1 van het zelfde artikel verwoorde subsidiariteitsbeginsel. Het evenredigheidsbeginsel in de context van artikel 5, lid 4 VEU heeft dan ook primair betrekking op de mate van ingrijpen in de nationale wetgeving of het nationale beleid. ${ }^{112}$

Het evenredigheidsbeginsel is dus verankerd in het Unieverdrag. Daarnaast gebruikt het Hof het evenredigheidsbeginsel bij de uitleg van het primaire en het secundaire Unierecht. Prechal en Heukels onderscheiden een aantal meer specifieke toepassingen van het evenredigheidsbeginsel: soms onderzoekt het Hof of een maatregel passend c.q. doeltreffend middel is om het doel te bereiken. ${ }^{113}$ Veel vaker echter onderzoekt het Hof of een maatregel noodzakelijk is om de doelstelling te realiseren, soms echter nadat eerst is vastgesteld dat de maatregel passend c.q. doeltreffend is.

110. A. Arnul 1990, blz. 4 en meer uitgebreid de hoofdstukken 4 en 8 .

111. Het Hof heeft ook een aantal arresten gewezen waarin bepaalde beperkingen worden toegelaten, hoewel zij niet vallen onder de uitzonderingsgronden van artikel 36 VwEU. De doctrine die met deze arresten is ingezet wordt ook wel de rule of reason genoemd. Zie voor een uitgebreide behandeling, A de Moor-van Vugt 1995, hoofdstuk 4, paragraaf 2. Zie ook P.J.G. Kapteyn \& P. VerLoren van Themaat 2003, blz. 559 e.v. over de 'rule of reason' (Cassis-de-Dijonexepties). Kapteyn en VerLoren van Themaat geven onder meer aan dat verdragstechnisch niet zozeer sprake is van een uitbreiding van artikel 36 VwEU (voorheen artikel $30 \mathrm{EG),} \mathrm{maar} \mathrm{eerder} \mathrm{sprake} \mathrm{is} \mathrm{van} \mathrm{een} \mathrm{interpretatie} \mathrm{van} \mathrm{artikel} 34$ VwEU (voorheen artikel $28 \mathrm{EG)}$

112. Zie P.J.G. Kapteyn \& P. VerLoren van Themaat 2003, hoofdstuk III, paragraaf 5.1, voor een uitgebreide beschrijving van het subsidiariteitsbeginsel en het proportionaliteitsbeginsel. Zie verder ook paragraaf 2.4 .2 van mijn onderzoek op welke plaats het subsidiariteitsbeginsel wordt afgezet tegenover de externe neutraliteit.

113. S. Prechal \& T. Heukels 1986, blz. 302 en 303. 
Een maatregel wordt niet noodzakelijk geacht indien de betrokken lidstaat het doel met een minder vergaand middel had kunnen bereiken. ${ }^{114}$

Het evenredigheidsbeginsel eist dus dat een maatregel 'geschikt' is om de doelstelling te bereiken en tegelijk wordt ook geëist dat deze 'onmisbaar' is. ${ }^{115}$ De maatregel is geschikt wanneer het in staat is het nagestreefde doel te bereiken. Vereist is dat er een causale relatie bestaat tussen maatregel en het doel. Deze toetsing levert in de jurisprudentie van het Hof de minste problemen op. ${ }^{116}$

De maatregel is onmisbaar wanneer hij niet kan worden vervangen door een alternatief optreden dat hetzelfde nuttig effect zou hebben ten aanzien van het gestelde doel en minder nadelig zou zijn voor een ander, door het Unierecht beschermd, doel of belang. ${ }^{117}$

Het derde element is dat de belasting (in de betekenis van gewicht) niet buiten verhouding mag staan tot het nagestreefde doel.

In het Fedesa-arrest ${ }^{118}$ komen de drie elementen naar voren:

"Volgens vaste rechtspraak van het Hof maakt het evenredigheidsbeginsel deel uit van de algemene beginselen van het gemeenschapsrecht. Volgens dit beginsel zijn maatregelen waarbij economische activiteiten worden verboden, slechts wettig wanneer zij geschikt en noodzakelijk zijn voor de verwezenlijking van de legitieme doelstellingen die met de betrokken regeling worden nagestreefd, met dien verstande, dat wanneer een keuze mogelijk is tussen meerdere geschikte maatregelen, die maatregel moet worden gekozen die de minste belasting met zich brengt en dat de veroorzaakte nadelen niet onevenredig mogen zijn aan het nagestreefde doel”. (r.o. 13)

Samengevat komt de toetsing aan het evenredigheidsbeginsel neer op de volgende drie elementen:

1. geschiktheid;

2. noodzakelijkheid;

3. evenwichtigheid van de maatregel.

114. Vooral in het kader van de toetsing aan artikel 36 VwEU en met betrekking tot de 'rule of reason' jurisprudentie van het Hof treft men deze toepassing van het evenredigheidsbeginsel aan. De desbetreffende overheidsmaatregel moet zo weinig mogelijk afbreuk doen aan het vrije verkeer van goederen.

115. Zie ook T. Tridimas 2006, blz. 139 t/m 141.

116. Zie J.H. Jans, R. de Lange, S. Prechal, R.J.G.M. Widdershoven, Inleiding tot het Europees Bestuursrecht, Nijmegen: Ars Aequi Libri 2002, blz. 185.

117. Zie, K. Lenaerts \& P. Van Nuffel 1999, blz. 159 en blz. 160 waar deze twee criteria verder worden ingevuld.

118. Hof 13 november 1990, nr. C-331/88, Fedesa e.a., Jur. 1990, blz. I-4023. De procedure heeft betrekking op het gebruik van stoffen met hormonale werking door veehouders. In r.o. $14 \mathrm{t} / \mathrm{m} 16$ wordt nader ingegaan op de geschiktheid en de noodzakelijkheid van de getroffen maatregelen. 
Van belang is dat niet in alle arresten van het Hof waarin het beginsel een rol speelt de bovenstaande drie elementen even duidelijk zijn te onderscheiden. Het lijkt er dan ook op dat het evenredigheidsbeginsel zich in de wisselende krachten van de elementen laat gelden. Dit maakt de toetsing van een bepaalde maatregel aan het evenredigheidsbeginsel niet eenvoudig. Ook in de vervolghoofdstukken zal blijken dat de bovenstaande drie elementen die verweven zijn in de toetsing aan het evenredigheidsbeginsel niet altijd expliciet naar boven komen in de jurisprudentie van het Hof bij de uitleg van het BTW-recht.

Al dan niet genoemd artikel 5, lid 4 VEU tartend, brengt het Hof in arrest Transport Service NV het evenredigheidsbeginsel in het spel om daarmee de grenzen van de werking van het Unierecht - d.w.z. de grenzen tot waar men positiefrechtelijk kan gaan - aan te geven. ${ }^{119}$ De lijn is deze: de BTW-richtlijn kent geen bepaling die de inning van BTW regelt. Daaruit volgt dat de lidstaten in beginsel volledige vrijheid hebben om de wijze van heffen (en naheffen) te regelen. Maar daarbij moet wel het overige Unierecht (buiten de BTW-richtlijn) in acht worden genomen. Het Hof heeft daarbij de algemene rechtsbeginselen op het oog die deel uitmaken van het primaire Unierecht. In het bijzonder het evenredigheidsbeginsel. Het Hof geeft immers aan, dat de maatregelen niet verder mogen gaan dan ter bereiking van het doel noodzakelijk is. Uit de beslissing inzake Transport Service NV blijkt dus, dat als het secundaire Unierecht (in casu de BTW-richtlijn) geen regeling bevat die de desbetreffende materie regelt, dit voor het Hof aanleiding is te toetsen aan de algemene rechtsbeginselen, in casu het evenredigheidsbeginsel (zie nader paragraaf 4.5.2.5).

\subsubsection{Rechtszekerheids- en vertrouwensbeginsel}

\subsubsection{Berekenbaarheid}

Het recht moet voorspelbaar zijn. Of zoals Scholten het heeft geformuleerd:

"Recht is ordening, het komt er dikwijls meer op aan, dàt er orde is dan hoè zij wordt verkregen. Het is volkomen onverschillig of de mensen rechts of links houden, doch het is van groot belang dat zij allen hetzelfde doen. De berekenbaarheid van het recht is een goed, waarom in het maatschappelijk leven altijd weer wordt gevraagd." 120

Dit geldt uiteraard ook voor de BTW-regelgeving. Belastingplichtigen moeten van te voren kunnen inschatten wat de belastinggevolgen zijn van hun handelen. ${ }^{121}$

119. Hof 3 maart 2004, nr. C-395/02, Transport Services NV, NTFR 2004/399, r.o. 27, 28 en 29

120. P. Scholten 1974, blz. 91

121. Volgens Nieuwenhuis heeft de rechtszekerheid twee aspecten. Namelijk oriëntering en realisering. Het recht moet bakens uitzetten. De justitiabelen moeten zich kunnen oriënteren. Het moet duidelijk zijn waar zij zich aan hebben te houden. Verder moet ook vertrouwd kunnen worden op de realisering van rechten. J.H. Nieuwenhuis 1997, blz. 62. 
Scholten trekt de lijn van berekenbaarheid van de wet door naar de jurisprudentie van de Hoge Raad. Het belang van de rechtszekerheid geeft aan ieder arrest van de Hoge Raad waarde voor de rechtsvinding. Scholten stelt dat:

"Is hiermee reeds aangegeven, hoezeer de rechtspraak een factor van betekenis bij de rechtsvinding kan zijn - het allerbelangrijkste is daarmee nog niet genoemd. Dat is het geval als in vertrouwen op de rechtspraak, op de regel door haar uitgesproken als regel van recht in het maatschappelijk leven gehele instellingen zijn gebouwd, bepaalde verhoudingen van wijde omvang zijn geregeld. Het is dan niet de jurisprudentie op zich zelve, maar de jurisprudentie als grondslag van in verband met het feitelijk handelen in de samenleving, waarop een beroep wordt gedaan." ${ }^{122}$

Belastingplichtigen richten hun handelen niet alleen op een inschatting van de BTWregelgeving, maar ook op de duiding van de regelgeving in de jurisprudentie. Ondanks het gegeven dat Scholten zijn Algemeen Deel schreef in een tijd dat het Hof nog niet bestond, lijkt mij dat zijn beschouwingen ook hier relevant zijn.

In lijn met het vorenstaande ligt het voor de hand dat de beslissingen van het Hof consistent zijn. Of in de terminologie van Scholten: berekenbaar. Is het recht eenmaal uitgelegd dan moeten de belastingplichtigen op die uitleg kunnen vertrouwen. Het arrest fungeert als een richtingaanwijzer waarvan men op aan kan. Helaas zal nog blijken dat de jurisprudentie op het terrein van de BTW-regelgeving niet altijd even consistent genoemd kan worden. Een voorbeeld hiervan is het in paragraaf 1.3 aangehaalde arrest van het Hof van 11 augustus 1995 inzake BulthuisGriffioen ${ }^{123}$ over de uitleg van artikel 13A, lid 1, sub g, Zesde richtlijn (thans: artikel 132, lid 1, sub g, BTW-richtlijn). De exploitatie van een kinderdagverblijf door een natuurlijk persoon viel niet onder de vrijstelling omdat de term 'instellingen' in deze bepaling duidt op rechtspersonen. Vier jaar later kwam het Hof terug op zijn beslissing. In het Gregg-arrest ${ }^{124}$ overweegt het Hof expliciet dat de vrijstelling niet enkel geldt voor rechtspersonen maar ook voor natuurlijke personen. Tegenover het voordeel dat het Hof op een kennelijk onjuiste beslissing terugkwam, staat dat de berekenbaarheid werd ondergraven. Overigens werd de berekenbaarheid van het recht volgens mij (zoals later bleek) door het eerste arrest aangetast. ${ }^{125}$

In deze paragraaf is naar voren gebracht dat regelgeving voorspelbaar moet zijn. En dat het gewenst is dat het Hof een voorspelbare, dus consistente lijn, volgt in zijn uitleg van het Unierecht. Tot zover het rechtszekerheids- en het vertrouwensbeginsel, de eisen

122. P. Scholten 1974, blz. 92.

123. Hof 11 augustus 1995, nr. C-453/93, Bulthuis-Griffioen, V-N 1995, blz. 2932.

124. Hof 7 september 1999, nr. C-216/97, Gregg, BNB 1999/395.

125. Het Hof verwijst veelvuldig naar eerdere beslissingen en bouwt daar vervolgens op door. Regelmatig wordt dit ingeluid met een overweging als: "Volgens vaste rechtspraak van het Hof (...)". Uit het Gregg-arrest blijkt dus dat het Hof zich niet altijd gebonden acht aan een eerdere beslissing. Brown en Kennedy besteden aandacht aan een aantal van dergelijke beslissingen buiten het BTW-recht en de aspecten die daarbij mogelijk een rol speelden. L.N. Brown \& T. Kennedy, The court of Justice of the European Communities, London: Sweet \& Maxwell 2000, blz. 369 t/m 375. 
van voorspelbaarheid en consistentie van rechtspraak, welke laatste eis overigens ook het gedrag van de uivoerende overheidsorganen regardeert. ${ }^{126}$

\subsubsection{Europees rechtelijk invulling van het rechtszekerheidsbeginsel en het vertrouwensbeginsel}

Het beginsel van de rechtszekerheid en het vertrouwensbeginsel worden meestal onderscheiden. Het rechtszekerheidsbeginsel beschermt verkregen rechten en zorgt dat de overheid in beginsel geen onverwachte koerswijzigingen uitvoert. Het rechtszekerheidsbeginsel houdt in dat particulieren te allen tijde in staat moeten zijn hun juridische positie te bepalen. Zo is in het Intertanko-arrest te vinden: ${ }^{127}$

"Het algemene rechtszekerheidsbeginsel, dat een fundamenteel beginsel van het gemeenschapsrecht vormt, verlangt onder meer dat een regeling duidelijk en nauwkeurig is, opdat de justitiabelen ondubbelzinnig hun rechten en verplichtingen kunnen kennen en dienovereenkomstig hun voorzieningen kunnen treffen." (r.o. 69)

Het geldend recht moet dus kenbaar zijn. Het rechtszekerheidsbeginsel heeft gevolgen voor de eisen van de bekendmaking van regelgeving, voor de terugwerkende kracht van deze regelgeving, voor de termijnen die gelden ten aanzien van de mogelijkheid om een beroep op een recht te doen of een vordering in te stellen. ${ }^{128}$

Het vertrouwensbeginsel wordt wel gezien als een onderdeel van het rechtszekerheidsbeginsel en houdt in dat de overheid de door haar bij een particulier gewekte gerechtvaardigde verwachtingen honoreert. Het Hof omschrijft het vertrouwensbeginsel als volgt in het Elmeka-arrest: ${ }^{129}$

"Met betrekking tot het beginsel van bescherming van het gewettigd vertrouwen van de begunstigde van een gunstige handeling, moet in de eerste plaats worden uitgemaakt of de handelingen van de administratieve instanties bij de voorzichtige en bezonnen marktdeelnemer een redelijk vertrouwen hebben gewekt (...). Indien deze vraag bevestigend wordt beantwoord, moet in de tweede plaats worden nagegaan of dit vertrouwen gewettigd is." (r.o. 32)

126. Happé brengt naar voren dat de fiscus de plicht heeft om consistent te handelen. Er kan echter geen sprake zijn van een mechanische, rigide toepassing van de consistentieplicht. Omstandigheden kunnen vereisen dat wordt teruggekomen op een eerdere beslissing. De consistentieplicht van de fiscus verlangt dat bij een volgend geval rekenschap wordt gegeven van zijn eerdere beslissing en deze tot uitgangspunt neemt bij zijn volgende beslissing. Het kan echter zo zijn dat tot een andere beslissing wordt gekomen. Happé is van mening dat de consistentieplicht dan een redengeving verlangt. R.H. Happé 1996, blz. 54 t/m blz. 57.

127. Hof 3 juni 2008, nr. C-308/06, Intertanko e.a., Jur. 2008, blz. I-4057.

128. Zie J.H. Jans e.a. 2002, blz. 210 en 211. In iets andere zin H.G Schermers, Algemene rechtsbeginselen als bron van gemeenschapsrecht, SEW 9 (1983), blz. 514. Schermers geeft aan dat het vertrouwensbeginsel nauw verbonden is met het beginsel van de rechtszekerheid. De rechtszekerheid stelt veilig wat in het verleden is verworven. Het vertrouwensbeginsel beschermt toekomstverwachtingen. Zowel het vertrouwensbeginsel als het rechtszekerheidsbeginsel zijn volgens Schermers algemene rechtsbeginselen.

129. Hof 14 september 2006, nrs. C-181/04 t/m C-183/04, Elmeka NE, V-N 2006/49.19. In deze procedure legt het Hof nader uit de reikwijdte van het nultarief in geval van bevoorrading van zeeschepen. 
In deze paragraaf wordt zowel de term 'vertrouwensbeginsel' als de term 'rechtszekerheidsbeginsel' gebruikt. Tevens is vermeld dat een aantal schrijvers onderscheid maakt tussen deze termen. Het vertrouwensbeginsel wordt door sommige schrijvers gezien als een species van het genus rechtszekerheidsbeginsel. Dit onderscheid laat ik voor wat het is. Daartoe vind ik mij gesteund door het feit, dat - zoals nader uit het onderzoek zal blijken - het Hof het rechtszekerheids- en het vertrouwensbeginsel regelmatig in één adem noemt.

Het is vaste jurisprudentie van het Hof dat elke lidstaat verplicht is om het nuttig effect van richtlijnen volledig te realiseren. ${ }^{130}$ Iedere lidstaat is dan ook verplicht om aan richtlijnen uitvoering te geven op een wijze, die volledig voldoet aan de eis van rechtszekerheid. ${ }^{131}$ Dat betekent dat de bewoordingen van de nationale bepalingen een dwingend karakter dienen te hebben. Dit geldt in het bijzonder indien de richtlijn rechten voor belastingplichtigen in het leven beoogt te roepen. ${ }^{132}$

De in de vorige paragraaf beschreven berekenbaarheid van het recht geldt uiteraard ook voor het Unierecht. Arnull geeft aan dat onderscheid kan worden gemaakt tussen de bescherming van verworven rechten en de bescherming van gerechtvaardigde belangen. ${ }^{133}$ Het eerste rust op de gedachte dat rechten niet willekeurig mogen worden beknot. Het tweede rust op de gedachte dat het onrechtvaardig is indien een belanghebbende kan vertrouwen op een bepaalde uitleg en dan vervolgens wordt verrast door een verandering van de regel.

Prechal en Heukels delen het rechtszekerheidsbeginsel in verscheidene subbeginselen, namelijk:

1. De formele rechtszekerheid: kenbaarheid.

2. De materiële rechtszekerheid, die weer onderverdeeld kan worden in het beginsel van de bescherming van de verworven rechten en het vertrouwensbeginsel. ${ }^{134}$

Het kenbaarheidvereiste blijkt onder meer uit de eis dat een besluit voor belanghebbende in een begrijpelijke taal moet zijn gesteld. In dit kader is het Kerry-Milkarrest $^{135}$ van belang. In deze zaak was aan de orde dat de Engelse tekst van een verordening afweek van de andere taalversies. Het Hof overweegt:

“(...) dat het wegwerken van taalkundige verschillen langs interpretatieve weg (...) afbreuk kan doen aan de rechtszekerheid, voor zover één of meer der betrokken teksten dan wellicht moet worden uitgelegd op een wijze die afwijkt van de eigenlijke en gebruikelijke betekenis der woorden." (r.o. 11)

130. Hof 8 april 1976, nr. 48/75, Royer, Jur. 1976, blz. 497, r.o. 75.

131. Hof 28 februari 1991, nr. C-360/87, Commissie/Italië (Grondwater I), Jur. 1991, blz. 791, r.o. 31.

132. Hof 30 mei 1991, nr. C-361/88, Commissie/Duitsland, Jur. 1991, blz. I-2567, r.o. 20 en 24.

133. A. Arnull 1990, blz. 3 waar tevens wordt verduidelijkt dat deze twee componenten onderdeel uitmaken van het rechtszekerheidsbeginsel.

134. S. Prechal \& T. Heukels 1986, blz. 292 t/m 296.

135. Hof 3 maart 1977, nr. 80/76, North Kerry Milk Products Ltd, Jur. 1977, blz. 425. 
Of het gaat om een verordening of om een richtlijn maakt kennelijk geen verschil in de visie van het Hof. Zo besliste het Hof over de richtlijn 75/117 (inzake gelijke beloning mannen en vrouwen) dat de implementatie in de Deense wet niet voldoende duidelijk en nauwkeurig was. ${ }^{136}$ Het Hof overweegt dat het beginsel van rechtszekerheid een ondubbelzinnige formulering eist op grond waarvan belanghebbenden hun rechten en plichten kennen.

Het rechtszekerheidsbeginsel handelt niet enkel over betrekkingen tussen belastingplichtigen en de overheid, maar is ook relevant in het kader van de omzetting van een richtlijn op fiscaal gebied. Een lidstaat moet ondubbelzinnig zijn rechten en verplichtingen kennen en dienovereenkomstig zijn voorzieningen kunnen treffen. Dat betekent dat een lidstaat zich moet kunnen baseren op de uitdrukkelijke en ondubbelzinnige tekst van de BTW-richtlijn. Dit blijkt uit de inbreukprocedure tegen het Verenigd Koninkrijk. ${ }^{137}$ Deze procedure handelt over de uitleg van de Dertiende richtlijn. De Commissie beriep zich in deze procedure - zonder succes - op de logica van het BTW-stelsel en op het feit dat overduidelijk sprake is van een vergissing in de tekst van de Dertiende richtlijn.

Het rechtszekerheidsbeginsel verzet zich er in principe tegen dat een communautaire maatregel op een datum ingaat die is gelegen voor de publicatiedatum. Van dit uitgangspunt kan worden afgeweken indien het te bereiken doel dit noodzakelijk maakt en het gewettigde vertrouwen van belanghebbenden is gewaarborgd. ${ }^{138}$ Aan dit aspect schenk ik nader aandacht in paragraaf 5.5 waar ook enkele voor de BTW belangrijke arresten worden behandeld. Ook speelt het rechtszekerheidsbeginsel een rol bij de beperking van het effect van een prejudiciële beslissing in de tijd. Daarmee bedoel ik dat het Hof in zijn beslissing kan bepalen dat het arrest pas effect heeft na een zekere periode, zodat de lidstaten de tijd krijgen om maatregelen te nemen. In paragraaf 5.6 komt dit onderwerp aan de orde.

Het rechtszekerheidsbeginsel is aan te merken als een algemeen rechtsbeginsel volgens de omschrijving zoals deze is vermeld in paragraaf 3.2.3 van dit hoofdstuk. Gesteld kan worden dat het rechtszekerheidsbeginsel een algemeen aanvaard element is van de rechtvaardigheidsgedachte. Uit de aangehaalde jurisprudentie blijkt dat het een algemeen rechtsbeginsel is met voldoende gewicht om de uitleg en toepassing van de regelgeving te beïnvloeden.

136. Hof 30 januari 1985, nr. 143/83, Commissie/Denemarken, Jur. 1985, blz. 427. In deze procedure ging het over de Deense wet welke bepaalde dat mannen en vrouwen gelijk loon moesten ontvangen voor 'gelijke arbeid', terwijl de richtlijn spreekt over 'arbeid waaraan gelijke waarde is toegekend'. 137. Hof 15 juli 2010, nr. C-582/08, Commissie/Verenigd Koninkrijk, V-N 2010/37.25, zie r.o. 49 en 50 De Commissie was van mening dat een buiten de EU gevestigde belastingplichtige recht heeft op teruggaaf van de voorbelasting die in een lidstaat is betaald voor goederen en diensten die worden gebruikt voor de handelingen in artikel 169, sub c, BTW-richtlijn (verzekeringshandelingen). Dit is echter niet uit de tekst van de Dertiende richtlijn te halen en sneuvelde dan ook bij het Hof. 138. Hof 25 januari 1979, nr. 98/78, Racke, Jur. 1979, blz. 69 en Hof 25 januari 1979, nr. 99/78, Decker, Jur. 1979, blz. 101. 


\subsubsection{Begrenzing nationale werking vertrouwensbeginsel}

Op het raakvlak van Unierecht en nationale recht kan een zekere spanning optreden indien algemene rechtsbeginselen uit het nationale recht de volledige doorwerking van het Unierecht verhinderen. Duidelijk is dat voor zover nationale rechtsbeginselen op een identieke wijze deel uitmaken van het Unierecht van geen spanningsveld sprake is. Het Hof stelt de eis, dat de nationale rechter bij de toepassing van de nationale rechtsbeginselen ten volle rekening houdt met het gemeenschapsbelang. ${ }^{139}$ Kapteyn en VerLoren van Themaat concluderen in dit kader:

"De handhaving van het gemeenschapsrecht brengt (...) met zich mee, dat de 'procedurele autonomie' van de lidstaten een verre van absoluut gegeven is. De beginselen van equivalentie en effectiviteit verlangen van de nationale rechter, voorgelicht door de jurisprudentie van het Hof, met name in het kader van de prejudiciële procedure van artikel 234 EG, dat hij de regels en beginselen van zijn nationale recht zodanig modelleert, dat aan de volledige doorwerking van het gemeenschapsrecht recht wordt gedaan."140

In paragraaf 3.4.3.2 is aan de orde geweest dat het vertrouwensbeginsel deel uitmaakt van het Unierecht. De vraag komt dan op, of de inhoud en/of toepassing van het Europese en nationale rechtsbeginsel met elkaar in overeenstemming zijn. Uit de jurisprudentie kan de conclusie worden getrokken dat noch een met het Unierecht strijdige praktijk in een lidstaat, noch een met het Unierecht strijdige handeling van een met het Unierecht belaste nationale instantie, bij een belanghebbende het in rechte te beschermen vertrouwen oproept dat de onjuiste handelwijze van de lidstaat gestand wordt gedaan. ${ }^{141}$ In diverse arresten van het Hof wordt daarentegen ruimte gelaten voor een nationale invulling van het vertrouwensbeginsel. ${ }^{142}$ Het Hof perkt deze ruimte echter weer in door de voorwaarde te stellen

139. Hof 21 september 1983, gevoegde zaken nrs. 205-215/82, Deutsche Milchkontor I, Jur. 1983, blz. 2633. Vgl. P.J.G. Kapteyn \& P. VerLoren van Themaat 2003, blz. 456 en 457 met een uitwerking van deze problematiek toegespitst op staatssteun die verleend is in strijd met het gemeenschapsrecht. 140. P.J.G. Kapteyn \& P. VerLoren van Themaat 2003, blz. 457.

141. Hof 26 april 1988, nr. 316/86, Krücken, Jur. 1988, blz. 2213, r.o. 22 t/m 26. Zie ook de conclusie van A-G Van Hilten van 5 maart 2009 (V-N 2009/18.6). Zij meent in een procedure op het terrein van de douanerechten dat het communautaire vertrouwensbeginsel geen contra-legemtoepassing toestaat (in casu opgeroepen door een nationaal beleidsbesluit dat in strijd is met het Unierecht). De HR stelt echter in deze procedure onder meer de volgende prejudiciële vraag: “(...) staat het communautaire recht eraan in de weg dat een belanghebbende zich in een geval als het onderhavige met vrucht kan beroepen op een nationaal beleidsbesluit waarin de nationale autoriteiten het vertrouwen wekken dat voor de tariefindeling van aangegeven goederen een beroep kan worden gedaan op een aan een derde verstrekte tariefinlichting voor hetzelfde goed?", HR 12 maart 2010, nr. 08/00309, V-N 2010/15.4, NTFR 2010/1026. Zie tevens Hof 10 november 2011, nrs. C-259/10, C-260/10, The Rank Group Plc, V-N 2011/ 62, NTFR 2011/2930, r.o. 62 t/m 64. In deze procedure geeft het Hof aan, dat een belastingplichtige geen aanspraak kan maken dat een bepaalde prestatie wordt onderworpen aan dezelfde fiscale behandeling als een andere prestatie, wanneer die laatste behandeling niet strookt met de toepasselijke nationale regelgeving.

142. Hof 5 maart 1980, nr. 265/78, Ferwerda, Jur. 1980, blz. 617 en Hof 6 mei 1982, nr. 54/81, Fromme, Jur. 1982, blz. 1449. 
dat geen afbreuk mag worden gedaan aan de doeltreffendheid van het Unierecht. Zo is beslist in rechtsoverweging 13 van het eerder aangehaalde Ferwerda-arrest dat de toepassing van het nationale recht geen wijziging mag brengen in de heffingsvoorwaarden en het bedrag van door het Unierecht voorziene heffingen. Zie ook de conclusie van advocaat-generaal Stix-Hackl van 1 december 2005 bij het Elmekaarrest. ${ }^{143}$ Zij kent bij de toepassing van het vertrouwensbeginsel betekenis toe aan het mogelijke gevaar dat een lidstaat ten gunste van een marktdeelnemer en ten nadele van de Europese Unie door zijn eigen met het Unierecht strijdige praktijk de volledige toepassing van het recht van de Unie belemmert. De advocaat-generaal overweegt over dit aspect:

“(...) Hierbij moet ook rekening worden gehouden met het algemeen belang op gebieden als bijvoorbeeld de staatssteun of de restituties bij uitvoer respectievelijk de eigen middelen van de Gemeenschap, ten aanzien waarvan de lidstaten soms geen enkel evident eigen belang hebben bij de correcte toepassing van de desbetreffende gemeenschapsvoorschriften. Tegen deze achtergrond moet door middel van strikte handhaving van het vertrouwensbeginsel worden voorkomen dat de lidstaten door hun eigen met het gemeenschapsrecht strijdige houding al met al de volledige toepassing van het gemeenschapsrecht ten opzichte van de marktdeelnemer kunnen verijdelen." (r.o. 45)

Stix-Hackl meent echter dat ter zake van de invordering van de BTW, die primair in het belang van de lidstaten geschiedt, dit anders moet worden beoordeeld. In een dergelijk geval is er waarschijnlijk veel minder sprake van het gevaar dat een lidstaat ten gunste van een marktdeelnemer en ten nadele van de Europese Unie door zijn eigen met het Unierecht strijdige praktijk de volledige toepassing van het recht van de Unie belemmert. In dit verband gaat het veeleer om de kwestie van de rechtsbescherming van de marktdeelnemer tegen de administratieve handelingen van de lidstaat bij de uitvoering van het Unierecht en valt volgens Stix-Hackl niet in te zien waarom een marktdeelnemer zich niet tegenover de autoriteiten van de lidstaat op het gemeenschapsrechtelijke beginsel van de bescherming van het gewettigd vertrouwen zou kunnen beroepen. ${ }^{144}$

Van Hilten meent dat de Hoge Raad zich mag laten leiden door de nationale invulling van het vertrouwensbeginsel, hoezeer de BTW ook een Europese belasting is. ${ }^{145}$ Volgens haar bereikt het Europees recht de belastingplichtige door de implementatie in de nationale wet. De belastingplichtige heeft in beginsel niets te maken met de BTW-richtlijnen. De belastingplichtige ontleent en kent zijn rechten uit de nationale wet en de uitvoering daarvan door de nationale belastingdienst. Volgens haar is

143. Hof van 14 september 2006, nrs. C-181/04, C-182/04 en C-183/04, Elmeka, V-N 2006/49.19. Zie in het bijzonder de pt. 42 e.v. in de conclusie van de A-G. Het Hof heeft zich niet uitgesproken over de toepassing van het vertrouwensbeginsel, maar dit overgelaten aan de nationale rechter.

144. Zie ook A. van Dongen, De algemene beginselen bestaan niet, NTFR 2007/164.

145. M.E. van Hilten in haar noot bij het arrest van de HR van 26 augustus 1998, nr. 33 518, BNB 1998/

372. Zie ook M.E. van Hilten, De Europese dimensie van door de fiscus opgewekt vertrouwen in de BTW en het douanerecht (oratie Leiden), Leiden: Rijks Universiteit Leiden 1998. 
de nationale belastingdienst dan ook gebonden aan het vertrouwensbeginsel zoals zich dat heeft ontwikkeld in het nationale belastingrecht. ${ }^{146}$ Zij verwijst in dit kader ook naar de jurisprudentie van het Hof, waarin is beslist dat de toepassing van het nationale recht, zo die gunstiger is voor een belastingplichtige, voorrang krijgt boven de toepassing van de richtlijn. ${ }^{147}$ Duidelijk is echter dat in de jurisprudentie van het Hof de in deze subparagraaf behandelde problematiek niet expliciet aan de orde is geweest. Behalve dan de in het begin behandelde jurisprudentie waar het Hof verwijst naar de beperkende invloed van het gelijkheidsbeginsel en het doeltreffendheidbeginsel op het vertrouwensbeginsel.

De door Van Hilten gevolgde benadering lijkt mij een gerechtvaardigde uitwerking. Wel vraag ik mij af hoe deze past in de context van het streven naar één interne markt. Zo is het denkbaar dat in bepaalde lidstaten de uitwerking en de kracht van de algemene rechtsbeginselen beperkter is dan in Nederland. Het gevolg hiervan zou dan zijn dat de uitwerking van het Unierecht in de ene lidstaat minder effectief is dan in een andere lidstaat. Een dergelijk effect zou onder bepaalde omstandigheden kunnen botsen met het streven naar één interne markt. In paragraaf 1.1 is naar voren gebracht dat het hele harmonisatie proces juist is begonnen om één interne markt tot stand te brengen. Of moet geconcludeerd worden, dat de rechtsbescherming van de belastingplichtigen toch van een hogere orde is? Het lijkt mij in ieder geval niet gewenst dat de stand van de jurisprudentie van de lidstaat waar de algemene rechtsbeginselen het minst zijn ontwikkeld, bepalend is voor het effect in de gehele EU.

\subsection{De klassieke BTW-beginselen en de algemene rechtsbeginselen}

\subsubsection{Waarom geen echte algemene rechtsbeginselen?}

In hoofdstuk 2 zijn diverse klassieke BTW-beginselen beschreven, namelijk het verbruiksbeginsel, territorialiteitsbeginsel, oorsprongslandbeginsel, bestemmingslandbeginsel en het neutraliteitsbeginsel. De vraag doet zich voor of deze klassieke BTW-beginselen aangemerkt kunnen worden als algemene rechtsbeginselen. Voldoen zij aan de omschrijving van algemene rechtsbeginselen zoals gegeven in paragraaf 3.2.3?

146. Ook Bijl meent dat de invloed van het Hof niet zo ver gaat dat het de werking van algemene beginselen van behoorlijk bestuur (bijvoorbeeld het rechtszekerheidsbeginsel) in het nationale recht kan inperken. D.B. Bijl, De heffing van omzetbelasting ten aanzien van onroerend goed (diss. Tilburg), Deventer: Kluwer 1990, blz. 32. Prechal en Heukels daarentegen menen echter dat de toepassing van nationale algemene rechtsbeginselen niet in conflict mag komen met het in het Unierecht ontwikkelde non-discriminatiebeginsel. Deze laatste twee schrijvers hebben dan echter een situatie op het oog waarin de nationale invulling van de algemene rechtsbeginselen beperkter is dan in het Unierecht en belastingplichtigen dan ook minder beschermen. In deze paragraaf gaat het echter om een situatie waarin de nationale invulling mogelijk de uitwerking van het Unierecht blokkeert. S. Prechal \& T. Heukels 1986, blz. 312. Zie verder ook in dit kader A.W. van der Woude, Belastingen begrensd (diss. Rotterdam), Delft: Eburon 2000, blz. 20.

147. Hof 26 februari 1986, nr. 152/84, Marshall, Jur. 1986, blz. 723 en Hof 8 oktober 1987, nr. 80/86, Kolpinghuis, Jur. 1987, blz. 3969. 
Het verbruiksbeginsel is volgens mij geen algemeen rechtsbeginsel. Zoals in paragraaf 2.2 is beschreven, is het verbruiksbeginsel sterk verweven met het rechtskarakter van de BTW. Dat wil dus zeggen, dat het verbruiksbeginsel aangeeft wie en wat men wil belasten in de BTW. De werking van het verbruiksbeginsel is dus per definitie beperkt tot de BTW. Voor bijvoorbeeld de directe belastingen, anders dan directe verbruiksbelastingen, heeft het duidelijk geen betekenis. Een universele rechtvaardigheidsnorm is er uiteraard niet in te onderkennen. Ook al wordt door velen een belasting op consumptie als een aantrekkelijk alternatief gezien voor de belastingen op winst en inkomen, en kan men daaraan rechtvaardigheidsoordelen verbinden. Het gegeven dat het verbruiksbeginsel geen algemeen rechtsbeginsel is, wil niet zeggen dat het Hof het niet hanteert bij de uitleg van de BTW-regelgeving. In paragraaf 2.2 zijn diverse arresten van het Hof beschreven waar het verbruiksbeginsel een beslissend effect heeft.

Bij de beschrijving van het territorialiteitsbeginsel in paragraaf 2.3.1 is naar voren gebracht dat algemeen aanvaard is, dat een land de bevoegdheid heeft belasting te heffen over belastbare feiten die plaatsvinden op zijn grondgebied. Denkbaar is dat wij het hier hebben over een universele norm die algemeen als rechtvaardig wordt ervaren. Duidelijk is dat deze norm zich ook laat gelden buiten het belastingrecht. Zo is het onbetwist dat een staat het strafrecht mag inrichten op een wijze dat strafbare feiten begaan op zijn grondgebied effectief strafbaar zijn. Mogelijk dat het uitgangspunt zich dus laat gelden binnen de gehele rechtsorde. Toch ben ik van mening dat wij niet te maken hebben met een algemeen rechtsbeginsel. Op zijn best een beperkt algemeen rechtsbeginsel. Zoals in de eerdergenoemde paragraaf van hoofdstuk 2 is behandeld staat het territorialiteitsbeginsel van diverse kanten onder druk. Mogelijk dat het in het verleden een algemene aanvaarde norm was. Nu echter wordt van diverse kanten inbreuk gemaakt op het uitgangspunt. ${ }^{148}$ Het wordt steeds moeilijker voor een staat om zijn eigen belastingstelsel te handhaven. Het territorialiteitsbeginsel staat in EU en WTO verband dan ook onder druk. Verder zal blijken, in het bijzonder in hoofdstuk 8, dat in geval van een heffingsconflict tussen de lidstaten het territorialiteitsbeginsel onvoldoende gewicht in de schaal legt om bij te dragen aan de uitleg van het BTW-recht. De bovenstaande aspecten perken de betekenis dusdanig in, dat volgens mij niet (meer) kan worden gesproken van een algemeen rechtsbeginsel.

Het oorsprongslandbeginsel en het bestemmingslandbeginsel kunnen volgens mij niet worden beschouwd als algemene rechtsbeginselen. In paragraaf 2.3.2.1 (zie het daar weergegeven schema) is verduidelijkt dat deze twee klassieke BTW-beginselen ten behoeve van de uitwerking, toepassingskenmerken hebben die men kan manipuleren. Zij kunnen kenmerkende toepassingen van de heffing toewijzen aan een lidstaat, namelijk toepasbaar tarief, het recht op de belastingopbrengst en het land

148. Kooijmans vermeldt dat de territoriale jurisdictie van een staat in beginsel alomvattend is, doch er worden door het internationale recht uitzonderingen op gemaakt. Kooijmans behandelt beperkingen van regeldoorvoerende en regelhandhavende bevoegdheid. P.H. Kooijmans, Internationaal publiekrecht, Deventer: Kluwer 2008, blz. 43 en 44. 
waar het belastbaar feit plaatsvindt. Daarmee blijven zij toewijzingsbeginselen. ${ }^{149}$ Bij de toewijzing van deze kenmerken spelen algemeen aanvaarde essentiële rechtvaardigheidsnoties geen of nauwelijks tot niet een rol. ${ }^{150}$ Het oorsprongslandbeginsel en het bestemmingslandbeginsel zijn methoden ter vermijding van internationale dubbele belastingheffing en volgens mij niet meer dan dat. ${ }^{151}$ Dat zij in hun uitwerking een rechtvaardigheidscomponent hebben, namelijk het voorkomen van niet-heffing dan wel dubbele heffing, heeft meer met de werking van het gelijkheidsbeginsel te maken (zie verder hoofdstuk 8).

Wat betreft de analyse van het neutraliteitsbeginsel verwijs ik naar de volgende subparagraaf. Dit beginsel heeft een aantal karakteristieken dat een aparte behandeling noodzakelijk maakt.

\subsubsection{Het neutraliteitsbeginsel en de algemene rechtsbeginselen}

Zoals in paragraaf 2.4.1 naar voren is gebracht, is de BTW gebaseerd op het uitgangspunt dat de heffing geen invloed heeft op de concurrentieverhoudingen en de allocatie van productiemiddelen (neutraliteitsbeginsel als stelselbeginsel). Tevens is aan de orde geweest, dat als naar een meer juridische invulling van het neutraliteitsbeginsel wordt gezocht het gelijkheidsbeginsel zich op de voorgrond dringt. Toch zijn deze begrippen niet synoniem. ${ }^{152}$ Het gelijkheidsbeginsel heeft een ruimere werking dan het begrip neutraliteit. Anderzijds lijkt het erop dat het neutraliteitsbeginsel casuïstiek oplost die niet met een beroep op het gelijkheidsbeginsel kan worden afgedaan omdat dit niet toereikend is. Dat neemt niet weg dat er wel degelijk een veld bestaat waar overlapping plaatsvindt.

149. Zie in dit kader ook A.H.R.M. Denie 1987, blz. 51. Hij kenmerkt het bestemmingslandbeginsel als een 'vermijdingsbeginsel'. En eigenlijk vindt hij dat men van een beginsel niet kan spreken.

150. Denie meent echter dat het bestemmingslandbeginsel een criterium is dat domineert bij de toewijzing van de omzetbelasting aan de ene of andere staat. Voor zover het bestemmingslandbeginsel internationaal dubbele belastingheffing voorkomt, is er volgens hem een duidelijke rechtvaardigheidsgedachte in te herkennen. A.H.R.M. Denie 1987, blz. 56.

151. R.F.W. van Brederode 1996, blz. 19 stelt dat: "Het oorsprongslandbeginsel en bestemmingslandbeginsel spelen een belangrijke rol in de heffing van de omzetbelasting volgens het BTW-stelsel om te bepalen aan de schatkist van welke Lid-Staat de belasting toekomt. Buiten het vraagstuk van de belastingallocatie hebben zij echter geen betekenis. Hoewel beide begrippen worden geëtiketteerd als beginselen zijn het geen beginselen in de eigenlijke zin van het woord omdat zij ethische lading ontberen."

152. In een wat andere context onderscheidt ook Vanistendael verschillende betekenissen van het neutraliteitsbeginsel. Deze schrijver herkent een dubbele betekenis. Ten eerste een economische dat de wetgever beïnvloedt (bijvoorbeeld harmonisatie van de BTW binnen het streven naar één interne markt). Ten tweede een algemeen en ongeschreven rechtsbeginsel dat de rechter leidt bij zijn beslissingen. F. Vanistendael 1991, blz. 232. 
Schematisch weergegeven:

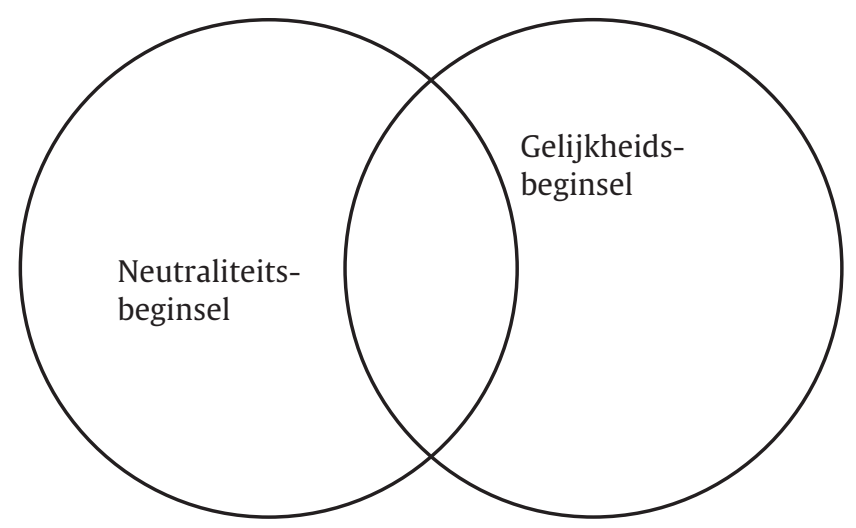

In paragraaf 3.4.1 van dit hoofdstuk is naar voren gebracht dat het gelijkheidsbeginsel nastreeft, dat het gelijke gelijk wordt behandeld en het ongelijke ongelijk. Met neutraliteit wordt in het algemeen gedoeld op gelijke concurrentieverhoudingen. In geval van externe neutraliteit wordt dan bedoeld, dat de BTW de concurrentieverhoudingen niet mag beïnvloeden in het geval dat grensoverschrijdende transacties worden verricht. Gefocust op het BTW resultaat betekent dat dus een gelijke behandeling, dan wel ongelijk indien objectief geen sprake is van vergelijkbare gevallen. De parallel is hier onmiskenbaar aanwezig. In dit stadium is het echter nog niet volledig duidelijk. Daarvoor is een analyse van de jurisprudentie van het Hof nodig. Paragraaf 4.4.4.2 verduidelijkt onder welke omstandigheden geen onderscheid bestaat tussen het gelijkheidsbeginsel en het neutraliteitsbeginsel. Deze beginselen hebben dan een gelijke betekenis in de jurisprudentie van het Hof. In de vervolghoofdstukken zal daarentegen worden aangetoond dat deze beginselen onder bepaalde omstandigheden wel degelijk een verschillende betekenis hebben. De bovenstaande figuur is dan ook verder ingekleurd door het Hof.

\subsection{Conclusies}

De algemene rechtsbeginselen hebben hun wortels in de rechtvaardigheidsgedachte die leeft in het rechtsbewustzijn van een samenleving. Daar ligt dan ook de grootste beperking van de algemene rechtsbeginselen. Wat is rechtvaardigheid en wat is het rechtsbewustzijn? Abstracte begrippen die het moeilijk maken greep te krijgen op het ontstaansproces van algemene rechtsbeginselen. In dit hoofdstuk vormt dat echter geen probleem. De aandacht wordt namelijk geconcentreerd op drie algemeen aanvaarde rechtsbeginselen welke geconcretiseerd zijn in een omvangrijke nationale en Europees rechtelijke jurisprudentie.

In de literatuur maken diverse schrijvers onderscheid tussen rechtsregels en rechtsbeginselen. Het onderscheid verduidelijkt de betekenis van algemene rechtsbeginselen. Het begrip algemeen rechtsbeginsel omschrijf ik strak in die zin dat, allerlei vage beginselen niet onder het bereik vallen. Algemene rechtsbeginselen worden 
omschreven als: grondslagen die onmiddellijk evident zijn en algemeen in het recht worden erkend als juridisch geldend. Het gaat tenslotte om algemene rechtsbeginselen die in staat zijn een dwingende kracht uit te oefenen op de uitleg van het recht en de BTW-regelgeving in het bijzonder.

Algemene rechtsbeginselen zijn te onderscheiden naar toepassingsveld. Ik onderscheid algemene rechtsbeginselen van formeel recht van interpretatiebeginselen. Met voorbeelden uit de jurisprudentie is toegelicht dat de algemene rechtsbeginselen de BTW-regelgeving kunnen verruimen en inperken. Tevens is geschetst dat de verruimende werking van de algemene rechtsbeginselen ook wel wordt aangeduid als een methode van rechtsvinding. Deze constatering maakt het noodzakelijk om in paragraaf 4.4 aandacht te besteden aan de karakteristieke methoden van rechtsvinding die het Hof toepast.

In paragraaf 3.4 is nader aandacht gegeven aan de drie algemene rechtsbeginselen die ik onderzoek. Vooral zijn de Europees rechtelijke aspecten behandeld. Het gelijkheidsbeginsel is op verschillende plaatsen verankerd in het Werkingsverdrag. Daarnaast heeft het Hof in een omvangrijke jurisprudentie het gelijkheidsbeginsel toegepast en daaraan invulling gegeven. Een belangrijke drijvende kracht achter het gelijkheidsbeginsel is niet alleen de rechtvaardigheidsgedachte, maar ook het streven naar één interne markt.

Het evenredigheidsbeginsel geeft aan, dat vereist is dat een maatregel 'geschikt' is om de doelstelling te bereiken en tegelijk wordt ook geëist dat deze onmisbaar is. Verder vereist het evenredigheidsbeginsel dat de maatregel evenwichtig is. Kortom: geschiktheid, noodzakelijkheid en evenwichtigheid.

Het rechtszekerheidsbeginsel heeft onder meer betrekking op, zoals Scholten heeft aangeduid, de berekenbaarheid van het recht. Het rechtszekerheidsbeginsel kan gezien worden als een verdere uitwerking van deze berekenbaarheid. Tevens is naar voren gebracht dat de verhouding tussen het in de nationale jurisprudentie ontwikkelde vertrouwensbeginsel en het Unierecht problematisch kan zijn. De doorwerking van het Unierecht in het nationale recht mag niet worden geblokkeerd. Het Hof heeft echter nog niet expliciet verduidelijkt op welke wijze deze problematiek opgelost moet worden.

De klassieke BTW-beginselen kunnen niet worden aangemerkt als algemene rechtsbeginselen. Hun toepassingsbereik is te beperkt. Dit is mogelijk inherent aan het gegeven dat zij verweven zijn met het rechtskarakter van de BTW. Een uitzondering op deze conclusie is het neutraliteitsbeginsel. Hiervoor geldt dat waar dit synoniem is aan het gelijkheidsbeginsel er 'in ieder geval' van een algemeen rechtsbeginsel kan worden gesproken en op de vraag of dit beginsel binnen het raam van de BTW verder reikt dan de toepassingsmogelijkheid van het gelijkheidsbeginsel, kom ik in paragraaf 4.4.4 en de hoofdstukken $6 \mathrm{t} / \mathrm{m} 13$ op terug. 
Dat de klassieke BTW-beginselen geen algemene rechtsbeginselen zijn, is een belangrijke constatering. Deze conclusie is namelijk van belang bij de analyse van de jurisprudentie van het Hof in geval van een botsing van de diverse beginselen. Aangestipt is het optimaliseringvereiste dat toegepast kan worden op conflicterende beginselen. In het vervolg van het onderzoek zal blijken, dat het mogelijk is dat een beslissing meerdere algemene rechtsbeginselen in een bepaalde mate realiseert en dat het zelfs voorkomt dat een algemeen rechtsbeginsel een bondgenoot vindt in het rechtskarakter van de BTW (paragraaf 4.4.4 en hoofdstuk 13). Het is dus zeker niet zo dat in alle gevallen de algemene rechtsbeginselen botsen dan wel elkaar uitsluiten. Daarvoor is echter eerst noodzakelijk dat onder meer in hoofdstuk 4 wordt uitgewerkt het verband tussen het Unierecht en ons nationale recht en de specifieke technieken die het Hof gebruikt om algemene rechtsbeginselen op te sporen en toe te passen.

In dit hoofdstuk is steeds uitgegaan dat bij een botsing van beginselen één beginsel de overhand krijgt. De vragen zijn dan: welk beginsel? En waarom juist dat beginsel? Denkbaar is echter dat uit de botsing van beginselen een nieuw beginsel ontstaat, dat gezien kan worden als een synthese. Een dergelijk beginsel is dan als het ware gebaseerd op een rationele consensus. Deze rationele consensus is onbereikbaar indien de uitgangspunten van de beginselen te ver uit elkaar liggen. 


\section{HOOFDSTUK 4}

\section{Algemene rechtsbeginselen en het Unierecht}

\subsection{Inleiding}

In dit hoofdstuk besteed ik aandacht aan de positie van de algemene rechtsbeginselen in het Europees recht. Aan de orde komt de betekenis en rol van de algemene rechtsbeginselen in het Unierecht. Om dit te verduidelijken is vereist om enkele relevante karakteristieken van het Unierecht te behandelen (paragrafen 4.2 en 4.3). Onder meer besteed ik aandacht aan 'communautaire rechtsbegrippen' dan wel 'autonome begrippen van het gemeenschapsrecht'.

In paragraaf 4.4 komt de rechtsvindingtechniek van het Hof aan de orde. In de vorige hoofdstukken zijn de termen als (fiscale) neutraliteit, gelijkheidsbeginsel en analoge argumentatie gebruikt, waarbij naar voren kwam dat deze begrippen verweven zijn. De paragrafen 4.4.3 en 4.4.4 gaan nader in op de raakvlakken tussen deze begrippen.

Paragraaf 4.5 besteedt vervolgens aandacht aan het primaire en secundaire Unierecht. In deze paragraaf vindt een verduidelijking plaats van de positie welke de algemene rechtsbeginselen in het recht van de Europese Unie innemen.

In de paragrafen 4.6 en 4.7 komen de rechtstreekse werking en de richtlijn/ beginselconforme interpretatie aan bod. Deze leerstukken zijn van invloed op de doorwerking van de algemene rechtsbeginselen in ons nationaal recht. Het hoofdstuk sluit af met een conclusie.

\section{Autonome rechtsorde}

Uit diverse arresten van het Hof komt naar voren dat de verdragen in het volkenrecht een nieuwe, eigen rechtsorde in het leven hebben geroepen. Zo overweegt het Hof in het Van Gend \& Loos arrest ${ }^{1}$ dat de Europese Unie:

“(...) in het volkenrecht een nieuwe rechtsorde vormt ten bate waarvan de Staten, zij het op een beperkt terrein, hun soevereiniteit hebben begrensd en waarbinnen niet slechts deze lidstaten, maar ook hun onderdanen gerechtigd zijn (...)"

1. Hof 5 februari 1963, nr. 26/62, Van Gend \& Loos, Jur. 1963, blz. 3. 
Het Costa-Enel-arrest ${ }^{2}$ voegt daar aan toe dat:

“(...) het E.E.G-Verdrag, anders dan met gewone internationale verdragen het geval is, een eigen rechtsorde in het leven heeft geroepen, die bij de inwerkingtreding van het Verdrag in de rechtsorde der lidstaten is opgenomen en waarmede de nationale rechters rekening dienen te houden (...)"

Vervolgens wordt daar aan toegevoegd dat het Unierecht 'uit een autonome bron voorvloeit'. Met deze bron worden - naar huidige termen - het Unieverdrag en het Werkingsverdrag bedoeld.

De communautaire rechtsorde vormt een rechtstreekse bron van rechten en plichten voor zowel de lidstaten als particulieren. Uit het Costa-Enel-arrest blijkt ook dat het Unierecht voorrang heeft boven het nationale recht. ${ }^{3}$ Tevens is van belang dat de toepassing en interpretatie van het Unierecht uitsluitend wordt beheerst door het recht van de Unie zelf en niet door enig beginsel of norm van nationaal of internationaal recht. Het Unierecht heeft dan ook een autonoom karakter. ${ }^{4}$

De karakterisering 'autonoom' dient juist op het terrein van de algemene rechtsbeginselen te worden gerelativeerd. Zo doet het Hof geregeld een beroep op 'algemene rechtsbeginselen die gemeenschappelijk zijn aan de rechtstelsels van de lidstaten'. Daarbij wordt een comparatieve methode gevolgd. Zoals in paragraaf 3.2 naar voren is gebracht zijn de algemene rechtsbeginselen diep geworteld in de westerse rechtsstelsels. Er bestaan dus gemeenschappelijke rechtsbeginselen in de rechtstelsels van de lidstaten en deze kunnen een bron voor het Unierecht zijn. Zo bekeken fungeert het communautaire rechtstelsel niet geheel autonoom van de rechtstelsels van de lidstaten. Juist op het terrein van de rechtsvinding vindt beïnvloeding plaats. Koopmans vestigt in dit verband de aandacht op een bijzonder aspect. Zo vermeldt hij dat er met de door het Hof geformuleerde algemene rechtsbeginselen iets merkwaardigs aan de hand is:

“(... zij worden eerst door het Hof opgespoord in de rechtstradities van de lidstaten, en als dat eenmaal gebeurd is maken zij als het ware de reis terug. Omdat zij namelijk als algemeen rechtsbeginsel worden geformuleerd, zijn nationale rechters nogal eens geneigd er een beroep op te doen, ook in zaken die met gemeenschapsrecht weinig te maken hebben." ${ }^{5}$

2. Hof 14 januari 1964, nr. 6/64, Costa Enel, Jur. 1964, blz. 1203.

3. De voorrang van Unierecht is een conflictregel: bij een conflict tussen een regeling van communautair recht en nationaal recht prevaleert het Unierecht. Zie voor de spanning die kan bestaan tussen voorrang van recht van de Unie en het beginsel van de nationale procedurele autonomie, R. Ortlep \& M.J.M. Verhoeven, De voorrangsregel versus het beginsel van nationale procedurele autonomie, SEW, nr. 12, december 2008, blz. 207 e.v.

4. Zie tevens Hof 13 november 1964, nr. 90/63 en 91/63, Commissie/Luxemburg en Commissie/België, Jur. 1964, blz. 1279. Zie ook Hof 19 november 1991, nrs. C-6/90 en C-9/90, Francovich en Bonifaci, Jur. 91, blz. I-5357 en dan in het bijzonder r.o. 31. Zie nader in de literatuur R. Barents \& L.J Brinkhorst, Grondlijnen van Europees recht, Deventer: Kluwer 2003, blz. 35.

5. T. Koopmans, Rechtsbeginselen in het Europees Gemeenschapsrecht, Ars Aequi 1991, nr 10, blz. 927. Zie voor voorbeelden van wat genoemd kan worden als de terugreis van algemene rechtsbeginselen, de in zijn artikel aangehaalde Engelse jurisprudentie. 
De algemene rechtsbeginselen beïnvloeden dus over en weer de nationale en de communautaire rechtsorde.

\subsection{Communautair rechtsbegrip dan wel autonoom begrip van gemeenschapsrecht}

Bij een eigen, autonome rechtsorde past een specifiek begrippenapparaat. Zo zijn in de jurisprudentie van het Hof diverse verwijzingen te vinden naar een dergelijk specifiek voor het Unierecht ontwikkeld begrippenapparaat. Zo blijkt uit het Cilfitarrest $^{6}$ dat,

“(...) zelfs wanneer de taalversies van de richtlijnen volledig overeenstemmen, het gemeenschapsrecht een eigen terminologie bezigt. Bovendien hebben de rechtsbegrippen in het gemeenschapsrecht niet noodzakelijkerwijs dezelfde inhoud als in de verschillende nationale rechtstelsels."

De literatuur duidt deze aan het Unierecht eigen terminologie veelal aan als communautaire rechtsbegrippen.

Van belang is dat een 'algemeen' communautair rechtsbegrip niet enkel geldt binnen een bepaald rechtsgebied, zoals voor ons onderwerp het BTW-recht, maar doorwerkt in het gehele Unierecht. In deze rol hebben de communautaire rechtsbegrippen een tweevoudige harmoniserende werking. Allereerst wordt bereikt dat er van een bepaald begrip een eenduidige uitleg is in de lidstaten die het aangaat. En op de tweede plaats wordt bereikt dat het begrip een eenduidige invulling krijgt binnen het gehele Unierecht, wat tot gevolg heeft dat het recht van de Unie tot een eenheid wordt gesmeed. In haar conclusie bij het TNT-arrest ${ }^{8}$ merkt advocaat-generaal Kokott op, dat het strookt met de praktijk van het Hof bij de uitlegging van de afzonderlijke begrippen van de BTW-richtlijn om de relevante niet-fiscale gemeenschapsrechtelijke regelingen in aanmerking te nemen, voor zover deze dezelfde doelstellingen nastreven.

6. Hof 6 oktober 1982, nr. 283/81, Cilfit, Jur. 1982, blz. 3415. Deze procedure geeft de kaders van de prejudiciële verwijzing aan.

7. Volgens Swinkels loopt het scala van begrippen in de BTW-richtlijn uiteen van communautaire begrippen tot quasi-nationale begrippen. Communautaire begrippen moeten in de lidstaten uniform worden ingevuld en toegepast. De quasi-nationale begrippen kunnen daarentegen praktisch geheel door de lidstaten worden ingevuld. Tussen deze uitersten liggen volgen Swinkels begrippen die zijn aan te duiden als de quasi-communautaire begrippen. De lidstaten hebben ten aanzien van deze laatste begrippen een zekere beoordelingsvrijheid. Swinkels verbindt de term quasi-communautair aan deze begrippen omdat de beoordelingsvrijheid van de lidstaten in meerdere of mindere mate wordt begrensd. Zie voor een verdere analyse van dit onderscheid J.J.P. Swinkels, De Belastingplichtige in de Europese BTW (diss Amsterdam UvA) 2000, blz. 50 t/m 57. Zie verder ook voor een uitgebreide analyse van de communautaire rechtsbegrippen en hun rol bij de harmonisatie van de BTW, A. van Dongen, De harmonisatie van de BTW (diss. Tilburg), Amersfoort: Sdu Uitgevers 2007. In het bijzonder blz. $238 \mathrm{t} / \mathrm{m} 243$ en $322 \mathrm{t} / \mathrm{m} 365$.

8. Hof 23 april 2009, nr. C-357/07, TNT Post UK Ltd., V-N 2009/21.16. Dit arrest legt de postvrijstelling uit na liberalisering. 
In een aantal BTW-arresten is enkel de eerste harmoniserende werking te ontdekken. ${ }^{9}$ In de casus De Fruytier, ${ }^{10}$ over de vraag of de levering van menselijke organen en bloed onder de vrijstelling valt, is te vinden:

“(...) De bewoordingen van een bepaling van de Zesde richtlijn die voor de vaststelling van haar betekenis en draagwijdte niet uitdrukkelijk naar het recht van de lidstaten verwijst, moeten dus normalerwijs in de gehele Unie autonoom en op eenvormige wijze worden uitgelegd." (r.o. 21)

Zelden komt het voor dat de betekenis die aan een begrip wordt toegekend in een richtlijn op een ander terrein dan de BTW, wordt doorgetrokken naar de BTWrichtlijn. Zie in dit kader bijvoorbeeld het CPP-arrest ${ }^{11}$ waarin het Hof er op wijst dat de BTW-richtlijn niet nader bepaalt het begrip 'handelingen ter zake van verzekeringen'(in de zin van artikel 135, lid 1, sub a, BTW-richtlijn; r.o. 16). Vervolgens overweegt het Hof:

“(...) Er is (...) geen reden om de term 'verzekeringen' anders uit te leggen naargelang hij in de verzekeringsrichtlijn dan wel in de Zesde richtlijn wordt gebruikt.” (r.o. 18)

Het latere gewezen Skandia-arrest ${ }^{12}$ brengt echter een nuancering aan. Het Hof geeft in dit arrest aan, dat de betekenis van de verzekeringsrichtlijnen niet zo ver gaat dat dit inhoudt dat alle handelingen die een verzekeringsmaatschappij verricht in fiscaal opzicht handelingen ter zake van verzekeringen zijn. Dit gezien de vaste rechtspraak waarin is omschreven dat de vrijstellingen in de BTW strikt dienen te worden uitgelegd (zie nader hoofdstuk 10). ${ }^{13}$

9. Een voorbeeld in de jurisprudentie van het Hof is het begrip 'verhuur'. In verscheidene arresten heeft het Hof verduidelijkt dat in de BTW-richtlijn niet verwijst naar een omschrijving van dit begrip in de wettelijke regelingen van de lidstaten en dat de bepaling dan ook uitgelegd moet worden in het licht van de context ervan en van de doelstellingen en de algemene opzet van de BTW-richtlijn, in het bijzonder rekening houdend met de ratio legis. Het Hof heeft in zijn rechtspraak gepreciseerd dat de verhuur van onroerende goederen in de zin van artikel 135, lid 1, sub 1, BTW-richtlijn (voorheen artikel 13, B, sub b, Zesde richtlijn) in wezen inhoudt dat een verhuurder tegen betaling voor een overeengekomen tijdsduur aan een huurder het recht verleent een goed te gebruiken alsof hij de eigenaar daarvan is en andere personen daarvan uit te sluiten. Zie Hof 18 november 2004, nr. C-284/03, Temco Europe, V-N 2005/21.22, NTFR 2004/1739, r.o. 19; Hof 25 oktober 2007, nr. C-174/06, Co.GE.P. srl, V-N 2007/49.17.

10. Hof 3 juni 2010, nr. C-237/09, N. De Fruytier, V-N 2010/30.13.

11. Hof 25 februari 1999, nr. C-349/96, Card Protection Plan, BNB 1999/224, V-N 1999/15.28.

12. Hof 8 maart 2001, nr. C-240/99, Skandia, V-N 2001/22.19.

13. Zie ook het arrest Abbey National II, waar het Hof bij de uitleg van het zinsdeel 'beheer van gemeenschappelijke beleggingsfondsen' (artikel 135, lid 1, sub g, BTW-richtlijn) aandacht besteedt aan een richtlijn op een ander terrein, namelijk richtlijn 85/611/EEG van de Raad van 20 december 1985 tot coördinatie van de wettelijke en bestuursrechtelijke bepalingen betreffende bepaalde instellingen voor collectieve belegging in effecten (icbe's) ( $\mathrm{Pb} \mathrm{L} \mathrm{375,} \mathrm{blz.} \mathrm{3).} \mathrm{Echter} \mathrm{gezien} \mathrm{onder} \mathrm{meer} \mathrm{de} \mathrm{verschillen} \mathrm{in}$ de taalversies speelt deze richtlijn geen beslissende rol bij de uitleg. Hof 4 mei 2006, nr. C-169/04, NTFR $2006 / 687$. 
Een algemeen communautair rechtsbegrip is dan ook niet vaak te ontdekken in de jurisprudentie op het terrein van de BTW. Juister zou dan ook zijn om de term 'autonoom begrip van gemeenschapsrecht' te gebruiken. ${ }^{14}$ Deze terminologie geeft beter aan dat enkel de eerste harmoniserende werking wordt beoogd.

Het Hof maakt dit onderscheid niet. Zie bijvoorbeeld het CPP-arrest ${ }^{15}$ waar het Hof aangeeft dat de vrijstellingen

“(...) autonome begrippen van gemeenschapsrecht zijn, die tot doel hebben verschillen in de toepassing van het BTW-stelsel tussen de lidstaten te voorkomen (...)."

In het SUFA-arrest ${ }^{16}$ wordt echter overwogen dat de vrijstellingen autonome communautaire rechtsbegrippen zijn. ${ }^{17}$ Het feit dat het Hof verschillende termen gebruikt lijkt niet weloverwogen te gebeuren gezien het feit dat de genoemde arresten naar elkaars rechtsoverwegingen verwijzen.

Het bovenstaande onderscheid is niet zonder betekenis. Zo kan het zijn dat een bepaald begrip enkel een communautaire betekenis heeft in de BTW-richtlijn, maar dat deze betekenis niet doorgetrokken kan worden naar andere richtlijnen waar hetzelfde begrip voorkomt. Of in omgekeerde richting, namelijk dat begrippen die te vinden zijn in richtlijnen op andere terreinen dan de BTW (of in het Werkingsverdrag) niet dezelfde betekenis hebben als eenzelfde begrip in de BTW-richtlijn. Mogelijk is een voorbeeld daarvan te vinden in het arrest Van der Steen. ${ }^{18}$ In dit arrest besliste het Hof dat een directeur/enig aandeelhouder niet belastingplichtig is omdat sprake is van een verhouding van ondergeschiktheid. ${ }^{19}$ In het arrest Asscher $^{20}$ oordeelde het Hof echter, dat een directeur van een vennootschap waarvan hij enig aandeelhouder is, zijn werkzaamheden niet in het kader van een positie van ondergeschiktheid verricht, zodat hij niet kan worden aangemerkt als 'werknemer' in de zin van artikel 45 VwEU (voorheen artikel 39 EG), maar moet worden beschouwd als een persoon die een werkzaamheid anders dan in loondienst uitoefent in de zin van artikel 49 VwEU (voorheen artikel 43 EG). In de Van der

14. In het AXA-arrest gebruikt het Hof de benaming 'autonome begrippen van Unierecht', Hof 28 oktober 2010, nr. C-175/09, AXA UK Plc, NTFR 2010/2509, r.o. 24. De term 'gemeenschapsrecht' is vervangen in 'Unierecht' als gevolg van het Verdrag van Lissabon dat per 1 december 2009 in werking is getreden. Zie nader paragraaf 1.6.

15. Hof 25 februari 1999, nr. C-349/96, Card Protection Plan, BNB 1999/224, V-N 1999/15.28, r.o. 15. 16. Hof 15 juni 1989, nr. 348/87, SUFA, FED 1989/559, r.o. 11.

17. In het arrest Tellmer Property formuleert het Hof het weer iets anders door te overwegen dat de vrijstellingen: “(...) autonome begrippen van gemeenschapsrecht zijn, die derhalve een communautaire omschrijving dienen te krijgen (...)”. Hof 11 juni 2009, nr. C-572/07, RLRE Tellmer Property sro, V-N 2009/ 29.17, NTFR 2009/1441. In dit arrest is beslist dat schoonmaakdiensten van gemeenschappelijke ruimte en verhuur twee aparte diensten zijn. Een identieke overweging is te vinden in Hof 25 oktober 2007, nr. C-174/06, CO.GE.P. Srl, V-N 2007/49.17, r.o. 26. Deze procedure gaat over de uitleg van het begrip verhuur.

18. Hof 18 oktober 2007, nr. C-355/06, J.A. van der Steen, V-N 2007/48.19.

19. Dit in tegenstelling tot het arrest van de HR van 26 april 2002, nr. 35 775, BNB 2002/275. V-N 2002/23.21. 20. Hof 27 juni 1996, nr. C-107/94, Asscher, BNB 1996/350, V-N 1996, blz. 2597, pt. 10. 
Steen-casus is het Asscher-arrest volgens het Hof echter niet van toepassing, omdat de Van der Steen zaak geen betrekking heeft op het vrije verkeer van personen, maar enkel de BTW betreft, meer bepaald de definitie van de hoedanigheid van belastingplichtige. Indien in de genoemde arresten algemene communautaire rechtsbegrippen aan de orde zijn, zou een eenduidige uitleg in de lijn van de verwachting liggen. Het Hof kiest voor verschillende sporen door te overwegen dat het verschillende velden van het Unierecht betreffen.

De term communautair rechtsbegrip kan dus misleidend zijn. Als een bepaalde term in de BTW-richtlijn wordt geduid als een communautair begrip, dan wordt daar niet zonder meer mee bedoeld dat deze term dezelfde betekenis heeft in het gehele communautaire recht. Veelal betekent het dat de term een autonome betekenis heeft onafhankelijk van de rechtstelsels van de lidstaten. Het doel dat dan wordt nagestreefd is het voorkomen van een verschillende uitleg in de lidstaten op het terrein van de heffing van BTW.

Het bovenstaande neemt niet weg dat het uitgangspunt is om begrippen in het communautaire recht eenduidig uit te leggen. Zie hierover nader paragraaf 4.4 van dit hoofdstuk. Dat kan tot gevolg hebben dat als op een bepaald terrein harmonisatie tot stand komt, de betekenis van een begrip kan veranderen. Een voorbeeld van een dergelijk effect treedt mogelijk op bij het begrip 'vast inrichting' in de moederdochter richtlijn. ${ }^{21}$ Van oudsher heeft het begrip vaste inrichting in de vennootschapsbelasting zijn eigen betekenis. Deze kan (kon) afwijken van de betekenis die het Hof toekent aan het begrip op het terrein van de BTW. Ik zal nader op het fenomeen vaste inrichting ingaan in paragraaf 8.3. Op deze plaats is van belang de constatering dat door het begrip vaste inrichting op te nemen in de moeder-dochter richtlijn de jurisprudentie op het terrein van de BTW betekenis kan krijgen voor de invulling van het dit begrip in de vennootschapsbelasting. Dit effect treedt op als het een 'algemeen' communautair rechtsbegrip is. Dat wil zeggen dat het begrip in het gehele Unierecht een identieke invulling heeft.

Indien, zoals in het bovenstaande voorbeeld, een begrip een communautaire uitleg krijgt, dan kan de betekenis gaan afwijken van de gangbare rechtspraktijk in een lidstaat. In het gegeven voorbeeld wordt dit veroorzaakt door beïnvloeding vanuit een ander deel van het Unierecht.

Zoals in het begin van deze paragraaf naar voren is gebracht zijn algemene communautaire rechtsbegrippen niet zo vaak te vinden in de BTW. Met communautair rechtsbegrip wordt, samenvattend gezegd, dan ook meestal gedoeld op een autonoom begrip van gemeenschapsrecht dat betekenis heeft in het Europees BTWrecht, onafhankelijk van de rechtstelsels van de lidstaten om zo een eenduidige uitleg in de lidstaten te bereiken.

21. Artikel 2, lid 2 van de moederdochter richtlijn. Richtlijn 2003/123/EG van 22 september 2003 tot wijziging van richtlijn 90/435/EEG, Pb L 7 van 13 januari 2004, blz. 41 t/m 44. 
Ik zal verder de term communautaire rechtsbegrip gebruiken. Het Hof heeft in diverse arresten rechtsbegrippen tot communautaire verheven. In de hoofdstukken $6 \mathrm{t} / \mathrm{m} 12$ passeren daarvan de voorbeelden.

\subsection{Rechtsvinding door het Hof van Justitie EU}

\subsubsection{Inleiding}

In artikel 19 VEU (voorheen artikel 220 EG) staat met betrekking tot de taakvervulling van het Hof onder meer:

“(...) Het verzekert de eerbiediging van het recht bij de uitlegging en toepassing van de Verdragen. (...)"

Deze bepaling van het Unieverdrag kent het Hof het monopolie toe om het recht uit te leggen. Verder bevat het artikel een 'open' definitie van het recht dat het Hof dient te verzekeren. Deze bepaling is dan ook te zien als een taakopdracht om in het kader van zijn rechtsprekende bevoegdheid het in veel opzichten onvolmaakte Unierecht te interpreteren.

Het zal duidelijk zijn dat het 'open' karakter van het Unierecht het mogelijk maakt dat niet geschreven algemene rechtsbeginselen zich laten gelden bij de vorming van het Unierecht. Opvallend is dat bij het Internationaal Gerechtshof juist is gekozen voor een vermelding van de rechtsbronnen in artikel 38 van het Statuut van het Internationaal Gerechtshof (San Francisco 1945). Zo vermeldt lid 1 van artikel 38 dat niet alleen verdragen en gewoonte, maar ook de door 'beschaafde volkeren erkende algemene rechtsbeginselen' tot de rechtsbronnen behoren. Volgens Kooijmans is de reden om de algemene rechtsbeginselen expliciet op te nemen, om zo het Internationaal Gerechtshof in de gelegenheid te stellen eventuele lacunes in het bestaande recht aan te vullen. ${ }^{22}$ Een andere benadering dus dan waar voor is gekozen in het Unieverdrag.

In de volgende subparagraaf schenk ik kort - en waar mogelijk met instructie aan de hand van fiscale jurisprudentie - aandacht aan de waaier van interpretatiemethoden die het Hof tot zijn beschikking heeft. ${ }^{23}$

22. P.H. Kooijmans, Internationaal publiekrecht, Deventer: Kluwer 2008, blz. 16.

23. De vraag wanneer interpretatie rechtsvorming is, komt neer op de vraag wanneer door interpretatie het geldend recht wordt veranderd. Het antwoord op de vraag waar de grens ligt tussen interpretatie en rechtsvorming valt buiten het kader van mijn onderzoek. Voor de geïnteresseerde lezer zie: F.T Groenewegen, Wetsinterpretatie en rechtsvorming (diss. Amsterdam UvA), Boom Juridische Uitgevers 2006, blz. 39 e.v. Zie ook voor het onderscheid tussen interpretatie en rechtsvorming F.T. Groenewegen, Wetsinterpretatie en rechtsvorming, Ars Aequi, 56 (2007) 1, blz. 91 e.v. 


\subsubsection{Interpretatiemethoden}

\subsubsection{Grammaticale interpretatiemethode}

Bij toepassing van de grammaticale interpretatiemethode speelt het probleem dat er 23 authentieke taalversies van de regelgeving zijn. ${ }^{24}$ Het kan dus voorkomen dat de regelgeving in de diverse taalversies discrepanties met zich meebrengt. Dat neemt niet weg dat het Hof wel degelijk waarde hecht aan de grammaticale interpretatiemethode. Mertens de Wilmars is zelfs van mening dat de grammaticale interpretatiemethode de eerste plaats inneemt. ${ }^{25}$ Als de juridische draagwijdte van een rechtsregel met zekerheid uit de bewoordingen kan worden gelezen, zoekt het Hof niet verder, tenzij die interpretatie tot een onzinnig resultaat leidt.

Zoals gezegd hebben de diverse taalversies van de regelgeving tot gevolg dat het bijna onvermijdbaar is dat taalkundig verschillen optreden. ${ }^{26}$ Toch is volgens Mertens de Wilmars dit niet de enige beperking die inherent is aan de toepassing van de grammaticale interpretatiemethode. Ook al is er overeenstemming in de terminologie, dan nog dekken in linguïstisch opzicht identieke begrippen als 'werknemer', 'onderneming', 'openbare orde', 'verjaring', enz., enz., vaak geheel of gedeeltelijk verschillende rechtsfiguren in de verscheidene rechtstelsels van de lidstaten. De juridische betekenis van een bepaalde rechtsterm komt meestal neer op de juridische betekenis die de nationale rechtsvinding daar in lengte van jaren aan heeft toegekend. Het uitgangspunt is dat een communautair interpretatiesysteem bepalingen in het Unierecht niet mag uitleggen door te verwijzen naar hun betekenis in de verscheidene nationale rechtsstelsels. Dit gezien het gevaar dat een dergelijke benadering tot gevolg zou kunnen hebben dat het Unierecht in de lidstaten uiteen gaat lopen.

24. Voor het Maltees en het Iers voorzien verordening (EG) nr. 930/2004 van de Raad (Pb L 169 van 1 mei 2004, blz. 1) en verordening (EG) nr. 920/2005 van de Raad (Pb L 156 van 18 juni 2005, blz. 3) in tijdelijke afwijkingsmaatregelen.

25. J. Mertens de Wilmars, in zijn oratie bij de aanvaarding van de Tinbergen-Leerstoel, Erasmus Universiteit Rotterdam, gehouden op 6 april 1990. Zie ook A-G Sharpton in haar conclusie bij het arrest Horizon College. Zij pleit in haar conclusie voor een zo letterlijk mogelijke uitleg van de onderwijsvrijstelling omdat een dergelijke uitleg het meest de belangen van de communautaire harmonisatie en de rechtszekerheid dient. A-G Sharpton, conclusie van 8 maart 2007, nr. C-435/05, Horizon College, V-N 2007/25.28, r.o. 37.

26. Uit het arrest Institute of the Motor Industry blijkt duidelijk welke lijn door het Hof wordt gevolgd indien verschillen tussen de taalversies aan de orde zijn. Het Hof overweegt: "Volgens vaste rechtspraak kan de in een van de taalversies van een gemeenschapsbepaling gebruikte formulering niet als enige grondslag voor de uitlegging van die bepaling dienen; evenmin kan er in zoverre voorrang aan worden toegekend boven de andere taalversies. Een dergelijke benadering zou immers onverenigbaar zijn met het vereiste van eenvormige toepassing van het gemeenschapsrecht. Wanneer er verschillen zijn tussen de taalversies, moet bij de uitlegging van de betrokken bepaling worden gelet op de algemene opzet en de doelstelling van de regeling waarvan zij een onderdeel vormt (...)", Hof 12 november 1998, nr. C-149/97, V-N 1997/3098, pt. 28, r.o. 16. Zie ook Hof 9 maart 2000, nr. C-437/97, EKW/Wein \& Co, Jur. 2000, blz. I-1157, r.o. 41 en 42. 
De spanning die staat op de grammaticale interpretatiemethode komt goed naar voren in de conclusie van advocaat-generaal Cosmas bij het Gregg-arrrest, ${ }^{27}$ dat al hiervoor in de paragrafen 1.2 en 3.4.3.1 werd besproken, het arrest dat in rechtstreekse tegenspraak tot het arrest Bulthuis-Griffioen ${ }^{28}$ uitsprak dat men onder instellingen ook kan verstaan een partnerschap dat geen rechtspersoonlijkheid bezit. In punt 9 van zijn conclusie wijst hij er op dat:

“(...) de gemeenschapswetgever bij de vaststelling van de regels betreffende de harmonisatie van de nationale fiscale wetgevingen de toepasselijke bepalingen van de Zesde richtlijn niet steeds duidelijk en consequent heeft geformuleerd. Dat is niet te wijten aan de wetgever zelf, doch aan terminologische moeilijkheden - vooral wanneer synoniemen in verschillende talen worden gezocht - om een steeds veranderende realiteit te vatten en om duidelijke, niet tijdsgebonden rechtsbegrippen te vinden die in alle staten kunnen gelden."

Vervolgens merkt hij op dat de paramedische verzorging de laatste decennia aanzienlijke wijzigingen heeft doorgemaakt wat zijn aard, organisatie en inhoud betreft. De institutionele vormen van verzorging vertonen grote verschillen in de lidstaten. Het gevolg is dat summiere termen als lichamen, organisaties, instellingen, naar behoren erkende inrichtingen of instellingen van sociale aard dan ook geen echt bevredigend beeld ervan kunnen geven. Cosmas stelt dan ook voor om niet zo zeer uit te gaan van letterlijke tekst van de desbetreffende bepaling in de BTW-richtlijn, maar te zoeken naar de 'echte betekenis ervan' door haar als een algemene en rationele regeling te onderzoeken. Vervolgens geeft hij aan dat de uitleggingmarge niet onbeperkt is. Cosmas brengt in zijn conclusie naar voren dat een uitlegging die een rechtsterm een volledig andere inhoud geeft dan in het gewone spraakgebruik of in een andere juridische context plaatst, niet deugdelijk is. De rechtsdefinitie van een term mag niet volledig afwijken van de tot dusver aangenomen betekenis ervan.

De grammaticale interpretatie kent, zo laat de Gregg-zaak zien, zo haar beperkingen. En hetzelfde kan meer algemeen gezegd worden waar spraak en geschreven taal geen voldoende houvast meer bieden, waar de woorden op zich zelf, of de woorden binnen de taalregels concreet tot abstract kunnen zijn en een verandering van betekenis kunnen ondergaan al naar gelang de context. Zo bevat bijvoorbeeld ook de BTW-richtlijn zowel evaluatieve termen als termen die enkel een beschrijvende functie hebben. Voor de uitleg van termen als 'misbruik' en 'fraude ${ }^{29}$ is veel meer het vellen van een waarde oordeel noodzakelijk dan voor het toekennen van een betekenis bij termen als: menselijke organen, gebouw, water, enz., die ook in de BTW-richtlijn zijn te vinden. Van de grenzen van de taalkundige grammatica maak ik verder geen studie; ik verwijs naar de literatuur. ${ }^{30}$

27. AG Cosmas in zijn conclusie van 17 november 1998 bij het Gregg-arrest van 7 september 1999, nr. C-216/97, Gregg \& Gregg, BNB 1999/395, V-N 1999/47.21. In deze procedure besliste het Hof dat de vrijstelling voor verpleeghuizen ook geldt voor een partnership dat geen rechtspersoonlijkheid bezit. 28. Hof 11 augustus 1995, nr. C-453/93, Bulthuis-Griffioen, V-N 1995/2932, pt. 32, FED 1995/703.

29. Zie bijvoorbeeld artikel 131, BTW-richtlijn.

30. Zie in dit kader meer in algemene zin over deze problematiek: T. Groenewegen, Wetsinterpretatie en rechtsvorming (diss. Amsterdam UvA), Den Haag: Boom Juridische Uitgevers 2006, blz. 28 t/m 33. 


\subsubsection{Historische interpretatiemethode}

Voor de toepassing van de historische interpretatiemethode zijn in het algemeen weinig aanknopingspunten te vinden in het geval dat het gaat om de uitleg van een bepaling in de BTW-richtlijn. De beraadslaging van de Raad en de Commissie vindt in het geheim plaats. De considerans is echter de belangrijkste bron om te ontdekken wat de communautaire wetgever heeft beoogd te bereiken met een bepaalde regeling. Op grond van artikel $296 \mathrm{VwEU}$ (voorheen $253 \mathrm{EG}$ ) is het verplicht dat verordeningen, richtlijnen en beschikkingen worden gemotiveerd. ${ }^{31}$ In geval van regelgeving gebeurt dat door middel van een considerans. De considerans geeft dan ook aanwijzingen over de uitleg van de desbetreffende regelgeving.

Een nadeel van deze interpretatiemethode is dat deze verstarrend kan werken. De considerans geeft een moment opname van opvattingen die relevant waren op het moment dat de regeling tot stand kwam. Deze opvattingen kunnen verouderen door diverse maatschappelijke ontwikkelingen.

Het Hof maakt geregeld gebruik van de considerans als bron van uitleg. Zie bijvoorbeeld de arresten met betrekking tot de plaats van de dienstverrichting in paragraaf 8.2 .

\subsubsection{Rechtsvergelijkende interpretatiemethode}

Rechtsvergelijking heeft een belangrijke plaats in de waaier van interpretatiemethoden. ${ }^{32}$ Deze rechtsvergelijking heeft niet zozeer het oogmerk de grootste gemene deler te vinden, maar is veeleer erop gericht elementen op te sporen waaruit communautaire rechtsbeginselen en rechtsregels kunnen worden opgebouwd, die passende oplossingen bieden voor de vragen waarvoor het Hof zich ziet gesteld. Dit komt goed tot uiting in het arrest Brasserie du Pêcheur: ${ }^{33}$

"Bij ontbreken van bepalingen in het Verdrag die uitdrukkelijk en precies de gevolgen regelen van schendingen van het gemeenschapsrecht door de Lid-Staten, staat het aan het Hof, bij de uitoefening van de hem door artikel 164 van het Verdrag toegekende opdracht de eerbiediging van het recht te verzekeren bij de uitlegging en de toepassing van het Verdrag, over een dergelijke vraag uitspraak te doen volgens de algemeen erkende interpretatiemethoden, met name met een beroep op de algemene beginselen van het communautaire rechtsstelsel en eventueel op de algemene beginselen die de rechtsstelsels van de Lid-Staten gemeen hebben." (r.o. 27)

31. Artikel 296 VwEU vermeldt: “(...) Rechtshandelingen worden met redenen omkleed en verwijzen naar de voorstellen, initiatieven, aanbevelingen, verzoeken of adviezen waarin de Verdragen voorzien. (...)."

32. Zie P.J.G. Kapteyn \& P. VerLoren van Themaat, Het recht van de Europese Unie en van de Europese Gemeenschappen, Deventer: Kluwer 2003, blz. 347. Deze schrijvers zijn van mening dat de rechtsvinding van het Hof voor een belangrijk deel in het teken staat van de rechtsvergelijking.

33. Hof 5 maart 1996, gevoegde zaken nrs. C-46/93 en C-48/93, Brasserie du Pêcheur, Jur. 1996, blz. I-1029. Het arrest gaat nader in op het beginsel van de aansprakelijkheid van een lidstaat voor aan particulieren veroorzaakte schade als gevolg van aan die lidstaat toe te rekenen schendingen van het Unierecht. 
Waar door het ontbreken van regels - hier gemis aan min of meer formele regels om een verdragsschending te redresseren - een rechtsvacuüm dreigt te ontstaan voorziet het Hof in dit mogelijke 'rechtstekort' door de algemene rechtsbeginselen binnen boord van het recht te halen. En bij het interpreteren binnen zijn taakstelling gaat men bij gebrek aan regels te rade bij de interpretatiemethoden waarbij men algemene rechtsbeginselen vindt. Deze algemene rechtsbeginselen op hun beurt zijn - kort gezegd - van tweeërlei afkomst: van het eigen communautaire stelsel, of van alle lidstaten gemeen. Die laatste moet men dan, naar ik aanneem, opsporen. De geëigende methode daarvoor is rechtsvergelijking tussen de lidstaten. Aldus heeft het Hof zich een toegang verschaft tot toepassing van algemene rechtsbeginselen, zelfs tot nog niet eerder gebruikte algemene rechtsbeginselen die enkel (eventueel) in de lidstaten, alle 27 lidstaten, te vinden zouden zijn.

Uit de aangehaalde rechtsoverweging kan men de conclusie trekken dat de rechtsvergelijkende interpretatiemethode een rol speelt bij de ontwikkeling van de algemene rechtsbeginselen in de jurisprudentie van het Hof. Veelal gebruikt het Hof de uitdrukking 'de algemene beginselen die de rechtstelsels van de lidstaten gemeen hebben'. ${ }^{34}$ Volgens Mertens de Wilmars verwijst een dergelijk zinsdeel naar een methode van rechtsvinding, namelijk door rechtsvergelijking worden de algemene rechtsbeginselen opgespoord die de rechtsstelsels van de lidstaten gemeen hebben. ${ }^{35}$ Zie ook de paragrafen 3.3.3 en 4.4.5.

Het open en onafgewerkte karaker van het Unierecht draagt bij aan de behoefte van algemene rechtsbeginselen.

Een belangrijk deel van het rechtsvergelijkende werk wordt door de advocaatgeneraal gedaan. Een goed voorbeeld daarvan op het terrein van de BTW is te vinden in de conclusie van advocaat-generaal Jacobs bij het arrest Stichting Goed Wonen $\mathrm{I}^{36}$ In zijn conclusie gaat de advocaat-generaal na in welke lidstaten vruchtgebruik bestaat en wat de belangrijkste kenmerken daarvan zijn in de betrokken lidstaten. Tevens gaat hij na of in de lidstaten waar geen vruchtgebruik bestaan vergelijkbare rechten voorkomen.

De rechtsvergelijkende interpretatiemethode is verwant aan de in de volgende paragraaf behandelde systematische interpretatiemethode.

34. Zie ook L.N. Brown \& T. Kennedy, The Court of Justice of the European Communities, London: Sweet \& Maxwell 2000, blz. 337 t/m 339.

35. J. Mertens de Wilmars, Algemene beginselen in het Europees recht, in: M. van Hoecke (red.), Algemene rechtsbeginselen, Antwerpen: Kluwer rechtswetenschappen 1991, blz. 273 e.v. In het aangehaalde arrest Brasserie du Pêcheur duidt het Hof dit aan als: "volgens de algemeen erkende interpretatiemethoden".

36. Hof 4 oktober 2001, nr. C-326/99, Stichting Goed Wonen I, V-N 2001/56.25. In deze procedure is beslist dat de Nederlandse erfpachtbepaling niet in strijd is met de BTW-richtlijn. 


\subsubsection{Systematische interpretatiemethode}

De systematische interpretatiemethode kijkt naar de context van de regeling in het systeem van de al bestaande regelgeving. ${ }^{37}$

De literatuur onderscheidt twee benaderingen ingeval de contextuele interpretatiemethode wordt toegepast bij de uitleg van een richtlijn. ${ }^{38}$ De eerst benadering houdt in dat wordt gekeken naar de zogenoemde verticale context van de richtlijn. Dat betekent dat van belang is de context met het Werkingsverdrag.

De andere benadering kijkt naar de horizontale context van een richtlijn. Deze interpretatiemethode kijkt bij de uitleg van een richtlijn naar de context met andere richtlijnen. ${ }^{39}$ Dit kunnen ook richtlijnen zijn op een ander terrein. ${ }^{40}$

Overigens gebruikt het Hof de systematische rechtsvindingmethode regelmatig in combinatie met de teleologische interpretatiemethode. ${ }^{41}$

\subsubsection{Teleologische interpretatiemethode}

Een teleologische interpretatie is een uitleg van de regelgeving (Werkingsverdrag, richtlijnen) naar het doel van de regelgeving. Als het Hof teleologisch interpreteert, dan legt het de regelgeving zo uit dat het doel het best tot zijn recht komt. Het doel van de regelgeving wordt ook wel aangeduid met ratio, strekking, oogmerk van de regelgeving.

Deze interpretatiemethode neemt - zoals in de vervolghoofdstukken zal blijken een belangrijke plaats in bij de uitleg van het Unierecht. De vraag komt dan op hoe het Hof het doel van de regelgeving kent dan wel opspoort. Allereerst is er uiteraard het globaal in de abstracte termen geformuleerde doel van het Unierecht gericht op het tot stand brengen van een economische en politieke Unie (zie paragraaf 1.1). Bij de uitleg van zowel het primaire als het secundaire Unierecht wordt regelmatig gekeken naar de considerans om zo meer specifiek het doel van een regeling te ontdekken.

37. Swinkels ziet de systematische interpretatiemethode als onderdeel van de contextuele methode. Zie J.J.P. Swinkels 2000, blz. 114 t/m 123

38. Zie L.N. Brown \& T. Kennedy, The Court of Justice of the European Communities, London: Sweet \& Maxwell 2000, blz. 337.

39. Zie bijvoorbeeld het SDC-arrest waar het Hof onder meer het zinsdeel 'handelingen betreffende' van artikel 13B, sub d, Zesde richtlijn uitlegt. Daarbij kijkt het Hof naar de context en de structuur van de Zesde richtlijn. Hof 5 juni 2007, nr. C-2/95, SDC, V-N 1997/206.

40. Zie paragraaf 4.3 over communautaire rechtsbegrippen.

41. In de overwegingen van het Hof komt vaak in dit kader het zinsdeel voor "Voor de uitleg van een gemeenschapsrechtelijke bepaling moet gekeken worden naar de context en de doelstelling van de regeling." Zie bijvoorbeeld het Eisman-arrest, van 24 oktober 1996, nr. C-217/94, Jur. 1996, blz. I-5287 en dan in het bijzonder r.o. 16. 
De toepassing van de teleologische interpretatiemethode vindt plaats op twee niveaus. Het meer concreet gerichte niveau van de regeling, dan wel op het meer abstracte niveau van het rechtssysteem. ${ }^{42}$

Het eerste niveau positioneert de uit te leggen regeling (bijvoorbeeld artikel in Werkingsverdrag of BTW-richtlijn) tegenover de doelstellingen welke de Uniewetgever met de regeling beoogt of tegenover het geheel van regelingen waar de regeling een onderdeel van vormt. Dit is bijvoorbeeld te vinden in de jurisprudentie waarin de regels worden uitgelegd, die betrekking hebben op de plaats waar diensten worden verricht (zie paragraaf 8.2). ${ }^{43}$

Het tweede niveau kijkt naar de achtergrond en de principes die ten grondslag liggen aan het hele rechtssysteem, of aan een relevant deel van het rechtssysteem. Zie bijvoorbeeld de jurisprudentie van het Hof over het verbod van misbruik van recht (paragraaf 5.3).

Het bovenstaande onderscheid is relevant, omdat de teleologische interpretatiemethode op het tweede niveau een duidelijke band kan hebben met de algemene rechtsbeginselen en zich alsdan losmaakt van de concrete bedoelingen van de gemeenschapswetgever, maar terug valt op algemene rechtsbeginselen waar een rechtstelsel op is gebaseerd. In het vervolg zal blijken dat het onderscheid tussen de twee niveaus in de BTW-jurisprudentie niet altijd even duidelijk is te herkennen.

\subsubsection{Analogieargumentatie}

\subsubsection{Inleiding}

Een probleem - ook bij de toepassing van de BTW regelgeving - kan zijn gelegen in een verschil van mening over de kwalificatie van de feiten. Tevens kan discussie ontstaan over de toepasbaarheid van een regel op de concrete feiten. Dit laatste type probleem van rechtstoepassing wordt in de literatuur onderverdeeld in 'interpretatieproblemen' en 'leemteproblemen'. ${ }^{4}$

42. M. van Hoecke, Algemene rechtsbeginselen als rechtsbron, in: M. van Hoecke (red.), Algemene rechtsbeginselen, Antwerpen: Kluwer rechtswetenschappen 1991, blz. 18 e.v.

43. Zie ook A-G Colomer in zijn conclusie van 12 juli 2001 bij het CSC-arrest. Hof 13 december 2001, nr. C-235/00, CSC Financial Services, V-N 2002/5.26. In zijn conclusie (punt $20 \mathrm{t} / \mathrm{m} \mathrm{26}$ ) past de A-G zowel de grammaticale als de teleologische interpretatiemethode toe op het niveau van de BTWrichtlijn om het zinsdeel 'handelingen (...) inzake aandelen' uit te leggen dat is te vinden in artikel 135, lid 1, sub f, BTW-richtlijn.

44. In de rechtstheorie vormt het begrip leemte een bron van discussie. Zo is omstreden of in een rechtssysteem een leemte kan bestaan en als deze al kan worden onderscheiden, hoe deze dient te worden opgevuld. Verder is het de vraag wat precies het verschil is tussen het opvullen van leemten en het interpreteren van bestaande rechtsregels. Zie H. Kloosterhuis, Van overeenkomstige toepassing, De pragma-dialectische reconstructie van analogie-argumentatie in rechtelijke uitspraken, (diss. Amsterdam UvA) 2002, blz. 35 t/m 37. Zie ook F.T. Groenewegen 2006, blz. 193 e.v. over analogie, leemte en rechtsvorming. Ik laat deze rechtstheoretische discussie voor wat het is gezien het feit dat deze buiten mijn onderzoeksveld valt. 
Bij een interpretatieprobleem is het niet duidelijk of de regel van toepassing is op het concrete geval doordat hij bijvoorbeeld een abstracte, open, evaluatieve of dubbelzinnige term bevat. In paragraaf 4.4 .2 is aandacht besteed aan interpretatietechnieken die de rechter tot zijn beschikking heeft om een dergelijk vraagstuk op te lossen.

Bij een leemteprobleem wordt het concrete geval in geen enkele regel genoemd en kan de vraag opkomen of het concrete geval op dezelfde wijze moet worden opgelost als vergelijkbare gevallen die wel geregeld zijn. Een leemteprobleem is op te lossen door gebruik te maken van een redeneerwijze. De literatuur noemt de a contrario-argumentatie en de analogieargumentatie redeneerwijzen die de rechter behulpzaam kunnen zijn bij het oplossen van een leemte in de regelgeving. ${ }^{45}$ In de subparagrafen 4.4.3.2 en 4.4.3.3 komt aan de orde dat een belangrijk aspect van deze redeneerwijzen het gelijkheidsbeginsel is. Gezien het gegeven dat het argumentatie technieken zijn die een leemte in de regelgeving invullen, en het legaliteitsbeginsel een belangrijk gegeven is in het belastingrecht, zal subparagraaf 4.4.3.4 ingaan op de aanvaardbaarheid van deze argumentatie technieken in het belastingrecht.

In voorgaande hoofdstukken zijn de termen: (fiscale) neutraliteit, gelijkheidsbeginsel en analoge-argumentatie gebruikt. Deze begrippen zijn vanuit verschillende invalshoeken behandeld. Paragraaf 4.4 .4 verduidelijkt hoe deze termen zich tot elkaar verhouden en wat de overeenkomsten zijn.

\subsubsection{Analogieargumentatie en het gelijkheidsbeginsel}

De analogieargumentatie houdt in dat een regel op een daarin niet geregeld geval wordt toegepast, omdat het niet geregelde geval gelijk is te stellen met de wel in de regel geregelde gevallen. ${ }^{46}$ Deze redenering heeft dus betrekking op gevallen die

45. Een derde redeneerwijze die is te onderscheiden is de rechtsverfijning. In geval van rechtsverfijning is de ter discussie staande rechtsregel weliswaar letterlijk van toepassing, maar toepassing wordt in strijd geacht met de bedoeling van de wet. Deze redenering neemt aan dat de regelgeving op een bepaald geval niet toegepast mag worden, ook al wordt dat geval in de wettekst genoemd. Zie P. Scholten 1974, blz. 5, 61 en 62; Zie verder H. Jansen, Van omgekeerde strekking (diss. Amsterdam UvA) 2003, blz. 32; Zie tevens T. Groenewegen 2006, blz. 193; Geppaart omschrijft het als volgt: “Bij de analogie doet zich het omgekeerde voor (...) van de figuur van de rechtsverfijning; daar (gaat) het immers om gevallen waarin de strekking van de wet beperkter is dan de woorden van het wettelijk voorschrift, hier - bij de analogie aan te duiden figuur - gaat het om gevallen waarin de strekking ruimer is dan de woorden." Rechtsverfijning kan aan de orde zijn wanneer tegen toepassing van de regel ernstige bedenkingen worden aangevoerd. Die bedenkingen hebben veelal hun grond in de strekking van de regelgeving. Geppaart vermeldt: “(...); rechtsverfijning vindt daarom veelal plaats in gevallen van teleologische rechtsvinding; daarvan onderscheidt de rechtsverfijning zich doordat zij beperkt is tot gevallen waarin de gelding van een wettelijke voorschrift afhankelijk wordt gesteld van een niet in de tekst van de wet te lezen element". Geppaart concludeert in zijn onderzoek dat de belastingrechter in beginsel terughoudend staat tegenover rechtsverfijning. Ch.P.A. Geppaart Fiscale rechtsvinding, een onderzoek naar de rechtsvinding door de rechter in belastingzaken in het bijzonder aan de hand van de rechtspraak in de periode 1 maart 1957 - 1 maart 1965, Amsterdam: NV Uitgeverij FED 1965, blz. 85. Ik besteed verder geen aandacht aan de rechtsverfijning. Ik vermeld deze methode slechts om de betekenis en inhoud van een analogieredenering aan te scherpen. 46. T. Groenewegen 2006, blz. 193, 202 en zie ook blz. 212. 
niet met zo veel woorden in de regelgeving zijn genoemd, maar sterke gelijkenis vertonen met gevallen die wel in de regelgeving worden genoemd. De rechter gebruikt argumentatie die is gebaseerd op een vergelijkingsrelatie. ${ }^{47}$

\section{Geppaart brengt naar voren dat: ${ }^{48}$}

"Het verlangen naar analogie wordt gedragen door het gelijkheidsbeginsel, dat er op gericht is dat in wezen gelijke gevallen voor het recht gelijk worden behandeld."

Een belangrijk rol bij de toepassing van een analogieredenering is weggelegd voor het gelijkheidsbeginsel. ${ }^{49}$ Deze constatering brengt ons niet direct veel verder. Want - zoals al naar voren gebracht in paragraaf 3.4.1 - bij de toepassing van het gelijkheidsbeginsel rijzen minst gesproken de volgende vragen: wanneer zijn twee gevallen gelijk? Welke kenmerk van deze gevallen is relevant voor het vaststellen van gelijkheid? Dit brengt met zich mee dat het criterium dat gelijke gevallen gelijk behandeld moeten worden, aanvulling behoeft: er is een maatstaf nodig om de gelijkheid vast te stellen. ${ }^{50}$ Groenewegen formuleert het als volgt: ${ }^{51}$

"Om aannemelijk te maken dat er sprake is van gelijke gevallen zijn nadere argumenten vereist. Omdat de redenering op zich zelf nooit tot een inhoudelijke conclusie kan leiden is de analogie geen zelfstandige interpretatiemethode of een zelfstandig argument."

Happé brengt naar voren dat het gelijkheidsbeginsel niet aangeeft in welk opzicht er van gelijkheid of ongelijkheid gesproken kan worden:

"Er ontbreekt een verwijzing naar een perspectief van waaruit de beoordeling kan plaatsvinden. $\mathrm{Er}$ is met andere woorden een waarde of doelstelling nodig die als maatstaf kan dienen voor de beoordeling van de gelijkheid of ongelijkheid van gevallen." ${ }^{52}$

Scholten wijst er op dat de vaststelling van de gelijkheid afhankelijk is van de ratio van de wettelijke bepaling die analoog wordt toegepast. ${ }^{53}$ Groenewegen verwoordt het aldus: ${ }^{54}$

47. H. Kloosterhuis, Van overeenkomstige toepassing. De pragma-dialectische reconstructie van analogie-argumentatie in rechtelijke uitspraken, (diss. Amsterdam UvA) 2002, blz. 15. Kloosterhuis wijst er op dat de rationele reconstructie van analogie-argumentatie in de praktijk nog al eens problematisch is. Één van de redenen hiervoor is dat men in de rechtstheoretische literatuur van inzicht verschilt over de vraag wat onder analogie-argumentatie moet worden verstaan en waarin het specifieke juridische kader is gelegen. Ik laat deze rechtstheoretische discussie voor wat het is gezien het feit dat dit onderwerp buiten het kader van mijn onderzoek valt. De geïnteresseerde lezer verwijs ik naar de dissertatie van Kloosterhuis.

48. Ch.P.A. Geppaart 1965, blz. 86.

49. Zie verder H. Kloosterhuis 2002, blz. 156 e.v.

50. T. Groenewegen 2006, blz. 202 en 203.

51. T. Groenewegen 2006, blz. 206.

52. R.H. Happé 1996, blz. 97 en 98

53. P. Scholten 1974, blz. 62. Zie ook Ch.P.A. Geppaart 1965, blz. 86

54. T. Groenewegen 2006, blz. 203. 
"Een regel bepaalt iets voor een aantal gevallen om een bepaald doel te bereiken. Als nu eenzelfde doel bereikt wordt door toepassing van die regel op daarin niet geregelde gevallen, dan zijn die laatste gevallen, gelet op het doel van de regel, gelijk te stellen met de wel in de regel genormeerde gevallen."

Volgens de literatuur is dus het motief om tot gelijkheid van gevallen te concluderen gelegen in de ratio van de bepaling die analoog wordt toegepast. Deze schrijvers menen dat uit de ratio van de analoog toe te passen regel wordt afgeleid of er sprake is van gelijke gevallen. In wezen gaat het om de vraag of het geval gelijk is ten opzichte van het geval uit de analoog toe te passen regel. De gelijkheid moet dus in verband te brengen zijn met de inhoud van de regel. In de betekenis van de regel moeten dan ook argumenten zijn te vinden om de regel toe te passen op die gevallen. Groenewegen meent dan ook, ik citeer: ${ }^{55}$

"In feite wordt het analoog toepassen van een regel dan gewone toepassing van een regel na interpretatie daarvan."

en hij concludeert dat de gevalsvergelijking wordt geplaatst in de context van de interpretatieve elementen. ${ }^{56}$ Het eerder in paragraaf 4.4.3.1 aangebrachte onderscheid tussen interpretatiemethoden en argumentatiemethoden dient dan ook te worden genuanceerd. De analogieargumentatie doet sterk denken aan een methode van rechtsvinding die is beschreven door Wiarda en door hem wordt aangeduid als de 'vergelijkingsmethode'. ${ }^{57}$ Ook deze methode is gebaseerd op een vergelijking van gevallen en stuurt het gelijkheidsbeginsel naar een oplossing. Paragraaf 7.2.2 licht aan de hand van de jurisprudentie op het terrein van het begin van de belastingplicht concreet toe de wijze waarop het Hof een analogieargumentatie toepast.

In de vervolghoofdstukken zal onder meer blijken of het Hof inderdaad interpretatieve argumenten gebruikt - zoals een onderzoek naar de ratio van een bepaling om een analoge toepassing van een regel te onderbouwen.

\subsubsection{Argumentatie a contrario dan wel naar analogie}

De literatuur maakt een onderscheid in een tweetal typen à contrarioredenering, namelijk een klassieke en een moderne variant. Deze twee typen verschillen wezenlijk van elkaar.

Bij toepassing van de klassieke a contrario-redenering wordt: ${ }^{58}$

“(...) uit de wet door 'omkering' van een rechtsregel afgeleid wat voor het niet-geregelde geval geldt (...)."

55. T. Groenewegen 2006, blz. 204.

56. Groenewegen concludeert dit na onderzoek van de jurisprudentie van de HR en een literatuur onderzoek, T. Groenewegen 2006, blz. 205.

57. G.J. Wiarda, Drie typen van rechtsvinding, bewerkt en van een nabeschouwing voorzien door T. Koopmans. Deventer: W.E.J. Tjeenk Willink 1999. Zie in het bijzonder blz. 107 t/m 116 .

58. H. Jansen 2003, blz. 50. Zie ook T. Groenewegen 2006, blz. 213. 
Anders geformuleerd: de regel geldt enkel voor de genoemde gevallen en per definitie niet voor de niet genoemde gevallen. Dat veronderstelt dus dat het onderwerp in de regel uitputtend is geregeld. Het Hof heeft de toepassing van de klassieke a contrario-redenering bij de uitleg van het Unierecht al ruime tijd geleden zo goed als afgewezen in de arresten Belgische Steenkool Federatie ${ }^{59}$ en Meroni. ${ }^{60}$ Deze jurisprudentie geeft namelijk aan dat een klassieke a contrario-redenering slechts kan worden aanvaard:

“(...) wanneer geen andere interpretatie deugdelijk blijkt en verenigbaar, hetzij met de tekst of de context, hetzij met het doel waartoe de tekst werd opgesteld."

De literatuur duidt tegenwoordig met de term a contrario-redenering op een andere modernere - betekenis dan hierboven weergegeven. De term heeft dan betrekking op de argumenten waarmee wordt verdedigd dat het concrete geval niet tot het toepassingsbereik van de regel kan worden gerekend. ${ }^{61}$ A contrario-argumentatie wordt in de moderne rechtstheorie als tegenhanger van de analogieargumentatie beschouwd. ${ }^{62}$ De argumentatie a contrario wordt in dezelfde soort situaties gebruikt als analogieargumentatie, echter met een tegengesteld resultaat. Met een a contrario-argumentatie wordt analoge toepassing van een regel afgewezen.

Een motivering om een regel a contrario toe te passen - in de moderne betekenis kan zijn gelegen in de onvergelijkbaarheid van het concrete geval met de in de regel genoemde gevallen ${ }^{63}$ De vraag komt dan op: hoe wordt de onvergelijkbaarheid vastgesteld? De literatuur wijst hiervoor aan de ratio of het doel van de regel. ${ }^{64}$ De ratio van de regel fungeert dan als criterium op grond waarvan het concrete geval verschilt van de gevallen die onder het bereik van de regel vallen. Geen verassende uitkomst, gezien het feit dat de moderne a contrario-argumentatie gezien wordt als de tegenhanger van de analogieargumentatie. In paragraaf 4.4.3.2 is naar voren gebracht dat het gelijkheidsbeginsel een belangrijke drijfveer van de analogieredenering is. De ongelijkheid van de gevallen is juist waar de moderne a contrarioredenering op is gebaseerd. Om de (on)gelijkheid op te sporen speelt de ratio van de bepaling een belangrijke rol. De moderne a contrario-redenering is in het kader van mijn onderzoek van belang gezien de verwevenheid met het gelijkheidsbeginsel en zal dan ook terug komen in de volgende hoofdstukken.

59. Hof 16 juli 1956 en 29 november 1956, nr. 8/55, Belgische Steenkool Federatie, Jur. 1956, blz. 211 e.v. en 309 e.v.

60. Hof 13 juni 1958, nr. 9/56, Meroni \& C. e.a., Jur. 1958, blz. 11.

61. H. Jansen 2003, blz. 14.

62. H. Jansen 2003, blz. 31. Zie ook T. Groenewegen 2006, blz. 217.

63. H. Jansen 2003, blz. 33.

64. H. Jansen 2003, blz. 34 


\subsubsection{Analogieargumentatie in het belastingrecht}

In de literatuur is de analoge toepassing van een bepaling in een aantal gevallen omstreden. In het bijzonder als het gaat om regels die verplichtingen opleggen. ${ }^{65}$ De literatuur acht een analogieargumentatie in het belastingrecht niet zonder meer onacceptabel. Geppaart meent dat een zinvolle interpretatie van het belastingrecht behoort te leiden naar het antwoord op de vraag op welke wijze de aan de wet ten grondslag liggende strekking zo juist mogelijk gerealiseerd kan worden; daarbij is volgens hem toepassing van analogie toelaatbaar. ${ }^{66}$ Wel meent hij dat toepassing van de analogie er niet toe mag leiden dat de grenzen te ruim worden getrokken ten laste van belastingplichtigen. Geppaart geeft de grens van de analoge toepassing als volgt weer: ${ }^{67}$

"In deze zin vindt de toepassing van de analogie haar grenzen in het beginsel van de rechtszekerheid: voor zover de norm kenbaar is, behoort een redelijke belastingplichtige er op bedacht te zijn dat de rechter die de aan de wet ten grondslag liggende norm opspoort, komt tot een rechtsvinding ten nadele van de belastingplichtige; buiten de kenbare norm mag evenwel de belastingheffing zich niet uitstrekken. Evenmin mag deze opvatting er toe leiden de betekenis van de woorden van de wet - van uitzonderlijk gewicht in het licht van de rechtszekerheid - opzij te zetten; het probleem betreft immers de vraag hoe de uitlegging moet worden begrensd in gevallen waarin de casus ligt buiten de woorden van de wet doch binnen de norm die daaraan ten grondslag ligt en waarvan de woorden van de wet de veelal gebrekkige formulering zijn."

Geppaart formuleerde zijn opvatting over de positie van de analogieredenering in het belastingrecht ruim 40 jaar geleden. Dat neemt niet weg dat in de literatuur nog steeds de opvatting is te vinden dat de analogie toelaatbaar is ten nadele van belastingplichtige, doch dat het beginsel van de rechtszekerheid - kenbaarheid van de norm - de grens van de analogieredenering bepaalt. ${ }^{68}$ Zie bijvoorbeeld IJzerman:

"In principe wordt de uiterste grens van het toepassingsgebied van analogie gevormd door de begrenzing van het gebied waar doel en strekking nog objectief traceerbaar zijn. Bij toepassing van analogie ten nadele van een belastingplichtige zal het legaliteitsbeginsel met zich mee brengen dat de kenbaarheid van de norm voor belanghebbende de grens vormt."

Daarbij meent IJzerman wel, dat bij de kenbaarheid van de norm het redelijk is om uit te gaan van de kenbaarheid zoals deze is voor een fiscaal deskundige belanghebbende. Verder meent hij dat als een belastingplichtige volstrekt overwegend

65. Het meest duidelijk is dat in het strafrecht waar een analogieverbod geldt.

66. Ch.P.A. Geppaart 1965, blz. 93.

67. Ch.P.A. Geppaart 1965, blz. 94.

68. R.L.H. IJzerman, Het leerstuk van de wetsontduiking in het belastingrecht (diss. Amsterdam UvA), Deventer: Kluwer 1991, blz. 88. Zie hierover nader J.H.M. Nieuwenhuizen, Rechtsvinding en fiscale werkelijkheid (diss. Tilburg), Deventer: Kluwer 2010, paragrafen 2.7 en 5.3.2. Zie tevens H.C.F. Schoordijk, Enige aspecten van privaat- en fiscaalrechtelijke rechtsvinding, WFR 1997/6251. Vgl. R.E.C.M. Niessen, Inleiding tot het Nederlands belastingrecht, Deventer: Kluwer 2010, blz. 191 en 192. 
fiscaal gemotiveerd handelt, hij zich begeeft in de risicosfeer. De rechtszekerheid die de wet biedt is niet bedoeld voor degenen die zich slechts richten op de frustratie van de werking van de wet. Met dit aspect zijn wij aangeland bij hetgeen aan de orde komt in paragraaf 5.3, namelijk het misbruik van het recht.

Gezien het feit dat de analogieredenering is gebaseerd op het gelijkheidsbeginsel en het gelijkheidsbeginsel onderwerp is van mijn onderzoek - komt in de volgende hoofdstukken ook aan bod de wijze waarop het Hof de analogieredenering toepast bij de uitleg van de BTW-richtlijn.

\subsubsection{Tussenconclusies}

De analogieredenering is gebaseerd op het gelijkheidsbeginsel. Dit beginsel behoeft voor de toepassing een nadere maatstaf of nadere maatstaven. Want wanneer zijn gevallen gelijk? In de literatuur is te vinden dat dit de ratio van de regel is. De volgende hoofdstukken onderzoeken of dit is terug te vinden in de jurisprudentie van het Hof bij de uitleg van de BTW-richtlijn.

De literatuur staat niet afwijzend tegenover toepassing van de analogie in het belastingrecht. Wel meent men dat de grens ligt in de kenbaarheid van de norm. Dit gezien de belangrijke positie van het rechtszekerheidsbeginsel in het belastingrecht. In de vervolghoofdstukken zal blijken waar het Hof bij de uitleg van de BTW-richtlijn de grens trekt. Ook zal blijken of het Hof enkel ten voordele van belastingplichtige toepast of (onder bepaalde omstandigheden) ook ten nadele van belastingplichtige. Verder zal in paragraaf 5.3, maar ook in de hoofdstukken 6 $\mathrm{t} / \mathrm{m} 13$, blijken of (in welke mate) de rechtszekerheid bescherming biedt aan degene die de BTW-richtlijn misbruiken.

\subsubsection{Fiscale neutraliteit, gelijkheidsbeginsel en analogieargumentatie}

\subsubsection{Inleiding}

In paragraaf 2.4.1 is vooral de nadruk gelegd op de neutraliteit ten aanzien van bepaalde economische verhoudingen tussen ondernemingen. Aan het slot van paragraaf 2.4.1 is naar voren gebracht dat een relatie aanwezig is tussen neutraliteit en het gelijkheidsbeginsel. De volgende subparagraaf werkt dit nader uit.

Paragraaf 4.4.3.2 laat zien dat het gelijkheidsbeginsel een belangrijke drijfveer is van de analoge toepassing van een regel. Er is verband tussen analogische werkwijze en de toepassing van het gelijkheidsbeginsel. Nu paragraaf 4.4.4.2 verduidelijkt dat er een relatie is tussen neutraliteit en gelijkheidsbeginsel, zal paragraaf 4.4.4.3 aandacht besteden aan de wijze waarop neutraliteit en analogie zich tot elkaar verhouden.

In paragraaf 4.4.4.4 formuleer ik enkele (tussen) conclusies die de vervolghoofdstukken nader uitwerken. 


\subsubsection{Fiscale neutraliteit en het gelijkheidsbeginsel}

Het Hof en de advocaten-generaal gebruiken de toevoeging 'fiscale' bij de term neutraliteit. ${ }^{69}$ In het vervolg zal ik dan ook de term 'fiscale neutraliteit' gebruiken. Het Hof wijst erop in het arrest Solleveld ${ }^{70}$ dat het de lidstaten niet is toegestaan om inbreuk te maken op de gemeenschapsrechtelijke beginselen en dan:

“(...), in het bijzonder het beginsel van gelijke behandeling, dat op het gebied van de BTW tot uitdrukking komt in het beginsel van fiscale neutraliteit (...)" (r.o. 35)

In het Ahold-arrest ${ }^{71}$ is de volgende formulering te vinden:

"Het beginsel van fiscale neutraliteit, dat de uitdrukking vormt van het beginsel van gelijke behandeling op het gebied van de btw, (...)" (r.o. 36)

Dat de fiscale neutraliteit voor de BTW een uitdrukking is van het gelijkheidsbeginsel krijgt in het arrest Marks \& Spencer III $^{72}$ een verfijning in die zin dat de fiscaal gelijke behandeling in de eerste plaats betrokken wordt op het object van heffing, in casu, de goederen (r.o. 47) en vervolgens blijken de goederen van belastingplichtigen te zijn die dus uit dien hoofde een BTW-gelijke behandeling toekomen (r.o. 49). De fiscale neutraliteit - gelijkheidsbeginsel van de BTW - blijkt men volgens dezelfde rechtsoverweging 49 evenwel te moeten onderscheiden van het algemene gelijkheidsbeginsel in belastingzaken. Dat algemene beginsel in belastingzaken moet men ruimer zien. Dat kan bijvoorbeeld de vorm aannemen van het non-discriminatiebeginsel, dat handelaren beschermt die al dan niet concurrenten in het BTW-veld zijn. Ik citeer (met weglating van de verwijzingen):

"In de eerste plaats verzet het beginsel van fiscale neutraliteit, dat een basisbeginsel van het gemeenschappelijke BTW-stelsel vormt (...), zich er met name tegen dat soortgelijke goederen, die dus met elkaar concurreren, uit het oogpunt van de btw ongelijk worden behandeld (...)." (r.o. 47)

69. Een enkele keer komt de term 'belasting neutraliteit' voor. Zie bijvoorbeeld A-G Kokott in haar conclusie van 15 januari 2009 bij het TNT-arrest (Hof 23 april 2009, nr. C-357/07, TNT, V-N 2009/21.16). Verder gebruikt het Hof in een enkel geval ook het zinsdeel "Het beginsel van de neutraliteit van de BTW ten aanzien van de fiscale belasting (...)", zie bijvoorbeeld het Rompelman-arrest, 14 februari 1985, nr. 268/83, BNB 1985/315, FED 1985/251, r.o. 23. Volgens mij is hier geen inhoudelijk andere betekenis mee bedoeld dan hetgeen te vangen is met de term fiscale neutraliteit.

70. Hof 27 april 2006, nrs. C-443/04 en C-444/04, Solleveld \& Van den Hout-Van Eijnsbergen, BNB 2006/256. Deze procedure gaat over de uitleg van de medische vrijstellingen.

71. Hof 10 juli 2008, nr. C-484/06, FE Koninklijke Ahold NV, V-N 2008/41.23. In deze procedure is beslist dat het afronden van BTW-bedragen een zaak van de lidstaten is. Een identieke overweging is te vinden in het arrest Royal Bank of Scotland Group Plc, 18 december 2008, nr. C-488/07, V-N 2008/ 62.26, r.o. 27. Dit arrest geeft aan dat de afrondingsregel bij de pro-rata berekening niet geldt wanneer een lidstaat gebruikt makt van de mogelijkheid om een afwijkende pro-rata-methode toe te passen. 72. Hof 10 april 2008, nr. C-309/06, Marks \& Spencer, V-N 2008/21.22. 
Vervolgens verduidelijkt het Hof het onderscheid met het gelijkheidsbeginsel:

"In de tweede plaats komt het gelijkheidsbeginsel ter zake van btw tot uitdrukking in het beginsel van fiscale neutraliteit (...). Van schending van het beginsel van fiscale neutraliteit kan evenwel slechts sprake zijn tussen concurrerende handelaars, zoals in punt 47 van het onderhavige arrest is aangegeven, terwijl schending van het algemene gelijkheidsbeginsel in belastingzaken de vorm kan aannemen van andere soorten van discriminatie jegens handelaars die niet noodzakelijk concurrenten zijn, maar zich in andere opzichten in een vergelijkbare situatie bevinden." (r.o. 49)

Uit het Marks \& Spencer III-arrest blijkt dus dat met fiscale neutraliteit wordt gedoeld op de BTW druk op goederen en diensten ${ }^{73}$ en dat die gelijk moet zijn tussen concurrenten. Terwijl het algemene gelijkheidsbeginsel ruimer is. Met dit laatste kan ook een andere ongelijke behandeling worden bedoeld, zonder dat sprake is van ongelijke behandeling van concurrenten. Uit de jurisprudentie van het Hof blijkt dit een terugkerend onderscheid. Zoals nog zal blijken in de vervolghoofdstukken, gebruikt het Hof de term fiscale neutraliteit als onderzocht wordt of ondernemers die dezelfde handelingen verrichten verschillend worden behandeld voor de BTW-heffing. ${ }^{74}$ In paragraaf 3.4.1 is al verduidelijkt, dat het gelijkheidsbeginsel als algemeen rechtsbeginsel aangeeft dat vergelijkbare situaties niet verschillend mogen worden behandeld, tenzij dit objectief gerechtvaardigd is. Bij een onderzoek naar schending van het gelijkheidsbeginsel worden omstandigheden met elkaar vergeleken, het is voor een dergelijk onderzoek niet vereist dat deze vergelijking gericht is op concurrentieverhoudingen.

73. In de aangehaalde overweging verwijst het Hof naar goederen. In verscheidene arresten heeft het Hof het over het begrip 'handelingen' dat ook diensten omvat, zie bijvoorbeeld ook Hof 28 juni 2007, C-363/05, J.P. Morgan Flemming, V-N 2007/36.25, r.o. 47: “Het beginsel van fiscale neutraliteit omvat tevens het beginsel van het opheffen van concurrentievervalsingen die voortvloeien uit een verschillende behandeling vanuit het oogpunt van de btw (...). De vervalsing is dan ook aangetoond zodra wordt vastgesteld dat diensten met elkaar concurreren en ongelijk worden behandeld vanuit het oogpunt van de btw (...). Het is in dat opzicht irrelevant of de vervalsing die daaruit voortvloeit, aanmerkelijk is." In het arrest Ampliscientifica is de omschrijving te vinden (met weglating van de verwijzingen): "Allereerst vormt het beginsel van fiscale neutraliteit een basisbeginsel van het gemeenschappelijke btw-stelsel (...), dat zich ertegen verzet enerzijds dat soortgelijke goederen, die dus met elkaar concurreren, uit het oogpunt van de btw ongelijk worden behandeld (...), en anderzijds dat soortgelijke economische verrichtingen, die bijgevolg met elkaar concurreren, met betrekking tot de btw ongelijk worden behandeld (...)", Hof 22 mei 2008, nr. C-162/07, Ampliscientifica Srl en Amplifin, V-N 2008/25.20, r.o. 25.

74. Zie bijvoorbeeld Hof 16 september 2008, nr. C-288/07, Isle of Wight, V-N 2008/47.21, r.o. 42, over de beoordeling van belastingplicht van gemeenten in geval van exploitatie van parkeerplaatsen; Hof 16 oktober 2008, nr. C-253/07, Canterburry Hockey Club, V-N 2008/49.18, r.o. 30, over de uitleg van de sportvrijstelling. 
Het Hof verbindt aan het adagium dat de fiscale neutraliteit vereist dat 'ondernemers die dezelfde handelingen verrichten voor de BTW-heffing niet verschillend worden behandeld' een aantal consequenties. Op deze plaats worden deze slechts kort aangestipt. In de volgende hoofdstukken vindt een verdere uitwerking plaats.

Zo volgt uit de fiscale neutraliteit: ${ }^{75}$

"Genoemd principe verzet zich er met name tegen, dat soortgelijke goederen, die dus met elkaar concurreren, uit het oogpunt van de BTW ongelijk worden behandeld (...). Het beginsel van fiscale neutraliteit sluit dus tevens de twee andere door de Commissie aangevoerde beginselen in, te weten de beginselen van uniformiteit van de BTW en van het opheffen van concurrentievervalsingen." (r.o. 22)

Uit deze overweging blijkt dat fiscale neutraliteit ook betekent uniformiteit van de BTW.

Uit de fiscale neutraliteit volgt ook:

“(...) dat de marktdeelnemers het organisatiemodel moeten kunnen kiezen dat hun uit strikt economisch oogpunt het beste uitkomt, (...)"76

zonder dat zij het risico lopen dat hun activiteiten worden uitgesloten van bijvoorbeeld de toepassing van een vrijstelling (zie verder paragraaf 10.4).

In de hierboven aangehaalde rechtsoverwegingen (zie bijvoorbeeld citaat uit het arrest Marks \& Spencer III) verduidelijkt het Hof, dat met betrekking tot de gelijksoortigheid van handelingen vanuit het oogpunt van de fiscale neutraliteit voor ogen moet worden gehouden, dat dit beginsel de gelijke behandeling inhoudt van ‘soortgelijke' (met elkaar concurrerende) goederen en diensten. Advocaat-generaal Stix-Hackl vermeldt in haar conclusie bij het Linneweber-arrest: ${ }^{77}$

"Wanneer het derhalve voor de gelijksoortigheid van goederen of diensten bepalend is of zij met elkaar concurreren of niet, ligt een analoge toepassing van de rechtspraak van het Hof betreffende artikel 90, tweede alinea, EG volkomen voor de hand." (punt 51)

Het onderdeel van het Werkingsverdrag (huidig artikel 110 VwEU) waar de advocaat-generaal naar verwijst bepaalt dat binnenlandse producten niet zijdelings mogen worden beschermd, wat betekent dat een product uit een andere lidstaat niet onderworpen mag worden aan een zwaardere belastingdruk, zodat de consument niet wordt gedreven naar een substitueerbare binnenlands product.

75. Hof 3 mei 2001, nr. C-481/98, Commissie/Frankrijk, V-N 2001/42.18.

76. Hof 3 april 2008, nr. C-124/07, J.C.M. Beheer BV, V-N 2008/17.16, r.o. 28.

77. Hof 17 februari 2005, nrs. C-453/02 en C-462/02, Linneweber \& Akriditis, V-N 2005/13.14, conclusie van 8 juli 2004. 
Dit leidt dan tot het volgende: ${ }^{78}$

"Volgens de rechtspraak van het Hof, dat het begrip gelijksoortigheid ruim heeft uitgelegd, moet bij de beoordeling daarvan worden onderzocht of de betrokken producten soortgelijke eigenschappen vertonen en aan dezelfde behoeften van de consument voldoen, waarbij niet de volstrekte identiteit, maar het soortgelijke en vergelijkbare gebruik de maatstaf is." (r.o. 23)

Het Hof heeft dit criterium bij de uitleg van de BTW-richtlijn bijvoorbeeld toegepast in de inbreukprocedure tegen Frankrijk, door aan de hand van de aankoopbeslissing van de consument te beoordelen of de voor vergoeding in aanmerking komende geneesmiddelen en niet voor vergoeding in aanmerking komende geneesmiddelen moeten worden beschouwd als soortgelijke goederen die met elkaar concurreren (zie verder paragraaf 9.3.2 voor een uitgebreidere behandeling in het licht van splitsen van vergoedingen dan wel eenheid van prestatie). ${ }^{79}$

In het NCC-arrest ${ }^{80}$ geeft het Hof een verdere verduidelijking van het onderscheid tussen fiscale neutraliteit en het gelijkheidsbeginsel (met weglating van de verwijzingen):

"Dienaangaande zij eraan herinnerd dat volgens vaste rechtspraak het beginsel van fiscale neutraliteit, en inzonderheid het recht op aftrek, als integrerend deel van het btw-stelsel, een fundamenteel beginsel van de bij de gemeenschapswetgeving ingevoerde gemeenschappelijke btw-regeling is." (r.o. 40)

"Met dit beginsel van fiscale neutraliteit heeft de gemeenschapswetgever ter zake van btw uitdrukking gegeven aan het algemene beginsel van gelijke behandeling." (r.o. 41)

"Terwijl laatstgenoemd beginsel, net als andere algemene beginselen van gemeenschapsrecht, een grondwettelijk karakter heeft, dient het beginsel van fiscale neutraliteit echter in wetgeving te worden uitgewerkt, hetgeen enkel kan geschieden door een besluit van afgeleid gemeenschapsrecht (...)." (r.o. 42)

In de laatste aangehaalde rechtsoverweging wijst het Hof erop dat de fiscale neutraliteit in het secundaire Unierecht dient te worden uitgewerkt (in casu de BTW-richtlijn).

78. Hof 27 februari 2002, nr. C-302/00, Commissie/Frankrijk, Jur. 2002, blz. I-2055, r.o. 23. Zie tevens Hof 11 augustus 1995, nrs. C-367/93 t/m C-377/93, Roders e.a., Jur. 1995, blz. I-2229, r.o. 27. Zie tevens Hof 10 november 2011, nrs. C-259/10, C-260/10, The Rank Group Plc, V-N 2011/62.20, NTFR 2011/2930, vooral r.o. 43 waar het Hof overweegt dat de 'soortgelijkheid' voornamelijk moet worden bepaald vanuit het oogpunt van de gemiddelde consument.

79. HvJ 3 mei 2001, nr. C-481/98, Commissie/Frankrijk, V-N 2001/42.18. In deze procedure besliste het Hof dat een lager BTW-tarief voor medicijnen die worden vergoed door de sociale zekerheid is toegestaan.

80. Hof 29 oktober 2009, nr. C-174/08, NCC Construction Danmark A/S, V-N 2009/56.14, NTFR 2009/2422. 
In deze paragraaf zijn een aantal arresten behandeld die verduidelijken dat fiscale neutraliteit een uitdrukking is van het gelijkheidsbeginsel. Dit gezien het feit dat fiscale neutraliteit focust op de concurrentieverhoudingen.

Afgezien van het bovenstaande aspect is er nog een onderscheidend kenmerk. Uit de jurisprudentie blijkt dat fiscale neutraliteit enkel opduikt bij de uitleg van de regelgeving en dan in het bijzonder de BTW-richtlijn. Het gelijkheidsbeginsel laat zich niet enkel gelden bij de uitleg van de BTW-richtlijn maar speelt ook een rol in de relatie overheid - belastingplichtige. Dat betekent dat de fiscale neutraliteit enkel is terug te vinden in de toepassing als interpretatiebeginsel, terwijl het gelijkheidsbeginsel niet enkel behulpzaam kan zijn bij de uitleg van de regelgeving maar ook een algemeen beginsel van formeel recht kan vormen (zie paragraaf 3.3.1 over deze toepassingsvelden).

\subsubsection{Fiscale neutraliteit en analogieargumentatie}

In paragraaf 4.4.3.2 is naar voren gebracht dat een belangrijke drijfveer van de analogieargumentatie het gelijkheidsbeginsel is. Vervolgens is in paragraaf 4.4.4.2 gebleken dat het Hof de fiscale neutraliteit ziet als een uitdrukking van het gelijkheidsbeginsel. De analogieredenering en de fiscale neutraliteit hebben dus het gelijkheidsbeginsel gemeen.

Beide spelen een rol bij de uitleg van de regelgeving. Een vraag die dan opkomt, is of de toepassing van de fiscale neutraliteit bij de uitleg van de BTW-richtlijn in veel gevallen niet neerkomt op een analoge toepassing van de regels. In paragraaf 4.4.3.2. is verduidelijkt dat een analoge toepassing van een regel gebaseerd kan zijn op de ratio van de bepaling. Denkbaar is dat ook bij de fiscale neutraliteit als interpretatiebeginsel in feite de ratio van de bepaling wordt gebruikt om te beoordelen of sprake is van soortgelijkheid van goederen of diensten. De volgende hoofdstukken besteden hier aandacht aan.

\subsubsection{Tussenconclusies}

Het gelijkheidsbeginsel heeft een ruimere werking dan het begrip fiscale neutraliteit. Zo focust fiscale neutraliteit op ongelijkheid tussen concurrenten. Verder speelt het gelijkheidsbeginsel ook in de relatie burger - overheid als beginsel van formeel recht. Daarentegen is fiscale neutraliteit enkel een interpretatiebeginsel. Anderzijds lijkt het erop dat het neutraliteitsbeginsel (als stelselbeginsel) casuïstiek oplost die niet met een beroep op het gelijkheidsbeginsel kan worden afgedaan omdat dit niet toereikend is (paragrafen 3.5.2 en 13.2.2).

Fiscale neutraliteit en een analogieargumentatie hebben het gelijkheidsbeginsel gemeen. Eerder zagen wij dat de analogieargumentatie vaak gebaseerd is op de ratio van een bepaling. De ratio van de bepaling schakelt de gevallen die worden vergeleken gelijk bij toepassing van een analogieredenering. Het is de vraag of, als het Hof bij de uitleg de fiscale neutraliteit gebruikt, in feite niet de ratio van de bepaling in het geding is. Hierop kom ik in de vervolghoofdstukken terug. 


\subsubsection{Primair Unierecht}

Het Europese recht is onder te verdelen in primair en secundair Unierecht. Ook voor deze studie is, zoals nader blijkt, het onderscheid van belang en ik besteed er kort aandacht aan. De volgende paragraaf zal aandacht besteden aan het secundaire Unierecht. Op deze plaats staat het primaire Unierecht centraal.

Tot het 'primair Unierecht' behoren het EG-Verdrag (nu Werkingsverdrag) en de latere wijzigingen daarvan bij latere verdragen zoals de Europese Akte, het Verdrag van Maastricht (EU-Verdrag, thans Unieverdrag), het Verdrag van Amsterdam en het Verdrag van Nice. Tot het primaire Unierecht behoren ook de vele protocollen die aan de verdragen zijn gehecht (zie artikel 51 VEU voorheen 311 EG). Het Unieverdrag en het Werkingsverdrag vormen de grondslag van alle bevoegdheden van de Europese instellingen en bieden het kader waaraan de uitoefening van deze bevoegdheden wordt getoetst. ${ }^{81}$

Het onderscheid tussen primair en secundair Unierecht is niet zonder betekenis. Het kan immers een rol spelen bij de uitleg van het recht van de Unie. Een conflict tussen het primaire en het secundaire Unierecht is niet mogelijk. Het secundaire Unierecht moet namelijk conform het primaire Unierecht worden uitgelegd. ${ }^{82}$ Zie in dit kader het arrest van 10 juli 1991 waar wordt overwogen, onder verwijzing naar eerdere jurisprudentie:

"Het is immers vaste rechtspraak (...), dat wanneer een bepaling van afgeleid gemeenschapsrecht voor meer dan één uitleg vatbaar is, die bepaling voor zover mogelijk in overeenstemming met het Verdrag en met de algemene beginselen van het gemeenschapsrecht moet worden uitgelegd." (r.o. 12)

Het primaire Unierecht staat in de Europees rechtelijke hiërarchie bovenaan. ${ }^{83}$ Het secundaire Unierecht is te zien als een verdere invulling van het primaire Unierecht. ${ }^{84}$

81. W.T. Eijsbouts, J.H. Jans, A. Prechal en L.A.J. Senden, Europees recht, Algemeen deel, Sinds het Verdrag van Lissabon, Groningen: Europa Law Publishing 2010, blz. 54 en 55.

82. Hof 10 juli 1991, nr. C-90/90, Neu e.a., Jur. 1991, blz. I-3617. Zie ook Hof 27 januari 1994, nr. C-98/91, Herbrink, Jur. 1994, blz. I-223 en Hof 4 december 1986, nr. 205/84, Commissie/Duitsland, Jur. 1986, blz. 3755, r.o. 62.

83. Zie ook over de hiërarchie van de rechtsbronnen, K. Lenaerts \& P. van Nuffel, Europees recht, Antwerpen - Apeldoorn: Maklu 1999, blz. 640 en 641. Wel is het zo dat het constante rechtspraak is van het Hof dat wanneer op communautair niveau een volledige harmonisatie tot stand is gebracht voor een bepaalde materie, iedere daarop betrekking hebbende nationale maatregel aan de bepalingen van de handeling tot verwezenlijking van die harmonisatie en niet aan het primaire recht moet worden getoetst. Zie Hof 17 april 2007, nr. C-470/03, AGM-COS.MET, Pb EG C 96 van 28 april 2007, blz. 2, in het bijzonder r.o. 50. Zie nader over deze complexe problematiek P.J.G. Kapteyn \& P. VerLoren van Themaat 2003, blz. 725.

84. Zie in dit kader de inbreukprocedure tegen het Verenigd Koninkrijk over de implementatie van de zogenoemde bijstandsrichtlijn. Hof 21 juli 2005, nr. C-349/03, Commissie/Verenigd Koninkrijk, Jur. 2005, blz. I-7321 en dan in het bijzonder r.o. 49. Zie verder het FCE-arrest waarin is beslist, dat $\rightarrow$ 
Jans e.a. menen dat het primaire Unierecht:

“(...) zijn inbedding vindt in algemene rechtsbeginselen, waaronder de grondrechten zijn begrepen". 85

Verder is van belang dat het Hof bij herhaling heeft beslist dat de lidstaten niet alleen hun nationale recht dienen uit te leggen conform het Unierecht,

“(...) maar dienen er ook op toe te zien dat zij zich niet baseren op een uitlegging van een bepaling van afgeleid gemeenschapsrecht die in conflict zou komen met de door de communautaire rechtsorde beschermde grondrechten of de andere algemene beginselen van gemeenschapsrecht." ${ }^{86}$

Uit deze jurisprudentie kan volgens mij de conclusie worden getrokken dat de algemene rechtsbeginselen tot het primaire Unierecht behoren. ${ }^{87}$

Van belang is ook dat het gelijkheidsbeginsel, evenredigheidsbeginsel en het rechtszekerheidsbeginsel hun basis vinden in het Unieverdrag en het Werkingsverdrag wat tot gevolg heeft dat zij een gelijke status hebben. ${ }^{88}$

\subsubsection{Secundair Unierecht}

\subsubsection{Algemeen}

De besluiten van de instellingen op basis van de bevoegdheden zoals neergelegd in de verdragen, worden aangeduid met de term 'secundair Unierecht'. De belangrijkste categorieën zijn: verordeningen, richtlijnen en beschikkingen. Ook in de BTW komen

$\rightarrow$ de vaststelling dat een nationale wettelijke regeling of praktijk onverenigbaar is met de BTWrichtlijn meebrengt dat niet meer hoeft te worden onderzocht of de in het Verdrag neergelegde fundamentele vrijheden, waaronder de vrijheid van vestiging zijn geschonden. Hof 23 maart 2006 nr. C-210/04, BNB 2006/184, V-N 2006/18.24, r.o. 50.

85. J.H. Jans e.a 2002, blz. 29.

86. Hof 26 juni 2007, nr. C-305/05, Ordre des barreaux francophones en germanophone e.a., r.o. 28. Zie in praktisch identieke zin maar dan toegespitst op het evenredigheidsbeginsel Hof 6 november 2003, nr. C-101/01, Lindqvist, Jur. 2003, blz. I-12971, r.o. 87.

87. Ook Kooijmans rekent de algemene rechtsbeginselen tot het primaire Unierecht. P.H. Kooijmans, Internationaal publiekrecht, Deventer: Kluwer 2008, blz. 266 en 267. Van Kesteren echter ziet de algemene rechtsbeginselen als derde rechtsbron, naast het primaire en secundaire Unierecht. Vgl. H.W.M. van Kesteren, misbruik van recht in de omzetbelasting (oratie Tilburg), Deventer: Kluwer 2004 blz. 9. Gorissen meent dat de beginselen van gelijke rang zijn als het primaire Unierecht. Zij komt tot deze conclusie omdat de grondslag en de toepassing van de algemene rechtsbeginselen is te vinden in het Werkingsverdrag, N.H.A. Gorissen, Gewekt vertrouwen in Europees perspectief. Een rechtsvergelijkend onderzoek naar de rol van het vertrouwensbeginsel in het Nederlandse, Belgische, Duitse en Europees (belasting)recht (diss. Maastricht), Amersfoort: Sdu Uitgevers 2008, blz. 219.

88. Zie hierover nader Tridimas 2006, blz. 50 en 51. Hij brengt naar voren dat één van de gevolgen hiervan is dat de EU bij het afsluiten van verdragen met derde landen of internationale organisaties deze algemene beginselen in acht moet nemen. Zie tevens de door hem aangehaalde jurisprudentie. 
wij regels met deze status tegen. Vandaar dat ik er hier kort op inga. Verder ga ik in op de maatstaven waar lidstaten zich aan moeten houden als een deel van het BTWrecht niet is terug te vinden in het secundaire Unierecht, omdat dit bepaalde deel nog in nationale handen is (paragraaf 4.5.2.5).

\subsubsection{Verordeningen}

Een verordening heeft een algemene strekking, is verbindend in al haar onderdelen en rechtstreeks toepasselijk in elke lidstaat (artikel 288, tweede alinea, VwEU).

Een verordening geeft regels en is zonder enige nadere uitvoeringshandeling van de lidstaat van toepassing. Het is niet noodzakelijk dat een verordening wordt omgezet in een nationale wet. Het is zelfs verboden. Dit om te voorkomen dat aan een verordening zijn uniforme toepasbaarheid wordt ontnomen. Het is echter wel zo dat in een nationale regelgeving maatregelen kunnen worden getroffen om een verordening te handhaven.

Zoals eerder naar voren is gebracht, is voor de BTW het secundaire Unierecht te vinden in richtlijnen en dan in het bijzonder in de BTW-richtlijn. Dat neemt niet weg dat verordeningen voor de BTW van belang kunnen zijn. Een voorbeeld daarvan is de BTW-Bijstandsverordening. ${ }^{89}$ Deze verordening regelt de administratieve samenwerking op het gebied van de BTW. De achtergrond van deze verordening is, om door middel van een snelle en goede gegevensuitwisseling tussen de lidstaten de BTW-fraude te bestrijden. ${ }^{90}$ Het mag dan zo zijn dat een verordening rechtstreeks van toepassing is, dat wil niet zeggen dat elke bepaling in een verordening zich leent om te worden toegepast door de nationale rechter. De BTW-Bijstandsverordening regelt samenwerking en gegevensuitwisseling tussen de lidstaten. Tevens regelt de verordening een aantal zaken van organisatorische aard. Een Nederlandse rechter kan daar echter weinig mee in een geschil tussen belastingplichtige en Belastingdienst. Dergelijke bepalingen zijn dan ook eerder gericht op het regelen van de verhoudingen tussen de lidstaten.

Sinds enige tijd kent de BTW een nieuw fenomeen. Namelijk een verordening als uitvloeisel van artikel 397, BTW-richtlijn. Dit artikel bepaalt dat de Raad op voorstel van de Commissie met eenparigheid van stemmen de nodige maatregelen vaststelt ter uitvoering van de BTW-richtlijn. Een voorbeeld hiervan is de BTW-verordening $1777 / 2005,{ }^{91}$ welke is vervangen door de per 1 juli van kracht zijnde verordening 282/2011. ${ }^{92}$ Deze verordening is een nadere uitwerking van enkele bepalingen die

89. Verordening 1798/2003, V-N 2003/57.23; de zogenoemde Bijstandsverordening. 90. Om de BTW-fraude efficiënter te bestrijden heeft de Raad een voorstel gedaan tot aanpassing van de BTW-Bijstandsverordening. Zie nader E.C.M. van der Hel - van Dijk, aanpassing verordening (EG) nr. 1798/2003: efficiëntere bestrijding BTW-fraude?, WFR 2010/525.

91. Verordening (EG) nr. 1777/2005 van 17 oktober 2005, Pb EG van 29 oktober 2005, L 288/1.

92. Verordening (EU) nr 282/2011 van 15 maart 2011, Pb EU van 23 maart 2011, L 77/1. 
zijn te vinden in de BTW-richtlijn (o.a. de regels die de plaats van dienst bepalen en de vrijstellingen). ${ }^{93}$ Dat dit fenomeen in de toekomst navolging krijgt blijkt uit het voorstel van de Commissie tot wijziging van de BTW-richtlijn wat betreft de behandeling van verzekerings- en financiële diensten. ${ }^{94}$ Deze voorstellen bevatten niet enkel een aanpassing van de relevante artikelen in de BTW-richtlijn, maar ook een op artikel 397, BTW-richtlijn gebaseerde verordening die de diverse begrippen definieert. ${ }^{95}$

\subsubsection{Richtlijnen}

Een richtlijn is verbindend ten aanzien van het te bereiken resultaat voor elke lidstaat waarvoor zij bestemd is, echter aan de nationale instanties wordt de bevoegdheid gelaten vorm en middelen te kiezen (artikel 288, derde alinea, VwEU). De richtlijn is dus gericht tot de lidstaten, zij moeten hun wetgeving daaraan aanpassen. ${ }^{96}$ Dat betekent dat de nationale bepalingen die uitvoering geven aan de richtlijn wel een dwingend karakter moeten hebben. De implementatie van een richtlijn door middel van ambtelijke instructies e.d. is niet voldoende. ${ }^{97}$ Het Salix-arrest ${ }^{98}$ omschrijft deze verplichting vrij dwingend met verwijzing naar het rechtszekerheidsbeginsel:

93. Althans volgens de considerans is de bedoeling van de BTW-verordening om duidelijkheid bij de toepassing van de BTW-richtlijn te scheppen. Het lijkt er echter op, dat op een aantal plaatsen BTWbegrippen breder worden ingevuld dan tot op dit moment in de jurisprudentie het geval is. Zie bijvoorbeeld paragraaf 8.3 over de 'inkoop-vi' die volgens de BTW-verordening geen uitgaande prestaties hoeft te verrichten. Voor zover de BTW-verordening begrippen uit de BTW-richtlijn nader invult is er geen Europeesrechtelijk probleem. Dit kan anders zijn, als er een tegenstrijdige uitleg is van de BTW-richtlijn door het Hof en de bepalingen in de BTW-verordening. Zie voor een uitgebreide analyse G.J. Slooten, De BTW-Verordening: mogen wijzigingen vermomd gaan als 'verduidelijking'? WFR 2012/86. Zie tevens G.G.M. Kortenaar, Gebruik uitvoeringsverordening als instrument in de Europese BTW, WFR 2012/98.

94. Com (2007) 747 def.

95. Com (2007) 746 def.

96. Zie R. Barents \& L.J. Brinkhorst 2003, blz. 162.

97. De omzetting van de richtlijn dient binnen een bepaalde tijd plaats te vinden. Gebeurt deze omzetting niet binnen de daartoe gestelde termijn dan is de lidstaat in gebreke en kan de Commissie een procedure wegens verdragschending beginnen in de zin van artikel 226 EG. Niet tijdige implementatie van de BTWrichtlijnen is diverse keren aan de orde geweest. Zie in dit kader de inbreuk procedure tegen Italië (Hof 24 november 1987, nr. 125/86, Commissie/Italië, Jur. 1987, blz. 4669). In dit arrest besliste het Hof, dat politieke problemen die het wetgevingsproces bemoeilijken, geen excuus zijn voor het niet-tijdig implementeren van een richtlijn. Zie ook de inbreukprocedure tegen Italië een paar jaar later (Hof 14 oktober 1992, nr. C-262/91, Commissie/Italië, Jur. 1992, blz. I-5269). Deze procedure is een vervolg op het eerder genoemde arrest van 24 november 1987. Eind 1991 had Italië nog steeds geen uitvoering gegeven aan het arrest van 24 november 1987 waarin Italië werd veroordeeld wegens niet-nakoming. Het Hof besliste in het arrest van 14 oktober 1992 dat dit niet toelaatbaar is en dat met het gevolg geven aan het arrest van 24 november 1987 onmiddellijk een begin moet worden gemaakt (zie verder ook het arrest van het Hof 1 december 1993, nr. C-234/91, Commissie/Denemarken, Jur. 1993, blz. I-6273).

98. Hof 4 juni 2009, nr. C-102/08, Salix, V-N 2009/28.13, NTFR 2009/1384, Deze procedure gaat onder meer over de bevoegdheid van lidstaten om vrijgestelde werkzaamheden van publiekrechtelijke lichamen als werkzaamheden van de overheid te beschouwen. 
"Elke lidstaat moet immers aan richtlijnen uitvoering geven op een wijze die ten volle voldoet aan de door de gemeenschapswetgever gestelde vereisten van rechtsduidelijkheid en rechtszekerheid, zulks in het belang van de in de lidstaten gevestigde betrokken personen. Daartoe moeten de bepalingen van een richtlijn worden uitgevoerd met een onbetwistbare dwingende kracht en met de vereiste specificiteit, nauwkeurigheid en duidelijkheid (...)." (r.o. 42)

Administratieve praktijken die naar hun aard volgens goeddunken van de administratie kunnen worden gewijzigd en waaraan onvoldoende bekendheid is gegeven kunnen niet worden beschouwd als een correcte uitvoering van de op het Werkingsverdrag gebaseerde verplichte implementatie in wetgeving (r.o. 43).

Indien implementatie van een richtlijn in nationale wetgeving heeft plaatsgevonden, dan zijn de lidstaten onbevoegd om het eenmaal aan de richtlijn aangepaste nationale recht te wijzigen. In de literatuur wordt dit effect van een richtlijn ook wel aangeduid als het 'blokkeringseffect'. Dit is het gevolg van de functie van een richtlijn en de voorrang van het Unierecht. Het gevolg hiervan is dat de BTWwetgeving tot een communautaire 'enclave' is geworden. ${ }^{99}$

Mortelmans e.a. onderkennen vier verschillende fasen in het proces van implementatie. Ten eerste de omzetting van de richtlijn in nationaal recht. ${ }^{100}$ Voor de BTW kan van belang zijn, dat de voor de BTW relevante richtlijnen aan de lidstaten keuzes laten, soms geldt zelfs geen verplichting om delen van een richtlijn om te zetten in wetgeving. Zo kent de BTW-richtlijn diverse zogenoemde 'kan-bepalingen'. Dit zijn bepalingen die de lidstaten de keuze laten of ze de desbetreffende bepaling willen opnemen in hun nationale wet. Een voorbeeld daarvan in onze nationale Wet OB is de bepaling met betrekking tot de regeling van de fiscale eenheid. De fiscale eenheid is opgenomen in onze Wet OB in artikel 7, vierde lid. De corresponderende bepaling is artikel 11, BTW-richtlijn. Op grond van deze bepaling mogen de lidstaten de fiscale eenheid opnemen in hun nationale wetgeving.

De tweede fase in het implementatieproces ziet op de operationalisering. In deze fase gaat het om het aanwijzen van de nationale instanties die met de uitvoering en toepassing belast zijn. Tevens bevat deze fase ook het treffen van maatregelen in verband met de handhaving en de te volgen procedures. Tot dergelijke maatregelen behoort ook het stellen van sancties op inbreuken op omgezette richtlijnen. ${ }^{101}$

99. Zie R. Barents \& L.J Brinkhorst 2003, blz. 165. Uitzondering op deze regel is als de richtlijn ruimte biedt om tot aanpassing over te gaan. In de BTW-richtlijn is deze ruimte onder meer te vinden in de zogenoemde kan bepalingen en artikel 395, BTW-richtlijn (zie voor de specifieke problematiek die dit oproept onder meer de paragrafen 5.2, 9.2.1 en 11.5.1).

100. K.J.M. Mortelmans, R.H. van Ooik \& S. Prechal, Europees recht en de Nederlandse rechter, Deventer: Kluwer 2004, blz. 17 e.v., zie ook S. Prechal, Directives in EC Law, Oxford: University Press 2005, blz. $73 \mathrm{t} / \mathrm{m} 91$.

101. Voor de BTW valt in dit kader te denken aan de bestuurlijke boete die de inspecteur op grond van artikel 40 Wet OB kan opleggen als de listingverplichting van artikel 37a Wet OB niet of niet tijdig is nagekomen. 
De derde fase in het implementatieproces betreft de bestuurlijke toepassing van de nationale implementatieregels in het concrete geval. In deze fase spelen allerlei bestuurlijke instanties een belangrijke rol.

De vierde fase is de handhaving van de communautaire c.q. nationale wetgeving. Een voorbeeld van falende handhaving op het terrein van de BTW is de inbreukprocedure tegen Italië. ${ }^{102}$ Het Hof besliste dat de controlepraktijken van Italië in strijd zijn met het Unierecht. De Italiaanse Staat heeft door af te zien van de controle van belastbare handelingen die zijn verricht in diverse tijdvakken, de verplichtingen niet nagekomen die op haar rusten krachtens de artikelen 2 en 22, Zesde richtlijn alsmede krachtens artikel 4, lid 3 VEU (voorheen artikel 10 EG; betrekking op loyale samenwerking tussen de Unie en de lidstaten). Het Hof motiveert deze beslissing door te wijzen op het feit dat de Italiaanse maatregel het beginsel van de fiscale neutraliteit op de helling zet:

“(...) doordat aanzienlijke verschillen in de behandeling van de belastingplichtigen op het Italiaanse grondgebied ontstaan. Om dezelfde reden wordt afbreuk gedaan aan de verplichting om de gelijkheid van de belastingheffing in alle lidstaten te waarborgen." (r.o. 44)

"Aangezien - zoals wordt verklaard in de vierde overweging van de considerans van de Zesde richtlijn - het beginsel van fiscale neutraliteit een gemeenschappelijke markt met een gezonde mededinging beoogt tot stand te brengen, wordt de werking zelf van de gemeenschappelijke markt aangetast door de Italiaanse wettelijke regeling, daar de belastingplichtigen in Italië de verwachting kunnen koesteren dat zij hun belastingschulden grotendeels niet hoeven te betalen." (r.o. 45)

In het arrest klinkt door dat het Hof de lidstaten bij de handhaving van de BTWregelgeving een zekere 'bewegingsvrijheid' geeft en dan in het bijzonder aangaande de wijze waarop de middelen waarover zij beschikken worden aangewend (r.o. 38). De beperking is te vinden in de verplichting om te waarborgen dat binnen een lidstaat dan wel in alle lidstaten geen aanzienlijke verschillen in de behandeling van de belastingplichtigen in het leven worden geroepen (r.o. 38). Ook het feit dat de Italiaanse maatregel tot gevolg heeft dat algemeen en zonder onderscheid wordt afgezien van de door de belastingadministratie uitgeoefende controle- en rectificatiebevoegdheid, speelt een rol bij het oordeel dat de Italiaanse Staat faalt in de handhaving van de BTW-regelgeving (r.o. 50).

Voor een juiste implementatie van een richtlijn is dus meer vereist dan enkel het opnemen van de bepalingen uit de richtlijn in de nationale wet. Dat betekent dat een implementatiegebrek ook kan zijn gelegen in het niet-toepassen of het niethandhaven. In de literatuur krijgt voornamelijk de eerste fase van het implementatieproces aandacht.

102. Hof 17 juli 2008, nr. C-132/06, Commissie/Italië, NTFR 2008/1604. 


\subsubsection{Beschikkingen}

Een beschikking is verbindend in al haar onderdelen voor degene tot wie zij uitdrukkelijk is gericht (artikel 288, vierde alinea VwEU). ${ }^{103}$ Een beschikking kan gericht zijn tot een lidstaat of tot een particulier. ${ }^{104}$ Twee vormen zijn te onderscheiden, namelijk beschikkingen met een particulier als adressant (bijvoorbeeld op het terrein van het kartelrecht) en beschikkingen met een lidstaat als adressant. Deze laatste categorie is weer onder te verdelen in beschikkingen met een concrete strekking (bijvoorbeeld op het terrein van de onrechtmatige staatssteun) en beschikkingen met een algemene strekking. Deze laatste categorie is voor de BTW relevant.

Een beschikking van algemene strekking en gericht tot de lidstaten dient te worden geïmplementeerd in de nationale regelgeving (als althans de beschikking zelf daar geen uitzondering op toelaat). Een beschikking is dan vergelijkbaar met een richtlijn. Beschikkingen gericht tot de lidstaten zijn verbindend voor alle organen van de betrokken lidstaat, de rechtelijke instanties daaronder begrepen. ${ }^{105}$ Uit het Carparrest $^{106}$ is te concluderen dat de jurisprudentie over de werking van richtlijnen kan worden doorgetrokken naar beschikkingen van algemene strekking, inclusief het verbod op horizontale ${ }^{107}$ en omgekeerde verticale werking. ${ }^{108}$

In de BTW literatuur gaat voornamelijk de aandacht uit naar richtlijnen. Echter ook in beschikkingen van algemene strekking is een deel van de BTW regelgeving te vinden. Zie bijvoorbeeld de maatregelen ter vereenvoudiging en voorkoming van misbruik gebaseerd op artikel 395, BTW-richtlijn. In de paragrafen 5.2, 9.2.1 en 11.5.1 - waar afwijking van de BTW-richtlijn op grond van een machtiging aan de orde is - besteed ik nader aandacht aan de BTW aspecten van dit deel van het secundaire Unierecht.

De vraag kan zich voordoen of een belastingplichtige zich op een beschikking van algemene strekking gericht tot een lidstaat kan beroepen in een nationale procedure

103. Het Hof acht kenmerkend voor een beschikking de beperktheid van de kring van degenen voor wie zij is bestemd. Zij is van toepassing op een beperkt aantal bepaalbare natuurlijke- of rechtspersonen. Zie Hof 14 december 1962, gevoegde zaken nrs 16/62 en 17/62, Fruit en Groente e.a., Jur. 1962, blz. 943. Het onderscheid tussen richtlijnen/verordeningen en beschikkingen is niet zonder belang gezien het feit dat particulieren het recht hebben om een direct beroep tot nietigverklaring in te stellen bij het Gerecht van eerste aanleg tegen beschikkingen die hun rechtstreeks en individueel raken. Dit aspect heeft voor de BTW (nog) niet gespeeld.

104. Zie verder M. Verhoeven, De rechtstreekse werking van de communautaire beschikking, Ars Aequi, maart 2008, blz. 214.

105. Hof 21 mei 1987, nr. 249/85, Albako, Jur. 1987, blz. 2345.

106. Hof 7 juni 2007, nr. C-80/06, Carp, Pb EG C 170/7, r.o. 20.

107. Met een verbod op horizontale werking wordt bedoeld dat particulieren zich tegenover elkaar niet kunnen beroepen voor de nationale rechter op bepalingen in richtlijnen.

108. Een verbod op omgekeerde verticale werking betekent dat de overheid zich niet kan beroepen op een bepaling in een richtlijn ten nadele van een particulier indien de richtlijn niet is geïmplementeerd. 
om zo bijvoorbeeld een belastingvrijstelling te verkrijgen. De jurisprudentie van het Hof is hier duidelijk in. Zo blijkt uit het Foselev-arrest ${ }^{109}$ dat een dusdanig beroep slaagt als een dergelijke beschikking de lidstaat een onvoorwaardelijke en voldoende duidelijke en nauwkeurige verplichting oplegt.

\subsubsection{Ontbreekt regeling in secundair Unierecht}

De BTW-regels zijn te vinden in verordeningen, richtlijnen en beschikkingen van algemene strekking. Het Hof heeft vaker verduidelijkt dat niet al het BTW-recht in het secundair Unierecht is geregeld. Ik doel dan op het feit dat diverse keren is aangegeven dat de BTW-richtlijn niet voorziet in regelgeving en dat de invulling onder voorwaarden - is overgelaten aan de lidstaten. Dit is iets anders dan dat de richtlijn een term bevat die een lidstaat mag invullen, zoals bijvoorbeeld de term 'gemeenschappelijke beleggingsfondsen' in artikel 135, lid 1, sub g, BTW-richtlijn. ${ }^{110}$ Of dat sprake is van een 'kan-bepaling'. Deze situaties maken namelijk deel uit van de BTW-richtlijn. Ik vermeld in deze paragraaf zaken waarin het Hof nationale 'speelruimte' voor regelgeving zag. Kort weergegeven gaat het dan om onder meer de volgende zaken:

- Transport Service beschikking ${ }^{111}$ : Deze beslist dat de BTW-heffing in alle schakels dient plaats te vinden. Ook als er een latere eindheffing plaatsvindt. Tevens geeft het Hof aan dat de BTW-richtlijn geen bepaling kent die de inning regelt en dat de lidstaten dan ook in beginsel een zekere vrijheid hebben.

- Wollny-arrest ${ }^{112}$ : Toegestaan is dat een lidstaat de maatstaf van heffing bij privégebruik van een zakelijk geëtiketteerd gebouw, conform de herzieningsregels bepaalt. Ook al bevat de BTW-richtlijn niet een dergelijke regeling.

- Securenta-arrest ${ }^{113}$ : De lidstaten mogen zelf de verdeelsleutel bepalen van het recht op aftrek als naast economische activiteiten tevens niet economische activiteiten worden verricht.

- Ahold-arrest ${ }^{114}$ : Afrondingsregels voor de berekening van de verschuldigde BTW moeten de lidstaten zelf bepalen.

- Stadeco-arest ${ }^{115}$ : Lidstaten mogen voorwaarden stellen aan teruggaaf van ten onrechte in rekening gebrachte BTW.

Op deze plaats ga ik niet nader in op de inhoudelijke kant van de zaken die aan de orde waren. Dat gebeurt op andere plaatsen in dit onderzoek. Op deze plaats besteed ik enkel aandacht aan de maatstaven die gelden als een deel van het BTW-recht noch

109. Hof 20 november 2008, nr. C-18/08, Foselev Sud-Ouest SarL, Jur. 2008, blz. I-8745.

110. Dit artikel vermeldt dat de lidstaten vrijstelling verlenen voor 'het beheer van gemeenschappelijke beleggingsfondsen, zoals omschreven door de lidstaten'. Het zinsdeel na de komma geeft de lidstaten een zekere ruimte om de term in te vullen. Anders dan bij een communautair rechtsbegrip, zie paragraaf 4.3

111. Hof 3 maart 2004, nr. C-395/02, Transport Service NV, V-N 2004/18.18.

112. Hof 14 september 2006, nr. C-72/05, Wollny, Jörg \& Stefanie, V-N 2006/50.13.

113. Hof 13 maart 2008, nr. C-437/06, Securenta, V-N 2008/14.20.

114. Hof 10 juli 2008, nr. C-484/06, FE Koninklijke Ahold NV, V-N 2008/41.23.

115. Hof 18 juni 2009, nr. C-566/07, Stadeco, V-N 2009/31.14, NTFR 2009/1614 
in verordeningen, noch in richtlijnen dan wel in beschikkingen van algemene strekking is geregeld. ${ }^{116}$

Als het Ahold-arrest wordt vergeleken met de Wollny-procedure dan lijkt een verschil in bevoegdheid van de lidstaten te bestaan. Zo bevat het Ahold-arrest de navolgende overweging:

"Dientengevolge is het, bij gebreke van een communautaire regeling, een aangelegenheid van de rechtsorde van de lidstaten om, binnen de door het gemeenschapsrecht gestelde grenzen, de methode en de regels vast te stellen voor de afronding van een uit hoofde van de btw aangegeven bedrag." (r.o. 31)

Het Wollny-arrest vermeldt:

"Aangezien de Zesde richtlijn evenwel niet de nodige aanwijzingen bevat voor een uniforme en nauwkeurige omschrijving van de regels ter bepaling van het bedrag van de betrokken uitgaven, dient te worden aanvaard dat de lidstaten ter zake een bepaalde beoordelingsmarge hebben, (...)" (r.o. 28)

In de Ahold-procedure is het 'een aangelegenheid van de rechtsorde van de lidstaten' terwijl in de Wollny-case is te vinden dat 'dient te worden aanvaard dat de lidstaten ter zake een bepaalde beoordelingsmarge hebben'. Het lijkt erop dat de bewoordingen in de Ahold-procedure de lidstaten meer ruimte geven. De term 'beoordelingsmarge' geeft namelijk een lidstaat minder ruimte om het nationaal in te vullen dan dat het een aangelegenheid is van de nationale rechtsorde. In beide arresten gaat het om onderwerpen waar geen regeling voor bestaat; dus vanwaar dan een dergelijk verschil? In de eerdergenoemde arresten geeft het Hof de grenzen aan. Als deze grenzen in de beschouwing worden betrokken dan blijkt al snel dat het bovenstaand onderscheid niet bestaat, althans dat met het verschil in gekozen bewoordingen geen onderscheid is beoogd. In de genoemde serie arresten heeft het Hof inmiddels een set grenzen het licht doen zien waaraan de lidstaten zich hebben te houden:

- De lidstaten dienen de regels vast te stellen in overeenstemming met het beginsel van de fiscale neutraliteit (Ahold, r.o. 32, Stadeco, r.o. 39, Securenta, r.o. 36).

- De rechtszekerheid dient gewaarborgd te zijn (Ahold, r.o. 32).

116. Niet alleen op het terrein van de invulling van het materiële BTW-recht is jurisprudentie over dit onderwerp te vinden. Zie verder ook de jurisprudentie op het terrein van de terugbetaling van ten onrechte geïnde nationale heffingen. Het is op dat terrein vaste rechtspraak dat bij gebreke van een Unieregeling het een aangelegenheid van het nationale recht van elke lidstaat is om onder meer de bevoegde rechter aan te wijzen en de procesregels te geven voor rechtsvorderingen die ertoe strekken, de rechten te beschermen die de justitiabelen aan het gemeenschapsrecht ontlenen, mits die regels niet ongunstiger zijn dan die welke voor soortgelijke nationale vorderingen gelden (gelijkwaardigheidsbeginsel), en zij de uitoefening van de door het gemeenschapsrecht verleende rechten in de praktijk niet onmogelijk of uiterst moeilijk maken (doeltreffendheidsbeginsel). Zie de arresten van 17 november 1998, nr. C-228/96, Aprile, Jur. blz. I-7141, r.o. 18; Hof 11 juli 2002, C-62/00, Marks \& Spencer, V-N 2002/49.28, r.o. 34; Hof 21 januari 2010, nr. C-472/08, Alstom Power Hydro, V-N 2010/ 11.22, r.o. 17; Hof 15 december 2011, nr. C-427/10, BAPV, V-N 2012/4.25, NTFR 2012/37. 
- Het doel van de betrokken bepaling en de plaats ervan in de systematiek van de BTW-richtlijn dient in acht te worden genomen (Wollny, r.o. 28, Securenta, r.o. 35).

- De regelgeving mag niet verder gaan dan ter bereiking van de doelstellingen van de BTW-richtlijn noodzakelijk is (Transport Service, in casu bestrijding van fraude, r.o. 29 en Stadeco, r.o. 39).

Deze voorwaarden overziend, komt het erop neer dat de maatregelen een toetsing aan de algemene rechtsbeginselen dienen te doorstaan en niet in strijd mogen zijn met het rechtskarakter van de BTW.

\subsection{Rechtstreekse werking}

Met rechtstreekse werking wordt bedoeld, dat de bepaling in het Unierecht door een belanghebbende met succes kan worden ingeroepen voor een nationale rechter. Onderscheid kan worden gemaakt tussen rechtstreekse werking van aan de ene kant richtlijnen en beschikkingen van algemene strekking en aan de andere kant rechtstreekse werking van verordeningen.

Zowel het primaire Unierecht als het secundaire Unierecht heeft rechtstreekse werking. Hierna ga ik in verband met de relevantie voor de BTW in op enkele facetten van de rechtstreekse werking.

Het Hof heeft in het Van Gend \& Loos-arrest ${ }^{117}$ beslist dat het Unierecht ${ }^{118}$ rechtstreeks van toepassing is op alle rechtssubjecten van de communautaire rechtsorde. In het arrest gaat het om de vraag of het verbod, van artikel 12 EEG (huidig artikel 30 VwEU), op de verhoging van invoerrechten in het communautaire handelsverkeer direct toepasbaar is door de nationale rechter. Dit, omdat het artikel in het verdrag duidelijk en in onvoorwaardelijke termen de verhoging van invoerrechten verbiedt. Particulieren kunnen zich direct op bepalingen in het Werkingsverdrag beroepen. ${ }^{119}$

Richtlijnen hebben verticale rechtstreekse werking, echter geen horizontale rechtstreekse werking, waarmee bedoeld is de werking tussen burgers onderling. Verticale rechtstreekse werking van richtlijnen is geregeld bij het Hof aan de orde geweest. Allereerst in het Becker-arrest. ${ }^{120}$ Deze procedure had betrekking op de vrijstelling van kredietbemiddeling die in Duitsland niet op tijd was geïmplementeerd in de wet. Becker deed echter een beroep op de vrijstelling van artikel 13, Zesde richtlijn (thans artikel 135, BTW-richtlijn).

117. Hof 5 februari 1963, nr. 26/62, Van Gend \& Loos, Jur. 1963, blz. 3

118. Het arrest verwijst naar het EEG-Verdrag, per 1 december 2009 is dat Werkingsverdrag, zie paragraaf 1.6 .

119. Bij de rechtstreekse werking van het secundaire Unierecht onderscheidt men verticale rechtstreekse werking en horizontale rechtstreekse werking. Met verticale rechtstreekse werking wordt bedoeld dat een bepaling kan worden ingeroepen voor de nationale rechter in de relatie overheid en particulier. Horizontale rechtstreekse werking heeft betrekking op de relatie tussen particulieren. 120. Hof 19 januari 1982, nr. 8/81, U. Becker, Jur. 1982, blz. 52. 
"Wanneer dus de bepalingen van een richtlijn inhoudelijk gezien onvoorwaardelijk en voldoende nauwkeurig lijken te zijn en uitvoeringsmaatregelen niet tijdig zijn getroffen, kunnen de particulieren zich op die bepalingen beroepen tegenover elk nationaal voorschrift dat niet met de richtlijn in overeenstemming is. Hetzelfde geldt wanneer die bepalingen rechten vastleggen die de particulieren tegenover de staat kunnen doen gelden." (r.o. 25)

De lijn van de rechtspraak van het Hof is een constante. ${ }^{121}$ Daaruit blijkt dat rechtstreekse werking geldt indien aan de navolgende voorwaarden is voldaan:

- De bepalingen zijn niet, niet tijdig of niet correct in nationaal recht geïmplementeerd.

- De bepalingen in de richtlijn zijn inhoudelijk onvoorwaardelijk en voldoende nauwkeurig.

Het Hof preciseert de laatste voorwaarde als volgt in het Comitato-arrest: ${ }^{122}$

"Een gemeenschapsbepaling is onvoorwaardelijk, wanneer de verplichting die zij oplegt, van geen enkele voorwaarde en haar uitvoering of werking van generlei handeling van de instellingen der Gemeenschappen of van de Lid-Staten afhankelijk is gesteld." (r.o. 9)

"Voorts is een bepaling voldoende nauwkeurig om door een justitiabele voor de nationale rechter te kunnen worden ingeroepen en door de rechter te kunnen worden toegepast, wanneer de verplichting die zij oplegt, in niet mis te verstane bewoordingen is gesteld." (r.o.10)

De lidstaten beschikken derhalve niet over een discretionaire bevoegdheid.

Ook procedurele bepalingen kunnen rechtstreekse werking hebben. Dit kan aan de orde zijn indien een communautaire bepaling een lidstaat verplicht een bepaalde nationale regeling bij de Commissie aan te melden. In dit geval kan voor de BTW gedacht worden aan artikel 395, BTW-richtlijn (voorheen artikel 27, Zesde richtlijn) (zie paragraaf 5.2).

121. Voor de BTW zijn in dit kader onder meer de volgende arresten van het Hof: Hof 1 februari 1977, nr. 51/76, VNO, BNB 1978/18. Belastingplichtige kan een beroep doen op een begrip in een richtlijn. Hof 10 juni 1982, nr. 255/81, Grendel, Jur. 1982, blz. 2301. Deze procedure heeft eveneens betrekking op te late implementatie van de vrijstelling voor kredietbemiddeling in Duitsland. Hof 22 februari 1984, nr. 70/83, Kloppenburg, Jur. 1984, blz. 1075. Het Hof heeft in dit arrest beslist dat beroep op terugwerkende kracht van een nog niet geïmplementeerde richtlijn, niet geldt voor de periode waarvoor de lidstaat uitstel d.m.v. een andere richtlijn heeft gekregen. Hof 14 juli 1988, nr. 207/87, Weissgerber, Jur. 1988, blz. 4433. Beroep op vrijstelling is mogelijk wanneer de belasting niet is afgewenteld en dat de afnemer deze niet kan aftrekken. Hof 17 februari 2005, nrs. C-453/02 en C-462/ 02, Linneweber e.a., V-N 2005/13.14, NTFR 2005/302. Rechtstreeks beroep mogelijk op de vrijstelling van kans- geldspelen van artikel 13B, sub f, Zesde richtlijn. Zie verder de volgende jurisprudentie van het Hof buiten het terrein van de BTW: Hof 4 december 1974, nr. 41/74, Van Duyn, Jur. 1974, blz. 1337. Hof 15 juli 1982, nr. 270/81, Felicitas, Jur. 1982, blz. 2771. Hof 26 februari 1986, nr. 152/84, Marshall I, Jur. 1986, blz. 723. Hof 8 oktober 1987, nr. 80/86, Kolpinghuis, Jur. 1987, blz. 3969.

122. Hof 23 februari 1994, nr. C-236/92, Camitato, Jur. 1994, blz. I-483. 
Voor het effect van het Unierecht is de rechtstreekse verticale werking van richtlijnen een belangrijk aspect. Zonder rechtstreekse werking zou de integratie mogelijk niet volledig gerealiseerd worden omdat de implementatie dan zou afhangen van de wil van de lidstaten.

Zoals blijkt, hebben richtlijnen geen horizontale directe werking. Dat betekent dat particulieren zich tegenover elkaar niet kunnen beroepen voor de nationale rechter op bepalingen in richtlijnen. ${ }^{123}$ Daarvoor is vereist dat de desbetreffende bepalingen eerst worden geïmplementeerd in de nationale wetgeving. ${ }^{124}$

Overigens kunnen nationale overheden in een beroep op de richtlijn wel tegenover elkaar komen te staan. Voor de BTW was dit het geval in onder meer het arrest van 26 maart 1987 Carpaneto Piacentino. ${ }^{125}$ In deze procedures beriep een gemeente zich op een bepaling in de BTW-richtlijn tegenover de centrale overheid. Aangezien het hier om de al dan niet belastingplicht van de lagere overheid ging, betreft dit een geval van verticale relatie.

Verder is nog van belang dat de overheid zich niet kan beroepen ten nadele van een particulier op een bepaling in een richtlijn indien deze richtlijn niet is geïmplementeerd (ook wel omgekeerde verticale werking genoemd). ${ }^{126}$ Zie in dit kader ook de doorwerking van richtlijnen door toepassing van de techniek van de richtlijnconforme interpretatie (paragraaf 4.7). Richtlijnconforme interpretatie kan onder omstandigheden tot gevolg hebben dat een geïmplementeerde richtlijn wel een belastingplichtige wordt tegengeworpen.

Een bijzonder fenomeen is de mogelijke asymmetrische rechtstreekse werking van richtlijnen. Deze kan zich voordoen indien een lidstaat een bepaalde regeling niet heeft geïmplementeerd en belanghebbende zich slechts op het gunstige deel van de richtlijn beroept en overigens bij de toepassing van een gunstig onderdeel van de Wet OB wenst aan te sluiten. Slaagt een dergelijk beroep? Een voorbeeld daarvan is de reisbureauregeling (zie artikel 26, Zesde richtlijn, thans de artikelen 306 t/m 310, BTW-richtlijn). Deze regeling is in het geheel niet geïmplementeerd in de Nederlandse Wet $\mathrm{OB}^{127}$ In

123. Bijzonder in deze context is Hof 8 juni 2006, nr. C-430/04, Halle, V-N 2006/46.14, NTFR 2006/938. In deze procedure oordeelde het Hof dat een particulier die met een publiekrechtelijk lichaam in concurrentie staat en naar voren brengt dat dit lichaam voor de activiteit die het als overheid uitoefent voor de heffing van BTW voordeliger wordt behandeld, zich kan beroepen op artikel 4, lid 5, tweede alinea, Zesde richtlijn. Via de band van de rechtstreekse werking wordt in deze procedure de concurrentievervalsing aangekaart.

124. Zie in dit kader de volgende arresten: Hof 14 juli 1994, nr. C-91/92, Faccini Dori, Jur. 1994, blz. I-3325. Hof 7 maart 1996, nr. C-192/94, El Corte Inglés, Jur. 1996, blz. I-1281. Hof 4 december 1997, nr. C-253-258/96, Kampelmann e.a., Jur. 1997, blz. I-6907.

125. Hof 26 maart 1987, nr. 231/87 en nr. 129/88, Carpaneto Piacentino, FED 1990/312.

126. Hof 26 februari 1986, nr. 152/84, Marshall I, Jur. 1986, blz. 723. Hof 8 oktober 1987, nr. 80/86, Kolpinghuis, Jur. 1987, blz. 3969.

127. Per 1 april 2012 zal de reisbureauregeling in Nederland zijn geïmplementeerd. Zie wetsvoorstel overige fiscale maatregelen, Tweede Kamer 2010- 2011, 32 505, nr. 2. 
het arrest van de Hoge Raad van 6 december $2000^{128}$ berekende een reisorganisator de verschuldigde omzetbelasting over - niet de omzet, maar - de in artikel 26, lid 2, Zesde richtlijn (thans artikel 308, BTW-richtlijn) omschreven winstmarge. Op de verschuldigde belasting bracht de reisorganisator echter in mindering de voorbelasting op de voet van artikel 15 Wet $\mathrm{OB}$. Hij hield daarbij geen rekening met artikel 26, lid 4, Zesde richtlijn (thans artikel 310, BTW-richtlijn), dat de aftrek van voorbelasting in dit verband uitsluit. Kortom, betalen over de winstmarge op grond van de BTW-richtlijn en de voorbelasting in aftrek brengen conform de Wet OB. Op deze plaats gaat het erom dat in het genoemde arrest de Hoge Raad een dergelijke asymmetrisch beroep (cherry picking) op de BTW-richtlijn afwijst. De regeling wordt gezien als één geheel. Heffing over de marge is onlosmakelijk verbonden aan een in die regeling voorziene aftrekbeperking. De Hoge Raad verwijst naar het Brinkmann-arrest ${ }^{129}$ van het Hof. Ook in het Becker-arrest (in het bijzonder rechtsoverwegingen $43 \mathrm{t} / \mathrm{m} \mathrm{46}$ ) en het Weissgerber-arrest is steun te vinden voor een afwijzing van een asymmetrisch beroep op de BTW-richtlijn. Het Becker-arrest:

“(...) dat volgens het stelsel van de richtlijn degenen die aanspraak kunnen maken op vrijstelling, juist doordat zij van deze mogelijkheid gebruik maken, enerzijds noodzakelijkerwijze afstand doen van het recht op aftrek van voorbelasting, en anderzijds, omdat zij van de belasting zijn vrijgesteld, deze ook niet kunnen afwentelen op degenen te wier behoeve zij hun diensten verrichten. Rechten van derden kunnen mitsdien in beginsel niet worden aangetast." (r.o. 44)

Een beroep op een nog niet geïmplementeerde vrijstelling in de BTW-richtlijn is slechts mogelijk indien wordt afgezien van het aftrekrecht. Ook in deze jurisprudentie is dus te lezen, dat in de benadering van het Hof niet van twee wallen kan worden gegeten. ${ }^{130}$

Minder aandacht dan voor de rechtstreekse werking van richtlijnen valt de rechtstreekse werking van beschikkingen van algemene strekking te beurt. Het Gradarrest $^{131}$ vormt daarop een uitzondering en op de relevantie van de rechtstreekse

128. HR 6 december 2000, nr. 35.704, NTFR 2000/1886.

129. Hof 15 juni 2000, nr. C-365/98, Brinkmann, NTFR 2000/1074, en dan in het bijzonder r.o. 33 t/m 39.

130. Zie nader over asymmetrisch beroep de conclusie van A-G Wattel van 25 februari 2004, nr. 39.344, V-N 2004/19.19 bij de VDP Dental-procedure. Wattel meent dat de jurisprudentie van het Hof geen uitsluitsel biedt over de mogelijkheid van een asymmetrisch beroep op de richtlijn. Hij wijst ondermeer op de conclusie van A-G Fennelly in de Victoria Film-procedure. Fennelly acht een asymmetrisch beroep mogelijk. Deze conclusie is niet gevolgd door een arrest omdat het Hof de Zweedse vragenstellende autoriteit niet als een rechtelijke instantie aanmerkte, zodat het Hof zich onbevoegd achtte de gestelde vragen te beantwoorden (Conclusie A-G Fennelly, 18 juni 1998, nr. C-134/97, Victoria Film A/S, Jur. 1998, blz. I-7023). Zie ook H.W.M. van Kesteren in zijn noot bij de zaak VDP Dental Laboratory, Hof 14 december 2006, nr. C-401/05, BNB 2007/94. Zie verder D.G. van Vliet, Selectief beroep op richtlijnregelingen mogelijk?, NTFR Beschouwingen 2007/20. Van Vliet gaat nader in op de vragen die het Charles Thijmen-arrest van het Hof oproept over de mogelijkheid van een asymmetrisch beroep. Zie tevens J.T. Sanders, Rechtstreeks beroep op richtlijnbepalingen in de BTW, BTWBrief nr. 6/7 2007, blz. 8 e.v.

131. Hof 6 oktober 1970, nr. 9/70, Grad, Jur. 1970, blz. 825. 
werking van beschikkingen kom ik terug in de paragrafen 5.2, 9.2.1 en 11.5.1 waar artikel 395, BTW-richtlijn aan de orde is.

De rechtstreekse werking van een verordening reikt verder dan die van een richtlijn. Dit is vooral van belang voor de verordeningen, genoemd in paragraaf 4.5.2.2, aangezien deze de BTW tot onderwerp hebben. In het bijzonder het feit dat de lidstaten verplichtingen kunnen inroepen t.o.v. particulieren. Bijvoorbeeld bij de eerder genoemde 'interpretatieverordening' of de douaneverordening, die ook voor de BTW bij invoer relevant kan zijn.

De vraag die opkomt, is op welke wijze de algemene rechtsbeginselen passen in het leerstuk van de rechtstreekse werking. De in deze paragraaf behandelde jurisprudentie heeft enkel betrekking op de rechtstreekse werking van richtlijnen.

Jans e.a. menen dat de rechtstreekse werking van de algemene rechtsbeginselen in de zin van objectieve rechtmatigheidtoets van de nationale regelgeving onomstreden is. ${ }^{132} \mathrm{Zij}$ menen ook dat aan de algemene rechtsbeginselen enkel kan worden getoetst in het kader van een toetsing aan een andere (geschreven) communautaire bepaling. Het geschil moet dan ook binnen de werkingssfeer van het Unierecht vallen. Een belangrijk instrument voor de doorwerking van de algemene beginselen is dan ook wat wordt genoemd de 'beginselconforme uitleg' (zie paragrafen 4.5.1 en 4.7). Wel past een nuancering. In het geval dat een algemeen rechtsbeginsel wordt gebruikt om de regelgeving te interpreteren, zal de hoogste nationale rechter al snel de verplichting hebben een prejudiciële vraag te stellen. Dit gezien het gegeven dat de uitleg van het Unierecht is toebedeeld aan het Hof.

\subsection{Richtlijn/beginselconforme interpretatie}

Een lidstaat heeft de plicht om het Unierecht toe te passen. Dit is een gevolg van de loyaliteitsverplichting die op de lidstaten rust op grond van artikel 4, lid 3 VEU. Gezien het feit dat de nationale rechter een orgaan van de lidstaat is, rust deze verplichting dus ook op de nationale rechter. De nationale rechter moet er zelfs vanuit gaan dat zijn lidstaat beoogd heeft de verplichtingen die uit een richtlijn voortvloeien correct en volledig te implementeren. ${ }^{133}$

In verscheidene arresten heeft het Hof beslist dat de nationale rechter de plicht heeft het nationale recht zo veel als mogelijk te interpreteren in overeenstemming met hetgeen in de relevante richtlijn staat. Dit blijkt onder meer uit het Silhouettearrest $^{134}$ en dan in het bijzonder rechtsoverweging 36 waar is vermeld:

132. J.H. Jans e.a. 2002, blz. 160.

133. Hof 16 december 1993, nr. C-334/92, Wagner Miret, Jur. 1993, blz. I-06911, vooral r.o. 20. Zie ook K.J.M. Mortelmans, R.H. van Ooik, S. Prechal, Europees recht en de Nederlandse rechter, verworvenheden en uitdagingen, Deventer: Kluwer 2004, blz. 31.

134. Hof 16 juli 1998, nr. C-355/96, Silhouette, Jur. 1988, blz. I-4799. 
“(..), dat volgens vaste rechtspraak een richtlijn uit zichzelf geen verplichtingen aan particulieren kan opleggen en dat een bepaling van een richtlijn als zodanig niet tegenover een particulier kan worden ingeroepen. Er zij evenwel op gewezen, dat volgens dezelfde rechtspraak de nationale rechter bij de toepassing van bepalingen van nationaal recht, ongeacht of zij van eerdere of latere datum dan de richtlijn zijn, deze zo veel mogelijk moet uitleggen in het licht van de bewoordingen en het doel van de richtlijn, teneinde het hiermee beoogde resultaat te bereiken en aldus aan artikel 189, derde alinea, EG-Verdrag te voldoen."

Uit de geciteerde rechtsoverweging blijkt dat de plicht tot richtlijnconforme interpretatie zo ver gaat dat deze zelfs geldt voor nationaal recht dat van vóór de ingangsdatum van de richtlijn dateert. ${ }^{135}$

Richtlijnconforme interpretatie dient om een conflict tussen een nationale wettelijke bepaling en het Unierecht op te lossen en kan dus tot gevolg hebben dat aan een al lang bestaande uitleg een einde wordt gemaakt door de werking van het recht van de Unie. Door Ploeger wordt dit 'van kleur verschieten' van een wettelijke bepaling het 'kameleoneffect' genoemd. ${ }^{136}$

De vraag komt op tot hoever de techniek van richtlijnconforme interpretatie strekt. Waar ligt de grens? Aan de techniek van richtlijnconforme interpretatie zijn wel degelijk grenzen gesteld. Het resultaat van de richtlijnconforme uitleg mag geen afbreuk doen aan de werking van de algemenen rechtsbeginselen, zoals het rechtszekerheidsbeginsel en het gelijkheidsbeginsel. Indien richtlijnconforme interpretatie een einde maakt aan een al lang bestaande uitleg van een bepaalde regeling, kan dit ten koste gaan van de rechtszekerheid. Botsing met het rechtszekerheidsbeginsel vindt plaats als de nationale rechter door richtlijnconforme interpretatie een resultaat bereikt, dat een belastingplichtige redelijkerwijs niet had kunnen verwachten.

Het lijkt mij dat de techniek van richtlijnconforme interpretatie niet zo ver kan gaan dat het stilzitten van de wetgever, in die zin dat de wetgever een wettelijke bepaling niet aanpast aan een richtlijn, door de rechter wordt gerepareerd door middel van richtlijnconforme interpretatie. ${ }^{137}$

135. Zie over dit aspect nader R. Barents \& L.J. Brinkhorst 2003, blz. 170 en 171. Zie in het kader van de verplichting tot richtlijnconforme interpretatie ook de arresten: Hof 10 april 1984, nr. 14/83, Von Colson en Kamann, Jur. 1984, blz. 1891, met name r.o. 26. Hof 13 november 1990, nr. C-106/89, Marleasing, Jur. 1990, blz. I-4135, in het bijzonder r.o. 7 en 8 . Hof 14 juli 1994, nr. C-91/92, Faccini Dori, Jur. 1994, blz. I-3325, in het bijzonder r.o. 26.

136. Zie noot bij HR 16 mei 1984, nr. 22 246, BNB 1984/212.

137. Zie over de grenzen van richtlijnconforme interpretatie K.J.M. Mortelmans, R.H. van Ooik, S. Prechal, Europees recht en de Nederlandse rechter, verworvenheden en uitdagingen, Deventer: Kluwer 2004, blz. 28 t/m 32. Zie ook S. Prechal, Richtlijnconforme interpretatie: Alice in wonderland, WFR 1991/1596 e.v. en A.W. van der Woude, Nogmaals richtlijnconforme uitleg van de Wet, WFR 1991/853. 
Ter Kuile merkt over richtlijnconforme interpretatie op:

“(...) dat kan over het algemeen bij kleine verschillen gemakkelijk; bij grote verschillen 'knapt de draad' op een gegeven moment en zal richtlijnconforme interpretatie niet langer mogelijk zijn, omdat wat wit is niet zwart genoemd kan worden." ${ }^{138}$

In het algemeen wordt aangenomen dat de rechter in ieder geval niet hoeft over te gaan tot een contra legem toepassing van het nationale recht, dat wil zeggen een interpretatie die tegen de tekst van de wet indruist. ${ }^{139}$

In de jurisprudentie van de Hoge Raad op het terrein van de BTW is het niet altijd duidelijk of de techniek van richtlijnconforme interpretatie aan de orde is. Ik schets een tweetal terreinen. Het ene waar de techniek wordt toegepast, het andere waar de afstand tussen Wet OB en richtlijn te groot blijkt, zodat de richtlijnconforme interpretatie het conflict tussen nationale wet en Unierecht niet kan oplossen.

In het kader van richtlijnconforme interpretatie is in de literatuur veel aandacht geschonken aan het zogenoemde grasland-arrest. ${ }^{140}$ In deze procedure ging het over grasland dat werd verkocht waarbij de verkoper zich verplichtte het land cultuurtechnisch gereed te maken, zodanig dat het bedrijfsklaar was voor het telen van bloembollen. Over de koopsom van de grond heeft de verkoper omzetbelasting in rekening gebracht. Met een beroep op de vrijstelling van artikel 15, eerste lid, letter a, onder $1^{\circ}$, Wet BRV bestrijdt de koper de hem opgelegde naheffingsaanslag in de overdrachtsbelasting, stellende dat de levering van het voor bloembollenteelt geschikt gemaakte grasland aan omzetbelasting was onderworpen en niet was gebruikt als bedrijfsmiddel. In geschil was of de verkregen grond was vervaardigd in de zin van artikel 11, eerste lid, onderdeel a, sub 1e Wet OB. De Hoge Raad stelde belanghebbende in het gelijk en besliste dat onder een 'vervaardigd goed' als bedoeld in de vermelde bepaling mede kunnen zijn begrepen onroerende zaken, niet zijnde bouwterreinen. De Hoge Raad oordeelde verder dat:

"Deze opvatting strookt met de bewoordingen van de bepaling, terwijl de geschiedenis van de totstandkoming daarvan geen aanwijzing inhoudt dat zij op een niet met deze bewoordingen overeenkomende wijze zou moeten worden uitgelegd. Weliswaar is, naar redelijkerwijs niet kan worden betwijfeld, deze bepaling, aldus verstaan, niet in overeenstemming met artikel 13 B, aanhef en onder h, van de Zesde Richtlijn, maar de wetgever heeft bij de aanpassing van de Wet aan deze Richtlijn, door de belastingheffing ter zake van de levering van onroerende zaken, gronden daaronder begrepen, te verbinden aan de vervaardiging daarvan, gekozen voor een van de Richtlijn afwijkend stelsel, zodat te dezer zake voor een uitlegging in overeenstemming met de Richtlijn geen plaats is." (r.o. 3.3)

138. B.H. ter Kuile, Hoe helder moet zonneklaar zijn? Over het onduidelijke beleid van de Hoge Raad rond prejudiciële verwijzingen ex art. 177 EG bij de omzetbelasting, Arnhem: Gouda Quint 1995, blz. 46.

139. Zie nader J.M. Prinssen, Doorwerking van Europees recht, De verhouding tussen directe werking, conforme interpretatie en overheidsaansprakelijkheid (diss. Amsterdam 2004), Deventer: Kluwer 2004, blz. 48.

140. HR 7 december 1994, nr. 29 153, BNB 1995/87. Zie ook A.E. De Moor, Waarom niet conform? Afscheidscollege, Deventer: Kluwer 1996, blz. 12 e.v. 
Vervolgens oordeelde de Hoge Raad dat de overheid zich niet ten nadele van een belastingplichtige op een bepaling van de BTW-richtlijn kan beroepen indien de nationale wet voor een belastingplichtige een gunstiger regeling inhoudt. Belanghebbende kon zich dan ook met vrucht beroepen op de wet zodat omzetbelasting verschuldigd was en voor de koper de vrijstelling van overdrachtsbelasting. Ik zal verder geen aandacht schenken aan de problematiek van artikel 11, eerste lid, onderdeel a, Wet OB. Op deze plaats is van belang de constatering dat de Hoge Raad geen mogelijkheid zag door toepassing van richtlijnconforme interpretatie de bepaling in de Wet OB te laten samenvallen met die in de BTW-richtlijn.

Een omstandigheid waarbij de Hoge Raad richtlijnconforme interpretatie wel mogelijk achtte, is te vinden in het arrest inzake de gratis medische diensten. ${ }^{141}$

“(...) het middel (werpt) de vraag op, welke betekenis bij de uitlegging van artikel 15, lid 2 , van de Wet moet worden toegekend aan de daarin opgenomen woorden 'prestaties van de ondernemer', als zijn bedoeld in artikel 11. Voor de beantwoording van die vraag is het volgende van belang.

Bij de aanpassing van de Wet aan de Zesde Richtlijn heeft de wetgever voor ogen gestaan de bepalingen inzake het ontstaan en de omvang van het recht op aftrek in overeenstemming te brengen met het bepaalde in artikel 17 van de Richtlijn. Aangezien volgens die bepaling de aftrek slechts is toegestaan van belasting die in rekening is gebracht ter zake van belaste leveringen en diensten, moet worden aangenomen dat de wetgever heeft beoogd de aftrek uit te sluiten van elke voorbelasting die moet worden toegerekend aan enige prestatie die bij de ondernemer aan wie de voorbelasting in rekening is gebracht, niet tot heffing van belasting leidt.

Naar de bewoordingen van artikel 15, lid 2, van de Wet is de aftrek evenwel slechts uitgesloten voor de belasting die kan worden toegerekend aan prestaties als zijn bedoeld in artikel 11. Met deze bewoordingen is het niet verenigbaar artikel 15, lid 2, aldus uit te leggen dat de vooraftrek is uitgesloten voor elke prestatie van de ondernemer die bij hem niet tot heffing van belasting leidt; aan de bedoeling van de wetgever zou evenwel te zeer afbreuk worden gedaan, indien onder de uitsluiting niet mede zou worden begrepen de belasting betrekking hebbende op prestaties die naar haar aard overeenkomen met de in artikel 11 vermelde leveringen en diensten, indien deze prestaties om enigerlei buiten de toepassing van artikel 11 gelegen reden, zoals het ontbreken van een vergoeding, aan de heffing van de belasting zijn onttrokken." (toevoeging: AHB) (r.o. 4.2)

Uit de bovenstaande overweging blijkt dat de Hoge Raad kijkt naar de bedoeling van de wetgever en naar de letterlijke tekst van de Wet OB. In dit geval besliste de Hoge Raad dat de betreffende bepaling in de Wet OB niet geheel overeenkomt met de bepaling in de BTW-richtlijn. Deze vaststelling echter leidt er niet toe dat recht op aftrek bestaat ingeval gratis vrijgestelde prestaties worden verricht. De Hoge Raad besliste dat met de techniek van de richtlijnconforme interpretatie het gat tussen richtlijn en Wet OB niet volledig kan worden gedicht. ${ }^{142}$

141. HR 24 april 1991, nr. 26 878, BNB 1991/206.

142. Op 1 januari 2007 is dit onderdeel van de Wet OB gewijzigd en in overeenstemming gebracht met de tekst van de BTW-richtlijn. Vgl. H.W.M. van Kesteren \& J.B.O. Bijl, Aftrek en handelingen die buiten het bereik van de BTW blijven, WFR 2006/1379. 
Zie voor een ander sprekend voorbeeld het arrest inzake de wandelvierdaagse. ${ }^{143}$ Belanghebbende in deze procedure organiseert jaarlijks een vierdaags wandelevenement en meende dat over de inschrijfgelden het verlaagde tarief van post b.3 Tabel I van toepassing is (het geven van gelegenheid tot sportbeoefening). Het Gerechtshof Arnhem stelde belanghebbende in het gelijk omdat het Gerechtshof meende dat uit de wetsgeschiedenis is af te leiden dat de wetgever met de wijziging van post b.3 Tabel I per 1 januari 2002 een ruimere werking heeft beoogd dan die van post 13 , bijlage $H$, Zesde Richtlijn (het recht gebruik te maken van sportaccommodaties) (thans post 14, Bijlage III, BTW-richtlijn). Volgens het Gerechtshof is daarom voor een richtlijnconforme uitleg van de tabelpost geen plaats. De Hoge Raad volgde echter het Gerechtshof niet. De Hoge Raad wijst er op dat de nationale rechter bij de uitlegging en toepassing van het nationale recht ervan moet uitgaan dat de staat de bedoeling heeft gehad uitvoering te geven aan de uit de BTW-richtlijn voortvloeiende verplichtingen:

“(...) Evenbedoelde verplichting kan mitsdien niet afstuiten op het resultaat van een wetshistorische uitlegging van de betrokken nationale bepaling, indien de bewoordingen van die bepaling een uitlegging toelaten die deze bepaling in overeenstemming doet zijn met de richtlijn. Het beginsel van de rechtszekerheid verlangt in dat geval niet dat de justitiabele die reden vindt zich nader te oriënteren omtrent de betekenis en reikwijdte van de wettelijke bepaling, met voorbijgaan aan het bepaalde in artikel 249 EG moet kunnen afgaan op uitsluitend de gevolgtrekkingen die hij meent te kunnen baseren op toelichtingen en uitlatingen die zijn gegeven of gedaan in het proces van het tot stand brengen van de wettelijke regeling. Dit is slechts anders indien in zulke toelichtingen of uitlatingen ondubbelzinnig uitdrukking is gegeven aan de welbewuste bedoeling om de nationale regeling te doen afwijken van hetgeen waartoe de richtlijn zou verplichten of de vrijheid zou laten." (r.o. 5.6)

Richtlijnconforme interpretatie kan dus afstuiten op het rechtszekerheidsbeginsel en dat is het geval als de wetgever blijk heeft gegeven welbewust te willen afwijken van de BTW-richtlijn en dat was in deze procedure dus niet het geval. ${ }^{144}$

Indien door middel van richtlijnconforme interpretatie verzoening van de Wet OB met de BTW-richtlijn niet mogelijk is dan heeft dat een aantal gevolgen. Allereerst zal dit tot gevolg hebben dat de Belastingdienst een bepaald geschil verliest. De gevolgen kunnen echter veel verder strekken. In bepaalde gevallen kan dit leiden tot schadevergoeding door de staat. ${ }^{145}$ Ook zal dan de werking van de formele rechtskracht aan de orde komen. Zie hiervoor paragraaf 5.4.

Het Hof verlangt richtlijnconforme interpretatie. Dit blijkt duidelijk wanneer het Hof overweegt dat een bepaalde term uit de BTW-richtlijn een communautaire inhoud heeft. De lidstaten kunnen van dergelijke termen ook niet afwijken. De wetgever

143. HR 10 augustus 2007, nr. 43169, V-N 2007/40.27, NTFR 2007/1513.

144. Overigens kreeg belanghebbende toch gelijk van de HR en bleef de beslissing van Gerechtshof in stand omdat met betrekking tot de infrastructuur sprake is van een sportaccommodatie.

145. Deze problematiek valt buiten het kader van mijn onderzoek en blijft dan ook onbehandeld. Zie hierover nader J.H. Jans e.a. 2002, blz. 367 t/m 415. 
dient dan ook bij dergelijke gevallen zorg te dragen dat de term in de Wet OB wordt gebruikt in de door het Hof daaraan toegekende betekenis.

In de paragrafen 4.5.1 en in het bijzonder 4.6 is naar voren gebracht dat het vaste rechtspraak is van het Hof om het secundaire Unierecht beginselconform uit te leggen. De nationale rechter, die de verplichting heeft om richtlijnconform uit te leggen, is ook gehouden het nationale recht conform de (communautaire) algemene beginselen te interpreteren. ${ }^{146}$ Dit blijkt onder meer uit het arrest inzake de Orde van Franstalige en Duitstalige Balies. ${ }^{147}$ In dit arrest wijst het Hof er op dat:

“(...) De lidstaten dienen niet alleen hun nationale recht conform het gemeenschapsrecht uit te leggen, maar dienen er ook op toe te zien dat zij zich niet baseren op een uitlegging van een bepaling van afgeleid gemeenschapsrecht die in conflict zou komen met de door de communautaire rechtsorde beschermde grondrechten of de andere algemene beginselen van gemeenschapsrecht." (r.o. 28)

De nationale rechter dient niet enkel richtlijnconform te interpreteren, maar ook beginselconform. Daarbij geldt dat een richtlijnconforme interpretatie (afgeleid recht) niet in strijd mag komen met een algemeen rechtsbeginsel.

\section{$4.8 \quad$ Conclusies}

In het geval een algemeen rechtsbeginsel zich laat gelden als interpretatiebeginsel dan is verwevenheid aan de orde met verscheidene interpretatiemethoden. Duidelijk is gemaakt dat, in het scala van interpretatiemethoden, de rechtsvergelijkende interpretatiemethode een belangrijke rol speelt bij de ontwikkeling van algemene rechtsbeginselen in de jurisprudentie van het Hof.

Naast interpretatiemethoden worden ook argumentatiemethoden onderscheiden. Behandeld zijn de analogieargumentatie en de a contrario-argumentatie. Een belangrijke drijfveer van de analogieargumentatie is het gelijkheidsbeginsel. Echter bij het onderzoek naar de gelijkheid van de gevallen speelt een interpretatief aspect een rol, namelijk de ratio van de bepaling.

Uit de jurisprudentie van het Hof blijkt dat fiscale neutraliteit een uitdrukking is van het gelijkheidsbeginsel. Fiscale neutraliteit is beperkter dan het gelijkheidsbeginsel. Het focust namelijk enkel op de gelijkheid van concurrenten. Het gelijkheidsbeginsel als algemeen rechtsbeginsel is ruimer en voorkomt alle vormen van ongelijkheid zonder objectieve rechtvaardiging. Verder geeft het gelijkheidsbeginsel ook maatstaven waar de overheid in de relatie met burgers zich aan moet houden en is dan toepasbaar als beginsel van formeel recht. Deze toepassing is afwezig bij de fiscale neutraliteit. Fiscale neutraliteit is slechts een interpretatiebeginsel dat aan de orde

146. J.H. Jans e.a. 2002, blz. 160.

147. Hof 26 juni 2007, nr. C-305/05, Orde van Franstalige en Duitstalige Balies e.a., Jur. 2007, blz. I-5305.

In deze case is beslist dat advocaten verplicht zijn om de bevoegde autoriteiten in kennis te stellen van elk feit dat zou kunnen wijzen op het witwassen van geld. 
kan zijn bij de uitleg van de BTW-regelgeving, terwijl het gelijkheidsbeginsel zowel toepasbaar kan zijn als beginsel van formeel recht dan wel als interpretatiebeginsel.

In deze paragraaf is ook een verduidelijking gegeven van de communautaire rechtsbegrippen. Een 'zuiver' communautaire rechtsbegrip is niet vaak te vinden in de jurisprudentie op het terrein van de BTW.

Verder is er op gewezen dat voor de doorwerking van de algemene beginselen de zogenoemde 'beginselconforme uitleg' van belang is. Deze beginselconforme uitleg is te vinden in de jurisprudentie van het Hof bij de uitleg van het Unierecht. Echter ook de nationale rechter, die de verplichting heeft om richtlijn conform uit te leggen, is gehouden het nationale recht conform de (communautaire) algemene rechtsbeginselen te interpreteren. Niet enkel richtlijnconforme interpretatie geldt, maar ook beginselconforme. Uiteraard binnen de bevoegdheden die de nationale rechter heeft bij de uitleg en toepassing van het Unierecht.

Hoofdstuk 5 gaat voornamelijk verder in op de algemene rechtsbeginselen van formeel recht. Vervolgens verhelderen de hoofdstukken $6 \mathrm{t} / \mathrm{m} 12$ de algemene rechtsbeginselen als interpretatiebeginsel. 


\section{Europeesrechtelijke leerstukken en de algemene rechtsbeginselen}

$5.1 \quad$ Inleiding

Het Hof heeft in de jurisprudentie een aantal leerstukken ontwikkeld die zonder enige twijfel zijn vormgegeven onder invloed van de algemene rechtsbeginselen.

In dit hoofdstuk besteed ik aandacht aan de jurisprudentie op het terrein van de machtiging voor maatregelen ter vereenvoudiging en voorkoming van misbruik (paragraaf 5.2). Dergelijke machtigingen vormen een belangrijk instrument voor de lidstaten, omdat deze een snelle en meer flexibele Brusselse en nationale regelgeving mogelijk maakt waar de normale, op uniforme besluitvorming gebaseerde regelgeving, doorgaans een lange en wat traag Europese weg is. Het speelveld is evenwel ingekaderd door het evenredigheidsbeginsel.

In paragraaf 5.3 komt het beginsel van het verbod op misbruik van recht aan de orde. Eerst schets ik de randvoorwaarden en vervolgens de algemene rechtsbeginselen die een rol spelen.

De formele rechtskracht van besluiten staat centraal in paragraaf 5.4. Daarbij komt de rol van het rechtszekerheidsbeginsel aan de orde.

In paragraaf 5.5 stel ik aan de orde de invloed van het rechtszekerheidsbeginsel op de terugwerkende kracht van regelgeving.

Uitspraken van rechters, en nog meer die van het Hof, kunnen grote gevolgen hebben voor de schatkist. Die gevolgen kunnen zelfs onoverkomelijk zijn. De vraag rijst dan of de rechter met dit voorzienbare gevolg iets moet doen. Moet een arrest altijd een werking ex tunc hebben? In paragraaf 5.6 licht ik toe onder welke voorwaarden de ex tunc-werking van arresten van het Hof wordt doorbroken. Tenslotte sluit ik in paragraaf 5.7 het hoofdstuk af met een conclusie.

\section{$5.2 \quad$ Maatregelen ter vereenvoudiging en voorkoming van misbruik}

Artikel 395, BTW-richtlijn (voorheen artikel 27, Zesde richtlijn) biedt de lidstaten de mogelijkheid om in hun nationale BTW wetgeving bepalingen op te nemen die 
afwijken van de BTW-richtlijn. Artikel 395, lid 1, BTW-richtlijn vermeldt dat de Raad op voorstel van de Commissie met eenparigheid van stemmen elke lidstaat kan machtigen, bijzondere, van de BTW-richtlijn afwijkende maatregelen te treffen ten einde de belastingheffing te vereenvoudigen of bepaalde vormen van belastingfraude of -ontwijking te voorkomen.

In artikel 395, lid $2 \mathrm{t} / \mathrm{m} \mathrm{4}$, BTW-richtlijn is de procedure te vinden die gevolgd moet worden wil de afwijkende maatregel van kracht zijn. Deze onderdelen zijn veranderd door de aanpassingsrichtlijn 2004/7/EG van 20 januari 2004. ${ }^{1}$ Voorheen was het mogelijk dat de goedkeuring tot aanpassing van de Zesde-richtlijn op grond van artikel 27, Zesde richtlijn stilzwijgend werd verleend. Het oude lid 4 regelde namelijk dat een besluit van de Raad tot aanpassing werd geacht te zijn genomen indien noch de Commissie, noch een lidstaat binnen twee maanden nadat de lidstaten in kennis waren gesteld, om behandeling van de zaak door de Raad had verzocht. Het huidige lid 3 regelt echter dat nu een voorstel, dan wel een mededeling met de eventuele bezwaren van de Commissie volgt. De mogelijkheid van een stilzwijgende goedkeuring door de Raad is dus geschrapt.

Dat de oude regeling van artikel 27, Zesde richtlijn tot onduidelijkheden leidde blijkt onder meer uit het Direct Cosmetic I-arrest ${ }^{2}$ en het Direct Cosmetic II-arrest. ${ }^{3}$ Het Hof heeft met name in het Direct Cosmetics I-arrest verduidelijkt, dat een lidstaat die de krachtens artikel 27, lid 2 (oud), Zesde richtlijn op hem rustende verplichting niet is nagekomen door de Commissie geen kennis te geven van een bijzondere maatregel die afwijkt van het de Zesde richtlijn en derhalve ingevolge artikel 27, lid 1, Zesde richtlijn machtiging van de Raad behoeft, die maatregel niet kan tegenwerpen aan een particulier. Een machtiging van de Raad is dus een vereiste om af te mogen wijken van de Zesde richtlijn. De nieuwe tekst van artikel 395, BTW-richtlijn zal waarschijnlijk een dergelijke procedure voorkomen. Nu is duidelijk dat de tekst van artikel 395, BTW-richtlijn geen stilzwijgende goedkeuring tot aanpassing van de regelgeving mogelijk maakt.

Uit de considerans van de aanpassingsrichtlijn 2004/7/EG blijkt dat de aanpassing van artikel 395, BTW-richtlijn is ingegeven door verschillende motieven. Ten eerste werden de regels tot aanpassing door de lidstaten verschillend toegepast. Dit kan in het bijzonder bij grensoverschrijdende transacties leiden tot verstoringen van de interne markt. Ten tweede voorkomt de nieuwe procedure dat een lidstaat in het ongewisse blijft over het gevolg dat de Commissie aan het verzoek om een afwijking wenst te geven. De nieuwe procedure stelt een lidstaat beter in staat om een verzoekprocedure te volgen.

Het gevolg van de aanpassing van artikel 395, BTW-richtlijn is niet alleen dat de rechtszekerheid voor de lidstaten toeneemt. Ook al blijkt uit de Considerans dat dit

1. Richtlijn 2004/7/EG, Pb 30 januari 2004, L 27/44.

2. Hof 13 februari 1985, nr. 5/84, Direct Cosmetics I, Jur. 1985, blz. 617.

3. Hof 12 juli 1988, nrs. 138 en 139/86, Direct Cosmetics II, Jur. 1988, blz. 3937. 
hetgeen is dat wordt beoogd met de aanpassing. Dat neemt niet weg dat ook de rechtszekerheid van belastingplichtigen is verbeterd. Het is nu duidelijk dat een expliciet besluit volgt. Dit besluit is aan te merken als een beschikking van algemene strekking gericht tot een lidstaat. Een beschikking van algemene strekking en gericht tot een lidstaat dient te worden geïmplementeerd in de nationale wetgeving, als deze althans onvoorwaardelijk is geformuleerd. Een beschikking is dan vergelijkbaar met een richtlijn. Het gevolg is dat belanghebbenden een beroep kunnen doen op de rechtstreekse werking van een dergelijke beschikking. Onder belanghebbende wordt niet alleen verstaan de lidstaat tot welke de beschikking is gericht, maar ook belastingplichtigen. Het in paragraaf 4.6 (directe werking) behandelde Grad-arrest ${ }^{4}$ van 40 jaar oud is dan ook relevant voor de BTW.

Uit de jurisprudentie van het Hof blijkt dat de mogelijkheden om af te wijken van de BTW-richtlijn niet onbegrensd zijn. De afwijkingen mogen niet verder gaan dan strikt noodzakelijk is ter bereiking van het doel. Dit blijkt onder meer uit het arrest van het Hof van 10 april 1984, Commissie/België. ${ }^{5}$ Deze lijn is nogmaals door het Hof bevestigd in het Skripalle-arrest ${ }^{6}$ en het K-Line-arrest. ${ }^{7}$ In het Skripalle-arrest is beslist dat de aanwezigheid van een machtiging niet noodzakelijkerwijs betekent dat een maatregel geoorloofd is. De machtiging strekt zich enkel uit over maatregelen die strikt noodzakelijk zijn voor de bestrijding van belastingontwijking of belastingfraude, indien althans niet vereenvoudiging het object van de machtiging is.

Het Hof heeft in het BATI-arrest de strekking van artikel 395, BTW-richtlijn verder verduidelijkt. In deze procedure staat centraal de houdbaarheid van een Belgische regel dat de diefstal van accijnsgoederen uit een belastingentrepot voor de BTW een belastbare levering is. Het Hof oordeelde dat de regel niet houdbaar is, gezien het gegeven dat de macht om als eigenaar te beschikken over het goed niet overgaat op de dief. Vervolgens kwam aan de orde de vraag of België de desbetreffende regeling mocht invoeren op grond van artikel 395, BTW-richtlijn. Allereerst overweegt het Hof dat België wel de regeling had aangemeld, maar dat niet duidelijk was dat het deze strekking had. Juiste melding van de regeling had dan ook niet plaatsgevonden. Ten overvloede overweegt het Hof dan - kort gezegd - dat de lidstaat ook materieel binnen de werkingssfeer van de machtiging moet blijven en niet zonder veel relatie daarmee eigen, wezenlijke en additionele regels mag maken, zoals in casu, het invoeren van een nieuw belastbaar feit (!) enkel om diefstal af te straffen. Dan zijn, zo kan men zeggen, de verhoudingen zoek. Het Hof formuleert het als volgt:

4. Hof 6 oktober 1970, nr. 9/70, Grad, Jur. 1970, blz. 825. Zie ook Hof 7 juni 2007, nr. C-80/06, Carp, Pb EG C 170/7. Zie nader M. Verhoeven, De rechtstreekse werking van de communautaire beschikking, Ars Aequi, maart 2008, blz. 214 e.v. Zij trekt uit het Carp-arrest de conclusie, dat op een beschikking van algemene strekking gericht tot een lidstaat de zogenoemde richtlijn jurisprudentie analoog kan worden toegepast. Dit is te verdedigen nu dergelijke beschikkingen net als richtlijnen een uitwerking in het nationale recht vergen.

5. Hof 10 april 1984, nr. 324/82, Commissie/België, Jur. 1984, blz. 1861, r.o. 29 en 30.

6. Hof 29 mei 1997, nr. C-63/96, Skripalle, V-N 1998/627.

7. Hof 9 juli 1992, nr. C-131/91, K-Line Air Services Europe BV, Jur. 1992, blz. 4513. 
" $\mathrm{Er}$ is niet aangetoond dat de betrokken afwijkende maatregel doelstellingen heeft als de vereenvoudiging van de belastingheffing of de strijd tegen belastingfraude of -ontwijking die als rechtvaardiging zouden kunnen dienen om diefstal van goederen te beschouwen als een levering van goederen onder bezwarende titel. Een dergelijke maatregel zou immers derogeren aan de fundamentele bepalingen van de Zesde richtlijn die de feiten vaststellen op grond waarvan BTW wordt verschuldigd, door er nieuwe categorieën belastbare feiten aan toe te voegen, en dat in de context van een onomstreden diefstal van goederen en zonder dat er aanwijzingen voor fraude zijn." (r.o. 42)

Het Hof heeft in het Ampafrance-arrest ${ }^{8}$ expliciet beslist dat toetsing dient plaats te vinden aan het evenredigheidsbeginsel. Dit is de lijn die uit de bovenstaande arresten is te destilleren. Voorts heeft het Hof ook beslist dat maatregelen geen terugwerkende kracht mogen hebben. ${ }^{9}$

De afwijkende maatregel op grond van artikel 395, BTW-richtlijn moet gericht zijn op het voorkomen van belastingfraude of -ontwijking, dan wel de belastingheffing te vereenvoudigen. Indien de maatregel gericht is op de vereenvoudiging van de belastingheffing wordt een extra eis gesteld, namelijk dat de maatregel geen noemenswaardige invloed mag hebben op het belastingbedrag dat verschuldigd is in het stadium van het eindverbruik. Deze voorwaarde is gesteld omdat de Commissie en de lidstaten willen voorkomen dat er een effect van de maatregel uitgaat op het bedrag dat een lidstaat bijdraagt aan de eigen middelen van de EU. Deze eis wordt uiteraard niet gesteld indien het gaat om maatregelen die gericht zijn op het voorkomen van belastingfraude of -ontwijking. ${ }^{10}$

Het Hof heeft op een aantal terreinen een verdere verduidelijking geven van artikel 395, BTW-richtlijn. Ik kom dan ook in de paragrafen 9.2.1 (minimummaatstaf van heffing) en 11.5.1 (beperking recht op aftrek) terug op de machtiging voor nationale van de BTW-richtlijn afwijkende maatregelen.

\subsection{Algemeen beginsel van het verbod van misbruik van recht}

Het Hof heeft in een aantal arresten beslist dat het verbod van 'misbruik van recht' onderdeel uitmaakt van het Unierecht. Dit blijkt onder meer uit de arresten Emsland-Stärcke ${ }^{11}$ en het Kefalas-arrest. ${ }^{12}$

8. Hof 19 september 2000, nrs. C-177/99 en C-181/99, Ampafrance, V-N 2000/48.19, NTFR 2000/1407. 9. Hof 29 april 2004, nr. C-17/01, W. Sudholz, V-N 2004/24.16, NTFR 2004/674 en zie ook paragraaf 11.5.1.3 voor een nadere behandeling van het aftrekrecht en het Sudholz-arrest.

10. Overigens zijn diverse maatregelen die de lidstaten mogen nemen op grond van artikel 395, BTWrichtlijn inmiddels opgenomen in de BTW-richtlijn. Zie bijvoorbeeld de regelingen die de minimummaatstaf van heffing invullen (paragraaf 9.2.2)

11. Hof 14 december 2000, nr. C-110/99, Emsland-Stärcke, Jur. 2000, blz. I-1569.

12. Hof 12 mei 1998, nr. C-367/96, Kefalas e.a., Jur. 1998, blz. I-2843. Zie verder ook Hof 3 december 1974, nr. 33/74, Binsbergen, Jur. 1974, blz. 1299; Hof 9 maart 1999, nr. C-212/97, Centros, Jur. 1999, blz. I-1459; Hof 12 december 2002, nr. C-324/00, Lankhorst-Hohorst GmbH, Jur. 2002, blz. I-9977. Zie voor de directe belastingen Hof 12 september 2006, nr. C-196/04, Cadbury Schweppes, NTFR 2006/1406. 
In het Emsland-Stärcke-arrest staat centraal de uitvoer van in Duitsland geproduceerde goederen naar Zwitserland. Emsland-Stärcke ontving op grond van deze uitvoer een uitvoerrestitutie. De goederen werden direct na de inklaring in Zwitserland in ongewijzigde staat met hetzelfde vervoermiddel onder douaneverband terugvervoerd naar de EU. Vervolgens werden de goederen ingeklaard in de EU. De Duitse douane vorderde de uitvoerrestitutie terug. De vraag was of deze vordering tot terugbetaling kan worden gebaseerd op het verbod van 'misbruik van recht'. Het Hof oordeelde dat verordeningen niet zo ruim mogen worden toegepast dat zij misbruik dekken. Misbruik van het Europees recht is aan de orde indien cumulatief aan de volgende voorwaarden wordt voldaan:

1. Uit het geheel van objectieve omstandigheden blijkt dat het door de regeling beoogde doel niet wordt bereikt.

2. Belanghebbende heeft de bedoeling om een op grond van een gemeenschapsregeling toegekend voordeel te verkrijgen door kunstmatig de voorwaarden te creëren waardoor het recht op dit voordeel ontstaat (subjectief element).

De nationale rechter behoort de aanwezigheid van de deze elementen vast te stellen volgens de nationale bewijsregels.

Uit het arrest aangaande Leusden $\&$ Holin Groep $^{13}$ is de conclusie te trekken dat het verbod op misbruik van recht zich ook laat gelden in de BTW. Het arrest geeft namelijk aan - onder verwijzing naar het eerdergenoemde Emsland-Stärcke-arrest wat als misbruik van recht kwalificeert. Onduidelijk is echter hoe het uitwerkt in de BTW en op welke wijze de voorwaarden dienen te worden ingevuld.

Mocht het arrest inzake gemeente Leusden \& Holin Groep nog twijfel overlaten over de toepasbaarheid van het verbod op 'misbruik van recht' voor de heffing van BTW, dan is dat in het Halifax-arrest ${ }^{14}$ weggenomen. Het Hof, in een ongebruikelijk korte rechtsoverweging:

"Dit beginsel van het verbod van misbruik geldt ook op het gebied van de BTW." (r.o. 70)

Het gaat hier naar ik meen om een logische stap. Niet goed valt in te zien waarom voor de BTW een uitzondering zou gelden. De BTW is een onderdeel van het Europese recht. Beginselrechtelijke uitgangspunten die binnen het Unierecht gelden, werken door in de BTW. ${ }^{15}$ Met deze constatering is echter nog niet alles even duidelijk.

13. Hof 29 april 2004, gevoegde zaken nrs. C-487/01 en C-7/02, Gemeente Leusden en Holin Groep BV, V-N 2004/24.17, NTFR 2004/670, r.o. 78.

14. Hof 21 februari 2006, nr. C-255/02, Halifax, BNB 2006/170, V-N 2006/13.20, NTFR 2006/359.

15. Van Hilten meent - op grond van het Kofoed-arrest (5 juli 2007, nr, C-321/05, V-N 2007/34.12) - dat het in het Europees recht ontwikkelde verbod van misbruik van recht enkel in een nationale BTW toepasbaar is als in het nationale recht een vergelijkbaar leerstuk is ontwikkeld. Zij meent dat het in het Unierecht ontwikkelde verbod van misbruik van recht in onze nationale BTW toepasbaar is, nu de HR het nationaal ontwikkelde fraus legis voor de omzetbelasting niet uitsluit. Conclusie A-G Van Hilten, 14 april 2011, nr. 09/03207 en nr. 09/03222, NTFR 2011/1444, paragraaf 6.2.5. 
Allereerst valt op dat het Hof in een serie arresten constructies om belasting te ontgaan heeft 'afgewezen' zonder het beginsel van het verbod van misbruik van recht daarvoor nodig te hebben:

- DFDS-arrest: ${ }^{16}$ De Deense reisorganisator DFDS A/S verkoopt reizen aan particulieren in het Verenigd Koninkrijk met tussenkomst van haar dochtermaatschappij DFDS Ltd. die aldaar als agent optreedt. DFDS A/S probeerde daarmee een voordeel te verwerven en lanceerde daarbij de stelling dat de plaats van de prestatie in Denemarken gelegen is, waar deze prestatie is vrijgesteld (op grond van de overgangsregeling van artikel 28 , lid 3, sub b, Zesde richtlijn; thans artikel 371, BTW-richtlijn). Het Hof overweegt echter dat de dochtermaatschappij in het Verenigd Koninkrijk kwalificeert als vaste inrichting en dat daar dan ook sprake is van belaste prestaties (zie verder paragraaf 8.4).

- RAL-arrest: ${ }^{17}$ Een op Guernsey gevestigde vennootschap exploiteert speelautomaten en huurt deze machines, personeel en ruimten van RAL in het Verenigd Koninkrijk. RAL verdedigde haar routing met de stelling dat de exploitatie niet belast is met Engelse BTW omdat artikel 9, lid 1, Zesde richtlijn de plaats van de dienst situeert op Guernsey. Het Hof besliste echter dat sprake is van een vermakelijkheidsdienst die op grond van artikel 9, lid 2, sub c, Zesde richtlijn belast is in de staat waar de activiteit materieel wordt verricht (in casu het Verenigd Koninkrijk) (zie verder paragraaf 8.2).

- Levob-arrest: ${ }^{18}$ De in Nederland gevestigde levensverzekeringsmaatschappij Levob schafte een standaardsoftware pakket aan in de Verenigde Staten. Het pakket werd geleverd in de Verenigde Staten aan Levob en vervolgens door Levob overgebracht naar Nederland waar het geïnstalleerd en aangepast werd door de leverancier FDP. Levob verdedigde daarbij de gedachte dat geen BTW verschuldigd was over aanschaf van de standaardsoftware in de VS. Het Hof besliste echter dat sprake was van één dienst die op grond van artikel 9, lid 2, sub e, Zesde richtlijn als ingenieursdienst (!) belast was in het land van de afnemer (in casu Nederland). Levob was dan ook BTW verschuldigd in Nederland over zowel de aanschaf als de installatie en aanpassingen van de software.

- BUPA-arrest: ${ }^{19}$ In 1997 werd bekend dat het zogenoemde nultarief (vrijstelling met recht op aftrek voorbelasting) voor ziekenhuizen in het Verenigd Koninkrijk zou worden beëindigd per 1 januari 1998. BUPA Hospitals besloot op voorhand 100 miljoen GBP aan geneesmiddelen en protheses te bestellen en deed een vooruitbetaling in 1997 om zo het nultarief nog te kunnen benutten. De goederen werden echter pas daadwerkelijk geleverd in de jaren 1998 t/m 2001 en het stond in 1997 nog niet volledig vast om wat voor goederen het zou gaan. Op de vraag van de Engelse rechter of sprake was misbruik van recht besliste het Hof dat de constructie niet werkt omdat de BTW-heffing aansluit bij de feitelijke goederenleveringen en

16. Hof 20 februari 1997, nr. C-260/95, DFDS, V-N 1997/1662, pt. 17.

17. Hof 12 mei 2005, nr. C-452/03, RAL, V-N 2005/32.26, NTFR 2005/728.

18. Hof 27 oktober 2005, nr. C-41/04, Levob Verzekeringen BV, BNB 2006/115, V-N 2005/54.19, NTFR 2005/1497.

19. Hof 21 februari 2006, nr. C-419/02, BUPA Hospitals Ltd., BNB 2006/172, NTFR 2006/467. 
niet bij de eerdere vooruitbetaling, ook al wordt men de BTW verschuldigd op het moment van de vooruitbetaling.

- Centralan-arrest: ${ }^{20}$ Zie nader hieronder.

Bij de bestudering van de feitencomplexen van deze arresten komt nogal sterk de indruk op dat belanghebbenden een geforceerde vorm hebben gekozen om zo de BTW-druk te beperken. Het Hof komt echter voor belanghebbenden tot een teleurstellend resultaat zonder het beginsel van het verbod van misbruik van recht toe te passen. De BTW-richtlijn wordt in deze procedures zo geïnterpreteerd, dat het Hof ook zonder toepassing van het verbod van misbruik tot een oplossing komt. Daarbij interpreteert het Hof de bewoordingen van de richtlijn, en soms nogal extensief: een rechtspersoon wordt, zonder dat de BTW de figuur van de vaste vertegenwoordiger kent, aangemerkt als vaste inrichting en het leveren van standaardsoftware inclusief het enigermate 'customizen' blijkt een ingenieursdienst te zijn.

Het Centralan-arrest is een pregnant voorbeeld waar het oneigenlijke karakter van de 'constructie' door interpretatie terzijde wordt geschoven. In deze procedure werd een onroerend investeringsgoed meerdere keren geleverd ${ }^{21}$ door dezelfde belastingplichtige gedurende de zogenoemde herzieningsperiode. ${ }^{22}$ Het Hof overweegt dat het stelsel van aftrek en herziening zoals dat is te vinden in artikel $167 \mathrm{t} / \mathrm{m} \mathrm{192}$, BTW-richtlijn (voorheen artikel $17 \mathrm{t} / \mathrm{m} 20$ Zesde Richtlijn) tot doel heeft een nauw en rechtstreeks verband te vestigen tussen het recht op aftrek van voorbelasting en het gebruik van de betrokken goederen en diensten voor belaste handelingen (r.o. 73). Vervolgens stelt het Hof vast dat deze doelstelling het meest toereikend kan worden verwezenlijkt door beide aan de orde zijnde leveringen in aanmerking te nemen naar rato van de respectieve waarde ervan (r.o. 74). De herziening van de in aftrek gebrachte voorbelasting op basis van de verhouding in waarden beantwoordt volgens het Hof dan ook het meest aan de eerder geformuleerde doelstelling van

20. Hof 15 december 2005, nr. C-63/04, Centralan Property Ltd., V-N 2005/61.19, NTFR 2006/90.

21. Of beide transacties daadwerkelijk beschouwd kunnen worden als een levering laat het Hof aan de nationale rechter over (r.o. 63). Het Hof geeft vervolgens aan wat de gevolgen zijn voor de toepassing van artikel 20, lid 3 Zesde richtlijn als de verwijzende rechter tot de slotsom komt dat sprake is van twee nauw met elkaar verbonden leveringen (r.o. 64 e.v).

22. Centralan droeg een gebouw over door twee opeenvolgende handelingen aan dezelfde afnemer, namelijk door het sluiten van een verhuurovereenkomst voor 999 jaar (vrijgesteld van BTW) en drie dagen later door het leveren van het 'rest' eigendomsrecht (belast met BTW). Centralan was van mening dat de voorbelasting op het pand dat zij in aftrek had gebracht niet hoefde te worden herzien omdat de levering belast had plaatsgevonden en de vrijgestelde verhuur buiten beschouwing moest blijven. Kennelijk veronderstelde Centralan dat de verhuur voor een periode van 999 jaar een dienst is en dan ook niet van belang is voor de herzieningsbepaling. Het Hof is echter van mening dat de verhuur en de drie dagen latere verkoop twee handelingen zijn die onlosmakelijk met elkaar zijn verbonden en die beiden de overdracht vormen van de macht om als eigenaar over het onroerend goed te beschikken. Het onroerend goed wordt dan geacht tot aan het einde van de herzieningsperiode te zijn gebruikt voor een economische activiteit die gedeeltelijk belast en gedeeltelijk vrijgesteld is, naar rato van de respectieve waarde van de twee handelingen. Dit betekende dat Centralan een fors gedeelte van de in aftrekgebrachte voorbelasting diende terug te betalen gezien het feit dat de 'rest' levering slechts een klein bedrag opleverde ten opzichte van de eerdere verhuur voor 999 jaar. 
het recht op aftrek van voorbelasting. In de tekst van herzieningsbepaling (artikel 20, lid 3, Zesde richtlijn, thans artikel 188 , lid 1, BTW-richtlijn) is deze pro-rata niet te vinden. Het Hof geeft zelfs aan (r.o. 77) dat de BTW-richtlijn niet voorziet in een dergelijke regeling, terwijl andere bepalingen in de BTW-richtlijn, in het bijzonder artikel 17, lid 5, Zesde richtlijn (huidig artikel 173, lid 1, BTW-richtlijn) wel uitdrukkelijk voorzien in een pro-rata regeling. Het Hof gebruikt vervolgens deze pro-rata methode om op dit geval toe te passen. En daarmee is het pleit beslecht; de aftrek van voorbelasting wordt tot de omvang van de vergoeding voor de verhuur niet gerestitueerd. Als ik het goed samenvat, geeft het Hof een gemengde kwalificatie over de feiten en het recht (of: interpretatie van feit en recht), gevolgd door een analoge toepassing van de pro-rata methode die wij voor dit geval in de richtlijn niet kennen, gemotiveerd met het doel van de aftrekregeling (zie hierover 4.4.3). ${ }^{23}$

Het gaat op deze plaats te ver om uitgebreid in te gaan op bovenstaande jurisprudentie. Van belang in dit kader is dat het Hof in diverse arresten niet kiest voor toepassing van het verbod van misbruik van recht om een constructie om belasting te ontgaan te verijdelen. Door een ruime interpretatie van de regelgeving die is te vinden in de BTW-richtlijn, komt het Hof tot een resultaat waardoor de constructie wordt getackeld. Het Hof volgt - kort weergegeven - de benadering: 1. interpretatie; 2. ruime interpretatie van de tekst binnen context en ratio; 3. toepassing van het beginsel van het verbod van misbruik van recht. ${ }^{24}$ Deze volgorde in toepassing van de verscheidene doctrines komt overeen met onze nationale rechtspraak. ${ }^{25}$

23. Overigens is niet alleen de uitleg van artikel 20 , lid 3, Zesde richtlijn in het geding. Ook is aan de orde de fiscale kwalificatie van de verhuur. Het Hof laat dit aan de nationale rechter over (r.o. 63) en beantwoordt de vragen over de uitleg van artikel 20, lid 3, Zesde richtlijn ervan uitgaande dat er een tweetal nauw met elkaar verbonden leveringen zijn (r.o. 64 e.v.).

24. Zie Hof 21 februari 2008, nr. C-425/06, Part Service Srl, V-N 2008/11.17. In deze procedure overweegt het Hof dat de nationale rechter moet beoordelen of de aan hem voorgelegde gegevens kenmerkend zijn voor één enkele handeling, ongeacht hoe zij contractueel is uitgewerkt. Om vervolgens er op te wijzen dat (r.o. 55): "In deze context kan hij zich genoodzaakt zien zijn analyse uit te breiden door naar aanwijzingen te zoeken die duiden op misbruik, het begrip dat aan de orde is in de prejudiciële verwijzing (cursief: AHB)."

25. Zie H.W.M. van Kesteren, Misbruik van recht in de omzetbelasting (oratie Tilburg), Deventer: Kluwer 2004, blz. 7 e.v. Van Kesteren brengt naar voren dat fraus legis een bijzonder rechtsmiddel is dat pas in stelling kan worden gebracht nadat andere methoden van rechtsvinding zijn uitgeput. Vgl. R.L.H. IJzerman, Het leerstuk van de wetsontduiking in het belastingrecht (diss. Amsterdam UvA), Deventer: Kluwer 1991, paragrafen 3.2.5 en 4.3. Zie tevens Geppaart 1965, blz. 192, waar hij naar voren brengt dat fraus legis slechts aan de orde kan zijn als de normale fiscale rechtsvindingsmethoden zijn uitgewerkt. Zie ook de conclusie van A-G Wattel, 11 december 2002, nrs. 37.641 t/m 37.448, V-N 2003/ 15.24, en dan in het bijzonder pt. 5.4 toegespitst op fiscaal rechtelijke kwalificatie van de feiten. Zie nader over de plaats in de algemene rechtsleer J.H.M. Nieuwenhuizen, Rechtsvinding en fiscale werkelijkheid (diss. Tilburg), Deventer: Kluwer 2010, blz. 18 en 19. Overigens is Nieuwenhuizen van mening dat fraus legis geen bijzondere techniek van rechtsvinding is maar in het verlengde ligt van de gebruikelijke rechtsvindingfactoren (blz. 247 e.v.). Zie ook de conclusie van A-G Van Hilten (14 april 2011, nr. 09/03207 en nr. 09/03222, NTFR 2011/1444) en dan paragraaf 6.9 waar zij er op wijst dat het verbod van misbruik van recht - gezien de inbreuk op het rechtszekerheidsbeginsel - een ultimum remedium is. In gelijke zin R.H. Happé 2011, blz. 33. 
Bijzonder in het Centralan-arrest is dat het Hof een uitleg geeft van de regelgeving die niet is te vinden in de tekst van de bepaling - dit ook expliciet overweegt - maar toch kiest voor een uitleg ten nadele van belanghebbende op grond van de ratio van de bepaling. De stappen die het Hof zet in de overwegingen die de beslissing dragen zijn gebaseerd op wat in paragraaf 4.4 .3 is beschreven als een analogieargumentatie. Naar mijn mening is het zo dat het Hof wel een zelfde volgorde toepast in doctrines als in onze nationale rechtspraak, echter eerder geneigd is 'constructies' te ontmantelen met een doel strekking uitleg en daarbij minder snel een bijzonder beginsel nodig heeft als misbruik van recht. Op dit punt is volgens mij wel een verschil met onze nationale praktijk. Zo wijst de literatuur erop dat fraus legis functioneert als ultimum remedium om de strekking van de wet praeter legem tot gelding te kunnen brengen, voorbij de uiterste grens van de in de wet gehanteerde bewoordingen. ${ }^{26}$

Naast de vorenstaande methode van extensieve uitleg van de BTW-richtlijn, is nu duidelijk dat het beginsel van het verbod van misbruik van recht binnen de BTW een plaats heeft gekregen. ${ }^{27}$ De vraag komt dan op in welke situaties het zich laat gelden.

Het Hof formuleert een tweetal voorwaarden in het Halifax-arrest:

1. De betrokken transacties leiden ertoe dat in strijd met het beoogde doel van de bepalingen die van toepassing zijn een belastingvoordeel wordt toegekend (r.o. 74). Vervolgens geeft het Hof aan dat strijdigheid met het doel van een regeling aan de orde is indien belastingplichtigen recht op aftrek van voorbelasting wordt toegekend, terwijl zij in het kader van hun normale handelstransacties de voorbelasting niet kunnen aftrekken (r.o. 80). ${ }^{28}$

2. Uit het geheel van objectieve factoren blijkt dat het wezenlijke doel van de transacties erin bestaat een belastingvoordeel te verkrijgen. Dit is niet het geval wanneer voor de betrokken transacties een andere verklaring bestaat dan louter de verkrijging van belastingvoordelen (r.o. 75). Of aan deze voorwaarden is

26. Zie bijvoorbeeld R.L.H. IJzerman 1991, blz. 61 e.v.

27. Op het onderscheid tussen extensief interpreteren, analogie en fraus legis ga ik niet in; zie onder meer: C.J. Oranje, Analogie en fraus legis, in: Leids fiscaal jaarboek 1986, Arnhem: Gouda Quint BV, blz. 135. R.L.H. IJzerman 1991, paragrafen 3.2.5 en 4.

28. Zie in kader het arrest Weald Leasing waar het Hof erop wijst dat, wanneer een onderneming ervoor kiest bedrijfsmiddelen te leasen in plaats van deze bedrijfsmiddelen rechtstreeks te verwerven, dit niet leidt tot een belastingvoordeel dat wordt toegekend in strijd met het doel dat door de relevante bepalingen van de BTW-richtlijn wordt nagestreefd, op voorwaarde dat de contractvoorwaarden inzake deze leasetransacties, in het bijzonder die met betrekking tot de vaststelling van de leasevergoeding, overeenstemmen met normale marktvoorwaarden en de betrokkenheid van een derde intermediair bij die transacties niet ertoe leidt dat de toepassing van die bepalingen wordt verhinderd. Daarbij is het niet van belang dat deze onderneming in de context van haar normale handelstransacties geen leaseactiviteiten uitoefent. Hof 22 december 2010, nr. C-13/09, Weald Leasing Ltd, V-N 2011/8.18, NTFR 2011/81, r.o. 45. Zie hierover de conclusie van A-G Van Hilten (14 april 2011, nr. 09/ 03207 en nr. 09/03222, NTFR 2011/1444) en dan in het bijzonder paragraaf 6.5.11. Zie verder T. Vroon, Vreemd is niet gek, BTW-Brief 2011/29. 
voldaan dient de nationale rechter te beoordelen. Wel geeft het Hof aan dat daarbij het artificiële karakter van de handelingen in aanmerking dient te worden genomen, evenals de banden van juridische, economische en/of persoonlijke aard tussen de bij de constructie betrokken belastingplichtigen (r.o. 81). ${ }^{29}$

Wanneer eenmaal is vastgesteld dat in een bepaalde casus sprake is van misbruik van recht dan rijst de vraag hoe dat misbruik wordt geredresseerd. Vooreerst laat het Hof de lidstaten daarin vrij. Daarbij moeten zij wel binnen de grenzen van het Unierecht blijven. ${ }^{30}$ Met deze voorwaarde is bedoeld dat de lidstaten geen maatregelen mogen treffen die verder gaan dan noodzakelijk is voor het bereiken van een juiste heffing. In deze voorwaarde lijkt besloten te liggen het in paragraaf 3.4.2 beschreven evenredigheidsbeginsel.

Bij misbruik van het BTW-recht dient volgens het Hof voor de heffing van BTW uitgegaan te worden van de situatie zoals deze zou zijn indien geen sprake zou zijn geweest van misbruik. De belastingadministratie kan dan BTW naheffen van elke transactie waarvan hij vaststelt dat daarmee misbruik is gemaakt van het recht op aftrek van voorbelasting. Daarbij dient dan wel de belasting te worden afgetrokken die belastingplichtigen artificieel verschuldigd waren in het kader van de constructie, uiteraard voor zover deze belasting door belanghebbende op aangifte is voldaan. Op deze wijze leidt de toepassing niet tot een sanctie (r.o. 93). Dat wil zeggen wat de heffing van enkelvoudige belasting betreft. Of een boete door de Belastingdienst kan worden opgelegd is een andere vraag. Het Hof geeft aan dat daarvoor een aparte rechtsgrondslag vereist is. In de Nederlandse situatie is dat de regelgeving op het terrein van het strafrecht dan wel het administratieve recht.

Nu door de rechtspraak van het Hof het verbod op misbruik van recht ook een plaats binnen de BTW heeft gekregen, is in deze studie de vraag naar de relatie met de algemene rechtsbeginselen relevant. In elk geval springen twee algemene rechtsbeginselen ogenblikkelijk in het oog, namelijk het rechtszekerheidsbeginsel en het gelijkheidsbeginsel.

29. Zie nader Hof 21 februari 2008, nr. C-425/06, Part Service SRL, V-N 2008/11.17. In dit arrest heeft het Hof verduidelijkt dat verkrijging van het belastingvoordeel het wezenlijke doel moet zijn geweest, ook al hebben daarnaast economische doelen op het vlak van bijvoorbeeld marketing, organisatie en garantie mogelijk een rol gespeeld. Zie ook Hof 22 december 2010, nr. C-277/09, RBSD, V-N 2011/8.19, NTFR 2011/82. In het RBSD-arrest wijst het Hof erop (r.o. 53) dat een belastingplichtige in de regel vrij is om die organisatorische structuren en die voorwaarden van een transactie te kiezen welke hem het meest geschikt lijken om zijn economische activiteiten uit te oefenen en de op hem rustende belastingdruk te verlichten. Zijlstra meent dat het gekunstelde karakter van de vormgeving is te meten aan de hand van de zakelijke verkeersopvattingen, P.F. Zijlstra, Belastingplanning en en rechtsmisbruik in de omzetbelasting, WFR 2011/167. Vgl. A-G Van Hilten in pt. 6.6.5 in haar conclusie van 14 april 2011 (nr. 09/03207 en nr. 09/03222, NTFR 2011/1444).

30. Zie Hof 22 december 2010, nr. C-13/09, Weald Leasing Ltd, V-N 2011/8.18, NTFR 2011/81, r.o. 48 t/m 53. 
Het Hof overweegt in het Halifax-arrest dat de gemeenschapsregeling met zekerheid kenbaar dient te zijn en de toepassing ervan voorzienbaar (r.o. 72). Vooral indien een regeling financiële gevolgen heeft is het rechtszekerheidsbeginsel een dwingend vereiste, zodat belanghebbenden de omvang van hun verplichtingen nauwkeurig kennen. Het beginsel van het verbod van misbruik van recht heeft tot gevolg dat belanghebbenden niet kunnen afgaan op de letterlijke tekst van de BTW-richtlijn. Vertrouwen dat zij kunnen ontlenen aan de regelgeving wordt opzij gezet. Advocaatgeneraal Maduro besteedt in zijn conclusie bij het Halifax-arrest aandacht aan de grenzen van het verbod van misbruik van het Unierecht:

"Het vaststellen van de werkingssfeer van dit communautaire beginsel voor het gemeenschappelijke BTW-stelsel komt in feite erop neer, waar de grens moet worden getrokken bij de uitlegging van de bepalingen van de BTW-richtlijnen die rechten toekennen aan de belastingplichtigen. Daartoe dient de objectieve analyse van het misbruikverbod te worden afgewogen tegen de beginselen van rechtszekerheid en vertrouwensbescherming, die ook 'deel uitmaken van de communautaire rechtsorde' en op basis waarvan de bepalingen van de Zesde richtlijn moeten worden uitgelegd. Uit deze beginselen volgt dat de belastingplichtigen hun fiscale verplichtingen vooraf moeten kunnen kennen en daartoe moeten kunnen afgaan op de gewone betekenis van de woorden van de BTW-wetgeving." (punt 84)

Het rechtszekerheidsbeginsel is niet het schild dat belanghebbende bescherming biedt als misbruik van recht aan de orde is. Wij raken hier de kern van misbruik van recht.

De rechtszekerheid wordt onthouden aan een bepaalde groep van belanghebbenden, namelijk zij die beogen door het creëren van kunstmatige condities, een recht op een fiscaal voordeel te verkrijgen in strijd met het doel van de regeling. Gezien het uitgangspunt dat de gekozen opzet enkel is gecreëerd met het oog op de fiscale gevolgen, zal veelal sprake zijn van een bewuste risicoaanvaarding die bij de aanwezigheid van strijd met het doel van de regeling, een doorbreking van de rechtszekerheid kan rechtvaardigen. ${ }^{31}$

Overigens is een relativering op zijn plaats van wat hierboven is aangeduid als een 'doorbreking van de rechtszekerheid'. Zoals eerder is geconstateerd, is één van de voorwaarden voor toepassing van het verbod van misbruik van recht, dat onverkorte toepassing van de letterlijke tekst van de regeling in strijd is met het doel dat wordt beoogd met de regeling. Het doel dat de regeling tracht te bereiken zal veelal kenbaar zijn voor belanghebbende. Deze kenbaarheid bij belanghebbende blijkt uit het feit dat hij kiest voor een gekunstelde opzet die geen ander doel dient dan het behalen van het fiscale voordeel. Uit het ontgaansmotief bij belanghebbende kan

31. Vgl. R.L.H. IJzerman 1991, blz. 88, 89 en 98, over doorbreking van de rechtszekerheid bij toepassing van analogie ten nadele van belanghebbende. 
blijken dat bij hem kenbaar is wat het doel is dat de regeling tracht te bereiken. ${ }^{32}$ Hij probeert namelijk het doel dat de regeling nastreeft juist te ontwijken. Een belanghebbende die kiest voor een dergelijk handelwijze, dient er op bedacht te zijn dat de rechter de regeling toepast conform het doel dat de regeling nastreeft. Strijd met het rechtszekerheidsbeginsel is pas aan de orde als het doel dat de regeling tracht te bereiken niet kenbaar is of kan zijn voor belanghebbenden.

De rol van het gelijkheidsbeginsel is onmiskenbaar. Nieuwenhuizen brengt naar voren dat een beroep op misbruik van recht in feite een beroep op een economische benadering is waarbij het eindresultaat van het samenstel van (rechts)handelingen als uitgangspunt wordt genomen. ${ }^{33}$ De reden hiervoor is dat dit eindresultaat uit een oogpunt van rechtsgelijkheid prevaleert boven het resultaat van de individuele transacties. ${ }^{34}$ Ook de toetsing aan doel en strekking van de wet is volgens Nieuwenhuizen gedeeltelijk terug te voeren op het rechtsgelijkheidsbeginsel. Nieuwenhuizen meent:

"Getoetst wordt wat de gevolgen zijn bij beoordeling van de individuele transacties en vervolgens wordt nagegaan of de gevolgen daarvan, uit een oogpunt van rechtsgelijkheid, in strijd komen met een andere wettelijke regeling of een hogere rechtsnorm (namelijk de bedoeling van de desbetreffende wet)." 35

32. IJzerman merkt in dit kader op toegespitst op fraus legis: "Het legaliteitsprincipe impliceert (...) dat belanghebbenden hun fiscale verplichtingen in beginsel moeten kunnen kennen uit de wet. Toepassing van fraus legis is een doorbreking van de rechtszekerheid geboden door de wettekst. Dat is mijns inziens slechts aanvaardbaar indien de (aanmerkelijke kans op) doorbreking voor belanghebbende eveneens kenbaar is, namelijk doordat de mogelijkheid van een dergelijke doorbreking gebonden is aan de voorwaarde dat gehandeld wordt om fiscaal voordeel te behalen, zonder dat overigens sprake is van reële zakelijke of anderszins aanvaardbare (...) motieven. Indien er naast het oogmerk van belastingbesparing mede sprake is van reële motieven dient de reële, praktische betekenis van de op grond van de laatstgenoemde motieven tot stand gekomen feiten te worden afgewogen tegen het zuivere streven naar belastingvoordeel. Belanghebbenden kunnen immers worden geacht in staat te zijn zelf te beoordelen of voorgenomen handelingen volstrekt overwegend fiscaal gemotiveerd zijn, zodat het tevoren voldoende duidelijk is dat het risico van toepassing van fraus legis aanwezig is." R.L.H. IJzerman 1991, blz. 102.

33. J.H.M. Nieuwenhuizen, Fraus legis (misbruik van recht) en fiscaal-rechtelijke kwalificatie in de BTW, WFR 2003/6557, blz. 1975. A-G Van Hilten daarentegen toetst enkel die handelingen die het belastingvoordeel hebben teweeggebracht aan de criteria van misbruik van recht, conclusie van 1 oktober 2009, nr, 08/05317, V-N 2009/65.19. De HR volgt haar conclusie niet en kijkt wel degelijk naar de laatste handeling die belanghebbende verricht om het totaal aan handelingen te beoordelen, HR 10 februari 2012, nr. 08/05317, V-N 2012/13.20, NTFR 2012/639, r.o. 3.5.2. Zie tevens J.H.M. Nieuwenhuizen 2010, blz. 37 waar hij naar voren brengt dat het Hof in het Halifax-arrest de neutraliteit (in de betekenis van het van BTW-druk bevrijden van transacties) naar voren brengt om de gelijkheid te beargumenteren.

34. Nieuwenhuizen formuleert het als volgt: "Het enkele feit dat de individuele transacties - op zichzelf bezien - onder bepaalde rechtsregels vallen en tot een bepaald fiscaal gevolg leiden, betekent niet dat andere rechtsregels, die zijn geschreven voor gevallen die gelijkwaardig zijn aan het uiteindelijke feitelijke resultaat, uit oogpunt van rechtsgelijkheid niet veel meer van toepassing behoren te zijn." J.H.M. Nieuwenhuizen 2010, blz. 247.

35. J.H.M. Nieuwenhuizen 2003, blz. 1975. 
Overigens zal het punt van de rechtsgelijkheid voor menigeen betwistbaar zijn. Men kan naar voren brengen dat een ieder die zich aan de woorden van de wet houdt gelijk wordt behandeld. Het lijkt mij dat hetgeen waar Nieuwenhuizen op duidt dan ook terug is te voeren op het bestaan van strijd met doel en strekking van de wet met het eindresultaat van het samenstel van (rechts)handelingen.

Uit het bovenstaande komt naar voren dat tussen de toepassing van de algemene rechtsbeginselen van gelijkheid en rechtszekerheid spanning bestaat. Het lijkt erop dat het ene beginsel slechts kan worden bereikt door het andere op te offeren. ${ }^{36}$ Voor zover het verbod op misbruik van recht steunt op het gelijkheidsbeginsel, wint dit beginsel het boven de rechtsbescherming die het rechtszekerheidsbeginsel biedt.

Met de beschrijving van de functie van de algemene rechtsbeginselen, die bij het verbod van misbruik van recht aan de orde zijn, is nog niet aangegeven wat het effect van de toepassing is. Het Hof zegt hierover:

“(...) justitiabelen ingeval van fraude of misbruik geen beroep op het gemeenschapsrecht kunnen doen." (r.o. 68)

Het verbod op misbruik van het Unierecht is geregeld aan de orde geweest. ${ }^{37}$ In meerdere arresten is dit uitgangspunt toegelicht met de overweging dat een gemeenschapsregeling niet zo ruim mag worden toegepast dat zij misbruik door ondernemers dekt, door betekenis toe te kennen aan transacties die niet zijn verricht in het kader van normale handelstransacties, maar uitsluitend met het doel om de door het Unierecht toegekende voordelen onverschuldigd te krijgen. ${ }^{38}$ Het bovenstaande uitgangspunt is in het Halifax-arrest vervolgens voor de BTW geoperationaliseerd.

In ieder geval is evident dat misbruik een beroep op het Unierecht uitsluit. Dit uitgangspunt raakt een universeel grondbeginsel in het recht en kan gezien worden als een klassiek voorbeeld van een algemeen rechtsbeginsel. ${ }^{39}$ Zo brengt Dworkin dit aspect naar voren om 'beginselen' te onderscheiden van 'regels' (zie in dit kader

36. C.J. Oranje 1986, blz. 135. Zie ook J.H.M. Nieuwenhuizen 2003, die aangeeft dat fraus legis in wezen niets anders is dan het afwegen van het beginsel van de rechtsgelijkheid en het beginsel van rechtszekerheid waarbij de rechtsgelijkheid uiteindelijk prevaleert. Zie verder ook paragraaf 3.2.2 waar is toegelicht dat rechtsbeginselen tegengesteld kunnen zijn i.t.t. rechtsregels.

37. Zie bijvoorbeeld: Hof 2 mei 1996, nr. C-206/94, Paletta, Jur. 1996, blz. I-2357, r.o. 25; Hof 12 mei 1998, nr. C-367/96, Kefalas e.a., Jur. 1998, blz. I-2843, r.o. 20; Hof 23 maart 2000, nr. C-373/97, Diamantis, Jur. 2000, blz. I-1705, r.o. 33. Zie specifiek voor de BTW: Hof 3 maart 2005, nr. C-32/03, I/S Fini H, V-N 2005/15.8, NTFR 2005/322, r.o. 32; Hof 6 juli 2006, nrs. C-439/04 en C-440/04, A. Kittel, V-N 2006/42.13, r.o. 54 .

38. Hof 3 maart 1993, nr. C-8/92, General Milk Products, Jur. 1993, blz. I-779, Hof 14 december 2000, nr. C-110/99, Emsland - Stärcke, Jur. 2000, blz. I-11569, r.o. 51; en uiteraard het eerder aangehaalde Halifax-arrest in r.o. 69.

39. Dat het een universeel uitgangspunt raakt blijkt onder meer uit het feit dat de wortels van het leerstuk en de naam 'fraus legis' stammen uit het Romeinse recht. Verder is de oorsprong van het uitgangspunt te vinden in het gemene recht. Zie voor een historisch overzicht R.L.H. IJzerman 1991, blz. 25 t/m 28 . 
meer uitgebreid voor dit onderscheid 3.2.2). ${ }^{40}$ Hij verwijst naar een klassieke beslissing in de Amerikaanse jurisprudentie uit 1889. Deze procedure had betrekking op een erfgenaam die zijn grootvader vermoordde om zo te erven gezien het feit dat hij genoemd werd in het testament van het slachtoffer. De rechter begon te overwegen dat het erfrecht tot gevolg heeft dat de dader erft. Echter de rechter vervolgde met te overwegen dat:

"No one shall be permitted to profit by his own fraud, or to take advantage of his own wrong, or to found any claim upon his own iniquity, or to acquire property by his own crime."

Het gevolg was, dat de dader ondanks het testament en het duidelijke erfrecht niet erfde. Dworkin verwijst naar deze procedure om het onderscheid tussen rechtsregels en rechtsbeginselen te verduidelijken. Verder brengt hij ook naar voren dat een beginsel als 'no man may profit from his own wrong' een beslissing kan onderbouwen en in een bepaalde richting kan wijzen. ${ }^{41}$ Echter het beginsel zal niet duidelijk een bepaalde beslissing opleggen. Ook andere algemene rechtsbeginselen zullen daarbij in de beschouwing moeten worden betrokken. Deze kunnen zelfs een andere kant op wijzen.

Uiteraard is de aangehaalde beslissing van een andere orde dan de constructies die een rol spelen in de jurisprudentie van het Hof over het verbod van misbruik van recht. Echter ook in de aangehaalde beslissing uit 1889 in de Amerikaanse jurisprudentie faalt het beroep op de letterlijke tekst gezien het uitgangspunt dat het recht niet mag worden misbruikt.

Ook de arresten en de bewoordingen van de uitspraken van het Hof kan men verstaan als toepassing van een apart beginsel ('beginsel van het verbod op misbruik van recht'). Van Kesteren lijkt deze conclusie te trekken. Hij meent dat het er alle schijn van heeft dat het leerstuk misbruik van recht is uitgegroeid van een hulpmiddel bij de interpretatie van de strekking van Europese rechtsregels, tot een zelfstandig beginsel. ${ }^{42}$

Advocaat-generaal Maduro ziet het verbod op misbruik van het Unierecht als een 'uitleggingsbeginsel', dat niet leidt tot afwijkingen van de bepalingen van de BTWrichtlijn. ${ }^{43}$ Het resultaat van de toepassing ervan is dat:

40. R. Dworkin, Taking rights seriously, London: Duckworth 1994, blz. 23.

41. R. Dworkin 1994, blz. 26.

42. H.W.M. van Kesteren 2004, blz. 10, Zie ook J.H.M. Nieuwenhuizen 2010, blz. 65. Hij meent dat ook al is er discussie over de precieze betekenis, er brede overeenstemming bestaat dat het een algemeen beginsel van Europees recht is. Happé duidt fraus legis aan als een rechtsbeginsel, R.H. Happé 2011, blz. 15. Recent heeft de HR het aangeduid als 'een algemeen beginsel van het recht van de Unie', HR 10 februari 2012, nr. 08/05317, V-N 2012/13.20, NTFR 2012/639, r.o. 3.3.2. Zie verder voor de nationale toepassing HR 30 maart 2012, nr. 09/03079, nog niet gepubliceerd.

43. A-G Maduro, conclusie van 7 april 2005 bij de arresten Halifax, C-255/02; Bupa, C-419/02; University of Huddersfield, C-223/03. 
“(...) de uitgelegde bepaling niet het betrokken recht verleent, omdat dat geclaimde recht kennelijk vreemd is aan de strekking en het doel van de vermeend misbruikte bepaling. Het belangrijkste gevolg van de toepassing van dit uitleggingsbeginsel is dat de verrichte economische activiteiten niet buiten beschouwing blijven voor de BTW en niet buiten de werkingssfeer van de Zesde richtlijn vallen. De uitlegging van de Zesde richtlijn aan de hand van dit beginsel kan alleen maar leiden tot de meest voor de hand liggende conclusie in het kader van de wetsuitlegging: dat het recht in feite niet wordt verleend, niettegenstaande de letterlijke betekenis van de bepaling. Als deze uitlegging al een afwijking meebrengt, dan alleen van de tekst van de bepaling, maar niet van de bepaling zelf, die immers méér inhoudt dan alleen de letterlijke betekenis." (punt 79)

Het Hof duidt, in de aangehaalde jurisprudentie, het verbod op het misbruik van het Unierecht niet expliciet aan als een algemeen rechtsbeginsel. In de rechtsoverwegingen is het daarentegen wel degelijk verwoord als een basisprincipe, dat niet enkel geldt in de BTW maar in het gehele Unierecht.

In paragraaf 3.2.3 zijn algemene rechtsbeginselen omschreven als grondslagen die onmiddellijk evident zijn en algemeen in het recht worden erkend als juridisch geldend. Duidelijk is dat het Hof het verbod op misbruik van recht erkent en dat ook in andere rechtsstelsels vergelijkbare uitgangspunten zijn te herkennen. Dat neemt niet weg dat de toepassing in het Nederlandse BTW-recht zeker niet onomstreden is. ${ }^{44}$ Dit gezien, zoals eerder naar voren is gebracht, het conflict dat ontstaat met het rechtszekerheidsbeginsel. Het Hof geeft het verbod op misbruik echter een onbetwistbare plaats in het recht van de Unie. Ik ben dan ook van mening dat het verbod op misbruik van recht voldoet aan de in paragraaf 3.2.3 gegeven omschrijving van een algemeen rechtsbeginsel. Dit beginsel kan aan de orde zijn indien een wetsuitleg vereist is die afwijkt van de letterlijke betekenis van de bepaling, maar niettemin in overeenstemming is met het doel dat de bepaling tracht te bereiken. Het verbod op misbruik van het Unierecht fungeert dan als een interpretatiebeginsel en is de rechter behulpzaam bij de uitleg van het Unierecht in overeenstemming met de bedoeling van de regels. ${ }^{45}$ In paragraaf 3.3.1 is het onderscheid toegelicht tussen beginselen van formeel recht en interpretatiebeginselen. Vervolgens is in paragraaf 3.3.2 behandeld een verruimende en inperkende werking van de algemene rechtsbeginselen. Deze werking is toegelicht met voorbeelden waarbij een inperkende dan wel verruimende werking in het voordeel van belanghebbende uitpakte. Het interpretatiebeginsel van het verbod op misbruik van Unierecht werkt in elk geval in het nadeel van belanghebbende.

44. Zie hierover uitgebreid de oratie van H.W.M. van Kesteren 2004. Van Kesteren besteedt onder meer aandacht aan de kritiek in de literatuur op de toepasbaarheid van fraus legis in de BTW. De HR heeft het verbod van misbruik van recht toegepast in de BTW in het arrest van 10 februari 2012, nr. 08/05317, V-N 2012/13.20, NTFR 2012/639.

45. Happé brengt naar voren dat het bij de algemene beginselen van behoorlijk bestuur gaat om het gedrag van de Belastingdienst, bij fraus legis om dat van de belastingplichtige. Op deze wijze hebben maatschappelijke, ethische opvattingen hun doorwerking in het recht, Happé 2011, blz. 15 en 16. Volgens mij kan het verbod van misbruik van recht ook worden aangeduid als een gedragsbeginsel, maar dan als een gedragsbeginsel gericht op het gedrag van de belastingplichtige. De in paragraaf 3.3.1 beschreven gedragsbeginselen focussen op het gedrag van de overheid. 
Zoals advocaat-generaal Tesauro stelt in zijn conclusie bij het Kefalas-arrest ${ }^{46}$ moet:

“(...) elke rechtsorde die naar een minimale volledigheid streeft, maatregelen bevatten, die ik als zelfbeschermingsmaatregelen zou willen aanduiden, teneinde te voorkomen dat de daardoor toegekende rechten op abusieve, buitensporige of verkeerde wijze worden uitgeoefend. Een dergelijk vereiste is de communautaire rechtsorde geenszins vreemd." (punt 24)

Het gemeenschappelijke BTW-stelsel staat bloot aan het risico, inherent aan elk rechtsstelsel, van praktijken die formeel met de regel overeenstemmen, maar die de mogelijkheden die de regel biedt, misbruiken op een wijze die strijdig is met de strekking en doelstellingen ervan. Het algemeen beginsel van verbod van misbruik van recht fungeert als laatste middel om doel en strekking van de regelgeving te doen prevaleren over de geïnterpreteerde regelgeving. Een ontwikkeld BTW-stelsel heeft behoefte aan een algemeen werkende methode om uitsluitend op belastingbesparing gericht handelen niet te aanvaarden op de wijze zoals door belanghebbende beoogd, indien een dergelijk handelen gekunsteld is en ingaat tegen doel en strekking van de bepalingen. ${ }^{47}$

\subsection{Formele rechtskracht van besluiten}

De beperkte termijn waarbinnen bezwaar en beroep kan worden ingesteld, kan tot gevolg hebben dat de toegang tot de rechter is beperkt en dat belanghebbende de effectuering van aan het Unierecht te ontlenen rechten niet kan verwezenlijken. ${ }^{48}$ Het kan namelijk voorkomen dat op enig moment het Hof de betekenis van een BTW-regel verduidelijkt zoals deze betekenis begrepen had moeten worden vanaf het moment dat deze in werking trad (ex tunc). Naar aanleiding van een dergelijk arrest kan blijken dat grote groepen belastingplichtigen al vele jaren bepaalde rechten hadden kunnen ontlenen aan het Unierecht. ${ }^{49}$ Denkbaar is dat men jarenlang in strijd met het Unierecht te veel belasting heeft betaald.

Het Hof neemt als uitgangspunt, dat de vaststelling en toepassing van een redelijke beroepstermijn voldoen aan het vereiste van doeltreffendheid en in beginsel dus is toegestaan. ${ }^{50}$ Wel dienen de procesregels te voldoen aan een tweetal randvoorwaarden. Ten eerste mogen de nationale procesregels voor rechten die gegrond zijn op het Unierecht niet ongunstiger zijn dan voor soortgelijke vorderingen gebaseerd

46. Hof 12 mei 1998, nr. C-367/96, A. Kefalas e.a., Jur. 1998, blz. I-2843, Conclusie A-G Tesauro in Jur. 1998, blz. I-2854. In vergelijkbare zin A-G Maduro in zijn conclusie bij het eerder aangehaalde Halifaxarrest, pt. 73 .

47. Zie R.L.H. IJzerman 1991, blz. 292.

48. Ook wel aangeduid met de term 'formele rechtskracht' van besluiten. Daarmee wordt bedoeld: het besluit heeft rechtskracht, die het niet ontleent aan zijn inhoud, maar aan het enkele feit dat er geen bezwaar of beroep meer tegen openstaat. Oftewel, het besluit is in rechte onaantastbaar. Zie nader N. Verheij, Relatief onaantastbaar? Over formele rechtskracht van besluiten (oratie Maastricht) 2005. 49. Zie nader J.H. Jans, R. de Lange, S. Prechal, R.J.G.M. Widdershoven, Inleiding tot het Europees bestuursrecht, Nijmegen: Ars Aequi Libri, blz. 343 e.v.

50. Hof 16 december 1976, nr. 33/76, Rewe, Jur. 1976, blz. 1989 en Hof 16 december 1976, nr. 45/76, Comet, Jur. 1979, blz. 2043. 
op het nationale recht (non-discriminatiebeginsel). Ten tweede mag het niet zo zijn dat de uitoefening van de rechten die gebaseerd zijn op het Unierecht uiterst moeilijk kunnen worden verwezenlijkt (doeltreffendheidbeginsel). Zo overweegt het Hof in het MyTravel-arrest: ${ }^{51}$

“(...) Bij het ontbreken van een gemeenschapsregeling op het gebied van verzoeken tot belastingteruggaaf, is het een aangelegenheid van het interne recht van elke lidstaat om de voorwaarden vast te stellen waaronder deze verzoeken kunnen worden gedaan, waarbij deze voorwaarden het gelijkwaardigheids- en het doeltreffendheidsbeginsel moeten eerbiedigen, dat wil zeggen dat zij niet ongunstiger mogen zijn dan die welke voor gelijksoortige vorderingen op basis van het nationale recht gelden, en dat zij evenmin van dien aard mogen zijn dat zij de uitoefening van de door het gemeenschapsrecht verleende rechten in de praktijk onmogelijk of uiterst moeilijk maken (...)." (r.o. 17)

De toepassing van fatale beroepstermijnen is te zien als een uitwerking van het rechtszekerheidsbeginsel. Het Hof heeft in het arrest AssiDomän Kraft Products ${ }^{52}$ namelijk beslist dat het rechtszekerheidsbeginsel twee kanten opwerkt, in die zin dat het niet enkel geldt voor particulieren, maar ook voor de belangen van de lidstaten. Het Hof oordeelde, dat de nietigverklaring van een aantal boetebeschikkingen niet meebrengt dat een dergelijk nietigverklaring ook geldt bij bedrijven die geen beroep hadden ingesteld. Het Hof onderbouwt deze beslissing met een verwijzing naar het rechtszekerheidsbeginsel, het vereiste van een goede rechtsbedeling en de proceseconomie.

In het Emmott-arrest ${ }^{53}$ is een uitzondering gemaakt op het uitgangspunt van de fatale beroepstermijnen wat betreft een niet juiste omzetting van richtlijnen. In het Emmott-arrest heeft het Hof beslist, dat een lidstaat die een richtlijn niet juist heeft omgezet, tot het moment van juiste omzetting, particulieren niet kan tegenwerpen dat zij te laat een procedure zijn gestart. Het zal duidelijk zijn dat deze lijn grote gevolgen kan hebben voor lidstaten die geconfronteerd worden met particulieren die zeer oude claims te gelden willen maken.

In latere arresten heeft het Hof de lijn van het Emmott-arrest nader verfijnd. Daaruit is te concluderen dat de werking van het Emmott-arrest enkel geldt voor een onjuiste omzetting van richtlijnen en niet in geval van schending van het Werkingsverdrag of verordeningen. Bij verdrag of verordening is namelijk omzetting in nationaal recht niet aan de orde. Bij deze schendingen kunnen redelijke beroepstermijnen in ieder geval worden tegengeworpen. ${ }^{54}$ Zie voor een uitzondering op deze lijn het hieronder behandelde Kühne en Heitz-arrest van het Hof.

51. Hof 6 oktober 2005, nr. C-291/03, MyTravel Plc, V-N 2005/58.23, NTFR 2005/1423. In deze procedure beslist het Hof dat een reisorganisator de BTW mag herberekenen op basis van de marktwaardemethode.

52. Hof 14 september 1999, nr. C-310/97, AssiDomän Kraft Products, Jur. 1999, blz. I-5363.

53. Hof 25 juli 1991, nr. C-208/90, Emmott, Jur. 1991, blz. I-4269.

54. Hof 28 september 1994, nr. C-128/93, Fisscher, Jur. 1994, blz. 4583 en Hof 24 oktober 1996, nr. C-435/93, Dietz, Jur. 1996, blz. I-5223, inzake schending EG-Verdrag; Hof 23 november 1995, nr. C-394/93, AlonsoPérez, Jur. 1995, blz. I-4101, inzake een schending van verordening. 
Het Hof heeft in een aantal arresten de materiële consequenties ingeperkt, door te beslissen dat de nationale wetgever de aanspraken in de tijd kan beperken. ${ }^{55}$ Jans e. a. vatten de jurisprudentie in die zin als volgt samen, dat een beroep op het Emmottarrest slechts succesvol kan zijn wanneer cumulatief aan de volgende voorwaarden is voldaan: ${ }^{56}$

1. de zaak moet betrekking hebben op een richtlijn die niet naar behoren is omgezet;

2. de belanghebbende heeft door de overschrijding van fatale beroeps-, aanvraag- of vervaltermijnen elke mogelijkheid verloren om zijn rechten voor de nationale rechter te doen gelden;

3. de overschrijding is te wijten aan 'misleidend' gedrag van de bevoegde autoriteiten.

Jans e.a. concluderen dat vooral deze laatste eis tot gevolg zal hebben, dat een succesvol beroep op het Emmott-arrest een grote uitzondering zal zijn. ${ }^{57}$

Het Kühne \& Heitz-arrest ${ }^{58}$ heeft een nieuwe impuls gegeven aan de discussies rond het leerstuk van de formele rechtskracht. Het Productschap voor Pluimvee en Eieren (verder: Productschap) vorderde exportsubsidies terug voor de uitvoer naar derde landen van kippenpoten. Het Productschap was namelijk van mening dat Kühne \& Heitz het uitgevoerde product voor de uitvoerrestitutie in de verkeerde post had ingedeeld. Kühne \& Heitz was het niet met deze beslissing eens en ging dan ook in beroep. Het College van Beroep voor het bedrijfsleven (verder: College van Beroep) stelde het Productschap in het gelijk, zonder een prejudiciële vraag te stellen over de tariefindeling. Op dat moment was de terugvorderingbeschikking onaantastbaar. Een aantal jaren later verscheen jurisprudentie van het Hof waaruit bleek dat het standpunt van Kühne \& Heitz toch juist was wat de kwalificatie van de kippenpoten betreft. ${ }^{59}$ Het College van Beroep had dus, na later bleek, een onjuiste beslissing genomen. Na het verschijnen van deze nieuwe jurisprudentie, heeft Kühne \& Heitz het Productschap verzocht om betaling van de volgens haar ten onrechte teruggevorderde restituties. Het Productschap wees dit verzoek af, waarna Kühne \& Heitz wederom in beroep ging. Het College van Beroep stelde vervolgens de prejudiciële vraag of het beginsel van gemeenschapstrouw, zoals dat is te vinden in artikel 4, lid 3 VEU (voorheen artikel $10 \mathrm{EG}$ ), niet meebrengt dat een bestuursorgaan moet terugkomen op een definitief geworden besluit teneinde de volle werking van het Unierecht te verzekeren.

55. Hof 27 oktober 1993, nr. C-338/91, Steenhorst-Neerings Jur. 1993, blz. I-5435; Hof 6 december 1994, nr. C-410/92, Johnson, Jur. 1994, blz. I-5483. En zie tevens over de toepassing van nationale verjaringstermijnen, Hof 2 december 1997, nr. C-188/95, Fantask, Jur. 1997, blz. I-6783, BNB 1998/285 m.n.v. P.J. Wattel.

56. Zie nader J.H. Jans, R. de Lange, S. Prechal, R.J.G.M. Widdershoven, Inleiding tot het Europees bestuursrecht, Nijmegen: Ars Aequi Libri, blz. 349 en 350.

57. In gelijke zin P.J. Wattel in zijn noot in BNB 1998/285 bij het eerdergenoemde Fantask-arrest.

58. Hof 13 januari 2004, nr. C-453/00, Kühne \& Heitz NV, NJ 2004/125, V-N 2004/8.3, NTFR 2004/116. 59. Hof 5 oktober 1994, nr. C-151/93, Voogd Vleesimport en -export, Jur. 1994, blz. I-4915. 
Het Hof herhaalt allereerst dat het beginsel van de rechtszekerheid tot gevolg heeft dat een besluit van een bestuursorgaan definitief wordt na het verstrijken van redelijke beroepstermijnen of na uitputting van alle rechtsmiddelen. Vervolgens formuleert het Hof echter een uitzondering op die regel. Een bestuursorgaan moet een onaantastbaar, maar met het Unierecht strijdig besluit opnieuw onderzoeken, indien aan vier voorwaarden is voldaan:

- Het bestuursorgaan is naar nationaal recht bevoegd om op het besluit terug te komen.

- Het in geding zijnde besluit definitief is geworden ten gevolge van een uitspraak van de hoogste nationale rechter.

- Uit latere rechtspraak van het Hof blijkt dat deze uitspraak berust op een onjuiste uitleg van het Unierecht, zonder dat een prejudiciële vraag is gesteld.

- Belanghebbende heeft zich onmiddellijk tot het bestuursorgaan gewend na kennis te hebben genomen van die rechtspraak van het Hof.

De reikwijdte van het Kühne \& Heitz-arrest blijkt evenwel niet zonder meer duidelijk te zijn. In ieder geval is de beslissing specifiek toegesneden op een bijzondere casus, te weten een rechter die het Unierecht onjuist toepast bij een belanghebbende. Een en ander blijkt uit een later arrest van het Hof. Dezelfde belanghebbende stelt de nieuwe jurisprudentie ogenblikkelijk aan de orde bij het bestuursorgaan, dat hem de terugvordering weigerde. ${ }^{60}$ Het lijkt mij dat sprake is van toch wel bijzondere omstandigheden. ${ }^{61}$ Zeker nu de reikwijdte beperkt is tot die belanghebbende die in eerste instantie door de rechter in het ongelijk is gesteld. Belanghebbenden die de onjuiste toepassing van het Unierecht niet hebben voorgelegd aan de rechter, kunnen na het verschijnen van de nieuwe jurisprudentie waaruit de juiste uitleg blijkt zich niet met succes beroepen op het Kühne \& Heitz-arrest. ${ }^{62}$

60. Voor het bestuursrecht blijkt uit artikel 8:88 AWB de bevoegdheid tot herziening van een onherroepelijk geworden rechtelijke beslissing. Daarvoor is vereist dat een belanghebbende een verzoek tot herziening doet, wat slechts in uitzonderlijke gevallen wordt toegewezen. Dit is voor het fiscale recht niet anders. Zie voor dit aspect nader H.J. Harten bij het arrest Hof 16 maart 2006, nr. C-234/04, R. Kapferer, SEW 2006/57. Zie ook Hof 12 februari 2008, nr. C-2/06, W. Kempter KG, SEW 2008/199, NTFR 2008/1872. Uit het Kempter-arrest blijkt dat het herzieningsverzoek niet onmiddellijk hoeft te worden ingediend. Het Hof geeft de lidstaten een zekere speelruimte en maakt een eind aan iedere speculatie dat het Unierecht een 'harde' termijn zou dicteren. De procedurele autonomie blijft op dit punt gewaarborgd, zolang de termijnen maar redelijk zijn, en de eisen van gelijkwaardigheid en doeltreffendheid geen geweld worden aangedaan.

61. Zie ook de conclusie van A-G Wattel van 25 mei 2010, nr. 09/05120, V-N 2010/32.7.

62. In dezelfde zin M.R. Mok in zijn noot bij het Kühne \& Heitz-arrest, NJ 2004/125. Het Hof heeft dit nog eens bevestigd in het arrest i-21 Germany GmbH \& Arcor AG van 19 september 2006, nrs. C-392/04 en C-422/04, r.o. 53, Jur. 2006, blz. I-8559 Verder is van belang dat het Kühne \& Heitz-arrest niet los kan worden gezien van het Köbler-arrest (Hof 30 september 2003, nr. C-224/01, Köbler, BNB 2004/151 m.n.v. P.J Wattel). Dit arrest opent de mogelijkheid tot schadevergoeding bij een onjuiste toepassing van het Unierecht door de hoogste nationale rechter. Zie R.J.G.M. Widdershoven \& R. Ortlep, Schendingen van EG-recht door rechters, NJ 2004/125. Zie ook nader M. de Jong, Kühne \& Heitz: formele rechtskracht onder omstandigheden 'doorbroken', TFB 2004/04. 
Belanghebbenden hebben in het kader van de BTW-heffing diverse keren een beroep gedaan op de Emmott-doctrine. Onder meer als gevolg van het zogenoemde SintOedenrode-arrest. In dit arrest besliste de Hoge Raad dat onder het begrip 'bouwterrein' in de Nederlandse omzetbelasting wetgeving uitsluitend moest worden verstaan 'bouwrijp gemaakte grond'. ${ }^{63}$ In het Emmen-arrest ${ }^{64}$ heeft het Hof beslist dat deze omschrijving niet in strijd is met artikel 135, lid 1, sub k, BTW-richtlijn (voorheen artikel 13B, sub b, Zesde richtlijn). Het probleem was dat de Belastingdienst in diverse aanschrijvingen een veel ruimere omschrijving van het begrip 'bouwterrein' had gegeven, waardoor gedurende deze periode teveel omzetbelasting was geheven, onder andere van de gemeente Almelo. Dit was in strijd met de BTWrichtlijn. De Belastingdienst verklaarde het door de gemeente Almelo ingediende bezwaarschrift niet ontvankelijk wegens termijn overschrijding. De gemeente Almelo legde zich niet neer bij deze beslissing en procedeerde door tot de Hoge Raad. De Hoge Raad oordeelde dat, gelet op de richtlijnconforme interpretatie die de Hoge Raad in het Sint-Oedenrode-arrest had gegeven, aan het begrip 'bouwterrein', nooit sprake was geweest van een onjuiste omzetting van de BTW-richtlijn. ${ }^{65}$ Dat in aanschrijvingen een met de richtlijn strijdige uitleg was gegeven aan het begrip 'bouwterrein' deed hieraan niet af, aangezien deze resoluties geen algemeen verbindende voorschriften inhouden. ${ }^{66}$ De gemeente Almelo beriep zich dus zonder succes op het Emmott-arrest. ${ }^{67}$

Op dit moment is actueel de vraag of belastingplichtigen met een beroep op het Charles-Tijmens-arrest ${ }^{68}$ met terugwerkende kracht alsnog te weinig in aftrek gebrachte voorbelasting terug kunnen krijgen. Dit gezien de door het Hof vastgestelde gedeeltelijke strijd van de Nederlandse Wet OB met de BTW-richtlijn wat betreft het recht op aftrek van voorbelasting. ${ }^{69}$ Dezelfde vraag kon tot voor kort ook worden gesteld met betrekking tot het mogelijk niet verbindend zijn van de

63. HR 21 november 1990, nr. 26 362, BNB 1991/19.

64. Hof 28 maart 1996, nr. C-468/93, Gemeente Emmen, V-N 1996/1545, pt. 24, FED 1996/690.

65. HR 8 juli 1996, nr 30 318, V-N 1996/2906.

66. Zie verder voor een niet succesvol beroep op de Emmott-doctrine: HR 4 september 1996, nr. 31456 , BNB 1997/43; Maple Tree-arrest van de civiele kamer van de HR 24 januari 2003, nr. C01/321, NTFR 2003/326 inzake de opbrengst van speelautomaten. HR 21 maart 2001, nr. 37 690, NTFR 2001/495 waarin is beslist dat een korte bezwaartermijn een beroep op het Unierecht niet onmogelijk maakt. HR 18 februari 2005, NTFR 2005/273, in geval van de verhuur van een vakantiewoning staat een niet correcte implementatie de formele rechtskracht niet in de weg.

67. Zie echter in dit kader ook het Marks \& Spencer-arrest waarin is beslist dat het doeltreffendheidbeginsel en het vertrouwenbeginsel zich verzetten tegen een nationale regeling die met terugwerkende kracht de termijn verkort waarbinnen kan worden verzocht om teruggaaf van betaalde BTW, wanneer deze zijn geïnd in strijd met de BTW-richtlijn. Hof 11 juli 2002, nr. C-62/00, Marks \& Spencer, V-N 2002/49.28, NTFR 2002/1014.

68. Hof 14 juli 2005, nr. C-434/03, Charles Thijmens, BNB 2005/284, V-N 2005/35.18, NTFR 2005/965. 69 . Voor een nadere uiteenzetting van deze problematiek zie paragraaf 6.5. 
nationale blokkade-regeling op de aftrek van voorbelasting bij voorzieningen voor relaties en personeel. ${ }^{70}$ Blokkeert de formele rechtskracht deze verzoeken? Gezien hetgeen is opgemerkt over het Emmott-arrest en het Kühne \& Heitz-arrest, ben ik van mening dat dergelijke verzoeken niet kansrijk zijn, vooral omdat de overgrote groep niet heeft doorgeprocedeerd tot de Hoge Raad. ${ }^{71}$ De belastingplichtigen die wel hebben doorgeprocedeerd tot de hoogste nationale rechtelijke instantie en toentertijd ten onrechte door de Hoge Raad in het ongelijk zijn gesteld, zoals nu blijkt uit het Charles-Tijmens-arrest, kunnen waarschijnlijk een succesvol beroep doen op het Kühne \& Heitz-arrest. Echter de overgrote groep van belastingplichtigen die in het verleden zich de weg tot de Hoge Raad hebben bespaard, voldoen niet aan de criteria zoals geformuleerd in het Kühne \& Heitz-arrest.

Naar mijn oordeel is plaats voor een nadere uitzondering op de formele rechtskracht. Het Hof verwacht van een belanghebbende dat, wil hij zijn op het Unierecht gebaseerde rechten veiligstellen, hij tegen een volgens hem onjuiste beslissing van de Belastingdienst in rechte opkomt tot de hoogste nationale rechter. Wat volgens mij echter niet van een belanghebbende mag worden verwacht is dat hij, nadat hij in het ongelijk is gesteld door de hoogste nationale rechter, eindeloos blijft door procederen over latere aangiftetijdvakken. Dit betekent volgens mij dan ook dat

70. De volgende categorieën van verstrekkingen zijn onverbindend: het aan personeel uitkeren van loon in natura (artikel 1, eerste lid, aanhef en onderdeel c, BUA), goederen en diensten die worden gebezigd voor andere persoonlijke doeleinden van het personeel (artikel 1, eerste lid, aanhef en onderdeel c, BUA), zie HR 14 november 2008, nr. 43.185, V-N 2008/11.23. Overigens heeft zowel de HR (in het eerder genoemde arrest) als het Gerechtshof Amsterdam (19 januari 2009, nrs. P07/00782 en 07/00783, V-N 2009/16.16) prejudiciële vragen gesteld over de houdbaarheid van het BUA. Deze zijn door het Hof beantwoord op 15 april 2010, nrs. C-538/08 en C-33/09, X Holding \& Oracle, V-N 2010/ 19.22. In deze procedure is beslist dat diverse categorieën van het BUA niet in strijd zijn met het Unierecht. Overigens geeft de beslissing voeding aan de vraag of de twee categorieën die eerder onverbindend zijn verklaard volgens het Hof toch door de beugel kunnen.

71. In het arrest van de HR van 5 oktober 2007 HR (nr. 43 268, V-N 2007/47.2, NTFR 2007/1829) staat deze vraag centraal. In deze procedure heeft belanghebbende in maart 2005 de inspecteur verzocht om ambtshalve vermindering van de op aangifte voldane omzetbelasting over de jaren 2000 - 2003. Belanghebbende had eerder geen bezwaar gemaakt. Belanghebbende was vervolgens van mening dat uit het Scandic-arrest (C-412/03) volgde dat het BUA (waaraan toepassing was gegeven bij de vaststelling van de omzetbelasting over 2000 - 2003), in strijd was met de BTW-richtlijn. De inspecteur merkte het verzoek aan als een bezwaarschrift tegen de eerder vastgestelde omzetbelasting, en vervolgens merkte hij het bezwaarschrift aan als niet-ontvankelijk wegens termijn overschrijding. Belanghebbende bracht in cassatie naar voren dat de inspecteur op grond van de arresten Emmott (C-280/90), Kühne \& Heitz (C-453/00) en Kapferer (C-234/04) gehouden was om op het verzoek te beslissen als ware het ingediend binnen de gestelde termijn. De HR volgde belanghebbende echter niet en oordeelde dat belanghebbende tegen haar eerdere voldoening op aangifte bezwaar had kunnen maken, dat zij dat heeft nagelaten en dat het maken van bezwaar destijds ook niet moeilijk is gemaakt. 
als belanghebbende eenmaal tot de hoogste instantie heeft geprocedeerd, ook voor latere aangiftetijdvakken de doctrine die is ontwikkeld in het arrest Kühne \& Heitz geldt. $^{72}$

Het lijkt mij dat in beginsel het rechtszekerheidsbeginsel dient te prevaleren en dat enkel in bijzondere gevallen, zoals in het Emmott-arrest (belanghebbende door het bestuursorgaan misleid) of zoals in het Kühne \& Heitz-arrest, de formele rechtskracht doorbroken kan worden. ${ }^{73}$

\subsection{Het rechtszekerheidsbeginsel en de terugwerkende kracht van regels}

In paragraaf 3.4.3.2 is het uitgangspunt naar voren gebracht dat een regel niet in werking mag treden voordat hij is bekendgemaakt. Uit de arresten Racke $^{74}$ en Decker $^{75}$ blijkt dat op dit uitgangspunt uitzonderingen mogelijk zijn indien het te bereiken doel dit vereist en het vertrouwen van particulieren op een passende wijze wordt gerespecteerd. ${ }^{76}$ Op de terugwerkende kracht van BTW-regels ga ik nader in. In het Schlosstrasse-arrest ${ }^{77}$ is de essentie weergegeven:

“(...) het voornemen om een aanvang te maken met economische activiteiten die tot belaste handelingen zullen leiden, te goeder trouw kenbaar is gemaakt en dit voornemen wordt ondersteund door objectieve elementen, geniet de belastingplichtige het recht om onmiddellijk de BTW af te trekken die verschuldigd of voldaan is voor goederen of diensten die hij heeft ontvangen met het oog op voorgenomen economische activiteiten, en verzetten het

72. Steun hiervoor is te vinden in het arrest Danske Slagterier. In deze procedure wijst het Hof erop dat schending van het doeltreffendheidbeginsel aan de orde kan zijn wanneer van de benadeelde personen wordt verlangd dat zij systematisch gebruik maken van alle hun ter beschikking staande rechtsmiddelen, zelfs wanneer dit buitensporige moeilijkheden zou opleveren of niet redelijkerwijs van hen kan worden verlangd (r.o. 62). Bezwaar maken tegen latere tijdvakken lijkt mij niet redelijk om te verwachten van een belanghebbende. Hof 24 maart 2009, nr. C-445/06, nr. C-445/06, Danske Slagterier, FED 2009/45. In deze procedure heeft het Hof beslist dat een verjaringstermijn van drie jaar niet in strijd is met het doeltreffendheidbeginsel.

73. Zie in dit kader verder: J.H. Jans, R. de Lange, S. Prechal, R.J.G.M. Widdershoven, Inleiding tot het Europees bestuursrecht, Nijmegen: Ars Aequi Libri 2002, blz. 343 t/m 353; J.M. Prinssen, Doorwerking van Europees recht, De verhouding tussen directe werking, conforme interpretatie en overheidsaansprakelijkheid. Europese Monografieën, nr. 73, Deventer: Kluwer 2004, blz. 230 t/m 235 (diss. Amsterdam UvA); G.J. van Slooten, Het arrest Charles-Tijmens en teruggaaf van voorbelasting achteraf: formele rechtskracht, maar pas na een redelijke termijn, BTW-Brief, nr. 8/9 2005; J.J.P. Swinkels, Europese ontwikkelingen omtrent onjuiste rechtspraak van de hoogste nationale rechter, Belasting Brief 2004/04; B.J.M. Terra, P.J. Wattel, European Tax Law, Fed Fiscale Studieserie, Deventer: Kluwer 2005, blz. $178 \mathrm{t} / \mathrm{m} \mathrm{184}$; E. Thomas, Formele rechtskracht en de terugbetaling van in strijd met Europees recht geheven belasting, MBB 2004/09.

74. Hof 25 januari 1979, nr. 98/78, Racke, Jur. 1979, blz. 59. Zie nader S. Prechal \& T. Heukels 1986, blz. 294. Zij verwijzen in dit kader naar Hof 19 maart 1975, nr. 28/74, Gillet, Jur. 1975, blz. 533.

75. Hof 25 januari 1979, nr. 99/78, Decker, Jur. 1979, blz. 101.

76. Hof 21 februari 1991, nrs. C-143/88 en C-92/89, Süderdithmarschen, Jur. 1991, blz. 415, in het bijzonder r.o. 49. Zie voor een uitgebreide behandeling van de Racke en Decker-doctrine M.R.T. Pauwels, Terugwerkende kracht van belastingwetgeving: gewikt en gewogen (diss. Tilburg), Amersfoort: Sdu Uitgevers 2009, blz. 441 e.v.

77. Hof 8 juni 2000, nr. C-396/98, Schlosstrasse, NTFR 2000/922, V-N 2000/44.21 
vertrouwens- en het rechtszekerheidsbeginsel er zich tegen, dat een wetswijziging die tot stand komt nadat deze goederen zijn geleverd of deze diensten zijn verricht, hem met terugwerkende kracht dit recht ontneemt." (r.o. 47)

Het Hof is duidelijk. Een wetswijziging kan niet met terugwerkende kracht een belastingplichtige het aftrekrecht ontnemen. ${ }^{78}$

In het Marks \& Spencer-arrest ${ }^{79}$ besliste het Hof, dat het doeltreffendheidbeginsel en het vertrouwensbeginsel zich verzetten tegen een nationale regeling die met terugwerkende kracht de termijn verkort waarbinnen kan worden verzocht om teruggaaf van BTW wanneer deze is geïnd, in strijd met de BTW-richtlijn.

In het Sudholz-arrest ${ }^{80}$ is beslist dat terugwerkende kracht van een machtiging om af te wijken van de BTW-richtlijn in strijd is met deze richtlijn. Paragraaf 11.5.1.3 behandelt het Sudholz-arrest.

Een vervolg op de vorenstaande jurisprudentie is het arrest van 29 april 2004 inzake Gemeente Leusden \& Holin-groep BV. ${ }^{81}$ In deze procedure verhuurde zowel de gemeente Leusden als de Holin-groep BV belast onroerende zaken. Op 31 maart 1995 werd een wetswijziging met onmiddellijke ingang aangekondigd die belaste verhuur niet meer mogelijk maakte voor verhuur aan huurders die de BTW voor minder dan $90 \%$ in aftrek konden brengen. Zowel de gemeente Leusden als de Holin-groep BV werden getroffen door de zogenoemde herzieningsbepalingen. ${ }^{82}$ De vraag was aan de orde of de wetswijziging het rechtszekerheids- en vertrouwensbeginsel schendt. Beide belastingplichtigen vertrouwden er bij het afsluiten van de verhuurovereenkomsten op, dat zij hun voorbelasting ongeschonden in aftrek konden brengen (dus zonder herziening). Nu werden zij getroffen door een omstandigheid buiten hun wil (namelijk de wetswijziging) die niet was te voorzien. Het Hof besliste echter dat het rechtszekerheids- en het vertrouwensbeginsel een lidstaat niet kunnen beletten een wetswijziging door te voeren die een regime invoert dat is toegestaan op grond van

78. Zie in dit kader ook het Belgocodex-arrest, Hof 3 december 1998, nr. C-381/97, BNB 1999/29, V-N 1999/14.25.

79. Hof 11 juli 2002, nr. C-62/00, Marks \& Spencer, V-N 2002/49.28, NTFR 2002/1014. In dezelfde zin Hof 12 mei 2011, nr. C-107/10, Enel, V-N 2011/27.6, r.o. 39.

80. Hof 29 april 2004, nr. C-17/01, W. Sudholz, V-N 24.16, NTFR 2004/674.

81. Hof 29 april 2004, nrs. C-487/01 en C-7/02, Gemeente Leusden \& Holin groep BV, V-N 2004/24.17, NTFR 2004/670.

82. Onroerende zaken en roerende zaken waarop de ondernemer afschrijft voor de inkomsten- of vennootschapbelasting (of zou moeten afschrijven indien hij aan deze belastingen zou zijn onderworpen) worden voor het recht op aftrek van voorbelasting nog enige jaren gevolgd (roerende zaken vijf jaren en onroerende zaken tien jaren). Indien het aftrekrecht in enig jaar ten opzichte van het investeringsjaar wijzigt, moet de afgetrokken voorbelasting worden herzien. Zie artikel 13 Uitv.besch Wet OB. 
de BTW-richtlijn. ${ }^{83}$ Wel moeten de lidstaten bij een dergelijke wetswijziging rekening houden met het gewettigd vertrouwen van belastingplichtigen. De afschaffing van het wettelijk kader waarvan de belastingplichtige heeft geprofiteerd door minder belasting te betalen (zonder dat sprake was van misbruik), kan echter als zodanig geen schending van een op het Unierecht gebaseerd gewettigd vertrouwen vormen.

De Hoge Raad besliste conform het arrest van het Hof, dat gezien de wetswijziging herziening van de afgetrokken BTW mogelijk is. ${ }^{84}$ Daarmee was nog niet alles beslist. De vraag was of ten gevolge van de wetswijziging een integratieheffing mogelijk is. ${ }^{85}$ Het Hof is daarover duidelijk in het Leusden \& Holin-arrest. Het Hof overweegt (r.o. 92 en 93), dat herziening van afgetrokken BTW op grond van artikel 187, BTW-richtlijn (voorheen artikel 20, lid 2, Zesde Richtlijn) mogelijk is. Echter, een heffing conform artikel 18, sub a, BTW-richtlijn niet (voorheen artikel 5, lid 7, sub a, Zesde richtlijn). Deze laatste bepaling betreft namelijk het door een belastingplichtige voor bedrijfsdoeleinden bestemmen van een goed, en niet een wetswijziging waarbij het recht wordt afgeschaft om voor belastingheffing te kiezen in geval van verhuur. De toepassing van de herzieningsregeling als gevolg van een omslag van belast naar vrijgesteld is dus niet in strijd met de richtlijn. Echter een heffing ineens zoals de integratieheffing wel. Dit lijkt mij ook een redelijk resultaat. Belanghebbende kon ten tijde van de investering niet vermoeden dat een toekomstige wetswijziging met terugwerkende kracht een belastbaar feit tot gevolg zou hebben. De Hoge Raad volgde het Leusden \& Holin-arrest en besliste dan ook dat de integratieheffing niet kan worden toegepast. ${ }^{86}$

Het Hof houdt niet voor altijd en absoluut vast aan het verbod op terugwerkende kracht, maar ziet - onder omstandigheden - een noodzakelijk terugwerkende kracht soms voor mogelijk. Het arrest Goed Wonen II $^{87}$ illustreert dit voor de BTW. Het arrest Gemeente Leusden \& Holin en evenmin het Schlosstrasse-arrest beantwoordt de vraag of een aangekondigde wetswijziging met terugwerkende kracht in werking kan treden, waardoor een eerder ontstaan recht op aftrek van voorbelasting alsnog

83. Pauwels is van mening dat uit de r.o. 66 is op te maken dat het Hof laat meewegen dat de Zesde richtlijn ruimte biedt voor bepaalde wijzigingen en dat belastingplichtigen daarmee rekening dienen te houden. Deze lijn past volgens hem grosso modo met de vaste jurisprudentie dat 'marktdeelnemers' niet mogen vertrouwen op de handhaving van een bestaande situatie die door de gemeenschapsinstellingen, handelend krachtens hun discretionaire bevoegdheid, kan worden gewijzigd, M.R.T. Pauwels 2009, blz. 462. Pauwels doelt op de mogelijkheid die 13 C, Zesde richtlijn biedt om een optiemogelijkheid in te voeren. Ik betwijfel echter of dit aspect van belang is bij de Zesde richtlijn. Veeleerder lijkt mij van belang de randvoorwaarden zoals deze zijn verwoord in de Racke en Deckerdoctrine.

84. HR 2 mei 2005, nr. 36.277, NTFR 2005/690, en HR 12 augustus 2005, nr. 36.924, NTFR 2005/1074. 85. Conform artikel 3, derde lid, onderdeel b Wet OB (voorheen artikel 3, eerste lid, onderdeel h Wet $\mathrm{OB})$.

86. HR 12 augustus 2005, nr. 35.977, NTFR 2005/1072, en HR 12 augustus 2005, nr. 36.923, NTFR 2005/ 1073. Zie ook over de invloed van de algemene rechtsbeginselen J.A. Kamminga, De rechtszekerheid van de terugwerkende kracht van BTW-anticonstructiewetgeving, WFR 2005/360. 87. Hof 26 april 2005, nr. C-376/02, Goed Wonen II, V-N 2005/23.16, NTFR 2005/600. 
wordt geblokkeerd. Het Goed Wonen II-arrest draait om de vraag, of terugwerkende kracht (van 29 december 1995 tot 31 maart 1995, 18.00 uur) verbonden aan de wetgeving ter bestrijding van constructies op het terrein van onroerende zaken, in strijd is met het rechtszekerheids- en vertrouwensbeginsel. Het Hof overweegt, dat het uitgangspunt is dat een gemeenschapsbesluit, of een nationale wet die onder het Unierecht valt, geen terugwerkende kracht heeft. Tevens beslist het Hof dat bij uitzondering van deze algemene regel kan worden afgeweken, indien aan twee voorwaarden is voldaan (r.o. 33):

1. Dit voor een doel van algemeen belang noodzakelijk is, en

2. het rechtmatige vertrouwen van de betrokkenen naar behoren in acht wordt genomen.

Wat betreft de eerste voorwaarde overweegt het Hof, dat de vrees dat tussen het tijdstip waarop tot de wetswijziging wordt besloten en het tijdstip waarop die wijziging in werking zou treden, op grote schaal constructies in het leven worden geroepen, een doel van algemeen belang kan vormen dat de techniek van de terugwerkende kracht van een wet rechtvaardigt. Het is echter de nationale rechter die moet beoordelen of in het concrete geval deze vrees gerechtvaardigd is. ${ }^{88}$

Met betrekking tot de tweede voorwaarde overweegt het Hof dat gezien het gegeven dat het in deze procedure om een nationale regeling gaat, bij de beoordeling of het rechtmatige vertrouwen van de betrokkenen naar behoren in acht wordt genomen, rekening moet worden gehouden met de informatiemethoden die normaliter worden gebruikt in de lidstaat die de desbetreffende regeling heeft vastgesteld en met inachtneming van de omstandigheden van het concrete geval. Het is echter de nationale rechter die moet beoordelen of de informatiemethode voldoende duidelijk is om een belanghebbende op wie de wet doelt, in staat stellen te begrijpen wat de gevolgen van de voorgenomen wetswijziging zijn. Het Hof spreekt echter uit dat van belanghebbenden verwacht kan worden dat zij in hoge mate in staat zijn de gevolgen van regelgeving op hun handelen in te schatten. De Hoge Raad heeft op 14 december 2007 beslist dat de terugwerkende kracht in overeenstemming is met het Unierecht en dat de aankondiging door middel van een persbericht is toegestaan. $^{89}$

In het begin van deze paragraaf heb ik naar drie klassieke arresten verwezen, namelijk het Racke-arrest, Decker-arrest en het Süderdithmarschen-arrest. Deze

88. Het is niet uit te sluiten dat de HR zich in de toekomst wederom zal moeten uitlaten over de aanvaardbaarheid van een wetswijziging die bij de inwerkingtreding terugwerkende kracht heeft. Ik doel dan op de antimisbruikmaatregel die is getroffen om te voorkomen dat de heffing van BTW kan worden ontgaan door de auto niet kosteloos, maar tegen een lage vergoeding ter beschikking te stellen voor privégebruik (Brief Staatssecretaris van Financiën van 17 juni 2011, nr. DV2011/318, V-N 2011/ 32.18). Het zal dan in het bijzonder gaan over de eerste voorwaarden, namelijk of sprake is van een doel van algemeen belang. Het is echter de vraag of zich een aanmerkelijk aankondigingeffect voordoet doordat ondernemers hun autoregeling tijdens het wetgevingsproces aanpassen om zo een voordeel te behalen.

89. HR 14 december 2007, nr. 34.514, V-N 2007/59.18, NTFR 2008/48. 
hebben geen betrekking op het BTW-recht. Uit de recente arresten die wel op dit gebied betrekking hebben, blijkt thans dat - twintig jaar later - het Hof nog dezelfde uitgangspunten hanteert, wanneer het gaat om de toepassing van het rechtszekerheids- en het vertrouwensbeginsel bij de beoordeling van de toelaatbaarheid van de techniek van de terugwerkende kracht.

\subsection{Beperking van de werking van een prejudiciële beslissing in de tijd}

\subsubsection{Algemene aspecten van de uitgestelde werking}

De hoofdregel is dat prejudiciële beslissingen de betekenis en de strekking van een bepaling van Unierecht preciseren, zoals deze moet worden of had moeten worden begrepen sinds haar inwerkingtreding (ex tunc). Dat betekent dat de uitgelegde rechtsregel door de nationale rechter ook moet worden toegepast op rechtsbetrekkingen die zijn ontstaan voor de datum van het arrest waarbij op de prejudiciële vraag is beslist. Het Hof wijst in het MyTravel $^{90}$-arrest erop:

“(...) dat wanneer het Hof in het kader van de hem bij artikel 234 EG verleende bevoegdheid een bepaling van gemeenschapsrecht uitlegt, het de betekenis en de strekking van deze bepaling zoals zij sedert het tijdstip van de inwerkingtreding ervan had moeten worden verstaan en toegepast, preciseert (...). Dit is slechts anders indien het Hof in zijn arrest, bij uitzondering, de strekking van deze uitlegging in de tijd beperkt (...)." (r.o. 16)

“Een arrest dat ingevolge een verzoek om een prejudiciële beslissing wordt gewezen, bedoelt gevolgen te hebben voor de rechtsverhoudingen die vóór het wijzen ervan zijn ontstaan. Daaruit volgt met name dat een aldus uitgelegd gemeenschapsrechtelijk voorschrift door een administratief orgaan in het kader van zijn bevoegdheden zelfs moet worden toegepast op rechtsverhoudingen die vóór de uitspraak van het arrest van het Hof waarbij de prejudiciële vraag wordt beantwoord, zijn ontstaan en gevormd (...)." (r.o. 17)

Als de uitlegging van een nationale wet tot gevolg heeft dat een lidstaat te veel BTW heeft geheven, dan dient een belanghebbende uiteraard wel tijdig bezwaar en beroep te hebben ingesteld wil hij zijn rechten kunnen effectueren. Zie voor dit aspect paragraaf 5.4 over de formele rechtskracht van besluiten.

Dikwijls heeft de praktijk zich jarenlang gedragen naar een bepaalde uitlegging van regels. Vaak ook rekent een lidstaat bij een bestaande regelgeving op inkomsten die onzeker worden wanneer een betwisting daarvan bij de rechter verkeerd uitpakt. Uitspraken van rechters, en zeker die van het Hof, kunnen grote gevolgen hebben voor de schatkist. Die gevolgen kunnen zelfs onoverkomelijk zijn. De vraag rijst dan of de rechter met dit voorzienbare gevolg iets moet doen. Moet een arrest altijd een werking ex tunc hebben?

90. Hof 6 oktober 2005, nr. C-291/03, MyTravel Plc, V-N 2005/58.23, NTFR 2005/1423, r.o. 16. In deze procedure besliste Het Hof dat volgens de reisbureauregeling de BTW mag worden herberekend op marktwaardemethode. Zie verder het Salumi-arrest van 27 maart 1980, gevoegde zaken nrs. 66/79, 127/79 en 128/79, Jur. 1980, blz. 1237, r.o. 9 (betreffende heffing m.b.t. de invoer van rundvlees). Zie tevens Hof 17 februari 2005, nrs. C-453/02 en C-462/02, Linneweber \& Akritidis, V-N 2005/13.14, r.o. 41 $\mathrm{t} / \mathrm{m} 45$. 
Het Hof staat bij wijze van uitzondering toe dat op zijn uitlegging van de regelgeving geen beroep kan worden gedaan om in het verleden te goeder trouw tot stand gekomen rechtsbetrekkingen opnieuw aan de orde te stellen. De uitlegging wordt dan van kracht vanaf de datum van het arrest (ex nunc) (door mij verder aangeduid als uitgestelde werking). ${ }^{91}$ Daarvoor moet echter cumulatief aan een tweetal voorwaarden zijn voldaan:

1. Particulieren of lidstaten zijn tot een met de strekking van een communautaire bepaling strijdig gedrag gebracht op grond van een objectieve, grote onzekerheid over de strekking van de communautaire bepalingen, aan welke onzekerheid het gedrag van andere lidstaten of van de Commissie eventueel heeft bijgedragen.

2. De beslissing van het Hof heeft ernstige economische gevolgen voor een lidstaat.

Ik zal beide voorwaarden in de volgende subparagrafen toelichten (paragrafen 5.6.2 en 5.6.3).

Het Hof heeft voor het eerst in het Defrene II-arrest ${ }^{92}$ een uitzondering gemaakt op de werking ex tunc. De breuk met de werking ex tunc is als volgt onderbouwd:

"Overwegende dat de praktische gevolgen van een rechtelijke uitspraak weliswaar zorgvuldig moeten worden afgewogen, doch dat dit er niet toe moet leiden dat de objectiviteit van het recht geweld wordt aangedaan en omwille van de weerslag die een rechtelijke beslissing voor het verleden kan hebben, de toepassing van dat recht in de toekomst in gevaar wordt gebracht." (r.o. 71)

Het Hof heeft er in diverse arresten op gewezen dat slechts bij hoge uitzondering van de principiële ex tunc werking kan worden afgeweken. ${ }^{93}$

91. In deze paragraaf besteed ik voornamelijk aandacht aan de uitgestelde werking in geval van prejudiciële procedures en inbreukprocedures gezien het belang van dergelijk procedures voor de heffing van BTW. Dat neemt niet weg dat de uitgestelde werking ook aan de orde kan zijn in procedures met betrekking tot beroepen tot nietigverklaring van communautaire handelingen op grond van artikel 264, tweede alinea VwEU. Zie in dit kader Hof 11 september 2003, nr. C-445/00, Oostenrijk/Raad, Jur. 2003, blz. I-8549, waar de gevolgen van de bestreden handeling worden gehandhaafd (r.o. 103 t/m 106) (betreffende ecopuntensysteem voor transito door Oostenrijk rijdende vrachtauto's) en Hof 10 januari 2006, nr. C-178/03, Commissie/Parlement, Jur. 2006, blz. I-107, waar de gevolgen in stand worden gelaten totdat binnen een redelijke termijn een nieuwe verordening is vastgesteld die is gebaseerd op passende rechtsgrondslagen (r.o. 65) (betreffende een verordening betreffende in- en uitvoer van gevaarlijke chemische stoffen). Tevens kan uitgestelde werking ook aan de orde zijn bij nieuwe wetgeving. Zie voor het onderscheid tussen eerbiedigende en uitgestelde werking en uitgestelde inwerkingtreding van wetgeving, M. Schuver-Bravenboer, Fiscaal overgangsbeleid. Een raamwerk voor het vormgeven en beoordelen van het overgangsbeleid van de fiscale wetgever (diss. Leiden), Deventer: Kluwer 2009, blz. 43 e.v.

92. Hof 8 april 1976, nr. 43/75, Defrenne II, Jur. 1976, blz. 455, r.o. 69 t/m 75. Het arrest heeft betrekking op de gelijke beloning van vrouwelijke en mannelijke werknemers.

93. Dit blijkt ook al uit het eerder aangehaalde Defrenne II-arrest. Het lijkt er op dat het Hof in de loop van de tijd de lat wat hoger legt. In het Defrenne II-arrest gebruikt het Hof het zinsdeel 'bij wijze van uitzondering' (r.o. 72). Terwijl bijvoorbeeld in het recenter Edis-arrest het Hof in zijn overwegingen het zinsdeel 'slechts bij hoge uitzondering' gebruikt, Hof 15 september 1998, nr. C-231/96, Edis, Jur. 1998, blz. I-4951, r.o. 16. 
Verder is in beginsel het uitgangspunt dat de uitgestelde werking van het arrest niet geldt voor degene die tijdig stappen hebben ondernomen ter waarborging van hun rechten. ${ }^{94}$ Voor de heffing van BTW gaat het dan om belanghebbenden die voor de datum van het arrest een bezwaarschrift bij de Belastingdienst hebben ingediend. ${ }^{95}$

Het Hof heeft in het Barber-arrest ${ }^{96}$ benadrukt dat een nationale rechter niet bevoegd is om te oordelen over de uitgestelde werking van het Unierecht. Ook als de nationale rechter meent dat de gewenste uitgestelde werking voor geen redelijke twijfel vatbaar is en overtuigd is dat het even duidelijk is voor de rechters in andere lidstaten en voor het Hof. Het antwoord op de vraag of uitgestelde werking aan de orde is, behoort tot de exclusieve bevoegdheden van het Hof. Indien een prejudiciële procedure voor het Hof loopt en geen van de prejudiciële vragen heeft betrekking op de uitgestelde werking van het Unierecht, dan kunnen de procespartijen dit onderwerp naar voren brengen. In een procedure op het terrein van de BTW zal dit dan de lidstaat zijn van de nationale rechter die de prejudiciële vraag heeft gesteld, en eventueel een andere lidstaat die intervenieert. Partijen hebben niet het recht de door de nationale rechter gestelde vragen uit te breiden, te beperken of te veranderen. ${ }^{97}$ Wel kan een partij verzoeken een eventueel nadelig antwoord op een door de nationale rechter gestelde prejudiciële vraag een uitgestelde werking toe te kennen. ${ }^{98}$

Het uitgangspunt is dus een werking ex tunc. Volgens vaste rechtspraak van het Hof moet de procespartij die zich op een afwijking van een algemeen uitgangspunt beroept, ervoor zorgen dat haar argumenten voldoende zijn uiteengezet en dat het Hof over voldoende informatie beschikt om op dat punt een beslissing te geven. ${ }^{99}$

94. Zie bijvoorbeeld Hof 15 januari 1986, nr. 41/84, Pinna, Jur. 1986, blz. 1, r.o. 29. Dit arrest heeft betrekking op gezinstoelagen.

95. A-G Stix-Hackl stelt een andere datum voor in haar conclusie van 14 maart 2006 bij het Banca Popolare-arrest over de Italiaanse IRAP, namelijk het einde van het belastingtijdvak waarin het arrest wordt gewezen (belastingtijdvak van de IRAP is een kalenderjaar) (punt 164). Deze conclusie is niet gevolgd omdat de IRAP niet is aangemerkt als een verkapte BTW en het Hof derhalve de vraag over de toepasbaarheid van de uitgestelde werking niet meer behoefde te beantwoorden. Zie nader F. Nanetti and G. Mazotti, The (un)lawfulness of IRAP in the European Legal system: the European Court of Justice's potential new trends with regard to temporal limitation of its interpretative decision, EC Tax Review 2006/3, blz. 166.

96. Hof 17 mei 1990, nr. 262/88, D.H. Barber, Jur. 1990, blz. I-1889. Zo besliste het Hof in r.o. 41: “(...)Een dergelijke beperking kan slechts door het Hof worden gesteld en enkel in het arrest waarin de gevraagde uitlegging wordt gegeven."

97. Hof 19 september 1998, Liïkenne, nr. C-412/96, Jur. 1998, blz. I-5141, r.o. 22 t/m 24

98. Zie bijvoorbeeld Hof 9 maart 2000, nr. C-437/97, EKW en Wien \& Co, Jur. 2000, blz. I-1157 inzake een regionale drankbelasting.

99. A-G Geelhoed duidt dit aan als een grondbeginsel van een procedure voor het Hof. Zie pt. 143 in zijn conclusie van 6 april 2006 bij het Test Claiments-arrest van 12 december 2006, nr. C-446/04, BNB 2007/130c*, V-N 2007/5.9, NTFR 2007/5.9. Dit beginsel klinkt ook door in Hof 31 maart 1992, nr. C-200/ 90, Dansk Denkavit APS en P. Poulsen Trading APS, V-N 1992/1463, pt. 17, waarin het Hof besliste dat de Deense regering de omstandigheden die een uitgestelde werking rechtvaardigen niet heeft aangetoond. In de deze procedure is beslist dat een Deense arbeidsbijdrage een verboden BTW is in de zin van artikel 401, BTW-richtlijn (voorheen artikel 33, Zesde richtlijn). 
De stelplicht en de bewijslast met betrekking tot het vervuld zijn van de voorwaarden rust dus op de lidstaat die dit onderwerp in een procedure naar voren brengt. In de vervolg paragrafen zal blijken dat dit grondbeginsel van procesvoering niet onbelangrijk is bij het onderwerp dat in deze paragraaf centraal staat.

\subsubsection{Onzekerheid over de strekking van de communautaire bepaling}

Zoals in de vorige paragraaf naar voren is gebracht, is één van de voorwaarden voor de toepassing van het leerstuk van de uitgestelde werking van een arrest van het Hof, dat het met het Unierecht strijdige gedrag is veroorzaakt door grote onzekerheid over de strekking van een communautaire bepaling. In deze voorwaarde is het in paragraaf 3.4.3.1 beschreven 'berekenbaarheid' van het recht te herkennen dat is verwerkt in het rechtszekerheidsbeginsel. Deze onzekerheid moet aan de hand van objectieve factoren zijn vast te stellen. Een door een lidstaat subjectief ervaren onzekerheid volstaat niet.

Uit de jurisprudentie blijkt dat diverse factoren de onzekerheid kunnen veroorzaken waarvan de belangrijkste bron van onzekerheid het gedrag van de Commissie kan zijn. Het gedrag van de Commissie kan bij een lidstaat de gedachte oproepen dat een bepaling van het Unierecht in de nationale regelgeving juist is geïmplementeerd.

In het eerdergenoemde Defrenne II-arrest is een situatie aan de orde waarbij het Hof vrij snel oordeelt dat het handelen of nalaten van de Commissie ten aanzien van een gemeenschapsbepaling onzekerheid veroorzaakt. Het gaat in dit arrest om een schending van het Unierecht, in casu de ongelijke beloning tussen vrouwelijke en mannelijke werknemers. De Commissie had deze ongelijkheid geconstateerd en zij riep daarom de lidstaten op er een einde aan te maken. Daarbij dreigde zij met het opstarten van een inbreukprocedure in de zin van artikel 258 VwEU. De Commissie gaf aan het dreigement echter geen vervolg. Het Hof merkte dit aan als relevant voor de beoordeling van de veroorzaakte onzekerheid. ${ }^{100}$

"Dat het feit dat de Commissie heeft verzuimd om ondanks waarschuwingen procedures wegens niet-nakoming overeenkomstig artikel 169 (huidig artikel 258 VwEU: toevoeging AHB) tegen de betrokken lidstaten in te leiden, aan een onjuiste opvatting nopens de werking van artikel 119 (huidig artikel $157 \mathrm{VwEU}$; beginsel van gelijke beloning: toevoeging AHB) steun heeft kunnen verlenen." (r.o. 73)

Andere handelingen van de Commissie die bij een lidstaat onzekerheid over de uitleg en toepassing van het Unierecht kunnen veroorzaken zijn blijkens de rechtspraak onder meer: ${ }^{101}$

100. In het Defrenne II-arrest treft dit aspect doel. In de procedure inzake Meilicke (Hof 6 maart 2007, nr. C-292/04, V-N 2007/14.3, NTFR 2007/523) komt A-G Stix-Hackl in haar conclusie van 5 oktober 2006 tot een andere conclusie. Zij meent dat het afzien van een formele niet-nakomingsprocedure in die zaak niet of nauwelijks heeft bijgedragen tot een mogelijke rechtsonzekerheid (punten $46 \mathrm{t} / \mathrm{m} \mathrm{54}$ ). 101. Zie voor een meer uitgebreide beschouwing over dit aspect M. Lang, Limitations of the Temporal Effects of Judgements of the ECJ, Intertax 2007 Volume 35, Issue 4, blz. 230. 
- Uitlatingen tijdens onderhandelingen over toelating tot de EU. ${ }^{102}$

- De Commissie heeft in correspondentie aan een lidstaat kenbaar gemaakt dat de regeling niet in strijd is met het Unierecht. ${ }^{103}$

- Een machtiging tot handhaving van een bepaalde regeling. ${ }^{104}$

Niet enkel een handeling van de Commissie kan onzekerheid bij de lidstaten veroorzaken. ${ }^{105}$ Zo oordeelde het Hof in het Bosman-arrest ${ }^{106}$ dat sprake was van een rechtsonzekerheid op grond van de bijzondere omstandigheid dat er een groot aantal verschillende, gedeeltelijk overlappende regelingen bestond.

Het Hof honoreert echter in veel gevallen het beroep van een lidstaat op de onzekerheid over de strekking van het recht van de Unie niet. Veelal is namelijk een lidstaat niet in staat de ongewisheid te onderbouwen. In paragraaf 5.6.1 is naar voren gebracht dat de lidstaat de stelplicht en bewijslast heeft en veelal slaagt een lidstaat daar niet in. ${ }^{107}$

102. Hof 9 maart 2000, nr. C-437/97, EKW en Wein \& Co, Jur. 2000, blz. I-1157, r.o. 58. Bijzonder is dat in zijn conclusie van 1 juli 1999 A-G Saggio dit aspect niet overtuigend vindt. Onder meer omdat het niet voldoende is gestaafd. In deze procedure heeft het Hof beslist dat een gemeentelijke drankbelasting niet in overeenstemming is met het Unierecht. Het verzoek van de uitgestelde werking door de Oostenrijkse regering is echter wel door het Hof gehonoreerd.

103. Hof 2 februari 1988, nr. 24/86, Blaizot, Jur. 1988, blz. 379. R.o. 32 en 33. Deze procedure heeft betrekking op de toegang tot onderwijs. Zie in dit verband ook de conclusie van A-G Jacobs van 17 maart 2005 inzake de toelaatbaarheid van de Italiaanse IRAP (Hof 3 oktober 2006, nr. C-475/03, Banca Popolare, V-N 2006/52.20). Hij meent in zijn conclusie dat brieven van de Commissie waarin is vermeld dat de Italiaanse IRAP niet in strijd is met de geldende communautaire BTW-bepalingen vertrouwen bij de Italiaanse regering hebben opgeroepen. Het Hof heeft niet geoordeeld over dit aspect omdat beslist is dat de IRAP geen verkapte BTW is en de vraag over de uitgestelde werking dan ook niet meer behandeld hoefde te worden. Zie verder Hof 14 september 2006, nr. C-228/05, Stradasfalti Srl, V-N 2006/47.15, NTFR 2006/1554. Het Hof besliste in deze procedure of Italië een regeling inzake het recht op aftrek van voorbelasting m.b.t. de aankoop, gebruik en onderhoud van motorvoertuigen niet kan handhaven op basis van artikel 17, lid 7, Zesde richtlijn. Uitgestelde werking van het arrest was niet aan de orde gezien het feit dat het BTW-comité de Italiaanse regering er steeds op had gewezen dat de Italiaanse regeling niet kon worden gehandhaafd op basis van artikel 17, lid 7, Zesde richtlijn.

104. Hof 16 juli 1992, nr. C-163/90, Legros, Jur. 1992, blz. I-4625, r.o. 31 e.v. Deze procedure heeft betrekking op de aanvaardbaarheid van een belastingregeling van de Franse overzeese departementen. 105. Het lijkt er op dat in zeer uitzonderlijke gevallen ook het Hof deze onzekerheid kan veroorzaken. Het moet dan gaan om een prejudiciële vraag die voor het eerst wordt voorgelegd terwijl een arrest van het Hof over een vraag in een aangrenzend rechtsgebied in redelijkheid onzekerheid kan hebben doen ontstaan. Zie Hof 4 mei 1999, nr. C-262/96, S. Sürül, Jur. 1999, blz. I-2685. Deze procedure heeft betrekking op gezinsbijdragen en de toekenning daarvan onder dezelfde voorwaarden aan Turkse onderdanen die toestemming hebben op het grondgebied van een lidstaat te verblijven.

106. Hof 15 december 1995, nr. C-415/93, Bosman, Jur. 1995, blz. I-4921, r.o. 143. In deze procedure is beslist dat het stelsel van transferbedragen en de beperkingen voor het opstellen van voetballers uit andere lidstaten in strijd is met de regels van het vrij verkeer van werknemers.

107. Zie onder andere Hof 15 maart 2005, nr. C-209/03, D. Bidar, Jur. 2005, blz. I-2119, r.o. 70. Betreffende gesubsidieerde leningen voor studenten. Hof 20 september 2001, nr. C-184/99, Grzelczyk, Jur. 2001, blz. I-6193, r.o. 54. Op het gebied van het stelsel van beurzen in België. 


\subsubsection{De voorwaarde van het gevaar van ernstige economische verstoringen}

In subparagraaf 5.6 .1 is naar voren gebracht dat aan de toepassing van het leerstuk van de uitgestelde werking tevens de eis is verbonden dat er een gevaar bestaat voor ernstige economische gevolgen. Een nadelig effect voor de schatkist van een lidstaat vormt geen rechtvaardiging voor een beperking in de tijd. Uit het Grzelczykarrest $^{108}$ blijkt dat op zich zelf de omvang van de financiële gevolgen voor een lidstaat niet beslissend is (r.o. 52). Hetzelfde arrest vermeldt als onderbouwing:

"Het Hof heeft immers slechts in zeer specifieke omstandigheden van deze mogelijkheid gebruikgemaakt, namelijk wanneer er een gevaar bestond voor ernstige economische gevolgen, inzonderheid gezien het grote aantal op basis van de geldig geachte wettelijke regeling te goeder trouw tot stand gekomen rechtsbetrekkingen, (...)" (r.o. 53)

Verder heeft het Hof in het Uudenkaupungin Kaupunki-arrest ${ }^{109}$ beslist dat enkel praktische moeilijkheden, waarmee een lidstaat rekening dient te houden bij een bepaalde uitkomst, ook geen reden is om een verzoek tot uitgestelde werking te honoreren.

Repercussies voor andere partijen zijn kennelijk wel een motief dat vaart geeft aan de onderbouwing door een lidstaat van het gevaar van ernstige economische gevolgen. Dit blijkt ook uit het EKW-arrest. ${ }^{110}$ In de deze procedure besliste het Hof dat de Oostenrijkse gemeentelijke drankbelasting in strijd was met het Unierecht. Het verzoek van de Oostenrijkse regering om uitgestelde werking van het arrest werd gehonoreerd. Aan de voorwaarde van ernstige economische gevolgen werd dus voldaan. Uit het arrest blijkt dat het Hof gevoelig was voor het argument dat Oostenrijkse gemeenten zouden komen te staan voor een niet te overzien aantal vorderingen tot terugbetaling, waaraan zij niet konden voldoen (r.o. 56). Ook uit de procedure over de vraag of de Italiaanse IRAP een verkapte (dus verboden) BTW is, blijkt dat repercussies voor andere partijen - namelijk de regio's - een factor van

108. Hof 20 september 2001, nr. C-184/99, Grzelczyk, Jur. 2001, blz. I-6193. Het Hof heeft in deze procedure het verzoek van de Belgische regering om de werking van het arrest uit te stellen afgewezen omdat het verzoek onvoldoende werd onderbouwd. Ook uit dit arrest blijkt dus, zoals door mij eerder naar voren is gebracht, dat de stelplicht en de bewijslastverdeling een belangrijk aspect is voor de uitkomst van een dergelijke procedure. Zie in dit kader ook Hof 17 februari 2005, gevoegde zaken nrs. C-453/02 en C-462/02, Linneweber e.a., Jur. V-N 2005/13.14, r.o. 44. In deze procedure heeft het Hof beslist dat de vrijstelling voor kansspelen van artikel 135, lid 1, sub i, BTW, richtlijn onafhankelijk is van de wijze van vormgeving en organisatie.

109. Hof 30 maart 2006, nr. C-184/04, Uudenkaupungin Kaupanki, V-N 2006/18.25, r.o. 56 en 57. Het Hof besliste in deze procedure dat de BTW-richtlijn de lidstaten verplicht te voorzien in een herziening van de aftrek. Overigens geeft A-G Stix-Hackl in haar conclusie van 15 september 2005 bij het arrest aan dat de Finse regering slechts vage gegevens verstrekte ter onderbouwing. Mogelijk speelt hier dus ook een rol dat de Finse regering tekort schiet in de op haar rustende bewijslast. Zie het slot van paragraaf 5.6.1.

110. Hof 9 maart 2000, nr. C-437/97, EKW en Wein \& Co, Jur. 2000, blz. I-1157. 
belang kunnen zijn. ${ }^{111}$ Zo is advocaat-generaal Jacobs in zijn conclusie bij het arrest gevoelig voor het feit dat als blijkt dat de IRAP in strijd is met de BTW-richtlijn het stelsel van financiering van de Italiaanse regio's terugwerkend wordt verstoord. ${ }^{112}$

\subsubsection{Slotsom over de uitgestelde werking van arresten}

In deze paragraaf is uiteengezet onder welke voorwaarden de werking van een arrest uitgesteld kan worden. De mogelijkheid om de werking van een arrest uit te stellen is vooral ontwikkeld in de jurisprudentie op andere delen van het Unierecht dan de BTW. Voornamelijk als gevolg van de procedure over de toelaatbaarheid van de Italiaanse IRAP (en de publiciteit rond de twee conclusies van de advocaten-generaal in deze zaak) is het ook bij BTW-specialisten in de aandacht komen te staan. In deze paragraaf zijn enkele procedures op het terrein van de BTW aangestipt waarin lidstaten niet slaagden het Hof te overtuigen van een gewenste uitgestelde werking. Volgens mij is het duidelijk dat wil een lidstaat succes hebben, dat dan gezorgd moet worden voor een zeer goede onderbouwing. Een verzoek tijdens de mondelinge behandeling (zoals in de eerder aangehaalde Uudenkaupungin Kaupanki-procedure) is dan veelal te laat en ongeschikt om het Hof te voorzien van de noodzakelijke gegevens.

Het is evident dat in het leerstuk van de uitgestelde werking van arresten het rechtszekerheidsbeginsel domineert. Het beginsel beschermt partijen tegen onverwachte schokken in de ontwikkeling van het recht van de Unie. Van belang is dat, wanneer aan een arrest uitgestelde werking wordt verleend, men een evenwicht vindt tussen het beginsel van een juiste en uniforme uitleg van het Unierecht en dat van de rechtszekerheid in de rechtsbetrekkingen die, hoewel op basis van een onjuiste uitleg, te goeder trouw zijn aangegaan.

Het spreekt vanzelf dat het gewenst is dat het Hof het leerstuk zeer beperkt blijft toepassen. Dit om de lidstaten te prikkelen om continu te monitoren of hun nationale regelgeving in overeenstemming is met het Unierecht.

111. Hof 3 oktober 2006, nr. C-475/03, Banca Popolare, V-N 2006/52.20. Het Hof is echter niet aan het vraagstuk van de uitgestelde werking toegekomen omdat geen sprake was van een vorm van verboden BTW.

112. Conclusie van 17 maart 2005, pt. 80. Zie ook de tweede conclusie in deze zaak van A-G Stix-Hackl van 14 maart 2006, pt. 156. Zij weegt tevens mee dat de procedure voor de Italiaanse rechter zeer lang heeft aangesleept en dat de Grote Kamer het ongebruikelijke besluit heeft genomen om de mondelinge behandeling te heropenen en een tweede terechtzitting te laten plaatsvinden, hetgeen nog meer aandacht heeft getrokken. Dit alles had tot gevolg dat nog meer vorderingen tegen de staat werden ingediend. 


\section{$5.7 \quad$ Conclusies}

Duidelijk is dat het evenredigheids- en het rechtszekerheidsbeginsel de toepassing van machtigingen om af te mogen wijken van de BTW-richtlijn beperkt (paragraaf 5.2). Het rechtszekerheidsbeginsel bepaalt ook de formele rechtskracht van besluiten en wel in die zin dat het onder bepaalde randvoorwaarden de lidstaten bescherming biedt tegen claims van belastingplichtigen (paragraaf 5.4).

In paragraaf 5.3 is aandacht geschonken aan het beginsel van het verbod op misbruik van recht. Het Hof heeft in het Halifax-arrest het beginsel een plaats gegeven in de BTW. In een serie arresten kiest het Hof niet voor toepassing van het verbod van misbruik van recht om een constructie om belasting te ontgaan te verijdelen. Door interpretatie van de bepalingen in de BTW-richtlijn, komt het Hof tot een resultaat waardoor de constructie wordt getackeld. Het beginsel van het verbod van misbruik van recht is een ultimum remedium die de letterlijke tekst niet beslissend laat zijn, maar de bedoeling. Het is evident dat misbruik een beroep op het Unierecht uitsluit. Het verbod op misbruik raakt een universeel basisprincipe in het recht.

Voorts zagen wij in paragraaf 5.5 de onmiskenbare invloed van het rechtszekerheidsbeginsel op de terugwerkende kracht van de regelgeving.

Het rechtszekerheidsbeginsel domineert in het leerstuk van de uitgestelde werking van arresten (paragraaf 5.6). Het beginsel beschermt lidstaten tegen onverwachte schokken in de ontwikkeling van het Unierecht. Wanneer aan een arrest uitgestelde werking wordt verleend, vindt men een evenwicht tussen het beginsel van een juiste en uniforme uitleg van het Unierecht en dat van de rechtszekerheid in de rechtsbetrekkingen die, hoewel op basis van een onjuiste uitleg, te goeder trouw zijn aangegaan. Duidelijk is ook dat in deze uitwerking het rechtszekerheidsbeginsel een inperkende werking heeft op de BTW-regelgeving (zie paragraaf 3.3.2). Het verhindert namelijk voor een bepaalde periode de juiste uitleg en toepassing van een Unieregeling.

In het Unierecht kan het gaan om de 'gezagsrelatie' tussen Uniewetgever en de lidstaat als implementator. Het rechtszekerheidbeginsel biedt dan bescherming aan de lidstaten (formele rechtskracht en uitgestelde werking van arresten). In de 'gezagsrelatie' tussen nationale wetgever en belastingplichtige biedt het rechtszekerheidsbeginsel bescherming aan de belastingplichtige (in beginsel geen terugwerkende kracht regelgeving). Het rechtszekerheidsbeginsel acteert dan als algemeen rechtsbeginsel van formeel recht (relatie Uniewetgever - lidstaat dan wel overheid - belastingplichtige) en niet als interpretatiebeginsel van de BTWrichtlijn. 



\section{HOOFDSTUK 6}

\section{Belastbare handelingen}

\section{Inleiding}

In het vorige hoofdstuk heb ik enkele leerstukken behandeld die vooral zijn vormgegeven onder invloed van de algemene rechtsbeginselen van formeel recht. In de hoofdstukken $6 \mathrm{t} / \mathrm{m} 12$ onderzoek ik de toepassing van algemene rechtsbeginselen als interpretatiebeginsel aan de hand van de kernpunten van de BTW-regels. Om te beginnen ga ik nu nader in op de belastbare handelingen.

De artikelen $2 \mathrm{t} / \mathrm{m}$ 4, en nader de artikelen $14 \mathrm{t} / \mathrm{m}$ 30, BTW-richtlijn (voorheen artikel 2 en artikelen $5 \mathrm{t} / \mathrm{m} \mathrm{7}$, Zesde richtlijn), definiëren de volgende belastbare handelingen: - Levering van goederen (artikel 2, sub a; artikel 14 t/m 19, BTW-richtlijn). ${ }^{1}$

- Intracommunautaire verwerving van goederen (artikel 2, sub b; artikel 3; artikel 4; artikel $20 \mathrm{t} / \mathrm{m} \mathrm{23,} \mathrm{BTW-richtlijn).}{ }^{2}$

- Diensten (artikel 2, sub c; artikel 24 t/m 29, BTW-richtlijn). ${ }^{3}$

- Invoer van goederen (artikel 2 sub d; artikel 30, BTW-richtlijn). ${ }^{4}$

De regelgeving kent vier belastbare feiten waaronder weer een varia aan specifiek geregelde vormen van leveringen, diensten, verwervingen en invoer ressorteren, bijvoorbeeld: 'huurverkoop-leveringen', 'opleveringen', 'fictieve leveringen', 'fictieve diensten', enz.

Artikel 2, sub a en c, BTW-richtlijn bepaalt dat BTW wordt geheven ter zake van leveringen van goederen en diensten die binnen het grondgebied van een lidstaat door een als zodanig handelende belastingplichtige onder bezwarende titel worden verricht. De bepaling vereist dus:

- een belastingplichtige (hoofdstuk 7);

- het grondgebied van een lidstaat (hoofdstuk 8);

- een bezwarende titel (hoofdstuk 9).

1. Artikelen 3 en $3 a$ Wet OB.

2. Artikel 17a Wet OB.

3. Artikel 4 Wet OB.

4. Artikel 18 Wet OB. 
Met ingang van 1 januari 1993 is een nieuw belastbaar feit in de BTW regelgeving opgenomen, namelijk de intracommunautaire verwerving van goederen die binnen het grondgebied van een lidstaat onder bezwarende titel wordt verricht. Deze wijziging was het gevolg van het verdwijnen van de fiscale grenzen (d.w.z. omzetbelastinggrenzen) tussen de lidstaten van de EU (paragraaf 2.3.2.2). Het belastbaar feit verwerving kwam in de plaats van het belastbaar feit 'invoer' tussen de lidstaten. Het doel van het belastbaar feit invoer is dat goederen, die vanuit derde landen afkomstig zijn, aan eenzelfde omzetbelastingdruk worden onderworpen als waaraan goederen zijn onderworpen die zich in het vrije verkeer van een lidstaat bevinden. Zo wordt een verstoring van de concurrentieverhoudingen voorkomen. Sinds het wegvallen van de fiscale grenzen tussen de lidstaten per 1 januari 1993 - en het daarvoor in de plaats komen van het belastbaar feit intracommunautaire verwerving - is het belastbare feit 'invoer' dus enkel nog relevant bij goederen die van buiten de EU komen.

Aan de orde is de betekenis van de algemene rechtsbeginselen bij de uitleg van de belastbare handelingen 'levering van goederen' en 'diensten'. ${ }^{5}$

De begrippen levering en dienst dienen binnen de communautaire rechtsorde een uniforme betekenis te hebben (zie paragraaf 6.2). In het begin van deze paragraaf is naar voren gebracht dat een ruim scala van handelingen belastbaar is op grond van de BTW-richtlijn. De BTW-richtlijn kent zelfs fictieve prestaties en dit draagt bij aan het ruime bereik van de heffing (paragraaf 6.5). ${ }^{6}$ Niet iedereen benadert de wet naar hoe zij bedoeld is. Zij blijkt fraudegevoelig en heeft blijkens de jurisprudentie aantrekkingskracht op fraudeurs. Uit de jurisprudentie blijkt echter dat het bereik van de heffing begrensd is bij het verschijnsel fraude (paragraaf 6.3) en in geval van illegale handelingen (paragraaf 6.4). De uitgangpunten daarvoor en de in dit hoofdstuk aan de orde komende algemene rechtsbeginselen vat ik in paragraaf 6.6 samen. Zij vormen het cement voor het bouwwerk van de belastbare handelingen.

Allereerst zal ik verduidelijken dat de belastbare handelingen 'levering van goederen' en 'diensten' een uniforme invulling hebben binnen de communautaire rechtsorde. Paragraaf 6.2 zal aangeven op welk grondbeginsel dit uitgangspunt is gebaseerd.

\footnotetext{
5. Het belastbare feit 'invoer' valt, zoals toegelicht in hoofdstuk 1, buiten het kader van mijn onderzoek. 6 . In de regelgeving en jurisprudentie zijn meerdere inbreuken op de ruime werking te vinden die niet in dit hoofdstuk zullen worden behandeld. Bijvoorbeeld de fiscale eenheid die is te vinden in artikel 11, BTW-richtlijn (artikel 7, vierde lid Wet OB). De fiscale eenheid heeft tot gevolg dat geen prestaties zijn te onderkennen tussen onderdelen van de fiscale eenheid. Een ander voorbeeld is het leerstuk kosten voor gemene rekening zoals dat in de jurisprudentie door de HR is ontwikkeld, zie 14 september 1988, nr. 25 005, BNB 1989/213. Zie nader D.M.P.M. Stevens, Het verrichten van diensten onder bezwarende titel als belastbaar feit in de omzetbelasting (diss. Maastricht) 2000, blz. 265 e.v.
} 
Het Hof verduidelijkt in een aantal arresten dat de richtlijn onder meer beoogt het gemeenschappelijk BTW-stelsel te baseren op een uniforme omschrijving van de belastbare handelingen. ${ }^{7}$ Daarbij past niet een invulling die afhangt van voorwaarden die van lidstaat tot lidstaat verschillen. Deze uniformering vindt plaats onder het etiket van de 'communautaire rechtsbegrippen' (paragraaf 4.3). De pijlers van het begrip belastbare handeling zijn dus te vinden in het communautaire recht.

Artikel 2, lid 1, sub a en c, BTW-richtlijn bepaalt dat de levering van goederen en diensten, '(...) die binnen het grondgebied van een lidstaat door een als zodanig handelende belastingplichtige onder bezwarende titel worden verricht' aan BTW zijn onderworpen. Het Hof gaat in het Tolsma-arrest ${ }^{8}$ nadrukkelijk in op het begrip 'bezwarende titel'. Het arrest vermeldt:

“(...), dat een dienst enkel 'onder bezwarende titel' in de zin van artikel 2 van de Zesde richtlijn wordt verricht en dus enkel belastbaar is, wanneer tussen de verrichter en de ontvanger van de dienst een rechtsbetrekking bestaat waarbij over en weer prestaties worden uitgewisseld, en de door de dienstverrichter ontvangen vergoeding de werkelijke tegenwaarde vormt voor de aan de ontvanger verleende dienst." (r.o. 14)

Elke partij bedingt iets van de ander, waarbij hetgeen bedongen is voorwaarde is voor het verrichten van de prestatie. Denie formuleert het als volgt, nog voor verschijnen van het Tolsma-arrest: ${ }^{9}$

"Wil het Hof een verplichting van de orgelman, dan zal het rechtstreekse verband duidelijk blijken een oorzakelijk verband te moeten zijn. Het oorzakelijke verband ontleed, wil dit zeggen:

- mijn prestatie is doelgericht op jouw vergoeding, terwijl

- deze een voorwaarde is voor mijn prestatie aan jou,

- en mijn prestatie is een voorwaarde voor jouw vergoeding aan mij.

Ik geef opdat ik krijg en tegelijk omdat ik krijg. Ik krijg omdat ik geef. De prestaties over en weer zijn onderling van elkaar afhankelijk. Spelen zonder wederkerigheid is dan geen muziek meer voor de schatkist. Het rechtstreekse verband heeft structuur."

7. Zie bijvoorbeeld Hof 8 februari 1990, nr. C-320/88, Safe Rekencentrum BV, BNB 1990/271, V-N 1990/ 2127, pt. 24, FED 1990/330, in het bijzonder r.o. 8. In dit arrest heeft het Hof beslist dat een economische eigendom overdracht een belaste levering is. Zie tevens Hof 11 februari, nr. C-88/09, Graphic Procédé, V-N 2010 , r.o. 14, waarin is beslist dat het vervaardigen van reproducties een levering is.

8. Hof 3 maart 1994, nr. C-16/93, Tolsma, BNB 1994/271, m.n.v. Finkensieper, V-N 1994/1065, pt. 25. In deze procedure gaat het om de vraag of een exploitant van een draaiorgel die geen aanspraak kan maken op een vergoeding van de voorbijgangers een dienst onder bezwarende titel verricht. Zie tevens Hof 21 maart 2002, Kennemer Golf \& Country Club, nr. C-174/00, BNB 2003/30, m.n.v. M.E. van Hilten, V-N 2002/20.13, FED 2002/249, r.o. 39. Zie ook Hof 14 juli 2005, nr. C-435/03, BATI, V-N 2005/37.21. Waarin is beslist dat diefstal van goederen geen levering is in de zin van artikel 2, Zesde richtlijn gezien het ontbreken van een financiële tegenprestatie in het voordeel van het slachtoffer. In vergelijkbare zijn Hof 23 maart 2006, nr. C-210/04, FCE Bank Plc, BNB 2006/184, V-N 2006/18.24, r.o. 34. In dezelfde zin Hof 18 juli 2007, nr. C-277/05, Sociéte Thermale d'Eugénie-les Bains, V-N 2007/34.25, NTFR 2007/1413, r.o. 19. 9. A.H.R.M. Denie, Minder muziek bij het jubileum van de BTW?, WFR 1994/6086, paragraaf 11. 
Er moet dus een rechtstreeks verband bestaan tussen de verrichte dienst en de ontvangen tegenwaarde. ${ }^{10}$

Wat betreft het vereiste rechtstreekse verband is het Apple and Pear-arrest ${ }^{11}$ van belang:

"Het begrip 'diensten welke onder bezwarende titel worden verricht' in de zin van artikel 2 aanhef en sub 1, van de Zesde richtlijn, onderstelt derhalve dat er een rechtstreeks verband bestaat tussen de verrichte dienst en de ontvangen tegenwaarde." (r.o. 12)

In deze procedure hield de belanghebbende zich bezig met de behartiging van de gemeenschappelijke belangen van haar leden (zowel de appel- als de perentelers). Zij verplichtte haar leden tot een bijdrage. Het Hof besliste dat de bijdrage niet belast is met BTW, omdat de uit de werkzaamheden van belanghebbende voortvloeiende voordelen de gehele sector ten goede komen en er geen rechtstreeks verband bestaat tussen de omvang van het voordeel dat individuele telers bij de dienstverlening van belanghebbende hebben en de verplichte bijdrage die zij moeten betalen (r.o. 15).

Het Town \& County-arrest ${ }^{12}$ kan gezien worden als een vervolg op de Tolsmaprocedure. Town \& County organiseert regelmatig het spel spot-the-bal. ${ }^{13}$ In de spelregels is bepaald dat de prijs die is te winnen slechts een ereschuld is. Town \& County heeft echter altijd de prijs aan de winnaar uitbetaald. Een van de vragen die de Engelse rechter stelt aan het Hof is, of een dienst die wordt verricht uit hoofde van een niet in rechte afdwingbare verplichting, omdat is overeengekomen dat de

10. Zie nader Hof 5 februari 1981, nr. 154/80, Coöperatieve Aardappelenbewaarplaats GA, BNB 1981/ 232, vooral r.o. 12. In het desbetreffende arrest heeft het Hof beslist dat als de tegenwaarde bestaat in een - niet nader bepaalde - waardedaling van de aandelen van de leden van de coöperatie, een dergelijke waarde daling niet kan worden beschouwd als een vergoeding die door de dienstverlenende coöperatie wordt ontvangen.

11. Hof 8 maart 1988, nr. 102/86, Apple and Pear Development Council, Jur. 1988, blz. 1443. Zie tevens Hof 21 maart 2002, nr. C-174/00, Kennemer Golf \& Country Club, BNB 2003/30, m.n.v. M.E. van Hilten, V-N 2002/20.13, FED 2002/249. In r.o 40 is beslist dat het gegeven dat een jaarlijkse contributie forfaitair is en niet is gekoppeld aan het afzonderlijk gebruik van de golfbaan, niet af doet aan het feit dat over en weer prestaties worden uitgewisseld. Het Hof besliste dan ook dat sprake is van een rechtstreeks verband tussen de contributie en het permanent ter beschikking stellen van het sportcomplex voor gebruik. Zie in dit verband ook Hof 18 juli 2007, nr. C-277/05, Sociéteé thermale d'Eugénie-les-Bains, V-N 2007/34.25, NTFR 2007/1413. In dit arrest is beslist dat voorschotten die in het kader van overeenkomsten inzake aan BTW onderworpen hotelreserveringen zijn betaald en door de het hotel worden behouden in geval van annulering onbelast zijn. Het Hof motiveert deze beslissing met de constatering dat een rechtstreeks verband ontbreekt.

12. Hof 17 september 2002, nr. C-498/99, Town \& County Factors, V-N 2002/50.21, NTFR 2002/1391.

13. Een foto geeft een moment van een voetbalwedstrijd weer waarop de voetbal onzichtbaar is gemaakt. Deelnemers krijgen de kans om d.m.v. een kruisje aan te geven waar de voetbal zich bevindt. De deelnemer met het kruisje dat het dichtst bij de plaats staat waar zich volgens de jury het middelpunt van de voetbal bevindt, wint de eerste prijs. De deelnemer met het kruisje dat na dat van de winnaar van de eerste prijs het dichtstbijzijnd is, wint de tweede prijs, enz. 
dienstverrichter ter zake van deze dienst slechts een ereschuld op zich neemt, een aan de BTW onderworpen handeling vormt. Het Hof begint met vast te stellen dat tussen de organisator van het spel en de deelnemers over en weer prestaties worden uitgewisseld in de zin van het Tolsma-arrest, waarbij de door organisatie ontvangen deelnamekosten de werkelijke tegenwaarde vormt van de dienst die hij aan de deelnemers verleent (r.o. 20).

Vervolgens overweegt het Hof dat een benadering volgens welke slechts sprake is van een rechtsbetrekking in de zin van het arrest Tolsma, indien de op de dienstverrichter rustende verplichting afdwingbaar is, afbreuk zou doen aan het nuttig effect van de richtlijn. Dit zou tot gevolg hebben dat onder de richtlijn vallende handelingen per lidstaat kunnen verschillen vanwege de divergenties die de diverse rechtsorden dienaangaande kunnen vertonen (r.o. 21). Ik kan het niet beter afsluiten dan met de woorden van het Hof zelf:

"Tot slot kan niet staande worden gehouden dat een rechtsbetrekking in de zin van het reeds aangehaalde arrest Tolsma ontbreekt omdat de uitvoering van de op de dienstverrichter rustende verplichtingen niet in rechte kan worden afgedwongen. Wanneer die verrichter en de ontvanger van de dienst zijn overeengekomen dat de uitvoering van deze verplichting niet in rechte kan worden afgedwongen, vormt een dergelijke overeenkomst immers reeds de uitdrukking van een rechtsbetrekking in bedoelde zin." (r.o. 23)

Wat de acceptatie van de belastbare handeling betreft, zij ten slotte volledigheidshalve verwezen naar paragraaf 2.2 waar het verbruik aan de orde is.

\subsection{Fraude}

In de vorige paragraaf zijn de elementen geschetst die vereist zijn om tot een belastbare handeling te komen voor de BTW. In deze paragraaf komt aan de orde de vraag of dit anders is in geval van (carrousel)fraude. ${ }^{14}$ Het ontbreken van een belastbare handeling in geval van fraude slaat door naar het recht op aftrek van voorbelasting. Indien transacties buiten het bereik van de BTW worden geplaatst heeft dat tot gevolg dat het recht op aftrek van voorbelasting verloren gaat. Hoofdstuk 11 besteedt aandacht aan het recht op aftrek van voorbelasting.

14. Deze vorm van fraude komt in verscheidene vormen voor. Doorgaans wordt gebruik gemaakt van een keten van belastingplichtigen die zijn gevestigd in binnen- en buitenland, die al dan niet daadwerkelijk goederen leveren en waarbij ten minste één van de betrokken ondernemers niet aan zijn betalings- en/of aangifteverplichtingen voor de BTW voldoet. Deze partij (ploffer genoemd) schrijft facturen uit met BTW, die hij niet voldoet aan de Belastingdienst. Zijn afnemer vraagt deze BTW terug of brengt in aftrek. Gezien het gebrek aan verhaalsmogelijkheden levert naheffing bij de zogenoemde ploffer niets op. Zie over de diverse vormen van carrouselfraude het zeer lezenswaardige en omvangrijke rapport van het European Union Committee van het House of Lords van 25 mei 2007 over the missing trader. Het rapport is verkrijgbaar via Internet: www.publications.parliament.uk/pa/ ld200607/ldselect/ldeucom/ldeucom.htm Zie verder voor een overzicht van de verschillende definities van carrouselfraude die in de literatuur zijn te vinden R.A. Wolf, Carrouselfraude (diss. Groningen), Den Haag: Sdu Uitgevers 2010, blz. 33 t/m 38. 
Het Optigen-arrest ${ }^{15}$ en het Kittel-arrest ${ }^{16}$ zijn van belang voor het antwoord op de vraag of sprake is van een belastbare handeling in geval van (carrousel)fraude. Het Hof heeft zowel in het Optigen-arrest (r.o. 49) als in het Kittel-arrest (r.o. 50) herhaalt dat uit constante jurisprudentie naar voren komt dat het beginsel van de fiscale neutraliteit zich verzet tegen een algemeen onderscheid tussen legale en illegale transacties. Niettemin is geen sprake van een prestatie in BTW technische zin ingeval een belastingplichtige zelf frauduleuze transacties verricht. In het Kittelarrest overweegt het Hof:

"Daarentegen is aan de criteria waarop de begrippen levering van goederen door een als zodanig handelende belastingplichtige en economische activiteit zijn gebaseerd, niet voldaan ingeval van belastingfraude door de belastingplichtige zelf (...)." (r.o. 53)

Ook in geval van bepaalde illegale handelingen - zoals de handel in drugs - is sprake van en uitzondering op de fiscale onderworpenheid. (zie paragraaf 6.4). Het naar mijn mening ongewenste gevolg hiervan kan zijn dat belanghebbenden het frauduleuze karakter van hun activiteiten benadrukken om zo onder een BTW-heffing uit te komen.

Optigen was betrokken bij transacties die deel uitmaakte van een zogenoemde carrouselfraude. Zij had echter geen kennis van de fraude door andere partijen in de keten van transacties. De verwijzende rechter wilde onder meer weten of handelingen die niet zelf het voorwerp van BTW-fraude zijn, maar die deel uitmaken van een carrouselfraude, zonder dat Optigen daar wetenschap van heeft, leveringen van goederen zijn en of in dergelijke omstandigheden het recht op aftrek van voorbelasting mag worden beperkt.

Het Hof overweegt, dat het gemeenschappelijke BTW-stelsel onder meer is gebaseerd op een uniforme omschrijving van de belastbare handelingen.

Voorts geeft het Hof aan dat de invulling van de belastbare handelingen, die in artikel 2, BTW-richtlijn is te vinden, de zinsdelen 'leveringen van goederen' en 'als zodanig handelende belastingplichtige' bevat. Deze twee begrippen hebben een objectief karakter en zij worden toegepast onafhankelijk van het oogmerk of resultaat van de betrokken handelingen (r.o. 44). Een onderzoek door de Belastingdienst naar hetgeen belastingplichtigen precies voorhebben gaat in tegen de rechtszekerheid. De rechtszekerheid is gediend door af te gaan op de objectieve aard van de betrokken handelingen. Het is dan ook in strijd met de rechtszekerheid indien

15. Hof 12 januari 2006, gevoegde zaken nr. C-354/03, nr. C-355/03, nr. C-484/03, Optigen, Fulcrum Electronics, Bond House Systems, V-N 2006/7.20, NTFR 2006/979.

16. Hof 6 juli 2006, gevoegde zaken nrs. C-439/04 en C-440/04, Axel Kittel, Recolta Recycling, V-N 2006/42.13. 
betekenis wordt toegekend aan het frauduleuze karakter van andere in de keten verrichte transacties. Iedere transactie moet op zichzelf worden beschouwd en de aard van een bepaalde handeling in de keten kan niet worden gewijzigd door vroegere of latere gebeurtenissen. ${ }^{17}$

Handelstransacties die niet in het kader van BTW-fraude zijn verricht vallen dus onder het bereik van de BTW. Dit is onafhankelijk van het oogmerk van een andere ondernemer dan de betrokken belastingplichtigen (in casu Optigen) die deel uitmaakt van dezelfde keten van levering en welke wel leveringen verricht die van frauduleuze aard zijn, waarvan Optigen geen weet heeft en ook geen kennis van kan hebben. ${ }^{18}$ In het arrest Netto Supermarkt verwoordt het Hof het als volgt:

“(...) dat een leverancier op de rechtmatigheid van de handeling die hij verricht moet kunnen vertrouwen zonder het gevaar te lopen zijn recht op btw-vrijstelling te verliezen, wanneer hij, zoals in het hoofdgeding, ook met betrachting van de zorgvuldigheid van een oplettend koopman, niet kan weten dat de voorwaarden voor vrijstelling in werkelijkheid niet vervuld zijn omdat de afnemer een vervalst bewijs van uitvoer heeft overgelegd." (r.o. 27)

Ook het recht op aftrek van voorbelasting blijft in stand, zie hierover nader hoofdstuk 11. Om de transactie te kunnen aanmerken als een belastbare handeling in de zin van artikel 2, BTW-richtlijn en het recht op aftrek van voorbelasting in stand te laten is dus van belang dat:

1. De belastingplichtige verricht de handelingen niet in het kader van BTW-fraude.

2. Het antwoord op de vraag of degene die levert of afneemt van de betrokken belastingplichtige frauduleus handelt is irrelevant (objectieve benadering).

3. De betrokken belastingplichtige heeft geen weet, dan wel kan ook geen kennis hebben van het feit dat transacties onderdeel zijn van een keten van fraudeleuze transacties (wetenschap).

Het Kittel-arrest voegt aan de derde voorwaarde toe, dat een belastingplichtige die wist of had moeten weten dat hij door zijn aankoop deelnam aan een transactie die onderdeel was van BTW-fraude, voor de toepassing van de BTW-richtlijn moet worden beschouwd als deelnemer aan deze fraude, ongeacht of hij winst haalt uit de doorverkoop van de goederen (r.o. 56). In een dergelijke situatie is de belastingplichtige de fraudeurs behulpzaam en wordt hij hun medeplichtige (r.o. 57). Op dit

17. Zie in dit verband Hof 3 maart 2004, nr. C-395/02, Transport Service NV, Jur. 2004, blz. I-1991, V-N 2004/18.18. In r.o. 26 is beslist dat het irrelevant is of de BTW over de latere verkoop van de betrokken goederen aan de eindverbruiker al dan niet aan de schatkist is betaald. Bij elke transactie inzake productie of distributie tot de kleinhandelsfase is BTW verschuldigd onder aftrek van de BTW waarmee de onderscheidene elementen van de prijs rechtstreeks waren belast.

18. Hof 21 februari 2008, nr. C-271/06, Netto Supermarkt GmbH \& co, V-N 2008/11.16, NTFR 2008/405, r.o. 27. In deze procedure werd een leverancier geconfronteerd met door zijn afnemers vervalste douaneformulieren. Echter een oplettend koopman mag toch het zogenoemde nultarief toepassen op de exportleveringen. 
punt wijkt de beslissing af van de conclusie van advocaat-generaal Ruiz-Jarabo Colomer van 14 maart 2006 bij het Kittel-arrest. De advocaat-generaal wil ook de belastingplichtige beschermen die wel degelijk van het bedrog op de hoogte is, maar daaraan niet deelneemt en zich daardoor ook niet verrijkt. Het Hof verwerpt deze gedachte in het Kittel-arrest:

\footnotetext{
"Derhalve staat het aan de nationale rechter het recht op aftrek te weigeren indien aan de hand van objectieve elementen wordt vastgesteld dat de belastingplichtige wist of had moeten weten dat hij door zijn aankoop deelnam aan een transactie die onderdeel was van BTW-fraude, en dit zelfs indien de betrokken handeling voldoet aan de criteria waarop de begrippen levering van goederen door een als zodanig handelende belastingplichtige en economische activiteit zijn gebaseerd." (r.o. 59)
}

Deze benadering spoort met hetgeen in paragraaf 5.3 is opgemerkt over misbruik van recht, namelijk dat in geval van fraude of misbruik geen beroep kan worden gedaan op het Unierecht. ${ }^{19}$ Zie in dit kader rechtsoverweging 59 in het Halifax-arrest waar het Hof erop wijst dat in geval van belastingfraude, bijvoorbeeld door valse aangifte of door het opstellen van onregelmatige facturen, zeker niet wordt voldaan aan de eisen die worden gesteld aan de begrippen leveringen van goederen en het verrichten van diensten. ${ }^{20}$

Kennelijk is het zo dat in geval van fraude (of misbruik van recht) een tweetal krachten tegenover elkaar staan. Namelijk aan één kant de werking van het rechtszekerheidsbeginsel. Deze kracht is gericht op het tot zijn recht laten komen van de objectieve feiten waaraan de BTW-richtlijn de belasting verbindt. Daartegenover staat het uitgangspunt dat justitiabelen in geval van fraude of misbruik geen beroep kunnen doen op het Unierecht en dat dan ook betekenis toekent aan het subjectieve motief en het doel van de handelingen. Indien deze krachten botsen, blijkt uit het Kittel-arrest dat de werking van het rechtszekerheidsbeginsel het onderspit delft.

Ontbreekt fraude dan wel de wetenschap daarover, dan bekijkt het Hof een transactie geïsoleerd, afgezien van hetgeen daar aan vooraf ging of op volgt. In essentie is deze benadering door het Hof gebaseerd op het rechtszekerheidsbeginsel. Het is echter de vraag of het rechtszekerheidsbeginsel wel tot zijn volle recht komt in de praktijk. De derde voorwaarde (wetenschap) onderzoekt de nationale rechter. Te verwachten is dat daarbij gekeken zal worden naar objectieve factoren (zoals een normale marktprijs, aard van de goederen, de wijze waarop de ondernemer wordt

19. Hof 21 februari 2006, nr. C-255/02, Halifax Plc., BNB 2006/170, m.n.v. D.B. Bijl, V-N 2006/13.20, NTFR 2006/359. Paragraaf 5.3 behandelt het arrest uitgebreid.

20. Dat neemt niet weg dat als op een factuur BTW is vermeld deze belasting verschuldigd kan zijn op grond van artikel 203, BTW-richtlijn. Zie Hof 18 juni 2009, nr. C-566/07, Stadeco BV, V-N 2009/31.14, zie dan met name r.o. 26 en 29. Wolf vindt de uitleg die het Hof geeft, toegespitst op carrouselfraude, weinig elegant. Volgens hem is er weinig basis in de BTW-richtlijn te vinden voor de uitleg in het Stadeco-arrest, dat een verlies aan belastinginkomsten ook kan optreden bij bedragen die niet als BTW aftrekbaar zijn. Zie hierover uitgebreid R.A. Wolf 2010, blz. 128 t/m 134. 
benaderd). ${ }^{21}$ Handelspartijen zullen behoefte hebben aan duidelijkheid wanneer zij verschoonbaar zijn en op welke wijze deze objectieve factoren worden ingevuld. Zolang dit aspect niet is uitgekristalliseerd - bijvoorbeeld in nationale regelgeving dan wel jurisprudentie - is het onzeker wanneer belastingplichtigen een beroep kunnen doen op het Unierecht en dan in het bijzonder op de BTW-richtlijn. ${ }^{22}$

\subsection{Illegale handelingen}

De begrippen levering en dienst hebben een objectief karakter, zie hiervoor paragraaf 6.3. In paragraaf 6.2 zijn behandeld de criteria waaraan voldaan moet zijn wil zich een belastbare handeling voordoen. Vereist is een rechtstreeks verband tussen prestatie en vergoeding. In paragraaf 2.2 is de invloed van het verbruiksbeginsel behandeld dat een onderdeel is van het rechtskarakter van de BTW. Het beginsel van de fiscale neutraliteit kent het begrip 'economische activiteiten' een ruime werkingssfeer toe. Deze paragraaf verduidelijkt de betekenis van de fiscale neutraliteit in geval van illegale handelingen. ${ }^{23}$

In de jurisprudentie van het Hof met betrekking tot de fiscale behandeling van illegale handelingen, is een ontwikkeling te ontdekken die start bij het Horvatharrest en (voorlopig) eindigt bij het Salumets-arrest. Het Hof heeft in het Horvatharrest $^{24}$ vastgesteld, dat heffing van douanerechten niet aan de orde is in geval van invoer van verboden middelen die in geen enkele lidstaat in het verkeer mogen worden gebracht en onmiddellijk na hun ontdekking in beslag worden genomen. Dit buiten de orde stellen van de fiscale onderworpenheid geldt niet voor de streng gecontroleerde en beperkte geoorloofde handel met het oog op farmaceutische en medische doeleinden. Vervolgens besliste het Hof in het Wolf-arrest ${ }^{25}$ en het Einberger I-arrest ${ }^{26}$ dat ook geen heffing van douanerechten plaatsvindt, ingeval de verdovende middelen niet bij de invoer zijn ontdekt maar later van de hand zijn gedaan.

In het Einberger II-arrest ${ }^{27}$ verklaarde het Hof voor recht, dat hetzelfde ook geldt voor de BTW bij invoer. Verdovende middelen die illegaal worden ingevoerd vallen

21. A-G Ruiz-Jarabo Colomer heeft in zijn conclusie bij het Kittel-arrest ook betekenis toegekend aan de positie van de belastingplichtige in de keten. Want naarmate hij zich dichter bij de fictieve transactie bevindt, is het vermoeden sterker dat hij aan het bedrog heeft deelgenomen. Zie tevens R.A. Wolf 2010, blz. 104 en 105.

22. Voor een beschouwing over de diverse matregelen die de lidstaten kunnen nemen om carrouselfraude te bestrijden, zie het rapport van de International VAT Association van maart 2007 getiteld, Combatting VAT Fraud in the EU, The Way Forward. Zie ook R.A. Wolf 2010, blz. 171 e.v. voor de bespreking van een aantal ideeën, waarbij tevens aan bod komt de (technische) uitvoerbaarheid en de vraag of de maatregelen carrouselfraude zullen dempen.

23. Zie in dit verband ook P.J. Wattel, De fiscale behandeling van het wederrechtelijke (diss. Amsterdam UvA), Deventer: Kluwer 1992, Fiscale Monografie nr. 58, blz. 236 e.v.

24. Hof 5 februari 1981, nr. 50/80, J. Horvath, Jur. 1981, blz. 385.

25. Hof 26 oktober 1982, nr. 221/81, W. Wolf, Jur. 1982, blz. 3681

26. Hof 26 oktober 1982, nr. 240/81, S. Einberger, Jur. 1982, blz. 3699.

27. Hof 28 februari 1984, nr. 294/82, S. Einberger, BNB 1987/6, FED 1985/541. 
geheel buiten het bereik van de BTW. In het Mol-arrest ${ }^{28}$ besliste het Hof, dat ook de levering van verdovende middelen op het grondgebied van een lidstaat geen BTWheffing plaatsvindt. In deze procedure hebben de Nederlandse, Franse en Duitse regering de vrees naar voren gebracht dat het onmogelijk zal blijken te zijn om een onderscheid te maken tussen de illegale handel in verdovende middelen en andere illegale activiteiten. Het Hof 'repliceert':

"Bij de heffing van BTW verzet het beginsel van fiscale neutraliteit zich inderdaad tegen een algemeen onderscheid tussen legale en illegale transacties. De levering van producten zoals verdovende middelen staat daar evenwel buiten: deze producten vormen een bijzonder geval doordat zij wegens hun aard in alle lidstaten onder een volstrekt verhandelingsverbod vallen, met uitzondering van het streng bewaakte handelsverkeer ten behoeve van gebruik voor medische en wetenschappelijke doeleinden. In een dergelijke specifieke situatie, waarin elke mededinging tussen een legale en een illegale economische sector uitgesloten is, kan het niet verschuldigd zijn van BTW het beginsel van fiscale neutraliteit niet aantasten." (r.o. 18)

Transacties die volstrekt verboden zijn en daarmee de mededinging niet kunnen vervalsen, blijven buiten de reikwijdte van de BTW. Daar blijkt dus uit dat de fiscale neutraliteit een rol speelt.

Het Hof heeft aan het bovenstaande in het Happy Family-arrest ${ }^{29}$ toegevoegd, dat de regel van niet-toepasselijkheid van de BTW eveneens geldt voor de illegale levering van hennepproducten, ook wanneer de autoriteiten van een lidstaat in het kader van een selectief vervolgingsbeleid de kleinschalige detailhandel in die verdovende middelen niet systematisch strafrechtelijk vervolgen. Daarbij overweegt het Hof mede dat de in de EU tot stand gebrachte harmonisatie van de BTW in gevaar zou komen, indien de werkingssfeer van die belasting met betrekking tot een illegale transactie zou afhangen van de wijze waarop het vervolgingsbeleid in de desbetreffende lidstaat gestalte krijgt, ook wanneer dergelijke transacties in die staat in beginsel verboden blijven (r.o. 30).

In het Witzemann-arrest ${ }^{30}$ wijst het Hof erop dat ook in geval van de invoer van vals geld geen heffing van BTW en douanerechten plaatsvindt. Het Hof trekt een parallel met verdovende middelen. Ook in geval van vals geld is namelijk in alle lidstaten een absoluut verbod op de invoer en handel van kracht.

De genoemde arresten verwijzen zowel naar internationale verdragen die de handel in verdovende middelen en vals geld verbieden als naar het Werkingsverdrag. Het is niet duidelijk of de beslissingen zijn gebaseerd op deze verdragen, dan wel dat de desbetreffende verdragen worden gebruikt om de BTW-richtlijn (dan wel verordening in geval van douanerechten) te interpreteren. Advocaat-generaal Jacobs gaat in zijn conclusie van 25 oktober 1990 bij het Witzemann-arrest op deze vraag in (punt 14 e.v). Hij komt tot de conclusie dat 'de werkelijke grondslag van de regel enigszins duister is'. Wel komt hij tot de conclusie dat het Hof in geen van de bovenstaande

28. Hof 5 juli 1988, nr. 269/86, W.J.R. Mol, BNB 1988/303, FED 1988/495.

29. Hof 5 juli 1988, nr. 289/86, Vereniging Happy Family Rustenburgerstraat, FED 1988/496.

30. Hof 6 december 1990, nr. C-343/89, M. Witzemann, BNB 1991/190, V-N 1991/2268, pt. 17, FED 1991/354. 
arresten heeft willen 'suggereren' dat de regel volgens welke geen BTW kan worden geven bij de invoer of levering van verdovende middelen, rechtstreeks aan het Werkingsverdrag of aan een algemeen rechtsbeginsel is ontleend. Het betreft volgens advocaat-generaal Jacobs uitleg van afgeleid recht, in casu de BTW-richtlijn.

Ook advocaat-generaal Fennelly ${ }^{31}$ meent dat de werkelijke grondslag enigszins duister is en vindt het jammer dat ook in het Witzemann-arrest geen verduidelijking is gegeven, ondanks de oproep daartoe door de Commissie en advocaat-generaal Jacobs. Wel meent hij dat de rechtspraak erom draait, dat verdovende middelen, doordat de handel erin in alle lidstaten volstrekt verboden is en enkel tot strafmaatregelen aanleiding kan geven, geen enkele rol spelen in de normale economie. Het beginsel van fiscale neutraliteit komt volgens hem eenvoudig niet aan de orde omdat elke mededinging tussen een legale en een illegale economische sector is uitgesloten. Zoals in paragraaf 4.4.4.2 is verduidelijkt, is de fiscale neutraliteit de uitdrukking van het gelijkheidsbeginsel bij de uitleg van de BTW-richtlijn.

Het Hof heeft de uitsluiting van de BTW enkel gehanteerd op het terrein van de handel in verdovende middelen en vals geld. In latere arresten heeft het Hof weliswaar deze regel herhaald, dat geen BTW kan worden geheven over producten die niet in het economische verkeer mogen worden gebracht, echter het Hof kwam niet meer tot een uitsluiting van de BTW-heffing. Zie:

- Het Lange-arrest ${ }^{32}$ waarin is beslist dat bij de toepassing van de vrijstelling van uitvoer geen onderscheid wordt gemaakt tussen legale en illegale transacties. De uitvoer van zogenoemde strategische goederen tegen de exportregels in komt dan ook in aanmerking voor de desbetreffende vrijstelling.

- Het Goodwin \& Unstead-arrest ${ }^{33}$ warin is bepaald dat BTW-heffing aan de orde is bij de levering van namaakparfums.

- Het Fischer-arrest ${ }^{34}$ waarin is beslist dat de organisatie van illegale kansspelen (in casu casino) onder het bereik van de BTW valt gezien het feit dat zij concurreren met legale kansspelen. Tevens is beslist dat de exploitatie van een kansspel onder het bereik van de vrijstelling van artikel 135, lid 1, sub i, BTWrichtlijn valt (voorheen artikel 13B, sub f, Zesde richtlijn) indien de overeenkomstige activiteit van een erkende openbare speelcasino is vrijgesteld. Dit gezien het beginsel van de fiscale neutraliteit.

- Het arrest Coffeeshop Siberië ${ }^{35}$ waarin is beslist dat het gelegenheid geven aan een ander tot handel in softdrugs (in casu door middel van de verhuur van een tafel) valt onder het bereik van de BTW.

31. Conclusie van 11 maart 1999 bij het arrest van het Hof 29 juni 1999, nr. C-158/98, VOF Coffeeshop Siberië, BNB 2000/178, V-N 1999/36.17, FED 1999/619.

32. Hof 2 augustus 1993, nr. C-111/92, W. Lange, Jur. 1993, blz. I-4677.

33. Hof 28 mei 1998, nr. C-3/97, Goodwin \& Unstead, V-N 1998/57.17.

34. Hof 11 juni 1998, nr. C-283/95, K. Fischer, V-N 1998/39.43.

35. Hof 29 juni 1999, nr. C-158/98, Coffeeshop Siberië, nr. C-158/98, BNB 2000/178, V-N 1999/36.17, FED 1999/619. 
- Het Salumets-arrest ${ }^{36}$ waar is verduidelijkt dat de heffing van BTW en douanerechten aan de orde is in geval van de illegale invoer van ethylalcohol uit derde landen.

Het Hof heeft in de bovenstaande arresten de lijn doorgetrokken, dat de BTWrichtlijn die een vergaande harmonisatie van de BTW beoogt, gebaseerd is op het beginsel van fiscale neutraliteit. Dit beginsel verzet zich bij de heffing van BTW tegen een algemeen onderscheid tussen legale en illegale transacties, met uitzondering van de gevallen waarin wegens de bijzondere kenmerken van bepaalde goederen elke mededinging tussen een legale en een illegale economische sector is uitgesloten. Een dergelijke uitsluiting doet zich in de bovenstaande vijf arresten niet voor, zodat de volle werking van het BTW-stelsel aan de orde is om verstoring van de mededinging tussen de legale en de illegale sector te voorkomen.

Wat opvalt, is dat zowel Jacobs in zijn conclusie bij het Witzemann-arrest, als Fennelly in zijn conclusie bij het arrest Coffeeshop Siberië, moeite hebben met de uitzondering die het Hof maakt voor de handel in softdrugs en vals geld op de ruime werking van de BTW. Gezien het feit dat de lijn is gebaseerd op een constant patroon in de jurisprudentie waarin praktisch dezelfde rechtsoverwegingen zijn te vinden, willen zij de beslissingen van het Hof niet principieel ter discussie stellen. Zij pleiten voor inperking en verduidelijking van de grondslag om geen BTW te heffen in geval van bepaalde illegale handelingen. Ook hebben beide advocaten-generaal moeite met het gegeven dat de belanghebbenden worden aangemoedigd om hun eigen crimineel gedrag te benadrukken om zo onder de heffing van BTW uit te komen. Illustraties hiervan zijn te vinden in de arresten Goodwin \& Unstead en het Coffeeshop Siberië-arrest. In deze beide procedures benadrukten belanghebbenden het illegale karakter van hun handelingen in de hoop zo buiten het bereik van de BTW te komen.

Fennelly brengt naar voren dat de gedachte dat een criminele activiteit, en in het bijzonder handel in drugs, juist door zijn crimineel karakter een speciaal gunstig belastingregime geniet hem tegen de borst stuit. Zowel Jacobs als Fennelly menen dat de meeste rechtsstelsels uitsluiten dat partijen zich te eigen bate mogen beroepen op hun eigen crimineel gedrag. ${ }^{37}$ Een dergelijk onbevredigend effect hebben wij ook gezien in paragraaf 6.3 waar is behandeld dat onder omstandigheden frauduleuze transacties buiten het bereik van de BTW blijven.

Fennelly doet in zijn conclusie de suggestie, kennelijk gericht tot de nationale rechter, om in de toekomst het Hof uitspraak te vragen wanneer het gaat over bijvoorbeeld de opbrengsten van minderjarigenprostitutie, kinderpornografie of mensenhandel, of voor die activiteit het vereiste absolute verbod geldt om onder de uitsluiting te vallen.

36. Hof 29 juni 2000, nr. C-455/98, Salumets e.a., Jur. 2000, blz. I-4993.

37. Zie paragraaf 5.3 . 
In artikel 14, BTW-richtlijn (voorheen artikel 5, Zesde richtlijn) is de belastbare handeling levering van goederen uitgewerkt en in artikel 24, lid 1, BTW-richtlijn (voorheen artikel 6, Zesde richtlijn) is de belastbare handeling dienst te vinden. Deze belastbare feiten leiden pas tot heffing indien zij onder bezwarende titel worden verricht (zie paragraaf 6.2). De BTW wil echter meer dan enkel deze handelingen onder de heffing brengen. Zij worden bij fictie aangevuld in artikel 16 (levering van goederen) (voorheen artikel 5, lid 6, Zesde richtlijn) ${ }^{38}$ en in artikel 26, lid 1, BTWrichtlijn (diensten) (voorheen artikel 6, lid 2, Zesde richtlijn). ${ }^{39}$ Deze bepalingen hebben tot gevolg dat bepaalde handelingen om niet met een levering of dienst onder bezwarende titel worden gelijkgesteld. Om een tweetal redenen worden dergelijke handelingen ook wel aangeduid als fictieve prestaties. ${ }^{40}$ Allereerst is in de literatuur de gedachte te vinden dat het bijvoeglijk naamwoord 'fictieve' terug slaat op het civiele recht. ${ }^{41}$ De BTW-richtlijn en de Wet OB sluiten in beginsel aan bij civielrechtelijke handelingen: het leveren van eigendom, het verrichten van diensten en dit alles onder bezwarende titel. De BTW-richtlijn en de Wet OB hebben daaraan niet voldoende bij het realiseren van de doelstellingen van de BTW. Daarom doet de regelgever alsof bepaalde handelingen - het onttrekken aan bedrijfsvermogen en het gebruiken van bedrijfsvermogen - ook als leveringen en diensten onder bezwarende titel behandeld moeten worden. Hij fingeert dus ten opzichte van het civiele recht leveringen en diensten. Een tweede reden waarom sprake is van 'fictieve' prestaties is omdat een vergoeding ontbreekt. In paragraaf 6.2 is verduidelijkt dat een rechtstreeks verband vereist is tussen prestatie en vergoeding wil zich een belastbaar feit voordoen. Bij de in artikelen 16 en 26, BTW-richtlijn genoemde belastbare handelingen ontbreekt juist een daadwerkelijke betaling. De artikelen 74 en 75, BTWrichtlijn bevatten aanvullende regels ter bepaling van de maatstaf van heffing zodat als het ware bij fictie toch sprake is van een belastbaar feit.

38. In artikel 16, BTW-richtlijn is te vinden:

"Met een levering van goederen onder bezwarende titel wordt gelijkgesteld het door een belastingplichtige aan zijn bedrijf onttrekken van een goed voor eigen privédoeleinden of voor privédoeleinden van zijn personeel, of dat hij om niet verstrekt of, meer in het algemeen, voor andere dan bedrijfsdoeleinden bestemt, ingeval met betrekking tot dat goed of de bestanddelen daarvan recht op volledige of gedeeltelijke aftrek van de BTW is ontstaan. (...)."

39. Zo bepaalt artikel 26, lid 1, BTW-richtlijn:

"Met diensten verricht onder bezwarende titel worden de volgende handelingen gelijkgesteld:

a) het gebruiken van een tot het bedrijf behorend goed voor privédoeleinden van de belastingplichtige of van zijn personeel, of, meer in het algemeen, voor andere dan bedrijfsdoeleinden, wanneer voor dit goed recht op volledige of gedeeltelijke aftrek van de BTW is ontstaan;

b) het om niet verrichten van diensten door de belastingplichtige voor eigen privédoeleinden of voor privédoeleinden van zijn personeel, of, meer in het algemeen, voor andere dan bedrijfsdoeleinden.

(...)."

40. Datzelfde kan ook worden gesteld over de artikelen 17 en 18, BTW-richtlijn.

41. Zie nader A.H.R.M. Denie, Liever BUA dan Europa, Forfaitair 2008/183, en dan in het bijzonder paragraaf 5 e.v. 
Artikel 26, lid 1, sub a, BTW-richtlijn kan naar de huidige stand van het recht niet meer los worden gezien van het leerstuk keuzevermogen, zoals dat in de jurisprudentie van het Hof tot ontwikkeling is gekomen. ${ }^{42}$ Het leerstuk houdt in dat een belastingplichtige kan kiezen om een roerend ${ }^{43}$ investeringsgoed, ${ }^{44}$ dat zowel voor belastingplichtige activiteiten als voor privédoeleinden wordt aangewend, te rekenen:

- volledig tot het ondernemingsvermogen;

- volledig tot het niet-ondernemingsvermogen;

- voor een deel tot het ondernemingsvermogen en voor het overige deel tot het niet-ondernemingsvermogen.

Indien een roerend investeringsgoed volledig tot het ondernemingsvermogen wordt gerekend dan kan de toerekenbare voorbelasting volledig in aftrek worden gebracht. Daar staat dan wel een heffing op grond van artikel 26, lid 1, sub a, BTW-richtlijn tegenover om zo het privégebruik te belasten. ${ }^{45}$

Indien daarentegen een belastingplichtige besluit een gemengd te gebruiken roerend investeringsgoed niet in zijn bedrijfsvermogen op te nemen - te etiketteren als privévermogen - dan is de toerekenbare voorbelasting niet aftrekbaar. Besluit de belastingplichtige een gedeelte van het roerende goed voor zijn bedrijf te gebruiken en dienovereenkomstig te etiketteren, dan is de voorbelasting aftrekbaar die is toe te rekenen aan het voor het bedrijf gebruikte gedeelte van het roerende goed. ${ }^{46}$

Het leerstuk van het keuzevermogen is dus een keuze tussen directe aftrek van de voorbelasting gevolgd door een fictieve heffing, dan wel het ontbreken van recht op aftrek en het ontbreken van een fictieve heffing. Deze keuze kan een belastingplichtige maken indien hij het roerende goed zowel voor belastingplichtige activiteiten gebruikt als voor privédoeleinden. ${ }^{47}$

42. Zie Hof 4 oktober 1995, nr. C-291/92, D. Armbrecht, BNB 1996/62, V-N 1995/3902 pt. 33, r.o. 20; Hof 8 maart 2001, L. Bakcsi, nr. C-415/98, BNB 2001/200, V-N 2001/18.30, r.o. 25; Hof 8 mei 2003, nr. C-269/ 00, W. Seeling, BNB 2004/1, V-N 2003/28.20, r.o. 40 e.v. Hof 21 april 2005, nr. C-25/03, HE, BNB 2005/ 229, m.n.v. M.E. van Hilten, V-N 2005/22.18, r.o. 46. Hof 14 juli 2005, nr. C-434/03, Charles en CharlesTijmens, BNB 2005/284, V-N 2005/35.18, r.o. 23.

43. Vanaf 1 januari 2011 geldt het leerstuk van het keuzevermogen enkel voor roerende investeringsgoederen. Voor die datum was het leerstuk ook mogelijk voor onroerende goederen. De in deze paragraaf behandelde jurisprudentie heeft betrekking op de periode dat het leerstuk van toepassing was op zowel roerende als onroerende goederen.

44. Onduidelijk is of het leerstuk ook op niet-investeringsgoederen kan worden toegepast. Zie verderop in deze paragraaf.

45. In geval van een levering is artikel 16, BTW-richtlijn aan de orde.

46. In deze zin Hof 4 oktober 1995, nr. C-291/92, D. Armbrecht, BNB 1996/62, V-N 1995/3902 pt. 33, zie in het bijzonder r.o. 28 en 29.

47. De Raad heeft op 22 december 2009 Richtlijn 2009/162/EU vastgesteld. Deze richtlijn wijzigt de BTW-richtlijn op een aantal onderdelen. Deze wijziging heeft tot gevolg dat de doctrine van het keuzevermogen aan belang is ingeboet. Uit de toelichting blijkt dat deze aanpassingen onder meer beogen de initiële aftrek te beperken tot het werkelijke gebruik van onroerend goed voor handelingen waarvoor recht op aftrek bestaat. Bij gemengd gebruik is het niet meer mogelijk om onmiddellijk de volledige voorbelasting in aftrek te brengen, maar wordt een correctiemechanisme voorgesteld om $\rightarrow$ 
Artikel 16, BTW-richtlijn kan ook van toepassing zijn in het geval een belastingplichtige bonnen aan consumenten bij de aankoop van producten verstrekt en die kunnen worden ingewisseld tegen een uit een speciale catalogus gekozen geschenken. Het Hof besliste in het Kuwait Petroleum-arrest ${ }^{48}$ dat het aanbieden van dergelijke geschenken niet is aan te merken als een prijskorting in de zin van artikel 79, sub b, BTW-richtlijn, maar moet worden gelijkgesteld met een belastbare handeling volgens artikel 16, BTW-richtlijn. ${ }^{49}$

De artikelen 16 en 26, lid 1, sub b, BTW-richtlijn zijn niet van toepassing indien een (lage) vergoeding van het personeel wordt gevraagd. Zo besliste het Hof in het Scandic-arrest ${ }^{50}$ dat de verkoop van kantinemaaltijden aan personeel tegen een lage verkoopprijs, niet valt onder het bereik van de artikelen 16 en 26, lid 1, sub b, BTWrichtlijn. Dit is zelfs niet het geval indien de verkoopprijs onder de kostprijs is. Ook die lage verkoopprijs is er een onder bezwarende titel en belet dus de toepassing van de fictieve levering. Dergelijke prestaties aan het personeel zijn slechts belast tegen de lage verkoopprijs (paragraaf 9.2.3). In het Danfoss-arrest ${ }^{51}$ is hier aan toegevoegd dat een fictieve heffing ook niet aan de orde is in het geval dat gratis maaltijden worden verstrekt in de bedrijfskantine aan zakenrelaties in het kader van bijeenkomsten die plaatsvinden binnen de onderneming, wanneer uit objectieve gegevens blijkt dat die maaltijden uitsluitend voor beroepsdoeleinden worden verstrekt. Daarentegen is deze bepaling in beginsel van toepassing op het om niet verstrekken van maaltijden door een onderneming aan haar personeel in haar bedrijfsruimten, tenzij de behoeften van de onderneming, zoals de noodzaak de continuïteit en het goede verloop van de zakelijke bijeenkomsten te garanderen, verlangen dat die maaltijden door de werkgever worden verstrekt. Deze uitleg betekent dat de 'zakelijke' consumptie niet onder het bereik van de fictieve heffingen valt. ${ }^{52}$ Een BTW-vrije lunch is dus mogelijk, ook al zal in veel gevallen het nuttigen van spijzen en dranken tevens de privédoeleinden van de werknemer dienen. Het lijkt mij te verwachten dat dit tot discussies zal leiden over de vraag wanneer met objectieve gegevens de zakelijkheid voldoende is aangetoond.

$\rightarrow$ rekening te houden met toenemend en afnemend zakelijk gebruik. De nieuwe richtlijn is geïmplementeerd 1 januari 2011 in de Wet OB. Zie Kamerstukken II 09/10, 32 400, nr. 1 - 4, V-N 2010/31.14. Zie tevens over de systematiek na 1 januari 2011, J.B.O. Bijl, Aftrek van BTW op kosten en investeringen met betrekking tot bedrijfsmiddelen, WFR 2010/872.

48. Hof 27 april 1999, nr. C-48/97, Kuwait Petroleum (GB) Ltd, V-N 1999/27.15.

49. Zie voor een vergelijking van het BTW-stelsel dat van toepassing is in geval van gratis artikelen die worden ingewisseld met een systeem waarbij een prijskorting wordt verleend bij inwisseling van een bon het arrest van het Hof van 15 oktober 2002, nr. C-427/98, Commissie/Duitsland, V-N 2002/54.22, in het bijzonder r.o. $68 \mathrm{t} / \mathrm{m} 78$.

50. Hof 20 januari 2005, nr. C-412/03, Hotel Scandic Gåsabäck, V-N 2005/8.22.

51. Hof 11 december 2008, nr. C-371/07, Danfoss A/S en AstraZenica A/S, V-N 2009/3.24, NTFR 2008/ 2508.

52. In de onderbouwing grijpt het Hof terug op het arrest Fillibeck (16 oktober 1997, nr. C-258/95, V-N 1998/2.35). In deze procedure besliste het Hof dat gratis vervoer van werknemers onder omstandigheden niet te zien is als een privé aangelegenheid van die werknemers maar als een dienst voor bedrijfsdoeleinden. 
Het doel van artikel 26, lid 1, sub a, BTW-richtlijn is te voorkomen dat een belastingplichtige belastingvrij kan genieten van een bedrijfsgoed, door het bedrijfsgoed waarvoor hij de voorbelasting heeft afgetrokken voor privé doeleinden te gebruiken. In het Puffer-arrest ${ }^{53}$ wijst het Hof erop dat artikel 26, lid 1, sub a, BTWrichtlijn erop is gericht de gelijke behandeling te verzekeren van de belastingplichtige die de BTW over de verkrijging van het goed heeft kunnen aftrekken, en de eindverbruiker die de BTW betaalt over de aankoop van het goederen. De bepaling is dan ook enkel van toepassing indien de belastingplichtige de toerekenbare voorbelasting in aftrek heeft gebracht.

Artikel 26, lid 1, sub b, BTW-richtlijn is meer in het algemeen bedoeld om te voorkomen dat een belastingplichtige belastingvrij diensten van zijn onderneming verkrijgt. Deze bepaling stelt geen enkele voorwaarde met betrekking tot de aftrekbare voorbelasting. In tegenstelling tot artikel 26, lid 1, sub a, BTW-richtlijn is deze bepaling niet bedoeld om de voorbelasting die in aftrek is gebracht op voor privé doeleinden gebruikte goederen te corrigeren door middel van een heffing. Het doel van artikel 26, lid 1, sub b, BTW-richtlijn is te voorkomen dat een belastingplichtige belastingvrij diensten van zijn onderneming ontvangt, waarover een particulier BTW zou moeten betalen.

Dat bij de fictieve gebruiksheffingen de fiscale neutraliteit een belangrijke rol speelt blijkt uit het Kühne-arrest. ${ }^{54}$ In dit arrest gebruikt de ondernemer in privé een auto van zijn bedrijf die hij tweedehands van een particulier heeft gekocht en ter zake waarvan hij dus bij de aankoop geen BTW heeft kunnen aftrekken. Aan de orde is de vraag of artikel 26, lid 1, sub a, BTW-richtlijn zich ertegen verzet, dat de afschrijving op een bedrijfsgoed ter zake van privégebruik wordt belast. Het Hof overweegt dat uit het systeem van de BTW-richtlijn volgt dat de desbetreffende bepaling wil voorkomen dat een voor privédoeleinden gebruikt bedrijfsgoed onbelast zou blijven. Daar volgt uit dat het privégebruik van een dergelijk goed enkel dan kan worden belast, wanneer voor dit goed recht op aftrek van voorbelasting is ontstaan op het moment van verkrijging. Het Hof overweegt vervolgens:

"Voor zover de belastingplichtige het restant-BTW dat op het tweedehands van een nietbelastingplichtige gekochte bedrijfsgoed drukt, niet mag aftrekken, dient ervan te worden uitgegaan, dat voor dit goed geen recht op aftrek van BTW is ontstaan in de zin van artikel 6, lid 2, eerste volzin, sub a, van de Zesde richtlijn, zodat de afschrijving op het goed wegens het privégebruik ervan niet op grond van deze bepaling mag worden belast.

Zou een bedrijfsgoed waarvoor geen recht op aftrek van het restant-BTW is ontstaan, wel aldus worden belast, dan zou dit tot dubbele belastingheffing leiden, wat in strijd is met het beginsel van de belastingneutraliteit, dat ten grondslag ligt aan het gemeenschappelijk BTW-stelsel waarvan de Zesde richtlijn deel uitmaakt." (rechtsoverwegingen 9 en 10)

53. Hof 23 april 2009, nr. C-460/07, Sandra Puffer, V-N 2009/25.17, NTFR 2009/1031, r.o. 54. Idem in Hof 11 december 2008, nr. C-371/07, Danfoss A/S en AstraZeneca A/S, V-N 2009/3.24, NTFR 2008/2508, r.o. 46.

54. Hof 27 juni 1989, nr. 50/88, H. Kühne, FED 1990/739. 
Duidelijk blijkt dat de bedoeling van de heffing is te bereiken dat het gebruik van het investeringsgoed één keer wordt getroffen door een heffing die ook daadwerkelijk drukt.

In verband met de hierboven ter sprake gebrachte relatie tussen de fictieve heffingen en het leerstuk van de vermogensetikettering is het van belang de inperking van dit leerstuk ter sprake te brengen. Deze inperking vond plaats in het VNLTO-arrest. ${ }^{55}$ Het Hof besliste dat het leerstuk niet aan de orde is bij het aanwezig zijn van nieteconomische activiteiten. De casus is als volgt. De land- en tuinbouworganisatie VNLTO heeft als doel het bevorderen van de belangen in de agrarische sector. Verder verricht VNLTO ook commerciële activiteiten waarvoor zij een afzonderlijke vergoeding berekent en waarvoor zij belastingplichtig is voor de BTW. Het Gerechtshof Leeuwarden oordeelde dat VNLTO geen BTW kan aftrekken voor zover zij goederen en diensten in het kader van de algemene belangenbehartiging bezigt. Belanghebbende legde zich niet neer bij dit oordeel en ging dan ook in cassatie. Zij meende - met een beroep op het arrest Charles \& Charles-Tijmens ${ }^{56}$ - in aanmerking te komen voor een volledig recht op aftrek van voorbelasting. De Hoge Raad oordeelde dat redelijkerwijs niet voor twijfel vatbaar is dat de uitkomst van het arrest Charles \& Charles-Tijmens inzake investeringsgoederen ook geldt voor rechtspersonen. ${ }^{57}$ Dit betekent dat de Hoge Raad het leerstuk ook van toepassing acht op niet-economische handelingen (in casu de algemene belangenbehartiging). Vervolgens stelde de Hoge Raad onder meer de prejudiciële vraag of het Charles \& Charles-Tijmens-arrest uitsluitend betrekking heeft op investeringsgoederen, dan wel op alle goederen en diensten die worden gebruikt voor zowel bedrijfsdoeleinden als voor andere dan bedrijfsdoeleinden. ${ }^{58}$

Het Hof komt niet aan de beantwoording van de vraag van de Hoge Raad toe, maar oordeelde dat gebruik voor niet-belastbare handelingen (in casu de algemene belangenbehartiging) geen belastbaar eigen gebruik 'voor andere dan bedrijfsdoeleinden' in de zin van artikel 26, lid 1, sub a, BTW-richtlijn is. Anders zou namelijk artikel 2, lid 1, BTW-richtlijn geen betekenis hebben. Artikel 26, lid 1, sub a, BTWrichtlijn is er dus niet op gericht als algemene regel te stellen dat handelingen die buiten de werkingssfeer van de BTW vallen, geacht moeten worden binnen de werkingssfeer te vallen. Nu het fictieve belastbare feit van artikel 26, lid 1, sub a, BTW-richtlijn niet aan de orde is, heeft dat tot gevolg dat ook het recht op aftrek van voorbelasting (voor zover toerekenbaar aan de algemene belangenbehartiging)

55. Hof 12 februari 2009, nr. C-515/07, Vereniging Noordelijke Land en Tuinbouworganisatie (VNLTO), BNB 2009/202 m.n.v. B.G. van Zadelhoff, V-N 2009/9.27, NTFR 2009/475.

56. Hof 14 juli 2005, nr. C-434/03, Charles \& Charles-Tijmens, BNB 2005/284, V-N 2005/35.18.

57. Deze beslissing is te vinden in HR 2 november 2007, nr. 42.415, BNB 2008/53. In het zelfde arrest stelde de HR ook de vragen inzake VLNTO aan het Hof. Zie voor een kritische beschouwing over de toepassing door de HR van het leerstuk op niet economische handelingen, C. Verweij, Brengt de zaakNLTO wel helder licht in de vermogensetikettering voor de BTW, WFR 2008/660.

58. Zie in dit kader ook de recent door de HR gestelde prejudiciële vragen over de aftrek van voorbelasting en het tijdelijk privé gebruiken van een aangepaste bedrijfsloods, HR 11 juni 2010, nr. 07/12617, V-N 2010/ 30.12, NTFR 2010/2079. 
buiten het bereik ligt. Uit het VNLTO-arrest is de conclusie te trekken dat een investeringsgoed kan worden gebruikt voor:

a. Bedrijfsdoeleinden.

b. Andere dan bedrijfsdoeleinden (waaronder privédoeleinden).

c. Niet economische doeleinden.

Het leerstuk van de vermogensetikettering (onmiddellijke aftrek van voorbelasting gevolgd door een fictieve heffing) geldt niet voor categorie c. Voor deze laatste categorie bestaat meteen - vanaf het moment van aanschaf - geen aftrek van voorbelasting en de investering, niettemin daarvoor gebruikt, dient de voorbelasting te worden gesplitst. ${ }^{59}$

$\mathrm{Nu}$ het Hof in de VNLTO-casus het leerstuk niet van toepassing acht blijft de vraag van de Hoge Raad (of het leerstuk ook geldt voor gewone goederen en (investerings) diensten) onbeantwoord. Ik kom op dit aspect terug nadat het arrest Mohsche is behandeld.

In het Puffer-arrest ${ }^{60}$ stelde de Oostenrijkse rechter een prejudiciële vraag toegespitst op het gemeenschapsrechtelijke algemene gelijkheidsbeginsel. De casus is als volgt. Sandra Puffer heeft een eensgezinswoning met zwembad laten bouwen die zij als privéwoning gebruikt, behalve een deel - $11 \%$ - dat zij bedrijfsmatig verhuurt. Puffer heeft het onroerend goed volledig tot haar bedrijfsvermogen bestemd en verzocht om aftrek van alle BTW die aan haar in rekening was gebracht voor de bouw van de woning en het zwembad. De Oostenrijkse Belastingdienst weigerde de aftrek van de voorbelasting die drukt op de bouw van het zwembad. Bovendien werd de aftrek van de voorbelasting die drukt op de overige bouwkosten slechts aanvaard voor het deel van het gebouw dat bedrijfsmatig werd gebruikt (in casu $11 \%$ ). Het geschil tussen Puffer en de Oostenrijkse Belastingdienst leidde uiteindelijk tot een prejudiciële procedure.

De Oostenrijkse rechter vraagt zich onder meer af of het leerstuk van het keuzevermogen - onmiddellijke aftrek gevolgd door een fictieve heffing - in strijd is met het gemeenschapsrechtelijke gelijkheidsbeginsel. Uit de prejudiciële vraag blijkt dat de Oostenrijkse rechter een vergelijking maakt tussen belastingplichtigen en nietbelastingplichtigen. Toepassing van het leerstuk leidt tot een cashflowvoordeel bij belastingplichtigen. Zo merkt de verwijzende rechter op dat de volledige en onmiddellijke aftrek van de BTW over de bouwkosten van een dergelijk onroerend goed voor gemengd gebruik en de latere, over tien jaar gespreide heffing van BTW over de uitgaven voor het als privéwoning gebruikte deel van het onroerend goed tot

59. Zie nader in de literatuur over de gevolgen van het VNLTO-arrest: S.T.M. Beelen, Aftrek van btw als (belaste) omzet ontbreekt (diss. Rotterdam), Deventer: Kluwer 2010, blz. 171 t/m 174; M.W.C. Soltysik, Het arrest VNLTO: alweer? Ja alweer, maar dan anders!, MBB 2010/06; R.J.M.C. Lantman \& M. Kasmer, Vermogensetiketering: enkel een privéaangelegenheid?, MBB 2010/3; J.P.M. Linssen, VNLTO: geen aftrek van BTW ter zake van algemene belangenbehartiging, BTW-Brief 2009, nr. 11, blz. 15. 60. Hof 23 april 2009, nr. C-460/07, Sandra Puffer, V-N 2009/25.17, NTFR 2009/1031. 
gevolg hebben dat de belastingplichtige voor deze periode een 'renteloze lening' krijgt, waarvoor een niet-belastingplichtige niet in aanmerking komt. De Oostenrijkse rechter becijferde het cashflowvoordeel op $5 \%$ van de nettoprijs voor de bouw van het deel van het onroerend goed dat voor privédoeleinden wordt gebruikt. De verwijzende rechter vraagt of een dergelijk cashflowvoordeel een ongelijke behandeling van belastingplichtigen en niet-belastingplichtigen in het leven roept, alsmede binnen de categorie van belastingplichtigen een ongelijke behandeling van belastingplichtigen die een uitsluitend voor privédoeleinden bestemd onroerend goed optrekken, en belastingplichtigen die een deel daarvan tot hun bedrijfsvermogen bestemmen. De Oostenrijkse rechter stelt in feite het door het Hof ontwikkelde leerstuk van de vermogensetikettering ter discussie.

Het Hof overweegt - na het leerstuk van de vermogensetikettering uiteen te hebben gezet - dat het vaste rechtspraak is dat het gemeenschapsrechtelijke gelijkheidsbeginsel wordt geschonden wanneer verschillende regels worden toegepast op vergelijkbare situaties of wanneer dezelfde regels worden toegepast op verschillende situaties (r.o. 52) en dat het gelijkheidsbeginsel ter zake van de BTW tot uitdrukking komt in het beginsel van de fiscale neutraliteit (r.o. 53). Vervolgens wijst het Hof erop dat het verschil in behandeling tussen belastingplichtigen en niet-belastingplichtigen voortvloeit uit de toepassing van:

“(...) het beginsel van fiscale neutraliteit, dat in de eerste plaats de gelijkheid van behandeling van belastingplichtigen verzekert. Dit mogelijke verschil ontstaat bovendien uit het feit dat deze belastingplichtigen hun economische activiteiten zoals omschreven in artikel 4 , lid 2, van de Zesde richtlijn verrichten. Ten slotte houdt dit verschil verband met het in de Zesde richtlijn geregelde specifieke statuut van de belastingplichtigen, dat met name inhoudt dat zij overeenkomstig artikel 21 van deze richtlijn de BTW verschuldigd zijn en moeten innen." (r.o. 56)

Het beginsel van de fiscale neutraliteit in deze overweging en die van rechtsoverweging 53 hebben bij nauwgezette lezing mijns inzien betrekking op de verhouding tussen ondernemers voor wie de fiscale neutraliteit in beginsel bedoeld is. Zowel in de prejudiciële vraag als in de overige behandeling (vergelijk r.o. 24 en 62) van het vraagstuk dat voorligt, betrekt het Hof bij de bespreking van het verschil tussen belastingplichtigen en niet-belastingplichtigen het gemeenschapsrechtelijke algemene gelijkheidsbeginsel. Bij deze vergelijking wordt het algemene gelijkheidsbeginsel te hulp geroepen en niet de voor de BTW gereserveerde fiscale neutraliteit.

Dit betekent dat de situatie van belastingplichtigen verschilt van niet-belastingplichtigen en dat een eventueel verschil in behandeling het gevolg is van de toepassing van verschillende regels op verschillende situaties, zodat het algemene gelijkheidsbeginsel geenszins geschonden is. Verder geeft het Hof aan (r.o. 59) dat het niet anders is voor een belastingplichtige die alleen vrijgestelde handelingen verricht, aangezien een dergelijke belastingplichtige dezelfde BTW-druk moet dragen als een niet-belastingplichtige en zijn omstandigheden (of in de woorden van het Hof: 'zijn statuut') dus in wezen is gelijkgesteld met dat van laatstgenoemde. Het Hof komt dus in het Puffer-arrest tot de slotsom dat de toepassing van het leerstuk 
van het keuzevermogen bij belastingplichtigen die belaste handelingen verrichten niet in strijd is met het algemene gelijkheidsbeginsel om de eenvoudige reden dat het geen vergelijkbare gevallen zijn.

Dit ligt weer anders in het Mohsche-arrest ${ }^{61}$ waar door de procespartijen een beroep wordt gedaan op de fiscale neutraliteit. Als de fiscale neutraliteit - als uitdrukking van het gelijkheidsbeginsel - wordt ingeroepen bij de uitleg van de fictieve gebruiksheffing in artikel 26, lid 1, sub a, BTW-richtlijn, dan kan het beginsel in de toepassing meerdere richtingen op wijzen. Afhankelijk van het antwoord op de vraag waarmee vergelijking dienst plaats te vinden (geobjectiveerde huurder, koper of andere relateerbaar figuur). Op deze problematiek is ook gewezen in de paragrafen 3.4.1 en 4.4.3. Dit is in het bijzonder aan de orde in het Mohsche-arrest. Mohsche gebruikte voor privédoeleinden een bedrijfsauto. Gezien het gegeven dat de voorbelasting in aftrek was gebracht, werd over het gebruik BTW geheven op grond van artikel 26, lid 1, sub a, BTW-richtlijn. De Duitse Belastingdienst stelde zich op het standpunt dat BTW verschuldigd is over de afschrijving van de auto en de kosten voor gebruik en onderhoud. Mohsche en de Commissie daarentegen meenden dat geen BTW verschuldigd is over kosten waarover geen voorbelasting in aftrek is gebracht, zoals verzekeringen, motorrijtuigenbelasting, garagehuur, parkeergelden.

In de Mohsche-procedure beriepen zowel de Commissie als de Duitse regering zich op de fiscale neutraliteit ter ondersteuning van hun standpunt. Zij verschilden echter van mening over de gevolgen voor de uitleg van artikel 26, lid 1, sub a, BTW-richtlijn. De Duitse regering meende dat Mohsche gelijkgesteld moet worden met een klant die een auto huurt van een belastingplichtige autoverhuurder. In een dergelijk geval is BTW verschuldigd over alle huurbetalingen (inclusief verzekeringen). Ongeacht het antwoord op de vraag of de verhuurder recht had op aftrek van BTW over de verzekeringen e.d. Op grond van deze gelijkstelling kwam de Duitse regering tot de conclusie dat het privégebruik in de zin van artikel 26, lid 1, sub a, BTW-richtlijn de kosten dient te omvatten die voor het gebruik van de auto zijn gemaakt. Ongeacht of daarvoor BTW in aftrek is gebracht. Dus ook de verzekeringskosten. ${ }^{62}$

De Commissie daarentegen stelde zich op het standpunt dat Mohsche gelijkgesteld dient te worden met een particuliere koper van een auto en niet met een huurder. Een particuliere koper wordt niet getroffen door een BTW-heffing over verzekeringen en andere kosten waar geen BTW over wordt berekend.

Zowel de Commissie als de Duitse regering brengen ter onderbouwing van hun standpunt het gelijkheidsbeginsel in stelling. Echter Mohsche wordt vergeleken met verschillende subjecten (huurder dan wel koper). Toepassing van de fiscale neutraliteit als uitdrukking voor de BTW van het gelijkheidsbeginsel wijst dan een

61. Hof 25 mei 1993, nr. C-193/91, G. Mohsche, FED 1995/550, m.n.v. D.B. Bijl.

62. Zie nader over het onderscheid tussen de begrippen 'goed' en 'bestanddeel' voor wat betreft de fictieve heffing van artikel 16, BTW-richtlijn, A.J. Blank \& M.J. Ziepzeerder, Gevolgen van het arrest Fischer en Brandenstein, WFR 2001/1249. 
verschillende richting uit. De Mohsche-procedure laat zien dat bij de toepassing van de fiscale neutraliteit bij de uitleg van de rechtsregel, goede nota genomen moet worden welke gevallen men met elkaar vergelijkt. Daarbij is het raadzaam om na te gaan wat de regelgeving nastreeft. Dit kan leren welke gevallen men met elkaar dient te vergelijken.

Het Hof besteedt in het arrest Mohsche niet expliciet aandacht aan de vraag met wie gelijkstelling dient plaats te vinden. Dit in tegenstelling tot advocaat-generaal Jacobs. De advocaat-generaal verdedigt in zijn conclusie dat een gelijkstelling dient plaats te vinden met de koper van een auto en niet met een huurder (laatste zin, punt 11). Indien Mohsche namelijk de auto uitsluitend had gekocht voor privédoeleinden dan zou hij zijn behandeld als een particuliere koper voor wie de verzekerings-, belasting- en dergelijke kosten eveneens niet met BTW in rekening worden gebracht.

Het Hof begint met vast te stellen dat moet worden onderzocht, of voor de belasting van het privégebruik van een bedrijfsgoed waarvoor een recht is ontstaan op aftrek van de bij de verkrijging erop drukkende belasting, naast het gebruik van het goed zelf, de door de belastingplichtige gemaakte kosten van onderhoud of gebruik in aanmerking moeten worden genomen, wanneer voor deze kosten geen recht op aftrek van voorbelasting is ontstaan. Vervolgens constateert het Hof dat de tekst van de bepaling geen enkele aanwijzing bevat over de betekenis van de woorden 'gebruik van een goed'. Deze woorden kunnen strikt worden opgevat, zodat enkel het gebruik van het goed zelf wordt bedoeld. Of in ruimere zin, zodat ook diensten en andere kosten in verband met dit gebruik eronder vallen. Het Hof geeft vervolgens aan dat de uitdrukking 'gebruik van een goed' strikt dient te worden uitgelegd (r.o. 13). Deze zienswijze is gebaseerd op de opvatting dat het privégebruik van een goed slechts bij uitzondering belastbaar is. Anders dan bij gewone diensten die in beginsel belastbaar zijn.

“De uitdrukking 'gebruik van een goed' dient dus strikt te worden uitgelegd, zodat zij uitsluitend het gebruik van het goed zelf omvat. Bijgevolg vallen de bijkomende diensten in verband met dit gebruik niet onder artikel 6, lid 2, sub a, van de Zesde richtlijn (thans artikel 26, lid 1, sub a, BTW-richtlijn: toevoeging: AHB)." (r.o. 14)

Het Hof komt tot een oplossing door het zinsdeel 'gebruik van een goed' beperkt uit te leggen waardoor bijvoorbeeld het onderhoud van het goed dat voor privé wordt gebruikt buiten het bereik van artikel 26, lid 1, sub a, BTW-richtlijn valt. ${ }^{63}$ De fiscale neutraliteit van de belasting lijkt daarbij geen rol te spelen.

63. Steun voor deze opvatting is ook te vinden in Hof 8 maart 2001, nr. C-415/98, L. Bakcsi, BNB 2001/ 200, V-N 2001/18.30. Zie in het bijzonder r.o. 33. Zie ook de eerder aangehaalde conclusie van A-G De Wit, nr. 42.415, V-N 2007/39.21. In het bijzonder pt. 4.25 t/m 4.51. Volledig duidelijk is het echter niet. Ondanks de vrij duidelijke overwegingen in het Bakci-arrest en Mohsche-arrest is het toch niet geheel duidelijk. In het eerder aangehaalde Kühne-arrest vindt namelijk wel degelijk een heffing plaats op grond van artikel 26, lid 1, sub a, BTW-richtlijn over de bijkomende diensten die in verband met het $\rightarrow$ 
Indien het 'gebruik van het goed' beperkt wordt uitgelegd en bijkomende diensten (zoals onderhoud) niet onder het bereik van artikel 26, lid 1, sub a, BTW-richtlijn vallen, heeft dat tot gevolg dat de voorbelasting die drukt op deze kosten niet voor aftrek in aanmerking komt. De belastingplichtige mag namelijk slechts de voorbelasting in aftrek brengen voor zover hij de door hem ontvangen goederen en diensten gebruikt ten behoeve van door hem verrichte belaste handelingen (artikel 168, BTWrichtlijn). Nu op zich geen fictieve heffing voordoet over de bijkomende diensten, ontbreekt een vereiste belaste handeling.

Op deze plaats kom ik kort terug op het eerder in deze paragraaf behandelde VNLTOarrest. Het Hof heeft in het VNLTO-arrest niet de vraag van de Hoge Raad beantwoord of het leerstuk van de vermogensetikettering ook van toepassing is op investeringsdiensten. Het kan zijn dat in het Mohsche-arrest een antwoord op deze vraag is te lezen. In de literatuur is gepleit om het leerstuk ook van toepassing te verklaren voor investeringsdiensten gezien het feit dat bedrijfseconomisch geen verschil bestaat tussen investeringsgoederen en investeringsdiensten. ${ }^{64}$ Dit zou dan een gelijke behandeling rechtvaardigen. Uit het Mohsche-arrest blijkt echter dat het Hof het leerstuk inzake de etikettering beperkt uitlegt gezien het feit dat het privégebruik slechts bij uitzondering belastbaar is. Deze benadering leidt dan vervolgens tot een strikte uitleg van de uitdrukking 'gebruik van een goed' in artikel 26, lid 1, sub a, BTW-richtlijn. Het kan zo zijn dat het Hof deze lijn doortrekt en het leerstuk dan ook niet van toepassing is op investeringsdiensten. ${ }^{65}$

Artikel 26, lid 1, sub b, BTW-richtlijn (voorheen artikel 6, lid 2, sub b, Zesde richtlijn) vult het belastbaar feit levering aan met een soortgelijke fictie voor diensten. Het doel dat het artikel beoogt te bereiken is in wezen identiek aan het eerder beschreven doel van artikel 16, BTW-richtlijn. Zo vermeldt het Baksci-arrest: ${ }^{66}$

\footnotetext{
$\rightarrow$ gebruik van de auto werden gemaakt (r.o. 29). Het verschil met het Mohsche-arrest is dat in die procedure alle voorbelasting die drukte op deze uitgave in aftrek was gebracht. Gezien het feit dat de prejudiciële vragen in het Kühne-arrest geen betrekking hebben op de fiscale behandeling van de bijkomende diensten, kan gesteld worden dat dit arrest de lijn in het Baksci-arrest en het Mohschearrest niet blokkeert. Overigens is het de vraag of het resultaat veel zal verschillen. Een heffing op grond van artikel 26, lid 1, sub a, BTW-richtlijn over de bijkomende diensten voor zover de voorbelasting die drukt op deze diensten in aftrek is gebracht, zal overeenkomen in resultaat met een benadering waarbij geen fictieve heffing plaatsvindt maar de voorbelasting niet aftrekbaar is. Overigens biedt lid 2 van artikel 26, BTW-richtlijn de lidstaten de mogelijkheid om af te wijken van het eerste lid voor zover deze afwijking niet leidt tot een verstoring van de mededinging. Dat lijkt mij niet het geval bij een heffing op grond van artikel 26, lid, sub a, BTW-richtlijn over de bijkomende diensten. 64. J.B.O. Bijl \& T.H. Anten, De BTW-heffing bij gebruik voor privé- of andere dan bedrijfsdoeleinden van bedrijfsmiddelen en diensten - een voorstel, WFR 2006/581; H.W.M. van Kesteren \& J.B.O. Bijl, BTW en onzakelijk gebruik of privégebruik, NTFR 2006/1591; H.A.S. Dragtenstein, Vermogensetikettering van diensten, een brug te ver?, BTW-Brief 2009, nr. 3, blz. 6. Zie ook de analyse van A-G De Wit in zijn conclusie van 28 juni 2007 (VNLTO-procedure), nr. 42.414, V-N 2007/39.21.

65. Vgl. S.T.M. Beelen 2010, paragraaf 3.3.2.2

66. Hof 8 maart 2001, nr. C-415/98, L. Bakcsi, BNB 2001/200, V-N 2001/18.30.
} 
“(...), dat artikel 5, lid 6, van de Zesde richtlijn (thans artikel 16, BTW-richtlijn: toevoeging AHB) met name tot doel heeft, te verzekeren dat een belastingplichtige die een goed aan zijn bedrijf onttrekt, en een gewone consument die een zelfde soort goed koopt, gelijk worden behandeld. Ter verwezenlijking van dit doel verhindert deze bepaling, dat een belastingplichtige die de BTW over de aankoop van een voor zijn bedrijf bestemd goed heeft kunnen aftrekken, geen BTW behoeft te betalen wanneer hij dit goed voor privédoeleinden aan zijn bedrijfsvermogen onttrekt, en dus onredelijke voordelen geniet in vergelijking met een gewone consument die het goed koopt en hierover BTW voldoet (...)." (r.o. 42)

Rechtsoverweging 45 voegt daar nog aan toe:

"Een dergelijke uitlegging is in overeenstemming met de door artikel 5, lid 6, van de Zesde richtlijn nagestreefde gelijke behandeling, daar de belastingplichtige geen onredelijk voordeel geniet in vergelijking met de gewone consument." ${ }^{67}$

De fiscale neutraliteit als uitdrukking voor de BTW van het gelijkheidsbeginsel werkt twee kanten op. ${ }^{68}$ Allereerst bereikt het dat een fictieve heffing aan de orde is als een belastingplichtige de voorbelasting in aftrek heeft gebracht en vervolgens het goed aan zijn bedrijf onttrekt en voor privédoeleinden gaat gebruiken. Op deze wijze wordt de belastingplichtige gelijkgesteld met 'de gewone consument'. De fiscale neutraliteit heeft echter ook tot gevolg dat de fictieve levering niet aan de orde is indien de belastingplichtige geen voorbelasting ter zake van het goed in aftrek heeft gebracht. Het Hof merkt daar over op in het Baksci-arrest:

"In een dergelijke situatie zou het heffen van belasting over een goed waarvoor geen recht op aftrek van het belastingrestant is ontstaan, immers leiden tot dubbele belastingheffing, hetgeen in strijd is met het beginsel van de belastingneutraliteit, dat ten grondslag ligt aan

het gemeenschappelijke BTW-stelsel waarvan de Zesde richtlijn deel uitmaakt (...).” (r.o. 46)

Uit het bovenstaande blijkt dat de fictieve heffingen van artikel 16 en 26, BTW-richtlijn gefundeerd zijn op de fiscale neutraliteit. Het doel is dat een belastingplichtige een identieke belastingdruk ervaart in vergelijking met de gewone consument.

\subsection{Conclusies}

In dit hoofdstuk zijn de kaders geschetst van de belastbare handelingen leveringen en diensten in de BTW-richtlijn. Het Hof plaatst een aantal handelingen onder bepaalde omstandigheden buiten het bereik van de BTW, namelijk in geval van de handel in verdovende middelen, de invoer van vals geld en carrouselfraude. In de

67. In identieke zin Hof 6 mei 1992, nr. C-20/91, P. de Jong, BNB 1992/377, V-N 1992/2794 pt. 17, FED 1992/636, zie in het bijzonder r.o. 15 en 18. Zie ook Hof 17 mei 2001, gevoegde zaken nrs. C-322/99 en C-323/99, Fischer \& Brandenstein, V-N 2001/32.27 vooral r.o. 56, 57 en 66, 67 met betrekking tot geïntegreerde bestanddelen van het goed. Zie Hof 21 april 2005, nr. C-25/03, HE, V-N 2005/22.18, in geval van mede eigendom, in het bijzonder r.o. 73.

68. Zie voor een situatie waar een beroep op de fiscale neutraliteit geen effect heeft Hof 8 mei 2003, nr. C-269/00, W. Seeling, BNB 2004/1, V-N 2003/28.20. In dit arrest is beslist dat een woonbedrijfspand geëtiketteerd kan worden als ondernemingsvermogen en dan ook leidt tot volledige aftrek van de voorbelasting. De gelijkstelling met verhuur, dat de Duitse regering verdedigde, werd door het Hof niet gevolgd (r.0. 53). 
jurisprudentie zijn geen duidelijke grondslagen te vinden waarop de bijzondere positie van de handel in verdovende middelen en vals geld is gebaseerd. Wel is het zo dat de fiscale neutraliteit bewerkstelligt dat onder meer verboden handel in wapens en namaakparfums binnen het bereik van de BTW vallen. Dit is dan gericht op het voorkomen van concurrentievervalsing tussen de legale sector en de illegale sector.

In geval van carrouselfraude klinkt in de jurisprudentie door dat een tweetal krachten tegenover elkaar staan. Namelijk aan één kant de werking van het rechtszekerheidsbeginsel. Deze kracht is gericht op het tot zijn recht laten komen van de belastbare feiten, die een objectief karakter hebben. Oogmerken, ook frauduleuze, spelen daarbij geen rol en kunnen door de uitvoerende instanties ook niet getoetst worden. Daartegenover staat het uitgangspunt dat justitiabelen in geval van fraude (en voor misbruik geldt hetzelfde) geen beroep kunnen doen op het Unierecht. Indien deze krachten botsen, blijkt uit het Kittel-arrest dat de werking van het rechtszekerheidsbeginsel het onderspit delft.

In het Puffer-arrest betrekt het Hof bij de bespreking van het verschil tussen belastingplichtigen en niet-belastingplichtigen het gemeenschapsrechtelijke algemene gelijkheidsbeginsel en niet de voor de BTW gereserveerde fiscale neutraliteit. Het Hof komt in het Puffer-arrest tot de slotsom dat de toepassing van het leerstuk van het keuzevermogen bij belastingplichtigen die belaste handelingen verrichten niet in strijd is met het algemene gelijkheidsbeginsel omdat de situatie van belastingplichtigen verschilt van niet-belastingplichtigen en dat een eventueel verschil in behandeling het gevolg is van de toepassing van verschillende regels op verschillende situaties.

De fictieve prestaties beogen de werking van de belastbare handelingen uit te breiden. Uit de behandelde jurisprudentie blijkt dat het fundament van de fictieve heffing de fiscale neutraliteit is als uitdrukking voor de BTW van het gelijkheidsbeginsel. Doel is dat een belastingplichtige een identieke belastindruk ervaart in vergelijking met de gewone consument. Uit het Mohsche-arrest blijkt dat toepassing van de fiscale neutraliteit bij de uitleg van de regelgeving inzake de fictieve heffingen problematisch kan zijn. Zoals in paragraaf 4.4.3.2 naar voren is gebracht kan uitleg aan de hand van de fiscale neutraliteit stuiten op de vraag: waar dient mee te worden vergeleken? Uit de Mohsche- procedure blijkt dat partijen daarover kunnen verschillen. Het Hof kiest in de Mohsche-procedure dan ook niet voor een uitleg gebaseerd op de fiscale neutraliteit, maar kiest voor een uitleg waarbij de uitzondering op de hoofdregel beperkt wordt uitgelegd en komt dan vervolgens tot een strikte uitleg van de fictieve heffingen. 


\section{HOOFDSTUK 7}

\section{Belastingplicht}

Inleiding

Van de ruim 40 zaken die op het gebied van de belastingplicht voor het Hof gespeeld hebben, kan worden geconstateerd dat ruim 30 betrekking hebben op drie thema's die de reikwijdte - en tevens de niet-onderworpenheid - van belastingplichtige personen scherp in beeld brachten, althans vroegen om een aanscherping van het probleem 'belastingplicht'- 'niet-belastingplicht'. Het is dan ook in die doorgaans moeilijke situaties van afbakening aannemelijk, dat bij de interpretatie algemene rechtsbeginselen een rol gaan spelen, daar waar de vage norm van de definitie ons niet verder brengt dan te zeggen, dat de heffing algemeen moet zijn. De drie thema's zijn: het moment waarop belastingplicht ontstaat (paragraaf 7.2), de belastingplicht van holdingmaatschappijen (paragraaf 7.3) en van overheidslichamen (paragraaf 7.4). Elk thema sluit af met een conclusie.

De belastingplicht is geregeld in de artikelen $9 \mathrm{t} / \mathrm{m} \mathrm{13}$, BTW-richtlijn (voorheen artikel 4, Zesde richtlijn). ${ }^{1}$ In de jurisprudentie van het Hof over de uitleg van de belastingplicht spelen algemene rechtsbeginselen een rol.

\section{2}

\section{Begin van belastingplicht}

\subsubsection{Geen belaste handelingen}

De jurisprudentie van het Hof waarin een verduidelijking plaatsvindt van het moment waarop belastingplicht ontstaat, gaat veelal over het al dan niet aanwezige recht op aftrek van voorbelasting. ${ }^{2}$ Het betreft dan gevallen waarin de belanghebbende nog niet daadwerkelijk begonnen is met de exploitatie en er dan ook nog geen met BTW belaste handelingen worden verricht. Dat neemt niet weg dat veelal

\footnotetext{
1. Het artikel is geïmplementeerd in artikel 7 Wet OB. De HR heeft beslist dat de term 'ondernemer' in onze nationale wet, geen andere inhoud heeft dan de term 'belastingplichtige' in de BTW-richtlijn. HR 2 mei 1984, nr. 22 153, BNB 1984/295.

2. Ook al gaat het in de jurisprudentie veelal om het recht op aftrek van voorbelasting, is dit niet het enige aspect dat van belang is om het startmoment van de belastingplicht zo nauwkeurig mogelijk te bepalen. De start van de belastingplicht beïnvloedt namelijk ook het moment waarop BTW in rekening gebracht moet worden.
} 
omvangrijke investeringen zijn gedaan en dat de investeerder dan ook de voorbelasting in aftrek wil brengen. Om in aanmerking te komen voor het recht op aftrek van voorbelasting is allereerst vereist dat men onder het bereik van de BTW-heffing valt, dus belastingplichtig is op grond van de artikelen $9 \mathrm{t} / \mathrm{m} \mathrm{13}$, BTW-richtlijn. De vraag is dan of sprake kan zijn van belastingplicht, ofschoon nog geen belaste handelingen worden verricht.

Ondanks het feit dat het Hof in de hierna aan de orde komende arresten deze problematiek heeft verduidelijkt, is het niettemin zo, dat enkele lidstaten in de BTWrichtlijn aanknopingspunten lezen om de belastingplicht te blokkeren en op deze wijze dan ook de weg naar het recht op aftrek van voorbelasting aan belastingplichtigen proberen te onthouden. In deze paragraaf geef ik kort aan welke argumenten zijn te vinden om de belastingplicht te blokkeren. De volgende paragrafen gaan in op de wijze waarop het Hof deze argumenten weerlegt en daarbij ook algemene rechtsbeginselen hanteert.

In dit kader dringt zich een vergelijking op met het in paragraaf 2.2 beschreven Hong Kong-arrest. In dit arrest is in rechtsoverweging 9 aangegeven, dat de voorbelasting niet aftrekbaar is aan het eind van de transactieketen. De BTW drukt dan op degene die de belasting niet kan afwentelen daar er geen verdere transacties tegen een bepaalde prijs zijn. Gezien het ontbreken van transacties tegen een bepaalde prijs is belastingplicht niet aan de orde. ${ }^{3}$ Deze benadering lijkt er op te duiden, dat ingeval een belanghebbende omvangrijke investeringen verricht met het voornemen deel te nemen aan het economische verkeer, pas sprake is van belastingplicht indien daadwerkelijk met BTW belaste handelingen worden gegenereerd. ${ }^{4}$ In het geval dat dergelijke met BTW belaste handelingen niet aanwezig zijn, vindt geen afwenteling plaats van BTW en is sprake van wat in het Hong Kong-arrest wordt aangeduid als een eindverbruiker (zie voor een meer uitgebreide behandeling paragraaf 2.2). Veelal zullen in geval van het opstarten van economische activiteiten, investeringen worden verricht voordat daadwerkelijk met BTW belaste omzet wordt behaald. Op grond van het Hong Kong-arrest is te verdedigen dat een dergelijke startende ondernemer niet is aan te merken als een belastingplichtige.

Tegen de bovenstaande redenering is in te brengen, dat ingeval voorbereidende werkzaamheden worden verricht, het oogmerk bestaat om wel degelijk belaste handelingen te gaan verrichten. Indien immers het oogmerk enige kans van slagen

3. Stevens is van mening dat latere jurisprudentie de implicaties van het Hong Kong-arrest afzwakken. Zij is van mening dat niet vereist is dat een activiteit onder bezwarende titel wordt verricht wil sprake zijn van een economische activiteit. Zie D.M.P.M. Stevens, Het verrichten van diensten onder bezwarende titel als belastbaar feit in de omzetbelasting (diss. Maastricht) 2001, paragraaf 3.3.2.2 4. Ook het Enkler-arrest van 26 september 1996, nr. C-230/94, V-N 1997/653, pt. 22. en het Floridiennearrest van 14 november 2000, nr. C-142/99, V-N 2000/53.17 lijken te wijzen in een richting, dat daadwerkelijk belastbare handelingen noodzakelijk zijn om te worden aangemerkt als belastingplichtige. 
heeft, is het moeilijker staande te houden dat men uitsluitend prestaties om niet verricht. ${ }^{5}$ Als deze benadering juist is, is vervolgens uit het Lennartz-arrest ${ }^{6}$ op te maken, dat het oogmerk moet bestaan op het tijdstip van aanschaf. Indien pas na de aanschaf, dit goed wordt gebruikt voor het verrichten van belaste handelingen, kan niet met terugwerkende kracht de aanschaf worden aangemerkt als te hebben plaatsgevonden in het economische verkeer. De voorbelasting is dan niet aftrekbaar.

Opvallend in de jurisprudentie op het terrein van de belastingplicht is, dat het Hof niet enkel de artikelen $9 \mathrm{t} / \mathrm{m} \mathrm{13}$, BTW-richtlijn uitlegt, maar ook veelal enige overwegingen wijdt aan het recht op aftrek van voorbelasting, zoals dat is geregeld in de artikelen 167 t/m 192, BTW-richtlijn (voorheen artikelen 17 en 19, Zesde richtlijn). Verwonderlijk is dit niet, gezien de eerdere constatering dat belanghebbende veelal aangemerkt wil worden als belastingplichtig, om vervolgens in aanmerking te komen voor het recht op aftrek van voorbelasting. Hoofdstuk 11 gaat in op het recht op aftrek van voorbelasting; van belang in het kader van deze paragraaf is dat ook de letterlijke tekst van artikel 168, BTW-richtlijn (voorheen 17, lid 2, Zesde richtlijn) het recht op aftrek niet zonder meer verleent. Het artikel vermeldt namelijk in de aanhef dat recht op aftrek van voorbelasting bestaat:

"Voor zover de goederen en diensten worden gebruikt voor belaste handelingen van een belastingplichtige, (...)"

De vereiste 'belaste handelingen' zullen veelal ontbreken in de beginfase, met als gevolg dat het recht op aftrek ontbreekt. Als tenminste de letterlijke tekst het enige uitgangspunt is. ${ }^{7}$

De algemene uitgangspunten zoals deze zijn geformuleerd in het Hong Kong-arrest over het begrip 'eindverbruiker', lijken er op te duiden dat een startende ondernemer buiten de reikwijdte van het begrip 'belastingplichtige' blijft. Zo er al sprake zou zijn van belastingplicht, dan lijkt de letterlijke tekst van artikel 168, BTWrichtlijn de weg naar het recht op aftrek te blokkeren. Deze overwegingen in de beschouwing betrokken, lijkt het erop dat de degene die een onderneming opstart veelal wordt geconfronteerd met voorbelasting die daadwerkelijk een kostenpost

5. Van Hilten is van mening dat het oogmerk relevant is. Zij is dan ook van mening dat de toevoeging in het eerste lid van artikel 4, Zesde richtlijn dat ieder belastingplichtig is 'ongeacht oogmerk of resultaat' met een korreltje zout moet worden genomen. Zie M.E. van Hilten, Gedachten over de grenzen van de belastingplicht in de omzetbelasting, WFR 1994/15. Zie ook J.J.P. Swinkels, De belastingplichtige in de Europese BTW (diss. Amsterdam UvA) 2000, paragraaf 4.8, blz. 188.

6. Hof 11 juli 1991, nr. C-97/90, Lennartz, V-N 1991/2402, FED 1991/647.

7. In dit kader kan ook artikel 183, BTW-richtlijn (voorheen artikel 18, lid 4, Zesde richtlijn) een rol spelen, waar is bepaald dat de lidstaten kunnen bepalen, dat als het bedrag van de toegestane aftrek groter is dan de verschuldigde belasting het overschot dient te worden overgebracht naar een volgende periode, waarin wel de verschuldigde belasting groter is dan de voorbelasting. Zie ook het in paragraaf 7.2.3 behandelde Gabalfrisa-arrest. In dit arrest staat de Spaanse regeling centraal, die slecht voorbelasting teruggeeft aan een startende ondernemer vanaf het tijdstip waarop daadwerkelijk een begin wordt gemaakt met de activiteiten. Deze regeling heeft betrekking op voorbelasting die in rekening is gebracht in een periode dat nog geen belaste handelingen worden verricht. 
vormt. Toch blijkt hierna dat, waar expliciet de positie van de startende ondernemer aan de orde is, deze uitgangspunten opzij worden gezet. De vraag is dan welke concepten de startende ondernemer in deze bijzondere positie plaatsen.

In verscheidene arresten heeft het Hof aangegeven op welke wijze de periode voorafgaand aan het daadwerkelijk verrichten van belaste handelingen voor de heffing van BTW dient te worden gekwalificeerd. In deze arresten is een duidelijke lijn te ontdekken waarin de fiscale neutraliteit als uitdrukking van het gelijkheidsbeginsel voor de BTW en het rechtszekerheidsbeginsel sturing geven aan de oplossing van de problematiek van de startende ondernemer. In dit kader schenk ik aandacht aan het Rompelman-arrest, ${ }^{8}$ Inzo-arrest, ${ }^{9}$ Ghent Coal-arrest, ${ }^{10}$ Gabalfrisaarrest, $^{11}$ Schloßstraße-arrest, ${ }^{12}$ Breitsohl-arrest ${ }^{13}$ en het FINI-arrest. ${ }^{14}$

\title{
7.2.2 De fiscale neutraliteit en de vergelijkingsmethode
}

In het Rompelman-arrest is de vraag aan de orde of de verkrijging van een toekomstig appartementsrecht in een nog te stichten gebouw, met het oogmerk om het te zijner tijd te verhuren, is te beschouwen als een economische activiteit in de zin van artikel 9, lid 1, BTW-richtlijn (voorheen artikel 4, lid 1, Zesde richtlijn). Het Hof heeft op deze vraag positief beslist. De onderbouwing van deze beslissing is te vinden in vooral rechtsoverweging 23. Met betrekking tot het moment waarop belastingplicht ontstaat overweegt het Hof namelijk:

\begin{abstract}
"Daarbij dient geen onderscheid te worden gemaakt naargelang van de juridische kwalificatie van die voorbereidende handelingen, met name niet tussen een vordering met betrekking tot toekomstig eigendom en de verkrijging van de eigendom zelf. Het beginsel van de neutraliteit van de BTW ten aanzien van de fiscale belasting van de ondernemer vereist bovendien, dat de eerste investeringsuitgaven die worden gedaan ten behoeve en ter verwezenlijking van een onderneming, als economische activiteiten worden aangemerkt. Het zou in strijd zijn met dat beginsel, indien die activiteiten werden geacht eerst een aanvang te nemen op het tijdstip waarop een onroerend goed daadwerkelijk wordt geëxploiteerd, dat wil zeggen wanneer de belastbare inkomsten ontstaan. Iedere andere uitlegging van art. 4 van de Zesde richtlijn zou de ondernemer bij het verrichten van zijn economische activiteiten belasten met de kosten van de BTW, zonder dat hij die overeenkomstig art. 17 zou kunnen aftrekken, en zou neerkomen op een willekeurig onderscheid tussen investeringsuitgaven vóór en tijdens de daadwerkelijke exploitatie van een onroerend goed. Ook in gevallen waarin de ter zake van de voorbereidende handelingen betaalde voorbelasting na de aanvang van de daadwerkelijke exploitatie van een onroerend goed wordt teruggegeven, heeft het goed gedurende de soms lange tijd tussen de eerste investeringsuitgaven en de daadwerkelijke exploitatie een geldelijke last te dragen. Een ieder die
\end{abstract}

8. Hof 14 februari 1985, nr. 268/83, Rompelman c.S., BNB 1985/315. Zie nader de aantekening van D.B. Bijl in FED 1985/251

9. Hof 29 februari 1996, nr. C-110/94, INZO, V-N 1996/1396, pt. 27.

10. Hof 15 januari 1998, nr. C-37/95, Ghent Coal Terminal NV, V-N 1998/29.14.

11. Hof 21 maart 2000, nr. C-110 t/m C-147/98, Gabalfrisa SL e.a. V-N 2000/22.12.

12. Hof 8 juni 2000, nr. C-396/98, Schloßstraße, V-N 2000/44.21.

13. Hof 8 juni 2000, nr. C-400/98, Breitsohl, V-N 2000/43.19.

14. Hof 3 maart 2005, nr. C-32/03, I/S Fini H, V-N 2005/15.8. Deze procedure heeft vooral betrekking op de periode na de ondernemingsactiviteiten. 
dergelijke investeringshandelingen verricht, welke ten nauwste verband houden met en noodzakelijk zijn voor de toekomstige exploitatie van een onroerend goed, is derhalve te beschouwen als belastingplichtige in de zin van art. 4."

Uit de bovenstaande rechtsoverweging blijkt dat het Hof meent dat voor de heffing van BTW de investeringen die vóór de daadwerkelijke start van de activiteiten zijn gedaan, op dezelfde wijze dienen te worden behandeld als de investeringen gedaan in de periode dat daadwerkelijk belaste handelingen worden verricht. Het Hof verwijst naar het beginsel van de fiscale neutraliteit. In het citaat komen zowel het subject als de handeling aan bod. Het subject is de persoon van de ondernemer in het algemeen en 'ieder die'. Het handelingsniveau komt in een veelheid van termen aan bod. ${ }^{15}$ In het citaat en de daarin gegeven bewoordingen van de fiscale neutraliteit ligt in het bijzonder de nadruk op het handelingsniveau. Daar bedoel ik mee, dat het niet zozeer gaat om het gelijk behandelen van personen, maar dat de investeringen gelijk dienen te worden behandeld. Deze benadering kan dus betrekking hebben op de toepassing van het gelijkheidsbeginsel bij dezelfde persoon, in die zin dat in de loop van de tijd door dezelfde persoon investeringen vóór en na de daadwerkelijke exploitatie kunnen worden verricht. Deze investeringen dienen gelijk te worden behandeld.

De toepassing van het neutraliteitsbeginsel op investeringsniveau is een constante lijn in de jurisprudentie. In zowel het Inzo-arrest (r.o. 16), Gabalfrisa-arrest (r.o. 45, laatste zinsdeel), Schloßstraße-arrest (r.o. 39) en het Breitsohl-arrest (r.o. 37) komt in dit kader exact dezelfde rechtsoverweging voor, namelijk dat iedere andere uitlegging van artikel 9, BTW-richtlijn zou neerkomen:

“(...) op een willekeurig onderscheid tussen investeringsuitgaven vóór en tijdens de daadwerkelijke exploitatie van een onderneming." 16

Bij de toetsing aan de fiscale neutraliteit wordt dus nagegaan of de investeringsuitgaven gelijk worden behandeld.

In het Rompelman-citaat spreekt het Hof over 'investeringsuitgaven (...) ter verwezenlijking van een onderneming' en brengt derhalve de 'onderneming' ter sprake. In de overweging over de fiscale neutraliteit van het INZO-arrest ${ }^{17}$ varieert het Hof nogal met dit wat hybride begrip (cursieven: AHB):

15. Handelingsniveau: handelingen, vordering, verkrijging, investeringsuitgaven, economische activiteiten, die activiteiten, geëxploiteerd, inkomsten, economische activiteiten, investeringsuitgaven, daadwerkelijke exploitatie, voorbereidende handelingen.

16. In het Ghent Coal-arrest wordt het door het Hof anders geformuleerd, in r.o. 15 verwijst het Hof naar de term 'activiteiten'. Ook in het Fini-arrest is deze overweging te vinden (r.o. 23), wel is in dit laatste arrest de term 'investeringsuitgave' vervangen door 'uitgaven'. Volgens mij heeft dit geen andere betekenis tot gevolg.

17. Hof 29 februari 1996, nr. C-110/94, INZO, V-N 1996/1396, pt. 27, r.o. 22. 
"Een andere uitlegging van de richtlijn zou overigens in strijd zijn met het beginsel van de neutraliteit van de BTW ten aanzien van de fiscale belasting van de ondernemingen. Zij zou bij de fiscale behandeling van identieke investeringsactiviteiten tot ongerechtvaardigde verschillen kunnen leiden tussen, enerzijds, ondernemingen die reeds belastbare handelingen hebben verricht, en, anderzijds, ondernemingen die door middel van investeringen proberen een aanvang te maken met activiteiten die belastbare handelingen zullen opleveren. Ook zouden willekeurige verschillen ontstaan tussen laatstbedoelde ondernemingen onderling, voor zover de definitieve aanvaarding van de aftrek zou afhangen van de vraag, of deze investeringen al dan niet tot belaste handelingen leiden."

Het Hof gaat in deze overweging niet na of vergelijkbare transacties gelijk worden behandeld, maar vergelijkt ondernemingen. Het woord 'onderneming' is te verstaan in meerdere betekenissen. Ten eerste in de zin van subject van handeling en ten tweede in de meer 'objectieve' betekenis van een samenstel van kapitaal en arbeid. In de rechtsoverweging vindt volgens mij een personificatie plaats: het lijkt dus zo te zijn, dat de term 'onderneming' in de meer subjectieve betekenis moet worden begrepen. De vergelijking heeft dus betrekking op subjecten. Daarop wordt de fiscale neutraliteit betrokken.

Uit de aangehaalde rechtsoverweging blijkt, zoals gezegd dat het Hof het 'recht' vindt door middel van vergelijking. Daarmee bedoel ik dat een onderneming die nog geen belastbare handelingen verricht maar deze wel beoogt te bereiken door het verrichten van investeringen, wordt vergeleken met een onderneming die daadwerkelijk belaste handelingen verricht. Deze benadering doet sterk denken aan een methode van rechtsvinding, beschreven door Wiarda en aangeduid als de 'vergelijkingsmethode' (zie voor een toelichting op de vergelijkingsmethode en de analogieargumentatie paragraaf 4.4.3). ${ }^{18}$ Wiarda vermeldt over deze methode van rechtsvinding door de rechter:

"Zij betekent dat ingeval de rechter voor zijn beslissing alleen op normen als redelijkheid en billijkheid of zorgvuldigheid e.d. is aangewezen, en hem voor het te berechten geval vooralsnog geen duidelijke toetsingsmaatstaf invalt, hij moet trachten zich naast het geval één of liefst meerdere gevarieerde, maar toch nog vergelijkbare gevallen voor de geest te stellen waarin de beslissing niet twijfelachtig, althans minder twijfelachtig zou zijn. Gaat het bijvoorbeeld om de vraag of een bepaalde handelwijze al dan niet in strijd is met de in het maatschappelijk leven betamende zorgvuldigheid, en is de wijze waarop die vraag moet worden beantwoord niet dadelijk evident, dan zal de rechter moeten trachten eerst een variant te vinden waar in die handeling zeker niet, en daarna een variant die zeker wel als onbehoorlijk zou moeten worden beschouwd. Vergelijking met de beide fictieve gevallen zal dan, door het zoeken naar de relevante verschillen, tot een verantwoorde beslissing van het gegeven geval kunnen leiden. Het zal als het ware gelokaliseerd moeten worden op de geleidelijkheidlijn die de beide varianten verbindt waarvan de oplossing wèl duidelijk is."

Vervolgens brengt Wiarda naar voren, dat de vergelijkingsmethode niet alleen goede diensten bewijst bij de toepassing van vage normen als redelijkheid en billijkheid,

18. G.J. Wiarda, Drie typen van rechtsvinding, bewerkt en van een nabeschouwing voorzien door T. Koopmans. Deventer: W.E.J. Tjeenk Willink 1999. Zie in het bijzonder blz. 107 t/m 116. 
maar ook bij de interpretatie van wettelijke voorschriften met een concrete inhoud. ${ }^{19}$ Men zoekt dan naar gevallen waarin het gaat om de vraag of een zeker wettelijk voorschrift zich leent voor een analoge toepassing op andere dan de daarin met zo veel woorden omschreven gevallen. Vergelijking maakt dan duidelijk hoe ver men kan gaan met een analoge toepassing van de wet (zie paragraaf 4.4.3).

Wiarda wijst er op, dat, ook al zijn er gevallen in de jurisprudentie van de Hoge Raad aan te wijzen waarin volgens de vergelijkingsmethode te werk wordt gegaan, veel talrijker echter de gevallen zijn waarin kan worden aangenomen dat hij deze methode heeft toegepast, zonder dat de toepassing ervan in de overwegingen is terug te vinden. ${ }^{20}$ In de nabeschouwing op het boek van Wiarda, brengt Koopmans naar voren dat de vergelijkingsmethode niet alleen typerend is voor wat de Nederlandse rechter doet: zij geldt voor rechtelijk werk in het algemeen. Ook in andere rechtsstelsels treft men de vergelijkingsmethode aan. ${ }^{21}$

Hoe dan ook, bij de vraag of de startende ondernemer, ondanks het feit dat hij geen belastbare handelingen verricht, als belastingplichtige kan worden aangemerkt, past het Hof de vergelijkingsmethode toe en daarbij zoekt het naar varianten waarbij het recht op aftrek van voorbelasting zeker niet wordt onthouden. En deze vergelijking leidt er vervolgens toe, dat geen (of te weinig) relevante verschillen zijn te ontdekken. Op deze wijze legt het Hof bloot de onredelijkheid die zou ontstaan indien een startende onderneming het recht op aftrek van voorbelasting wordt onthouden.

Het spreekt - zoals in paragraaf 4.4 .3 al is toegelicht - dat de vergelijkingsmethode niet goed denkbaar is zonder het gelijkheidsbeginsel. Het Hof zoekt naar een geval voor wie de richtlijn in elk geval is geschreven, en vergelijkt dat met het geval dat centraal staat in de prejudiciële vraag. ${ }^{22}$ De vergelijkingsmethode als interpretatiemethode grenst aan de toepassing van de analogieargumentatie. Met analogieargumentatie wordt bedoeld, dat een regel wordt toegepast op een geval, dat hij naar de letter en bedoeling, voor zover deze kenbaar is, niet bestrijkt, maar op het geregelde lijkt. ${ }^{23}$ De vergelijkingsmethode zorgt als het ware voor de rechtvaardiging van de toepassing van de analogieargumentatiemethode (zie paragraaf 4.4.3). De vergelijking van gevallen zorgt voor een zekere objectivering van de rechtsvinding. In die zin, dat de richting die is gekozen bij de uitleg van het recht bepaald meer is dan een intuiitieve ingeving van de rechter.

In paragraaf 7.2.1 zijn argumenten naar voren gebracht om de startende ondernemer de belastingplicht en dan ook het recht op aftrek van voorbelasting te onthouden. De

19. G.J. Wiarda 1999, blz. 113.

20. G.J. Wiarda 1999, blz. 110.

21. Koopmans verwijst in dit kader naar jurisprudentie van het U.S. Supreme Court, zie G.J. Wiarda 1999, blz. 123.

22. Zie bijvoorbeeld de eerder in deze paragraaf aangehaalde r.o. 22 van het INZO-arrest. In deze r.o. is duidelijk sprake van vergelijking van gevallen.

23. Zie P. Scholten, Asser - Scholten (Algemeen deel), Zwolle: W.E.J. Tjeenk Willink 1974, blz. 60. 
vergelijkingsmethode maakt echter duidelijk dat een dergelijke uitleg van de BTWrichtlijn onrechtvaardig is en dat dan ook beter recht wordt gedaan aan de werking van de fiscale neutraliteit als naar analogie artikel 9, BTW-richtlijn van toepassing is.

Op verscheidene plaatsen is er op gewezen dat de fiscale neutraliteit als uitdrukking voor de BTW van het gelijkheidsbeginsel als interpretatiebeginsel op zich zelf niet werkend is en behoeft een vergelijking om het effectief te maken (onder meer de paragrafen 3.4.1, 4.4.3.en 4.4). Het bepaalt namelijk niet met welk geval de gelijkheid zich voordoet (gewenst is) en er is dan altijd een nader criterium nodig dat de gelijkheid onderbouwt. Deze onderbouwing is dan meestal te vinden in de ratio van de bepaling. De ratio geeft dan aan dat de gevallen vergelijkbaar zijn. Op deze plaats kom ik kort terug op de in het begin van deze subparagraaf integraal opgenomen rechtsoverweging 23 uit het Rompelman-arrest. Het Hof overweegt daar namelijk dat de ongelijke behandeling tussen investeringsuitgave vóór en tijdens de daadwerkelijke exploitatie neerkomt op een willekeurig onderscheid. De neutraliteit (in de betekenis van het bevrijden van de voordruk) onderbouwt de gelijke behandeling. Het Hof overweegt namelijk dat dit beginsel vereist dat voorbereidende handelingen worden bevrijd van de voordruk en wel op een identieke wijze als de investeringshandelingen gedurende de exploitatie.

Veelal zal de toepassing van de vergelijkingsmethode zijn voorbehouden aan het Hof. De Hoge Raad kan, gezien de verplichting van artikel 267 VwEU, de vergelijkingsmethode niet snel toepassen bij de uitleg van de BTW-regelgeving. Wel kan het zo zijn dat de uitkomst van de toepassing van de vergelijkingsmethode voor de Hoge Raad aanleiding kan zijn tot het stellen van prejudiciële vragen.

\subsubsection{Startende ondernemer en vertrouwens- en rechtszekerheidsbeginsel}

In de vorige paragraaf is aangegeven, dat belastingplicht ook ontstaat bij het verrichten van voorbereidende handelingen. Daarbij heeft het Hof aan de verschillende situaties waarin de startende en de niet startende ondernemer verkeert, aandacht besteed. Zo is aandacht besteed aan: de gevallen waarin de beoogde economische activiteit niet tot stand komt of juist is beëindigd, de aangeschafte goederen voor consumptieve aangelegenheden worden gebruikt, of zelfs het geval dat sprake is van fraude. In de arresten met betrekking tot de startende ondernemer komt ook de toepassing van het vertrouwens- en het rechtszekerheidsbeginsel aan de orde. ${ }^{24}$ Daarbij is op te merken dat, zoals in paragraaf 7.2.1 al naar voren is

24. Zoals in paragraaf 3.4 .3 is verduidelijkt, wordt het rechtszekerheidsbeginsel in het algemeen onderscheiden van het vertrouwensbeginsel. In die zin, dat het rechtszekerheidsbeginsel verkregen rechten beschermt, en zorgt dat de overheid in beginsel geen onverwachte koerswijzigingen uitvoert. Het vertrouwensbeginsel brengt mee, dat in contacten met bestuursorganen gewekte, gerechtvaardigde, verwachtingen in beginsel gehonoreerd moeten worden. Burgers kunnen die verwachtingen hebben op grond van regelgeving, dan wel beleid, als toezeggingen en andere handelingen in hun individuele geval. Zie in dit kader nader J.H. Jansen, R. de Lange, S. Prechal \& R.J.G.M Widdershoven, Inleiding tot het Europees bestuursrecht, Nijmegen: Ars Aequi Libri 2002. In het bijzonder blz. 215 waar het desbetreffende onderscheid wordt verduidelijkt. 
gebracht, de vraag of belastingplicht aanwezig is, nauw is verweven met de vraag of sprake is van recht op aftrek van voorbelasting. Hoofdstuk 11 gaat nader in op de invloed van de algemene rechtsbeginselen op het recht op aftrek van voorbelasting. Deze paragraaf verduidelijkt de werking van het vertrouwens- en het rechtszekerheidsbeginsel vanuit het perspectief van de startende ondernemer. Het begin van de reeks arresten op dit onderwerp is het bekende Rompelman-arrest. Het Hof overweegt daarin (cursief: AHB):

"Met betrekking tot de vraag of art. 4 aldus moet worden uitgelegd, dat de wilsverklaring dat een toekomstig goed zal worden verhuurd, voldoende is om aan te nemen dat het verworven goed bestemd is om te worden aangewend voor een belastbare handeling, en dat derhalve degene die investeert, op die grond als belastingplichtige is aan te merken, moet in de eerste plaats worden opgemerkt dat degene die om aftrek van BTW verzoekt, zal hebben aan te tonen dat aan de voorwaarden voor aftrek is voldaan en, inzonderheid, dat hij als belastingplichtige is aan te merken. Art. 4 verzet zich er derhalve niet tegen, dat de belastingdienst verlangt dat de wilsverklaring wordt ondersteund door objectieve gegevens, zoals de omstandigheid dat ontworpen ruimtes zich specifiek lenen voor commerciële exploitatie." (r.o. 24)

Een tweetal onderwerpen verdienen nader aandacht. Ten eerste gebruikt het Hof het woord 'wilsverklaring'. Deze enkele wilsverklaring is voldoende en is de link tussen de investering en de toekomstige gebeurtenis in de vorm van het genereren van belastbare handelingen. De term 'wilsverklaring' duidt erop dat de enkele wil onvoldoende is. Vereist is dat de wil zich openbaart door middel van een verklaring. Van Kesteren vermeldt, dat de wil bevestiging dient te vinden door de uiterlijke feiten. ${ }^{25}$ Als de feiten de wil tegenspreken, wordt aan de vermeende wil geen gevolg verbonden. Het lijkt mij echter zo te zijn, dat niet zozeer de daadwerkelijke 'wil', maar de wilsverklaring bevestiging in de feiten moet vinden. Voorts ligt de bewijslast bij de belastingplichtige en deze moet met objectieve gegevens komen ter ondersteuning van de wilsverklaring. ${ }^{26}$ In de Rompelman-zaak speelt het rechtszekerheidsbeginsel nog geen rol. Dat verschijnt in de INZO-zaak.

In het INZO-arrest zet het Hof de ingeslagen weg voort. In de casus van het arrest verricht belanghebbende een rentabiliteitsstudie naar het ontwikkelen van een procedé om drinkwater te winnen en te verkopen. Als gevolg van de bij het onderzoek gebleken rentabiliteitsproblemen, trok een aantal investeerders zich terug en werd afgezien van het project. In rechtsoverweging 18 overweegt het Hof dat als de belastingadministratie eenmaal de belastingplicht heeft 'erkend', het verrichten van een rentabiliteitsstudie is aan te merken als een economische activiteit. Vervolgens overweegt het Hof (r.o. 21), dat het rechtszekerheidsbeginsel eraan in de weg staat om op grond van feiten en omstandigheden die zich hebben voorgedaan na de vaststelling van de rechten en verplichtingen door de belastingadministratie, aan de betrokken belastingplichtige met terugwerkende kracht de

25. H.W.M. van Kesteren, Fiscale rechtswil (diss. Leiden), Arnhem: Gouda Quint BV 1994, blz. 250.

26. Zie in dit kader ook K.M. Braun, Aftrek van voorbelasting in de BTW (diss. Leiden), Deventer: Kluwer 2002, paragraaf 7.9.8., waar ondermeer aandacht wordt geschonken aan de diverse problemen inzake de vereiste objectieve gegevens die door een belanghebbende moeten worden overgelegd. 
belastingplicht te ontnemen. Indien de belastingplicht eenmaal is 'erkend' door de belastingdienst, dan geniet de belastingplichtige dus een zekere bescherming onder de paraplu van het rechtszekerheidsbeginsel. De term 'erkend' verwijst naar een handeling van de Belastingdienst, namelijk het vaststellen van de rechten en verplichtingen. In het Rompelman-arrest is een door objectieve feiten ondersteunde 'wilsverklaring' van de belastingplichtige vereist. Het lijkt er dus op, dat over en weer handelingen zijn vereist, namelijk een 'wilsverklaring' die door de andere partij dient te worden 'erkend'. ${ }^{27}$ Mocht men deze conclusie hebben willen trekken dan blijkt uit het Breitsohl-arrest dat dit niet juist is. Erkenning is geen algemeen vereiste voor het (beginnend) ondernemerschap.

In het Breitsohl-arrest was wederom aan de orde een situatie waarin de voorgenomen economische activiteiten op een mislukking uitliepen. Het Hof geeft een belangrijke aanvulling (cursief: AHB):

"Het ontstaan van het recht op aftrek van de ter zake van de eerste investeringsuitgave voldane BTW is dus geenszins afhankelijk van een formele erkenning van de hoedanigheid van belastingplichtige door de belastingadministratie. Die erkenning heeft alleen tot gevolg, dat die hoedanigheid, zodra zij eenmaal erkend is, gevallen van fraude of misbruik daargelaten, niet meer met terugwerkende kracht aan de belastingplichtige kan worden ontnomen zonder dat het vertrouwens- en het rechtszekerheidsbeginsel worden geschonden." (r.o. 38)

Uit deze rechtsoverweging blijkt dat, hetgeen mogelijk wordt gesuggereerd in het INZO-arrest, namelijk dat over en weer handelingen zijn vereist, in de vorm van een verklaring die vervolgens dient te worden erkend door de Belastingdienst, niet noodzakelijk is voor de verwerving van de hoedanigheid van belastingplichtige en het recht op aftrek van voorbelasting. Een dergelijk vereiste lijkt mij ook niet passen in een publiekrechtelijke relatie. De materieel uit de wet voortvloeiende rechten en plichten zouden mede afhankelijk kunnen zijn van de keus van de uitvoerder van de wet, hetgeen op gespannen voet zou staan met het rechtszekerheidsbeginsel. Dat neemt niet weg dat uit de rechtspraak van het Hof tevens blijkt dat de 'wilsverklaring' en een eventueel daarop volgende 'erkenning' als belastingplichtige, niet zonder betekenis is. Het Hof overweegt in het INZO-arrest:

“Dienaangaande zij met de Commissie beklemtoond, dat de hoedanigheid van belastingplichtige slechts definitief wordt verworven, indien de verklaring van het voornemen om een aanvang te maken met de beoogde economische activiteiten, door de belanghebbende te goeder trouw is afgelegd. In geval van fraude of misbruik, bijvoorbeeld wanneer de betrokkene heeft voorgewend een bepaalde economische activiteiten te willen verrichten, doch in werkelijkheid goederen ten aanzien waarvan aftrek mogelijk is, in zijn privévermogen heeft pogen op te nemen, kan de belastingadministratie met terugwerkende kracht terugbetaling van de afgetrokken bedragen vorderen, omdat deze aftrek op basis van valse verklaringen is verleend. (cursief: AHB)" (r.o. 24)

27. De redactie van V-N kan de 'erkenning' als belastingplichtige niet geheel plaatsen. De redactie van $\mathrm{V}-\mathrm{N}$ is van mening, dat het voor de hand ligt te veronderstellen dat het hier gaat om het vaststellen of er activiteiten zullen worden verricht die op zich aan de heffing van BTW zijn onderworpen. Zie de aantekening bij het INZO-arrest, V-N 1996/1396, pt. 27. 
Van belang is dat de wilsverklaring te goeder trouw is afgelegd. ${ }^{28}$ In het Ghent Coalarrest was een situatie aan de orde waarin voorbelasting in aftrek was gebracht van grond die nooit was gebruikt voor de aanvankelijk beoogde economische activiteiten. In het Ghent Coal-arrest sluit het Hof in rechtsoverweging 21 aan bij het hierboven aangehaalde INZO-arrest. Om daar vervolgens in rechtsoverweging 22 aan toe te voegen, dat de belastingplicht niet verloren gaat door omstandigheden die buiten de wil van belastingplichtige hem hebben belet, de goederen en diensten die tot aftrek hebben geleid, voor zijn belastbare handelingen te gebruiken. ${ }^{29}$ Onder dergelijke omstandigheden bestaat namelijk geen enkel gevaar van fraude of misbruik dat een inbreuk op het rechtszekerheidsbeginsel rechtvaardigt.

Het Hof geeft in het INZO-arrest een aantal voorbeelden van situaties waarin de verklaringen niet te goeder trouw zijn afgelegd. Zo is dat het geval indien de betrokkene heeft voorgewend bepaalde economische activiteiten te willen verrichten, doch in werkelijkheid goederen ten aanzien waarvan aftrek mogelijk is, in zijn privévermogen heeft proberen op te nemen. Daarbij is controle en correctie achteraf geoorloofd. Zie in dit kader het Schloßstraße-arrest ${ }^{30}$ en dan in het bijzonder rechtsoverwegingen $48 \mathrm{t} / \mathrm{m} \mathrm{50}$, waar het Hof aangeeft dat als bij controle achteraf blijkt dat belanghebbende niet te goeder trouw heeft gehandeld, het rechtszekerheidsbeginsel belanghebbende niet beschermt tegen een eventuele naheffingsaanslag. Verder acht het Hof (r.o. 51) herziening achteraf op grond van de artikelen 184 t/m 192, BTWrichtlijn (voorheen artikel 20, Zesde richtlijn) mogelijk, als blijkt dat het gebruik van bijvoorbeeld onroerend goed wijzigt.

28. Het Gabalfrisa-arrest ondersteunt dit, waar het Hof overweegt (r.o. 46): “(...) In dit verband moet worden beklemtoond, dat de hoedanigheid van belastingplichtige slechts definitief wordt verworven, indien de verklaring van het voornemen om een aanvang te maken met de economische activiteiten, door de belanghebbende te goeder trouw is afgelegd. In geval van fraude of misbruik, bijvoorbeeld wanneer de betrokkene heeft voorgewend bepaalde economische activiteiten te willen verrichten, doch in werkelijkheid goederen ten aanzien waarvan aftrek mogelijk is, in zijn privévermogen heeft pogen op te nemen, kan de Belastingdienst met terugwerkende kracht terugbetaling van de afgetrokken bedragen vorderen, omdat deze aftrek op basis van valse verklaringen is verleend." Wederom geeft het Hof dus aan dat de verklaring te goede trouw dient te zijn afgelegd. In het Gabalfrisa-arrest komt ook de uitleg aan de orde van artikel 22, Zesde richtlijn. Zie in dit kader hoofdstuk 12 waar in het bijzonder aandacht wordt besteed aan het rechtszekerheidsbeginsel in de context van de administratieve verplichtingen.

29. In dit kader is ook het Schloßstraße-arrest van belang, Hof 8 juni 2000, nr. C-396/98, V-N 2000/44.21. In het desbetreffende arrest werd achteraf het recht op aftrek van voorbelasting onmogelijk als gevolg van een wijziging in de nationale wet waardoor niet meer kon worden gekozen voor belaste verhuur. Het Hof geeft aan dat de wetswijziging een omstandigheid betreft buiten de wil van belanghebbende is. Op deze gronden kan de Belastingdienst niet het recht ontnemen om de voorbelasting in aftrek te brengen. Zie in dit kader ook hoofdstuk 11 en Hof 26 april 2005, nr. C-376/02, Stichting Goed Wonen II, V-N 2005/23.16. In dit arrest is beslist dat een wetswijziging niet in strijd is met het vertrouwens- en het rechtszekerheidsbeginsel. Zie ook de eindbeslissing HR 14 december 2007, nr. 34.514, V-N 2007/59.18.

30. Hof 8 juni 2000, nr. C-396/98, Schloßstraße, V-N 2000/44.21. Zie verder de conclusie van A-G RuizJarabo Colomer in deze procedure en dan voornamelijk de pt. 46 t/m 50. 
Het is ter beoordeling van de nationale rechter of een verklaring te goeder trouw is afgelegd en wordt ondersteund door objectieve gegevens. ${ }^{31}$ In de aangehaalde rechtsoverwegingen is regelmatig nog een opvallend zinsdeel te vinden, dat bespreking behoeft (cursief: AHB):

“(...) de hoedanigheid van belastingplichtige slechts definitief wordt verworven, indien de verklaring, (...), door belanghebbende te goede trouw is afgelegd.(...)"

Het lijkt erop dat de belastingplicht, in geval van de start van een onderneming, een additionele voorwaarde kent. De belastingplicht is pas definitief, indien de verklaring van belanghebbende te goede trouw is afgelegd. De formulering doet denken aan een opschortende voorwaarde. Eerst moet aan deze voorwaarde zijn voldaan en dan pas verwerft de startende ondernemer definitief de status van belastingplichtige. Dit lijkt dus te wijzen op een conditionele belastingplicht voor de startende ondernemer. Een dergelijk conclusie lijkt mij niet juist. Deze conclusie zou namelijk inhouden, dat het Hof aan de hand van het rechtszekerheidsbeginsel een materiële invulling geeft aan de omschrijving van het fenomeen belastingplicht. Deze materiële invulling zou zich dan vervolgens toespitsen op de positie in de BTW van de startende ondernemer. Volgens mij gaat echter de reikwijdte van hetgeen het Hof in dit kader overweegt verder dan enkel de positiebepaling van de startende ondernemer. Het Hof bespreekt de formele publiekrechtelijke rechtsrelatie tussen de belastingplichtige en de overheid. Deze relatie houdt in, dat indien de Belastingdienst een bepaald standpunt inneemt, een persoon (al dan niet belastingplichtig) wordt beschermd tegen onverwachte koerswijzigingen van de Belastingdienst. De bescherming strekt zich enkel uit tot die personen die te goede trouw verklaringen hebben afgelegd. Ingeval dat valse verklaringen zijn afgelegd, wordt het gegeven vertrouwen niet gehonoreerd (zie in dit kader ook paragraaf 3.4.3 en paragraaf 12.2).

De erkenning door de belastingdienst van de wilsverklaring maakt - onder omstandigheden - deel uit van de publiekrechtelijke rechtsrelatie tussen een belastingplichtige en de overheid. Het rechtszekerheidsbeginsel fungeert dan niet als interpretatiebeginsel, maar als algemeen rechtsbeginsel van formeel recht.

\subsubsection{Conclusies}

Bijzonder aan de startende ondernemer is, dat veelal investeringsuitgaven worden gedaan, zonder dat daar direct belastbare handelingen tegenover staan. Deze omstandigheid blokkeert de belastingplicht niet. Zelfs niet als de beoogde economische activiteit niet van de grond komt. Uit de jurisprudentie van het Hof blijkt dat deze invulling van artikel 9, BTW-richtlijn wordt gestuurd door de werking van de fiscale neutraliteit als uitdrukking van het gelijkheidsbeginsel. In het proces van rechtsvinding vervult de fiscale neutraliteit een bijzondere rol. Als het antwoord op

31. In paragraaf 4.4.2.1 bracht ik naar voren, dat termen als 'goede trouw' en 'fraude' niet zijn geharmoniseerd en lastig zijn om te interpreteren. Het is aan de nationale rechter om aan deze termen betekenis te geven. 
een prejudiciële vraag niet direct evident is, dan past het Hof de zogenoemde vergelijkingsmethode (analogieargumentatie) toe. In de regel zelf is dan kennelijk niet direct een rechtvaardiging voor een bepaalde beslissing te vinden. De rechter zoekt dan naar een variant waarin de toepassing van de BTW-richtlijn evident is. Vergelijking van beide gevallen leidt vervolgens, tot het ontdekken van een relevant verschil, dat een ongelijke behandeling rechtvaardigt, of tot een gelijke behandeling als er geen relevant verschil is. Ik constateer dat de toepassing van de vergelijkingsmethode bij de startende ondernemer in feite gebaseerd is op de werking van de fiscale neutraliteit als uitdrukking voor de BTW van het gelijkheidsbeginsel. De fiscale neutraliteit fungeert als interpretatiebeginsel.

De vergelijkingsmethode (of de werking van de fiscale neutraliteit) rechtvaardigt een analoge toepassing van artikel 9, BTW-richtlijn bij de startende ondernemer. ${ }^{32}$ De expliciete toepassing van de vergelijkingsmethode heeft tot gevolg dat de redenering van de rechter inzichtelijk is en dat het dan ook meer is dan een sprong die is gebaseerd op intuïtie.

Een startende ondernemer kan pas belastingplichtig worden indien hij zijn wilsverklaring ondersteunt met objectieve gegevens. De status van belastingplichtige is niet afhankelijk van de erkenning door de Belastingdienst. Tussen belanghebbenden en de overheid bestaat een publiekrechtelijke rechtsrelatie. Die blijkt in de hiervoor behandelde jurisprudentie niet enkel te bestaan uit de materieelrechtelijke belastingrelatie tussen burger en overheid - vastlegging belastingplicht, subbegrippen daarvan als 'economische activiteiten' enz. enz. in de richtlijn (zie ook hoofdstukken hierna) - maar ook in een beginselrechtelijke formele relatie door het rechtszekerheidsbeginsel, vertrouwensbeginsel en de goede trouw. En deze beginselen van formeel recht vindt het Hof bij de interpretatie van het materiële recht!

De erkenning van de belastingplicht door de belastingdienst is niet geheel onbelangrijk. Heeft erkenning namelijk plaatsgevonden, dan wordt belanghebbende beschermd door het vertrouwens- en het rechtszekerheidsbeginsel. De werking van deze beginselen is conditioneel. Vereist is namelijk dat belanghebbende de wilsverklaring te goede trouw heeft afgelegd.

\subsection{Holdingmaatschappijen}

\subsubsection{Algemeen}

Holdingmaatschappijen komen voor in diverse modaliteiten. Zo zijn te onderkennen zogenoemde zuiver holdings, dat wil zeggen vennootschappen die enkel aandelen houden. Maar ook vennootschappen die naast het houden van aandelen, diverse activiteiten verrichten zoals het verstrekken van rentedragende leningen, geven van adviezen en het verrichten van managementdiensten. Verder zijn te onderkennen

32. Zie ook paragraaf 4.4 .3 waar is verduidelijkt dat de analogie-argumentatie is gebaseerd op het gelijkheidsbeginsel. 
beleidsbepalende holdings. Daar bedoel ik mee holdings die zich mengen in het beheer van de deelnemingen zonder daarvoor een vergoeding in rekening te brengen.

Kenmerkend voor dergelijke typen vennootschappen is dat zij aandelen houden. Dit roept de vraag op of van belastingplicht sprake kan zijn indien enkel aandelen worden gehouden.

Allereerst zal in paragraaf 7.3.2 een verduidelijking plaatsvinden van de sector benadering die het Hof volgt. Het Hof onderscheidt veelal bij holdingmaatschappijen die aan de BTW onderworpen prestaties verrichten, een zogenoemd nietondernemersdeel. Paragraaf 7.3.3 besteedt aandacht aan de Welthgrove-procedure en de fiscale neutraliteit. Paragraaf 7.3.4 vergelijkt het lot van startende ondernemer met dat van de beleidsbepalende holding en in het bijzonder ga ik in deze paragraaf in op de toepassing van de analoge toepassing van artikel 9, BTWrichtlijn. Deze subparagraaf over holdingmaatschappijen sluit af met een conclusie.

\subsubsection{Sector benadering bij holdingmaatschappijen}

Het Hof heeft in het Polysar-arrest ${ }^{33}$ beslist, dat het enkel houden van aandelen niet leidt tot belastingplicht:

“(...) De financiële deelneming in andere ondernemingen als zodanig is namelijk niet aan te merken als exploitatie van een zaak om er duurzaam opbrengst uit te verkrijgen, omdat het eventuele dividend, de opbrengst van deze deelneming, voortspruit uit de loutere eigendom van het goed." (r.o. 13)

Met deze rechtsoverweging lijkt de discussie rond de belastingplicht beslecht. De eerste drie woorden van de volgende rechtsoverweging roepen echter zo veel vragen op, dat zij nog jarenlang de pennen van diverse schrijvers in beweging brengen (cursief: AHB):

"Dit ligt anders wanneer de deelneming gepaard gaat met een zich direct of indirect moeien in het beheer van de vennootschappen waarin wordt deelgenomen, onverminderd de rechten die de houder van de deelnemingen als aandeelhouder of vennoot heeft."

De vraag komt op: Wat ligt anders? Bedoelt het Hof dat onder bepaalde omstandigheden wel degelijk sprake is van de exploitatie van een vermogensbestanddeel en dus van belastingplicht? Of bedoelt het Hof dat in een dergelijk geval het dividend kan worden aangemerkt als de vergoeding voor een prestatie, zoals Van Hilten oppert in haar dissertatie ${ }^{34}$ De bovenstaande rechtsoverweging is niet duidelijk en

33. Hof 20 juni 1991, nr. C-60/90, Polysar Investment Netherlands BV, V-N 1991/2140, pt. 35, FED 1991/633. 34. Van Hilten meent dat hetgeen de 'moeiende holding' méér aan dividend ontvangt dan andere aandeelhouders (die niet moeien) als vergoeding voor een prestatie kan worden aangemerkt. M.E. van Hilten, Bancaire en financiële prestaties in de Europese BTW (diss. Leiden), Deventer: Kluwer 1992, onderdeel III.3, paragraaf 1.3, blz. 184 e.v. 
heeft dan ook geleid tot vele beschouwingen in de vaklitteratuur. ${ }^{35}$ Het Hof heeft pas een aantal jaren later in het Floridienne-arrest ${ }^{36}$ en de Welthgrove-beschikking ${ }^{37}$ duidelijkheid gegeven. Uit deze beslissingen blijkt een duidelijke lijn van het Hof: dat zuivere holdings en holdings die zich mengen in het beheer van hun deelnemingen, zonder daarvoor een vergoeding te bedingen, niet belastingplichtig zijn.

Het bovenstaande betekent niet dat de fiscale status van holdingmaatschappijen volledig duidelijk is. Het mag dan wel zo zijn dat duidelijkheid is gegeven voor wat betreft zuivere holdings en holdings die zich mengen in het beheer van de deelnemingen (zogenoemde beleidsbepalende holdings), maar daarvoor in de plaats zijn nieuwe probleemvelden ontstaan. Zo blijkt uit het Floriedienne-arrest dat het Hof kiest voor een sector benadering. Daar bedoel ik mee, dat het Hof een rechtspersoon als het ware knipt in diverse sectoren en voor iedere sector nagaat of sprake is van belastingplicht. ${ }^{38}$ Zo zijn binnen rechtspersonen sectoren te onderkennen, waarvoor belastingplicht bestaat en sectoren waarvan geen sprake is van belastingplicht. ${ }^{39}$ Een NV of een BV kan dan ook een niet-ondernemersdeel hebben. Dit in tegenstelling tot de vennootschapsbelasting. Zo vermeldt artikel 2, lid 5, Wet VPB, dat onder meer naamloze vennootschappen en besloten vennootschappen:

“(...) worden geacht hun onderneming te drijven met behulp van hun gehele vermogen."

35. Zie onder meer: D.B. Bijl, De houdstermaatschappij in de omzetbelasting, WFR 1991/5977, blz. 1301 - 1309; D.B. Bijl, annotatie bij het Polysar-arrest in FED 1991/633; U Tromp, Nieuws over holdings, BTW-Brief 1991, nr. 3, blz. 1; U. Tromp, Hof over holdings, BTW-Brief 1991, nr. 5 (50); R.N.G. van der Paardt, Holdings en BTW, MBB 1992/7-8, blz. 209 - 215; W.A.P. Nieuwenhuizen, Ondernemer in de omzetbelasting: een beetje zwanger is mogelijk!, WFR 1993/6080, blz. 1772; J.T. Sanders, Over BTW en aandelen en BTW over aandelen (I), BTW-Brief 1995, nr. 6/7, blz. 3; W.A.P. Nieuwenhuizen, Holdingproblemen: drie keer is scheepsrecht, BTW Bulletin 1997, nr. 10, blz. 1 -5; T. Braakman en H.W. M. van Kesteren, De BTW-positie van de moeiende houdstermaatschappij, WFR 1998/6281, blz. 323 e.v.; J.J.P. Swinkels, De belastingplichtige in de Europese BTW (diss. Amsterdam UvA) 2000, blz. 225-228 en 252-263.

36. Hof 14 november 2000, nr. C-142/99, Floridienne \& Berginvest, V-N 2000/53.17.

37. Hof 12 juli 2001, C-102/00, Welthgrove BV, BNB 2002/182, V-N 2001/42.14, FED 2001/541.

38. Zie Paul Farmer, Taxable persons and the 'private life' of companies, The EC Tax Journal, Volume 2 1996/97, Issue 1, blz. 41 en zie verder A.H. Bomer en H. W.M. van Kesteren, De houdstermaatschappij: Geknipt voor de BTW, WFR 1999/6329, blz. 264. Voor een meer uitgebreide behandeling G.J. van Norden, Het concern in de BTW (diss. Tilburg), Deventer: Kluwer 2007, paragraaf 5.2.8.

39. Deze lijn is terug te vinden in de nationale jurisprudentie in de uitspraak van Hof 's-Gravenhage 17 juni 1998, nr. BK-96.02279, FED 1998/624. Overigens hoeft een dergelijke 'knip' het recht op aftrek van voorbelasting bij holdings niet te blokkeren. In de uitspraak van het Gerechtshof Amsterdam van 26 november 2009 (nr. P08/01220, V-N 2010/12.21), is beslist dat een zogenoemde holdingplus volledig recht op aftrek van voorbelasting heeft gezien pt. 11 van de holdingresolutie (18 februari 1991, nr. VB91/347). Het lijkt mij dat pt. 11 van de holdingresolutie in strijd is met de BTW-richtlijn zoals is uitgelegd in het Securenta-arrest (Hof 13 maart 2008, nr. C-437/06, V-N 2008/14.20). Het Hof wijst er namelijk op dat slechts aftrekrecht bestaat voor zover sprake is van economische activiteiten. Hetgeen niet het geval is wat betreft passief houden van aandelen waar pt. 11 van de holdingresolutie op doelt. Zie ook Beelen, Aftrek van btw als (belaste) omzet ontbreekt (diss. Rotterdam), Deventer: Kluwer 2010, paragrafen 4.4.11 en 5.5.6. 
Een dergelijk fictieartikel is in een Europese belasting als de BTW, gezien de huidige stand van harmonisatie van het ondernemingsrecht, onmogelijk. Aansluiten bij de rechtsvorm wat betreft de omvang van de belastingplicht is geen optie, gezien het gegeven dat de diverse rechtsvormen in de lidstaten niet zijn geharmoniseerd. In de BTW past dan ook een meer materiële benadering ter bepaling van de omvang van de belastingplichtige activiteiten. ${ }^{40}$

De tweedeling in ondernemersdeel en niet-ondernemersdeel kan tot complexe situaties leiden omdat het Hof het ondernemersdeel en het niet-ondernemersdeel niet absoluut bepaalt of scherp afbakent. Het blijkt dat het mogelijk is dat een sector binnen een rechtspersoon die apart getoetst aan de criteria van de belastingplicht, niet aangemerkt kan worden als te behoren tot het ondernemersgedeelte, niettemin op een dusdanige wijze kan zijn verbonden met het ondernemersgedeelte dat het betreffende deel toch tot het ondernemersdeel behoort. ${ }^{41}$ Het zal duidelijk zijn dat deze benadering in het bijzonder lastige vragen oproept voor het recht op aftrek van voorbelasting. Voor de behandeling daarvan verwijs ik naar hoofdstuk 11.

\subsubsection{Beleidsbepalende holding en de fiscale neutraliteit}

Het-dit-ligt-anders-argument heeft, zie vorige paragraaf, een hele keur aan Nederlandse schrijvers in beroering gebracht en de Hoge Raad verleid tot het stellen van prejudiciële vragen. Kan een holding, kort gezegd, met enkel een deelneming op de balans belastingplichtig worden door zich slechts met het beleid van de dochters te bemoeien? Het antwoord op deze vraag is nogal van belang voor 'holdinglanden' zoals Nederland, maar het antwoord in de zaken Welthgrove en Floridienne is, zoals hiervoor gezien, 'neen', en dus blijft ook de in onze nationale economie van belang zijnde beleidsbepalende holding buiten de BTW-deur staan, hoezeer ook deel uitmakend van de 'productieketen'. ${ }^{42}$

In de Welthgrove-zaak gaat het om een klassieke Nederlandse holding, die zich enkel mengt in het beheer van de deelnemingen. ${ }^{43}$ Welthgrove heeft in lidstaten

40. Een andere lijn is, in de richtlijn aangeven per lidstaat voor welke rechtsvormen sprake is van belastingplicht. Voor het aanwijzen van rechtsvormen waarvoor een bepaalde regeling geldt, is gekozen in de zogenoemde moeder dochterrichtlijn. In deze richtlijn is in een bijlage vermeld de rechtsvormen per lidstaat waarvoor artikel 2, onder a van die richtlijn geldt (Richtlijn 90/435/EEG van de Raad van 23 juli 1990 betreffende de gemeenschappelijke fiscale regeling voor moedermaatschappijen en dochterondernemingen uit verschillende lidstaten, Pb L 225 van 20 augustus 1990).

41. Zie A.H. Bomer \& H.W.M. van Kesteren, De houdstermaatschappij: Geknipt voor de BTW, WFR 1999/ 264. Zie tevens A.H. Bomer, Kleurveranderingen bij holdings en de rechtszekerheid, BTW Bulletin, november 2001, nr. 11

42. Hof 12 juli 2001, nr. C-102/00, Welthgrove BV, BNB 2002/182, V-N 2001/42.14, FED 2001/541. Op 22 maart 2002 volgt het arrest van de HR op de beschikking van het Hof. Het arrest van de HR is gepubliceerd in BNB 2002/183, m.n.v. M.E van Hilten.

43. Van Hilten is van mening dat het aanhouden van participaties door een belastingplichtige wel degelijk bedrijfshandelingen zijn, of althans handelingen in de niet-consumptieve sfeer. Dat geldt volgens haar in het bijzonder indien de aandeelhouder een rechtspersoon is. Anders dan een particulier kan een rechtspersoon volgens haar niet rechtstreeks consumeren. Daar zal altijd een $\rightarrow$ 
buiten Nederland deelnemingen. Welthgrove heeft geen ander personeel in dienst dan de statutaire directie. De statutaire directie van de vennootschap houdt zich actief bezig met de begeleiding van de dochtermaatschappijen. Zij berekent daarvoor geen vergoeding aan de dochters. Haar 'inkomsten' bestaan uit van de dochters afkomstig dividend. Centraal staat de vraag of Welthgrove belastingplichtig is, d.w.z. het antwoord op de vraag of de vennootschap economische activiteiten verricht in de zin van artikel 4, Zesde richtlijn. Het Hof verwijst naar het eerder gewezen Floridienne-arrest. Het besliste daarin dat enkel inmenging in het beheer van de deelnemingen onvoldoende is om in aanmerking te komen voor belastingplicht. De vennootschap moet daarvoor een wederprestatie verkrijgen, anders komt, men populair gezegd, de wet niet binnen:

“(...) dat de inmenging van een holding in het beheer van haar dochtervennootschappen slechts een economische activiteit in de zin van artikel 4, lid 2, van de Zesde richtlijn vormt wanneer zij gepaard gaat met handelingen die aan de BTW zijn onderworpen op grond van artikel 2 van die richtlijn." (r.o. 18)

Artikel 2 van die richtlijn (thans hetzelfde artikelnummer) bepaalt het toepassingsgebied van de BTW tot leveringen en diensten onder bezwarende titel en wanneer derhalve economische activiteiten niet daarmee gepaard gaan is het lot van de beleidsbepalende vennootschap beslecht: geen belastingplicht en mitsdien ook geen toegang tot de aftrek van voorbelasting. ${ }^{44}$ Managen is fiscaal slechts relevant als er een fee tegenover staat.

$\rightarrow$ uitdeling aan vooraf gaan. Aandelenbezit door een belastingplichtige betreft volgens haar een bedrijvigheid die geen consumptief karakter heeft en daarom vrij van omzetbelasting moet blijven. In de BTW kan dat worden bereikt door het aandelenbezit binnen de sfeer van de belastingplicht te brengen. Voor de aftrek van voorbelasting zou dat betekenen dat de BTW die drukt op de kosten van de deelneming(en) voor aftrek in aanmerking komen naar rato van de belaste prestaties van de desbetreffende belastingplichtige. M.E. van Hilten, Gedachten over de grenzen van de belastingplicht in de omzetbelasting, WFR 1994/15.

44. Nog niet alle vragen met betrekking tot beleidsbepalende holdings zijn opgelost. Zo is nog geen duidelijkheid gegeven over hetgeen het Hof bedoelt met het zinsdeel 'mengen in het beheer van de deelnemingen'. In het arrest van het Hof van 27 september 2001, nr. C-16/00, Cibo Participations SA, V-N 2001/55.7, FED 2002/31, stelde de Franse rechter onder meer de prejudiciële vraag, welk criterium gehanteerd moet worden voor de definitie van inmenging? Het Hof heeft echter deze vraag niet beantwoord. Het lijkt er op dat twee invullingen van het desbetreffende zinsdeel op dit moment mogelijk zijn. Ten eerste de invulling die historisch in Nederland wordt gegeven. Namelijk dat uit directie verslagen moet blijken dat belangrijke bestuursbeslissingen worden genomen door de moedermaatschappij. Coördinatie op enkel financieel en fiscaal terrein is onvoldoende (zie HR 26 augustus 1998, nr. 33 662, BNB 1999, blz. 384; FED 1999, blz. 224, V-N 1998, blz. 4398). Een tweede uitleg is ook mogelijk. Deze wordt voornamelijk opgeroepen door de Franse tekst van het Floridiennearrest, Hof 14 november 2000, nr. C-142/99, V-N 2000/53.17. R.o. 19 vermeldt namelijk: “(...), dans la mesure où elle implique la mise en oevre de transactions soumises à la TVA (...)" wat kan worden vertaald als 'voor zover (de inmenging) leidt tot het verrichten van handelingen die aan BTW zijn onderworpen'. Mogelijk is dus dat het Hof met het zinsdeel 'mengen in het beheer van de deelneming', doelt op een belaste dienstverlening die wordt verricht aan de dochtermaatschappij. Zie tevens Hof 29 oktober 2009, nr. C-29/08, SKF, V-N 2009/56.13, NTFR 2009/2421 en dan in het bijzonder r.o. 30. 
Een en ander houdt nu in, dat, hoewel de directie van de holdingvennootschap zich mengt in het beheer van de deelnemingen, de vennootschap buiten het bestek van de BTW blijft staan hoewel het economisch gezien bepaald geen verkeerde gedachte zou zijn, zie ook de literatuur ${ }^{45}$ daaromtrent, haar in verband met haar rol in de 'productieketen' de belastingplicht te verlenen. De Nederlandse rechtspraktijk doet dit ook daadwerkelijk door voor de beleidsbepalende holding de toegang tot het vormen van een fiscale eenheid met de dochters te verschaffen. ${ }^{46}$ Aldus komt ook de BTW op de kosten die de holding genereert voor aftrek van voorbelasting in aanmerking en wordt er 'belastingschoon' geproduceerd.

In de idee de beleidsbepalende holding op het BTW-toneel te krijgen is bij het 'ditligt-anders-argument' in de literatuur ook het dividend als mogelijk relevant feit naar voren gebracht. Het dividend aan de omzet-zijde van holdingvennootschappen speelde (met rente-inkomsten) ook een rol in de berekeningswijzen van toe te rekenen voorbelasting. Doet dividend mee in de omzet? De Franse regering wees al in de Polysar-procedure die gedachte van de hand en refereerde daartoe naar de tweede en achtste overweging van de considerans van de Eerste richtlijn. ${ }^{47}$ Daaruit bleek volgens haar dat de noodzaak van de totstandbrenging van de harmonisatie van de BTW is het uitschakelen van de factoren die de mededingingsvoorwaarden kunnen vervalsen en dat dit aldus is te bereiken door in elk land op soortgelijke goederen dezelfde belasting te laten rusten, ongeacht de lengte van de productiedistributieketen. Om dit doel te bereiken is BTW verschuldigd, berekend over de prijs van de goederen en diensten, onder aftrek van het bedrag aan BTW dat rechtstreeks rust op de kosten van de verschillende bestanddelen van de prijs. Dividend moet worden aangemerkt als een winstdeling en makt dus nooit onderdeel uit van de kostprijs, in tegenstelling tot een management fee en rente. Volgens de Franse regering is dit een rechtvaardigingsgrond om de dividenden buiten het bereik van de BTW te houden.

Zou men niet al door de antwoorden in de arresten Polysar en die over een zuivere holding en voorbelasting handelt, zijn bediend dan was de Nederlandse twijfel of dividend bij beleidsbepalende holdings nog een rol kon spelen wel door het arrest Floridienne en de Welthgrove-beschikking ten leste definitief beantwoord. Dividenden zijn geen tegenprestatie voor enige economische activiteit en de ontvangst ervan valt buiten de werkingssfeer van de BTW, welke uitsluiting natuurlijk samenhangt met de kenmerken van het dividend zoals het zijn van uitkering uit de winst waar men als eigenaar van het aandeel recht op heeft. Een verband met een dienst, zelfs als deze door de aandeelhouder zou worden verricht, is niet het rechtstreeks verband dat nodig is om het dividend als tegenprestatie te kunnen aanmerken (zie r.o. 21-23 in de Welthgrove-beschikking). De economische visie de beleidsbepalende holding graag een rol te laten meespelen kan de fiscale toets niet doorstaan. Een fee is een rechtsfeit, dividend is een irrelevant feit.

45. Vgl. G.J. van Norden 2007, blz. 146 en 147. Zie tevens K.M. Braun 2002, blz. 111.

46. Besluit van 18 februari 1991, nr. VB91/374, FED 1991/266.

47. Zie voor de opmerkingen van de Franse regering, Jur. 1991, blz. I-3111. 
En daarmee een vergelijking tussen enerzijds een beleidsbepalende holding die voor de dochters werkzaamheden verricht en daarvoor een bedrag aan fees in rekening brengt enerzijds en anderzijds een beleidsbepalende holding die dezelfde werkzaamheden onderneemt en zich - zo de winst van dochters het toelaat - tot een zelfde bedrag aan dividenden laat uitkeren, een ondeugdelijke. Het gevolg voor de rechtspraktijk is behalve helder ook gemakkelijk: de beleidsbepalende holding en dochters hebben het in eigen hand te bepalen of de moedervennootschap belastingplichtig voor de BTW wordt (fee) of niet, een keuze die zal afhangen van het recht op aftrek op voorbelasting die de dochters hebben (dan fee) of niet, zoals in de sector van vrijgestelde prestaties.

Indien overigens het HvJ EU zou hebben beslist, dat een beleidsbepalende holding belastingplichtig is, dan zouden er ook nieuwe problemen hebben kunnen rijzen. ${ }^{48}$ Zo zou de vraag rijzen of de dividenden een vergoeding vormen voor een vrijgestelde prestatie. Indien dat het geval zou zijn, ontstaat een ongelijke situatie. Een beleidsbepalende holding heeft dan namelijk geen recht op aftrek van voorbelasting voor zover het dividend wordt ontvangen van deelnemingen die zijn gevestigd binnen de EU (artikel 169, sub c, BTW-richtlijn). Gelijkheid tussen de vennootschappen zou dan eerst kunnen ontstaan indien het dividend een vergoeding zou zijn voor een belaste prestatie. Met als curieus resultaat dat BTW in rekening gebracht moet worden, indien dividend wordt uitgekeerd aan een aandeelhouder die zich mengt in het beheer van de deelnemingen. Waarschijnlijk zou een dergelijk resultaat ook ongewenst zijn. Aandeelhouders zouden dan ten eerste moeten beseffen of zij zich in voldoende mate mengen in het beheer om te kunnen worden aangemerkt als belastingplichtige. Vervolgens moeten zij afwachten of er dividend (dan wel hoe hoog) wordt vastgesteld en vervolgens zouden zij dan alsnog BTW in rekening moeten brengen aan de vennootschap die het dividend uitkeert. Het zal duidelijk zijn dat een dergelijk traject ook zijn problemen oproept.

\subsubsection{Analoge toepassing bij de startende ondernemer en niet bij de holdingmaatschappij}

In paragraaf 7.2.2 is behandeld, dat een analoge toepassing van artikel 9, BTW-richtlijn tot gevolg heeft dat een startende ondernemer belastingplichtig is. Het Hof ziet geen rechtvaardigingsgrond om een startende ondernemer die nog niet tot daadwerkelijke exploitatie is overgegaan, anders te behandelen dan een ondernemer die prestaties verricht die aan de BTW zijn onderworpen. Een startende ondernemer wordt door het Hof vergeleken met een belastingplichtige (ondernemer).

In de vorige paragraaf blijkt dat, een beleidsbepalende holding niet vergelijkbaar is met een management vennootschap. De holding is wel actief voor de dochters maar

48. Een andere mogelijkheid is om een beleidsbepalende holding als belastingplichtige aan te merken zonder dat er een belaste of vrijgestelde output is. Vergelijkbaar met een startende ondernemer. In de literatuur is hier onder meer voor gepleit door D.M.P.M. Stevens in haar dissertatie, Het verrichten van diensten onder bezwarende titel als belastbaar feit in de omzetbelasting, blz. 60 - 66 . 
mist wederprestaties daarvoor en verricht dus geen economische activiteit. ${ }^{49}$ Daarmee is dan al het pleit beslecht. Dan is er geen vergelijking meer te maken met, een gelijkstelling te creëren aan, laat staan een analogie neer te zetten met alle anderen die economische activiteiten verrichten. De holding hoezeer actief ook, wordt buiten de wet gezet en komt terecht in de wereld van eindverbruikers van particulieren. En hetzelfde lot ondergaat Wellcome Trust, die aandelen verkoopt; het is een in het Verenigd Koninkrijk opererende Ltd, waarin honderden miljoenen omgaan, die actief is, groot van omvang en zich bedient van adviseurs. Zij verricht geen economische activiteiten in de zin van artikel 4, Zesde richtlijn; zij komt terecht in de wereld van particuliere beleggers.

Het interessante van de rechtspraak van het Hof is nu dat er toch een vergelijking met die particuliere beleggers wordt gemaakt ${ }^{50}$ weliswaar mede ten antwoord op het standpunt van belanghebbende en daarmee ook ter adstructie van de beslissing die dus niet zelfstandig door zo'n vergelijking gedragen zou kunnen worden - maar toch wordt zij gemaakt en geeft zij inzicht in de gedachtegang van het Hof; nogal pregnant gezegd: $\mathrm{u}$ komt het huis van de BTW niet in, $\mathrm{u}$ bent gewoon een particuliere belegger.

Nadat het Hof geconcludeerd had, dat een trust die zich in de door de verwijzende rechter herschreven situatie bevindt, vanuit het oogpunt van artikel 4, Zesde richtlijn moet worden geacht zich te beperken tot het beheer van een investeringsportefeuille op dezelfde wijze als een particulier investeerder, vervolgt het Hof:

\begin{abstract}
"Anders dan verzoekster in het hoofdgeding stelt, kan overigens niet worden uitgegaan van de omvang van een aandelenverkoop, zoals de tweede verkoop in de hoofdzaak, noch van de omstandigheid dat in het kader van een dergelijke verkoop een beroep is gedaan op consultancybureaus, als criteria om een onderscheid te maken tussen de activiteiten van een particulier investeerder, die buiten het toepassingsgebied van de richtlijn vallen, en die van een investeerder waarvan de operaties een economische activiteit vormen. Nog daargelaten dat aanzienlijke aandelenverkopen ook door particuliere investeerders kunnen worden verricht, zou de zienswijze van verzoekster in het hoofdgeding hierop neerkomen, dat de kwalificatie van een operatie als economische activiteit afhankelijk zou worden gesteld van de vaardigheid en de competentie van de investeerder.
\end{abstract}

Wat het beginsel van de fiscale neutraliteit betreft, dit heeft niet de strekking die verzoekster in het hoofdgeding daaraan toekent. Dit beginsel houdt weliswaar in, dat alle economische activiteiten gelijk moeten worden behandeld, doch het veronderstelt eveneens, dat de betrokken activiteit als economische activiteit kan worden gekwalificeerd, wat in casu niet het geval is.

Zoals de advocaat-generaal bovendien in punt 27 van zijn conclusie heeft aangetoond, zou, indien de activiteiten van de trust als een economische activiteit in de zin van de richtlijn werden beschouwd, en dus de aftrekbaarheid van de als voorbelasting betaalde BTW werd erkend, dit een investeerder als de trust bevoordelen ten opzichte van andere particuliere investeerders, (...)" (rechtsoverwegingen $37 \mathrm{t} / \mathrm{m}$ 39)

49. Zie, kort gezegd voor moeien tegen fee overweging 19, Floridienne, en overweging 35 van Wellcome Trust en daar ook de niet aanwezige handel, makelaardij in aandelen. 50. Vgl. ook r.o. 28 in het Floridienne-arrest. 
Uit de bovenstaande overwegingen blijkt dus dat de aandelen die Wellcome verkoopt buiten het bereik van de BTW vallen, zoals bij een particuliere investeerder. Rechtsoverweging 38 bevestigt dat fiscale neutraliteit slechts is weggelegd voor economische activiteiten. In paragraaf 7.2.2 blijkt dat de investering van de startende ondernemer onder druk van de fiscale neutraliteit wel de kwalificatie economische activiteit kon krijgen.

Hoewel beleidsbepalende houdstermaatschappijen zijn te positioneren tussen twee uitersten - de particuliere belegger die aandelen houdt en de holdings die hun aandelenbezit vergezeld laten gaan met managementactiviteiten tegen vergoeding of anderszins belastingplichtig zijn - kan de balans niet omslaan naar een positie tussen de belaste ondernemers, deel uitmakend van de distributie- productiekolom en kunnen zij dus niet BTW vrij aandelen houden, verwerven of afstoten. In die zin neemt het Hof hen de maat van een particuliere belegger. ${ }^{51}$ Wellcome viel een vergelijking met een particuliere investeerder te beurt. In die zin hebben de overwegingen de inslag van een a contrario-argumentatie in de moderne betekenis van het woord, zoals in paragraaf 4.4.3.3 beschreven.

\subsubsection{Conclusies}

De positie van zuivere holdings en beleidsbepalende holdings is duidelijk. Het Hof heeft namelijk uitgemaakt, dat geen sprake is van belastingplicht. De beleidsbepalende holding is niet vergelijkbaar met een management vennootschap. Hoewel beleidsbepalende houdstermaatschappijen zijn te positioneren tussen twee uitersten - de particuliere belegger die aandelen houdt en de holdings die hun aandelen bezit vergezeld laten gaan met managementactiviteiten tegen vergoeding of anderszins belastingplichtig zijn, slaat de balans niet door naar een positie tussen de belaste ondernemers die deel uitmaken van de distributie-productiekolom. In die zin zijn zij te vergelijken met een eindverbruiker.

\subsection{Belastingplicht van publiekrechtelijke lichamen}

\subsubsection{Inleiding}

Publiekrechtelijke rechtssubjecten, die in deze paragraaf worden aangeduid als publiek rechtelijke lichamen, begeven zich steeds nadrukkelijker op markten waarin

51. Braun brengt naar voren dat naar zijn mening het gerechtvaardigd en zelfs noodzakelijk is om een dergelijke beleidsbepalende holding aan te merken als (fictief) ondernemer, ook als voor dat moeien niet een afzonderlijke vergoeding wordt ontvangen, omdat belanghebbenden om hen moverende redenen voor moeten kunnen kiezen om de feitelijke leiding vanuit een holding uit te oefenen, zonder dat dit nadelige consequenties heeft voor de aftrekbaarheid van voorbelasting. K.M. Braun 2002, blz. 111. 
voorheen hoofdzakelijk particuliere (commerciële) bedrijven actief waren. ${ }^{52}$ De hieruit voortvloeiende klachten over concurrentievervalsing krijgen ruime publiciteit en hebben de politieke aandacht. ${ }^{53}$ Concurrentievervalsing kan vanuit diverse invalshoeken worden bekeken en dan ook verschillend worden gedefinieerd. ${ }^{54}$ Deze paragraaf doelt met de term concurrentievervalsing op een situatie waarin een overheidslichaam niet belastingplichtig is, terwijl particuliere (commerciële) bedrijven bij gelijke of soortgelijke prestaties BTW in rekening moeten brengen. Het overheidslichaam dat geen BTW in rekening brengt, kan uiteraard de aan haar in rekening gebrachte BTW niet in aftrek brengen. Het voordeel dat zij behaalt ten opzichte van een particulier (commercieel) bedrijf, is dat de kosten waarop geen BTW drukt (bijvoorbeeld de loonsom), onbelast worden doorberekend aan haar afnemers. Het overheidslichaam dat niet-belastingplichtig is, kan dan concurreren met particuliere (commerciële) bedrijven tegen lagere marktprijzen indien de afnemers particulieren zijn dan wel andere partijen zonder aftrekrecht.

Denkbaar is ook dat een overheidslichaam, dat opereert op een markt waar het door zijn gunstiger BTW-positie hogere winsten kan behalen, vervolgens dit voordeel gebruikt om zijn prijzen te verlagen op een andere markt waar het zich in een gelijke BTW-positie bevindt als particuliere (commerciële) bedrijven. Op deze wijze ontstaat door middel van 'kruissubsidiëring' concurrentievervalsing op andere markten. ${ }^{55}$ Duidelijk is dat indien een overheidslichaam dat niet belastingplichtig is en vervolgens in concurrentie treedt met een onderneming in de particuliere sector die wel normaal belastingplichtig is, de concurrentieverhoudingen ernstig verstoord kunnen raken. Zoals in deze paragraaf zal blijken, treft men in de BTW-richtlijn bepalingen aan die deze verhoudingen proberen te corrigeren indien concurrentievervalsing aan de orde is. ${ }^{56}$

52. De rechtspersoonlijkheid is geregeld in artikel 2:1 BW. In het eerste lid is bepaald dat de Staat, de provincies, de gemeenten, de waterschappen, alsmede alle lichamen waaraan krachtens de Grondwet verordenende bevoegdheid is verleend, rechtspersoonlijkheid bezitten. Het begrip 'publiekrechtelijk lichaam' is een communautair begrip, Zie B.G. van Zadelhoff, Onroerende goederen en belasting over toegevoegde waarde (diss. Amsterdam UvA), Deventer: Kluwer 1992, blz. 146 en 147. Zie ook S.A. Stevens, De belaste overheid (diss. Tilburg), Deventer: Kluwer 2003, blz. 399.

53. NRC van 24 oktober 1995, inzake de klacht van de Raad van de Centrale Ondernemingsorganisaties. Zie tevens - maar dan gericht op de vennootschapsbelasting - de notitie van de Staatssecretaris aan de Kamers, brief van 25 september 2007, nr. DB07-452, V-N 2007/54.15.

54. E.P.H. Pijnacker Hordijk \& T.M. Snoep, NJB 14 juni 1996, blz. 923. In dit artikel plaatsen de schrijvers enkele kanttekeningen vanuit mededingingsrechtelijk perspectief.

55. Van kruissubsidiëring is in het algemeen sprake wanneer een onderneming de kosten van haar activiteiten binnen een bepaalde markt geheel of gedeeltelijk ten laste brengt van haar activiteiten op een andere markt. Zie E.P.H. Pijnacker Hordijk \& T.M. Snoep, NJB 14 juni 1996, blz. 923.

56. Het is te verwachten dat de invoering van het BTW-Compensatiefonds invloed zal hebben op de concurrentieverhoudingen. De bedoeling van het fonds is immers om bepaalde verstoringen die de BTW veroorzaakt bij uitbesteding weg te nemen. Gezien het feit dat het BTW-Compensatiefonds (nog) geen onderwerp is geweest van een procedure voor het Hof, laat ik dit aspect verder rusten. Zie verder voor de werking van het BTW-Compensatiefonds, B. Bijl, H. Wolvers \& M. Wassenaar, Het BTWCompensatiefonds, Den Haag: Sdu Uitgevers. Zie tevens A.H.R.M. Denie, De komst van het BTWcompensatiefonds, in BTW in Utopia, opstellen aangeboden aan D.B. Bijl, Deventer: Kluwer 2001. 
Deze paragraaf behandelt de wijze waarop de algemene rechtsbeginselen de jurisprudentie van het Hof sturen op het terrein van de belastingplicht van publiekrechtelijke lichamen. Hoofdzakelijk zal in dit kader het gelijkheidsbeginsel aan bod komen.

\subsubsection{Ruime werkingssfeer van de BTW}

Zoals in paragraaf 7.2 met betrekking tot de startende ondernemer naar voren is gebracht, kent de BTW-richtlijn de BTW een ruime werkingssfeer toe. Ook in de jurisprudentie van het Hof met betrekking tot de belastingplicht van publiekrechtelijke lichamen is deze lijn terug te vinden. ${ }^{57}$ Het Hof concludeert uit artikel 9, BTW-richtlijn dat het begrip economische activiteiten een ruime werkingssfeer heeft, alsook een objectief karakter, in die zin dat de activiteiten op zichzelf moeten worden beschouwd, onafhankelijk van het oogmerk of het resultaat van de activiteiten. In paragraaf 7.2 is met betrekking tot de startende ondernemer aangegeven, dat deze lijn in het bijzonder is gebaseerd op de fiscale neutraliteit als uitdrukking van het gelijkheidsbeginsel voor de BTW. Deze paragraaf gaat nader na of de fiscale neutraliteit ook bij publiekrechtelijke lichamen een rol speelt bij het bepalen van de belastingplicht.

In een Nederlandse zaak over de belastingplicht van notarissen en gerechtsdeurwaarders heeft het Hof al in 1987 bepaald, dat de ruime werking van het begrip belastingplicht niet wordt ingeperkt ten gunste van wettelijk geregelde beroepen. Ook het feit dat een bepaalde activiteit wordt ondernomen uit het oogpunt van algemeen belang door bij de wet opgedragen en wettelijk geregelde ambtsverrichtingen, is van geen belang. Het Hof baseert deze conclusie op het feit dat artikel 25, sub c, BTW-richtlijn (voorheen artikel 6, lid 1, Zesde Richtlijn) bepaalde krachtens de wet verrichte activiteiten expliciet aan de heffing van de BTW onderwerpt. ${ }^{58}$ Artikel 25, sub c, BTW-richtlijn beschouwt namelijk als een belastbare handeling het verrichten van een dienst op grond van een vordering door of namens de overheid, dan wel krachtens de wet. Wel is het zo dat de tekst van artikel 13, BTW-richtlijn (voorheen artikel 4, lid 5, Zesde richtlijn) onderdelen bevat die de ruime werking van de belastingplicht beperken. Dit komt aan de orde in de volgende paragrafen.

\subsubsection{Correctie op de ruime werkingssfeer}

De BTW-richtlijn corrigeert op verscheidene plaatsen de ruime werking van de belastingplicht (zie ook hoofdstuk 9 over de vrijstellingen in de BTW). Artikel 13, BTW-richtlijn (voorheen Artikel 4, lid 5, Zesde richtlijn) zorgt voor een correctie wat betreft de belastingplicht van publiekrechtelijke lichamen.

57. Zie onder meer Hof 26 maart 1987, nr. 235/85, Commissie/Nederland inzake de belastingplicht van notarissen en deurwaarders bij verrichting van hun ambtelijke werkzaamheden, V-N 1987/2310, pt. 52, FED 1987/341, r.o. 6 en 9.

58. Hof 26 maart 1987, nr. 235/85, Commissie/Nederland, V-N 1987/2310, pt. 52, FED 1987/341, r.o. 10. 
Artikel 13, BTW-richtlijn bepaalt:

“1. De Staat, de regio's, de gewesten, de provincies, de gemeenten en de andere publiekrechtelijke lichamen worden niet als belastingplichtigen aangemerkt voor de werkzaamheden of handelingen die zij als overheid verrichten, ook niet indien zij voor die werkzaamheden of handelingen rechten, heffingen, bijdragen of retributies innen.

Wanneer deze lichamen evenwel zodanige werkzaamheden of handelingen verrichten, moeten zij daarvoor als belastingplichtige worden aangemerkt, indien een behandeling als niet-belastingplichtige tot een verstoring van de mededinging van enige betekenis zou leiden.

De publiekrechtelijke lichamen worden in elk geval als belastingplichtig beschouwd voor de in bijlage I genoemde werkzaamheden, voor zover deze niet van onbeduidende omvang zijn.

2. De lidstaten kunnen werkzaamheden van publiekrechtelijke lichamen die uit hoofde van de artikelen 132, 135, 136, 371, 374 tot en met 377, artikel 378, lid 2, artikel 379, lid 2, en de artikelen 380 tot en met 390 zijn vrijgesteld, als werkzaamheden van de overheid beschouwen."

Op de volgende onderdelen in deze bepaling zal ik nader ingaan:

A. De Staat, de regio's, de gewesten, de provincies, de gemeenten en de andere publiekrechtelijke lichamen (paragraaf 7.4.4)

B. De werkzaamheden of handelingen die zij als overheid verrichten (paragraaf 7.4.5).

C. Verstoring van de mededinging van enige betekenis (paragraaf 7.4.6). ${ }^{59}$

D. De in bijlage I genoemde werkzaamheden voor zover deze niet van onbeduidende omvang zijn (paragraaf 7.4.7).

E. Werkzaamheden die zijn vrijgesteld kunnen worden beschouwd als werkzaamheden van de overheid (paragraaf 7.4.8).

\subsubsection{Publiekrechtelijke lichamen}

Bij het beschrijven van de belastingplicht van de overheidslichamen focust artikel 13 , lid 1, BTW-richtlijn zich op:

“De Staat, de regio's, de gewesten, de provincies, de gemeenten en de andere publiekrechtelijke lichamen (...)."

Denie vraagt zich af wat de richtlijn bedoelt met: andere publiekrechtelijke lichamen. Zijn dat enkel territoriale? Hij is van mening dat de richtlijn op de onderdelen van de tekst nogal rekkelijk is. ${ }^{60}$

59. De corresponderende bepaling in de Zesde richtlijn vermeldt 'concurrentievervalsing van enige betekenis' in plaats van 'verstoring van de mededinging van enige betekenis'. Volgens mij moet aan deze verandering in terminologie geen betekenis worden toegekend. Ik gebruik in paragraaf 7.4.6 de terminologie van de Zesde richtlijn, gezien het feit dat het Hof bij zijn uitleg is uitgegaan van de Zesde richtlijn.

60. A.H.R.M. Denie, De overheid in de omzetbelasting (diss. Leiden), Deventer: Kluwer 1987, blz. 97 en in het bijzonder noot 145 . 
In de inbreukprocedure tegen Nederland, de zaak over de notarissen en gerechtsdeurwaarders, is de uitleg van het bovengenoemde zinsdeel voor het eerst expliciet aan de orde. ${ }^{61}$ In deze procedure staat hun belastingplicht centraal bij het verrichten van werkzaamheden in het algemeen belang, die bij wet zijn opgedragen en geregeld. Het Hof overweegt, dat de uitleg van artikel 13, BTW-richtlijn dient te worden geplaatst in het algemene kader van het bij de BTW-richtlijn ingevoerde gemeenschappelijke stelsel van de BTW. Het kader dat het Hof in het vizier heeft, is de algemene werkingssfeer en het feit dat alle vrijstellingen uitdrukkelijk en nauwkeurig moeten zijn omschreven. Het is niet zo dat de werkzaamheden van een persoon niet leiden tot belastingplicht omdat zij bestaan in het verrichten van handelingen die gewoonlijk tot de taak van de overheid behoren. Vereist is dat deel wordt uitgemaakt van het staatsapparaat en dan ook geen sprake is van een zelfstandige economische activiteit.

Onder welke voorwaarden sprake is van een zelfstandige economisch activiteit is aan de orde geweest in het arrest over de belastingplicht van de Spaanse belastingontvangers. ${ }^{62}$ Deze procedure heeft betrekking op de uitleg van artikel 11, BTWrichtlijn (voorheen artikel 4, lid 4, Zesde richtlijn). Toch bespreek ik dit arrest in een paragraaf die betrekking heeft op artikel 13, BTW-richtlijn, omdat het van belang kan zijn in welke mate niet-publiekrechtelijke lichamen worden geabsorbeerd door een publiekrechtelijk lichaam. In deze procedure was onder meer de vraag aan de orde, of belastingontvangers, die worden benoemd door de lokale overheid waarvoor zij de belasting innen, in een verhouding van ondergeschiktheid staan, ten opzichte van de overheid die van hun diensten gebruik makt. De lokale overheid benoemt de ontvangers en zij zijn functioneel bij de vervulling van hun taak ondergeschikt aan de lokale overheid. De ontvangers hebben recht op een beloning in de vorm van een incassopremie, zijnde een percentage van de geïnde bedragen alsmede een deel van de boete wegens te late betaling.

Advocaat-generaal Tesauro is van mening dat bij de beoordeling van de graad van zelfstandigheid twee aspecten van belang zijn. ${ }^{63}$ Ten eerste moet worden beoordeeld aan de hand van de nationale regelgeving of de ontvangers niet zijn geïntegreerd in de

61. Hof 26 maart 1987, nr. 235/85, Commissie/Nederland, V-N 1987/2310, pt. 52, FED 1987/341, Jur. 1987, blz. 1471, r.o. $16 \mathrm{t} / \mathrm{m} 23$

62. Hof 25 juli 1991, nr. C-202/90, Ayuntamiento de Sevilla/Spaanse ontvangers, V-N 1991/2162, pt. 45, Jur. 1991, blz. 4247, V-N 1991/2162, pt. 45. Zie ook Hof 12 juni 2008, nr. C-462/05, V-N 2008/29.20. In deze procedure besliste het Hof dat Portugal ten onrechte het BTW-tarief van $5 \%$ toepaste op tolgelden voor de brug over de Taag. In deze procedure was ook aan de orde of het consortium dat de overgang exploiteerde onderdeel was van het staatsapparaat. Het Hof geeft aan dat wanneer een werkzaamheid bestaande in het verrichten van handelingen die tot de prerogatieven van het openbaar gezag behoren, aan een zelfstandige derde wordt toevertrouwd of door lichamen die geen deel uitmaken van de organisatie van het overheidsbestuur, wordt uitgeoefend in de vorm van een zelfstandige economische werkzaamheid, dat dan de in artikel 4, lid 5, eerste alinea, Zesde richtlijn geregelde uitsluiting niet van toepassing is.

63. A-G Tesauro, conclusie van 4 juni 1991, Ayuntamiento de Sevilla/Spaanse ontvangers, Jur., blz. 4257 en 4258 , pt. 6 . 
lokale overheid. Hierbij is van belang of zij over de organisatorische vrijheid beschikken ten aanzien van het voor hun werkzaamheden in te zetten personeel en materieel. Ten tweede is volgens de advocaat-generaal van belang de wijze waarop aan de beloningsstructuur vorm is gegeven. Vervolgens concludeert hij dat de ontvangers het economische risico dragen, gezien het gegeven dat de vergoeding evenredig is aan elke afzonderlijke prestatie, en de daarmee gepaarde onzekerheid duidelijk aanwezig is. Indien een belastingvordering namelijk niet is geïnd, dan is sprake van een inkomensderving.

Het Hof neemt de benadering van de advocaat-generaal niet geheel over. Het onderscheidt drie aspecten. Ten eerste de organisatorische verwevenheid, ten tweede de verdeling van het economisch risico en ten derde de verantwoordelijkheid (aansprakelijkheid) van de lokale overheid. ${ }^{64}$

Ten aanzien van het eerste facet, de organisatorische verwevenheid, overweegt het Hof (r.o. 12) dat niet van belang is dat de ontvangers functioneel afhankelijk zijn van het gemeentelijke gezag voor de wijze waarop hun juridische band met de gemeente in het licht van artikel 11, BTW-richtlijn moet worden gekwalificeerd. Wanneer organisatorische verwevenheid dan wel van belang is geeft het Hof niet aan. Kennelijk is de invloed van dit criterium op deze plaats niet zo groot.

Ten aanzien van de verdeling van de economische risico's kijkt het Hof naar de beloningsstructuur.

“(...) wanneer de ontvangers de economische risico's van hun werkzaamheden dragen, in zoverre de winst die zij daaruit behalen, niet alleen afhangt van het bedrag aan geïnde belastingen, maar ook van de uitgaven in verband met de organisatie van het voor hun werkzaamheden ingezette personeel en materieel." (r.o. 13)

Het derde aspect dat het Hof bekijkt is de verantwoordelijkheidsverdeling (rechtsoverwegingen 14 en 15). Bij de verantwoordelijkheidsverdeling is volgens het Hof niet van belang de vraag of de lokale overheid aansprakelijk kan worden gesteld wanneer de ontvangers als gemachtigde van de overheid handelen. Beslissend is de aansprakelijkheid die voortvloeit uit hoofde van de contractuele relatie die de ontvangers zijn aangegaan met de lokale overheid, evenals hun aansprakelijkheid voor schade aan derden wanneer zij niet als gemachtigde van de overheid handelen.

$\mathrm{Na}$ het beoordelen van de bovenstaande drie aspecten, besliste het Hof dat de belastingontvangers zelfstandig belastingplichtig zijn en dus niet worden geabsorbeerd door de lokale overheid. Uit het bovenstaande vloeit voort dat voornamelijk

64. In deze aspecten lijkt een parallel te ontdekken met de verhouding die bestaat tussen hoofdhuis en vaste inrichting. Vgl. paragraaf 8.4.1. 
van belang is de verdeling van de economische risico's en de eventuele aansprakelijkheid tussen de contractspartijen. ${ }^{65}$

De vijf inbreukprocedures over tolheffing tonen aan dat de rechtsvorm waarin een activiteit wordt verricht verstrekkende gevolgen kan hebben voor de BTW-heffing. Deze lidstaten berekenden geen BTW over de tolwegexploitatie (Frankrijk, Verenigd Koninkrijk, Ierland, Griekenland en Nederland). De Commissie meende echter dat de exploitatie van tolwegen een economische activiteit is en dat dan ook BTW dient te worden berekend. De lidstaten waren echter van mening dat deze activiteit is aan te merken als handelingen die worden verricht als overheid en dat dan ook op grond van artikel 13, BTW-richtlijn BTW-heffing niet aan de orde is. Het Hof stelde de lidstaten die de tolwegexploitatie hadden ondergebracht in een privaatrechtelijk lichaam in het ongelijk (Frankrijk, Verenigd Koninkrijk en Ierland). Dit gezien het feit dat niet een publiekrechtelijk lichaam de activiteit verricht. ${ }^{66}$ De lidstaten die deze activiteit hebben ondergebracht in een publiekrechtelijk lichaam zijn door het Hof echter wel in het gelijk gesteld (Griekenland en Nederland). ${ }^{67}$ In deze laatste procedures merkte het Hof deze activiteit aan als overheidshandelingen en dat dan ook terecht geen BTW was voldaan over de tolheffing. De Commissie voerde zonder resultaat aan, dat het geen verschil mag uitmaken of een publiek- dan wel privaatrechtelijk lichaam de tolgelden ontvangt. Het Hof overweegt dat de Commissie in de procedures warin de tolwegexploitatie plaatsvindt in een publiekrechtelijk lichaam, niet heeft aangetoond (en zelfs niet heeft proberen aan te tonen!) dat de publiekrechtelijke lichamen onder dezelfde voorwaarden handelen als een particuliere marktdeelnemer. De Commissie schoot dus tekort in de bewijsvoering.

\subsubsection{De werkzaamheden of handelingen die zij als overheid verrichten}

Artikel 13, BTW-richtlijn bepaalt dat de werkzaamheden als overheid moeten worden verricht. Wat precies onder de term 'als overheid' moet worden verstaan is mogelijk te ontdekken in de voorgeschiedenis van de BTW-richtlijn (dan wel Zesde richtlijn). Het eerste verslag van de Commissie aan de Raad over de werking

65. Dit lijkt een andere benadering dan was te vinden in de inmiddels ingetrokken aanschrijving van 25 april 1996, Toelichting Gemeenten, nr. D69/4141, paragraaf 8, lid 4. In deze aanschrijving was te vinden dat lichamen waarvan de aandelen middellijk dan wel onmiddellijk voor $100 \%$ in handen zijn van de gemeente, alsmede bij lichamen waarvan de bestuurders uitsluitend door de gemeente worden benoemd en ontslagen en waarvan het vermogen bij liquidatie ter beschikking van de gemeenten komt, worden gedeeltelijk in een identieke BTW-positie gebracht als publiekrechtelijke lichamen die handelen als overheid. Deze aanschrijving is ingetrokken gezien de invoering van het BTW-Compensatiefonds.

66. Hof 12 september 2000, in de volgende arresten: nr. C-276/97, Commissie/Frankrijk, Jur. 2000, blz. I-6251; nr. C-359/97, Commissie/Verenigd Koninkrijk, Jur. 2000, blz. I-6355 en nr. C-358/97, Commissie/Ierland, Jur. 2000, blz. I-6301.

67. Hof 12 september 2000 de arresten nr. C-260/98, Commissie/Griekenland en nr. C-408/97, Commissie/Nederland, BNB 2000/377 en V-N 2000/41.19. 
van het gemeenschappelijk BTW-stelsel constateert, dat het aan de lidstaten wordt overgelaten de werkzaamheden die 'als overheid' worden verricht te definiëren. ${ }^{68}$ Het opnemen van een communautaire definitie was op het moment dat de Zesde richtlijn werd vastgesteld niet mogelijk wegens de belangrijke verschillen op dit gebied tussen de lidstaten.

In de tekst van de Tweede richtlijn is te vinden dat het de lidstaten is toegestaan om publiekrechtelijke rechtssubjecten niet aan te merken als belastingplichtigen. Het uitgangspunt is dat zij niet-belastingplichtig zijn, met de keuze mogelijkheid voor de lidstaten in de vorm van een zogenoemde 'kan-bepaling' om tot belastingplicht over te gaan. ${ }^{69}$

In het Voorstel tot een Zesde richtlijn is gekozen voor een ander uitgangspunt. ${ }^{70}$ Het Voorstel tot de Zesde Richtlijn vermeldt namelijk: ${ }^{71}$

“De staat, de provincies, de gemeenten en de publiekrechtelijke lichamen worden in beginsel niet als belastingplichtige aangemerkt, voor de werkzaamheden die zij ter uitoefening van het openbaar gezag verrichten. Indien deze lichamen evenwel de in lid 1 bedoelde handelingen verrichten, [toegevoegd aan het eerder ingediende voorstel; AHB: welke, afgezien van de nationale wetgeving, in economisch opzicht door privaatrechtelijke personen zouden kunnen worden uitgevoerd, ${ }^{72}$ ] moeten zij voor deze handelingen als belastingplichtige worden aangemerkt. Onder deze bepaling vallen de werkzaamheden van de radio- en televisiediensten, alsmede de interventiebureaus in de landbouw voor wat hun handelingen betreft met betrekking tot landbouwproducten die worden verricht op grond van de verordeningen houdende gemeenschappelijke ordening van de markten dezer producten."73

68. Com (83) 426 def., 14 september 1983, blz. 30 en 31.

69. Tweede richtlijn in de twee laatste alinea's van Bijlage A, nr. 2 ad artikel 4 van de Tweede richtlijn: “De Staat, de provincies, de gemeenten en de andere publiekrechtelijke lichamen worden in beginsel niet als belastingplichtige aangemerkt voor de werkzaamheden die zij ter uitoefening van het openbaar gezag verrichten. Indien deze lichamen evenwel de werkzaamheden van een fabrikant, handelaar of diensterrichter uitoefenen, kunnen zij voor deze werkzaamheden als belastingplichtige worden aangemerkt." Artikel 20, Tweede richtlijn bepaalt dat de Bijlage een integrerend onderdeel vormt van de Tweede richtlijn. Tweede richtlijn, 76/228 van de raad van 11 april 1967, Pb 1967, blz. 1303.

70. Zie voor een uitgebreide beschouwing en analyse over de ontwikkeling van het begrip 'als overheid': J.J.P. Swinkels, De belastingplichtige in de BTW (diss Amsterdam UvA) 2000, blz. 266 e.v.

71. Voorstel voor een Zesde richtlijn, 23 juni 1973 bij de Raad ingediend. Bulletin van de Europese Gemeenschappen, Supplement 11/73, blz. 40.

72. Wijziging in het Voorstel voor een Zesde richtlijn, V-N 23 november 1974, blz. 1011.

73. In de toelichting op artikel 4 van het Voorstel voor een Zesde richtlijn wordt echter de term 'overheid' gebruikt. De toelichting vermeldt namelijk: "Voorts is bepaald dat rechtspersonen van publiekrechtelijke aard als belastingplichtige moeten worden beschouwd, voor zover zij economische bedrijvigheden uit oefenen die in feite los gezien kunnen worden van het begrip overheid, d.w.z bedrijfswerkzaamheden die zouden kunnen worden uitgeoefend door civielrechtelijke personen, zonder afbreuk te doen aan fundamentele bevoegdheden en de taken van de staten, provincies, gemeenten en andere publiekrechtelijke lichamen op het gebied van overheidsadministratie, rechtswezen, veiligheid of nationale defensie.

Uit deze definitie vloeit met name voort dat de exploitatie van snelverkeerswegen, binnenlandse vaarwegen en haveninstallaties als economische bedrijvigheid zijn te beschouwen, welke belast kunnen worden." 
In de definitieve tekst van de Zesde richtlijn is het zinsdeel 'de werkzaamheden die zij ter uitoefening van het openbaar gezag verrichten' vervangen door 'de werkzaamheden of handelingen die zij als overheid verrichten'. De term 'als overheid' lijkt een ruimere strekking te hebben dan 'openbaar gezag'. Advocaat-generaal Mischo concludeert dan ook dat de Raad een ruimere inhoud heeft gegeven dan het Voorstel van de Commissie door het begrip 'als overheid' te introduceren. ${ }^{74}$ De Raad heeft in de definitieve tekst van de Zesde richtlijn positie gekozen tussen de Tweede richtlijn en het Voorstel tot de Zesde richtlijn. Echter voor de beantwoording van de vraag hoe ruim het betreffende zinsdeel kan worden uitgelegd, moet het antwoord komen van het Hof.

Het Hof overweegt met betrekking tot artikel 13, BTW-richtlijn, dat de nietbelastingplichtigheid van de publiekrechtelijke lichamen afhankelijk wordt gesteld van de voorwaarde dat zij als overheid handelen. Het Hof heeft dan ook voor recht verklaard, dat artikel 13, BTW-richtlijn eerste alinea aldus moet worden uitgelegd:

“(...) dat werkzaamheden door publiekrechtelijke lichamen 'als overheid' verricht in de zin van deze bepaling, die zijn welke door hen worden verricht in het kader van het specifiek voor hen geldende juridische regime, met uitsluiting van de werkzaamheden die zij onder dezelfde juridische voorwaarden als particuliere economische subjecten verrichten. Het staat aan elke lidstaat de passende wetgevingstechniek te kiezen om de bij deze bepaling vastgestelde regel van niet-belastingplichtigheid in nationaal recht om te zetten. (cursief: AHB)" (r.o. 19) ${ }^{75}$

In deze beslissing sluit het Hof dus bepaalde werkzaamheden uit van de verrichtingen 'als overheid', namelijk indien particuliere (commerciële) ondernemingen deze werkzaamheden verrichten onder dezelfde juridische voorwaarden. Deze inperking is volgens mij te zien als een duidelijke verwijzing naar de fiscale neutraliteit als uitdrukking van het gelijkheidsbeginsel zoals dat in paragraaf 4.4.4.2 is beschreven.

Een nadere verduidelijking is te vinden in het Porto-arrest. ${ }^{76}$ Deze procedure focust op de vraag of de verhuur van parkeerruimte voor voertuigen door een publiekrechtelijk lichaam, een door dit lichaam als overheid verrichte werkzaamheid is in de zin van artikel 13 , eerste alinea, BTW-richtlijn.

“(...) dat de verhuur van parkeerruimte voor voertuigen door een publiekrechtelijk lichaam een door dit lichaam als overheid verrichte werkzaamheid in de zin van artikel 4, lid 5 , eerste alinea, van de Zesde richtlijn is, indien die werkzaamheid wordt verricht in het kader van een specifiek voor publiekrechtelijke lichamen geldend juridisch regiem. Dit is het geval wanneer het verrichten van die werkzaamheid gebruikmaking van overheidsprerogatieven omvat." (r.o. 24)

Bij het onderwerp parkeren gaat het, zo blijkt uit rechtsoverweging 22, om overheidsprerogatieven zoals het toestaan of het beperken van het parkeren op een

74. A-G Mischo, conclusie van 15 maart 1989, gevoegde zaken nrs. 231/87 en 129/88, Carpaneto Piacentino I, Jur. 1989, blz. 2351 e.v. Zie in het bijzonder pt. 43.

75. Hof 17 oktober 1989, gevoegde zaken nrs. 231/87 en 129/88, Carpaneto Piacentino I, FED 1990/313. 76. Hof 14 december 2000, nr. C-446/98, Câmara Municipal do Porto, V-N 2001/3.20. 
openbare weg of het beboeten van overschrijding van de toegestane parkeertijd. Indien overheidsbemoeiingen als deze zich voordoen, dan is daaruit op te maken dat deze werkzaamheid aan een publiekrechtelijk regiem is onderworpen. Het Porto-arrest geeft derhalve een nadere duiding aan de betekenis van het zinsdeel 'als overheid'.

Ter verdere opheldering en mede omdat het hier om een communautair begrip zou kunnen gaan (zie paragraaf 4.5) bezie ik of er naast de normen 'als overheid', 'specifiek juridisch regime' en 'overheidsprerogatieven' verdere aanwijzingen, buiten het terrein van de BTW-richtlijn zijn te vinden om de niet-belastingplicht van de overheidslichamen in te kaderen. Het Hof heeft immers ook bij de uitleg van artikel 45, lid 4, VwEU (voorheen artikel 39, lid 4 EG), over het begrip 'overheidsdienst' enkele beslissingen genomen. Artikel 45, leden 1 tot en met 3 VwEU regelt het vrije verkeer van werknemers tussen de lidstaten en streeft dan ook naar afschaffing van discriminatie naar nationaliteit. Artikel 45, lid 4 VwEU bepaalt dat de eerdere leden van het artikel niet van toepassing zijn op de betrekkingen in overheidsdienst. Het betreft dus een inperking van het discriminatieverbod. Voorzichtigheid is geboden bij het zoeken naar aanknopingspunten in de jurisprudentie van het Hof op het terrein van artikel 45, lid 4 VwEU. Dit gezien het feit dat de term 'als overheid' in artikel 13, BTW-richtlijn niet identiek is aan het begrip 'overheidsdienst' in artikel 45 , lid 4 VwEU en de functie en orde van de bepalingen verschillend zijn. Dat neemt niet weg dat het hier om een vergelijkbaar begrip gaat, algemeen gesproken, de functie ervan is de overheid van het 'normale handelsverkeer' uit te zonderen en, naar blijkt, de algemene rechtsbeginselen zich bij artikel 45, lid 4 VwEU laten gelden.

In de zaak Commissie/België ${ }^{77}$ van 17 december 1980 stelde België de Belgische nationaliteit verplicht voor betrekkingen bij gemeenten of openbare instellingen. Het ging om een scala van functies, waaronder die voor ongeschoolde werknemers. De Belgische regering beriep zich op artikel 45, lid 4 VwEU (toentertijd artikel 48, lid 4 EG-Verdrag). Het Hof overweegt:

“Door deze bepaling (bedoeld wordt artikel 45, lid 4 VwEU: toevoeging AHB) worden een aantal betrekkingen die, al dan niet rechtstreeks, deelneming aan de uitoefening van openbaar gezag inhouden en die werkzaamheden omvatten strekkende tot de bescherming van de algemene belangen van de staat of van andere openbare lichamen, aan de werkingssfeer van de eerste drie leden van artikel 48 onttrokken (huidig 45 VwEU: toegevoegd AHB). Dergelijke betrekkingen onderstellen immers bij de functionaris een bijzondere band van solidariteit ten opzichte van de staat en een wederkerigheid van rechten en plichten die de grondslag vormen van de nationaliteitsverhouding." (r.o. 10)

Vervolgens overweegt het Hof dat de eerste drie leden van het artikel zijn gebaseerd op het beginsel van vrije en gelijke behandeling. Het vierde lid onttrekt bepaalde sectoren aan de werking van dit beginsel. Het Hof overweegt vervolgens dat indien men de uitleg van het begrip 'overheidsdienst' zou uitbreiden tot betrekkingen die, hoewel afhangend van de staat of van andere publiekrechtelijke lichamen, generlei 
medewerking aan overheidswerkzaamheden in eigenlijke zin inhouden, dat dan een groot aantal betrekkingen aan de toepassing van de beginselen van het Werkingsverdrag zouden worden onttrokken. Het gevolg zou dan een ongelijke behandeling tussen de lidstaten kunnen zijn (r.o. 11). Het Hof laat vervolgens de kwalificatie van het begrip 'overheidsdienst' afhangen van de vraag:

“(...) of de betrokken functies al dan niet typerend zijn voor de specifieke taak van de overheid, voor zover deze is belast met de uitoefening van het openbaar gezag en verantwoordelijk is voor de bescherming van de algemene belangen van de staat." (r.o. 12)

De verwijzing naar 'de uitoefening van openbaar gezag', komt overeen met de tekst van het Voorstel voor een Zesde richtlijn. Het Hof geeft in deze procedure echter slechts algemene aanwijzingen over de reikwijdte van artikel 45 , lid 4 VwEU. ${ }^{78}$

Het 'openbaar gezag' speelt eveneens een rol in artikel 51 VwEU (voorheen artikel 45 EG), kort gezegd, een uitzondering op de vrijheid van vestiging, welke in de daarvoorliggende artikelen, $49 \mathrm{t} / \mathrm{m} 50 \mathrm{VwE}$ is geregeld (voorheen $43 \mathrm{t} / \mathrm{m} 44 \mathrm{EG}$ ). Op grond van die artikelen is het verboden om de vrijheid van vestiging van onderdanen van een lidstaat op het grondgebied van een andere lidstaat te beperken. Artikel 51 VwEU bepaalt onder meer dat dit verbod op de beperking van de vrijheid van vestiging niet van toepassing is op de werkzaamheden ter uitoefening van het openbaar gezag, zelfs niet indien deze slechts voor een bepaalde gelegenheid geschieden. De term 'openbaar gezag' vormde (in het aanvankelijke voorstel tot Zesde richtlijn, zie hiervoor) de voorloper van de huidige term 'als overheid' in artikel 13, eerste alinea BTW-richtlijn en het is mitsdien interessant te beoordelen of de term 'openbaar gezag' in artikel 51 VwEU een aanknopingspunt biedt voor de interpretatie van de BTW-richtlijn. Daarbij is het van belang dat het meerdere het mindere zal inhouden; de advocaat-generaal Mischo vermeldt dat de term 'als overheid' ruimer is dan de term 'openbaar gezag'. Men kan dan stellen dat de werkzaamheden die onder het bereik van artikel 51 VwEU vallen, zeker onder artikel 13, eerste alinea, BTW-richtlijn zijn te begrijpen. Echter, uit de inbreuk procedure tegen Spanje blijkt, dat ook de uitleg van artikel 51 VwEU in belangrijke mate wordt gestuurd door geheel andere uitgangspunten dan die van artikel 13, BTW-richtlijn. ${ }^{79}$

"Hoewel de lidstaten krachtens in het Verdrag voorziene uitzonderingen het vrije verkeer van kapitaal en de vrijheid van vestiging aan beperkingen kunnen onderwerpen in bepaalde omstandigheden die verband houden met de uitoefening van het openbaar gezag, de

78. In ieder geval blijkt uit deze procedure dat het enkele feit dat de betrokkene arbeid verricht in het kader van een publiekrechtelijke dienstbetrekking of bij een orgaan van de overheid irrelevant is. Uit het desbetreffende arrest blijkt wel dat voor functies van gemeentelijke tuinlieden, rangeerders bij de spoorwegen of van verplegend personeel geen nationaliteitseis mag worden gesteld.

79. Hof 13 mei 2003, C-463/00, Commissie/Spanje, Jur. 2003, blz. I-4581. In Spanje was de vervreemding van participaties in bepaalde overheidsbedrijven onderworpen aan een vergunningenstelsel. In de praktijk betekende dat goedkeuring vooraf door de overheid. Het Hof besliste dat dit in strijd is met artikel 63 VwEU (vrijheid kapitaal verkeer). Het arrest geeft echter tevens weer de uitleg van artikel 51 VwEU. 
openbare orde, de openbare veiligheid en de volksgezondheid, moeten deze uitzonderingen restrictief worden uitgelegd en mag de strekking ervan niet eenzijdig door de lidstaten worden bepaald. Bovendien moeten zij voldoen aan het evenredigheidsbeginsel, moeten zij in overeenstemming zijn met het rechtszekerheidsbeginsel en mogen zij niet om zuiver economische redenen worden opgelegd (zie arresten van 31 maart 1993, Kraus, C-19/92, Jurispr. blz. I-1663, en 30 november 1995, Gebhard, C-55/94, Jurispr. blz. I-4165)." (r.o. 34)

Bij de beantwoording van de vraag of de jurisprudentie op het terrein van de artikelen 45, lid 4 en 51 VwEU bruikbaar is voor de BTW, zijn de doelstellingen van de deze bepalingen van belang. Zoals is geconstateerd, is lid 4 van artikel 45 VwEU een inperking van het discriminatieverbod zoals dat is verankerd in de eerste drie leden van artikel $45 \mathrm{VwEU}$. In paragraaf 3.4.1.2 is verduidelijkt dat op grond van het Ruckdeschel-arrest het discriminatieverbod op één lijn geplaatst kan worden met het gelijkheidsbeginsel, en lid 4 is dan ook een inperking van het gelijkheidsbeginsel. Arnull komt tot de conclusie, dat het evenredigheidsbeginsel de jurisprudentie op het terrein van de artikelen 45 , lid 4 en 51 VwEU beheerst. ${ }^{80}$ Arnull vermeldt:

"By requiring strict compliance with the principles of proportionality, the Court has managed to prevent Member States from using Articles 48(4) and 55(1) (huidig 45(4) en 51(1) VwEU; toegevoegd AHB) simply as a device for evading the Treaty rules on the free movement of persons." 81

Zoals Arnull constateert voorkomt het evenredigheidsbeginsel dat lid 4 de uitgangspunten van de eerste drie leden van artikel 45 VwEU gaat overwoekeren. Artikel 13, BTW-richtlijn werkt anders. Dit artikel perkt de omvang van de belastingplicht in. De reikwijdte van artikel 13, BTW-richtlijn wordt afgeremd door de fiscale neutraliteit als uitdrukking voor de BTW van het gelijkheidsbeginsel (in de zin van voorkoming van concurrentievervalsing). De fiscale neutraliteit voorkomt dat artikel 13, BTWrichtlijn het uitgangspunt van een ruime belastingplicht in gevaar brengt. Kortom, de correctie op artikel 45 VwEU en de vrijheid van vestiging (artikel 49 t/m 50 VwEU) wordt beheerst door het evenredigheidsbeginsel. Daarentegen beheerst het gelijkheidsbeginsel de correctiebepaling van artikel 13, BTW-richtlijn en in de jurisprudentie van het Hof op dit artikel zijn geen aanwijzingen te ontdekken waaruit blijkt dat het evenredigheidsbeginsel bij de uitleg ervan en rol speelt. Deze verschillen in uitgangspunten hebben tot gevolg dat de jurisprudentie op het gebied van artikel 45 VwEU beperkt bruikbaar is om de kaders van artikel 13, BTW-richtlijn te bepalen. ${ }^{82}$

Ten slotte dient nog de vraag beantwoording wanneer een overheidslichaam onder dezelfde juridische voorwaarden presteert als een particuliere (commerciële) onderneming. De lidstaten kunnen zich ertoe beperken in hun wetgeving de in de

80. A. Arnull, The general principle of EEC Law and the individual, New York: St. Martin's Press 1990, blz. $100 \mathrm{t} / \mathrm{m}$ 104. Het Hof heeft een aantal beslissingen genomen over de betekenis van artikel 45, lid 4 en artikel 51 VwEU. Het gaat te ver om deze jurisprudentie in dit kader te behandelen, Zie nader over deze problematiek J.J.P. Swinkels 2000, blz. 274 t/m 279.

81. A. Arnull 1990, blz. 100

82. Afgezien van de andere bezwaren die opgeworpen kunnen worden tegen een vergelijkbare uitleg van deze bepalingen. Paragraaf 4.3 gaat nader in op de betekenis en rol in het Europees recht van communautaire rechtsbegrippen. 
BTW-richtlijn gebruikte formulering op te nemen, dan wel een lijst vaststellen van de werkzaamheden waarvoor de publiekrechtelijke rechtssubjecten niet als belastingplichtige moeten worden aangemerkt. De invulling van het begrip in het kader van het specifiek voor hen geldend juridisch regime' wordt aan de nationale rechter overgelaten. ${ }^{83}$

\subsubsection{Concurrentievervalsing van enige betekenis}

Advocaat-generaal Mischo concludeerde bij het Carpaneto Piacentino II-arrest dat ingeval concurrentievervalsing van enige betekenis aan de orde is, de rechter die daarmee wordt geconfronteerd tot belastingplicht moet beslissen. ${ }^{84}$ Opvallend is dat advocaat-generaal Mischo kennelijk is teruggekomen op zijn eerdere conclusie bij het arrest Carpaneto Piacentino I. In deze eerdere procedure concludeerde hij dat de terminologie 'concurrentievervalsing van enige betekenis' niet voldoende nauwkeurig is om door een publiekrechtelijk lichaam tegenover een nationale wettelijke bepaling in te roepen. ${ }^{85}$

Het Hof overweegt in het arrest Carpaneto Piacentino ${ }^{86}$ met betrekking tot de voorwaarde dat geen concurrentievervalsing van enige betekenis mag ontstaan:

“(...) Deze alinea beoogt dus de belastingneutraliteit, een van de belangrijkste doelstellingen van de Zesde richtlijn, te verzekeren in gevallen waarin de publiekrechtelijke lichamen in het kader van het specifiek voor hen geldende juridische regime werkzaamheden verrichten die ook in concurrentie met die lichamen door particulieren kunnen worden verricht onder een privaatrechtelijk regiem of op basis van overheidsconcessies." (r.o. 22)

Vervolgens beslist het Hof dat de lidstaten verplicht zijn op grond van artikel 288, derde alinea VwEU (voorheen artikel 249, derde alinea EG), publiekrechtelijke lichamen als belastingplichtig aan te merken, indien een behandeling als niet-belastingplichtige tot concurrentievervalsing van enige betekenis kan leiden (r.o. 23). ${ }^{87}$ Zij zijn

83. Hof 17 oktober 1989, gevoegde zaken nrs. 231/87 en 129/88, Carpaneto Piacentino I, FED 1990/312, en dan in het bijzonder r.o. 16. Dit arrest heeft betrekking op de belastingplicht van een publiekrechtelijk lichaam ingeval grafplaatsenconcessies en overige verkopen worden verricht.

84. A-G Mischo, conclusie van 28 maart 1990, nr. C-4/89, Carpaneto Piacentino II, Jur. 1990, blz. 1878, pt. 16. Dit arrest heeft betrekking op de belastingplicht van een publiekrechtelijk lichaam in geval van het verlenen van begraafplaatsconcessies en het verrichten van overige verkopen. Overigens was een dergelijke concurrentievervalsing in deze procedure niet aan de orde.

85. A-G Mischo, conclusie van 15 maart 1989, bij de gevoegde zaken nrs. 231/87 en 129/88, Carpanetp Piacentino I, Jur. 1989, blz. 3255, pt. 23 en 24.

86. Hof 17 oktober 1989, gevoegde zaken nrs. 231/87 en 129/88 Carpaneto Piacentino I, FED 1990/312, r.o. 22.

87. Een particulier die concurreert met een publiekrechtelijk lichaam en stelt dat dit lichaam voor de activiteiten die het als overheid uitoefent niet of te laag wordt aangeslagen in de BTW, kan zich in het kader van een geding met de nationale belastingadministratie beroepen op artikel 13, BTW-richtlijn. Hof 8 juni 2006, nr. C-430/04, Halle, V-N 2006/46.14, NTFR 2006/938. 
echter niet verplicht dit criterium letterlijk in hun nationale recht over te nemen of kwantitatieve grenzen voor niet-belastingplichtigheid vast te stellen. ${ }^{88}$

Of sprake is van concurrentievervalsing van enige betekenis speelde ook in de inbreukprocedures over de vraag of BTW moet worden berekend over tolheffing. Zoals in paragraaf 7.4.4 is beschreven, besliste het Hof dat een aantal lidstaten BTW moest berekenen over tolheffing en dat een aantal lidstaten (waaronder Nederland) daar niet toe verplicht zijn. Dit gezien het feit dat in deze laatste lidstaten de tolheffing plaatsvindt door een publiekrechtelijk lichaam. Bij een drietal lidstaten voerde de Commissie aan, dat ook al wordt de betreffende activiteit verricht door een publiekrechtelijk lichaam, deze niet onder het bereik van artikel 13, BTWrichtlijn valt gezien het feit dat sprake is van concurrentievervalsing. Het Hof stelde echter de Commissie in het ongelijk omdat deze stelling niet werd onderbouwd. ${ }^{89}$

Het Hof heeft een verdere verduidelijking gegeven in het arrest Isle of Wight. ${ }^{90}$ Centraal in deze procedure staat de vraag of enkele plaatselijke overheden in het Verenigd Koninkrijk BTW verschuldigd zijn inzake de exploitatie van afgesloten parkeerterreinen voor auto's. De nationale rechter wil onder andere weten of bij de beoordeling of sprake is van concurrentievervalsing, gekeken moet worden naar de plaatselijke markt, of naar het grondgebied van een lidstaat. Het Hof besliste dat de concurrentievervalsing van enige betekenis moet worden beoordeeld met betrekking tot die werkzaamheden als zodanig, zonder dat die beoordeling betrekking heeft op een specifieke plaatselijke markt.

Het Hof baseert zijn beslissing onder meer op het beginsel van de fiscale neutraliteit en onderbouwt dat als volgt:

"De stelling van de betrokken plaatselijke overheden komt er echter op neer dat sommige plaatselijke overheden wel en andere niet als btw-plichtigen moeten worden behandeld naargelang op de plaatselijke markten waarop zij werkzaam zijn, al dan niet concurrentievervalsing ontstaat, ook al is de betrokken dienstverrichting, namelijk de exploitatie van

88. Zie in dit kader ook het eerder genoemde Porto-arrest en dan voornamelijk r.o. 36 t/m 39. In het Porto-arrest is ook beslist, dat de lidstaten mogen bepalen in hun nationale wet wat moet worden verstaan onder concurrentievervalsing.

89. Hof 12 september 2000, nr. C-260/98, Commissie/Griekenland, Jur. 2000, blz. I-6537, zie vooral r.o. 37 en 38, Hof 12 september 2000, nr. C-408/97, Commissie/Nederland, V-N 2000/41.19. Zie in het bijzonder r.o. 37 en 38, meer recent het arrest van 8 maart 2001, nr. C-276/98, Commissie/Frankrijk, V-N 2001/25.15.

90. Hof 16 september 2008, nr. C-2888/07, Isle of Wight Council e.a., V-N 2008/47.21. Zie verder ook Hof 13 december 2007, nr. C-408/06, F. Götz, V-N 2008/3.21. In Duitsland organiseerden regionale publiekrechtelijke lichamen centraal de aan- en verkoop van melkquota. De Landesanstalt für Landwirtschaft honoreerde een bod van Götz. Op de nota van de Landesanstalt was echter geen BTW vermeld. Volgens het Hof kan de Landesanstalt geen concurrentievervalsing van enige betekenis ondervinden. Dit gezien het feit dat de Landesanstalt niet wordt geconfronteerd met particuliere marktdeelnemers die handelingen verrichten die concurreren met de door de overheid verrichte handelingen. 
parkeerterreinen, in wezen dezelfde. Deze stelling impliceert dus niet alleen dat particuliere marktdeelnemers en publiekrechtelijke lichamen verschillend worden behandeld wanneer het behandelen van deze laatste als niet-belastingplichtigen slechts tot geringe concurrentievervalsing leidt, maar ook dat een verschil in behandeling binnen de groep van publiekrechtelijke lichamen wordt ingevoerd." (r.o. 45)

“Daartegenover staat dat, wanneer deze concurrentievervalsing wordt geanalyseerd met betrekking tot de werkzaamheid als zodanig, ongeacht de concurrentiesituatie op een bepaalde plaatselijke markt, de eerbiediging van het beginsel van fiscale neutraliteit is verzekerd, aangezien dan alle publiekrechtelijke lichamen als btw-plichtigen of als nietbtw-plichtigen worden behandeld. Aan dat beginsel wordt dan alleen afbreuk gedaan in de verhouding tussen de publiekrechtelijke lichamen en de particuliere marktdeelnemers en alleen voor zover het slechts gaat om een geringe concurrentievervalsing." (r.o. 46)

Het Hof analyseert welk criterium leidt tot de minste verstoring van het fiscale neutraliteitsbeginsel. Niet alleen het beginsel van de fiscale neutraliteit draagt de beslissing, maar ook het rechtszekerheidsbeginsel.

"De stelling dat de concurrentievervalsing in de zin van artikel 4, lid 5, tweede alinea, van de Zesde richtlijn moet worden beoordeeld met betrekking tot elke plaatselijke markt waarop de plaatselijke overheden parkeerplaatsen op parkeerterreinen te huur aanbieden, vooronderstelt aldus dat de concurrentiesituatie op een groot aantal markten, waarvan de afbakening bijzonder moeilijk kan zijn omdat deze markten niet noodzakelijk samenvallen met het gebied waarvoor de plaatselijke overheden bevoegd zijn, voortdurend wordt herbeoordeeld op basis van vaak ingewikkelde economische analyses. Bovendien kunnen er verschillende plaatselijke markten bestaan op het grondgebied van eenzelfde plaatselijke overheid." (r.o. 49)

$(\ldots)$

"Aldus zullen de plaatselijke overheden noch de particuliere marktdeelnemers met de zekerheid die voor het voeren van hun bedrijf is vereist, kunnen voorzien of op een bepaalde markt de exploitatie van parkeerterreinen door de platselijke overheden aan btw zal worden onderworpen." (r.o. 51)

In deze rechtsoverwegingen zien wij dat wat in paragraaf 3.4.3.1 is aangeduid als de gewenste 'berekenbaarheid' van het recht. Belanghebbenden moeten kunnen voorzien welke financiële gevolgen de BTW-richtlijn voor hen heeft. En daarvoor is vereist dat zij in staat zijn de omvang van hun verplichtingen nauwkeurig te kennen.

Volgens het Hof dient niet enkel rekening te worden gehouden met de daadwerkelijke concurrentie, maar ook met potentiële concurrentie op de relevante markt, voor zover een en ander reëel is en niet zuiver hypothetisch. ${ }^{91}$ Bovendien moet de uitdrukking 'van enige betekenis' zo worden begrepen dat de daadwerkelijke of potentiële concurrentievervalsing van meer dan onbeduidende omvang dient te zijn.

91. Het Hof voegt daar in het Salix-arrest aan toe dat ook van belang is om rekening te houden met concurrentievervalsing die in het nadeel is van een publiekrechtelijk lichaam. Hof 4 juni 2009, nr. C-102/08, Salix, V-N 2009/28.13, NTFR 2009/1384, r.o. 65 t/m 76. 
Diverse schrijvers besteden aandacht aan de uitleg van de term concurrentievervalsing. ${ }^{92}$ Zo komt de vraag op of nationaal dan wel internationaal sprake dient te zijn van een verstoring van de mededingingsverhoudingen. Stevens trekt uit de tolgeldarresten de conclusie dat bij de vraag of de concurrentieverhoudingen worden verstoord, uitsluitend de concurrentieverhoudingen op nationaal niveau van belang zijn. ${ }^{93}$ Ook al is deze conclusie mogelijk uit de tolgeld-arresten te trekken, lijkt het mij onwaarschijnlijk dat het Hof een dergelijke verstoring zal tolereren. Zo als in hoofdstuk 1 naar voren is gebracht, dient de BTW-richtlijn niet geïsoleerd binnen het Unierecht te worden uitgelegd, maar dient de BTW-richtlijn te worden uitgelegd in het kader van het streven naar één interne markt op Europees niveau. Een grensoverschrijdende vervalsing van de concurrentieverhoudingen past daar niet in. Het eerder behandelde Isle of Wight-arrest lijkt een iets andere benadering te ondersteunen. Niet zo zeer een onderscheid nationaal of internationaal is van belang bij de toetsing aan de al dan niet aanwezige concurrentievervalsing, maar een beoordeling met betrekking tot de werkzaamheden als zodanig is van belang. Bepalend is of zich concurrentie voordoet met betrekking tot de activiteit, zonder dat die beoordeling betrekking heeft op een specifieke plaatselijke markt.

De vraag komt op hoe het bovenstaande zich verhoudt tot de in paragraaf 7.4.5 geconstateerde inperking van de terminologie 'als overheid'. In de genoemde paragraaf is geconstateerd, dat een publiekrechtelijk lichaam niet als overheid handelt indien zij haar werkzaamheden verricht onder dezelfde juridische voorwaarden als particuliere economische subjecten. Deze invulling van de terminologie 'als overheid' lijkt concurrentievervalsing uit te sluiten. De toevoeging 'verstoring van de mededinging van enige betekenis' zoals dat is te vinden in artikel 13, BTWrichtlijn is kennelijk dan ook door het Hof verwerkt in de uitleg van de terminologie 'als overheid'. In ieder geval kan volgens mij zowel de Belastingdienst als een overheidslichaam zich beroepen op concurrentievervalsing van enige betekenis. Dit gezien de uitleg die het Hof geeft aan de invulling 'als overheid'. ${ }^{94}$

92. Denie meent dat de norm van het concurrentiemotief in artikel 13, BTW-richtlijn een weinig gezaghebbende is gezien het gebrek aan scherpte. De onvastheid van de norm wordt door de richtlijn zelf erkend door te bepalen dat in elk geval voor de in bijlage I genoemde werkzaamheden sprake is van belastingplicht. Vervolgens wordt ook deze aanwijzing weer onderuit gehaald, want zij geldt slechts voor zover de werkzaamheden niet van onbeduidende omvang zijn. A.H.R.M. Denie 1987, blz. 98.

93. S.A. Stevens 2003, blz. 410. Zie verder J.J.P. Swinkels 2000, blz. 283. Van Zadelhoff meent dat bij de beoordeling of niet belastingplicht van een publiekrechtelijk lichaam tot concurrentievervalsing leidt, rekening zal moeten worden gehouden met alle (potentiële) aanbieders op die nationale markt. Daarbij zullen ook (potentiële) buitenlandse aanbieders in aanmerking moeten worden genomen. Het blijft echter volgens hem een beoordeling ten aanzien van de binnenlandse markt. B.G. van Zadelhoff, Belastingplichtige in de BTW, Deventer: Kluwer 2008, blz. 44 en 45.

94. Zie J.L.M.J. Vervloed, Optreden als overheid, BTW-Brief 1990, nr. 5, blz. 1. Hij meent dat een inspecteur een overheidslichaam kan tegenwerpen dat een overheidshandeling tot concurrentievervalsing leidt. Ten eerste constateert hij dat nergens in de Nederlandse wetgeving de prestaties 'als overheid' worden gedefinieerd. Een overheidslichaam kan zich dan ook niet verweren met een beroep op de nationale wetgeving. Ten tweede heeft de HR aangegeven, dat aan de term 'belastingplichtige' $\rightarrow$ 


\subsubsection{Werkzaamheden van niet onbeduidende omvang}

Het Hof heeft in het Carpaneto Piacentino I-arrest beslist dat de lidstaten niet verplicht zijn het criterium 'niet van onbeduidende omvang' in hun belastingwetgeving op te nemen als voorwaarde voor belastingplichtigheid voor de in de lijst van bijlage I genoemd werkzaamheden. ${ }^{95}$ Dat neemt niet weg dat deze bepaling voldoende nauwkeurig is omschreven in de BTW-richtlijn. Met als gevolg dat een belanghebbende een beroep op deze bepaling kan doen. Het zinsdeel 'niet van onbeduidende omvang' kan als het activiteiten betreft van een marginale omvang, wel tot gevolg hebben dat een direct beroep op toepassing van Bijlage I van de BTWrichtlijn niet opgaat.

Overigens ben ik het met Swinkels en Stevens eens dat Bijlage I een beperkte functie heeft. Belastingplicht zal namelijk bijna altijd al bestaan op grond van de eerste en tweede alinea van artikel 13, BTW-richtlijn. ${ }^{96}$

\subsubsection{Vrijgestelde werkzaamheden als werkzaamheden van de overheid}

Artikel 13, lid 2, BTW-richtlijn bepaalt dat de lidstaten werkzaamheden van publiekrechtelijke lichamen die zijn vrijgesteld op grond van de artikelen 132, 135, 136, 371, 374 tot en met 377, artikel 378, lid 2, artikel 379, lid 2, en de artikelen 380 tot en met 390 (voorheen artikel 13 en 28, Zesde richtlijn) kunnen beschouwen als werkzaamheden van de overheid. Het gevolg is dat dan geen sprake is van belastingplicht en dat een eventuele interne levering en dienst in de zin van artikel 18, sub a, b en c, BTW-richtlijn (voorheen artikel 5, lid 7, Zesde richtlijn) en artikel 27, BTW-richtlijn (voorheen artikel 6, lid 3, Zesde richtlijn) achterwege blijven. Invoering van deze

$\rightarrow$ in de BTW-richtlijn dezelfde betekenis moet worden toegekend als aan het begrip 'ondernemer' in de Wet OB. Dat betekent dus dat de jurisprudentie van het Hof met betrekking tot publiekrechtelijke lichamen het uitgangspunt is. In andere zin E.R. van der Wal \& M.S. Hartendorf, En spelletje monopoly: over concurrentievervalsing bij gelegenheid geven tot parkeren door gemeenten, BTW-Brief nr. 6/7 2004, blz. 12 e.v. Zij zijn van mening dat als een gemeente handelt 'als overheid', vervolgens afzonderlijk dient te worden getoetst of sprake is van concurrentievervalsing van enige betekenis waardoor de betreffende gemeente toch als ondernemer moet worden aangemerkt.

95. Hof 17 oktober 1989, gevoegde zaken nrs. 231/87 en 129/88, Carpaneto Piacentino I, Fed 1990/312, r.o. 28. Op zich is dat bijzonder gezien het uitgangspunt dat richtlijnen behoren te worden omgezet in nationale regelgeving. Zie verder over de uitleg van Bijlage I, Hof 3 april 2008, nr. C-442/05, Zweckverband, V-N 2008/20.17. Het Hof heeft in deze procedure beslist dat de aanleg van een individuele aansluiting die bestaat uit het leggen van een leiding waardoor de waterinstallatie van een gebouw wordt aangesloten op de vaste waterdistributienetten, onder het begrip 'levering van water' in de zin van deze bijlage valt, zodat een publiekrechtelijk lichaam dat als overheid handelt, voor deze handeling belastingplichtig is.

96. J.J.P. Swinkels 2000, blz. 287 en S.A. Stevens 2003, blz. 414. Zie ook D.B. Bijl, M.E. van Hilten \& D.G. van Vliet, Europese BTW en Nederlandse omzetbelasting, Deventer: Kluwer 2001, blz. 56. Zij wijzen erop dat de aanwijzingen dateren van 1969 en dan ook grotendeels overbodig zijn geworden door de jurisprudentie van het Hof. 
mogelijkheid kan ook de toepassing van regels inzake de plaats van dienst beïnvloeden (hoofdstuk 8). ${ }^{97}$

Het Hof benadrukt in het Salix-arrest ${ }^{98}$ dat de lidstaten de mogelijkheid hebben om werkzaamheden van publiekrechtelijke lichamen die zijn vrijgesteld te beschouwen als werkzaamheden van de overheid. Omzetting van artikel 13, lid 2, BTW-richtlijn in nationaal recht is dus niet verplicht. Als een lidstaat gebruik wil maken van de mogelijkheden van deze bepaling dan moet daar dus voor worden gekozen en dient implementatie in de nationale wet plaats te vinden. Daarbij mogen de lidstaten de wetgevingstechniek kiezen die hun het meest geschikt lijkt. Zij kunnen zich beperken tot het overnemen van de bewoordingen van de BTW-richtlijn, dan wel een lijst vaststellen van vrijgestelde werkzaamheden van publiekrechtelijke lichamen die als werkzaamheden van de overheid worden beschouwd. Zonder een dergelijke implementatie kan een lidstaat zich niet beroepen op deze bepaling ten nadele van een belanghebbende.

De relatie tussen artikel 13, lid 2, BTW-richtlijn en de eerder genoemde artikelen die de vrijstellingen regelen is aan de orde geweest in de inbreukprocedure tegen de Bondsrepubliek Duitsland. ${ }^{99}$ In deze procedure besliste het Hof dat de Bondsrepubliek Duitsland ten onrechte de diensten die vervoersondernemingen ten behoeve van de Deutsche Bundespost verrichtten, vrijstelde van de heffing van BTW op grond van artikel 132, lid 1, sub a, BTW-richtlijn (voorheen artikel 13A, lid 1, letter a, Zesde richtlijn). In het arrest beslist het Hof tevens dat de vrijstelling haar volle betekenis behoudt indien een lidstaat de postwerkzaamheden opdraagt aan een niet-publiekrechtelijk lichaam. Op deze wijze vermijdt de richtlijn, dat de BTW-heffing de organisatie van het postwezen beïnvloedt. De postwerkzaamheden blijven vrijgesteld, ook indien zij door een concessiehouder worden verricht. Het Hof heeft bij deze uitleg de fiscale neutraliteit als uitdrukking van het gelijkheidsbeginsel op het oog. Dit blijkt uit de vermelding, dat moet worden voorkomen dat bij de uitleg van de artikelen 13 en 132, BTW-richtlijn beïnvloeding plaatsvindt van de wijze waarop een bepaalde activiteit wordt georganiseerd. Uit het arrest blijkt dat het volgens het Hof kennelijk zo werkt, dat indien een bepaalde activiteit niet voldoet aan de voorwaarden van artikel 13, BTW-richtlijn, dit niet in de weg hoeft te staan aan de eventuele toepasbaarheid van de vrijstellingen. De genoemde vrijstellingsbepalingen kunnen dus als een vangnet werken, indien door de voorwaarden in artikel 13, BTWrichtlijn bepaalde activiteiten niet van de belastingplicht worden uitgezonderd. Bijvoorbeeld omdat zij niet worden verricht door een publiekrechtelijk lichaam, maar door bijvoorbeeld een privaatrechtelijk lichaam dat gedelegeerde overheidstaken vervult.

97. Afgezien van deze regelingen zijn ook van belang de toepasbaarheid van eventuele herzieningsbepalingen en de mogelijkheid om een fiscale eenheid te vormen.

98. Hof 4 juni 2009, nr. C-102/08, Salix, V-N 2009/28.13, NTFR 2009/1384, r.o. 51 t/m 58.

99. Hof 11 juli 1985, nr. 107/84, Commissie/Bondsrepubliek Duitsland, Jur. 1985, blz. 2663. 
De verhouding tussen artikel 13, BTW-richtlijn en de vrijstellingsbepalingen is tevens expliciet aan de orde geweest in het Welden-arrest van het Hof. ${ }^{100}$ In de die procedure verhuurde een gemeente een gebouw aan een brouwerij die daarin een horecabedrijf exploiteerde. Een dergelijke activiteit zou op grond van artikel 135, lid 1, sub 1, BTW-richtlijn (voorheen artikel 13B, letter b, Zesde richtlijn) vrijgesteld kunnen zijn met de mogelijkheid om op grond van artikel 137, lid 1, sub d, BTWrichtlijn (voorheen artikel 13C, sub a, Zesde richtlijn) te opteren voor belastingheffing. De Duitse rechter stelde onder meer de prejudiciële vraag of een dergelijke activiteit op grond van artikel 13, lid 2, BTW-richtlijn is aan te merken als werkzaamheden verricht 'als overheid', hoewel particuliere marktdeelnemers die werkzaamheden onder dezelfde juridische voorwaarden verrichten.

Het Hof besliste dat de lidstaten bevoegd zijn de in lid 2 van artikel 13 genoemde vrijgestelde werkzaamheden van belastingplicht uit te sluiten. Zelfs indien zij op dezelfde wijze worden verricht als door een particuliere marktdeelnemer. Het Hof voegt daar wel ogenblikkelijk aan toe dat als eenmaal een dergelijke activiteit wordt geacht te zijn verricht als overheid, de nationale rechter in voorkomend geval dient te beoordelen of geen sprake is van concurrentievervalsing van enige betekenis in de zin van de tweede alinea van artikel 13, lid 1, BTW-richtlijn. Kortom, de activiteiten van overheidslichamen die vallen onder het bereik van de genoemde vrijstellingen kunnen worden getransformeerd naar niet-belastingplichtige overheidsactiviteiten. Is er echter sprake van concurrentievervalsing, dan vervalt de niet-belastingplichtige status weer. ${ }^{101}$ Op deze wijze blijft dan ook de werking van de fiscale neutraliteit gehandhaafd. Met Swinkels ben ik van mening - gezien de toetsing aan concurrentievervalsing - dat lid 2 van artikel 13, BTW-richtlijn enkel van toepassing is op de echte overheidsactiviteiten van de genoemde vrijstellingsbepalingen. ${ }^{102}$ Deze bepaling werkt slecht één richting op. Daar bedoel ik mee dat de lidstaten onder bepaalde voorwaarden de bevoegdheid hebben om een belastingplichtige die vrijgestelde prestaties verricht, aan te merken als een niet-ondernemer in de zin van artikel 13, BTW-richtlijn. De lidstaten hebben echter niet de mogelijkheid om een niet-ondernemer in de zin van artikel 13, BTW-richtlijn, aan te merken als een belastingplichtige die vrijgestelde prestaties verricht.

\subsubsection{Publiekrechtelijke lichamen en de fiscale neutraliteit}

Bij de beoordeling van de belastingplicht bij publiekrechtelijke lichamen speelt de fiscale neutraliteit als uitdrukking voor de BTW van het gelijkheidsbeginsel een prominente rol. Publiekrechtelijke lichamen worden vergeleken met privaatrechtelijke economische subjecten. Het Hof tolereert geen ongelijke behandeling onder

100. Hof 6 februari 1997, nr. C-247/95, Marktgemeinde Welden, V-N 1997/1659, pt. 16.

101. Dit uitgangspunt is door het Hof nog eens herhaald in r.o. 43 van het Porto-arrest. Het Hof overweegt namelijk, dat willen de werkzaamheden die vallen onder het bereik van de in artikel 13 , BTW-richtlijn genoemde vrijstellingen worden gelijkgesteld met niet-belastingplichtige overheidsactiviteiten, voldaan moet zijn aan de eis dat geen concurrentievervalsing aan de orde is.

102. J.J.P. Swinkels 2000, blz. 291. 
gelijke omstandigheden. Vergelijking vindt plaats op het niveau van wat het Hof ${ }^{103}$ noemt 'economische subjecten'. ${ }^{104}$

In paragraaf 3.4.1.2 is aan de orde geweest dat een schending van het de fiscale neutraliteit als uitdrukking van het gelijkheidsbeginsel onder omstandigheden kan zijn te rechtvaardigen. Een dergelijke rechtvaardiging wordt begrensd door het evenredigheidsbeginsel. Onder de uitleg en werking van artikel 13, BTW-richtlijn ben ik geen relativering of 'achterstelling' van de fiscale neutraliteit door een ander beginsel tegengekomen.

Artikel 13, BTW-richtlijn beperkt de ruime werking van de belastingplicht voor publiekrechtelijke lichamen. De fiscale neutraliteit stelt grenzen aan die beperking. Het voorkomt een te grote concurrentieverstoring door de publieke sector ten opzichte van de private.

Op drie verschillende plaatsen laat de fiscale neutraliteit zich gelden bij de begrenzing van artikel 13, BTW-richtlijn:

1. Door te bepalen dat sprake is van belastingplicht indien de in Bijlage I genoemde werkzaamheden worden verricht en voor zover deze niet van onbeduidende omvang zijn (paragraaf 7.4.7).

2. Indien sprake is van concurrentievervalsing van enige betekenis in de zin van de tweede alinea van artikel 13, lid 1, BTW-richtlijn (paragraaf 7.4.6).

3. Door de wijze waarop het Hof het begrip 'als overheid' interpreteert. Deze interpretatie sluit concurrentievervalsing uit (paragraaf 7.4.5).

De hierboven genoemde categorieën 1 en 2 zijn te zien als een vorm van codificatie van de fiscale neutraliteit in de BTW-richtlijn. De lidstaten en de Commissie waren bij het opstellen van de BTW-richtlijn beducht voor concurrentievervalsing en op deze wijze probeerden zij dat te voorkomen.

Categorie 3 is volledig gebaseerd op interpretatie door het Hof van het begrip 'als overheid' in artikel 13, BTW-richtlijn. Bij de bepaling van de werkzaamheden die worden verricht als overheid heeft het Hof bij de interpretatie gebruik gemaakt van de fiscale neutraliteit als uitdrukking van het gelijkheidsbeginsel. Belastingplicht is aan de orde bij werkzaamheden die publiekrechtelijke lichamen verrichten onder dezelfde juridische voorwaarden als particuliere economische subjecten.

103. Opvallend is dat het Hof in de jurisprudentie op het terrein van de holdingmaatschappijen terughoudend is in het toepassen van de fiscale neutraliteit bij de interpretatie van artikel 9, BTWrichtlijn. Zie bijvoorbeeld Hof 20 juni 1996, nr. C-155/94, Wellcome Trust Ltd, V-N 1997/1034, pt. 17, FED 1996/577 en dan in het bijzonder r.o. 38. Paragraaf 7.3.4 besteedt aan dit aspect aandacht. 104. Nationaal gebruiken wij hiervoor de term 'entiteiten'. 
Van de bovenstaande drie categorieën lijkt de derde categorie de belangrijkste te zijn. Zoals eerder naar voren is gebracht in paragraaf 7.4.7, kan worden betwijfeld of categorie 1 nog zelfstandig bestaansrecht heeft. Categorie 2 is tot op dit moment in de jurisprudentie van het Hof enkel expliciet aan de orde geweest in de arresten Isle of Wight ${ }^{105}$ en Salix. ${ }^{106}$ Zoals echter eerder is geconstateerd (zie de paragrafen 7.4.6 en 7.4.7) heeft het Hof de uitwerking van de categorieën 1 en 2 overgelaten aan de lidstaten. Op deze wijze is het effect van de betreffende zinsdelen van artikel 13, BTWrichtlijn op communautair niveau afgezwakt. De derde categorie komt in bijna alle arresten over de belastingplicht van publiekrechtelijke lichamen terug en behoort dan ook tot de standaard overwegingen van het Hof. ${ }^{107}$ De fiscale neutraliteit, zoals dat zich laat gelden bij de toepassing van artikel 13, BTW-richtlijn, is door interpretatie gevonden. Achteraf kan men vaststellen dat de opstellers van de BTW-richtlijn niet de categorieën 1 en 2 in de tekst van de BTW-richtlijn hadden hoeven op te nemen. De fiscale neutraliteit blijkt namelijk op te komen in het begrip 'als overheid'.

Verscheidene schrijvers vragen zich af of artikel 13, BTW-richtlijn wel voldoende concurrentievervalsing voorkomt. ${ }^{108}$ Zij sluiten niet uit dat een ongelijke behandeling aan de orde kan zijn. Deze zienswijze deel ik niet. Volgens mij is de fiscale neutraliteit als uitdrukking van het gelijkheidsbeginsel voldoende sterk in het Europese recht verankerd, en in het bijzonder in het begrip 'als overheid' van artikel 13, BTW-richtlijn om te voorkomen dat de concurrentieverhoudingen worden verstoord. Wel is het zo dat het begrip door middel van zogenoemde case law zich verder zal ontwikkelen.

105. Hof 16 september 2008, nr. C-288/07, Isle of Wight, V-N 2008/47.21, NTFR 2008/1890. Overigens neemt het Hof in het Isle of Wight-arrest aan, omdat dit aspect door de nationale rechter niet wordt voorgelegd, dat de in het geding aan de orde zijnde werkzaamheden overheidshandelingen zijn. En focust dan ook in het antwoord op 'concurrentievervalsing van enige betekenis'. Verder heeft dit aspect bijna een rol gespeeld in de diverse tolzaken. De Commissie was echter niet in staat om dit hard te maken. Zie paragraaf 7.4.6. De vraag is echter of het Hof met dit aspect iets had gedaan indien de Commissie wel degelijk in staat was haar stelling te onderbouwen. Waarschijnlijk had volgens mij het Hof de oplossing voor de concurrentievervalsing gezocht in de door mij beschreven derde categorie, namelijk door middel van interpretatie van het begrip 'als overheid'.

106. Hof 4 juni 2009, nr. C-102/08, Salix, V-N 2009/28.13, NTFR 2009/1384.

107. Zie ook J.T. Sanders in zijn noot bij het arrest Isle of Wight, NTFR 2008/1890.

108. Stevens is van mening dat het een tekortkoming is dat het Hof enkel concurrentieverstoringen op nationaal niveau in de beschouwing betrekt. Zie S.A. Stevens 2003, blz. 414. Zie ook J.J.P. Swinkels 2000, blz. 294. Zie verder B.G. van Zadelhoff 1992, blz. 148. 
In paragraaf 7.2 bij de behandeling van de startende ondernemer is naar voren gebracht dat de fiscale neutraliteit een verruimde werking heeft op de belastingplicht, in die zin dat het ook input-handelingen onder de economische activiteiten van het begrip belastingplichtige heeft gebracht. Ook op de belastingplicht van publiekrechtelijke lichamen heeft de fiscale neutraliteit een verruimende werking, in die zin dat het het begrip 'als overheid' beperkt. Het perkt namelijk de uitleg van Hof van handelingen 'als overheid' in (voor de betekenis van de termen 'verruimen' en ‘beperken’ zie paragraaf 3.3.2).

Uit de jurisprudentie op het terrein van de startende ondernemer en de overheidsactiviteiten blijkt dat de fiscale neutraliteit als uitdrukking van het gelijkheidsbeginsel als een krachtige interpretatiebeginsel fungeert in de betekenis als in paragraaf 4.4 .4 beschreven. 


\section{HOOFDSTUK 8}

\section{Rationaliteit van de plaats van dienst}

Bij de behandeling van het territorialiteitsbeginsel in paragraaf 2.3.1 is naar voren gebracht dat onder meer uit het Trans Tirreno Express-arrest ${ }^{1}$ blijkt dat de artikelen, die een antwoord geven op de vraag in welk land een bepaalde dienstverrichting plaatsvindt (43 t/m 59 ter, BTW-richtlijn; voorheen artikel 9, Zesde richtlijn) pas aan de orde zijn als er een heffingsconflict is tussen de lidstaten. Is geen sprake van een heffingsconflict (zie hierover 2.3.1), dan zijn de genoemde artikelen niet aan de orde maar beheerst de onbeperkte werking van onderworpenheid aan de belasting en geografisch toepassingsbereik de heffing aan BTW (artikelen 2 en 5 t/m 8, BTWrichtlijn; voorheen artikelen 2 en 3, Zesde richtlijn). Dit hoofdstuk gaat verder daar waar paragraaf 2.3.1 is geëindigd en besteedt aandacht aan de vraag, op welke wijze de algemene rechtsbeginselen zich laten gelden als er een heffingsconflict aan de orde is. Met een heffingsconflict doel ik op een situatie waarin twee of meer lidstaten één en dezelfde transactie (in dit geval een dienst) met BTW willen belasten.

De regels over de plaats van dienst wijzen de heffing toe aan één lidstaat en daarmee zouden de mogelijke heffingsconflicten tussen de lidstaten zijn beslecht. Dat neemt niet weg dat tussen de lidstaten nog wel degelijk heffingsconflicten voorkomen door onder meer interpretatieverschillen. ${ }^{2}$ In dit hoofdstuk staat centraal de wijze

1. Hof 23 januari 1986, nr. 283/84, Trans Tirreno Express Spa, Jur. 1986, blz. 231.

2. In haar conclusie bij het Heger-arrest (7 maart 2006, nr. C-166/05, V-N 2006/47.14, pt. 27) stelt A-G Sharpton dat de gemeenschapswetgever binnen de Zesde richtlijn een zekere mate van interne spanning heeft gecreëerd, aangezien de algemene regels betreffende de plaats van een dienst op het oorsprongs- en niet op het bestemmingslandbeginsel berusten, hoewel het grondbeginsel van de BTW, als verbruiksbelasting, is dat zij behoort te worden geheven op de plats van het verbruik. Zie verder Hof 22 december 2010, nr. C-277/09, RBSD, V-N 2011/8.19, NTFR 2011/82. In het RBSD-arrest geeft het Hof aan dat bij reële structuren een heffingslek bij grensoverschrijdende structuren niet gedicht kan worden met behulp van het leerstuk misbruik van recht. Overigens zijn er meerdere oorzaken te constateren van heffingsconflicten, bijvoorbeeld overgangsregelingen en zogenoemde kan-bepalingen, zie verder paragraaf 2.4.2. Zie in dit verband ook H.W.M. van Kesteren en M.W.C. Soltysik, Misbruik en onvoltooide harmonisatie, WFR 2007/481. 
waarop de algemene rechtsbeginselen een dergelijk conflict helpen beslechten. Of anders geformuleerd, de wijze waarop het Hof de algemene rechtsbeginselen gebruikt bij de uitleg van artikel 9, Zesde richtlijn. ${ }^{3}$

De Raad heeft een akkoord bereikt over wat ook wel wordt aangeduid als het 'BTWpakket'. Het BTW-pakket bestaat onder meer uit een aanpassing van de regels op het gebied van de plaats van dienst en is voor een belangrijk deel ingegaan op 1 januari $2010 .{ }^{4}$ De nieuwe regeling houdt in dat voor diensten aan belastingplichtigen (B2B) zo veel als mogelijk wordt aangesloten bij het bestemmingslandbeginsel. De Considerans vermeldt in overweging $3:^{5}$

"Alle diensten moeten in beginsel worden belast op de plaats waar zij werkelijk worden verbruikt. (...)."

De nieuwe regels voor B2B-diensten ${ }^{6}$ zijn opgenomen in artikel 44, BTW-richtlijn en komen neer op een toewijzing van de heffing aan de plaats waar de afnemer is gevestigd. ${ }^{7}$ De regels voor B2C-diensten ${ }^{8}$ zijn te vinden in artikel 45 , BTW-richtlijn en komen neer op het toewijzen van de heffing aan de plaats waar de dienstverrichter

3. De regelgeving die de plaats van heffing inzake diensten bepaalt is onder te verdelen in een drietal perioden:

- $\quad$ Vanaf 1 januari 1978 tot 1 januari 2007 was de Zesde richtlijn van kracht en regelde artikel 9,

Zesde richtlijn de plaats van dienst.

- Vanaf 1 januari 2007 tot en met 31 december 2009 was de regelgeving opgenomen in de artikelen 43 en 52 t/m 59, BTW-richtlijn. De omzetting van de Zesde richtlijn naar de BTWrichtlijn betreft - zoals in hoofdstuk 1 toegelicht - geen inhoudelijke wijziging.

- $\quad$ Vanaf 1 januari 2010 is de regelgeving inzake de plaats van dienst ingrijpend veranderd. Vanaf deze datum is de regelgeving te vinden in de artikelen $43 \mathrm{t} / \mathrm{m} 59$ ter, BTW-richtlijn. De jurisprudentie die in dit hoofdstuk aan de orde is heeft betrekking op de periode dat de Zesde richtlijn nog van kracht was. Bij het bespreken van de algemene rechtsbeginselen zijn deze gerelateerd aan de tekst van de Zesde richtlijn. Bij het behandelen van deze jurisprudentie zal ik dan ook vooral verwijzen naar de artikelen in de Zesde richtlijn.

4. Het BTW-pakket bestaat uit aanpassing van de regeling inzake de plaats van dienst, een vernieuwde teruggaafprocedure en een verbetering van de administratieve samenwerking en uitwisseling van informatie ter bestrijding van fraude. Zie Richtlijn 2008/8/EG (Pb 20 februari 2008, L 44/11, Richtlijn 2008/9/EG (Pb 20 februari 2008, L 44/23) en Verordening (EG) 143/2008 (Pb 20 februari 2008, L 44/1). 5. Richtlijn 2008/8/EG.

6. B2B betekent business-to-business. In deze context omvat de tweede B ook belastingplichtigen die tevens niet-economische activiteiten verrichten en voor BTW-doeleinden geregistreerde niet-belastingplichtigen rechtspersonen (zie artikel 43, BTW-richtlijn).

7. Het nieuwe artikel 44, BTW-richtlijn luidt: "De plaats van een dienst, verricht voor een als zodanig handelende belastingplichtige, is de plaats waar de belastingplichtige de zetel van zijn bedrijfsuitoefening heeft gevestigd. (...)"

8. B2C betekent business-to-consumer. In deze context omvat de $\mathrm{C}$ niet die personen welke naast nieteconomische activiteiten ook economische activiteiten verrichten en omvat tevens niet de voor BTWdoeleinden geregistreerde niet-belastingplichtige rechtspersonen (zie artikel 43, BTW-richtlijn). 
woont of is gevestigd. ${ }^{9}$ De hierboven geschetste hoofdregels kennen echter diverse uitzonderingen. Met betrekking tot enkele B2B-diensten - bijvoorbeeld diensten in het onroerend goed, personenvervoer, restauratie en catering en de verhuur van vervoermiddelen - is niet de hoofdregel van toepassing, maar gelden in verband met de aard daarvan afwijkende regels. ${ }^{10}$ Vanaf 1 juli $2011^{11}$ is de BTW-verordening (EU) nr. 282/ 2011 van kracht die als doel heeft te zorgen voor een eenvormige toepassing van het BTW-stelsel in het bijzonder betreffende de plaats van de belastbare handelingen. ${ }^{12}$ of deze verordening interpretatieverschillen tussen de lidstaten zal verminderen is echter de vraag gezien - zoals verderop in de paragrafen 8.3 en 8.5 zal blijken - vooral op het terrein van het hoofdhuis (zetel)/vaste inrichting een verdere verfijning van de regelgeving heeft plaatsgevonden. Te verwachten valt dan ook dat op een aantal terreinen afbakeningsproblemen zullen optreden. Dat betekent dat de maatstaven die zijn te vinden in de jurisprudentie van het Hof relevant zullen blijven.

Interpretatieverschillen van de regels die de plaats van een dienst bepalen kunnen zich op verscheidene terreinen voordoen. Ik noem de drie belangrijkste. Vooreerst is er het voor de internationale praktijk belangwekkende probleem hoofdhuis (zetel)/ vaste inrichting. Over het al dan niet aanwezig zijn van een vaste inrichting handelt onder meer de Aro Lease-zaak van 17 juli 1997. ${ }^{13}$ Daarin stelde België dat de verhuur van voertuigen plaatsvindt vanuit een vaste inrichting in België en dat dan ook over de verhuur in België BTW moest worden voldaan. Nederland stelde zich daarentegen op het standpunt dat geen sprake was van een vaste inrichting in België en dat de verhuur derhalve plaatsvond vanuit de zetel in Nederland. De Nederlandse Belastingdienst was dan ook van mening dat in Nederland BTW over de verhuur van de voertuigen moest worden voldaan. Beide lidstaten waren van plan dezelfde dienst te belasten. Het Hof besliste dat geen sprake was van een vaste inrichting in België en de dienst dan ook in Nederland was onderworpen aan de heffing van BTW (zie verder paragraaf 8.3 ).

Een heffingsconflict kan zich voorts voordoen in het prealabele geval dat de lidstaten van mening verschillen over het antwoord op de vraag of sprake is van een levering of van een dienst. De plaats van levering van goederen wordt door andere regels

9. Het nieuwe artikel 45, BTW-richtlijn luidt: "De plaats van een dienst, verricht voor een nietbelastingplichtige, is de plaats waar de dienstverrichter de zetel van zijn bedrijfsuitoefening heeft gevestigd. (...)" Uitgezonderd voor BTW-doeleinden geïdentificeerde rechtspersonen die niet belastingplichtig zijn (zie artikel 43, BTW-richtlijn).

10. Uit de MvT blijkt dat de achtergrond een historische reden is (bijvoorbeeld wat betreft bepaalde vervoersdiensten), dan wel om recht te doen aan het beginsel dat de belasting dient te worden geheven in de lidstaat waar de dienst daadwerkelijk wordt verbruikt (bijvoorbeeld restaurant- en cateringdiensten), Kamerstukken II 2008/09, 31907, nr. 3, V-N 2009/19.5.

11. De artikelen die betrekking hebben op langdurig verhuur van vervoermiddelen zijn van kracht vanaf 1 januari 2013 en de artikelen inzake belastingheffing op langs elektronische weg verrichte diensten vanaf 1 januari 2015, zie overweging 46 van de Considerans en artikel 65, Verordening (EU) nr. 282/2011.

12. Uitvoeringsverordening (EU) nr. 282/2011, Pb EU van 23 maart 2011, L 77/1.

13. Hof 17 juli 1997, nr. C-190/95, ARO Lease BV, V-N 1997/2933, pt. 7. 
beheerst dan de plaats waar een dienst wordt verricht. De hoofdregel is, ingeval het goed niet wordt verzonden of vervoerd, de plaats waar het goed zich op het tijdstip van de levering bevindt. ${ }^{14}$ Ingeval dat daarentegen een dienst wordt verricht was tot 1 januari 2010 de hoofdregel, dat de dienst daar wordt verricht waar de dienstverrichter de zetel van zijn bedrijfsuitoefening heeft of een vaste inrichting heeft gevestigd van waaruit hij de dienst verricht. ${ }^{15}$ In het arrest van 2 mei 1996 leidde dit tot een heffingsconflict tussen Denemarken en Duitsland. ${ }^{16}$ Het heffingsconflict dat dreigde kan als volgt enigszins gestileerd worden geschetst. Denemarken meende dat het serveren van maaltijden op een veerboot als een dienst was te beschouwen en gezien het gegeven dat de zetel van de bedrijfsuitoefening zich in Denemarken bevond, diende dan ook in Denemarken te worden belast. Duitsland echter meende dat sprake was van een levering en dat dan ook Duitse BTW moest worden voldaan op het moment dat de levering plaatsvond en de veerboot in Duits territoriale wateren voer. Het Hof besliste dat onder omstandigheden sprake is van een dienst en dat de plaats van het belastbaar feit dan ook geregeld wordt door artikel 9, lid 1, Zesde richtlijn (zie verder paragraaf 8.3). ${ }^{17}$ De heffing werd dan ook toegewezen aan Denemarken.

Ten slotte is er het terrein van de uitzonderingen op de hoofdregel van de plaats van dienst. Ook daarover twisten de lidstaten over de juiste uitleg om de adequate plaats van de prestatie aan te wijzen. ${ }^{18}$ Zo kan de ene lidstaat de diensten van een arbiter

14. Artikel 31, BTW-richtlijn. In geval van levering van goederen met vervoer, zie de artikelen $32 \mathrm{t} / \mathrm{m}$ 36, BTW-richtlijn. Artikel 37 beheerst de levering van goederen aan boord van een schip, vliegtuig of trein en de artikelen 38 en 39, BTW-richtlijn regelt de levering van gas of elektriciteit via distributiesystemen.

15. Artikel 9, lid 1, Zesde richtlijn. Na 1 januari 2010 bepalen de artikel 44 en 44, BTW-richtlijn dat gestileerd weergegeven - in geval van diensten verricht aan belastingplichtigen (B2B) wordt aangesloten bij de plaats waar de afnemer is gevestigd. Ingeval echter van diensten verricht aan particulieren (B2C) komen neer op het toewijzen van de heffing aan de plaats waar de dienstverichter woont of is gevestigd.

16. Hof 2 mei 1996, nr. C-231/94, Faaborg-Gelting-Linien A/S, V-N 1996/2120, pt. 22.

17. Een ander voorbeeld van een conflict als gevolg van een verschillend oordeel over de vraag 'levering of dienst' beschrijft Denie inzake de verschillende beslissingen in België enerzijds en Duitsland en Nederland anderzijds waar het gaat om verschillende vormen van grensoverschrijdende leasing. A.H.R. M. Denie, Het intraverkeer: definitief met problemen, in: Belastingen in België, Duitsland en Nederland, Euregiobundel, Arnhem: 1995 Gouda Quint, blz. 197 e.v.

18. In het Eerste verslag van de Commissie aan de Raad over de werking van het gemeenschappelijk BTW-stelsel werd al aandacht besteed aan deze problematiek. Hoofdstuk III, onderdeel C van het verslag staat stil bij mogelijke interpretatieproblemen die aan de orde kunnen komen bij de uitleg van artikel 9, lid 2, letter e, Zesde richtlijn. Interpretatieproblemen die worden genoemd betreffen vooral de afbakening van de diensten op het gebied van reclame, de diensten verricht door raadgevende personen en accountants alsmede die diensten die de informatieverschaffing betreffen. De Commissie vermeldt over de problematiek in het Eerste verslag: "Zonder het belang van de moeilijkheden te willen overdrijven is de Commissie niettemin voornemens te blijven streven naar verdere opheldering in het kader van de werkzaamheden van het Raadgevend Comité voor de BTW." Kennelijk verwachtte de Commissie toentertijd veel van de overlegprocedure tussen de lidstaten zoals deze is te vinden in artikel 398, BTW-richtlijn (voorheen artikel 29, Zesde richtlijn). Inmiddels is in het Raadgevend $\rightarrow$ 
kenmerken als die van een advocaat, welke werd genoemd in één van de uitzonderingen op de hoofdregel in het tot 1 januari 2010 van kracht zijnde artikel 9, Zesde richtlijn. De plaats van dienst is dan daar waar de ontvanger van de dienst is gevestigd. ${ }^{19}$ Terwijl een andere lidstaat deze prestatie niet kenmerkend vindt voor een advocaat en de hoofdregel van artikel 9, lid 1, Zesde richtlijn toepast. Het Hof heeft in het Hoffmann-arrest beslist dat de diensten van een arbiter niet hetzelfde doel hebben als de diensten die worden verricht door een advocaat en dat dan ook de hoofdregel van toepassing was. ${ }^{20}$ Hoffmann was daarom ook tot 1 januari 2010 BTW verschuldigd in de lidstaat waar hij was gevestigd. In deze procedure betrof het een $\mathrm{B} 2 \mathrm{~B}$ prestatie. Per 1 januari 2010 is deze dienst belast in de lidstaat waar de afnemer is gevestigd (artikel 44, BTW-richtlijn). Dat neemt niet weg dat deze procedure duidelijk maakt dat uitzonderingen op een hoofdregel - en zoals eerder naar voren gebracht kent de nieuwe regelgeving deze ook - interpretatieproblemen tot gevolg kunnen hebben.

De drie probleemvelden zullen in dit hoofdstuk aan de orde komen. Het hoofdstuk behandelt de problematiek van de toepassing van de regels op het terrein van de plaats van dienst niet uitputtend, maar beperkt zich tot heffingsconflicten waarbij de rechtsbeginselen hun invloed openbaren. ${ }^{21}$

$\rightarrow$ Comité voor de BTW verscheidene keren aandacht besteed aan interpretatie verschillen van artikel 56, BTW-richtlijn. Zie bijvoorbeeld voor een overzicht de International VAT-Monitor 2008, Nov/Dec, VAT Committee Guidelines 1977 - 2008. Wat betreft reclamediensten heeft het Hof dit begrip in verscheidene arresten verduidelijkt. Zie de arresten van 17 november 1993, nr. C-68/92, Commissie/ Frankrijk, V-N 1994/592, pt. 36 en nr. C-69/92, Commissie/Luxemburg, Jur. 1993, blz. I-05907, en nr. C-73/92, Commissie/Spanje, Jur. 1993, blz. I-05997. Een dienst die regelmatig tot een verschillende behandeling door de lidstaten leidt is 'management'. Afgezien van het probleem dat het in de praktijk het vaak lastig is om te bepalen wat precies de 'managementdienst' inhoudt (is het toch geen advies?), lijkt het erop dat landen als Denemarken, Finland, Zweden en Spanje dergelijke diensten onder het bereik van artikel 9, lid 2, sub e, Zesde richtlijn vinden vallen, terwijl landen als Nederland en Engeland artikel 9, lid 1, Zesde richtlijn van toepassing vinden. Zie J. Voyez, Changing Face of Article 9, Taxation 6 december 2001, blz. 246 e.v. Dit probleem is sinds 1 januari 2010 opgelost nu dergelijke diensten onder het bereik vallen van artikel 44, BTW-richtlijn en de heffing is toegewezen aan de lidstaat waar de afnemer woont of is gevestigd.

19. In het TRR-arrest (Hof 6 november 2008, nr. C-291/07, V-N 2008/55.20) is beslist dat voor de toepassing van artikel 9, lid 2, letter e, Zesde richtlijn het niet van belang is dat de belastingplichtige afnemer de diensten gebruikt voor onbelaste handelingen.

20. Hof 16 september 1997, nr. C-145/96, B. von Hoffmann, V-N 1997/3865, pt. 25. Zie vooral r.o 22: "Aangaande de diensten van een advocaat moet worden opgemerkt, dat indien het onderhandelen met oog op een compromis, de dienst van een advocaat waarmee de dienst van een arbiter de meeste overeenkomst vertoont, wordt vergeleken met de beslechting van een geschil door een arbiter, deze beide diensten niet hetzelfde doel blijken te hebben. Terwijl een advocaat die onderhandelingen voert, zich bij het zoeken van een compromis gewoonlijk laat leiden door opportuniteitsoverwegingen en een afweging van belangen, laat een arbiter zich bij de beslechting van een geschil leiden door overwegingen van rechtvaardigheid of billijkheid."

21. Zie verder voor de toepassing van de regels inzake de plaats van dienst onder vigeur van de Zesde richtlijn B.J.M. Terra, The Place of Supply in European VAT, Dordrecht: Kluwer Law International 1998. Zie voor de regelgeving vanaf 1 januari 2010 M.E. van Hilten \& J.B.J. Boender, BTW-pakket, plaats van dienst, teruggaaf en antifraude-maatregelen in de btw vanaf 2010, Deventer: Kluwer 2010. Zie tevens M.M.W.D. Merkx, De woon- en vestigingsplaats in de btw (diss. Tilburg), Deventer: Kluwer 2011. 
Allereerst zal ik in dit hoofdstuk aandacht besteden aan het doel van de regelgeving. Vervolgens zal ik de begrippen 'vaste inrichting' en 'zetel van de bedrijfsuitoefening' behandelen. Aan het slot van dit hoofdstuk besteed ik aandacht aan de bijzondere bepalingen die zijn te vinden in artikel 59 bis, BTW-richtlijn (voorheen artikel 9, lid 3, Zesde richtlijn). Deze bepalingen zijn ingevoerd ter voorkoming van concurrentievervalsing. Het hoofdstuk sluit ik af met een conclusie.

\subsection{Doel van de regels met betrekking tot de plaats van dienst}

In paragraaf 2.3.1, handelend over het territorialiteitsbeginsel, bleek dat onder meer uit het Trans Tirreno Express-arrest ${ }^{22}$ is op te maken dat de werkingssfeer van de BTW van toepassing is op het nationale grondgebied van een lidstaat, echter dat de BTW-richtlijn de vrijheid van een lidstaat niet beperkt om het toepassingsgebied uit te breiden tot buiten het grondgebied van een lidstaat, mits geen inbreuk wordt gemaakt op de bevoegdheid van andere lidstaten. ${ }^{23}$ Tevens blijkt uit de in paragraaf 2.3.1 behandelde jurisprudentie dat de regels met betrekking tot de plaats van dienst enkel van toepassing zijn in geval van een heffingsconflict. Het territorialiteitsbeginsel is het uitgangspunt, maar de kracht ervan is uitgeput op het moment van een heffingsconflict. ${ }^{24}$

In dit kader is het waard om de zevende overweging van de Considerans van de Zesde richtlijn te vermelden:

“(...) dat de vaststelling van de plaats van de belastbare handelingen heeft geleid tot competentieconflicten tussen de lidstaten, met name met betrekking tot de levering inclusief montage van een goed en met betrekking tot diensten; dat de plaats van diensten in beginsel moet worden vastgesteld op de plaats waar de dienstverrichter de zetel van zijn bedrijfsuitoefening heeft gevestigd, maar dat die plaats evenwel in bepaalde gevallen moet worden vastgesteld in het land van de ontvanger van de diensten, met name voor sommige diensten tussen belastingplichtigen waarvan de kosten in de prijs van de goederen worden opgenomen." 25

22. Hof 23 januari 1986, nr. 283/84, Trans Tirreno Express Spa, Jur. 1986, blz. 231, ondermeer r.o. 19. Zie in dit kader ook Hof 4 juli 1998, nr. 168/84, Günther Berkholz, Jur. 1985, blz. 2251, in het bijzonder r.o. 16. 23. Dat een dergelijke inbreuk al snel aan de orde is blijkt uit Hof 15 september 2005, nr. C-58/04, Antje Köhler, V-N 2005/47.24. In het Köhler-arrest wordt, in geval van een tussenstop van een cruiseschip buiten de gemeenschap, de fiscale behandeling van de levering van goederen toegewezen aan de staat waar de tussenstop plaatsvindt. Vgl. Hof 29 maart 2007, nr. C-111/05, Aktiebolaget NN, V-N 2007/18.22. 24. Het Hof vermeldt in drie arresten hoe de heffing dient te worden toegewezen bij reclamediensten (voorheen artikel 9, lid 2, sub e, Zesde richtlijn): “Dit laatste artikel is een conflictregel voor de vaststelling van de plaats van belasting van diensten op het gebied van de reclame en daarmee voor de afbakening van de competentie van de Lid-Staten." Hof 17 november 1993, nr. C-68/92, Commissie/ Frankrijk, V-N 1994/592 pt. 36, r.o. 14 en nr. C-69/92, Commissie/Luxemburg, Jur. 1993, blz. I-5907, r.o. 15, en nr. C-73/92, Commissie/Spanje, Jur. 1993, blz. I-5997, r.o. 12.

25. Het slot van deze overweging speelt een belangrijke rol in de drie inbreukprocedures tegen Frankrijk, Luxemburg en Spanje over de plaats van dienst van diensten op het gebied van reclame. Het Hof overweegt: "De gemeenschapswetgever heeft derhalve geoordeeld, dat voor zover de ontvanger van de dienst de goederen of diensten waarvoor reclame wordt gemaakt, gewoonlijk levert in de $\rightarrow$ 
Ondanks de gemeenschappelijke, dwingend te volgen regels die primair conflicten tussen de lidstaten zouden moeten voorkomen, heeft het Hof ruim 30 arresten nodig gehad om te verduidelijken in welke lidstaat een dienst belast is met BTW. ${ }^{26}$ In verscheidene arresten komt naar voren wat het doel van deze regelgeving is. Een sleutelarrest is het Berkholz-arrest. ${ }^{27}$ Dit arrest vermeldt:

"Voor de beantwoording van de eerste vraag van het Finanzgericht moet worden te rade gegaan met het doel dat met artikel 9 in het kader van het algemene systeem van de richtlijn wordt nagestreefd. Gelijk uit de zevende overweging van de considerans kan worden afgeleid, beoogt deze bepaling de toepassingsgebieden van de nationale wettelijke regelingen inzake de belasting over de toegevoegde waarde rationeel af te bakenen, door de plaats waar de diensten fiscaal moeten worden geacht te zijn verricht, uniform vast te stellen. Lid 2 van artikel 9 vermeldt een hele reeks specifieke aanknopingspunten, terwijl lid 1 dienaangaande een algemene regel stelt. Doel van deze bepaling is, gelijk - zij het slechts voor specifieke situaties - blijkt uit artikel 9, lid 3, bevoegdheidsconflicten die tot dubbele belasting kunnen leiden, en het niet-belasten van inkomsten te vermijden." (r.o. 14)

Uit deze rechtsoverweging blijkt dat het doel van de regelgeving is 'de toepassingsgebieden (...) rationeel af te bakenen' en 'bevoegdheidsconflicten (...) te vermijden'. Ik bekijk deze elementen hierna nader, daarmee scherper krijgend wat het Hof met deze criteria bedoelt.

Het criterium de toepassingsgebieden van de nationale wettelijke regelingen inzake de BTW rationeel af te bakenen treffen wij niet slechts aan in het Berkholz-arrest, maar ook in het Trans Tirreno Express-arrest, ${ }^{28}$ het Hamann-arrest, ${ }^{29}$ het DFDS-arrest, ${ }^{30}$ en

$\rightarrow$ staat waar hij gevestigd is - waarbij de BTW wordt geheven van de eindconsument - de BTW over de dienst op het gebied van de reclame door de ontvanger van die dienst aan de staat moet worden voldaan. Deze rechtvaardiging vormt één van de elementen waarmee rekening met worden gehouden bij de uitlegging van het begrip 'diensten op het gebied van de reclame' in artikel 9, lid 2, sub e, van de Zesde richtlijn." Zie ook Hof 9 maart 2006, nr. C-114/05, Gillan Beach Ltd, V-N 2006/46.15, r.o. 16 en 17, waarin is beslist dat het organiseren van een watersportbeurs is belast in de lidstaat waar deze beurs wordt georganiseerd.

26. Verscheidene van deze arresten behandel ik in dit hoofdstuk. Voor een volledig overzicht van de jurisprudentie over de uitleg van artikel 43 t/m 59, BTW-richtlijn, zie W.A.P. Nieuwenhuizen, BTW Jurisprudentie van het Hof van Justitie, Deventer: Kluwer 2010, paragraaf 3.

27. Hof 4 juli 1985, nr. 168/84, Günter Berkholz, Jur. 1985, blz. 2251.

28. Hof 23 januari 1986, nr. 283/84, Trans Tirreno Express Spa, Jur. 1986, blz. 231, r.o. 14 vermeldt onder meer: “(...),artikel 9 beoogt de toepassingsgebieden van de nationale wettelijke regelingen inzake BTW rationeel af te bakenen, (...)."

29. Hof 15 maart 1989, nr. 51/88, Hamann, FED 1990/91. In r.o. 17 is te vinden: “(...),de werkingssfeer van de rechtsregels van de Lid-Staten, met name die betreffende diensten, aan de hand van rationele criteria af te bakenen".

30. Hof 20 februari 1997, nr. C-260/95, DFDS A/S, V-N 1997/1662, pt. 17. In dit kader wordt aangegeven in r.o. 18: “(...),beoogt artikel 9 de toepassingsgebieden van de nationale wettelijke regelingen inzake de belasting over de toegevoegde waarde rationeel af te bakenen, door de plaats waar de diensten fiscaal moeten worden geacht te zijn verricht, uniform vast te stellen,(...)". 
het Binder-arrest ${ }^{31}$ zijn vergelijkbare rechtsoverwegingen te vinden. ${ }^{32}$ Het Berkholzarrest vermeldt dat de rationele afbakening dient plaats te vinden:

“(...), door de plaats waar de diensten fiscaal moeten worden geacht te zijn verricht, uniform vast te stellen." (r.o. 14)

Het Hof overweegt ook in het Trans Tirreno-arrest en het Binder-arrest dat met rationele afbakening wordt bedoeld dat de plaats van dienst uniform dient te worden vastgesteld. Kortom, rationeel afbakenen in de context van de plaats van dienst regelgeving betekent uniformiteit. Op deze constatering kom ik na de bespreking van het andere criterium terug, namelijk het vermijden van 'bevoegdheidsconflicten'.

Uit het Berkholz-arrest is tevens op te maken dat het doel van de regelgeving is:

“(...) bevoegdheidsconflicten die tot dubbele belasting kunnen leiden, en het niet-belasten van inkomsten te vermijden”. (slot van r.o. 14)

Deze benadering speelt een sleutelrol bij de uitleg van de regelgeving. Het Hof herhaalt deze overweging in het DFDS-arrest ${ }^{33}$ Linthorst-arrest, $^{34}$ Binder-arrest, ${ }^{35}$

31. Hof 6 november 1997, nr. C-116/96, Reisbüro Binder, V-N 1998/4.13. In dit kader is te vinden in r.o. 12: “(...), dat de toepassingsgebieden van de nationale wettelijke regelingen inzake BTW rationeel beoogt af te bakenen door de plaats waar de diensten fiscaal moeten worden geacht te zijn verricht, uniform vast te stellen, (...)".

32. Het Hof formuleert het iets anders in de inbreukprocedure tegen Frankrijk inzake afvalverwijdering. Hof 25 januari 2001, nr. C-429/97, Commissie/Frankrijk, Jur. 2001, blz. 637. In r.o. 40: “Enerzijds zij erop gewezen, dat aangezien het in casu gaat om de kwalificatie voor toepassing van de BTW van een complexe dienst in zijn geheel beschouwd, de aanknoping bij artikel 9, lid 1, of lid 2, sub c, vierde streepje, van de Zesde richtlijn van dien aard moet zijn, dat een rationele en homogene belastingheffing wordt verzekerd." In plaats van 'rationeel af te bakenen' heeft het Hof het over het verzekeren van een 'rationele en homogene belastingheffing'. Het lijkt mij dat het Hof geen wezenlijk andere lijn voor ogen heeft.

33. Hof 20 februari 1997, C-260/95, DFDS A/S, V-N 1997/1662, pt. 17.

34. Hof 6 maart 1997, nr. C-167/95, Maatschap Linthorst, Pouwels \& Scheres c.s., V-N 1997/1400, pt. 31, r.o. 10: “(...), dat het Hof met betrekking tot de verhouding tussen artikel 9, lid 1, en artikel 9, lid 2, van de Zesde richtlijn reeds heeft gepreciseerd, dat artikel 9, lid 2, een hele reeks specifieke aanknopingspunten vermeldt, terwijl lid 1 dienaangaande een algemene regel stelt. Doel van deze bepalingen is, zoals - zij het slechts voor specifieke situaties - uit artikel 9, lid 3, blijkt, bevoegdheidsconflicten die tot dubbele belasting kunnen leiden, en het niet-belasten van inkomsten te vermijden (...)". 35. Hof 6 november 1997, nr. C-116/96, Reisbüro Binder, V-N 1998/4.13, r.o. 12. 
Dudda-arrest, ${ }^{36}$ de inbreuk procedure tegen Frankrijk, ${ }^{37}$ SPI-arrest ${ }^{38}$ de inbreukprocedure tegen Duitsland ${ }^{39}$ en meer recent het arrest RCI Europe. ${ }^{40}$ Met het gebruik van het woord 'bevoegdheidsconflict' heeft het Hof kennelijk een situatie op het oog waarbij minimaal twee lidstaten eenzelfde dienst met BTW willen belasten. ${ }^{41}$ Het Hof overweegt tevens dat het doel van de regels is het voorkomen dat geen enkele lidstaat de betreffende dienst belast met BTW. Het Hof noemt in de overwegingen vaak een situatie van niet-heffing tezamen met een situatie van dubbele heffing en geeft dan vervolgens aan dat het doel van de regelgeving is het voorkomen van dergelijke situaties. Er mag dus geen overlap in heffing zijn en er mag geen leemte in het heffingsbereik van de BTW vallen. Om dat te vermijden dient een uniforme heffing te bestaan.

Het lijkt er derhalve op, dat de criteria 'rationele afbakening', 'uniforme vaststelling' en 'bevoegdheidsconflicten die tot dubbele belasting kunnen leiden, en niet-belasten van inkomsten te vermijden' op hetzelfde neerkomen. Namelijk, dat een transactie binnen de Europese Unie niet meer dan één keer getroffen mag worden door de BTWheffing en dat het ook niet zo mag zijn dat een transactie geen enkele keer wordt getroffen. De artikelen die de plaats van een dienst bepalen beogen een heffingsbereik zonder overlap en zonder gaten.

Dat neemt niet weg dat het bovenstaande uitgangspunt wel degelijk een beperking kent in de toepassing. Dat blijkt uit de inbreukprocedure tegen Frankrijk (inzake afvalverwerking), in welk arrest onder meer is beslist dat een complexe dienst die bestaat uit diverse handelingen met betrekking tot afval (zoals de inzameling, het

36. Hof 26 oktober 1996, nr. C-327/94, Jürgen Dudda, V-N 1997/1225, pt. 18, r.o. 20: “(...) Doel van deze bepalingen is, zoals - zij het slechts voor specifieke situaties - uit artikel 9, lid 3, blijkt, bevoegdheidsconflicten die tot dubbele belasting kunnen leiden, en niet-belasten van inkomsten te vermijden (...)."

37. Hof 25 januari 2001, nr. C-429/97, Commissie/Frankrijk (inzake afvalverwijdering), Jur. 2001, blz. I-637, r.o. 41: “(...) Doel van deze bepaling is, zoals - zij het slechts voor specifieke situaties uit artikel 9, lid 3, blijkt, bevoegdheidsconflicten die tot dubbele belasting kunnen leiden, en het nietbelasten van inkomsten te vermijden. Voor elke situatie dient de vraag te worden gesteld, of zij valt onder een van de in artikel 9, lid 2, genoemde gevallen; zo niet dan is lid 1 van toepassing (...)."

38. Hof 15 maart 2001, nr. C-108/00, SPI, V-N 2001/22.16, r.o. 15: "Dienaangaande zij eraan herinnerd dat het Hof, met betrekking tot de verhouding tussen de leden 1 en 2 van artikel 9 van de Zesde richtlijn, reeds heeft gepreciseerd, dat artikel 9, lid 2, een hele reeks bijzondere aanknopingspunten aangeeft, terwijl lid 1 dienaangaande een regel van algemene strekking stelt. Doel van deze bepaling is enerzijds bevoegdheidsconflicten vermijden die tot dubbele belasting kunnen leiden, en anderzijds niet-belasting van inkomsten vermijden (...)."

39. Hof 6 december 2007, nr. C-401/06, Commissie/BRD, V-N 2007/59.15, r.o. 29. In deze procedure is beslist dat de hoofdregel van artikel 9, lid 1, Zesde richtlijn van toepassing is op de diensten van een executeur, ook al worden deze diensten in Duitsland gewoonlijk door een advocaat verricht.

40. Hof 3 september 2009, nr. C-37/08, RCI Europe, V-N 2009/47.23, r.o. 20. Het Hof wijst de heffing in geval van timesharing toe aan de plaats van het onroerend goed.

41. Het arrest Gillian Beach duidt artikel 9, lid 2, Zesde richtlijn aan als een 'conflictregel' voor de afbakening van de competentie van de lidstaten. In dit arrest is beslist dat het organiseren van een watersportbeurs belast is in de lidstaat waar deze beurs wordt georganiseerd. Hof 9 maart 2006, nr. C-114/05, Gillian Beach Ltd, V-N 2006/46.15, r.o. 20. 
vervoer, de recycling, de eigenlijke verwijdering) valt onder het bereik van artikel 9, lid 1, Zesde richtlijn. ${ }^{42}$ Tijdens deze procedure drong de Franse regering aan op toepassing van artikel 9, lid 2, sub c, vierde streepje, Zesde richtlijn. Dit standpunt zou tot gevolg hebben dat de dienst belast is daar waar die daadwerkelijk wordt verricht en niet in de Staat waar de dienstverrichter zijn zetel heeft. Frankrijk ondersteunde zijn zienswijze met onder meer te verwijzen naar het gevaar van het ontstaan van een situatie waarin geen BTW-heffing plaatsvindt. Dat zou het geval kunnen zijn indien de hoofdaannemer die de dienst verricht buiten de Europese Unie is gevestigd, ook al wordt hij materieel verricht door een onderaannemer in Frankrijk. ${ }^{43}$ Het Hof is in deze procedure niet gevoelig voor dit argument en beslist:

“De hypothese waarop de Franse regering doelt, vloeit voort uit de grenzen van de territoriale werkingssfeer van het communautaire BTW-stelsel en kan om die redenen de uitlegging van artikel 9 van de Zesde richtlijn niet aantasten." (r.o. 52)

De toepassing van de regels inzake de plaats van dienst gaat niet zo ver dat in alle situaties verdamping van BTW-heffing is te voorkomen. Waar niet is - geen regel, geen territoir waarop de regel geldt - is de regelgever aan zet. ${ }^{44}$ Een andere benadering zou uiteraard in strijd komen met het rechtszekerheidsbeginsel. ${ }^{45}$ Verder heeft het Hof in het RBSD-arrest ${ }^{46}$ beslist dat bij een heffingslek veroorzaakt door een interpretatieverschil tussen de lidstaten in geval van een reële grensoverschrijdende structuur, het heffingslek niet gedicht kan worden met toepassing van het beginsel van het verbod van misbruik van recht (zie paragraaf 5.3). In deze procedure wordt het heffingslek veroorzaakt door een verschillende uitleg in het Verenigd Koninkrijk en Duitsland bij de toepassing van de regels inzake de plaats van dienst in geval van leasing. De Engelse rechter stelde in deze case onder meer

42. Hof 25 januari 2001, nr. C-429/97, Commissie/Frankrijk, Jur. 2001, blz. I-637.

43. Van Dongen wijst erop dat mogelijk de onderaannemer een vaste inrichting vormt van de hoofdaannemer die buiten de EU is gevestigd. Vooral de DFDS-leer kan volgens haar een dergelijk effect hebben. Zij sluit niet uit dat deze leer wat soepel wordt toegepast indien en lek dreigt naar derde landen. Zie A. van Dongen, NTFR 2001/215.

44. Terra merkt op naar aanleiding van de afwijzing door het Hof van het standpunt van de Franse regering: "Volgens het HvJ vloeit dit voort uit de grenzen van de territoriale werkingssfeer van het communautaire BTW-stelsel en om die redenen kan dit de uitlegging van Artikel 9 niet aantasten." Zie B.J.M. Terra, Europees indirect belastingrecht, Nijmegen: Ars Aequi Libri 2001, blz. 233.

45. Ook in het Dudda-arrest is een nuancering te vinden. In r.o. 32 is te vinden dat een beroep op het gevaar van misbruik en belastingontduiking niet altijd doel treft. Zo wijst het Hof op de mogelijkheden die de lidstaten hebben om op grond van onder meer artikel 207, BTW-richtlijn een dergelijk risico het hoofd te bieden. Hof 26 september 1996, nr. C-327/94, J. Dudda, V-N 1997/1225, pt. 18.

46. Hof 22 december 2010, nr. C-277/09, V-N 2011/8.19, NTFR 2011/82. Het heffingslek ontstaat doordat in de lidstaat van de lessor (Duitsland) de leasing van voertuigen als een levering van een goed ziet, die belast is in de lidstaat waar de auto zich bevindt op het moment van levering (in deze procedure het VK). De lidstaat van de lessee (VK) beschouwt de lease als een dienst belast in Duitsland. Zie nader over het RBSD-arrest T. Vroon, Vreemd is niet gek, BTW-Brief 2011/29. Zie tevens A.H.R.M. Denie, Het intraverkeer: definitief met problemen, in: Belastingen in België, Duitsland en Nederland, Euregiobundel, Arnhem: 1995 Gouda Quint, blz. 197 e.v. 
vragen over de toepassing van het verbod van misbruik van recht en niet over de toepassing van de regels inzake de plaats van dienst in geval van leasing.

De functie van de regels op het gebied van de plaats van dienst kan omschreven worden als op rationele wijze vermijden van een bevoegdheidsconflict tussen lidstaten (dan wel een situatie van niet-heffing). Zij bakenen de jurisdicties af, wijzen de diensten toe aan een - de regel beantwoordende - bepaalde lidstaat en hebben in die zin weinig van doen met algemene rechtsbeginselen. Doch dezelfde set aan regels voorzien welbeschouwd in twee te onderscheiden toepassingsvelden; behalve op het interne verkeer tussen de lidstaten van de EU, zien deze regels ook op de zakenrelaties, inclusief het B2C-verkeer, tussen EU en derde landen. Daarbij is het dan bepaald niet onmogelijk achter dezelfde set aan regels een onderscheid te maken naar gelang het toepassingsgebied - binnen EU of extern - en daarbij verschillende gronden en/of verschillen in interpretatierichting neer te zetten. Zo zal men bij de toepassing van de regels binnen de EU niet het bredere kader van het Unierecht uit het oog verliezen. In hoofdstuk 1 heb ik aandacht gevraagd voor de geschiedenis van de BTW passend in de ontwikkeling van het Unierecht, namelijk het streven naar één interne markt. Regelgeving en uitleg van het Hof staan dan ook niet op zichzelf, maar kunnen gezien worden als een onderdeel van het streven naar integratie op de vele terreinen die het Unierecht bestrijken. Ook al komt in de jurisprudentie op het terrein van de regels betreffende de plaats van dienst geen expliciete verwijzing voor naar het primaire Unierecht, dat neemt derhalve niet weg dat het bij de interpretatie als vanzelf zijn kracht laat gelden. Een expliciete verwijzing naar het Unierecht zien wij overigens wel in de - voor de praktijk niet meer relevante - Gaston Schul-zaak ${ }^{47}$ handelend over de vermijding van dubbele BTWheffing op een in Frankrijk geleverde roerende zaak aan een particulier gevolgd door een heffing bij invoer aan de Nederlandse grens. In lijn met deze zaak is het binnen één interne markt ook niet goed denkbaar dat grensoverschrijdende diensten dubbel worden belast. Zou dat namelijk het geval zijn, dan is een ongelijke behandeling aan de orde tussen gelijksoortige grensoverschrijdende diensten en diensten verricht binnen één lidstaat. Elders in de rechtspraak is het beginsel van de fiscale neutraliteit geformuleerd (zie paragraaf 4.4.4.2). Dit beginsel vormt een uitdrukking van het beginsel van de gelijke behandeling op het terrein van de BTW. Het beginsel van de fiscale neutraliteit verzet zich ertegen dat soortgelijke diensten die met elkaar concurreren, uit oogpunt van de BTW ongelijk worden behandeld. Het doel dat de regels inzake de plaats van dienst nastreven heeft in zijn uitwerking als resultaat dat grensoverschrijdende diensten gelijk worden behandeld met diensten die worden verricht binnen één lidstaat. Dit is conform het uitgangspunt van de interne markt en beantwoordt aan het beginsel van de fiscale neutraliteit zoals dat op andere terreinen dan de plaats van dienst regels door het Hof is geformuleerd.

Het beginsel van gelijke behandeling vraagt om een gelijke behandeling van soortgelijke goederen en diensten. Merkx brengt in dit kader naar voren dat om dit te bereiken de BTW die is verschuldigd voor een goed of dienst altijd gelijk moet zijn, 
ongeacht de plaats waar de consument het aanschaft en de plaats waar de leverancier van het product is gevestigd. Dit zal volgens haar het meest nauwkeurig worden benaderd door een heffing in het land waar het verbruik plaatsvindt. ${ }^{48}$

Wat betreft grensoverschrijdende diensten tussen de interne markt en derde landen reflecteren de regels aan de eisen van het bestemmingsland beginsel, wat - zoals in paragraaf 2.3.2.1 is beschreven - verankerd is in de WTO. Dit wil niet zeggen, dat de fiscale neutraliteit, die gelijkheid tussen interne en externe diensten verlangt is uitgespeeld. De allocatieregels die het externe verkeer EU-derdelanden raken, kunnen soms - regelmatig door taxplanning geïnspireerd - de concurrentieverhoudingen tussen spelers van buiten en binnen de EU op hun kop zetten, waardoor maatregelen ter correctie daarvan weer voor een gelijk speelveld moeten zorgen; zie paragrafen 8.6.1 en 8.6.2.

\subsection{Vaste inrichting fiscaal rationeel?}

Het begrip vaste inrichting (secundaire vestigingsplaats) speelt, zoals wij hierna zullen zien, een belangrijke rol. Zowel bij B2B-diensten als bij B2C-diensten kan de aanwezigheid kan een vaste inrichting de plaats van heffing beïnvloeden. ${ }^{49}$

De algemene regel inzake de plaats van dienst voor B2B-diensten is gebaseerd op de plaats waar de afnemer van de diensten is gevestigd. Mochten deze diensten worden verricht voor een vaste inrichting van de ondernemer en deze vaste inrichting is gevestigd op een andere plaats dan die waar hij de zetel van de bedrijfsuitoefening heeft gevestigd, dan is de plaats van deze diensten de plaats waar de vaste inrichting zich bevindt. ${ }^{50}$

Voor B2C is de hoofdregel dat de plaats van dienst gesitueerd is op de plaats waar de dienstverrichter de zetel van zijn bedrijfsuitoefening heeft gevestigd. Als de betreffende diensten vanuit een vaste inrichting van de dienstverrichter worden verricht, en dat is een andere plaats dan waar hij de zetel van zijn bedrijfsuitoefening heeft gevestigd, dan geldt als plaats van dienst de plaats waar deze vaste inrichting zich bevindt. ${ }^{51}$

Ook onder vigeur van de Zesde richtlijn kon de aanwezigheid van een vaste inrichting relevant zijn voor de toekenning van de heffing aan een lidstaat. Zo bepaalt artikel 9, lid 1, Zesde richtlijn dat:

“Als plaats van een dienst wordt aangemerkt, de plaats waar de dienstverrichter de zetel van zijn bedrijfsuitoefening of een vaste inrichting heeft gevestigd van waaruit hij de dienst verricht, (...)."

48. M.M.W.D. Merkx, De woon- en vestigingsplaats in de btw (diss. Tilburg) 2011, blz. 80 en 81 49. Zie ook over de vaste inrichting de Uitvoeringsverordening (EU), nr. 282/2011 van 15 maart 2011, Pb EU van 23 maart 2011, L 77/1. Deze verordening is ingegaan op 1 juli 2011.

50. Artikel 44, BTW-richtlijn.

51. Artikel 45, BTW-richtlijn. 
De aanwezigheid van een vaste inrichting (secundaire vestigingsplaats) in een lidstaat kan dus tot gevolg hebben dat in die lidstaat BTW op aangifte moet worden voldaan en niet in de lidstaat waar het hoofdhuis (primaire vestigingsplaats) is gevestigd.

Verder kan een rechtspersoon die buiten de Europese Unie is gevestigd maar een vaste inrichting heeft in Nederland, een teruggaaf verzoek van de in rekening gebrachte BTW indienen overeenkomstig artikel 14 jo 17 Wet OB. Een verzoek om teruggaaf van in rekening gebrachte BTW op grond van de Dertiende richtlijn is dan niet nodig. ${ }^{52}$

Daarnaast moet een rechtspersoon die is gevestigd buiten Nederland en geen vaste inrichting in Nederland heeft een fiscaal vertegenwoordiger aanstellen om in aanmerking te komen voor een vergunning op grond van artikel 23 Wet $\mathrm{OB}^{53}$ Een vergunning om als fiscaal vertegenwoordiger op te treden wordt alleen verstrekt indien een zekerheid wordt gesteld tot een door de inspecteur vastgesteld bedrag, wat kosten met zich brengt. ${ }^{54}$

Ook artikel 12, tweede lid en derde lid Wet OB noemen de term 'vaste inrichting' en bepalen dat onder bepaalde omstandigheden de verschuldigdheid van BTW wordt verlegd naar de afnemer van de prestatie. ${ }^{55}$ Verder bepaalt artikel 12, vierde lid Wet $\mathrm{OB}$ dat verlegging van de belastingschuld voor een buitenlandse ondernemer met een vaste inrichting in Nederland toch mogelijke is, namelijk als de vaste inrichting niet bij de levering of dienst is betrokken. ${ }^{56}$ Tevens komt de term 'vaste inrichting' voor in artikel 37e Wet OB, welk artikel de bewijsregel weergeeft voor leveringen en diensten die in Nederland worden verricht. Afgezien van de genoemde gevolgen van een vaste inrichting kent de Nederlandse Wet OB in artikel 7, vierde lid de mogelijkheid dat een vaste inrichting wordt opgenomen in een fiscale eenheid. De BTWrichtlijn kent deze mogelijkheid niet in artikel 11, BTW-richtlijn (voorheen artikel 4,

52. Zie artikel 33, tweede en vijfde lid Wet OB. Per 1 januari 2010 is een nieuwe richtlijn van kracht die de Achtste richtlijn vervangt voor een elektronische procedure van teruggave voor belastingplichtigen die in een andere lidstaat zijn gevestigd dan de lidstaat van teruggaaf. De Achtste richtlijn is ingetrokken en vervangen door de richtlijn van 12 februari 2008 2008/9/EG, Pb 20 februari 2008, L 44/23.

53. De toepassing van artikel 23 Wet OB heeft tot gevolg dat onder bepaalde voorwaarden de belasting ter zake van invoer van goederen wordt geheven van de ondernemers die de goederen afnemen.

54. Artikel 24c Uitvoeringsbesluit omzetbelasting 1968.

55. Deze regeling is gebaseerd op artikel 194, 195 en 196, BTW-richtlijn (voorheen artikel 21, lid 1, sub a en b, Zesde richtlijn). Opvallend is deze met artikel 12 Wet OB corresponderende bepaling de term 'vaste inrichting' niet gebruikt maar verwijst naar 'de belastingplichtige afnemer' (artikel 196) dan wel 'degene is voor wie de goederenlevering of dienst wordt verricht' (artikel 194, BTW-richtlijn). 56. Artikel 192 bis, BTW-richtlijn. 
lid 4, Zesde richtlijn). ${ }^{57}$ Uit deze opsomming van enkele voorbeelden van regelgeving waar vaste inrichtingen mee in aanraking kunnen komen, blijkt dat de aanwezigheid van een vaste inrichting (of het ontbreken daarvan) voor de heffing van BTW dus nog al wat gevolgen kan hebben.

In vijf arresten op het terrein van de BTW heeft het Hof aangegeven onder welke voorwaarden sprake is van een vaste inrichting. ${ }^{58}$ Deze jurisprudentie gaat in alle gevallen om de uitleg van het begrip vaste inrichting zoals dat voorkomt in het hierboven aangehaalde artikel 9, lid 1, Zesde richtlijn. ${ }^{59}$ Het zal dan ook duidelijk zijn dat de betekenis van het begrip vaste inrichting in deze arresten van het Hof in belangrijke mate wordt gestuurd door het in de vorige paragraaf geformuleerde doel van de regels. ${ }^{60}$

Een sleutelrol vervult wederom het Berkholz-arrest. ${ }^{61}$

"Eveneens dienen de belastingautoriteiten van elke lidstaat in het kader van de door de richtlijn geboden keuzemogelijkheid te bepalen, welke plaats fiscaal het nuttigst wordt aangemerkt als plaats waar een bepaalde dienst is verricht. Volgens artikel 9, lid 1, lijkt de plaats waar de dienstverrichter de zetel heeft van zijn bedrijfsuitoefening heeft gevestigd in dit verband de voorkeur te verdienen, daar het in aanmerking nemen van een andere inrichting van waaruit de dienst wordt verricht, slechts van belang is ingeval de zetel ter zake niet tot een fiscaal rationele oplossing leidt of een conflict met een andere lidstaat doet ontstaan." (r.o. 17)

57. Overigens wordt in de literatuur betwijfeld of ook de BTW-richtlijn niet de mogelijkheid kent dat een vaste inrichting deel kan uitmaken van een fiscale eenheid. Zie in dit kader W.P Otto en E.M. Vrouwenvelder, Het grenzeloze gemak van de fiscale eenheid, BTW-Brief nr. 8/9 2002. Gezien het gegeven dat artikel 11, BTW-richtlijn spreekt over 'personen' die in het binnenland zijn gevestigd, kan volgens deze schrijvers zowel een vaste inrichting als een hoofdhuis deel uitmaken van een fiscale eenheid. Als het hoofdhuis dan wel de vaste inrichting ten minste in Nederland is gevestigd. Ze in dit kader ook G.J. van Norden, Fiscale eenheid voor de BTW uitgebreid, WFR 2002/6502, blz. 1541. Van Norden is van mening dat de uitsluiting van een vaste inrichting om deel uit te kunnen maken van het fenomeen fiscale eenheid naar alle waarschijnlijkheid een onrechtvaardige inbreuk op de vrijheid van vestiging vormt en tevens in strijd is met het discriminatieverbod uit de meeste belastingverdragen. 58. Hof 4 juli 1985, nr. 168/84, Günter Berkholz, Jur. 1985, blz. 2251; Hof 2 mei 1996, nr. C-231/94, Faaborg-Gelting-Linien A/S, V-N 1996/2120, pt. 22; Hof 20 februari 1997, nr. C-260/95, DFDS A/S, V-N 1997/1662, pt. 17; Hof 17 juli 1997, nr. C-190/95, ARO Lease BV, V-N 1997/2933, pt. 7; Hof 7 mei 1998, nr. C-390/96, Lease Plan Luxembourg SA, V-N 1998/57.19.

59. In het DFDS-arrest was de uitleg van de begrippen 'zetel van zijn bedrijfsuitoefening' en 'vaste inrichting' aan de orde zoals deze termen voorkomen in de reisbureauregeling van artikel 307, BTWrichtlijn (voorheen artikel 26, lid 2, Zesde richtlijn). Het Hof overweegt (r.o. 17) echter, dat voor de uitleg van deze begrippen te rade dient te worden gegaan bij artikel 9, lid 1, Zesde richtlijn. Vervolgens vervolgt het Hof in het DFDS-arrest de lijn van het eerder door mij behandelde Berkholz-arrest. Het DFDS-arrest wordt door mij dan ook verder behandeld in het kader van het verdelen van de heffingsbevoegdheid tussen de lidstaten.

60. Zie ook over de vaste inrichtingen problematiek de Uitvoeringsverordening (EU), nr. 282/2011 van 15 maart 2011, Pb EU van 23 maart 2011, L 77/1. Deze verordening gaat in op 1 juli 2011.

61. In het Faaborg-Gelting Linien-arrest is in r.o. exact hetzelfde te vinden. Hof 2 mei 1996, nr. C-231/ 94, V-N 1996/2120, pt. 22. 
Uit de rechtsoverweging blijkt dat de zetel van de bedrijfsuitoefening de voorkeur verdiend. Een andere inrichting is slechts aan de orde indien:

- de zetel niet tot een rationele oplossing leidt of;

- een conflict met een andere lidstaat ontstaat indien de zetel het uitgangspunt is.

Omgekeerd betekent dit dat daarmee ook vaststaat wanneer de vaste inrichting 'aan de beurt' is om de prestatie te lokaliseren. Dit doet vermoeden, dat ook al is er een vaste inrichting aanwezig in een lidstaat, de zetel het uitgangspunt blijft. Slechts indien één van de bovenstaande criteria aan de orde is, wordt voor het aanknopingspunt van de heffing overgesprongen naar de vaste inrichting. ${ }^{62}$

Het Hof gebruikt in het Berkholz-arrest voor het eerst de uitdrukking 'rationele oplossing'. De introductie van het element 'rationele oplossing' doet enigszins raadselachtig aan. ${ }^{63}$ Wanneer is in dit verband sprake van rationaliteit? In de vorige paragraaf is aandacht besteed aan de invulling van de term 'rationele afbakening'. Daar is onder meer geconcludeerd dat met de term 'rationele afbakening' wordt gedoeld op het vermijden van bevoegdheidsconflicten. Wordt met rationele oplossing ook gedoeld op het vermijden van bevoegdheidsconflicten? Om twee redenen aarzel ik om deze conclusie te trekken. Ten eerste wordt de term 'rationele afbakening' gebruikt door het Hof bij de verklaring van de zingeving van de regeling inzake de plaats van dienst. Met de term 'rationele oplossing' doelt het Hof op het antwoord op de vraag of hetzij de vaste inrichting moet worden gebruikt om de heffing bij aan te knopen, hetzij de zetel. De vraag is of daar een belangrijk nuance verschil inzit, dan wel wordt uiteindelijk toch hetzelfde beoogd weer te geven. De tweede reden waarom ik aarzel is de formulering van de rechtsoverweging zelf. Het Hof overweegt namelijk, dat de vaste inrichting slechts van belang is ingeval de zetel niet tot een fiscaal rationele oplossing leidt of een conflict met een andere lidstaat doet ontstaan. ${ }^{64}$ Het gebruik van het woord 'of doet vermoeden dat we het over twee verschillende voorwaarden hebben die het overspringen van de heffing van de zetel naar de vaste inrichting kunnen bepalen. In de volgende paragraaf bij de behandeling van het DFDS-arrest kom ik hierop terug.

62. Over de desbetreffende elementen vermelden Bijl, Van Hilten \& Van Vliet dat: “Deze laatste toevoeging komt ons merkwaardig voor, gelet op het bepaalde in artikel 9, lid 1, van de Zesde richtlijn dat deze conditie in het geheel niet kent." Zie D.B. Bijl, M.E. van Hilten \& D.G. van Vliet, Europese BTW en Nederlandse omzetbelasting, Deventer: Kluwer 2001, blz. 101. Zie tevens M.M.W.D. Merkx, De woon- en vestigingsplaats in de btw (diss. Tilburg), Deventer: Kluwer 2011, blz. 307 e.v. Zij brengt naar voren dat het voor de hand ligt op grond van de regels die vanaf 1 januari 2010 van kracht zijn de diensten toe te rekenen aan de vestiging die zich het meeste met het verrichten van de diensten heeft bezig gehouden.

63. Terra wijst er op dat in het Berkholz-arrest in de Nederlandse vertaling de voorwaarde van 'doelmatigheid' wordt gesteld en in het Faaborg-Gelting-arrest de term 'fiscaal rationele oplossing'. Een verschil dat in de oorspronkelijke procestaal niet voorkomt ('sinvolle Lösung'). Het element 'fiscaal rationele oplossing' vormt echter wel de kern in het DFDS-arrest. Zie: Terra, Europees indirect belastingrecht, Nijmegen: Ars Aequi Libri 2001, blz. 237.

64. Zie r.o. 15 in het eerder aangehaalde ARO Lease-arrest. 
Het Hof heeft in het Berkholz-arrest de voorwaarden voor een vaste inrichting aangegeven:

"Uit het onderlinge verband tussen de in artikel 9 gebruikte begrippen en uit het hiervoren vermelde doel van deze bepaling blijkt, dat slechts kan worden overwogen een andere inrichting dan de zetel aan te merken als plaats waar de dienst wordt verricht, indien de inrichting een zekere bestendigheid vertoont, doordat zij duurzaam over het personeel en de technische middelen beschikt die voor bepaalde diensten noodzakelijk zijn. Het aan boord van een zeeschip installeren van speelautomaten die van tijd tot tijd worden onderhouden, kan niet als een dergelijke inrichting worden beschouwd, vooral niet wanneer de vaste zetel van de exploitant van deze automaten een bruikbaar aanknopingspunt is voor de belastingheffing." (r.o. 18)

Vereisten voor de aanwezigheid van een vaste inrichting zijn dus:

- een zekere bestendigheid;

- duurzaam beschikken over personeel en technische middelen die noodzakelijk zijn om de prestaties te kunnen verrichten. ${ }^{66}$

Advocaat-generaal Mancini denkt daar echter anders over in zijn conclusie bij het Berkholz-arrest. ${ }^{67}$

“(...) aangezien in de zevende overweging van de considerans weliswaar over 'zetel' wordt gesproken, maar duidelijk niet in technische zin - helpt de considerans van de richtlijn ons ook niet verder. Ik stel dan ook voor terug te grijpen op het algemene beginsel, volgens hetwelk de BTW wordt geheven op de plaats van het verbruik. Op grond daarvan moet namelijk de voorkeur worden gegeven aan het criterium, met behulp waarvan de dienst het meest nauwkeurig kan worden gelokaliseerd, en het lijdt geen twijfel dat van beide criteria het - kennelijk nauwkeuriger - criterium van de vaste inrichting hiervoor het meest geschikt is."

Mancini sluit aan bij de plaats van het 'verbruik' en wel omdat dit het algemene beginsel van de BTW is en komt dan i.c. uit bij de vaste inrichting. De bewoordingen van het door Mancini gebruikte criterium stemmen overeen met wat ik in paragraaf 2.2 verbruiksbeginsel heb genoemd, maar aldaar niet heb betrokken op een criterium ten behoeve van de allocatie van diensten en dus niet op het internationale vlak heb betrokken. In de literatuur komt men dit wel tegen onder de idee dat een

65. Zie ook r.o. 17 in het Faaborg-Gelting-Linien-arrest.

66. De BTW-verordening vermeldt in de leden 1 en 2 van artikel 11: “(..) voldoende mate van duurzaamheid en een - wat personeel en technische middelen betreft - geschikte structuur (...)”. Dit lijkt mij in lijn met het Berkholz-arrest, waarbij wel de kanttekening geplaatst moet worden dat de inkoop-vi van lid 1 gericht is op inrichtingen die de “(...) voor haar eigen behoeften verrichte diensten te kunnen afnemen en ter plaatste te gebruiken”. De inkoop-vi is (nog) niet in de jurisprudentie aan de orde geweest. Zie uitgebreid over deze criteria M.M.W.D. Merkx, De woon- en vestigingsplaats in de btw (diss. Tilburg) 2011, blz. 286 t/m 307.

67. AG Mancini in zijn conclusie van 6 juni 1985 bij het Berkholz-arrest, Jur. 1985, blz. 2252, pt. 2, halverwege een na laatste alinea. 
verbruiksbelasting het bestemmingslandbeginsel volgt refereert aan de conclusie. ${ }^{68}$ Wij zien het beginsel wel terug in het DFDS-arrest, behandeld in de volgende paragraaf.

Het Hof eist dat de noodzakelijke middelen aanwezig zijn om de dienst te kunnen verrichten. Dit zal sterk afhankelijk zijn van de aard van de dienst. Aan de verhuur van auto's zijn dan andere eisen te stellen dan aan het verstrekken van maaltijden.

Het Hof merkt speelautomaten op een boot, een restauratieruimte op een boot en een vloot van auto's niet aan als een vaste inrichting. Van de prejudiciële procedures over de invulling van het begrip 'vaste inrichting' was volgens mij een restauratieruimte het meest kansrijk om te worden aangemerkt als een vaste inrichting. Vooral ook als deze kennelijk toch wel duurzaam over het personeel en de technische middelen beschikt die noodzakelijk zijn om de diensten te verrichten. Het Hof besliste echter in het Faaborg-Gelting-arrest dat een restauratieruimte op een schip niet is aan te merken als een vaste inrichting.

"Dit is kennelijk niet het geval met een restauratieruimte op een schip, vooral niet wanneer, zoals in casu, de vaste zetel van de exploitant van het schip een bruikbaar aanknopingspunt voor de belastingheffing vormt," (r.o. 18)

Afgezien van het startpunt van interpretatie, namelijk de prioriteit welke aan de zetel boven de vaste inrichting wordt verleend, zou de vraag kunnen zijn of men de restauratie op de boot überhaupt tot een 'vaste inrichting' zou kunnen promoveren. Het is duidelijk dat een op zee deinende boot niet meteen als 'vast' zal worden ervaren en ook in de rechtspraak in de directe belastingen speelde 'vaste grond onder de voeten' een rol. ${ }^{69}$ Hoe dan ook: het vraagstuk vast versus beweging verdwijnt in de voorrang van de zetel als deze althans een bruikbaar aanknopingspunt biedt om de belastingheffing aan op te hangen. Zoals eerder naar voren is gebracht, blijkt duidelijk dat het Hof de voorkeur heeft om de zetel van de bedrijfsuitoefening als uitgangspunt te nemen. Ook al is voldaan aan de vereisten van een vaste inrichting (duurzaamheid en beschikken over personeel en technische middelen om de dienst te kunnen verrichten), dan nog wil dat niet tot gevolg

68. zie voor een bespreking van dit verband en het in elke geval juridisch dwingende verband tussen indirecte belasting en bestemmingslandbeginsel, alsmede de uitwisselbaarheid van begrippen in de indirecte belasting met die in de directe belasting, Denie, De overheid in de omzetbelasting (diss Leiden), Deventer: Kluwer 1987, blz. 47 t/m 48 en de verwijzingen op laatstgenoemde pagina.

69. Zie voor een uitgebreide beschouwing over de problematiek in de directe belastingen, Arvid A. Skaar, Permanent Establishment, Erosion of a Tax Treaty Priciple, Deventer/Boston: Kluwer Law and Taxation Publishers 1991, blz. 126 t/m 152. Interessant is met name de op blz. 137 aangehaalde Duitse jurisprudentie op het terrein van de directe belastingen. Ook op het terrein van de directe belastingen is aan de orde geweest de vraag of een restaurant op een veerboot die vaart tussen Duitsland en Denemarken kan worden aangemerkt als een vaste inrichting. De Duitse rechter besliste dat vereist is een directe verbinding met de grond. Dus ook voor de heffing van de directe belastingen was geen sprake van een vaste inrichting. Uit de door Skaar beschreven jurisprudentie maak ik echter op dat dit leerstuk voor de heffing van de directe belastingen meer is uitgekristalliseerd dan in de jurisprudentie op het terrein van de BTW. 
hebben dat de diensten worden verricht vanuit de vaste inrichting. De aanwezige vaste inrichting is dus niet in alle gevallen het aangrijpingspunt voor de BTWheffing. Alleen onder bijzondere omstandigheden springt het aanknopingspunt van de belastingheffing over naar een andere inrichting. ${ }^{70}$ Namelijk ingeval de zetel niet tot een rationele oplossing leidt of een conflict met een andere lidstaat ontstaat indien de zetel het uitgangspunt is. ${ }^{71}$ Dit lijkt te duiden op een aanzienlijke beperking van de functie van het begrip 'vaste inrichting' in de BTW. ${ }^{72}$ In ieder geval een duidelijk andere invulling van het begrip vaste inrichting zoals dat in de verdragen ter voorkoming van dubbele belasting in de directe belastingen gebruikelijk is. ${ }^{73}$ Zo kan het dus voorkomen dat voor de heffing van VPB sprake is van een vaste inrichting, terwijl voor de heffing van BTW de zetel van de bedrijfsuitoefening het uitgangspunt blijft.

Bij het onderzoek of sprake is van een vaste inrichting gaat het Hof systematisch te werk. Dit blijkt onder meer uit het ARO Lease-arrest en dan in het bijzonder uit de rechtsoverwegingen 17,18 en 19.

“Opgemerkt zij, dat de diensten die bij het leasen van auto's worden verricht, hoofdzakelijk bestaan in het onderhandelen over het opmaken, ondertekenen en beheren van overeenkomsten en in het feitelijk ter beschikking stellen aan de cliënten van de overeengekomen auto's, die eigendom blijven van de leasemaatschappij." (r.o. 18)

70. Ook Merkx trekt deze conclusie uit de jurisprudentie. Wel is zij van mening dat bevoegdheidsconflicten beter te vermijden zijn als wordt uitgegaan van de vestiging die bij het verrichten van de dienst het meest is betrokken. Zij ziet ook steun voor dit uitgangspunt in de tekst van artikel 45, BTWrichtlijn (tekst vanaf 2010) waar wordt gesproken over diensten verricht 'vanuit' een vaste inrichting. M.M.W.D. Merkx 2011, blz. 307 en 312.

71. Vgl. M.M.W.D. Merkx, De woon- en vestigingsplaats in de btw (diss. Tilburg) 2011, blz. 309 en 310. Zij meent dat in geval van een bevoegdheidsconflict tussen lidstaten de voorkeur voor de zetel van bedrijfsuitoefening vervalt en heffing plaatsvindt in het land waar een andere inrichting is gevestigd. 72. Farmer en Lyal trekken uit het Berkholz-arrest de conclusie dat het Hof terughoudend is in het aanvaarden van een vaste inrichting als uitgangspunt om bij aan te knopen voor de BTW-heffing. Zij brengen echter naar voren dat het Berkholz-arrest gelezen moet worden in het licht van het aan de orde zijnde feitencomplex. In het Berkholz-arrest gaat het om een belastingplichtige die probeerde te ontsnappen aan de Europese belasting jurisdictie door te proberen een vaste inrichting te creëren buiten de reikwijdte van de BTW-regelgeving. In een 'echte' casus is de meest geschikte benadering om aan te knopen bij degene waarvan primair de middelen worden gebruikt om de desbetreffende dienst te kunnen verrichten. P. Farmer \& R. Lyal, EC Tax Law, Oxford: Clarendon Press 1994, blz. 160.

73. Zie artikel 5, lid 2 OECD-model 1977, waar wordt aangegeven wat in ieder geval aangemerkt kan worden als een permanent establishment. Zie voor een vergelijking van het begrip 'vaste inrichting' in de BTW en directe belastingen: Pasquale Pistone, Fixed Establisment and Permanent Establishment, VAT Monitor 1999, nr. 3, blz. $101 \mathrm{t} / \mathrm{m}$ 106. Pistone spreekt de wens uit tot een grotere rol van de vaste inrichting in de BTW-heffing. Volgens hem wordt beter recht gedaan aan het neutraliteitsbeginsel ingeval voor de heffing wordt aangeknopt bij de vaste inrichting. Tussen binnenlandse aanbieders en aanbieders met een zetel in een andere staat ontstaat dan minder snel een ongelijkheid voor de heffing van BTW. Verder wijst Pistone erop, dat door technische ontwikkelingen de geografische locatie van personeel minder belangrijk is. Het aangrijpingspunt voor de BTW dreigt bij dergelijke diensten verloren te gaan bij een beperkte uitleg van het begrip vaste inrichting, met alle concurrentie verstoringen van dien. Ook brengt Pistone naar voren dat in een 'globalized economy' een al te groot verschil tussen het begrip vaste inrichting in de BTW en income tax, niet gewenst is. 
Eerst stelt het Hof vast welke elementen kenmerkend zijn om de dienst te kunnen verrichten. Dit zal dus afhangen van de aard van de dienst. Na deze elementen te hebben geïdentificeerd, vervolgt het Hof:

"Hieruit volgt, dat wanneer een leasemaatschappij in een Lid-Staat niet over eigen personeel en niet over een structuur met een voldoende mate van duurzaamheid beschikt in het kader waarvan overeenkomsten kunnen worden opgemaakt of beslissingen van dagelijks bestuur kunnen worden genomen, dat wil zeggen een structuur die geschikt is om een zelfstandige verrichting van de betrokken diensten mogelijk te maken, niet kan worden aangenomen, dat zij in die Lid-Staat over en vaste inrichting beschikt." (r.o. 19)

Het begrip vaste inrichting, zo blijkt ook hier, vraagt om een feitelijke invulling. Tot hier hebben wij samengevat gezien het aspect van het begrip dat om een feitelijke invulling vraagt en de voorrang die, behoudens uitzondering, de zetel boven de vaste inrichting krijgt.

In de BTW-verordening is een verduidelijking gegeven van de vereisten voor een vaste inrichting. Bijzonder is dat artikel 11, lid 1, BTW-verordening bepaalt - voor de toepassing van artikel 44, BTW-richtlijn (B2B) - dat onder een vaste inrichting dient te worden verstaan iedere andere inrichting dan de zetel van de bedrijfsuitoefening die gekenmerkt wordt door een voldoende mate van duurzaamheid en een - wat personeel en technische middelen betreft - geschikte structuur om de voor haar eigen behoeften verrichte diensten te kunnen afnemen en ter plaatse te gebruiken (inkoop-vi). ${ }^{74}$ In de literatuur is naar voren gebracht dat de introductie van de inkoop-vi in de BTW-verordening een uitbreiding is van de gangbare praktijk gezien het feit dat geen uitgaande prestaties zijn vereist. ${ }^{75}$ In ieder geval heeft de jurisprudentie enkel betrekking op de vaste inrichting die diensten verricht en is nog niet aan de orde geweest een vaste inrichting die diensten inkoopt. De BTWverordening breidt dan ook het begrip vaste inrichting uit in vergelijking met de jurisprudentie en schept zo onzekerheid voor de praktijk. ${ }^{76}$

\subsection{Het begrip vaste inrichting in het DFDS-arrest}

\subsubsection{Hulporgaan}

Het DFDS-arrest bouwt het begrip vaste inrichting met enkele elementen uit. Ik behandel deze hierna. In deze procedure is sprake van een Deense vennootschap

74. Vgl. artikel artikel 45, BTW-richtlijn jo. artikel 11, lid 2, sub a, BTW-verordening voor de definitie van de vaste inrichting die uitgaande diensten verricht.

75. I. Lejeune, E. Cortvriend en D. Accorsi, Implementing Measures Relating to EU Place-of-Supply Rules: Are Business Issues Solved and Is Certainty Provided?, International VAT Monitor May/June 2011, blz. 144. Zie ook voor een kritische beschouwing M.M.W.D. Merkx, Btw-uitvoeringsverordening uitvoerbaar?, WFR 2011/1308.

76. Zie voor een kritische beschouwing over het fenomeen BTW-verordening G.G.M. Kortenaar, Gebruik uitvoeringsverordening als instrument in de Europese BTW, WFR 2012/98. De vraag komt op hoe de BTW-verordening zich verhoudt tot de BTW-richtlijn. Zie hierover G.J. Slooten, De BTWverordening: mogen wijzigingen vermomd gaan als 'verduidelijking'? 
met een dochtervennootschap die is opgericht naar Engels recht en is gevestigd in Engeland. De Deense vennootschap heeft als doel de scheepvaart, het reizen en het vervoer en heeft een contract gesloten met de Engelse dochtermaatschappij waarin is bepaald dat de dochtervennootschap het algemene verkoop- en reserveringsbureau is voor het Verenigd Koninkrijk en Ierland. De reizen worden verkocht op naam van de moedermaatschappij. Met de verkoop van de reizen op naam van de moedermaatschappij heeft het DFDS-concern kennelijk de bedoeling om BTW-vrij reizen aan te bieden. Denemarken heeft immers gebruik gemaakt van de in artikel 371 juncto Bijlage X, deel B, sub 13, BTW-richtlijn (voorheen artikel 28, derde lid, sub b, juncto bijlage $\mathrm{F}$, post 27, Zesde richtlijn) opgenomen mogelijkheid om diensten van reisorganisatoren vrij te stellen van BTW. Indien de dienst van de moeder in Denemarken plaatsvindt, dan is dus geen BTW-heffing aan de orde. De Engelse Belastingdienst is daarentegen van mening dat de Engelse vennootschap BTW moet betalen over de voor haar rekening verkochte rondreispakketten omdat de dochtermaatschappij is aan te merken als een vaste inrichting van de moedermaatschappij in Denemarken. Het Hof start met te verwijzen naar, zoals in paragraaf 8.2, omschreven doel van de regels betreffende de plaats van dienst. Vervolgens herhaalt het Hof de overweging uit het Berkholz-arrest waarin is beslist dat de voorkeur uitgaat naar de zetel. Het Hof overweegt echter dat de zetel niet leidt tot een fiscaal rationele oplossing:

“(...), aangezien daardoor wordt voorbijgegaan aan de feitelijke plaats van verkoop van de rondreizen, die door de nationale autoriteiten, ongeacht de bestemming van de reiziger, op goede gronden als het nuttigste aanknopingspunt wordt beschouwd." (r.o. 22)

"Gelijk de advocaat-generaal in de punten 32-34 van zijn conclusie heeft beklemtoond, vormt de inaanmerkingneming van de economische realiteit een fundamenteel criterium van de plaats van belastingheffing over diensten van reisbureaus, namelijk de vaste inrichting van waaruit die diensten worden verricht, heeft juist tot doel rekening te houden met de mogelijke spreiding van de activiteiten van de reisbureaus over verschillende plaatsen op het grondgebied van de Gemeenschap. Het systematisch toepassen van de zetel van de bedrijfsuitoefening zou overigens tot verstoringen van de mededinging kunnen leiden, aangezien het ondernemingen die activiteiten in een Lid-staat verrichten, er dreigt toe aan te zetten om, teneinde aan belastingheffing te ontsnappen, hun zetel te vestigen op het grondgebied van een andere Lid-staat, die gebruik heeft gemaakt van de mogelijkheid om de betrokken diensten te blijven vrijstellen van BTW." (r.o. 23)

Onder dergelijke omstandigheden, zo vervolgt het Hof, vormt de vaste inrichting het aanknopingspunt voor deze diensten. Kennelijk is dus het gevaar dat een situatie ontstaat dat geen heffing plaatsvindt een reden om de vaste inrichting als uitgangspunt te nemen. Tot zover geen verrassend uitgangspunt gezien het feit dat al eerder naar voren is gebracht dat het doel van de regelgeving is het voorkomen van dubbele belasting dan wel een situatie van niet-heffing.

In paragraaf 8.3 is geconcludeerd dat een andere inrichting dan de zetel van de bedrijfsuitoefening als uitgangspunt dient te worden genomen als onder meer de zetel niet leidt tot een rationele oplossing. De vorige alinea maakt duidelijk dat een dergelijke situatie aan de orde is als een situatie van niet-heffing van belasting binnen de Europese Unie zich voordoet. 
Na de bovenstaande overwegingen gaat het Hof over tot het onderzoeken of er een vaste inrichting aanwezig is waarbij de heffing kan aanknopen. Als een vaste inrichting kan worden beschouwd een onderdeel van de rechtspersoon en is dan ook per definitie niet onafhankelijk van de zetel. Hier lijkt toch een belangrijke hobbel aanwezig te zijn. De Engelse dochtermaatschappij is een zelfstandig rechtspersoon in de vorm van een limited company waarvan de aandelen voor de volle honderd procent worden gehouden door de Deense moedermaatschappij. Dan zijn er zijn er juridisch twee onafhankelijk van elkaar opererende personen. Het Hof neemt echter een - gelet op de commentaren in de BTW-wereld - verrassende stap:

"In dit verband volstaat de door het VAT Tribunal genoemde omstandigheid, dat de kantoren van de Engelse dochtermaatschappij, die een eigen rechtspersoon is, aan deze dochtermaatschappij en niet aan DFDS toebehoren, op zich niet om aan te tonen, dat eerstgenoemde daadwerkelijk onafhankelijk is van laatstgenoemde. Integendeel, uit de verwijzingsbeschikking, inzonderheid uit de vermelding dat DFDS het gehele kapitaal van haar dochtermaatschappij bezit en dat aan deze dochtermaatschappij door de moedermaatschappij een aantal contractuele verplichtingen zijn opgelegd, blijkt, dat de in het Verenigd Koninkrijk gevestigde vennootschap slechts als assistent van laatstgenoemde optreedt." (r.o. 26)

Kennelijk volstaat in dit verband het bezit van de volle $100 \%$ van het aandelen kapitaal en een contractueel intensieve relatie tot de constatering dat sprake is van een 'assistent'. In de literatuur is op diverse plaatsen twijfel geuit over de juistheid van deze beslissing. ${ }^{77}$ Zo vermeldt de redactie van Vakstudie Nieuws:

"Dit is een behoorlijk verstrekkende conclusie. Het heeft iets weg van een fiscale eenheid over de grenzen. Het zal duidelijk zijn dat we en lastig gebied betreden. De grenzen zullen in de praktijk verder moeten worden afgebakend. Een echt onafhankelijke agent optredende voor een aantal reisbureaus lijkt hier in elk geval niet onder te vallen." ${ }^{78}$

Van Hilten is wat scherper in haar kritiek op deze benadering van het Hof. ${ }^{79} \mathrm{Zij}$ is van mening dat het gegeven dat de dochtermaatschappij slechts één opdrachtgever heeft, die bovendien $100 \%$ van de aandelen bezit - hetgeen een zekere afhankelijkheid impliceert - daarbij niet zou mogen uitmaken. Zij wijst er op dat de BTWrichtlijn niet de figuur van de onzelfstandige rechtspersoon kent, behalve waar het

77. D.B. Bijl, M.E. van Hilten \& D.G. van Vliet vermelden de volgende kritiek op het DFDS-arrest: “Het Hof gaat naar onze mening in dit arrest ten onrechte voorbij aan de omstandigheid dat de betreffende dochtermaatschappij, beoordeeld naar de criteria van artikel 4 van de Zesde richtlijn, een zelfstandige belastingplichtige in de zin van de omzetbelasting is, tenzij zou moeten worden aangenomen dat de dochtermaatschappij niet aan het zelfstandigheidvereiste zou voldoen (...). Wellicht heeft bij de beslissing van het Hof een rol gespeel dat in de voorgelegde casus sprake was van een 'BTWbesparende constructie'; wij houden het er vooralsnog op dat het in casu om een incident gaat en dat het niet de algemene regel is dat een buitenlandse belastingplichtige die gebruikt maakt van de diensten van een dochtervennootschap als agent (laat staan die van een derde als agent) in het binnenland alleen daardoor al en vaste inrichting in het binnenland heeft." D.B. Bijl, M.E. van Hilten \& D.G. van Vliet 2001, blz. 103.

78. V-N 1997/1662, pt. 17.

79. M.E. Van Hilten, Vaste inrichting en BTW: (on)zelfstandig en niet onafhankelijk, WFR 1997/1369. 
gaat om rechtspersonen die deel uitmaken van een fiscale eenheid en die figuur is, zoals blijkt uit de tekst van thans artikel 11, BTW-richtlijn, 'over de grens' niet mogelijk. Zij wijst er tevens op dat de beslissing van het Hof mogelijk gestuurd is door de jurisprudentie op het terrein van de mededinging. In ieder geval wijst de conclusie van de advocaat-generaal in deze zaak naar het arrest Vereniging voor Vlaamse reisbureaus. ${ }^{80}$ De advocaat-generaal heeft zich dan ook voornamelijk geconcentreerd op de arresten van het Hof over de vraag wanneer een handelsagent in het kader van artikel 101 VwEU (voorheen artikel 81 EG) als een van de opdrachtgever onafhankelijke eenheid kan worden beschouwd. ${ }^{81}$ Van Hilten is echter van mening dat de eventuele afhankelijkheid van een (neven)vestiging niet het onderscheidend criterium is voor de BTW. Het gaat volgens haar veeleer om de (juridische) zelfstandigheid die bepalend is voor diens status. ${ }^{82}$

Zonder dat het Hof expliciet verwijst naar de jurisprudentie op het terrein van de mededinging, kan men het ermee eens zijn, dat de jurisprudentie op dat terrein doorklinkt in het DFDS-arrest. ${ }^{83}$ Uit de eerder aangehaalde conclusie van advocaat La Pergola (en de in zijn conclusie aangehaalde jurisprudentie) maak ik het volgende op. Het Hof neemt in de beschouwing mee de jurisprudentie toegespitst op handelsagenten. De jurisprudentie van artikel $101 \mathrm{VwEU}$ (voorheen artikel $81 \mathrm{EG)}$ ) is enkel van toepassing indien de agent onafhankelijk is. Is daarentegen de handelsagent geïntegreerd in de onderneming van de opdrachtgever, dan verdwijnt hij als zelfstandig marktdeelnemer. ${ }^{84}$ Het Hof gebruikt de criteria die zijn ontwikkeld in de jurisprudentie op het terrein van artikel 101 VwEU om na te gaan of een handelsagent een van de opdrachtgever onafhankelijke eenheid is. Of anders geformuleerd, nagegaan wordt of een rechtspersoon kennelijk onderdeel uitmaakt van het bedrijf van een rechtspersoon in een ander staat en dan ook dusdanig daarvan afhankelijk is dat sprake is van een vaste inrichting.

80. Hof 1 oktober 1987, nr. 311/85, Vereniging voor Vlaamse reisbureaus, Jur. 1987, blz. 3801.

81. De artikelen $101 \mathrm{t} / \mathrm{m} 106 \mathrm{VwEU}$ (voorheen $81 \mathrm{t} / \mathrm{m} 86 \mathrm{EG}$ ) omvatten regels die concurrentievervalsing door ondernemingen verbieden.

82. Zie in praktisch gelijke zin Geschriften van de Vereniging voor Belastingwetenschap, Samenwerkingsverbanden in de omzetbelasting, no. 214 waar op blz. 18 als commentaar op het DFDS-arrest is vermeld: "Er lijkt hier sprake van een doelredenering: eerst wordt bezien welke plaats van de dienst wenselijk is en vervolgens wordt een vaste inrichting gecreëerd om die plaats te realiseren. Naar onze mening is de civielrechtelijke zelfstandigheid van een rechtspersoon een belangrijk uitgangspunt bij de beoordeling van het ondernemerschap en wordt daarop hier door het Hof van Justitie EG op niet overtuigende wijze en inbreuk gemaakt."

83. Zie ook Merkx, De woon- en vestigingsplaats in de btw (diss. Tilburg) 2011, blz. 297 en 298.

84. Zie in dit kader ook de conclusie van A-G Tesauro bij het arrest van het Hof van 24 oktober 1995 nr. C-266/93, Volkswagen en VAG Leasing, Jur. 1995, blz. I-3479. 
Uit de jurisprudentie op het terrein van de reikwijdte van artikel 101 VwEU zijn de volgende criteria te ontwikkelen wat betreft 'afhankelijkheid'. Uit het eerder genoemde arrest Vereniging van Vlaamse Reisbureaus blijkt namelijk dat:

“(...) een reisagent als door de nationale rechter bedoeld, moet worden beschouwd als een zelfstandig tussenpersoon, die een autonome dienstverleningscapaciteit uitoefent. Immers, enerzijds verkoopt een reisagent georganiseerde reizen van een zeer groot aantal touroperators, anderzijds verkoopt een touroperator zijn reizen via een zeer groot aantal reisagenten. (...) een dergelijke reisagent (kan) dan ook niet worden aangemerkt als een in de onderneming van deze of gene touroperator geïntegreerd hulporgaan." (r.o. 20)

Deze overweging vormt de sleutel in de conclusie van advocaat-generaal La Pergola bij het DFDS-arrest. In tegenstelling echter tot de uitkomst in het arrest inzake de Vereniging van Vlaamse reisbureaus, concludeert La Pergola tot afhankelijkheid. Hij baseert deze conclusie op de volgende elementen:

- de moedermaatschappij bezit het volledige aandelenkapitaal;

- DFDS Ltd. mag enkel als agent van de moedermaatschappij optreden en niet voor andere partijen (dit is een verschil in het feitencomplex in vergelijking met het arrest inzake de Vereniging van de Vlaamse Reisbureaus);

- de noodzaak dat de moedermaatschappij goedkeuring verleent met betrekking tot besluiten van DFDS Ltd.(zoals het in dienst nemen van kader personeel, afsluiten belangrijke contracten, geen beoordelingsmarge bij de prijszetting).

Op grond van deze elementen concludeert La Pergola:

“(...), dat de Engelse vennootschap, wanneer men door het scherm van de rechtsvorm heenkijkt, als een hulporgaan van de moedermaatschappij optreedt."

Vervolgens ondersteunt de advocaat-generaal deze conclusie met een verwijzing naar het arrest Volkswagen en VAG Leasing ${ }^{85}$ waarin het Hof overweegt over het element 'risico':

“Tussenpersonen verliezen hun hoedanigheid van zelfstandig marktdeelnemer slechts wanneer zij geen van de risico's dragen die voortvloeien uit de overeenkomsten die zij voor rekening van de opdrachtgever hebben gesloten."

De Engelse vennootschap lijkt geen enkel financieel risico te dragen met betrekking tot de contracten die zij als agent van de Deense vennootschap met de consumenten afsluit. ${ }^{86}$ Kortom, de lastige hobbel die moest worden genomen, neemt La Pergola onder verwijzing naar de arresten van het Hof over de uitleg van artikel 101 VwEU

85. Hof 24 oktober 1995, nr. C-266/93, Volkswagen en VAG Leasing, Jur. 1995, blz. I-3479.

86. Uit het FCE-arrest blijkt ook dat de aanwezigheid van bedrijfsrisico van belang is voor de zelfstandigheid van een vaste inrichting ten opzichte van het hoofdhuis. In dit arrest is beslist dat een bijkantoor in Italië afhankelijk is van het hoofdkantoor in Engeland doordat het hoofdkantoor het economisch bedrijfsrisico draagt. Het bijkantoor en het hoofdkantoor worden in het FCE-arrest aangemerkt als één belastingplichtige. Wel is het zo dat in het FCE-arrest sprake is van één rechtspersoon in tegenstelling tot het DFDS-arrest. Hof 23 maart 2006, nr. C-210/04, FCE Bank plc., BNB 2006/ 184, V-N 2006/18.24, NTFR 2006/468. 
(voorheen artikel 81 EG). In het DFDS-arrest volgt het Hof deze lijn en komt tot de conclusie dat de Limited in Engeland afhankelijk is van de Deense vennootschap. ${ }^{87}$ Vervolgens komt dan de vraag aan bod of DFDS Ltd voldoet aan de overige vereisten van een vaste inrichting. Deze vraag beantwoordt het Hof vervolgens aan de hand van de criteria die ik in paragraaf 8.3 heb beschreven.

Uit het bovenstaande is volgens mij de conclusie te trekken dat in het Unierecht onder omstandigheden een rechtspersoon afhankelijk (hulporgaan) kan zijn van de moedermaatschappij. In het DFDS-arrest was dit een noodzakelijke stap om tot de constatering van een vaste inrichting te komen. Uiteraard roept deze constatering andere vragen op. ${ }^{88}$ Bijvoorbeeld of er belaste prestaties zijn te onderkennen tussen vaste inrichting en hoofdhuis. ${ }^{89}$ Het zijn tenslotte verschillende rechtspersonen. In het FCE-arrest is beslist dat de diensten die het hoofdhuis verricht aan de vaste inrichting in een andere lidstaat niet zijn onderworpen aan de BTW. ${ }^{90}$

Duidelijk is ook dat gezien het gegeven dat de BTW deel uitmaakt van het Europees recht, elementen uit het overige Unierecht zich kunnen doen laten gelden in de BTW. In dit geval is de jurisprudentie van het Hof op het terrein van de mededinging van belang voor de uitleg van de BTW-richtlijn en dan in het bijzonder bij de beantwoording van de vraag of een vaste inrichting aanwezig is.

Verder is ook duidelijk dat het DFDS-arrest past in de lijn die is te destilleren uit de in paragraaf 8.2 behandelde arresten op het terrein van de regelgeving die de plaats

87. Het verschijnen van het DFDS-arrest was voor de Engelse Belastingdienst aanleiding om aan te geven onder welke omstandigheden sprake is van een rechtspersoon die aangemerkt kan worden als een vaste inrichting van de moedermaatschappij. Zie Business Brief 12/98, 21 mei 1998. Inmiddels heeft ook de Engelse rechter in vergelijkbare zin beslist als het DFDS-arrest. Zie Commissioners of Customs and Excise v Chinese Channel Ltd (Hong Kong) [1998] STC 347. Onder meer is volgens de Engelse rechter van belang de reële functie van de overeenkomst. In deze procedure was Chinese Channel in Engeland afhankelijk van de gelieerde rechtspersoon in Hong Kong, in die zin dat zij geen risico liep en geen contracten mocht afsluiten. De Engelse rechter besliste dat zij niet werkelijk onafhankelijk was en dan ook kon worden aangemerkt als een vaste inrichting van de rechtspersoon in Hong Kong.

88. Terra brengt in het kader van het DFDS-arrest onder meer naar voren dat: "It is also possible that in other circumstances an agent will be considered to act merely as an auxiliary organ of another company. The reasoning of the ECJ leaves scope for an 'economic' approach in other cases. The ramifications of his decision cannot be foreseen at this stage. It is for example unclear whether only an agent acting solely on behalf of another company would qualify as fixed establishment." B.J.M. Terra 1998, blz. 137.

89. Zie ook M.E. van Hilten, Bancaire en financiële prestaties in de Europese BTW, met name paragraaf 3.2.3.2. Zij verwijst onder meer naar en brief van de Commissie ( 5 april 1989 van DG XXI aan Coopers \& Lybrand te Parijs, kenmerk MMM/cva/251) waaruit is op te maken dat de vaste inrichting weliswaar 'onderdeel' van de belastingplichtige is, doch dat zij voor de heffing van BTW zo veel mogelijk als afzonderlijke vestiging dient te worden bezien. Het lijkt er echter op dat voor de Nederlandse BTWpraktijk deze discussie is beslecht door het verschijnen van het arrest van de HR van 14 juni 2002, nr. 35 976, V-N 2002/32.20. Uit dit arrest is onder meer op te maken dat geen met BTW belaste diensten plaatsvinden tussen een vaste inrichting en een buitenlands hoofdhuis.

90. Hof 23 maart 2006, nr. C-210/04, FCE Bank plc., BNB 2006/184, V-N 2006/18.24, NTFR 2006/468. 
van een dienst toewijst aan een lidstaat. Door het Hof wordt namelijk bereikt dat een leemte in de BTW-heffing tussen Denemarken en Engeland wordt gedicht door de gegeven invulling van het begrip 'vaste inrichting'. Het betreft echter wel een mogelijke leemte die de lidstaten over zich zelf hebben afgeroepen door de overgangsregeling die een vrijstelling voor reisbureaus mogelijk maakt (artikel 371 juncto Bijlage X, deel B, sub 13, BTW-richtlijn). Kennelijk speelt dit aspect voor het Hof geen rol in deze prejudiciële procedure bij het nastreven van het voorkomen van een situatie van niet-heffing van BTW.

\subsubsection{Economische realiteit}

Zowel in het DFDS-arrest als in het ARO Lease-arrest inzake de plaats van dienst regels komt de term 'economische realiteit' voor. Ook in het Planzer-arrest ${ }^{91}$ (over de uitleg van de Achtste en Dertiende richtlijn) en in de zaak Tanoarch ${ }^{92}$ (over de overdracht van een aandeel in een octrooi), komt een verwijzing naar de economische realiteit voor. Mede omdat dit voor de praktijk leidende arresten zijn en het Hof in de economische realiteit steun vindt om de regelgeving betreffende de plaats van dienst uit te leggen, ga ik na welke betekenis de economische realiteit in de rechtspraak heeft.

In het ARO Lease-arrest komt de term 'economische realiteit' in de volgende context voor:

“De uitleg van de Commissie en de Deense regering zou derhalve indruisen tegen de bedoeling van de wetgever die, rekening houdend met de economische realiteit, met betrekking tot vervoermiddelen ervoor heeft gekozen om in de hoofdregel van artikel 9, lid 1, een betrouwbaar, eenvoudig en bruibaar criterium op te nemen, te weten de zetel van de bedrijfsuitoefening of een vaste inrichting." (r.o. 26)

Bij de uitleg van de regelgeving inzake de plaats van dienst is de 'economische realiteit' een factor waar rekening mee moet worden gehouden.

De vraag die zich nu voordoet is op welke wijze de economische realiteit de uitleg van de regelgeving stuurt. Het DFDS-arrest, en ik citeer volledig, zegt daar het volgende over:

91. Hof 28 juni 2007, nr. C-73/06, Planzer Luxembourg Sàrl, V-N 2007/36.23. Centraal staat in deze procedure de vraag of belanghebbende vervoersdiensten verricht vanuit een vaste inrichting in Luxemburg dan wel vanuit de zetel in Zwitserland. Het Hof geeft invulling aan het begrip 'zetel van zijn bedrijfsuitoefening' in het kader van artikel 1, punt 1, Dertiende richtlijn. In r.o. 43 en 45 wordt verwezen naar de economische realiteit. Zie tevens op het terrein van de maatstaf van heffing Hof 7 oktober 2010, nrs. C-53/09 en C-55/09, LMUK en Baxi, V-N 2010/55.21, NTFR 2010/2378. Zie ook de conclusie van AG Jääskinen in de Lebara-procedure, conclusie van 8 december 2011, nr. C-520/10, V-N 2012/9.18, r.o. 31.

92. Hof 27 oktober 2011, nr. C-504/10, V-N 2011/57.20, NTFR 2011/2572, r.o. 45. 
“Gelijk de regering van het Verenigd Koninkrijk heeft betoogd, leidt een dergelijke aanknoping (gedoeld wordt op de zetel: toevoeging AHB) echter niet tot een fiscaal rationele oplossing, aangezien daardoor wordt voorbijgegaan aan de feitelijke plaats van verkoop van de rondreizen, die door de nationale autoriteiten, ongeacht de bestemming van de reiziger, op goede gronden als het nuttigste aanknopingspunt wordt beschouwd" (r.o. 22)

"Gelijk de advocaat-generaal in de punten 32-34 van zijn conclusie heeft beklemtoond, vormt de inaanmerkingneming van de economische realiteit een fundamenteel criterium voor de toepassing van het gemeenschappelijk stelsel van BTW. De alternatieve oplossing voor het bepalen van de plaats van belastingheffing over diensten van reisbureaus, namelijk de vaste inrichting van waaruit die diensten worden verricht, heeft juist tot doel, rekening te houden met de mogelijke spreiding van de activiteiten van de reisbureaus over verschillende plaatsen op het grondgebied van de Gemeenschap. Het systematisch toepassen van de oplossing van de zetel van de bedrijfsuitoefening zou overigens tot verstoringen van de mededinging kunnen leiden, aangezien het ondernemingen die activiteiten in een Lid-Staat verrichten, er dreigt toe aan te zetten om, teneinde aan belastingheffing te ontsnappen, hun zetel te vestigen op het grondgebied van een andere lid-Staat, die gebruik heeft gemaakt van de mogelijkheid om de betrokken diensten te blijven vrijstellen van BTW." (r.o. 23)

Het Hof brengt in deze twee overwegingen een heel scala van elementen naar voren, namelijk: fiscaal rationele oplossing, feitelijke plaats van verkoop van de rondreizen, nuttigste aanknopingspunt, de economische realiteit, de alternatieve oplossing van artikel 26, Zesde richtlijn (reisbureauregeling) en vervolgens de verstoring van de mededinging. Om daar in de volgende rechtsoverweging aan toe te voegen:

“Onder deze omstandigheden moet worden aangenomen, dat de dienst die een reisorganisator aan de reiziger verleent vanuit een vaste inrichting in een andere Lid-Staat dan die waar hij de zetel van zijn bedrijfsuitoefening heeft gevestigd, belastbaar is in de Lid-Staat waar die vaste inrichting is gevestigd." (r.o. 24)

Uit het feit dat deze overweging begint met het zinsdeel 'onder deze omstandigheden', kan volgens mij de conclusie worden getrokken dat het scala van elementen dat in de rechtsoverwegingen 22 en 23 wordt genoemd de beslissing in het DFDSarrest tot een bijzondere maakt, namelijk een beslissing voor dit geval. Het betrachten van de economische realiteit leidt tot een beschouwing die is ingekapseld in de feitelijke situatie. ${ }^{93}$ Het criterium is dus een hulpmiddel om tot een rationele oplossing te komen bij de uitleg van de regelgeving inzake de plaats van dienst.

\subsection{Zetel van de bedrijfsuitoefening}

In de literatuur en de jurisprudentie van het Hof op het terrein van de BTW is vooral aandacht voor het antwoord op de vraag of sprake is van een vaste inrichting in een bepaalde lidstaat. De vraag waar de zetel van de bedrijfsuitoefening is gevestigd, komt minder vaak aan bod. ${ }^{94}$ Hof heeft - zoals in paragraaf 8.3 is behandeld - beslist

93. Van Kesteren meent dat de economische realiteitsleer in het DFDS-arrest doelt op wat wij nationaal verstaan onder fiscale kwalificatie of conversie. H.W.M. van Kesteren, Misbruik van recht in de omzetbelasting (oratie Tilburg), Deventer: Kluwer 2004, blz. 14.

94. Zie ook de Uitvoeringsverordening (EU), nr. 282/2011 van 15 maart 2011, Pb EU van 23 maart 2011, L $77 / 1$. 
dat de zetel van de bedrijfsuitoefening het uitgangspunt is om bij aan te knopen bij de toepassing van de regels inzake de plaats van dienst. Slechts onder bepaalde condities springt de heffing over naar de vaste inrichting (zie paragraaf 8.3). De aanwezigheid van de zetel van de bedrijfsuitoefening in een bepaalde lidstaat kan dus belangrijke gevolgen hebben voor de heffing van BTW. Indien een rechtspersoon is opgericht naar Nederlands recht dan is ook de (statutaire) zetel in principe in Nederland. ${ }^{95}$ In zoverre is de plaats van oprichting ook de plaats van de zetel. Voor de regels aangaande de plaats van dienst kan niet zonder meer worden aangesloten bij de plaats van de (statutaire) zetel. Dit blijkt onder meer uit de letterlijke tekst van de artikelen 44 en 45, BTW-richtlijn, waar wordt vermeld dat sprake moet zijn van de 'zetel van zijn bedrijfsuitoefening. ${ }^{96}$ De letterlijke tekst van deze bepaling lijkt er op te wijzen dat sprake moet zijn van een zekere 'substance'. In ieder geval lijkt de tekst van de bepaling aan te geven dat enkel een statutaire vestigingsplaats onvoldoende is om bij aan te knopen bij de toepassing van regels inzake de plaats van dienst. ${ }^{97}$

Verder is in dit kader wederom het Berkholz-arrest van belang, waarin het Hof bij de beantwoording van de vraag wie de desbetreffende dienst verrichtte, in een zinswending verduidelijkt de wijze waarop de zetel zich verhoudt tot een vaste inrichting.

“(...) zetel van de dienstverrichter dan wel in een andere vaste inrichting”. (r.o. 16)

Het woord 'andere' in het zinsdeel duidt erop dat een zetel ook aangemerkt moet kunnen worden als een vaste inrichting. Dat betekent dat een zetel eveneens moet beschikken over een zekere bestendigheid, en duurzaam moet beschikken over personeel en technische middelen die noodzakelijk zijn om de desbetreffende diensten te kunnen verrichten (zie paragraaf 8.3). Deze rechtsoverweging ondersteunt dan ook de zienswijze dat enkel een statutaire vestigingsplaats onvoldoende is.

In het kader van het bovenstaande is ook het Factortame-arrest ${ }^{98}$ van belang waar is beslist:

95. Zie Asser - Van der Grinten II, hoofdstuk II, paragraaf 4, nr. 57.

96. Identiek zinsdeel is te vinden in artikel 9, lid 1, Zesde richtlijn.

97. In dit kader vermelden D.B. Bijl, M.E. Van Hilten \& D.G. Van Vliet over artikel 9, lid 1, Zesde richtlijn: "Duidelijk is dat de plaats waar of van waaruit de economische activiteiten daadwerkelijk worden verricht gaat vóór de woon- of verblijfplaats en vóór de statutaire vestigingsplaats." Zie: D.B. Bijl, M.E. van Hilten \& D.G. van Vliet 2001, blz. 101.

98. Hof 25 juli 1991, nr. C-221/89, Factortame e.a. Jur. 1991, blz. I-3956. Het Hof besliste in dit arrest ondermeer dat artikel 49 VwEU zich ertegen verzet dat een lidstaat voor de registratie van een vissersvaartuig als voorwaarde stelt dat: a. De eigenaars van het vaartuig onderdanen van die lidstaat of vennootschappen naar het recht van deze lidstaat zijn en in dit laatste geval 75\% van de aandelen in eigendom toebehoren aan onderdanen van die lidstaat. b. En deze eigenaars naargelang het geval, metterwoon in die lidstaat gevestigd zijn. 
“(...), dat het begrip vestiging in de artikelen 52 en volgende EEG-verdrag (huidig: artikel 49 VwEU: toevoeging AHB) inhoudt, dat daadwerkelijk een economische activiteit wordt uitgeoefend door middel van en duurzame vestiging voor onbepaalde tijd in een andere Lid-Staat." (r.o. 20)

Bij de analyse van het Factortame-arrest dienen twee aspecten niet uit het oog te worden verloren. Ten eerste richt het Hof zich op het begrip 'vestiging'. ${ }^{99}$ Artikel 9, lid 1, Zesde richtlijn (en ook de nieuwe regelgeving in de artikelen 44 en 45, BTWrichtlijn) gebruikt de terminologie 'zetel van zijn bedrijfsuitoefening'. Ten tweede gaat het betreffende onderdeel in het Factortame-arrest over het recht van vestiging en niet over de toewijzing van de bevoegdheid tot belastingheffing aan een lidstaat. Dat neemt niet weg, dat zoals in paragraaf 8.4.1 is beschreven, in het DFDS-arrest de jurisprudentie van het Hof doorklinkt die is gewezen op andere terreinen van het Unierecht. In ieder geval lijkt de jurisprudentie van het Hof op dit terrein te ondersteunen dat enkel een statutaire vestigingsplaats onvoldoende is. ${ }^{100}$

In het Planzer-arrest ${ }^{101}$ is een omschrijving gegeven van de zetel van de bedrijfsuitoefening. Bij het bepalen van de plaats van de zetel van de bedrijfsuitoefening van een vennootschap dienen een aantal factoren als uitgangspunt waarvan de belangrijkste zijn de statutaire zetel, de plaats van het centrale bestuur, de plaats waar de bestuurders van de vennootschap vergaderen en de plaats waar het algemene beleid van deze vennootschap wordt bepaald. Ook andere elementen, zoals de woonplaats van de hoofdbestuurders, de plaats waar de algemene vergaderingen worden gehouden, waar de administratie en de boekhouding zich bevinden en waar de financiële en vooral de bankzaken hoofdzakelijk worden geregeld, kunnen van belang zijn. ${ }^{102}$ Een fictieve vestiging, zoals die welke kenmerkend is voor een 'brievenbusmaatschappij' of een 'schijnvennootschap', kunnen niet worden aangemerkt als zetel van de bedrijfsuitoefening. Artikel 10, BTW-verordening geeft een aantal criteria voor de toepassing van de artikelen 44 en 45 , BTW-richtlijn van wat wordt verstaan onder de term 'zetel van zijn bedrijfsuitoefening'. In de BTWverordening zijn de criteria uit het Planzer-arrest terug te vinden.

99. In het arrest wordt geen onderscheid gemaakt tussen 'vaste inrichting' en 'zetel van de bedrijfsuitoefening'.

100. Zie voor een meer uitgebreide beschouwing over de jurisprudentie van het Hof op het terrein van het recht van vestiging, P.J.G. Kapteyn \& P. VerLoren van Themaat, Het recht van de Europese Unie en van de Europese Gemeenschappen, Deventer: Kluwer 2003, blz. 598 t/m 616.

101. Hof 28 juni 2007, nr. C-73/06, Planzer Luxembourg Sàrl, V-N 2007/36.23. Centraal staat in deze procedure de vraag of belanghebbende vervoersdiensten verricht vanuit een vaste inrichting in Luxemburg dan wel vanuit de zetel in Zwitserland. Het Hof geeft invulling aan het begrip 'zetel van zijn bedrijfsuitoefening' in het kader van artikel 1, punt 1, Dertiende richtlijn. Zie tevens Hof 6 oktober 2011, nr. C-421/10, Stoppelkamp, V-N 2011/50.20, NTFR 2011/2519.

102. Zie M.M.W.D. Merkx, De woon- en vestigingsplaats in de btw (diss. Tilburg) 2011, blz. 255 e.v. 


\subsubsection{Achtergrond van artikel 59 bis, BTW-richtlijn}

In geen van de bepalingen met betrekking tot de plaats van dienst komt de doelstelling van de regelgeving expressis verbis aan de orde met uitzondering van artikel 59bis, BTW-richtlijn.

"Ten einde dubbele heffing of niet-heffing van belasting alsmede verstoring van de mededinging te voorkomen, kunnen de lidstaten met betrekking tot diensten waarvan de plaats van verrichting valt onder de artikelen 44, 45, 56 en 59:

a. de plaats van een dienst of van alle diensten, die krachtens die artikelen op hun grondgebied is gelegen, aanmerken als buiten de Gemeenschap te zijn gelegen, wanneer het werkelijke gebruik en de werkelijke exploitatie buiten de Gemeenschap geschieden;

b. de plaats van een dienst of van alle diensten, die buiten de Gemeenschap is gelegen, aanmerken als op hun grondgebied te zijn gelegen, wanneer het werkelijke gebruik en de werkelijke exploitatie op hun grondgebied geschieden.

$(\ldots) "$

Uit de aanhef van deze bepaling blijkt duidelijk wat wordt beoogd, namelijk het voorkomen van dubbele BTW-heffing dan wel verdamping van BTW. Dubbele belastingheffing wordt voorkomen door voor bepaalde prestatie te bepalen dat de plaats van dienst geacht wordt buiten de Europese Unie te zijn gelegen. Verdamping wordt voorkomen door juist te bepalen dat de plaats van de desbetreffende dienst in de Europese Unie is gelegen.

De Zesde richtlijn kent een vergelijkbare bepaling in artikel 9, lid 3, Zesde richtlijn. De achtergrond van deze bepaling is identiek aan het huidige artikel 59 bis, BTWrichtlijn, namelijk het voorkomen van concurrentieverstoringen. Wel is de werking van het huidige artikel 59 bis, BTW-richtlijn ruimer dan artikel 9, lid 3, Zesde richtlijn en wel in die zin dat onder het huidige artikel meer diensten vallen (namelijk de diensten die vallen onder het bereik van de artikelen 44, 45, 56 en 59, BTW-richtlijn). Artikel 9, lid 3, Zesde richtlijn was enkel van toepassing op de diensten genoemd in artikel 9, lid 2, sub e, Zesde richtlijn.

Artikel 59 bis, BTW-richtlijn is een zogenoemde kan-bepaling. ${ }^{103}$ Daar wordt mee bedoeld dat de lidstaten niet verplicht zijn de bepaling te implementeren in hun nationale regelgeving. Nederland heeft alleen letter b geïmplementeerd, en wel in artikel $6 \mathrm{j}$ Wet OB. Verder is het zo dat Nederland geen gebruik heeft gemaakt per 1 januari 2010 om het bereik uit te breiden nu het huidig artikel 59 bis, BTW-richtlijn meer diensten bestrijkt. ${ }^{104}$

103. Dit in tegenstelling tot artikel 59 ter, BTW-richtlijn wat betreft de telecommunicatiediensten. 104. Zie voor een overzicht wat betreft de implementatie van deze kan-bepaling in de diverse lidstaten, W. van der Corput, New EU VAT Rules Applicable from 1 january 2010 (2), International VAT Monitor, january/february 2010, blz. 9 e.v. 
Artikel 59 bis, BTW-richtlijn kan in combinatie met artikel 194, BTW-richtlijn (voorheen artikel 21, lid 1, letter a, Zesde richtlijn) tot gevolg hebben dat ook een niet-belastingplichtige BTW verschuldigd kan zijn. Een dergelijke BTW-heffing beoogt een verstoring van de mededinging te voorkomen. Denkbaar is dat als bijvoorbeeld een niet belastingplichtige holding een belastingadvies afneemt van een Nederlandse adviseur, de holding BTW in rekening krijgt gebracht die niet in aftrek kan worden gebracht gezien het ontbreken van belastingplicht. Als echter de holding deze dienst zou afnemen van een dienstverrichter die is gevestigd buiten de Europese Unie, dan wordt geen Europese BTW in rekening gebracht. Het hoeft geen verder betoog dat zonder nadere voorziening de concurrentieverhoudingen verstoord dreigen te raken. Artikel 59 bis, BTW-richtlijn beoogt de concurrentieverhoudingen zuiver te houden. Dat wil zeggen: diensten verricht tussen een persoon binnen de Europese Unie en een persoon die is gevestigd buiten de Europese Unie dienen concurrentieneutraal en dus gelijk te worden behandeld met de diensten verricht tussen personen die beide binnen de Europese Unie zijn gevestigd. Daarmee bedoel ik dat de gelijksoortige diensten gelijk dienen te worden behandeld. Om een dergelijke gelijkheid te bereiken kan het gevolg zijn dat een niet-belastingplichtige de BTW moet voldoen inzake een prestatie die wordt verricht door een dienstverrichter die is gevestigd buiten de Europese Unie.

Opvallend is dat de tekst van artikel 59 bis, BTW-richtlijn als voorwaarde vermeldt dat 'het werkelijke gebruik en de werkelijke exploitatie' op hun grondgebied (sub b) dan wel buiten de gemeenschap (sub a) dient te zijn gelegen. ${ }^{105}$ Opvallend, omdat de artikelen 44 en 45, BTW-richtlijn 'slechts' vermelden dat het moet gaan om diensten verricht 'voor een' (niet)-belastingplichtige om het belastbaar feit te verleggen naar een andere lidstaat. ${ }^{106}$ Afgaande op de letterlijke tekst is te verdedigen, dat ingeval de artikelen 44 en 45, BTW-richtlijn slechts een 'afnemer' moet zijn te identificeren, terwijl in geval van de toepassing van artikel 59 bis, BTW-richtlijn vereist is dat de afnemer de desbetreffende dienst tevens werkelijk gebruikt en werkelijk exploiteert. Het gevolg daarvan zou dan kunnen zijn, dat het volgens deze bepalingen mogelijk moet zijn om een 'afnemer' aan te wijzen die niet 'werkelijk gebruikt' dan wel 'werkelijk exploiteert'. Dit lijkt mij een vrij uitzonderlijke categorie van afnemers. Verder ontgaat mij de reden van een dergelijke inperking. Zeker gezien het doel van de bepaling, namelijk het voorkomen van concurrentieverstoringen. In de volgende paragraaf ga ik nader in op deze problematiek.

105. De diverse taalversies van de Zesde richtlijn wijken wat deze termen betreft af. Zo vermeldt de Engelse versie van de BTW-richtlijn niet de term 'werkelijke exploitatie' maar zoekt aansluiting bij het genot ('effective use and enjoyment'). Zie M.E. van Hilten, Bancaire en financiële prestaties in de Europese BTW, blz. 234 en 235.

106. Ook onder de Zesde richtlijn is een dergelijk verschil aan de orde en wel tussen artikel 9, lid 3 en artikel 9, lid 2, sub e. 
Ook al staat de nationale jurisprudentie in mijn onderzoek niet centraal, toch is in dit kader een beslissing van het Gerechtshof 's-Gravenhage van belang. ${ }^{107}$ In deze beslissing gebruikte het Gerechtshof een algemeen rechtsbeginsel om artikel $6 \mathrm{j}$ Wet OB, tweede lid, Wet OB (artikel 9, lid 3, Zesde richtlijn) uit te leggen.

In deze procedure staat een zuivere holding centraal. Deze holding is niet belastingplichtig voor de BTW. De aandelen die de holding houdt zijn in beheer gegeven bij een bankinstelling die is gevestigd in Zwitserland. In verband met deze dienstverlening ontvangt de holding van de bank rekeningafschriften waarop 'administratieve charges' in rekening zijn gebracht. De inspecteur is van mening dat belanghebbende op grond van artikel $6 \mathrm{j}$ (toentertijd artikel 6, tweede lid, onderdeel e Wet OB), jo artikel 12 , derde lid Wet OB de BTW verschuldigd is.

Het Gerechtshof start met in zijn overwegingen te verwijzen naar het doel van de bepaling die in deze procedure aan de orde is. Het overweegt namelijk:

"De regeling in artikel 6, tweede lid, onderdeel e, van de Wet (huidig artikel 6j Wet OB: toevoeging AHB) heeft tot doel verstoringen in de concurrentieverhoudingen te voorkomen en tegen te gaan door in nader omschreven gevallen de plaats van dienst van buiten de Gemeenschap te verleggen naar Nederland. De mogelijkheid tot het treffen van een zodanige regeling wordt geboden door artikel 9, derde lid, sub b, van de Zesde richtlijn inzake omzetbelasting (...). In die mogelijkheid komt een van de twee algemene pijlers van de regeling met betrekking tot de plaats van dienst tot uiting, te weten het voorkomen van niet-heffing." (r.o. 6.2)

Nadat het doel van de bepaling is geïdentificeerd, gebruikt het Gerechtshof dit element om de tekst van de bepaling uit te leggen.

"Onder de plaats waar het werkelijk gebruik van een dienst plaatsheeft, moet naar het 's Hofs oordeel worden verstaan de plaats waar in termen van de omzetbelasting die dienst daadwerkelijk wordt genoten, dat wil zeggen de plaats waar de dienst wordt verbruikt. Bij die beoordeling is naar 's Hofs oordeel enkel de persoon van de afnemer bepalend. Mede gelet op de omstandigheid dat de regeling in artikel 6, tweede lid, onderdeel d, van de Wet aansluit bij de plaats waar de afnemer van de desbetreffende dienst woont of is gevestigd, ziet het Hof, in ogenschouw nemende de onder 6.2 weergegeven doelstelling, geen aanleiding te veronderstellen dat zulks bij de toepassing van artikel 6 , tweede lid, onderdeel e, van de Wet wezenlijk anders zou liggen. Voor zover belanghebbende dan ook heeft gesteld dat het werkelijk genot van de in geding zijnde diensten niet bij belanghebbende zelf lag, maar bij haar aandeelhouder dan wel uiteindelijk bij diens aandeelhouder, treft die stelling, wat daarvan overigens ook zij, geen doel." (r.o. 6.7)

Uit deze rechtsoverweging blijkt dat het Gerechtshof een aansluiting maakt tussen toentertijd van kracht zijnde artikelen 6, tweede lid, onderdeel d en 6, tweede lid, onderdeel e Wet OB. Zoals in de vorige subparagraaf is aangegeven lijkt de letterlijke

107. Hof 's-Gravenhage 11 december 1996, nr. 95/2558, FED 1997/174, m.n.v. W.A.P. Nieuwenhuizen. Zie ook het arrest van de HR dat daar op volgde en waar ook de uitspraak van het Gerechtshof wordt vermeld, HR 5 januari 2000, nr. 32 957, BNB 2000/130, m.n.v. M.E van Hilten. 
tekst te doen vermoeden, dat artikel 6, tweede lid, onderdeel e van de Wet OB (huidig artikel 6j Wet $\mathrm{OB}$ ) een zwaardere eis kent door de voorwaarde van het 'werkelijk gebruik en exploitatie' te stellen. Het Gerechtshof kent echter meer betekenis toe aan het doel van de desbetreffende bepaling, namelijk het voorkomen van verstoringen in de concurrentieverhoudingen. ${ }^{108}$

Tegen de uitspraak van het Gerechtshof heeft belanghebbende beroep ingesteld. De Hoge Raad overweegt:

“(...) dat voor de beoordeling van de vraag waar het werkelijk gebruik als bedoeld in artikel 9, lid 3 van de Zesde richtlijn (...) plaatsvindt (huidig artikel 59 bis,BTW-richtlijn: toevoeging $\mathrm{AHB}$ ), niet bepalend is waar de afnemer van de diensten gevestigd of woonachtig is. In zoverre zijn zij gegrond. Naar redelijkerwijs niet voor twijfel vatbaar is, is in een dergelijk geval als het onderhavige de plaats van het werkelijk gebruik in de zin van de bepalingen de plaats waar de afnemer de diensten afneemt."

De Hoge Raad volgt dus niet de lijn van het Gerechtshof en kijkt niet naar het doel van de bepaling. In casu worden de aandelen gehouden in Zwitserland en zo bekeken is er dus wat voor te zeggen dat het daadwerkelijk gebruik (dan wel verbruik) van de desbetreffende dienst dan ook in Zwitserland plaatsvindt. ${ }^{110}$ Overigens blijkt uit het zinsdeel 'in een dergelijk geval als het onderhavige' dat het volgens de Hoge Raad een feitelijke aangelegenheid is. Van geval tot geval zal dus de locatie van het 'gebruik' moeten worden getoetst. Ik kan mij voorstellen dat het werkelijk gebruik voor goederen eenvoudiger is vast te stelen dan voor diensten. Diensten zijn in het algemeen niet tastbaar, wat de lokalisering van het 'werkelijk gebruik' niet eenvoudiger maakt. ${ }^{111}$

Het Hof heeft in het arrest Athesia Druck ${ }^{112}$ de termen 'werkelijk gebruik' en 'werkelijke exploitatie' uitgelegd en tevens een belangrijke beperking van artikel 59 bis, BTW-richtlijn geformuleerd. De in Oostenrijk gevestigde Athesia Advertising kocht advertentieruimte in bij Italiaanse media op eigen naam en voor in Duitsland en Oostenrijk gevestigde klanten. Zij deed dit vanuit Oostenrijk en beschikte niet over een vaste inrichting in Italië. Wel had zij een dochtermaatschappij (Athesia Druck) aangewezen als fiscaal vertegenwoordiger. Van betekenis is dat het geschil

108. Ook het door mij in hoofdstuk 3 beschreven verbruiksbeginsel gebruikt het Gerechtshof, namelijk door aan te sluiten bij de plaats waar de dienst daadwerkelijk wordt genoten. Dat wil zeggen daadwerkelijk wordt verbruikt.

109. HR 5 januari 2000, nr. 32 957, BNB 2000/130, m.n.v. M.E. van Hilten.

110. Ook Terra deelt de mening dat het gaat om de plaats waar de afnemer de dienst afneemt. In deze procedure was dat Zwitserland. Verder meent hij: “Dat de ratio 'het voorkomen van concurrentievervalsing' in casu niet uit de verf komt, ligt aan de formulering van artikel 9, lid 3, sub b: 'werkelijk gebruik en werkelijke exploitatie in het binnenland'. Via een achterdeur de vestigingsplaats er bij halen, op grond van de ratio is in strijd met de rechtszekerheid." Terra 2001, blz. 245.

111. Zie ook J.L.M.J. Vervloed, IJsland ijlt na, BTW-Brief 1997/4, blz. 9 -11. Vervloed gaat nader in op de begrippen 'werkelijk gebruik' en 'werkelijke exploitatie'.

112. Hof 19 februari 2009, nr. C-1/08, Athesia Druck Srl, V-N 2009/11.19, NTFR 2009/476. 
betrekking heeft op de jaren 1993/1994 en dat in die periode Oostenrijk nog geen lid was van de Europese Unie.

Voor een goed begrip van het arrest is van belang de diverse diensten te onderscheiden. Het betreft dus diensten van Italiaanse media aan Athesia Advertising gevestigd te Oostenrijk. Deze laatste vennootschap verrichtte weer diensten aan klanten gevestigd in Oostenrijk en Duitsland. Het zijn deze laatste diensten waar de Italiaanse Belastingdienst zijn pijlen op richtte. De Italiaanse Belastingdienst stelde onder meer dat deze diensten in Italië belastbaar zijn op grond van artikel 9, lid 3, Zesde richtlijn (huidig artikel 59 bis, BTW-richtlijn) omdat het werkelijk gebruik en de werkelijke exploitatie in Italië lag. Naar mijn mening een bijzonder standpunt omdat zowel de dienstverrichter als de afnemers niet in Italië waren gevestigd.

Het Hof besliste de vraag over de invulling van het werkelijk gebruik en werkelijke exploitatie in het voordeel van de Italiaanse Belastingdienst:

"Gepreciseerd moet worden dat bij diensten op het gebied van de reclame onder het land waarin het werkelijke gebruik en de werkelijke exploitatie, in de zin van artikel 9, lid 3, sub b, van de Zesde richtlijn, geschieden, wordt verstaan het land van waaruit de reclameboodschappen worden verspreid.

Los van het feit dat de ontvangers van deze diensten zich overal ter wereld kunnen bevinden, staat immers buiten twijfel dat de Italiaanse media vooral in Italië worden verspreid.

Derhalve moeten in omstandigheden als die van het hoofdgeding het gebruik en de werkelijke exploitatie van reclameboodschappen worden aangemerkt als verricht in Italië." (r.o. $29 \mathrm{t} / \mathrm{m} \mathrm{31}$ )

Het Hof kijkt dus naar waar het 'publiek' van de reclameboodschappen is gevestigd. $\mathrm{Na}$ deze overwegingen vervolgt het Hof dat de reclamediensten mogen worden aangemerkt:

“(...) als diensten die zijn verricht op het grondgebied van de staat en die als zodanig belastbaar zijn, maar dat zij de diensten die de eerste ontvanger die buiten de Gemeenschap is gevestigd ten behoeve van zijn klanten verricht, niet als belastbaar mogen aanmerken." (r.o. 32)

En voegt daar vervolgens aan toe:

"Een dienstverrichting die, volgens de in artikel 9, lid 1, van de Zesde richtlijn gestelde criteria, buiten de Gemeenschap ligt (maatschappelijke zetel in een derde land en geen vaste inrichting in een lidstaat) en die niet wordt bedoeld in lid 2, sub e, van ditzelfde artikel, kan niet onder de afwijking bedoeld in artikel 9, lid 3, sub b, van de Zesde richtlijn vallen." (r.o. 33)

In de literatuur zijn diverse beschouwingen te vinden over de betekenis van deze overwegingen. ${ }^{113}$ Volgens mij bevatten deze twee overwegingen een belangrijke en

113. H.W.M. van Kesteren \& J.L.M.J. Vervloed, Reclamediensten en werkelijk gebruik, BTW-Brief 2009, nr. 5, blz. 3. Zie tevens N. Hinssen, Athesia Druck, reparatie IJsland-route mislukt?!, BTW-Bulletin, Juni 2009, nr. 6, blz. 1 . 
ook logische beperking van artikel 59 bis, BTW-richtlijn. Van belang is dat het gaat in deze procedure om diensten tussen een dienstverrichter (Oostenrijk) en afnemers (Oostenrijk/Duitsland) die alle buiten Italië zijn gevestigd. Volgens mij heeft het Hof dan ook willen duidelijk maken dat diensten die plaatsvinden tussen partijen die beide buiten de desbetreffende lidstaat (in casu Italië) zijn gevestigd niet onder het bereik van artikel 59 bis, BTW-richtlijn vallen. Deze inperking lijkt mij logisch want past namelijk in de lijn die het Hof volgt bij de uitleg van de regels op het gebied van de plaats van dienst. Een andere uitleg zou namelijk betekenen dat diensten tussen twee ondernemingen die niet in de Europese Unie zijn gevestigd door een lidstaat op grond van artikel 59 bis, BTW-richtlijn in de heffing kunnen worden getrokken als het gebruik in die lidstaat kan worden geconstateerd. Een dergelijke uitleg gaat al snel verder - lijkt mij - dan de doelstelling die ten grondslag ligt aan artikel 59 bis, BTW-richtlijn, namelijk het voorkomen van concurrentieverstoringen. Verder verricht in deze procedure de in Oostenrijk gevestigde dienstverrichter (ook) reclamediensten aan belastingplichtige afnemers in Duitsland. Dat betekent dat deze diensten op grond van het toen van kracht zijnde artikel 9, lid 2, sub e, Zesde richtlijn in Duitsland met BTW zijn belast. Het standpunt van de Italiaanse Belastingdienst dat deze diensten in Italië belast zijn op grond van artikel 9, lid 3, Zesde richtlijn heeft dan ook een dubbele BTW-heffing tot gevolg. In paragraaf 8.2 is naar voren gebracht dit nu juist hetgeen is dat het Hof probeert te voorkomen bij de uitleg van de regels inzake de plaats van dienst.

\section{$8.7 \quad$ Conclusies}

Uit de in paragraaf 8.2 behandelde arresten blijkt dat het doel van de regels is het voorkomen van dubbele heffing dan wel een situatie waarin een dienst onbelast blijft. Een dergelijke situatie wordt bereikt door de heffing aan één enkele lidstaat toe te wijzen. De regels inzake de plaats van dienst kunnen dus een inbreuk maken op het territorialiteitsbeginsel. Van belang is de constatering dat kennelijk alleen inbreuk wordt gemaakt op het territorialiteitsbeginsel in geval van een bevoegdheidsconflict tussen lidstaten.

De functie van de regels op het gebied van de plaats van dienst kan omschreven worden als op rationele wijze vermijden van een heffingsconflict tussen lidstaten (dan wel een situatie van niet-heffing). Het zijn bevoegdheidsregels en hebben welbeschouwd weinig van doen met algemene rechtsbeginselen. Zij bakenen jurisdicties af, wijzen de heffing toe aan een - de regel beantwoordende - bepaalde lidstaat. Doch dezelfde set regels voorzien welbeschouwd in twee te onderscheiden toepassingsvelden; behalve op het interne verkeer tussen de lidstaten, zien deze regels ook op diensten tussen EU en derde landen. Daarbij is het bepaald niet onmogelijk achter dezelfde set aan regels een onderscheid te maken naar gelang het toepassingsgebied binnen EU of extern - en daarbij verschillende gronden neer te zetten. Zo zal men bij de toepassing van de regels binnen de EU niet het bredere kader van het Unierecht uit het oog verliezen. In hoofdstuk 1 heb ik aandacht gevraagd voor de geschiedenis van de BTW passend in de ontwikkeling van het Unierecht, namelijk het streven naar één interne markt, Regelgeving en uitleg van het Hof staan dan ook niet op zichzelf, maar 
kunnen worden gezien als een onderdeel van het streven naar integratie op de vele terreinen die het Unierecht bestrijken. Ook al komt in de jurisprudentie inzake de plaats van dienst geen expliciete verwijzing voor naar het primaire Unierecht, dat neemt niet weg dat het bij de interpretatie als vanzelf zijn kracht laat gelden. Een expliciete verwijzing naar het Unierecht zien wij overigens wel in de - voor de praktijk niet meer relevante - Gaston Schul-zaak ${ }^{114}$ handelend over de vermijding van dubbele BTW-heffing op een in Frankrijk geleverde roerende zaak aan een particulier gevolgd door een heffing bij invoer aan de Nederlandse grens. In lijn met deze zaak is het binnen één interne markt ook niet goed denkbaar dat grensoverschrijdende diensten dubbel worden belast. Zou dat namelijk het geval zijn, dan is een ongelijke behandeling aan de orde tussen gelijksoortige grensoverschrijdende diensten en diensten verricht binnen één lidstaat. Het beginsel van de fiscale neutraliteit verzet zich ertegen dat soortgelijke diensten die met elkaar concurreren, uit oogpunt van de BTW ongelijk worden behandeld. Het doel dat de regels inzake de plaats van dienst nastreven heeft in zijn uitwerking als resultaat dat grensoverschrijdende diensten gelijk worden behandeld met diensten die worden verricht binnen één lidstaat. Dit is conform het uitgangspunt van de interne markt en beantwoordt aan het beginsel van de fiscale neutraliteit zoals dat op andere terreinen dan de plaats van dienst regels door het Hof is geformuleerd.

Wat betreft grensoverschrijdende diensten tussen de interne markt en derde landen reflecteren de regels aan de eisen van het bestemmingslandbeginsel, wat verankerd is in de WTO. Dit wil niet zeggen, dat de fiscale neutraliteit, die gelijkheid tussen interne en externe diensten verlangt is uitgespeeld. De toewijzingsregels die het externe verkeer EU-derdelanden raken, kunnen soms - regelmatig door taxplanning geïnspireerd - de concurrentieverhoudingen tussen spelers van buiten en binnen de EU op hun kop zetten, waardoor maatregelen ter correctie daarvan weer voor een gelijk speelveld moeten zorgen (zie paragrafen 8.6.1 en 8.6.2).

In de arresten die in paragraaf 8.3 zijn behandeld heeft het Hof verduidelijkt dat de zetel van de bedrijfsuitoefening de voorkeur heeft om bij aan te knopen voor de BTW-heffing. Dit lijkt de betekenis van het concept vaste inrichting voor de heffing van BTW in te perken. Enkel onder bepaalde voorwaarden springt de heffing over naar de vaste inrichting. Namelijk indien de zetel niet tot een rationele oplossing leidt of een conflict met een andere lidstaat ontstaat indien de zetel het uitgangspunt is. Overigens staat deze voorwaarde los van de vraag of er wel een vaste inrichting is.

Een vaste inrichting is aanwezig indien de inrichting duurzaam over personeel en technische middelen beschikt die noodzakelijk zijn om de desbetreffende diensten te kunnen verrichten. Denkbaar is dat voor verschillende diensten verschillende middelen noodzakelijk zijn. Afhankelijk van de aard van de diensten. Zo bekeken kunnen de voorwaarde voor de aanwezigheid van een vaste inrichting verschillen, afhankelijk van het type dienst dat wordt verricht. Duidelijk is ook dat in de BTW het begrip vaste inrichting anders is ingevuld dan in de belastingen op inkomen. In veel 
gevallen zal er eerder sprake zijn van een vaste inrichting voor de heffing van bijvoorbeeld VPB dan voor de heffing van BTW. Als dan ook de voorkeursregeling (voor de zetel van de bedrijfsuitoefening) in de beschouwing wordt getrokken lijkt het erop dat de vaste inrichting voor de heffing van BTW ondergeschikt is aan de zetel van de bedrijfsuitoefening.

In het DFDS-arrest is een bijzondere invulling gegeven aan het fenomeen vaste inrichting. In deze case worden de diensten één keer getroffen door de BTW-heffing. Het Hof zet de stap dat de in Engeland gevestigde rechtspersoon afhankelijk is van de moedermaatschappij in Denemarken.

Artikel 11, lid 1, BTW-verordening bepaalt - voor de toepassing van artikel 44, BTWrichtlijn - dat onder een vaste inrichting dient te worden verstaan iedere andere inrichting dan de zetel van de bedrijfsuitoefening die gekenmerkt wordt door een voldoende mate van duurzaamheid en een - wat personeel en technische middelen betreft - geschikte structuur om de voor haar eigen behoeften verrichte diensten te kunnen afnemen en ter plaatse te gebruiken (inkoop-vi). De introductie van de inkoop-vi in de BTW-verordening is een uitbreiding van het vi-concept zoals dat is te vinden in de jurisprudentie gezien het feit dat geen uitgaande prestaties zijn vereist.

Per 1 januari 2010 is de regelgeving inzake de plaats van dienst ingrijpend veranderd voor belastingplichtigen. Te verwachten is dat het Hof bij de uitleg van deze nieuwe regels zal blijven baseren op het zelfde doel, namelijk het voorkomen van dubbele heffing dan wel niet-heffing. Dit gezien het feit dat dit uitgangspunt niet enkel is verankerd in de uitleg van de regels die de plaats van dienst bepalen onder vigeur van de Zesde richtlijn, maar ook omdat dit uitgangspunt past bij het streven naar één interne markt. 


\section{HOOFDSTUK 9}

\section{Maatstaf van heffing}

De maatstaf van heffing is te vinden in de artikelen $72 \mathrm{t} / \mathrm{m} 92$ BTW-richtlijn (voorheen artikel 11, Zesde richtlijn). De Wet OB duidt de maatstaf van heffing aan met de term 'vergoeding' (artikelen 8 en 8a, Wet OB). De BTW-richtlijn kent een ruim begrip van de maatstaf van heffing en bepaalt in artikel 73, BTW-richtlijn dat deze omvat:

“ (...) alles wat de leverancier of dienstverrichter (...) als tegenprestatie verkrijgt of moet verkrijgen van de zijde van de afnemer of van een derde, met inbegrip van subsidies die rechtstreeks met de prijs van deze handelingen verband houden."1

De definitie heeft ondanks de ruime strekking toch nog tot interpretatievragen aanleiding gegeven. Uit de jurisprudentie blijkt dat de belastinggrondslag bestaat in al hetgeen dat als tegenprestatie wordt ontvangen. ${ }^{2}$ Het Hof heeft beslist dat het moet gaan om de daadwerkelijk ontvangen tegenprestatie en niet om een volgens objectieve maatstaven geschatte waarde. ${ }^{3}$ In de woorden van het Goldsmiths-arrest: ${ }^{4}$

1. Voor goederenleveringen en diensten bedoelt in de artikelen $74 \mathrm{t} / \mathrm{m} 77$ (fictieve prestaties) geldt een afwijkende maatstaf van heffing.

2. Hof 5 februari 1981, nr. 154/80, Coöperatieve aardappelenbewaarplaats, BNB 1981/232. Hof, 23 november 1988, nr. 230/87, Naturally yours Cosmetics Ltd, Jur. 1988, blz. 6365.

3. De BTW-richtlijn kent enkele uitzonderingen. Zie onder meer de artikelen 16, 26, 27, BTW-richtlijn. Zie verder paragraaf 6.5 .

4. Hof 3 juli 1997, C-330/95, Goldsmiths (Jewellers) Ltd, V-N 1997/2988, pt. 18. In deze procedure is beslist dat de weigering van een teruggaaf BTW van oninbare vorderingen gezien het feit dat de vergoeding in natura is, in strijd is met de BTW-richtlijn. Zie ook Hof 2 juni 1994, nr. C-33/93, Empire Stores Ltd, V-N 1995/3109, pt. 21, FED 1995/502. Zie tevens recent het Astra Zeneca-arrest waar het Hof de verschillende aspecten kernachtig weergeeft in r.o. 28: "Het is tevens vaste rechtspraak dat de maatstaf van heffing voor goederenleveringen of diensten wordt gevormd door de daartoe werkelijk ontvangen tegenprestatie. Deze tegenprestatie is dus de subjectieve waarde, dat wil zeggen de werkelijk ontvangen waarde, en niet een volgens objectieve maatstaven geschatte waarde. Bovendien moet deze tegenprestatie kunnen worden uitgedrukt in een geldbedrag (...)." Beslist is in het Astra Zeneca-arrest dat een onderneming wanneer zij aankoopbonnen die zij tegen een prijs inclusief BTW heeft aangeschaft, aan haar werknemers verstrekt die in ruil daarvoor afzien van een gedeelte van hun loon in contanten, daarmee een dienst onder bezwarende titel verricht. Hof 29 juli 2010, nr. C-40/09, Astra Zeneca UK Ltd, V-N 2010/41.12. 
"Deze bepaling is de uitdrukking van een fundamenteel beginsel van de Zesde richtlijn, dat inhoudt dat de maatstaf van heffing de werkelijk ontvangen tegenprestatie is (...), en dat tot gevolg heeft, dat de fiscus uit hoofde van de BTW niet meer kan ontvangen dan de belastingplichtige heeft geïnd (...)." (r.o. 15)

Het Hof heeft in het eerder gewezen Gibbs-arrest ${ }^{5}$ (r.o. 20) verduidelijkt dat de neutraliteit - in de betekenis van het bevrijden van de voorbelasting (stelselbeginsel) - de interpretatie stuurt van de maatstaf van heffing. Ook in dit arrest is te lezen dat het op grond van het neutraliteitsbeginsel niet de bedoeling van het BTWsysteem is, dat de fiscus meer ontvangt dan de eindverbruiker daadwerkelijk betaalt (r.o. 23 en 24$)^{6}$

De maatstaf van heffing is dan ook subjectief, namelijk hetgeen partijen daadwerkelijk hebben ontvangen. ${ }^{7}$ Het Hof duidt het subjectieve karakter zelfs aan als een 'fundamenteel beginsel'. Gezien het subjectieve begrip vergoeding kan een dergelijke prijs afwijken van wat gebruikelijk of normaal is op de markt. Een marktprijs, of een objectieve vergoeding is in de BTW dus niet de leidraad voor de heffing. Het subjectieve uitgangspunt van de BTW-richtlijn houdt niet in dat de lidstaten daaraan altijd gebonden zijn. Onder omstandigheden is het immers geoorloofd daarvan af te wijken (zie paragraaf 9.2). Bij het gebruik maken van de afwijking laat het Hof het evenredigheidsbeginsel een vormgevende rol spelen.

In paragraaf 9.3 komt het zogenoemde leerstuk 'splitsen van vergoedingen' (ook wel genoemd 'eenheid van prestatie') aan de orde. Indien verscheidene prestaties worden verricht dan dienen deze in beginsel afzonderlijk in de heffing te worden betrokken. Op deze regel bestaan echter uitzonderingen. Het betreft een leerstuk dat is ontwikkeld in de jurisprudentie en waarvan de werking niet is beperkt tot de maatstaf van heffing. Gekozen is echter, gezien de verwevenheid met de maatstaf van heffing, om het in dit hoofdstuk te behandelen.

\subsection{Minimum maatstaf van heffing}

\subsubsection{Grenzen aan het bereik van artikel 395 BTW-richtlijn}

Zoals uit de vorige paragraaf blijkt, kent de BTW een subjectieve maatstaf van heffing. Dat neemt niet weg dat diverse lidstaten hebben geprobeerd een minimummaatstaf

5. Hof 24 oktober 1996, nr. C-317/94, Elida Gibbs Ltd, V-N 1996/4573, pt. 25. Het Hof besliste in dit arrest, dat een kortingsbon en een geld terug bon leidt tot een verlaging van de maatstaf van heffing. Zie ook Hof 15 oktober 2002, nr. C-427/98, Commissie/Duitsland, V-N 2002/54.22.

6. Paragraaf 2.4 besteedt aandacht aan deze benadering in het licht van het rechtskarakter van de BTW. Paragraaf 6.5 schenkt aandacht aan de wijze waarop de problematiek van de kortingsbonnen moet worden gezien in relatie tot gratis artikelen die door belastingplichtigen worden weggegeven in het kader van een reclamecampagne.

7. In het Freemans-arrest heeft het Hof beslist dat de maatstaf van heffing pas wordt verlaagd op het tijdstip waarop de afnemer de korting opneemt. Tot dat tijdstip is de maatstaf van heffing de volledige catalogusprijs. Het moet dus gaan om een prijs verminderd met een daadwerkelijk geëffectueerde korting. Hof 29 mei 2001, nr. C-86/99, Freemans, V-N 2001/35.27. 
van heffing te introduceren. Een dergelijke regeling beoogt misbruik van de BTW te voorkomen dan wel te bestrijden. Artikel 395, BTW-richtlijn (voorheen artikel 27, Zesde richtlijn) biedt de lidstaten namelijk de mogelijkheid om in hun nationale BTWwetgeving bepalingen op te nemen die afwijken van de BTW-richtlijn. ${ }^{8}$ In de hierna aan de orde komende arresten heeft het Hof artikel 27, Zesde richtlijn verduidelijkt. Deze jurisprudentie is van betekenis voor de uitleg van het huidige artikel 395, BTWrichtlijn.

Blijkens het Direct Cosmetics-arrest en een inbreukprocedure tegen Frankrijk zijn afwijkingen van de BTW-richtlijn slechts verenigbaar met het Unierecht, voor zover zij binnen de kaders van artikel 395, BTW-richtlijn blijven. ${ }^{9}$ In paragraaf 5.2 zijn enkele procedurele aspecten aan de orde geweest. Onder meer is aandacht geschonken aan het gegeven dat artikel 395, BTW-richtlijn is gewijzigd. In die zin dat de kennisgevingprocedure is veranderd in een daadwerkelijke goedkering door de Raad door middel van een beschikking. Paragraaf 11.5.1 besteedt aandacht aan de toepassing van artikel 395, BTW-richtlijn op het terrein van het aftrekrecht en in paragraaf 5.2 kwam de machtiging in het algemeen ter sprake. In deze paragraaf is de machtiging op het terrein van de maatstaf van heffing aan de orde. ${ }^{10}$

Het Hof heeft, zoals hierna zal blijken, verduidelijkt dat de mogelijkheid om op grond van artikel 395, BTW-richtlijn af te wijken van een subjectieve maatstaf van heffing niet onbeperkt is. Het evenredigheidsbeginsel speelt daarbij een belangrijke rol.

De toetsing aan het evenredigheidsbeginsel vindt plaats in drie stappen: op geschiktheid om het beoogde doel te dienen; op minst belemmerende mogelijkheid en op de evenredigheid zelf (zie paragraaf 3.4.2.2). Ook op het terrein van de minimum maatstaf van heffing zet het Hof niet in alle gevallen de drie stappen in extenso neer.

8. Artikel 395, lid 1, eerste alinea, BTW-richtlijn vermeldt dat de Raad op voorstel van de Commissie met eenparigheid van stemmen elke lidstaat kan machtigen, bijzondere, van de BTW-richtlijn afwijkende maatregelen te treffen ten einde de belastingheffing te vereenvoudigen of bepaalde vormen van belastingfraude of -ontwijking te voorkomen (zie de paragrafen 5.2 en 11.5.1).

9. Hof 13 februari 1985, nr. 5/84, Direct Cosmetics, Jur. 1985, blz. 617, r.o. 24. In deze procedure besliste het Hof dat een maatregel die gebaseerd is op artikel 27 , lid 5, Zesde richtlijn en deze regeling wordt na enige tijd gewijzigd, de nieuwe maatregel op grond van artikel 27, lid 2 (oud), Zesde richtlijn ter kennis van de Commissie moet worden gebracht. Zie ook Hof 6 juli 1995, nr. C-62/93, BP Soupergaz, Jur. 1995, blz. I-1883. In dit arrest geeft het Hof aan dat het toezenden van een gehele wet aan de Commissie niet voldoet aan het vereiste van in kennisstellen. Vereist is dat de specifieke gegevens aan de Commissie kenbaar moet worden gemaakt. Inmiddels is deze procedure veranderd en is een beschikking van de Raad vereist. Zie voor de Europees rechtelijke aspecten van een dergelijke beschikking paragraaf 4.5.2.4. Zie verder ook Hof 21 september 1988, nr. 50/87, Commissie/Frankrijk, BNB 1994/306, FED 1991/203 m.n.v. D.B. Bijl, en dan in het bijzonder r.o. 22.

10. In het arrest Hof 14 juli 2005, nr. C-435/03, BATI, V-N 2005/37.21, NTFR 2005/1019, is de strekking van artikel 395, BTW-richtlijn verduidelijkt op het terrein van het belastbaar feit. In deze procedure staat centraal de houdbaarheid van de Belgische regelgeving waarin is bepaald dat de diefstal van accijnsgoederen uit een belastingentrepot voor de BTW een belastbare levering is. Het Hof besliste dat artikel 395, BTW-richtlijn geen basis biedt voor een dergelijke vergaande afwijking van de BTW-richtlijn. 
Allereerst zal ik aandacht besteden aan de inbreuk procedure tegen België, vervolgens aan het K-Line-arrest, en dan aan het Skripalle-arrest, waarna ik naga of uit deze jurisprudentie een richtinggevende lijn is te destilleren.

In de eerst genoemde zaak is het de vraag of de Belgische regelgeving op het vlak van de levering van personenauto's verenigbaar is met de BTW-richtlijn. ${ }^{11}$ De Belgische BTW-regelgeving hanteerde bij het invoeren en leveren van nieuwe personenauto's een minimum maatstaf voor de heffing. Deze maatstaf mocht niet lager zijn dan de catalogusprijs die geldt op het tijdstip waarop de belasting verschuldigd wordt. De Commissie meende dat een dergelijke regeling in strijd is met de regelgeving van de maatstaf van heffing zoals deze is neergelegd in de BTW-richtlijn.

Het Hof overweegt dat de maatregel van dien aard moet zijn, dat zij belastingfraude of -ontwijking voorkomt, doch mag in beginsel slechts afwijken van de in de BTWrichtlijn vastgestelde belastinggrondslag voor zover zulks strikt noodzakelijk is ter bereiking van het doel (r.o. 28). Vervolgens houdt het Hof het voor onbetwist, dat de Belgische regering op goede gronden mocht aannemen dat er in de automobielsector een reëel gevaar voor belastingontwijking of -fraude bestaat, waarin maatregelen als die, welke krachtens artikel 395, BTW-richtlijn hun rechtvaardiging vinden. Toegestaan is dat dergelijke maatregelen bepaalde forfaitaire elementen behelzen (r.o. 30). In deze overweging zou gelezen kunnen worden (zij het niet al te expliciet) dat een dergelijke maatregel de toets aan de geschiktheid doorstaat.

Het Hof gaat vervolgens na of de maatregel onmisbaar (en dus noodzakelijk) is (minst belemmerende mogelijkheid). Dit blijkt expliciet uit rechtsoverweging 30 waar het Hof stelt dat het wel van belang is dat een dergelijke maatregel niet verder afwijkt van de BTW-richtlijn dan noodzakelijk is ter voorkoming van het gevaar van ontwijking of fraude.

Het Hof overweegt vervolgens:

"De Belgische regeling, die voor alle nieuwe wagens uitgaat van de aan de Belgische overheid meegedeelde catalogusprijs, wijzigt de belastinggrondslag evenwel dermate ingrijpend en algemeen, dat niet kan worden gezegd dat zij zich bepaalt tot de afwijkingen die ter voorkoming van het ontwijkings- of fraudegevaar noodzakelijk zijn. Zo staat met name niet vast, dat het ter verwezenlijking van het beoogde doel noodzakelijk is, de belastbare grondslag vast te stellen op basis van de Belgische catalogusprijs of alle prijskortingen en -rabatten zo volstrekt buiten beschouwing te laten als thans het geval is." (r.o. 31)

Gezien het ontbreken van de noodzakelijkheid van de maatregel doorstaat de regeling niet de toets aan het evenredigheidsbeginsel. De noodzakelijkheid ontbreekt omdat de regeling niet is aan te merken als het minst belemmerende alternatief (zie paragraaf 3.4.2.2).

11. Hof 10 april 1984, nr. 324/82, Commissie/België, Jur. 1984, blz. 1861. Zie ook het vervolg in de procedure van 4 februari 1988, nr. 391/85, Commissie/België, Jur. 1988, blz. 579. In deze laatste procedure werd België veroordeeld wegens het niet juist nakomen van het arrest van 10 april 1984. 
In het K-Line-arrest gaat het om de minimum maatstaf voor gebruikte auto's. ${ }^{12}$ K-Line verkocht een gebruikte auto aan een andere belastingplichtige. De Belgische Belastingdienst was van mening dat de verkoopprijs niet hoog genoeg was. Volgens de Belgische regelgeving moest de maatstaf van heffing voldoen aan een bepaald minimumbedrag (in casu 55\% van de catalogusprijs). In deze procedure beriep België zich onder meer op artikel 395, BTW-richtlijn. Het Hof pareerde dit argument met een verwijzing naar het hierboven behandelde arrest van 10 april 1984 en om vervolgens te beslissen dat de desbetreffende maatregel te ingrijpend en te algemeen is (r.o. 25).

De bovenstaande lijn is doorgezet in het Skripalle-arrest. ${ }^{13}$ Skripalle verhuurde woningen aan een vennootschap van zijn vrouw en zoon. De Duitse Belastingdienst vond de maatstaf van heffing te laag en verhoogde deze, op grond van de Duitse wetgeving tot de kosten van de omzet. Deze van de richtlijn afwijkende regeling was gebaseerd op artikel 395, BTW-richtlijn. Bijzonder in deze procedure is dat in casu de vergoeding die in rekening werd gebracht in overeenstemming was met de normale marktprijs, echter lager was dan de minimum maatstaf van heffing volgens de Duitse regelgeving.

Het Hof overweegt, dat in het kader van thans artikel 395, BTW-richtlijn, mag worden afgeweken van de regeling die de maatstaf van heffing vaststelt. Een dergelijke afwijking mag echter niet verder gaan dan strikt noodzakelijk is ter bereiking van het nagestreefde doel. De Duitse regeling dient dan ook getoetst te worden aan deze voorwaarde. Bij het uitvoeren van deze toets start het Hof met de constatering, dat er tussen familieleden of tussen nauw met elkaar verbonden personen een gevaar voor belastingfraude of -ontwijking kan bestaan die maatregelen rechtvaardigen als die welke volgens artikel 395, BTW-richtlijn getroffen mogen worden (r.o. 25). Een gevaar voor belastingfraude of -ontwijking bestaat echter niet als de maatstaf van heffing overeenkomt met de normale marktprijs. In dat geval dekt artikel 395, BTW-richtlijn niet de nationale maatregel. Het gegeven dat een zekere mate van abstractie altijd een maatregel kenmerkt is in dit geval geen rechtvaardiging. In dit geval was het namelijk niet uitzonderlijk dat de fictieve maatstaf van heffing hoger was dan de normale huur zoals deze op de huurmarkt tot stand komt. De Duitse regeling had een uitzondering moeten maken voor de gevallen waarin de overeengekomen huur overeenkomt met de marktprijs, maar lager is dan de fictieve maatstaf van heffing (r.o. 29). Nu dat niet het geval is gaat de maatregel verder dan strikt noodzakelijk is ter bereiking van het nagestreefde doel.

Ik concludeer dat, afgezien van het feit dat de rechtspraak op het terrein van de minimum maatstaf de eerdere rechtspraak inzake de criteria van het evenredigheidsbeginsel bevestigt, onder omstandigheden forfaitaire regelingen zijn toegestaan. Ook is duidelijk dat gelieerde verhoudingen aanleiding kunnen zijn om op grond van artikel 395, BTW-richtlijn maatregelen ter voorkoming van misbruik te 
introduceren. Daarbij moet wel in het oog worden gehouden, dat dergelijke maatregelen niet verder mogen gaan dan strikt noodzakelijk is om het beoogde doel te bereiken. Dit betekent dat de fictieve maatstaf niet hoger mag zijn dan de normale marktprijs.

\subsubsection{De minimummaatstaf van heffing in de BTW-richtlijn}

Per 1 januari 2007 is de nieuwe BTW-richtlijn van kracht. Deze richtlijn bevat (in tegenstelling tot de Zesde richtlijn) de mogelijkheid dat een lidstaat een minimummaatstaf van heffing introduceert indien het transacties betreft in gelieerde verhoudingen. ${ }^{14}$

Op grond van artikel 80, BTW-richtlijn kunnen de lidstaten bepalen dat voor goederenleveringen of diensten waarbij sprake is van gelieerde verhoudingen de maatstaf van heffing de zogenoemde 'normale waarde' is. Artikel 72, BTW-richtlijn bepaalt dat de normale waarde het volledige bedrag is dat een afnemer bij vrije mededinging zou moeten betalen. Indien geen vergelijkbare verrichtingen voor handen zijn, dan wordt in geval van goederenleveringen aangesloten bij de aankoopprijs dan wel de kostprijs. In geval van diensten wordt bij gebrek aan een marktprijs aangesloten bij de uitgaven die gemaakt zijn om deze dienst te kunnen verrichten.

Objectivering van de vergoeding kan enkel aan de orde zijn in een drietal situaties, namelijk:

1. Wanneer de tegenprestatie lager is dan de normale waarde en de afnemer geen volledig recht op aftrek van voorbelasting heeft (artikel 80, lid 1, onder a, BTWrichtlijn).

2. Wanneer de tegenprestatie lager is dan de normale waarde en degene die de handeling verricht geen volledig recht op aftrek van voorbelasting heeft en de handeling is vrijgesteld (artikel 80, lid 1, onder b, BTW-richtlijn).

3. Wanneer de tegenprestatie hoger is dan de normale waarde en degene die de handeling verricht geen volledig recht op aftrek van voorbelasting heeft (artikel 80, lid 1, onder c, BTW-richtlijn).

Uit de bovenstaande drie situaties blijkt dat wisselend wordt aangesloten bij de afnemer dan wel degene die de prestatie verricht. Ook blijkt in situatie 3 dat niet enkel een te lage vergoeding wordt geobjectiveerd. De drie matregelen trachten te bereiken dat partijen niet het recht op aftrek van voorbelasting manipuleren. De zesentwintigste overweging in de Considerans bij de BTW-richtlijn vermeldt daarom het volgende:

14. Nederland had al op grond van een machtiging van de Raad de mogelijkheid om in geval van gelieerde verhoudingen in bepaalde gevallen de maatstaf van heffing aan te passen. Zie Beschikking van de Raad, 27 februari 2006, Pb L 65/45 van 7 maart 2006. Op dit moment is in de Tweede Kamer het wetsvoorstel constructiebestrijding (on)roerende zaken aanhangig (Wijziging van de Wet op de omzetbelasting 1968 in verband met de aanpak van constructies met betrekking tot (on)roerende zaken alsmede in verband met een aanpassing op enkele onderdelen, Kamerstukken II 2004/05, 30 061, nr. 2). 
"De lidstaten moeten zich in bepaalde welomschreven omstandigheden kunnen uitspreken over de waarde van goederenleveringen, diensten en intracommunautaire verwervingen, teneinde te voorkomen dat zij, doordat via het inschakelen van verbonden partijen een belastingvoordeel wordt behaald, belastinginkomsten derven."

Hieruit blijkt dat ook van belang is dat de partijen gelieerd zijn. Dit is het geval indien er familiale of andere nauwe persoonlijke, bestuurlijke, eigendom-, lidmaatschaps-, financiële of juridische banden bestaan zoals door de lidstaten omschreven. Ook een dienstverband tussen werkgever en werknemer, het gezin van de werknemer of andere personen die nauwe banden met hem hebben, gelden volgens artikel 80, lid 1, BTW-richtlijn als nauwe betrekkingen. De BTW-richtlijn biedt de lidstaten dus de mogelijkheid om snel te constateren dat partijen gelieerd zijn.

In artikel 80, lid 3, BTW-richtlijn is bepaald dat de lidstaten het BTW-Comité in kennisstellen als zij de regeling implementeren en het geen maatregelen betreffen die voor 13 augustus 2006 door de Raad in overeenstemming met artikel 395, BTWrichtlijn zijn toegestaan. Dit betekent dat geen beschikking van algemene strekking meer vereist is zoals onder de Zesde richtlijn op grond van 27, Zesde richtlijn. Dat is ook logisch gezien het feit dat de regelgeving nu is opgenomen als een zogenoemde 'kan-bepaling'.

De vraag die nu opkomt, is of de jurisprudentie die betrekking heeft op de uitleg van artikel 395, BTW-richtlijn wat betreft de maatstaf van heffing nog relevant is. Of anders geformuleerd: dienen de lidstaten bij de implementatie van artikel 72 en 80, BTW-richtlijn rekening te houden met de criteria die het Hof heeft geformuleerd in de jurisprudentie over de uitleg van artikel 395, BTW-richtlijn?

In paragraaf 9.2.1 is gebleken dat de reikwijdte van artikel 395, BTW-richtlijn vooral wordt ingeperkt door het evenredigheidsbeginsel. In de drie behandelde procedures doorstond een forfaitaire regeling niet de toets aan het evenredigheidsbeginsel. Een toetsing van een forfaitaire maatstaf van heffing aan het evenredigheidsbeginsel zal onder de werking van de BTW-richtlijn minder snel spelen. De letterlijke tekst van de artikelen 72 en 80, BTW-richtlijn voorkomt dat de lidstaten een regeling invoeren die een maatstaf van heffing kent die fictieve elementen bevat (zoals een percentage van de catalogusprijs in het K-Line-arrest) of een matstaf van heffing die hoger is dan de marktprijs (zoals in het Skripalle-arrest). De tekst van artikel 72, BTWrichtlijn geeft namelijk een definitie van de 'normale waarde'.

Toch kan het evenredigheidsbeginsel wel degelijk van belang zijn. Zo bepaalt artikel 80, BTW-richtlijn dat de lidstaten in geval van gelieerdheid, om belastingfraude en -ontwijking te voorkomen, kunnen bepalen dat de maatstaf van heffing de normale waarde is. Kortom, het doel dat wordt nagestreefd is het voorkomen van belastingfraude en -ontwijking. Het Hof zal dan ook - gezien het evenredigheidsbeginsel - nagaan of een nationale maatregel geschikt is om dit doel te bereiken en of de regeling de minst belemmerende mogelijkheid is die een lidstaat kan invoeren. 
De vraag kan worden gesteld of een regeling die een minimum vergoeding introduceert, niet tevens moet voldoen aan de fiscale neutraliteit als uitdrukking van het gelijkheidsbeginsel. Het lijkt mij dat een schending van de fiscale neutraliteit niet snel aan de orde zal zijn. Artikel 80, BTW-richtlijn stelt namelijk als voorwaarde dat sprake is van gelieerde verhoudingen. Men veronderstelt dat gelieerde partijen de hoogte van de vergoeding kunnen manipuleren en dat misbruik dan ook mogelijk is. Beoogd wordt juist om aan te sluiten bij gangbare marktprijzen. Artikel 80, BTWrichtlijn knoopt aan bij de normale waarde, dat wil zeggen het bedrag dat in geval van vrije mededinging zou moeten worden betaald. Gesteld kan dan worden dat de bevoegdheid tot afwijking van de maatstaf van heffing, juist tot doel heeft de werking van de fiscale neutraliteit te bevorderen. Vervuiling van de vergoeding die een mogelijke gelieerdheid veroorzaakt wordt dan namelijk verwijderd. Het doel van de maatregel, namelijk aansluiten bij marktprijzen, probeert gelijkheid op transactie niveau te bevorderen.

\subsubsection{Lage verkoopprijs aan personeel (Scandic-arrest)}

Om belastingvrije consumptie via het aftrekrecht van de onderneming te voorkomen zijn er binnen het systeem van de BTW twee oplossingen denkbaar: men blokkeert de aftrek van voorbelasting op bijvoorbeeld maaltijden of dranken, of men heft bij de verstrekking daarvan belasting over de onttrekking, alsdan een fictieve levering/ dienst genoemd.

Wanneer een lidstaat geen gebruik kan maken van de blokkade van de voorbelasting omdat de BTW-richtlijn die niet kent of omdat men bij de overgang in 1979 of bij toetreding niet in een eigen nationale regeling heeft kunnen voorzien, kan de lidstaat zich enkel bedienen van een heffing over een fictieve levering/dienst. ${ }^{15}$ Een zodanige heffing werkt prima wanneer de ondernemer bijvoorbeeld gratis maaltijden verstrekt (fictieve levering plus fictieve maatstaf zijn geregeld in de artikelen 16 en 74 van de BTW-richtlijn), maar men komt in de problemen wanneer de ondernemer 'iets tussendoor' doet, in de zin van bijvoorbeeld het verstrekken van maaltijden aan personeel tegen een prijs lager dan de kostprijs. De Zweedse regeling loste dit op door een dergelijke verstrekking te belasten als een fictieve levering op grond van artikel 16, BTW-richtlijn (voorheen artikel 5, lid 6, Zesde richtlijn).

Het Hof geeft in het Scandic-arrest ${ }^{16}$ een oordeel over de gevolgen van de verkoop van lunches in een bedrijfsrestaurant aan personeelsleden tegen een bedrag lager dan de kostprijs. De Zweedse rechter stelde de vraag, of in een dergelijke situatie een levering op grond van artikel 16, BTW-richtlijn (voorheen artikel 5, lid 6, Zesde richtlijn) dan wel een dienst op grond van artikel 26, lid 1, sub b, BTW-richtlijn

15. In artikel 176, BTW-richtlijn is bepaald dat de lidstaten, totdat de Raad een definitieve regeling heeft vastgesteld ter beperking van de aftrek op uitgaven met een consumptief karakter, elke uitsluiting kunnen handhaven waarin hun wetgeving op 1 januari 1979 dan wel, voor de lidstaten die na die datum tot de Gemeenschap zijn toegetreden, op de datum van hun toetreding voorzag. 16. Hof 20 januari 2005, nr. C-412/03, Hotel Scandic Gåsabäck, V-N 2005/8.22. 
(voorheen artikel 6, lid 2, sub b, Zesde richtlijn) aan de orde kan zijn. Het Hof besliste dat de betreffende artikelen zich verzetten tegen een nationale regeling, die handelingen waarvoor een werkelijke tegenprestatie wordt betaald, als een onttrekking van een goed of een verrichting van een dienst voor privé doeleinden beschouwt, ook indien deze tegenprestatie lager is dan de kostprijs van het geleverde goed of de dienst.

Uit het Scandic-arrest blijkt dat verstrekkingen aan personeelsleden tegen een lage vergoeding niet worden getroffen door een fictieve levering of dienst. De verstrekkingen zijn immers tegen een werkelijke tegenprestatie en dus onder bezwarende titel verricht. Gezien het feit dat de BTW-richtlijn op dit terrein ook geen aftrekbeperking kent, wordt er slechts BTW geheven over de lage vergoeding wat tot concurrentievervalsing kan leiden met niet bedrijfsrestaurants. Een fictieve prestatie is ook niet aan de orde als de vergoeding zo laag is dat deze een symbolisch karakter heeft. Dit blijkt tevens uit het Scandic-arrest waar het Hof erop wijst (r.o. 26) dat wil sprake zijn van een fictieve prestatie, ingeval een symbolische vergoeding wordt gevraagd, een machtiging is vereist. Een dergelijk gevaar van belastingontwijking kan op twee manieren worden voorkomen. Ten eerste zoals in het Scandic-arrest door het Hof naar voren wordt gebracht, door middel van een machtiging om als lidstaat een fictieve prestatie te mogen invoeren. Dan wel door de introductie van een regeling die de symbolische vergoeding aanpast aan de marktprijs. Het Scandicarrest is gewezen voor de datum van de BTW-richtlijn en dan ook in een periode waarin een machtiging vereist was om aan te sluiten bij marktprijzen. Onder de huidige regeling betekent dit dat in geval van een symbolische vergoeding geen fictieve prestatie plaatsvindt, maar dat de symbolische vergoeding kan worden opgehoogd naar de marktprijs (zie paragraaf 9.2.2).

De artikelen 72 en 80, BTW-richtlijn bieden de lidstaten de mogelijkheid om de verkoopprijs die wordt berekend aan personeel (bijvoorbeeld in bedrijfsrestaurants) te objectiveren. Zoals in paragraaf 9.2.2 is opgemerkt, kan volgens artikel 80, BTWrichtlijn al snel sprake van gelieerdheid zijn en valt personeel van de belastingplichtige daar in elk geval onder.

Wel is het zo dat de lidstaten bij de introductie van een dergelijke regeling niet enkel oog dienen te hebben voor de letterlijke tekst van de artikelen 72 en 80, BTWrichtlijn, maar ook de algemene rechtsbeginselen dienen te eerbiedigen en dan in het bijzonder het evenredigheidsbeginsel. En uiteraard dient er ook objectief gezien sprake te zijn van een situatie die kan leiden tot belastingontwijking. Een dergelijk belastingontwijking kan aan de orde zijn indien bestedingen met een sterk consumptief karakter via de onderneming lopen en vervolgens tegen een lage vergoeding bij personeelsleden terecht komen. Uit de jurisprudentie die in de vorige paragraaf is behandeld blijkt dat het Hof - bij de beoordeling van de toelaatbaarheid van een fictieve maatstaf van heffing op grond van artikel 395 BTW-richtlijn - nagaat of de maatregel geschikt is en het minst belemmerende alternatief is om het nagestreefde doel te bereiken. Indien een lidstaat een nationale regeling treft 
teneinde Scandic-achtige situaties te bestrijden dan zullen deze criteria in acht moeten worden genomen.

\subsection{Gesplitste vergoedingen en eenheid van prestatie}

\subsubsection{Algemeen kader}

Het Hof heeft in zijn jurisprudentie een lijn uitgezet die aangeeft onder welke omstandigheden voor de heffing van BTW sprake is van één prestatie dan wel meerdere prestaties. Een dergelijk onderscheid kan van invloed zijn op de uiteindelijke BTW die op de eindverbruiker drukt. Zo is het denkbaar dat bij een combinatie van prestaties die tegen één vergoeding wordt verricht een splitsing zal moeten worden aangebracht indien voor de afzonderlijke prestaties verschillende tarieven van toepassing zijn. ${ }^{17}$

Eenzelfde benadering kan ook aan de orde zijn bij de toepassing van de vrijstellingen. De vraag doet zich dan voor of één prestatie kan worden onderkend die onder de vrijstelling valt, dan wel meerdere prestaties die niet alle onder het bereik van een vrijstelling vallen. ${ }^{18}$

Het probleem laat zich ook gelden op het gebied van de regelgeving die bepaalt waar het belastbaar feit plaatsvindt. Zo is denkbaar dat een splitsing zal moeten worden aangebracht tussen een dienst en een levering. Gezien het gegeven dat een andere regelgeving van toepassing is op de plaats waar een dienst wordt verricht dan waar een levering plaatsvindt, kan dit tot gevolg hebben dat de gescheiden feiten zich in verschillende lidstaten als belastbare voltrekken. ${ }^{19}$

Niet alleen het onderscheid tussen levering en dienst kan van belang zijn. Ook kan relevant zijn of onderscheid is te maken tussen meerdere diensten. Onder vigeur van de Zesde richtlijn was het denkbaar dat een dienst was te onderkennen waar de hoofdregel van artikel 9, lid 1 op van toepassing was en dan ook belastbaar was in de lidstaat waar de dienstverrichter de zetel van zijn bedrijfsuitoefening had gevestigd, terwijl daarnaast mogelijk een dienst was te onderscheiden die naar zijn aard valt onder één van de uitzonderingen op de hoofdregel zoals deze bijvoorbeeld waren te

17. Hof 3 mei 2001, nr. C-481/98, Commissie/Frankrijk, V-N 2001/42.18. En zie ook Hof 8 mei 2003, nr. C-384/01, Commissie/Frankrijk, V-N 2003/29.22.

18. Hof 23 februari 1988, nr. 353/85, Commissie/Verenigd Koninkrijk, Jur. 1988, blz. 817. Verkoop van brillen e.d. is geen levering die samenhangt met de medische vrijstelling. Zie ook Hof 27 oktober 1993, nr. C-281/91, Muys en De Winter, BNB 1994/95, V-N 1993/4006, pt. 47. Dit arrest geeft aan onder welke omstandigheden rente is vrijgesteld dan wel een deel van de vergoeding is van de levering van een bouwterrein.

19. Hof 27 oktober 2005, nr. C-41/04, Levob Verzekeringen BV, BNB 2006/115, V-N 2005/54.19. Levering en aanpassing van software is één dienst. Zie ook Hof 2 mei 1996, nr. C-231/94, Faaborg-Gelting-Liniën A/S, V-N 1996/2120, pt. 22. Het verstrekken van spijzen en dranken in een restauratie op een veerboot is een dienst (en geen levering) gezien het feit dat deze verstrekkingen verband houden met een serie van diensten zoals toebereiding en bediening. 
vinden in artikel 9, lid 2, letter e, Zesde richtlijn en aldus belastbaar was in de lidstaat waar de afnemer de zetel van zijn bedrijfsuitoefening had gevestigd. Met de ingrijpende aanpassing van de regels inzake de plaats van dienst zal het belang afnemen, althans wat het oude onderscheid artikel 9, lid 1 dan wel artikel 9, lid 2, letter e, Zesde richtlijn betreft. Niettemin, zoals in hoofdstuk 8 naar voren gebracht, zijn er nog steeds uitzonderingen op de hoofdregel en zal dan ook op dat terrein het vraagstuk eenheid/verscheidenheid ongetwijfeld op de agenda blijven. Het probleem blijft ook bestaan daar waar eenzelfde bepaling als in artikel 9, lid 2, letter e, Zesde richtlijn van toepassing is gebleven voor het geval niet belastingplichtige lichamen afnemers van de dienst zijn (het huidige artikel 59 bis, BTW-richtlijn).

De verschillen in heffing op deze gebieden - hoog/laag tarief, vrijgesteld/belast en hier/daar belastbaar - welke afhankelijk zijn van het onderscheid in en de precieze duiding van de prestaties, zijn financieel niet van belang ontbloot. Het is dan ook niet verwonderlijk dat het Hof regelmatig heeft moeten oordelen over de vraag of sprake is van een eenheid van prestaties dan wel van meerdere prestaties. Daarbij speelt dan ook vaak de kwestie of de vergoeding voor deze prestaties dient te worden gesplitst. Inmiddels begint de jurisprudentie al een zekere omvang te krijgen. Ruim 23 arresten hebben direct betrekking op de splitsingsproblematiek. Daarnaast behandel ik enkele arresten die zijdelings met de problematiek van doen hebben maar wel licht werpen op de koers die het Hof vaart.

In paragraaf 9.3.2 zal ik de algemene lijn in de jurisprudentie schetsen. Deze lijn zoek ik uiteraard in de vraag of en in welke mate deze wordt bepaald door algemene rechtsbeginselen. Sturen ook zij het voorliggende vraagstuk van eenheid/verscheidenheid?

\subsubsection{De lijn in de jurisprudentie van het Hof van Justitie EU}

Bij het onderzoek naar de relevante arresten op dit punt heb ik 23 arresten $^{20}$ onderzocht die - gegeven de onderwerpen waar het over gaat (maatstaf, vrijstelling, plaats van dienst) - ondergebracht kunnen worden in het thema eenheid of verscheidenheid. Ik zal deze uiteraard niet in extenso behandelen. Er zijn gegeven

20. Hof 12 juni 1979, nr. 126/78, NV Nederlandse Spoorwegen, BNB 1980/2; Hof 1 juli 1982, nr. 222/81, BAZ Bausystem AG, Jur. 1982, blz. 2527; Hof 8 juli 1986, nr. 73/85, Kerrutt, Jur. 1986, blz. 2219; Hof 23 februari 1988, nr. 353/85, Commissie/Verenigd Koninkrijk, Jur. 1988, blz. 817; Hof 13 juli 1989, nr. 173/88, M. Henriksen, FED 1990/72; Hof 27 oktober 1993, nr. C-281/91, Muys en De Winter, BNB 1994/95, V-N 1993/40006, pt. 47; Hof 2 mei 1996, nr. C-231/94, Faaborg-Gelting-Linien, V-N 1996/ 2120, pt. 22; Hof 22 oktober 1998, nr. C-308/96, Madgett \& Baldwin, V-N 1998/59.20; Hof 25 februari 1999, nr. C-349/96, CPP, BNB 1999/224, V-N 1999/15.28; Hof 27 april 1999, C-48/97, Kuwait Petroleum Ltd, V-N 1999/27.15; Hof 18 januari 2001, nr. C-150/99, Stockholm Lindöpark, V-N 2001/11.21; Hof 3 mei 2001, nr. C-481/98, Commissie/Frankrijk, V-N 2001/42.18; Hof 15 mei 2001, C-34/99, Primback, V-N 2001/32.20; Hof 3 juli 2001, nr. C-380/99, Bertelsmann AG, V-N 2001/39.21; Hof 8 mei 2003, nr. C-384/01, Commissie/Frankrijk, V-N 2003/29.22; Hof 6 oktober 2005, nr. C-291/03, MyTravel Plc, V-N 2005/58.23, NTFR 27 oktober 2005; Hof 27 oktober 2005, nr. C-41/04, Levob, BNB 2006/115, V-N 2005/54.19; Hof 6 juli 2006, nr. C-251/05, Talacre Beach Caravan Sales, V-N 2006/41.16, NTFR $\rightarrow$ 
mijn vraagstelling, zie slot vorige paragraaf, twee typen arresten op dit punt: enerzijds arresten waarin het Hof op zoek is naar een model om het onderwerp 'eenheid of delen' leiding te geven. Zonder dat het Hof in die arresten terug hoeft te vallen op algemene rechtsbeginselen (m.n. de zaken Henriksen, CPP en Madget \& Baldwin); anderzijds zijn er enkele arresten waarin het Hof wel aan de toepassing van een rechtsbeginsel, namelijk de fiscale neutraliteit refereert en dit ter ondersteuning van de beslissing bezigt (de arresten Kerrutt, NS, My Travel, Rank en de twee inbreuk procedures tegen Frankrijk waar - en dat zou men in de eerste aanleg wellicht niet verwachten - de fiscale neutraliteit de verscheidenheid van behandeling tussen nagenoeg gelijke producten niet in de weg staat. Het betreft mijns inziens bijzondere gevallen met grote belangen; zie hierna).

Allereerst besteed ik aandacht aan de arresten van de eerste soort, te beginnen met de zaak Henriksen-arrest ${ }^{21}$ waar de vraag aan de orde is, of de verhuur van twaalf garages, verdeeld over twee gebouwen, is vrijgesteld van BTW-heffing. De toen geldende Zesde richtlijn bepaalde expliciet in artikel 13B, onderdeel b, sub 2 dat de 'verhuur van parkeerruimte voor voertuigen' belast is met BTW (thans artikel 135, lid 2, sub b, BTWrichtlijn). Henriksen verhuurde echter niet alleen garages maar ook woonhuizen en de verhuur daarvan is vrijgesteld. Een deel van de garages werd verhuurd aan bewoners van die huizen en een ander deel aan andere personen in de omgeving van het complex. De vraag die het Hof moest beantwoorden was of artikel 135, lid 2, sub b, BTW-richtlijn zo moet worden uitgelegd dat onder de belaste 'verhuur van parkeerruimte voor voertuigen' ook valt de verhuur van gesloten garages, indien deze verhuur nauw verband houdt met de vrijgestelde verhuur van woningen.

Het Hof besliste (enigszins gestileerd weergegeven), dat de verhuur van parkeerruimte in beginsel belast is, maar dat die verhuur niet kan worden uitgesloten van de vrijstelling indien de verhuur nauw verband houdt met de verhuur van woningen. Het Hof besliste tevens dat sprake is van een nauw verband indien de beide verhuurcontracten één enkele economische handeling vormen. ${ }^{22}$ Dit is het geval wanneer, in de eerste plaats, de parkeerruimte voor voertuigen en de woningen deel uitmaken van één onroerend complex en, in de tweede plaats, beide goederen door dezelfde eigenaar aan dezelfde huurder zijn verhuurd. Onder dergelijke omstandigheden is dus één prestatie te herkennen. Namelijk de vrijgestelde verhuur van

$\rightarrow$ 2006/1021; Hof 29 maart 2007, nr. C-111/05, Aktiebolaget NN, V-N 2007/18.22; Hof 21 juni 2007, nr. C-453/05, L. Volker, NTFR 2007/1202; Hof 21 februari 2008, nr. C-425/06, Part Service Srl, V-N 2008 11.17; Hof 11 juni 2009, nr. C-572/07, RLRE Tellmer Propertt Sro, V-N 2009/29.17, NTFR 2009/1441; Hof 19 november 2009, nr. C-461/08, Don Bosco, V-N 2009/59.17, NTFR 2009/2583.

21. Hof 13 juli 1989, nr. 173/88, M. Henriksen, FED 1990/72.

22. Het Don Bosco-arrest verwoordt het iets anders. In r.o. 37 komt de zelfde terminologie voor als in het Henriksen-arrest, namelijk 'economische handeling'. Echter in r.o. 39 geeft het Hof aan dat gekeken dient te worden naar het 'economisch doel' van de handelingen. In dit arrest is beslist dat de levering van een terrein en de door de verkoper op zich genomen sloopwerkzaamheden voor de BTW één prestatie vormen. Hof 19 november 2009, nr. C-461/08, Don Bosco, V-N 2009/59.17, en zie ook de kritische noot van J.T. Sanders bij dit arrest in NTFR 2009/2583. 
woningen. De beslissing is dan kennelijk dat je wel twee bedragen kunt zien op een afrekening, maar dat deze onlosmakelijk bij elkaar horen. ${ }^{23}$

Een verdere verduidelijking van het thema eenheid of verscheidenheid is te vinden in het CCP-arrest. ${ }^{24}$ Card Protection Plan Ltd. (verder: CCP) biedt houders van kredietkaarten tegen betaling van een bepaald bedrag een plan aan ter bescherming tegen financiële schade en de ongemakken van het verlies of de diefstal van hun kaarten en van een aantal andere voorwerpen zoals autosleutels, een paspoort of verzekeringsdocumenten.

In het CPP-arrest speelt onder meer de vraag of de handelingen van CPP vanuit BTWoogpunt twee zelfstandige dienstverrichtingen moeten worden geacht te omvatten, namelijk een vrijgestelde verzekeringsdienst en een belastbare kaartregistratie dienst, dan wel of één van deze diensten de hoofddienst is waarbij de andere bijkomend is, zodat deze laatste het lot van de hoofddienst deelt.

Het Hof overweegt dat op grond van artikel 2, lid 1, BTW-richtlijn (voorheen artikel 2, eerste lid, Zesde richtlijn) het uitgangspunt is, dat elke prestatie zelfstandig is en de vergoeding gesplitst dient te worden (r.o. 29). De hoofdregel is dus splitsen. Het Hof gaf echter ook aan dat de dienstverrichting waarbij economisch gesproken één dienst wordt verleend, deze niet kunstmatig uit elkaar moet worden gehaald. ${ }^{25}$ In dit kader is het volgens het Hof van belang vast te stellen, wat de kenmerkende elementen van de betrokken handeling zijn teneinde te bepalen of de belastingplichtige de modale consument meerdere van elkaar te onderscheiden hoofddiensten dan wel één enkele dienst verleent. ${ }^{26}$

Onder verwijzing naar het Madgett \& Baldwin-arrest ${ }^{27}$ maakt het Hof vervolgens duidelijk dat een dienst moet worden beschouwd als bijkomend bij een hoofddienst wanneer hij voor de klanten geen doel op zich is, doch een middel om de hoofddienst van de dienstverrichter zo aantrekkelijk mogelijk te maken. ${ }^{28}$ In die omstandigheid is

23. Vgl. Hof 11 juni 2009, nr. C-572/07, RLRE Tellmer Propertt sro, V-N 2009/29.17, NTFR 2009/1441. In dit arrest is beslist dat het schoonmaken van gemeenschappelijke ruimten en de verhuur van appartementen voor de BTW twee te onderscheiden diensten zijn. Het Hof baseert de beslissing mede op het feit dat de diensten apart worden gefactureerd (r.o. 23).

24. Hof 25 februari 1999, nr. C-349/96, CPP, BNB 1999/224, V-N 1999/15.28.

25. In het eerder aangehaalde Don Bosco-arrest formuleert het Hof het als volgt in r.o. 37: “(...) wanneer twee of meer elementen of handelingen die de belastingplichtige levert aan of verricht voor de klant, zo nauw met elkaar verbonden zijn dat zij objectief gezien één enkele ondeelbare economische handeling vormen, waarvan splitsing kunstmatig zou zijn (...)".

26. Zie ook Hof, 21 juni 2007, nr. C-453/05, L. Volker, r.o. 17, NTFR 2007/1202.

27. Hof 22 oktober 1998, nr. C-308/96, Madgett \& Baldwin, V-N 1998/59.20. De reisbureauregeling kan onder omstandigheden van toepassing zijn op zowel hotel als aanvullende diensten.

28. Zie ook Hof 3 juli 2001, nr. C-380/99, Bertelsmann AG, V-N 2001/39.21, r.o. 20. In het arrest is verduidelijkt dat in geval van het verstrekken van een premieartikel voor het aanbrengen van nieuwe leden niet enkel de aankoopprijs de maatstaf van heffing is, maar ook de verzendkosten. 
het feit dat één prijs wordt berekend niet beslissend. ${ }^{29}$ Indien duidelijk is dat de klanten de bedoeling hebben om twee verschillende diensten af te nemen, in casu een verzekering en een kaartregistratie, dient ondanks die ene prijs het gedeelte daarvan dat betrekking heeft op de verzekering, die hoe dan ook vrijgesteld is, afzonderlijk te worden bepaald. Daartoe moet volgens het Hof de eenvoudigste berekenings- of beoordelingsmethode worden gevolgd. Het Hof besliste vervolgens dat het aan de nationale rechter is aan de hand van de gegeven uitleg, om te beslissen of CPP de betreffende dienst dient te splitsen.

Een arrest op het terrein van de keuze tussen eenheid of verscheidenheid waarin wel een algemeen rechtsbeginsel een rol speelt is het bijna 25 jaar oude Kerrutt-arrest. ${ }^{30}$ In dit arrest is de vraag aan de orde of de aanneming van werk en diensten tot oprichting van een gebouw in het kader van een 'pakket' overeenkomst onder de vrijstelling voor de 'levering van een gebouw en het erbij behorend terrein' vallen (artikelen 13B, sub g en 28, lid 3, sub b, juncto bijlage f, punt 16, Zesde richtlijn). De Duitse regering en de Commissie zijn beiden van mening, dat de levering van goederen en de dienstverrichtingen ingevolge artikel 2, punt 1, Zesde richtlijn aan de BTW zijn onderworpen en niet kunnen worden geacht deel uit te maken van de 'levering van een gebouw, een gedeelte van een gebouw en het erbij behorende terrein' in de zin van de vrijstelling in de artikelen 13B, sub g, en 28 , lid 3, sub b, juncto bijlage f, punt 16, bij de Zesde richtlijn. Het Hof overweegt:

“Uit de bewoordingen 'levering van een gebouw (...) en het erbij behorend terrein' blijkt reeds, dat van een dergelijke homogene transactie slechts kan worden gesproken, wanneer de twee categorieën van goederen - het gebouw en het terrein - volgens het recht inzake koop en verkoop het voorwerp uitmaken van een en dezelfde levering, zoals bij de levering van een bebouwd terrein." (r.o. 13)

29. Indien één vergoeding wordt ontvangen voor afzonderlijke prestaties waarop verschillende BTWregimes van toepassing zijn, dan is splitsing van de vergoedingen vereist. Uit het Madgett en Baldwinarrest is op te maken dat allereerst bij de splitsing dient te worden aangesloten bij de marktwaarde van de verscheidene prestaties. Bij het ontbreken van de marktwaarde wordt de kostprijsmethode gehanteerd. Zie in dit kader HR 23 februari 2007, nr. 42 387, V-N 2007/12.20 inzake een manegehouder die zowel belaste als vrijgestelde handelingen verrichtte en daarvoor één vergoeding berekende. Zie ook J.L.M.J. Vervloed, Één betaling voor diverse prestaties, BTW-Brief, nr.4 2007, blz. 5 e.v.

30. Hof 8 juli 1986, nr. 73/85, Kerrutt, Jur. 1986, blz. 2219. Zie in dit kader ook het NS-arrest. In deze procedure is beslist dat een remboursvergoeding een bijkomende dienst is bij een belaste vervoersdienst en niet een zelfstandig vrijgestelde invorderingsdienst. Ook in deze procedure ondersteunt de neutraliteit ten aanzien van de mededinging de beslissing. Hof 12 juni 1979, nr. 126/78, NV Nederlandse Spoorwegen, BNB 1980/2 m.n.v. C.P. Tuk, r.o. 12 vermeldt: “(...) dat, waar de verrichting van die diensten onsplitsbaar is, het ter verwezenlijking van de doelstelling van de btw-richtlijnen neutraliteit ten aanzien van de mededinging - noodzakelijk is de inning van de prijs van de vervoerde goederen te beschouwen als een met betrekking tot het vervoer bijkomende dienst, ten einde deze aldus in alle lid-staten te onderwerpen aan de belasting over de toegevoegde waarde, de gelijkheid van behandeling tussen de verschillende wijzen van vervoer te bewerkstelligen en te waarborgen dat deze dienst in alle lid-staten op dezelfde wijze wordt belast". 
En vervolgt:

Deze benadering is in overeenstemming met het doel van de Zesde richtlijn. Zoals de Bondsrepubliek Duitsland heeft beklemtoond, moeten volgens deze richtlijn, ten einde een ten opzichte van de mededinging neutrale belastingheffing te waarborgen, de verschillende belastbare handelingen die niet tot een enkele handeling kunnen worden samengevoegd, ieder afzonderlijk aan de belasting over de toegevoegde waarde worden onderworpen. (r.o. 14).

Uit deze twee overwegingen blijkt dat een uitleg naar de bewoordingen van de richtlijn steun vindt in het waarborgen van een neutrale belastingheffing ten opzichte van de mededinging. Het Hof besliste dat de leveringen van goederen en de dienstverrichtingen - niet zijnde de levering van een bouwterrein - in het kader van een 'pakket' overeenkomsten tot aanneming van werk en het verrichten van diensten met het oog op de oprichting van een gebouw zijn onderworpen aan de BTW.

Fiscale neutraliteit houdt in dat het BTW-resultaat van de bijkomende prestatie niet de concurrentieverhoudingen mag verstoren doordat zij een ander BTW-regime gaat volgen. Een dergelijke verstoring kan optreden doordat zij het fiscale regime van de hoofdprestatie gaat delen. Een BTW-regime dat kan afwijken van het regime dat van toepassing is op prestaties door ondernemers die enkel deze prestatie aanbieden. Splitsen is in elk geval aan de orde indien de bijkomende prestatie voor de klant een doel op zich vormt. Deze parameters kennen dan ook als doel te voorkomen dat door het meeliften van de bijkomende prestatie het regime van de hoofdprestatie zou worden gedeeld, waardoor een aanmerkelijke invloed op de concurrentieverhoudingen zou kunnen optreden. Het uitgangspunt is dan verscheidenheid. Ter ondersteuning daarvan kan ook worden gewezen op de negende Considerans van de Zesde richtlijn, waar is aangegeven dat de communautaire wetgever beoogde dat:

“( ...) de maatstaf van de heffing moet worden geharmoniseerd, opdat de toepassing van het communautaire tarief op de belastbare handelingen in alle Lid-Staten tot vergelijkbare resultaten leidt."

De huidige BTW-richtlijn vermeldt in de vijfentwintigste overweging van de Considerans in bijna identieke bewoordingen:

"De maatstaf van heffing moet worden geharmoniseerd opdat de toepassing van de BTW op de belastbare handelingen in alle lidstaten tot vergelijkbare resultaten leidt."

De harmonisatie beoogt te waarborgen dat situaties die uit economisch oogpunt soortgelijk zijn voor de toepassing van de BTW gelijk worden behandeld. Deze harmonisatie draagt er aan bij de fiscale neutraliteit te waarborgen. ${ }^{31}$ Dit zie je ook

31. Deze lijn is ook expliciet terug te vinden in het arrest MyTravel (r.o. 33), waar het Hof overweegt (r.o. 33): “(...) dat de gemeenschapswetgever blijkens de negende overweging van de considerans $\rightarrow$ 
terug in de mislukte inbreukprocedure tegen Frankrijk, arrest van 8 mei $2003 .^{32}$ In Frankrijk kunnen nutsbedrijven op basis van de Franse regelgeving het verlaagde tarief toepassen op het vastrecht (het vaste deel van de levering van gas en elektriciteit), en het normale tarief op de levering van het gas en elektra zelf. Volgens de Commissie was dit in strijd met artikel 12, lid 3, sub a en b, Zesde richtlijn (thans artikelen 98 t/m 101, BTW-richtlijn). Het Hof sluit echter een verlaagd tarief op één aspect van de levering niet uit. Wel mag geen schending plaatsvinden van:

“(...) het beginsel van fiscale neutraliteit, dat inherent is aan het gemeenschappelijk BTWstelsel en dat zich ertegen verzet dat soortgelijke goederen, die dus met elkaar concurreren, uit het oogpunt van de BTW ongelijk worden behandeld (...)". (r.o. 25)

Vervolgens concludeert het Hof dat de Commissie niets heeft aangevoerd waaruit een dergelijke schending in casu blijkt. ${ }^{33}$

Het bovengenoemde arrest ligt in lijn met de uitkomst van een eerdere inbreukprocedure tegen Frankrijk. ${ }^{34}$ De Commissie was een inbreukprocedure tegen Frankrijk begonnen omdat de Franse regelgeving een (lager) verlaagd tarief $(2,1 \%)$ kent voor geneesmiddelen die worden vergoed door de sociale verzekering, terwijl voor andere geneesmiddelen het verlaagde tarief van $5,5 \%$ geldt. Het Hof is van mening dat het beginsel van de fiscale neutraliteit niet geschonden is. De twee categorieën van geneesmiddelen zijn namelijk geen soortgelijke goederen die met elkaar concurreren. Wanneer immers een geneesmiddel op de lijst van voor vergoeding in aanmerking komende geneesmiddelen is opgenomen, is dit voor de consument een beslissend voordeel ten opzichte van een geneesmiddel dat niet voor vergoeding in aanmerking komt. Dat de consumenten bij de aankoop kiezen voor geneesmiddelen uit de categorie die voor vergoeding in aanmerking komt, is niet een gevolg van een lager BTW-tarief. Het verlaagde BTW-tarief voor geneesmiddelen die voor vergoeding in aanmerking komen, heeft niet tot gevolg dat de verkoop daarvan wordt begunstigd ten opzichte van niet voor vergoeding in aanmerking komende geneesmiddelen. De twee categorieën van geneesmiddelen bevinden zich dus niet in een concurrentieverhouding waarin de verschillende BTW-tarieven een rol zouden kunnen spelen.

$\rightarrow$ van de Zesde richtlijn, wilde dat de maatstaf van de heffing werd geharmoniseerd 'opdat de toepassing van het communautaire tarief op de belastbare handelingen in alle lidstaten tot vergelijkbare resultaten leidt'. Deze harmonisatie bedoelt dus te waarborgen dat situaties die uit economisch of handelsoogpunt soortgelijk zijn, voor toepassing van het BTW-stelsel gelijk worden behandeld. Deze harmonisatie draagt er aldus toe bij de neutraliteit van dit stelsel te waarborgen". Hof 6 oktober 2005, nr. C-291/03, MyTravel Plc, V-N 2005/58.23, NTFR 27 oktober 2005. In dit arrest is beslist dat een reisorganisator BTW mag herberekenen met toepassing van de marktwaardemethode. 32. Hof 8 mei 2003, nr. C-384/01, Commissie/Frankrijk, V-N 2003/29.22.

33. Het lijkt erop dat de beslissing van de HR van 26 april 2002 (nr. 36 802, BNB 2002/192c, V-N 2002/ 23.22) in lijn is met dit arrest van het Hof. De HR besliste dat het voor 1999 geldende gedifferentieerde tariefsysteem ter zake van waterleveranties (enkel een verlaagd tarief voor de eerste $f 60$ ) niet in strijd was met de BTW-richtlijn.

34. Hof 3 mei 2001, nr. C-481/98, Commissie/Frankrijk, V-N 2001/42.18. 
In het Rank-arrest ${ }^{35}$ overweegt het Hof, dat de soortgelijk van twee dienstverrichtingen voornamelijk moet worden bepaald vanuit het oogpunt van de gemiddelde consument, met vermijding van kunstmatige onderscheiden op basis van onbeduidende verschillen. Twee dienstverrichtingen zijn soortgelijk wanneer zij overeenkomstige eigenschappen vertonen en aan dezelfde behoeften van consumenten voldoen waarbij het vergelijkbare gebruik de maatstaf is.

Op de toepassing van het beginsel van de fiscale neutraliteit is een nuancering te vinden in het Talacre Beach Caravan-arrest. ${ }^{36}$ Het Hof besliste dat één enkele levering (in casu caravan plus uitrusting) verschillende BTW-regimes kan volgen (in casu nultarief en normaal tarief). Het lijkt erop dat in het bijzonder het gegeven dat in deze procedure de overgangsregeling van artikel 28 van de toenmalige Zesde richtlijn een rol speelde een reden was om af te wijken van de algemene lijn. ${ }^{37}$ Het Hof overweegt namelijk:

“(...) weliswaar volgt uit (...) (de) rechtspraak dat één enkele levering in beginsel aan één BTW-tarief is onderworpen, doch deze rechtspraak verzet zich niet tegen de afzonderlijke belastingheffing over bepaalde onderdelen van deze levering wanneer enkel een dergelijke belastingheffing de voorwaarden eerbiedigt die artikel 28 , lid 2, sub a, van de Zesde richtlijn aan de toepassing van vrijstellingen met teruggaaf van de voldane belasting verbindt". (r.o. 24) (toevoeging: AHB)

Uit de arresten Kerrutt, NS en My Travel blijkt dat de uitleg naar de bewoordingen van de richtlijn, steun vindt in de fiscale neutraliteit. In de twee beschreven inbreukprocedures tegen Frankrijk toetst het Hof de nationale regeling expliciet aan de fiscale neutraliteit.

\section{$9.4 \quad$ Conclusies}

De Raad kan op voorstel van de Commissie een lidstaat machtigen van de BTWrichtlijn afwijkende maatregelen te treffen, teneinde de belastingheffing te vereenvoudigen of bepaalde vormen van belastingfraude of -ontwijking te voorkomen (artikel 395, BTW-richtlijn). In paragraaf 9.2.1 zijn een drietal procedures behandeld waarin lidstaten op grond van artikel 395, BTW-richtlijn een fictieve maatstaf van heffing hadden ingevoerd ter voorkoming van bepaalde vormen van belastingfraude of -ontwijking. Het Hof gaat na of deze maatregelen in overeenstemming zijn met het evenredigheidsbeginsel. In het bijzonder is van belang dat een dergelijke nationale maatregel geschikt is om het doel te bereiken en of de regeling de minst belemmerende mogelijkheid is die een lidstaat kan invoeren. Inmiddels is de mogelijkheid om onder bepaalde voorwaarden in gelieerde verhoudingen belasting

35. Hof 10 november 2011, nrs. C-259/10, C-260/10, The Rank Group Plc, V-N 2011/62.20, NTFR 2011/ 2930, r.o. 43 en 44.

36. Hof 6 juli 2006, nr. C-251/05, Talacre Beach Caravan Sales, V-N 2006/41.16, NTFR 2006/1021.

37. Op grond van deze overgangsregeling kon het Verenigd Koninkrijk om redenen van sociaal belang een vrijstelling met teruggaaf (nultarief) toepassen ten behoeve van eindverbruikers indien een dergelijke regeling op 1 januari 1991 in de nationale regelgeving bestond. Het Verenigd Koninkrijk had een nultarief voor de levering van caravans maar niet voor de binnenuitrusting. 
te heffen over de normale waarde opgenomen in artikel 80, BTW-richtlijn. Te verwachten valt dat als een lidstaat gebruik makt van deze mogelijkheid, een dergelijke maatregel zal moeten voldoen aan de geschiktheid en de minst belemmerende mogelijkheid zal dienen te zijn in het voorkomen van bepaalde vormen van belastingfraude of -ontwijking.

De regeling in de BTW-richtlijn die de lidstaten de mogelijkheid geeft om een normale waarde als maatstaf van heffing te introduceren heeft tot resultaat het bevorderen van de werking van de fiscale neutraliteit als uitdrukking voor de BTW van het gelijkheidsbeginsel. Vervuiling van de maatstaf van heffing veroorzaakt door een gelieerdheid van partijen wordt dan namelijk verwijderd. Het aansluiten bij de marktprijs zal de fiscale neutraliteit bevorderen.

Bij de behandeling van het Scandic-arrest in paragraaf 9.2.3 is tevens aan de orde geweest de mogelijkheid die de artikelen 72 en 80, BTW-richtlijn de lidstaten biedt om de verkoopprijs die wordt berekend aan personeel (bijvoorbeeld in bedrijfsrestaurants) te objectiveren. Wel is het zo dat de lidstaten bij de introductie van een dergelijke regeling niet enkel oog dienen te hebben voor de letterlijke tekst van de artikelen 72 en 80, BTW-richtlijn, maar ook de algemene rechtsbeginselen dienen te eerbiedigen en dan in het bijzonder het evenredigheidsbeginsel. En uiteraard dient er ook objectief gezien sprake te zijn van een situatie die kan leiden tot belastingontwijking. Een dergelijke belastingontwijking kan aan de orde zijn indien bestedingen met een sterk consumptief karakter via de onderneming lopen en vervolgens tegen een lage vergoeding bij personeelsleden terecht komen. Bij de beoordeling van de toelaatbaarheid van een fictieve maatstaf van heffing gebaseerd op artikel 395, BTW-richtlijn, blijkt het Hof na te gaan of de maatregel geschikt is en deze het minst belemmerende alternatief is om het nagestreefde doel te bereiken. Indien een lidstaat een nationale regeling treft teneinde Scandic-achtige situaties te bestrijden dan zullen deze criteria in acht moeten worden genomen.

Het Hof heeft bij het thema eenheid of verscheidenheid al in en vroeg stadium gekozen voor zo veel mogelijk splitsen van de prestatie als er voor de klant zelfstandige prestaties zijn te onderkennen en het hem daarom ook te doen is, zodat kunstmatig splitsen of samenvoegen in elk geval geen leidraad is als het gaat om tarifering, toepassen van vrijstellingsbepalingen of toewijzen van de heffing aan een lidstaat. Uit de arresten Kerrutt, NS en My Travel blijkt dat de uitleg naar de bewoordingen van de richtlijn, steun vindt in de fiscale neutraliteit. In de beschreven inbreukprocedures tegen Frankrijk toetst het Hof de nationale regeling expliciet aan de fiscale neutraliteit en komt tot de beslissing dat verscheidenheid van behandeling tussen nagenoeg gelijke producten is toegestaan. Beslissend daarbij is dat de categorieën producten niet in een concurrentieverhouding staan waarin verschillende BTW-tarieven een rol spelen. 


\section{HOOFDSTUK 10}

\section{Vrijstellingen}

\section{$10.1 \quad$ Inleiding}

Dit hoofdstuk behandelt de invloed van de algemene rechtsbeginselen op de vrijstellingen van de BTW-richtlijn die zijn te vinden in de artikelen $131 \mathrm{t} / \mathrm{m}$ 137, BTWrichtlijn (voorheen artikel 13, Zesde richtlijn). ${ }^{1}$ De behandeling is anders van opzet dan de vorige hoofdstukken. Ik behandel namelijk niet elke vrijstelling afzonderlijk. De onderdelen zijn geschreven vanuit de algemene rechtsbeginselen.

Allereerst schenk ik kort aandacht aan het raamwerk en de achtergrond van de vrijstellingen (paragraaf 10.2). Vervolgens licht ik de benadering toe die het Hof toepast bij de uitleg van de vrijstellingen. Het Hof volgt namelijk in bijna elk arrest op het terrein van de vrijstellingen dezelfde aanpak in de beantwoording van de prejudiciële vraag. Deze benadering schets ik in paragraaf 10.3. In paragraaf 10.4 komt vervolgens de werking van de fiscale neutraliteit als uitdrukking voor de BTW van het gelijkheidsbeginsel aan bod. Paragraaf 10.5 behandelt de invloed van het rechtszekerheidsbeginsel op de uitleg van de vrijstellingsbepalingen. Bij de behandeling van de vrijstellingen in de artikelen $131 \mathrm{t} / \mathrm{m} \mathrm{137,} \mathrm{BTW-richtlijn} \mathrm{schenk}$ ik geen aandacht aan het evenredigheidsbeginsel. Voor zover dit speelt bij deze vrijstellingen behandel ik het in paragraaf 11.5 in de context van het recht op aftrek van voorbelasting.

Ik sluit de behandeling van de genoemde vrijstellingen af met een conclusie (paragraaf 10.6). Na deze conclusie behandel ik de vrijstelling met recht op aftrek van voorbelasting in geval van intra communautaire leveringen. Deze vrijstelling behandel ik dus onafhankelijk van de vrijstellingen in de artikelen 131 t/m 137, BTWrichtlijn. De reden van de aparte behandeling is gelegen in het wezenlijke verschil van deze vrijstellingen ten opzichte van de andere vrijstellingen. De BTW-vrijstelling van de intracommunautaire levering (artikel 138, BTW-richtlijn) heeft, anders dan de overige vrijstellingen, die hun grond vinden in subjectieve redenen of de aard van bepaalde activiteiten, een expliciet sui generis-karakter. Aan de vrijstelling van artikel 138, lid 1, BTW-richtlijn, die recht geeft op aftrek van voorbelasting, ligt 
daarom een geheel andere logica ten grondslag dan aan de voornoemde vrijstellingen: namelijk de goede werking te waarborgen van het BTW-stelsel op intracommunautair niveau. Om de belastingheffing in het land van bestemming te waarborgen wordt - zoals advocaat-generaal Cruz Villalón het formuleert - de belastingketen min of meer kunstmatig in tweeën gesplitst. ${ }^{2}$

\subsection{Raamwerk en achtergrond van de vrijstellingen}

Zoals in hoofdstuk 7 is geschetst is het begrip 'belastingplichtige' ruim. Dat heeft tot gevolg dat allerlei entiteiten binnen het bereik van de BTW vallen die op het particuliere vlak liggen of activiteiten verrichten waarvan men het ongewenst vindt dat deze binnen het heffingsbereik van de BTW vallen. Door de activiteiten van dergelijke belastingplichtigen als vrijgesteld aan te merken, bereikt men materieel hetzelfde als het aanmerken als niet-ondernemer. Namelijk geen belastingheffing over de omzet en geen recht op aftrek van voorbelasting. Dergelijke vrijstellingen het gaat hier om de vrijstellingen op grond van het algemeen belang, zoals die op het gebied van onderwijs en zorg - zijn in het bijzonder te vinden in artikel 132, BTWrichtlijn (voorheen artikel 13A, Zesde richtlijn). ${ }^{3}$

Een kleine groep vrijstellingen heeft betrekking op financiële prestaties, in het bijzonder op die van banken en verzekeringsmaatschappijen. Het spreekt dat het uiterst lastig is om de diverse financiële prestaties in de heffing van de BTW te betrekken. Dit uit technische overwegingen of op grond van politieke en maatschappelijke overwegingen. Om deze redenen zijn verscheidene financiële prestaties in artikel 135, BTW-richtlijn (voorheen artikel 13B, Zesde richtlijn) vrijgesteld. ${ }^{4}$

Ook de BTW-heffing met betrekking tot onroerende zaken vormt een probleem. Eén van de problemen is dat een onroerende zaak gezien de lange levensduur de ene keer in het bezit is van een ondernemer en dan weer in de particuliere sfeer terecht kan komen. Om deze reden is de levering en verhuur van onroerende zaken niet altijd belast. De ene keer geldt een vrijstelling en onder bepaalde voorwaarden wordt daarentegen wel degelijk BTW geheven. ${ }^{5}$ De vrijstellingen die betrekking hebben op onroerende zaken zijn te vinden in artikel 135, BTW-richtlijn (voorheen artikel 13B, Zesde richtlijn).

2. Zie de conclusie van A-G P. Cruz Villalón van 29 juni 2010, nr. C-285/09, bij de strafzaak tegen R, V-N 2010, 33.20.

3. Zie voor een onderscheid van de diverse vrijstellingen A.H.R.M. Denie, De overheid in de omzetbelasting, (diss. Leiden), Deventer: Kluwer 1987, paragraaf 7.2.

4. Zie voor een uitgebreide beschouwing over de achtergrond van de financiële vrijstellingen: M.E. van Hilten, Bancaire en financiële prestaties in de Europese BTW (diss. Leiden), Deventer: Kluwer 1992, blz. $5 \mathrm{t} / \mathrm{m} 45$.

5. Zie voor een uitgebreide behandeling van de regeling die van toepassing is bij onroerende zaken: M.E. van Hilten \& H.W.M. van Kesteren, Omzetbelasting, Deventer: Kluwer 2007, blz. 255 t/m 297. D.B. Bijl, De heffing van omzetbelasting ten aanzien van onroerend goed (diss. Tilburg), Deventer: Kluwer 1990. B.G. van Zadelhoff, Onroerende goederen en belasting over toegevoegde waarde (diss. Amsterdam UvA), Deventer: Uitgeverij FED 1992. 
Artikel 132 beschrijft de vrijstellingen van algemeen belang. In artikel 135, BTWrichtlijn zijn de meer technische vrijstellingen opgenomen. Daarmee bedoel ik dat gezien het karakter van de prestaties (in de financiële sfeer en onroerende zaken) het in de heffing betrekken uiterst complex is. Verder spelen zowel bij de vrijstellingen in artikel 132 als in artikel 135 allerlei historische en nationale overwegingen een rol op grond waarvan deze prestaties zijn vrijgesteld. Artikel 137, BTW-richtlijn (voorheen artikel 13C, Zesde richtlijn) biedt de mogelijkheid om bepaalde prestaties in de financiële sfeer en op het terrein van de verhuur/levering van onroerende zaken op verzoek van de belastingplichtigen te belasten.

In de volgende paragraaf schets ik de wijze waarop het Hof de inhoudelijke werking van de vrijstellingen inkadert.

\subsection{Benadering van de vrijstellingen door het Hof van Justitie EU}

In praktisch alle arresten van het Hof waarin de vrijstellingen van de artikelen 132 en 135, BTW-richtlijn worden uitgelegd, is dezelfde structuur terug te vinden. Deze structuur bestaat uit de volgende uitgangspunten die in wisselende volgorde voorkomen in de arresten:

1. Beginsel van de strikte uitleg

2. Autonome begrippen van gemeenschapsrecht

3. Doelstelling van de vrijstelling

4. Beperkte discretionaire bevoegdheid

Ik zal deze uitgangspunten nader toelichten.

\section{Beginsel van de strikte uitleg}

In bijna elk arrest op het terrein van de vrijstellingen start het Hof met te overwegen dat de vrijstellingen afwijkingen zijn op het algemene beginsel dat BTW wordt geheven over elke dienst die door een belastingplichtige onder bezwarende titel wordt verricht en dan ook strikt dienen te worden uitgelegd. ${ }^{6}$ In een enkel arrest voegt het Hof daar nog aan toe dat het beginsel van de strikte uitleg niet betekent dat de bewoordingen die in de vrijstelling worden gebruikt aldus moeten worden uitgelegd dat zij geen effect meer sorteren. ${ }^{7}$

6. Zie in dit kader Hof 15 juni 1989, nr. 348/87, SUFA, FED 1989/559, r.o. 13. Hof 12 september 2000, Commissie/Verenigd Koninkrijk, nr. C-359/97, Jur. 2000, blz. I-6355, r.o. 64. Hof 20 juni 2002, nr. C-287/ 00, Commissie/Bondsrepubliek Duitsland, r.o. 30, V-N 2002/34.17, FED 2002/535. Hof 11 december 2008, nr. C-407/07, Stichting CBIT, V-N 2008/60.20, NTFR 2008/2507, r.o. 30. Hof 23 april 2009, nr. C-357/07, TNT Post UK Ltd., V-N 2009/21.16, NTFR 2009/1030, r.o. 31. Hof 25 maart 2010, nr. C-79/09, Commissie/Nederland, NTFR 2010/849, r.o. 49.

7. Hof 18 november 2004, nr. C-284/03, Temco Europe SA, V-N 2005/21.22, NTFR 2004/1739, r.o. 17. Zie ook Hof 25 oktober 2007, nr. C-174/06, CO.GE.P. Srl, V-N 2007/49.17, r.o. 28. Zie verder A-G Sharpton in haar conclusie van 9 oktober 2008 bij het arrest Stichting CBIT van 11 december 2008, nr. C-407/07, V-N 2008/60.20, NTFR 2008/2507. In pt. 14 van haar conclusie vermeldt zij: “(...) een strikte uitlegging - en een strikte uitlegging mag niet worden verward met een restrictieve uitlegging - kan worden getemperd naargelang van de aard van de betrokken uitzondering. (...)" Zie tevens A-G Jacobs in $\rightarrow$ 
Voorts heeft het Hof beslist, dat uitzonderingen op de vrijstellingen ruim dienen te worden uitgelegd. Dit gezien het feit dat handelingen die in de BTW-richtlijn zijn vermeld onder een uitzondering op de vrijstelling, zijn geplaatst onder het algemene stelsel dat alle belastbare handelingen aan de BTW onderwerpt. ${ }^{8}$

Verder heeft het Hof in het arrest inzake Stichting Kinderopvang Enschede ${ }^{9}$ het navolgende beslist:

“Bovendien wordt met artikel 13, A, van de Zesde richtlijn (thans artikelen 132 t/m 134: toevoeging $\mathrm{AHB}$ ) beoogd om bepaalde activiteiten van algemeen belang van BTW vrij te stellen. Deze bepaling sluit evenwel niet alle activiteiten van algemeen belang uit van de toepassing van BTW, maar enkel die welke erin worden opgesomd en zeer gedetailleerd omschreven (arrest van 20 november 2003, Taksatorringen, C-8/01, Jurispr. blz. I-13711, punt 60, en arrest Ygeia, reeds aangehaald, punt 16)." (r.o. 14)

Het moet dus gaan om handelingen zoals deze zijn omschreven in artikel 132 dan wel artikel 135, BTW-richtlijn en daarbij geldt een strikte toepassing. ${ }^{10}$ Extensieve interpretatie is in beginsel dan ook niet aan de orde. In subparagraaf 3 van deze paragraaf zal echter blijken dat bij de uitleg van de vrijstellingen regelmatig het doel van de bepaling in de beschouwing wordt betrokken.

\section{Autonome begrippen van gemeenschapsrecht}

Het Hof overweegt in diverse arresten dat de vrijstellingen autonome begrippen van gemeenschapsrecht zijn, die tot doel hebben verschillen in de toepassing van het BTW-stelsel tussen de lidstaten te voorkomen. ${ }^{11}$ In het SUFA-arrest geeft het Hof aan dat dit is te herleiden uit de elfde overweging van de considerans van de Zesde richtlijn. ${ }^{12}$ De elfde overweging vermeldt:

$\rightarrow$ zijn conclusie van 13 december 2001 bij het arrest Zoological Society of London, nr. C-267/00, van 21 maart 2002, V-N 2002/25.19. In pt. 19 vermeldt hij: “I agree that exemptions from VAT should be strictly interpreted but should not be whittled away by interpretation. The Commission is right in that regard to contrast the notions of 'strict and 'restrictive interpretation. As a corollary, limitations on exemptions should not be interpreted narrowly, but nor should they be construed so as to go beyond their terms. Both the exemptions and any limitations on them must be interpreted in such a way that the exemption applies to that to which it was intended to apply and no more. (...)"

8. Hof 3 maart 2005, nr. C-428/02, FML, V-N 2005/15.10, NTFR 2005/357, r.o. 43.

9. Hof 9 februari 2006, nr. C-415/04, Stichting Kinderopvang Enschede, BNB 2006/154, V-N 2006/11.25, NTFR 2006/430, r.o.13

10. Van Hilten meent dat sinds het SUFA-arrest gepredikte woordelijke uitlegging van vrijstellingsbepalingen ten spijt, er niet zo heel veel arresten zijn waarin het Hof een vrijstellingsbepaling strikt naar haar bewoordingen uitlegt, M.E. van Hilten, Over de neutraliteit van de omzetbelasting en het hellend vlak van de uitzonderingen (oratie Amsterdam VU), Deventer: Kluwer 2010, blz. 31. Zie tevens M.E. van Hilten, Vrijstellingen: hoe eng is strikt?, WFR 2009/1328.

11. Hof 20 juni 2002, nr. C-287/00, Commissie/BRD, V-N 2002/34.17, FED 2002/535, NTFR 2002/935, r.o. 44. Hof 25 februari 1999, nr. C-349/96, CPP, BNB 1999/224, V-N 1999/15.28, r.o. 15. HvJ 8 maart 2001, nr. C-240/99, Skandia, V-N 2001/22.19, NTFR 2001/448, r.o. 23. Hof 25 maart 2010, nr. C-79/09, Commissie/Nederland, NTFR 2010/849, r.o. 48.

12. Hof 15 juni 1989, nr. 348/87, SUFA, FED 1989/559, r.o. 11. 
"Overwegende dat, met het oog op een vergelijkbare heffing van de eigen middelen in alle Lidstaten, een gemeenschappelijke lijst van vrijstellingen dient te worden vastgesteld."

Uit deze overweging blijkt dat een uniforme uitleg van de vrijstellingen noodzakelijk is door het gegeven dat een deel van de eigen middelen van de Europese Unie wordt gefinancierd uit de opbrengst van de BTW. ${ }^{13}$

Een voorbeeld van een communautair rechtsbegrip dat is te vinden in de vrijstellingsbepalingen is de term 'verhuur' in artikel 135, lid 1, sub l en lid 2, BTW-richtlijn. Dit is expliciet beslist in de zaak Goed Wonen I waar het Hof erop wijst dat niet aangesloten dient te worden bij het civiele recht van de lidstaten. ${ }^{14}$ Anders zou namelijk worden voorbijgegaan aan de aanzienlijke verschillen tussen de rechtsordes van de lidstaten op het gebied van rechten die aan de houders de bevoegdheid verschaffen onroerend goed te gebruiken. ${ }^{15}$

Het gegeven dat de vrijstellingen door het Hof zijn aangeduid als communautaire rechtsbegrippen heeft een aantal gevolgen voor de rechtsvinding. Voor een behandeling van de betekenis van communautaire rechtsbegrippen verwijs ik naar paragraaf 4.3 .

\section{Doelstelling van de vrijstelling}

Het Hof besteedt tevens aandacht aan de doelstelling die een vrijstelling nastreeft. Zo overweegt het Hof over de vrijstellingen op het medische terrein in het Ygeia-arrest: ${ }^{16}$

"De in artikel 13, A, lid 1, sub b, van de Zesde richtlijn bedoelde vrijstelling van handelingen die nauw samenhangen met de ziekenhuisverpleging en medische verzorging heeft immers ten doel ervoor te zorgen dat medische verzorging en ziekenhuisverpleging niet ontoegankelijk worden vanwege de verhoogde kosten indien zij, of de handelingen die daarmee nauw samenhangen, aan BTW zouden worden onderworpen (arrest Commissie/Frankrijk, reeds aangehaald, punt 23)." (r.o. 23)

Uit de jurisprudentie van het Hof blijkt dat bij de uitleg van de medische vrijstellingen rekening dient te worden gehouden met het doel van deze vrijstelling, namelijk kostenreductie. Dit is terug te vinden in verscheidene arresten waarin de

13. Zie M.E. van Hilten \& H.W.M. van Kesteren, Omzetbelasting, Deventer: Kluwer 2007, paragraaf 3.4.2. Zie verder A. van Dongen, De harmonisatie van de BTW, (diss. Tilburg), Amersfoort: Sdu Uitgevers 2007, blz. 175 e.v.

14. Hof 4 oktober 2001, nr. C-326/99, Stichting Goed Wonen I, V-N 2001/56.25, r.o. 46 t/m 49

15. Zie in dit verband J.J.P. Swinkels, BTW-actualiteiten betreffende verhuur van onroerende zaken, WFR 2009/1344.

16. Hof 1 december 2005, nrs. C-394/04 en C-395/04, Ygeia, V-N 2005/60.23, NTFR 2005/1724. In deze procedure is door het Hof beslist dat de verhuur van telefoons en TV's in ziekenhuizen niet onder het bereik van de vrijstelling van artikel 132, lid 1, sub b, BTW-richtlijn valt (voorheen artikel 13, A, lid 1, sub b, Zesde richtlijn). 
reikwijdte van de vrijstellingen op het medische vlak zijn uitgelegd. Zie in dit kader onder meer de volgende arresten:

- Kügler-arrest ${ }^{17} \quad$ : Onder omstandigheden is ambulante verpleeghulp vrijgesteld.

- Dornier-arrest ${ }^{18} \quad$ : Poliklinische behandeling door niet artsen valt niet onder de vrijstelling van artikel 132, lid 1 , sub b, BTW-richtlijn (voorheen artikel 13A, lid 1 , sub b, Zesde richtlijn), tenzij deze als nevenprestatie bij ziekenhuisverpleging wordt verleend.

- d'Abrumenil-arrest ${ }^{19} \quad$ : Medisch onderzoek is enkel vrijgesteld indien het gericht is op gezondheidsherstel of -behoud.

- Unterpertinger-arrest ${ }^{20} \quad$ : Medisch deskundigenrapport in het kader van een invaliditeitspensioen is niet vrijgesteld.

- L.u.P.-arrest ${ }^{21} \quad$ : Vrijstelling van toepassing op privaatrechtelijk laboratorium onderzoek zonder toezicht van een arts.

Het Hof heeft de bovenvermelde lijn wel genuanceerd in het arrest VDP Dental Laboratory. ${ }^{22}$ In deze procedure is beslist dat de vrijstelling van de levering van tandtechnische werken enkel geldt voor tandartsen en tandtechnici (artikel 132, lid 1, sub e, BTW-richtlijn). Uit oogpunt van kostenreductie kan deze vrijstelling niet worden uitgebreid naar niet-tandartsen of niet-tandtechnici. Het Hof onderbouwt deze beslissing door te overwegen dat anders de tekst van de bepaling radicaal zou worden gewijzigd en de voorwaarde ter zake van de hoedanigheid van de leverancier haar betekenis zou verliezen. Opvallend is het resultaat wel. Omdat de beslissingen van het Hof op het gebied van de vrijstellingen doorgaans betrekking hebben op de handelingen van belastingplichtigen en de kwaliteit van de persoon van de belastingplichtige daarin geen rol speelt; juist niet een rol kan spelen. ${ }^{23}$ En indien de fiscale neutraliteit bij de vrijstelling een rol speelt wordt zij dus betrokken op de handelingen (zie paragraaf 10.4). In casu is, zoals blijkt, de vrijstelling echter zo letterlijk aan de kwaliteit van de - bij professionele naam geduide - persoon gebonden, dat de vrijstelling voor enkel die beperkte beroepsgenoten geldt. ${ }^{24}$ Dan

17. Hof 10 september 2002, nr. C-141/00, Ambulanter Pflegedienst Kügler, FED 2003/55, NTFR 2002/ 1390, r.o. 29.

18. Hof 6 november 2003, nr. C-45/01, Dornier, V-N 2003/58.18, FED 2004/195, NTFR 2003/1905, r.o. 43. 19. Hof 20 november 2003, nr. C-307/01, P. d'Ambrumenil, V-N 2003/61.19, NTFR 2003/1974, r.o. 58 t/m 59. 20. Hof 20 november 2003, nr. C-212/01, M. Unterpertinger, V-N 2003/61.19, FED 2004/70, NTFR 2003/ 1973, r.o. $40 \mathrm{t} / \mathrm{m} 41$.

21. HvJ 8 juni 2006, nr. C-106/05, L.u.P. GmbH, V-N 2006/33.17, r.o. 25.

22. Hof 14 december 2006, nr. C-401/05, VDP Dental Laboratory, BNB 2007/94c, V-N 2007/6.21, NTFR $2007 / 158$.

23. Zie bijvoorbeeld Hof 27 april 2006, nrs. C-443/04 en C-444/04, Solleveld \& Van den Hout - Van Eijnsbergen, BNB 2006/256. In deze procedure is beslist dat bij het omschrijven van de vrijstelling voor medische diensten de fiscale neutraliteit in acht dient te worden genomen. Zie verder paragraaf 10.4. 24. Artikel 132, lid 1, sub e vermeldt: "de door tandtechnici in het kader van de uitoefening van hun beroep verrichte diensten, alsmede de levering van tandprothesen door tandartsen en tandtechnici”. 
is ook de fiscale neutraliteit niet meer aan de beurt te spreken, althans niet verder dan tot de tandtechnici en tandartsen en is ook voor een verruiming van de vrijstelling tot handelingen buiten die professionals geen plaats. Hetzelfde geldt een mogelijke doelstelling; zij kan de strikte tekst - en in dit geval een nogal afwijkende strikte - niet opzij zetten.

Dat de vrijstelling kostenreductie nastreeft speelt niet enkel bij de uitleg van de medische vrijstellingen een rol. Ook bij de uitleg van de onderwijsvrijstelling en bij de vrijstelling van diensten van sociale aard komt dit aspect terug in de jurisprudentie van het Hof. ${ }^{25}$ Zie in dit kader de inbreukprocedure van de Commissie tegen Duitsland over de onderwijsvrijstelling (met weglating van de verwijzingen): ${ }^{26}$

“(...) de vrijstelling van diensten die nauw samenhangen met het universitair onderwijs, moet verzekeren dat het volgen van universitair onderwijs niet ontoegankelijk wordt vanwege de verhoogde kosten indien het onderwijs zelf, of de dienstverrichtingen en de leveringen van goederen die daarmee nauw samenhangen, aan BTW zouden worden onderworpen (...). BTW heffen op onderzoeksprojecten die onder bezwarende titel worden verricht door openbare instellingen voor hoger onderwijs, heeft evenwel geen stijging van de kostprijs van het universitair onderwijs tot gevolg." (r.o. 47)

Het Hof overweegt in het TNT-arrest ${ }^{27}$ - over de uitleg van de postvrijstelling dat alle bepalingen van artikel 132, BTW-richtlijn (voorheen artikel 13A, Zesde richtlijn) tot doel hebben bepaalde activiteiten van algemeen belang te begunstigen. Deze algemene doelstelling neemt in de postsector de vorm aan van een meer specifieke doelstelling om tegen lage prijzen postdiensten aan te bieden die aan de essentiële behoeften van de bevolking beantwoorden. Uit het TNT-arrest trek ik dan ook de conclusie dat bij alle vrijstellingen die zijn te vinden in artikel 132, BTW-richtlijn het aspect van de kostenreductie van belang is bij de uitleg van de reikwijdte van deze vrijstellingen. Het betreft immers vrijstellingen - zoals het Hof heeft aangeduid - die tot doel hebben bepaalde activiteiten van algemeen belang te begunstigen.

Uit deze jurisprudentie is de conclusie te trekken dat bij de uitleg van de vrijstellingen op het medische terrein, onderwijs en bij de vrijstelling van diensten van sociale aard, rekening dient te worden gehouden met de doelstelling van deze vrijstellingen, namelijk het voorkomen dat door een BTW-heffing de kostprijs van deze diensten stijgt en dat daardoor deze prestaties voor bepaalde groepen eindverbruikers

25. Voor de vrijstellingen van sociale aard (artikel 132, lid 1, sub g en h, BTW-richtlijn) komt dit aspect terug in het Kingscrest-arrest. Zie Hof 26 mei 2005, nr. C-498/03, V-N 2005/29.19, r.o. 30.

26. Hof 20 juni 2002, nr. C-287/00, Commissie/Duitsland, V-N 2002/34.17, FED 2002/535. In dit arrest is beslist dat onderzoeksactiviteiten van universiteiten belast zijn met BTW. Onder meer op grond van het gegeven dat BTW-heffing op onderzoeksprojecten die onder bezwarende titel worden verricht door openbare instellingen voor hoger onderwijs, geen stijging van de kostprijs van het universitair onderwijs tot gevolg heeft.

27. Hof 23 april 2009, nr. C-357/07, TNT Post UK Ltd., V-N 2009/21.16, NTFR 2009/1030, r.o.32 en 33. 
ontoegankelijk worden. ${ }^{28}$ Dit aspect kan tot gevolg hebben dat het beginsel van de strikte uitleg niet al te strikt dient te worden toegepast.

Afgezien van de vrijstellingen op het terrein van het algemeen belang heeft het Hof het aspect van de kostenreductie ook geïntroduceerd in de financiële vrijstellingen, namelijk in de arresten Velvet Steel, ${ }^{29}$ Swiss $\mathrm{RE}^{30}$ en $\mathrm{SEB}^{31}$ over de uitleg van de vrijstelling van kredietverlening.

Het probleem van de kostenreductie is echter dat uit de voorgeschiedenis van de Zesde richtlijn niet duidelijk is te achterhalen dat zij het doel is van de vrijstellingen. Van Hilten acht deze ontwikkeling in de jurisprudentie, waarin het Hof aan de hand van kennelijk zelf ontwikkelde ratio legis vrijstellingsbepalingen uitlegt niet juist. ${ }^{32}$ Het is namelijk niet de taak van het Hof om een doel aan een bepaling toe te kennen. Dat is de taak van de communautaire wetgever. Zij brengt naar voren dat het ontbreken van een 'kenbare' toelichting waaruit het doel en strekking van de desbetreffende bepaling blijkt, tot gevolg heeft dat een vrijstellingsbepaling niet aan de hand van haar ratio kan worden uitgelegd. Het ligt dan voor de hand om bij de uitleg zo dicht mogelijk bij de bewoordingen van de bepalingen te blijven, hoe redelijk de door het Hof veronderstelde ratio van een bepaling ook is.

Ik deel de kritiek van Van Hilten, ofschoon het te veronderstellen is dat bij het ontwerp van de Zesde richtlijn kostenreductie een rol heeft gespeeld bij de introductie van de vrijstellingen van algemeen belang en sociale aard. Ook al is dit niet expliciet te vinden in de toelichting bij de Zesde richtlijn. Bij de uitleg van de meer technische vrijstellingen zoals de financiële is dat echter minder voor de hand liggend. Bij de financiële vrijstellingen speelt namelijk ook mee dat deze zijn geïntroduceerd om te verhelpen de moeilijkheden in verband met de vaststelling van de belastbare grondslag bij financiële producten. ${ }^{33}$ Wat de vrijstellingen betreft met een sociaal karakter en ten gunste van bepaalde activiteiten met een algemeen belang - zoals met name in artikel 132, BTW-richtlijn - kan ik mij wel vinden in een uitleg waarbij het Hof kijkt naar kostenreductie.

Overigens is kostenreductie niet het enige doel dat van belang is bij de uitleg van de vrijstellingen in artikel 132, BTW-richtlijn. Zo overweegt het Hof in het Unterpertinger-arrest $^{34}$ - een arrest dat handelt over een medisch rapport ter vaststelling van een invaliditeitspensioen - over de medische vrijstellingen:

28. Dit aspect is overigens niet expliciet terug te vinden in het arrest van 14 juni 2007, nr. C-434/05, Horizon College, BNB 2008/100, V-N 2008/28.21, NTFR 2007/1088. In de prejudiciële vraag had de HR dit aspect echter wel naar voren gebracht, zie NTFR 2005/1681.

29. Hof 19 april 2007, nr. C-445/05, Velvet Steel Immobilien, V-N 2007/21.18, r.o. 24

30. Hof 22 oktober 2009, nr. C-242/08, Swiss RE Germany Holding GmbH, V-N 2009/53.21, r.o. 49.

31. Hof 10 maart 2011, nr. C-540/09, SEB, NTFR 2011/640, r.o. 21.

32. M.E. van Hilten 2010, blz. 36.

33. Zie r.o. 24 in het eerder aangehaalde arrest Velvet Steel.

34. Hof 20 november 2003, nr. C-212/01, M. Unterpertinger, V-N 2003/61.19, FED 2004/70, NTFR 2003/ 1973. 
"Zoals de advocaat-generaal in de punten 66 tot en met 68 van haar conclusie terecht heeft opgemerkt, is het doel van een medische dienst bepalend voor het antwoord op de vraag of hij van BTW moet worden vrijgesteld. Indien dus een medische dienst wordt verricht in een context waarin kan worden vastgesteld dat het voornaamste doel van de dienst niet bescherming, met inbegrip van instandhouding of herstel, van de gezondheid is, maar het verstrekken van een advies waarom is gevraagd voor het nemen van een beslissing met rechtsgevolgen, valt die dienst niet onder de vrijstelling van artikel 13, A, lid 1, sub c, van de Zesde richtlijn." (r.o. 42)

Van belang is dus ook datgene waar de dienst op is gericht. Zo is van belang bij de diensten die in het kader van de uitoefening van medische en paramedische beroepen kunnen worden verricht, dat zij vallen onder het begrip 'gezondheidkundige verzorging', de gerichtheid op de gezondheid van de mens.

4. Beperkte discretionaire bevoegdheid

Artikel 131, BTW-richtlijn kadert de toepassing van de vrijstelling met de volgende randvoorwaarden in:

“(...), onder de voorwaarden die de lidstaten stellen om een juiste en eenvoudige toepassing van deze vrijstellingen te verzekeren en elke vorm van fraude, ontwijking en misbruik te voorkomen." 35

Dit zinsdeel geeft aan dat de lidstaten voorwaarden kunnen stellen die niet zijn te vinden in de letterlijke tekst van de vrijstellingsbepalingen. Deze discretionaire bevoegdheid is door het Hof erkend in het Linneweber-arrest. In hetzelfde arrest geeft het Hof ook de grens aan van deze discretionaire bevoegdheid, namelijk de werking van de fiscale neutraliteit. ${ }^{36}$ Paragraaf 10.4 gaat nader in op dit aspect.

In deze paragraaf is de structuur geschetst die in veel arresten van het Hof is terug te vinden. De uitgangspunten 1, 2 en 3 treft men in (bijna) alle arresten aan. Deze uitgangspunten lijken dan ook wel een mantra die het Hof uitspreekt als de uitleg van de vrijstellingen aan de orde is. Uitgangspunt 4 laat zich uiteraard slechts zien als het formeel aan de orde is.

\subsection{Gelijkheidsbeginsel}

In paragraaf 4.4 .4 is aan de orde geweest de wijze waarop de begrippen fiscale neutraliteit, gelijkheidsbeginsel en gelijke concurrentieverhoudingen zich tot elkaar verhouden. De term fiscale neutraliteit komen wij op een aantal plaatsen tegen in de jurisprudentie op het terrein van de vrijstellingsbepalingen. Zoals in paragraaf 4.4.4 is verduidelijkt heeft men met deze term op het oog een gelijke behandeling voor de

35. In de Zesde richtlijn is een praktisch identieke zinsdeel te vinden in de aanhef van zowel A als B van artikel 13 , Zesde richtlijn.

36. Hof 17 februari 2005, nrs. C-453/02 en C-462/02, Linneweber e.a., V-N 2005/13.14, NTFR 2005/302. De discretionaire bevoegdheid van de lidstaten is te vinden in r.o. 34. De grens van deze bevoegdheid wordt aangegeven in r.o. 37. 
BTW-heffing van ondernemers die dezelfde handelingen verrichten. ${ }^{37}$ Tevens is in paragraaf 4.4.4.2 behandeld dat het beginsel een tweetal andere beginselen omvat, te weten de beginselen van uniformiteit van de BTW en van het opheffen van concurrentievervalsing. ${ }^{38}$ Zoals is verduidelijkt moet met betrekking tot de fiscale neutraliteit voor ogen worden gehouden dat dit beginsel de gelijke behandeling van soortgelijke met elkaar concurrerende goederen en diensten inhoudt, en derhalve tevens, zoals het Hof heeft vastgesteld, een uitdrukking vormt van het beginsel van het opheffen van concurrentievervalsing. ${ }^{39}$

Artikelen 132 t/m 134, BTW-richtlijn (voorheen artikel 13A, Zesde richtlijn) kennen de voorwaarden dat geen verstoring van de mededinging mag optreden. Daarbij springen in het bijzonder enkele onderdelen van artikel 133, BTW-richtlijn in het oog (voorheen 13A, lid 2, Zesde richtlijn). Artikel 133, BTW-richtlijn geeft de lidstaten de mogelijkheid om enkele aanvullende voorwaarden te stellen aan de in artikel 132 geformuleerde vrijstellingen voor activiteiten van algemeen belang. Zo vermeldt sub d van artikel 133, BTW-richtlijn dat lidstaten de voorwaarden kunnen stellen dat de vrijstellingen genoemd in artikel 132, lid 1, sub b (verpleging en verzorging), $g$ (maatschappelijk werk en sociale zekerheid), h (bescherming van jongeren), i (school- of universitair onderwijs), 1 (instellingen zonder winstoogmerk), m (sportorganisaties) en n (culturele diensten), BTW-richtlijn niet mogen leiden tot verstoring van de mededinging ten nadele van belastingplichtige commerciële ondernemingen. De lidstaten kunnen deze non-concurrentievoorwaarde stellen aan andere dan publiekrechtelijke instellingen. Uit het arrest Horizon College ${ }^{40}$ blijkt dat deze uitsluiting van de vrijstelling een specifieke uitdrukking vormt:

“(...) van het beginsel van fiscale neutraliteit dat zich er met name tegen verzet dat soortgelijke diensten, die dus met elkaar concurreren, uit het oogpunt van de BTW ongelijk worden behandeld". (r.o. 43)

In het vervolg van deze paragraaf blijkt dat de fiscale neutraliteit een belangrijke rol speelt bij de uitleg van de vrijstellingen. Op deze plaats is van belang dat het Hof de fiscale neutraliteit herkent in de tekst van artikel 133, BTW-richtlijn waar is vermeld dat enkele in het bijzonder genoemde vrijstellingen niet mogen leiden tot verstoring van de mededinging ten nadele van belastingplichtige commerciële ondernemingen. Zoals eerder in paragraaf 4.4.4 al naar voren is gebracht, kan een verbod op verstoring van de concurrentieverhoudingen worden gezien als een uitdrukking van het gelijkheidsbeginsel voor de BTW.

De door de lidstaten in te voeren voorwaarde dat de vrijstelling niet tot concurrentievervalsing mag leiden is facultatief, het betreft namelijk een zogenoemde

37. Zie bijvoorbeeld Hof 16 oktober 2008, nr. C-253/07, Canterbury Hockey Club, V-N 2008/49.18, r.o. 30. 38. Hof 3 mei 2001, nr. C-481/98, Commissie/Frankrijk, V-N 2001/42.18, r.o. 22.

39. Hof 3 mei 2001, nr. C-481/98, Commissie/Frankrijk, V-N 2001/42.18, r.o. 22. zie tevens over dit aspect uitgebreid A-G Stix-Hackl in de conclusie van 8 juli 2004 bij het arrest Linneweber \& Akriditis van 17 februari 2005, nrs. C-453/02 en C-462/02, V-N 2005/13.14.

40. Hof 14 juni 2007, nr. C-434/05, Horizon College, BNB 2006/238, V-N 2008/100, NTFR 2007/1088. 
'kan-bepaling'. Verder valt op dat artikel 133, BTW-richtlijn enkel noemt 'andere dan publiekrechtelijke lichamen'. Voorts valt op dat alsdan het verbod op vervalsing van de mededinging enkel geldt voor een aantal vrijstellingen. Niet worden genoemd de vrijstellingen in artikel 132, BTW-richtlijn, lid 1, sub a (openbare postdiensten), c (medische verzorging), d (levering menselijke organen), e (tandtechnici), f (koepelvrijstelling), $\mathrm{j}$ (privélessen), $\mathrm{k}$ (geestelijke bijstand), o (fondsverwervende vrijstellingen), p (ziekenvervoer), q (radio- en televisieorganisaties). Voor een deel is dat te verklaren gezien het feit dat in enkele van deze vrijstellingen al in de tekst van de bepaling als voorwaarde is gesteld dat geen concurrentievervalsing mag optreden (artikel 132, lid 1, sub f en o). Echter voor een deel is niet direct duidelijk waarop dit onderscheid is gebaseerd.

Uit het arrest JCM Beheer ${ }^{41}$ volgt dat het beginsel van de fiscale neutraliteit tot gevolg heeft dat de marktdeelnemers het organisatiemodel moeten kunnen kiezen dat hun uit strikt economisch oogpunt het beste uitkomt, zonder het risico te lopen dat hun activiteiten worden uitgesloten van de vrijstelling. In het arrest JCM Beheer is dit aspect toegespitst op de vrijstelling van artikel 135, lid 1, sub a, BTW-richtlijn (voordien artikel 13, B, aanhef, sub a, Zesde richtlijn) (verzekeringstussenpersonen). De verwijzing naar het 'organisatiemodel' in deze context komt in een aantal arresten op het terrein van de financiële vrijstellingen terug. Onder meer in de arresten:

- Abbey National $\mathrm{II}^{42} \quad$ : In deze procedure geeft het Hof een verduidelijking van het zinsdeel 'beheer van gemeenschappelijke beleggingsfondsen' dat is vrijgesteld op grond van artikel 135, lid 1, sub g, BTW-richtlijn (voordien artikel 13, B, sub d, punt 6, Zesde richtlijn).

- Ludwig $^{43} \quad$ : Het Hof geeft een verheldering in dit arrest van de vrijstelling voor kredietbemiddeling van artikel 135, lid 1, sub b, BTW-richtlijn (voordien artikel 13, B, sub d, punt 1, Zesde richtlijn).

In de in paragraaf 3.4.3.1 behandelde arresten - Bulthuis-Griffioen en Gregg - heeft het Hof het aspect van de vrijheid van organisatie toegespitst op de vrijheid van rechtsvormkeuze. Daar ging het om de relatie met het rechtszekerheidsbeginsel. Op deze plaats kan daar aan worden toegevoegd dat de neutraliteit ten aanzien van de rechtsvorm stevig is verankerd in de jurisprudentie van het Hof. De neutrale rechtsvormkeuze is een uitdrukking van het gelijkheidsbeginsel. Zo legt de rechtsvorm-neutrale behandeling de nadruk op de vergelijkbaarheid van de transacties en dat de rechtsvorm waarin de transacties worden verricht niet van belang is voor het fiscale lot van de prestaties die een belastingplichtige verricht. ${ }^{44}$

41. Hof 3 april 2008, nr. C-124/07, J.C.M. Beheer, V-N 2008/17.16, r.o. 28

42. Hof 4 mei 2006, nr. C-169/04, Abbey National II, Jur. 2006, blz. I-4027, r.o. 68.

43. Hof 21 juni 2007, nr. C-453/05, V. Ludwig, V-N 2007/31.23, blz. I-5083, r.o. 35

44. Zie ook Hof 16 oktober 2008, nr. C-253/07, Canterburry Hockey Club, V-N 2008/49.18, in het bijzonder r.o. 30. Het Hof verduidelijkt, toegespitst op de vrijstelling van artikel 132, lid 1, sub $\mathrm{m}, \rightarrow$ 
De rechtsvorm-neutrale behandeling verwoordt het Kügler-arrest ${ }^{45}$ als volgt:

"Het beginsel van fiscale neutraliteit verzet zich er namelijk meer in het bijzonder tegen, dat ondernemers die dezelfde handelingen verrichten verschillend worden behandeld bij de BTW-heffing. Aan dit beginsel zou dus afbreuk worden gedaan, wanneer de vrijstelling voor de in artikel 13, A, lid 1, sub c, genoemde verrichtingen op het gebied van de gezondheidskundige verzorging van de mens zou afhangen van de rechtsvorm waarin de belastingplichtige zijn werkzaamheid uitoefent (zie in die zin arrest Gregg, reeds aangehaald, punt 20)." (r.o. 20)

Ook het Hoffmann-arrest ${ }^{46}$ besteedt aandacht aan het feit dat de rechtsvorm geen onderscheidend criterium mag zijn. Het woord 'instellingen '- dat is te vinden in de tekst van de vrijstellingsbepaling - zegt iets over een organisatie als entiteit en daarachter kan een rechtspersoon - bijvoorbeeld een stichting - schuilgaan, maar ook een combinatie van natuurlijke personen en/of rechtspersonen. Hoe dan ook zit er een of andere vormkeuze achter. En de zelfstandig opererende natuurlijk persoon wordt dan de vrijstelling niet machtig? Enkele lidstaten ondernemen een poging om onder de neutraliteit van de rechtsvorm uit te komen door naar voren te brengen dat het geen vergelijkbare gevallen zijn. Zo brengen zij naar voren:

“(...) Een solist kan derhalve niet als een instelling worden beschouwd, omdat hij kennelijk niet beschikt over een geheel van menselijke en materiële hulpbronnen en evenmin over de organisatorische structuur die daarvoor nodig is, in tegenstelling tot een zangkoor, een orkest of een kamermuziekensemble." (r.o. 20)

De lidstaten voegen daar vervolgens aan toe:

"Optredens van solisten en optredens van instellingen zijn niet gelijksoortig. Optredens van een solist hebben een zeer uitgesproken persoonlijk karakter en naambekendheid speelt daarbij een grote rol. Zij zijn derhalve niet te vergelijken met optredens van zangkoren, orkesten of kamermuziekensembles." (r.o. 22)

Deze poging om onder de werking van de neutraliteit ten aanzien van de rechtsvorm uit te komen treft gelukkig geen doel. Het Hof overweegt namelijk:

\footnotetext{
$\rightarrow$ BTW-richtlijn (sportbeoefening) (voorheen artikel 13A, lid 1, sub m, Zesde richtlijn), dat het beginsel van de fiscale neutraliteit zich ertegen verzet dat ondernemers die dezelfde handelingen verrichten verschillend worden behandeld bij de BTW-heffing. Zie paragraaf 4.4.4 over de wijze waarop fiscale neutraliteit en het gelijkheidsbeginsel zich tot elkaar verhouden.

45. Hof 10 september 2002, nr. C-141/00, Ambulanter Pflegedienst Kügler, FED 2003/55, NTFR 2002/ 1390. Zie verder Hof 6 februari 2003, nr. C-45/01, Dornier, V-N 2003/58.18, FED 2004/195, NTFR 2003/ 1905, r.o. $19 \mathrm{t} / \mathrm{m}$ 21. Het eerste arrest op het terrein van de BTW waar dit aspect aan de orde kwam was de inbreuk procedure tegen Duitsland, Hof 11 juli 1985, nr. 107/84, Commissie/Duitsland, Jur. 1985, blz. 2655. In deze procedure is beslist dat de diensten áán de Deutsche Budespost niet onder de postdienstenvrijstelling vallen. In r.o. 16 van dit arrest is te vinden dat de postwerkzaamheden vrijgesteld blijven, of zij nu door een publiekrechtelijk lichaam worden verricht, dan wel worden uitbesteed aan een concessiehouder. Zie over deze procedure ook paragraaf 7.4.8.

46. Hof 3 april 2003, nr. C-144/00, M. Hoffmann, BNB 2003/196, V-N 2003/20.12, NTFR 2003/631.
} 
"In het bijzonder kunnen dergelijke artiesten, net zoals culturele groepen, hun activiteit professioneel, semiprofessioneel of als amateur uitoefenen, en dat doen om er winst mee te maken of op vrijwillige basis en zonder vergoeding of eventueel tegen een vergoeding die alleen hun kosten dekt. In die verschillende gevallen treedt de artiest op als een geïndividualiseerde entiteit die een culturele taak vervult, op dezelfde wijze als een culturele groep, zelfs al verzorgt hij zijn optreden met eigen middelen en ongeacht de juridische vorm die hij voor zijn activiteit heeft gekozen." (r.o. 26)

Dus ook de natuurlijk persoon, die er voor gekozen heeft om zich niet van een juridische vorm te voorzien, maar kiest voor het 'originele' optreden als zelfstandig natuurlijk persoon, mag delen in de vrijstelling. Maar het aanknopingspunt in de Hoffmann-procedure is natuurlijk de activiteit die men verricht. In het bijzonder op het terrein van de vrijstellingen is het uiterst belangrijk dat soortgelijke diensten, die met elkaar concurreren uit het oogpunt van de BTW gelijk worden behandeld. Ook wanneer de neutraliteit ten aanzien van de rechtsvorm niet aan de orde is, speelt in de arresten over de vrijstellingen natuurlijk de gelijkschakeling tussen gelijke en soortgelijke prestaties een rol. Het Hof gebruikt dan de gelijke behandeling als sleutel ter bepaling van de reikwijdte van de desbetreffende vrijstelling. In het Ygeiaarrest overweegt het Hof: ${ }^{47}$

"Zoals de advocaat-generaal in punt 47 van zijn conclusie heeft opgemerkt, is de heffing van BTW over dergelijke prestaties in overeenstemming met het beginsel van fiscale neutraliteit, dat zich er met name tegen verzet dat soortgelijke diensten, die dus met elkaar concurreren, uit het oogpunt van de BTW ongelijk worden behandeld (arrest van 23 oktober 2003, Commissie/Duitsland, C-109/02, Jurispr. blz. I-12691, punt 20)." (r.o. 32)

In dit arrest is de vraag aan de orde of de verhuur van telefoons en televisietoestellen in ziekenhuizen kan delen in de vrijstelling van artikel 132, lid 1, sub b, BTW-richtlijn (ziekenhuisverpleging en medische verzorging) (voorheen artikel 13A, lid 1, sub b, Zesde richtlijn). Om deze vraag te beantwoorden gaat het Hof nauwgezet na of concurrentievervalsing aan de orde kan zijn.

"Anders dan Ygeia betoogt en zoals de Duitse regering terecht heeft aangevoerd, concurreert een inrichting voor medische verzorging, wanneer zij prestaties zoals in het hoofdgeding levert, met belastingplichtigen die soortgelijke prestaties leveren, zoals de leveranciers van telefonie- en televisiediensten in het geval van de aan ziekenhuispatiënten aangeboden diensten, en hotels en restaurants in het geval van de verstrekking van logies voor hun begeleiders." (r.o. 33)

Vervolgens komt het Hof tot de conclusie dat de vrijstelling niet van toepassing is. ${ }^{48}$ Uitgangspunt is dus de vergelijkbaarheid van de transacties die worden verricht. ${ }^{49}$

47. Hof 1 december 2005, nrs. C-394/04 en C-395/04, Ygeia e.a. V-N 2005/60.23, NTFR 2005/1724

48. Zie nader Van Hilten voor een kritische beschouwing over de uitleg dat het beginsel van de fiscale neutraliteit zich verzet tegen een verschillende behandeling van soortgelijke diensten, die met elkaar concurreren, uit oogpunt van BTW verschillend worden behandeld. M.E. van Hilten 2010, blz. 41 en 42. Ik ga daar op deze plaats niet nader op in, maar besteed daar uitgebreid aandacht aan in hoofdstuk 13.2. 49. Ook in diverse andere arresten op het terrein van de vrijstellingen in artikel 135, BTW-richtlijn is het gelijkheidsbeginsel in deze vorm terug te vinden. Zie bijvoorbeeld Hof 27 oktober 1993, nr. C-281/ 91, Muys en de Winter, BNB 1994/95, V-N 1993/4006, pt. 47, r.o. 13 en 14 waaruit blijkt dat de $\rightarrow$ 
Verder is van belang dat ook de omstandigheid dat concurrentievervalsing in de toekomst kan optreden relevant kan zijn. Zie in dit kader het Taksatoringen-arrest waar aan de orde was de uitleg van artikel 132, lid 1, sub f, BTW-richtlijn (koepelvrijstelling) (voorheen artikel $13 \mathrm{~A}$, lid 1 , sub f, Zesde richtlijn). ${ }^{50}$ De vervalsing is aangetoond zodra wordt vastgesteld dat diensten met elkaar concurreren en ongelijk worden behandeld vanuit het oogpunt van de BTW. Het is in dat opzocht irrelevant of de vervalsing die daaruit voortvloeit aanmerkelijk is. ${ }^{51}$

Verder verduidelijkt het TNT-arrest, ${ }^{52}$ dat bij de beoordeling van de vergelijkbaarheid van de handelingen het niet volstaat om afzonderlijke diensten te vergelijken, maar moet ook rekening worden gehouden met de context waarin deze worden verricht. Het Hof heeft met zijn beslissing in het TNT-arrest duidelijkheid verschaft over de werkingssfeer van de vrijstelling met betrekking tot de door de openbare postdiensten verrichte diensten (artikel 132, lid 1, sub a, BTW-richtlijn, voorheen artikel 13A, lid 1, sub a, Zesde richtlijn). Toegespitst op TNT verlangt de fiscale neutraliteit niet dat de handelingen die TNT verricht in het Verenigd Koninkrijk op dezelfde manier voor de BTW-heffing worden behandeld als de handelingen van Royal Mail. TNT heeft namelijk niet de verplichting om vergelijkbare diensten aan te bieden in het Verenigd Koninkrijk. Het is weliswaar mogelijk dat TNT deels soortgelijke diensten als Royal Mail verricht, bijvoorbeeld het ophalen en sorteren van postzendingen, maar de fiscaal bevoordeelde universele dienst bestaat juist uit het ter beschikking stellen van een openbaar postnetwerk als een geheel van infrastructuur (zoals het in alle hoeken en gaten verplicht bezorgen van post) en diensten van een bepaalde kwaliteit tegen een bepaalde prijs. Bijgevolg volstaat het bij de beoordeling van de vergelijkbaarheid van de handelingen niet om de afzonderlijke diensten te vergelijken, maar moet ook worden nagegaan of deze diensten deel uitmaken van een totaalaanbod van het openbare postnetwerk. ${ }^{53}$ Vanwege deze speciale context waarbinnen de universele postdienst plaatsheeft, staat de fiscale neutraliteit er niet aan in de weg dat andere deelnemers (zoals TNT) die dezelfde handelingen verrichten voor hun postdiensten niet onder de vrijstelling vallen.

$\rightarrow$ vrijstelling voor kredietverstrekking niet enkel is voorbehouden aan banken. Zie verder Hof 17 februari 2005, nrs. C-453/02 en C-462/02, Linneweber e.a., V-N 2005/13.14, NTFR 2005/302, r.o. $22 \mathrm{t} / \mathrm{m} 30$ met betrekking tot de exploitatie van kansspelen in niet erkende speelbanken. Zie ook Hof 4 mei 2006, nr. C-169/04, Abbey National Plc II, NTFR 2006/687, r.o. 56 waarin is verduidelijkt dat artikel 135, lid 1, sub g van toepassing is op gemeenschappelijke beleggingsfondsen ongeacht de rechtsvorm gezien het feit dat de fiscale neutraliteit zich ertegen verzet dat ondernemers die dezelfde handelingen verrichten verschillend worden behandeld.

50. Hof 20 november 2003, nr. C-8/01, Taksatoringen, V-N 2003/13.18, FED 2004/259, NTFR 2003/1975. R.o. 64 vermeldt: “Bijgevolg moet de BTW-vrijstelling worden geweigerd indien er een reëel gevaar bestaat dat de vrijstelling op zich op korte termijn of in de toekomst tot concurrentievervalsing kan leiden."

51. Hof 28 juni 2007, nr. C-363/05, JP Morgan Fleming Claverhouse Investment Trust Plc, V-N 2007/ 36.25 , r.o. 47.

52. Hof 23 april 2009, nr. C-357/07, TNT Post UK Ltd., V-N 2009/21.16, NTFR 2009/1030, r.o. 38.

53. Aan de analyse van de context besteedt in het bijzonder A-G Kokott aandacht in haar conclusie bij het TNT-arrest. Zie pt. 63 in haar conclusie. 
In het kader van deze paragraaf is het arrest Idéal Tourisme ${ }^{54}$ nog van belang. Het arrest heeft niet direct betrekking op de vrijstellingen genoemd in de artikelen 132 en 135, BTW-richtlijn maar betreft de uitleg van de vrijstelling met recht op aftrek van voorbelasting voor internationaal luchtvervoer artikel 148, sub f juncto artikel 169, sub b en artikel 371, bijlage X, deel B, BTW-richtlijn (voorheen artikel 15, lid 6 juncto artikel 17, lid 3 en artikel 28, lid 3, sub b, Bijlage F, Zesde richtlijn) (nultarief in de Nederlandse terminologie). Het principe dat door het Hof in het Idéal Tourisme-arrest formuleert kan echter van belang zijn voor de vrijstellingen genoemd in de artikelen 132 en 135, BTW-richtlijn, aangezien zij, ondanks hun verschil in karakter, door dezelfde overgangsregeling worden beheerst.

In het Idéal Tourisme-arrest verricht belanghebbende grensoverschrijdend personenvervoer per touringcar. Dit vervoer is belast met BTW. Belanghebbende betoogt dat sprake is van concurrentievervalsing gezien het feit dat personenvervoer per vliegtuig onder de vrijstelling valt met recht op aftrek van voorbelasting. Op bepaalde trajecten concurreren beide vormen van personenvervoer met elkaar. De regeling in de BTW-richtlijn plaatst personenvervoer per vliegtuig in een gunstiger positie. Het Hof is echter niet gevoelig voor dit argument. Het wijst erop dat het communautaire BTW-stelsel een geleidelijke harmonisatie betreft, en tot op dit moment slechts een gedeeltelijke harmonisatie (r.o. 37). Het Hof overweegt vervolgens:

"Zoals de Belgische Staat ter terechtzitting heeft verklaard, is die voorgenomen harmonisatie nog niet verwezenlijkt, aangezien de Zesde richtlijn in artikel 28 , lid 3 , sub b, de lidstaten zonder voorbehoud heeft toegestaan, sommige van vóór de Zesde richtlijn daterende bepalingen van hun nationale wettelijke regeling te blijven toepassen, die zonder die toestemming onverenigbaar met de richtlijn zouden zijn. Voor zover een lidstaat dergelijke bepalingen handhaaft, voert hij dus niet de Zesde richtlijn uit, en schendt hij derhalve noch die richtlijn noch de algemene communautaire beginselen die de lidstaten volgens voornoemd arrest Klensch e.a. in acht moeten nemen wanneer zij de gemeenschapsregeling uitvoeren." (r.o. 38)

Vervolgens geeft rechtsoverweging 39 aan (met weglating van de verwijzingen):

"In een dergelijke situatie staat het aan de gemeenschapswetgever, de definitieve communautaire regeling voor de vrijstellingen van de BTW vast te stellen en aldus de nationale BTW-wetgevingen geleidelijk te harmoniseren (....."

Uit het arrest Idéal Tourisme blijkt dat het gegeven dat geen volledige harmonisatie voor de BTW is bereikt een reden kan zijn voor het Hof om concurrentievervalsing toe te staan. Daarbij is van belang dat het een terrein moet betreffen dat nog niet is geharmoniseerd omdat het bijvoorbeeld onder een overgangsregeling valt. Voor de vrijstellingen valt dan te denken aan artikel 371, BTW-richtlijn (voorheen artikel 28, Zesde richtlijn). Artikel 371 bepaalt dat de lidstaten die op 1 januari 1978 vrijstelling verleenden voor de in de lijst van X, deel B, genoemde handelingen, mogen deze, onder de in iedere betrokken lidstaat op die datum bestaande voorwaarden, blijven 
vrijstellen. Het feit dat men hier niet heeft geharmoniseerd, wil overigens niet zeggen dat het Hof de begrippen niet eenduidig zou kunnen uitleggen; dat is iets anders dan het vraagstuk van de concurrentievervalsing dat in het arrest Idéal Tourisme aan de orde is.

\subsection{Rechtszekerheidsbeginsel}

In de jurisprudentie op het terrein van de vrijstellingen laat ook het rechtszekerheidsbeginsel zich gelden. ${ }^{55}$

Het rechtszekerheidsbeginsel duikt op in het Cantor-arrest. ${ }^{56}$ De eigenaar van een kantoorpand in Londen verhuurde voor een periode van vijftien jaar een deel van het pand aan Wako International Ltd. In 1993 kwamen Wako International Ltd en Cantor overeen, met instemming van de eigenaar, dat Cantor de huur zou overnemen. In deze overeenkomst werd Cantor de nieuwe huurder en nam alle krachtens de huurovereenkomst op Wako International Ltd rustende verplichtingen over. Als tegenprestatie voor de overname van de huur betaalde Wako International Ltd aan Cantor een bedrag van $£ 1,5$ miljoen. In deze procedure gaat het om de vraag of Cantor over dit bedrag BTW is verschuldigd. Het Hof besliste dat de overdracht tegen vergoeding van een huurrecht door de huurder aan een derde (niet de eigenaar/ verhuurder) niet onder het bereik van de vrijstelling voor de verhuur van onroerend goed valt (artikel 135, lid 1, sub 1, BTW-richtlijn, voorheen artikel 13B, sub b, Zesde richtlijn). Belanghebbende bracht in deze procedure naar voren dat zij ook had kunnen kiezen voor een andere vormgeving die wat betreft het economisch gevolg op hetzelfde uit zou zijn gekomen, zonder dat dan BTW verschuldigd zou zijn (r.o. 31). Zo zou de huurder de eigenaar van het onroerend goed (en niet een derde) een vergoeding kunnen betalen opdat deze de vervroegde opzegging van de huurovereenkomst zou aanvaarden, of de (oorspronkelijke) huurder had er voor kunnen kiezen het onroerend goed onder te verhuren tegen een lagere prijs (in plaats van een vergoeding te betalen aan de nieuwe huurder opdat deze de huur over zou nemen). Het Hof is echter van oordeel dat dit niet rechtvaardigt dat de vrijstelling van artikel 135, lid 1, sub l, BTW-richtlijn van toepassing is.

Ter adstructie zij hier opgemerkt dat het in het Cantor-arrest om een wezenlijk andere zaak gaat dan in de Lübock Fine-casus. ${ }^{57}$ In het Lübock Fine-arrest heeft het Hof beslist dat als een huurder, die afstand doet van zijn huur, het onroerend goed tegen vergoeding opnieuw ter beschikking stelt aan degene aan wie hij zijn recht ontleent, evenals de huur zelf onder het bereik van de vrijstelling valt van artikel 135, lid 1, sub 1, BTW-richtlijn. In het Cantor-arrest komt het Hof dus tot een andere beslissing. Cruciaal onderscheid is dat in dit laatste arrest het huurrecht niet weer ter beschikking komt van de eigenaar maar overgaat naar een derde.

55. Zie in dit kader ook hoofdstuk 11 over het recht op aftrek van voorbelasting en waar dan ook in paragraaf 11.5.2 de zogenoemde optie regeling bij verhuur aan de orde komt.

56. Hof 9 oktober 2001, nr. C-108/99, Cantor Fitzgerald International, V-N 2001/58.20, NTFR 2001/1488. 57. Hof 15 december 1993, nr. C-63/92, Lubbock Fine \& Co, BNB 1999/193, V-N 1994/830, pt. 24. 
De beslissing in het Cantor-arrest steunt op een verwijzing naar het rechtszekerheidsbeginsel.

“Deze benadering zou indruisen tegen de doelstellingen van het BTW-stelsel, namelijk de rechtszekerheid en een juiste en eenvoudige toepassing van de in artikel 13 , B, sub b, voorziene vrijstellingen te waarborgen. In dit verband zij in herinnering gebracht, dat om de verrichtingen rond de toepassing van de BTW te vergemakkelijken, uitzonderingsgevallen daargelaten, moet worden afgegaan op de objectieve aard van de betrokken handeling (...). Een belastingplichtige die ter bereiking van een bepaald economisch doel de keuze heeft tussen vrijgestelde handelingen en belastbare handelingen, moet zijn beslissing derhalve in zijn eigen belang nemen volgens de regels, rekening houdend met het objectieve BTWstelsel (zie in die zin, arrest BLP Group, reeds aangehaald, punten 25 en 26). Het beginsel van fiscale neutraliteit houdt niet in, dat een belastingplichtige die de keuze tussen twee handelingen heeft, er één kan kiezen en de gevolgen van de andere kan laten gelden." (r.o. 33)

Uit deze rechtsoverweging blijkt dus dat het rechtszekerheidsbeginsel een objectivering van de handeling tot gevolg heeft. Niet van belang is dat belanghebbende een keuze heeft gehad om zijn handelingen anders vorm te geven om een zelfde economisch resultaat te bereiken. Het is aan belanghebbende om vooraf de vooren nadelen af te wegen. Indien eenmaal een keuze voor een bepaalde vorm is gemaakt, zijn de subjectieve motieven van belanghebbende niet van belang. Dit gezien het feit dat het rechtszekerheidsbeginsel stuurt naar een eenvoudig stelsel waarin uit de objectieve handelingen van een belastingplichtige de BTW-gevolgen blijken. ${ }^{58}$ Een onderzoek naar mogelijke motieven dan wel andere mogelijk handelingen met een zelfde economisch resultaat passen in een dergelijk stelsel niet.

De laatste zin van de aangehaalde rechtsoverweging roept nog een vraag op. De zin luidt:

"Het beginsel van fiscale neutraliteit houdt niet in, dat een belastingplichtige die de keuze tussen twee handelingen heeft, er één kan kiezen en de gevolgen van de andere kan laten gelden."

Deze zin kent bewoordingen die wij kennen uit de rechtspraak met betrekking tot het leerstuk over het asymmetrisch beroep (zie paragraaf 4.6). Het lijkt mij niet dat in deze procedure belanghebbende van mening was dat de desbetreffende handeling onder de vrijstelling valt en dat zij toch recht op aftrek van voorbelasting zou hebben. De problematiek van een asymmetrisch beroep op de BTW-richtlijn speelde in deze procedure niet. Waar het Hof naar het mij voorkomt op doelt is het

58. In vergelijkbare zin het arrest MKG-Kraftfahrzeuge van 26 juni 2003, nr. C-305/01, V-N 2003/34.13, FED 2003/513, NTFR 2003/1144. R.o. 64 vermeldt: “Ook zij erop gewezen dat de handelingen die krachtens artikel $13, \mathrm{~B}$, sub d, punt 3, van de Zesde richtlijn zijn vrijgesteld, uitsluitend worden gedefinieerd aan de hand van de aard van de genoemde dienstverrichtingen, zonder enige vermelding van de hoedanigheid van de personen die de betrokken diensten verrichten of ontvangen. Uit de rechtspraak van het Hof blijkt trouwens dat gelet op de doelstellingen van het gemeenschappelijk BTW-stelsel, namelijk de rechtszekerheid en een juiste en eenvoudige toepassing van de in artikel 13 van de richtlijn voorziene vrijstellingen te waarborgen, uitzonderingsgevallen daargelaten, moet worden afgegaan op de objectieve aard van de betrokken handeling (...)." 
probleem, dat als het beroep van belanghebbende gehonoreerd zou zijn in die zin dat alsdan de vrijstelling van toepassing ware, dan ook de vraag opkomt of het spiegelbeeld ook mogelijk is: Een belanghebbende die graag onder het bereik van een vrijstelling uit wil komen (gezien het recht op aftrek van voorbelasting) dan een beroep kan doen op de werking van het gelijkheidsbeginsel. Een dergelijke belastingplichtige zou dan kunnen stellen dat zijn handelingen (die in beginsel zijn vrijgesteld) een zelfde economisch resultaat hebben als vergelijkbare niet vrijgestelde handelingen. Bijvoorbeeld de belanghebbende in het eerdergenoemde Lubbock Fine-arrest zou met een betoog dat is gebaseerd op het gelijkheidsbeginsel (en een verwijzing naar het latere Cantor-arrest indien in die procedure het argument van Cantor gehonoreerd zou zijn) kunnen stellen dat de vrijstelling niet van toepassing is. De economische gevolgen zijn namelijk vergelijkbaar met een handeling die niet onder de vrijstelling valt. Een dergelijke benadering wordt dus in het Cantor-arrest geblokkeerd.

Het bovenstaande aspect ondersteunt de conclusie dat het Hof een verstandige beslissing heeft genomen door uit te gaan van de objectieve aard van de betrokken handeling. De regelgeving dient dus niet te worden toegepast op feitelijke situaties naar rato van de theoretisch gewenste situaties.

\subsection{Conclusies}

In de jurisprudentie van het Hof op het terrein van de vrijstellingen is een duidelijk vast patroon te onderkennen. Allereerst is het beginsel van de strikte uitleg in bijna ieder arrest het uitgangspunt. Het tweede uitgangspunt is, dat de vrijstellingen communautaire rechtsbegrippen zijn (zie voor de betekenis in de rechtsvinding paragraaf 4.3). Bij de verklaring van die communautaire rechtsbegrippen maakt het doel dat achter de gemeenschappelijke vrijstellingen ligt deel uit. En daarbij let men dus ook op de doelstellingen anders dan die welke expressis verbis uit de bepalingen zelf kenbaar zijn. Het Hof legt bij de medische vrijstellingen de kostenreductie ten grondslag aan de vrijstellingen en hetzelfde doet het - mijns inziens ietwat betwistbaar - driemaal bij de financiële vrijstellingen.

Uit de in paragraaf 10.4 behandelde jurisprudentie is de conclusie te trekken dat bij de uitleg nog een belangrijk aspect een rol speelt, namelijk de fiscale neutraliteit. Het Hof heeft in een aantal arresten beslist dat de toepassing van een vrijstelling onafhankelijk is van de rechtsvorm waarin de activiteit wordt uitgeoefend. De neutraliteit van de rechtsvorm bereikt dat gelijksoortige transacties gelijk worden behandeld. Deze neutraliteit van de rechtsvorm is het uitgangspunt en vormt een uitdrukking van het gelijkheidsbeginsel.

De uitleg van de vrijstellingen dient in overeenstemming te zijn met het beginsel van de fiscale neutraliteit, dat zich er met name tegen verzet dat soortgelijke diensten, die dus met elkaar concurreren, uit het oogpunt van de BTW ongelijk worden behandeld. Bij de beoordeling van de vergelijkbaarheid van de handelingen volstaat het blijkens het TNT-arrest niet om enkel de afzonderlijke diensten te vergelijken, 
maar kan men genoopt zijn ook rekening te houden met de context waarin deze worden verricht.

Bij de toepassing van het gelijkheidsbeginsel aanvaardt het Hof in het arrest Idéal Tourisme wel zekere imperfecties, gezien het gegeven dat de BTW-richtlijn geen volledige harmonisatie kent.

In de jurisprudentie met betrekking tot de vrijstellingen komt men de toepassing van het rechtszekerheidsbeginsel tegen daar waar belanghebbenden een beroep doen op een vrijstelling terwijl de vrijstelling volgens de letterlijke tekst van de bepaling niet op hen van toepassing is, met als argument dat men voor een naastliggende, alsdan vrijgestelde vorm zou hebben kunnen kiezen. Daartoe leent het rechtszekerheidsbeginsel zich niet. Men kan daaronder geen bescherming krijgen wanneer men de (belaste, 'richtlijnduidelijke') vorm heeft gekozen. Niet van belang is dat belanghebbende een keuze heeft gehad om zijn handelingen anders vorm te geven, om een zelfde economisch resultaat te bereiken. Het interessante van dit geval waarin het rechtszekerheidsbeginsel juist geen bescherming kan geven, is mijns inziens dat het zich leent voor bredere toepassing dan enkel op het terrein van de vrijstellingen. Zo is het denkbaar dat het een rol kan spelen bij de toepassing van het verlaagde tarief, het antwoord op de vraag of sprake is van belastingplicht of het recht op aftrek van voorbelasting.

\section{Intracommunautaire leveringen}

Op 1 januari 1993 is een overgangsregeling ingevoerd. Deze beoogt de afschaffing van de fysieke grenzen en de daarbij horende controles op het handelsverkeer tussen de lidstaten (zie paragraaf 2.3.2.2). Voor het grensoverschrijdende intracommunautaire handelsverkeer is door de overgangsregeling een nieuw belastbaar feit ingevoerd, namelijk de intracommunautaire verwerving (artikel 20, BTW-richtlijn; voorheen artikel 28 bis, lid 1, sub a). ${ }^{59}$ Aangezien volgens de overgangsregeling de intracommunautaire verwerving in het land van bestemming van het goed wordt belast, moet de daarmee samenhangende intracommunautaire levering in het land van herkomst worden vrijgesteld (artikel 138, lid 1, BTW-richtlijn; voorheen artikel 28 quater, A, sub a, Zesde richtlijn) met recht op aftrek van voorbelasting (of, zoals in de Nederlandse regelgeving vormgegeven: een nultarief). De belastingheffing over intracommunautaire verwerving is in de plaats gekomen van de belastingheffing bij invoer.

Volgens de arresten Collee ${ }^{60}$ en Twoh, ${ }^{61}$ berust de overgangsregeling op:

“(...) het beginsel dat de belastingopbrengst toekomt aan de lidstaat waar het eindverbruik plaatsvindt." (in beide arresten r.o. 22)

59. Hoofdstuk XVI bis bij richtlijn 91/680. Zie nader over de overgangsregeling paragraaf 2.3.2.2. 60. Hof 27 september 2007, nr. C-146/05, Collée, BNB 2008/12, V-N 2007/47.20.

61. Hof 27 september 2007, nr. C-184/05, Twoh International, BNB 2008/13, V-N 2007/47.21. In iets andere bewoordingen r.o. 31 van het EMAG-arrest van 6 april 2006, nr. C-245/04, V-N 2006/21.18, NTFR $2006 / 526$. 
Dit wordt bereikt doordat elke belaste verwerving van goederen in de lidstaat van 'aankomst', als pendant heeft in de lidstaat van 'vertrek' een vrijstelling met recht op aftrek van voorbelasting.

In de BTW-richtlijn is geen bepaling te vinden over het bewijs waarover de belastingplichtige moet beschikken om in aanmerking te komen voor de vrijstelling met recht op aftrek. ${ }^{62}$ Artikel 131 BTW-richtlijn bepaalt slechts in algemene bewoordingen dat de lidstaten de voorwaarden moeten vaststellen:

“(...) om een juiste en eenvoudige toepassing van deze vrijstelling te verzekeren en elke vorm van fraude, ontwijking en misbruik te voorkomen".

Weliswaar zijn in de artikelen $241 \mathrm{t} / \mathrm{m}$ 273, BTW-richtlijn bepaalde formele verplichtingen voor de belastingplichtigen neergelegd betreffende de boekhouding, de facturering, de aangifte alsmede de indiening van de zogenoemde listing bij de Belastingdienst, echter artikel 273 geeft de lidstaten de bevoegdheid om andere verplichtingen voor te schrijven die zij noodzakelijk achten ter waarborging van de juiste heffing van de belasting en ter voorkoming van belastingfraude (zie nader paragraaf 12.1). Het Hof wijst in het R-arrest ${ }^{63}$ erop dat geen enkele bepaling van de richtlijn in concreto bepaalt welke bewijzen de belastingplichtigen moeten leveren om in aanmerking te komen voor de BTW-vrijstelling met recht op aftrek in geval van een intracommunautaire levering.

Het Hof heeft er echter in dit kader op gewezen dat de lidstaten bij de uitoefening van hun bevoegdheden de algemene beginselen van het Unierecht, waaronder in het bijzonder het rechtszekerheids- en het evenredigheidsbeginsel, moeten naleven. ${ }^{64}$

Verder is van betekenis dat de bewijslast van het recht op toepassing van een fiscale uitzonderingsmaatregel of toekenning van een belastingvrijstelling rust op degene die aanspraak maakt op een dergelijk recht. Bijgevolg dient voor de toepassing van artikel 131 de goederenleverancier het bewijs te leveren dat de macht om als

62. In onze nationale regelgeving bepaalt artikel 12, eerste lid, Uitv.besl. OB 1968 dat de toepassing van het nultarief dient te blijken uit het boeken en bescheiden. Per 1 januari 2006 geldt artikel 12, tweede lid, onderdeel a, ten tweede, Uitv.besl. OB 1968 dat bepaalt dat de ondernemer die een intracommunautaire levering verricht ook moet beschikken over het BTW-nummer van de afnemer van de goederen.

63. Hof 7 december 2010, nr. C-285/09, R., V-N 2011/2.11, NTFR 2010/2842. In deze procedure werd het nultarief geweigerd omdat niet werd voldaan aan de aanvullende voorwaarden. In deze procedure stond vast dat de verkoper actief deelnam aan fraude.

64. Hof 27 september 2007, nr. C-184/05, Twoh International BV, BNB 2008/13, V-N 2007/47.21, r.o. 25. In deze procedure besliste het Hof dat als een belastingplichtige in bewijsnood komt bij het aantonen van het zogenoemde nultarief, de belastingautoriteiten van de lidstaat van waaruit goederen in het kader van een intracommunautaire levering worden verzonden of vervoerd, niet verplicht zijn de autoriteiten van de lidstaat waarvoor de goederen volgens de leverancier bestemd zijn, om inlichtingen te verzoeken. Zie tevens Hof 11 mei 2006, nr. C-384/04, Federation of Technological Industries e.a., V-N 2006/27.14, r.o. 29 en 30; Hof 7 december 2010, nr. C-285/09, R., V-N 2011/2.11, NTFR 2010/2842, r.o. 45. Zie verder Hof 21 december 2011, nr. C-499/10, VOM, V-N 2012/8.24, NTFR 2012/174, r.o. 24. 
eigenaar te beschikken over het goed aan de afnemer is overgedragen en de leverancier heeft aangetoond dat dit goed naar een andere lidstaat is verzonden of vervoerd, zodat het goed het grondgebied van de lidstaat van levering fysiek heeft verlaten. ${ }^{65}$

Kortom, een aantal uitgangspunten gelden wat betreft de bewijslast in geval van een intracommunautaire levering:

- Allereerst rust de bewijslast op de leverancier dat de goederen daadwerkelijk naar een andere lidstaat zijn verzonden of vervoerd, zodat vaststaat dat de goederen de lidstaat van de leverancier hebben verlaten.

- De BTW-richtlijn vermeldt geen regels die de bewijslast weergeven.

- De lidstaten zijn vrij in het stellen van regels betreffende de bewijslast, echter daarbij dienen zij wel de algemene rechtsbeginselen in acht te nemen.

Wat de rol van de algemene rechtsbeginselen betreft zijn een tweetal arresten in dit kader van belang, namelijk het Teleos-arrest ${ }^{66}$ en het Collée-arrest. ${ }^{67}$

Allereerst zal ik het Teleos-arrest behandelen. Teleos gevestigd in het Verenigd Koninkrijk verkocht mobiele telefoons aan een afnemer in Spanje. Deze leveringen vonden 'af fabriek' plaats, wat betekent dat de mobiele telefoons in het Verenigd Koninkrijk ter beschikking werden gesteld aan de koper en dat deze zorg droeg voor het vervoer naar een andere lidstaat. Teleos overlegde aan de Engelse Belastingdienst diverse bewijzen waaruit bleek dat de goederen naar een andere lidstaat waren overgebracht. De Engelse Belastingdienst aanvaardde deze bewijzen, echter kwam later op dit standpunt terug toen uit een nader onderzoek bleek, dat deze bewijzen vals waren. De Engelse Belastingdienst concludeerde dan ook dat de mobiele telefoons het Verenigd Koninkrijk niet hadden verlaten en dat Teleos dan ook BTW had moeten berekenen aan de Spaanse afnemer.

Het Hof onderbouwt (r.o. 48) de beslissing met een verwijzing naar het rechtszekerheidsbeginsel. Dit beginsel is een dwingend vereiste in het geval van een regeling die financiële consequenties kan hebben, teneinde de belanghebbenden in staat te stellen de omvang van hun verplichtingen nauwkeurig te kennen. Het Hof heeft in het Teleos-arrest (r.o. 50) geoordeeld dat het in strijd zou zijn met het rechtszekerheidsbeginsel, wanneer een lidstaat die de voorwaarden voor de vrijstelling van een intracommunautaire levering heeft bepaald, in het bijzonder door vaststelling van een lijst van documenten die aan de bevoegde autoriteiten moeten worden overgelegd, en aanvankelijk de door de leverancier verstrekte documenten ten bewijze van het recht op vrijstelling heeft aanvaard, deze leverancier later zou kunnen verplichten over deze levering BTW te betalen, wanneer blijkt dat de betrokken goederen wegens fraude van de afnemer waarvan de leverancier geen

65. Hof 27 september 2007, nr. C- 409/04, Teleos Plc, V-N 2007/47.19, BNB 2008/11, r.o. 42.

66. Hof 27 september 2007, nr. C-409/04, Teleos Plc, V-N 2007/47.19. BNB 2008/11.

67. Hof 27 september 2007, nr. C-146/05, Collée, V-N 2007/47.20, BNB 2008/12. 
kennis had en ook niet kon hebben, het grondgebied van de lidstaat van levering in werkelijkheid niet hebben verlaten. ${ }^{68}$

Niet enkel het rechtszekerheidsbeginsel speelt in het Teleos-arrest een rol, ook het evenredigheidsbeginsel gebruikt het Hof ter onderbouwing van de beslissing. Het Hof is van oordeel dat de lidstaten in overeenstemming met dit beginsel middelen moeten aanwenden waarmee het door het nationale recht nagestreefde doel weliswaar doeltreffend kan worden bereikt, maar die de doelstellingen en beginselen van de betrokken Unieregeling zo min mogelijk aantasten. Zo mogen de door de lidstaten vastgestelde maatregelen weliswaar de rechten van de schatkist zo doelmatig mogelijk proberen te beschermen, maar zij mogen niet verder gaan dan voor dit doel noodzakelijk is.

Het Hof wijst erop dat het doel van voorkoming van belastingfraude rechtvaardigt dat de leveranciers soms zware verplichtingen worden opgelegd. De verdeling van de risico's tussen de leverancier en de belastingautoriteiten, naar aanleiding van fraude door een derde, moet evenwel verenigbaar zijn met het evenredigheidsbeginsel. Vervolgens overweegt het Hof (r.o. 58), dat een regeling waarbij de verantwoordelijkheid voor de betaling van de BTW volledig bij de leverancier komt te liggen, ongeacht of hij al dan niet bij de fraude betrokken is, het geharmoniseerde BTW-stelsel niet noodzakelijk beschermt tegen fraude en misbruik door de afnemer. Kortom, het middel is niet geschikt om het doel te bereiken. ${ }^{69}$

Uit het Teleos-arrest blijkt dat de omstandigheden dat de leverancier te goeder trouw heeft gehandeld, dat hij alles heeft gedaan wat redelijkerwijs binnen zijn mogelijkheden ligt en dat zijn betrokkenheid bij fraude uitgesloten is, belangrijke indicatoren zijn om uit te maken of deze leverancier kan worden verplicht tot nabetaling van de BTW. ${ }^{70}$

Collée gevestigd in Duitsland verricht een intracommunautaire levering van goederen aan een Belgische afnemer. Het is echter voor de provisie die hij kan verdienen aantrekkelijker om te leveren aan een in Duitsland gevestigde stroman, die vervolgens de goederen levert aan de Belgische afnemer. De Duitse Belastingdienst

68. Zie in dit kader ook r.o. 26 in het arrest Netto Supermarkt over toepassing vrijstelling/nultarief bij ontbreken wetenschap omtrent vervalst bewijs (Hof 21 februari 2008, nr. C-271/06, V-N 2008/11.16, NTFR 2008/405).

69. In het R-arrest geeft het Hof aan dat het Unierecht - ingeval aan betrokkenheid bij fraude door de verkoper - er niet aan in de weg staat dat het nultarief wordt geweigerd; Hof 7 december 2010, nr. C-285/09, R., V-N 2011/2.11, NTFR 2010/2842.

70. Wolf meent dat het beginsel van fiscale neutraliteit vereist dat, wanneer aan de materiële voorwaarden is voldaan, de BTW-vrijstelling wordt verleend. De wetenschap van de leverancier is volgens hem dan niet van belang. De Belastingdienst kan mogelijk dan wel met een beroep op de Kittel-doctrine het recht op aftrek weigeren bij de afnemer. R.A. Wolf, Carrouselfraude, Een Europees probleem vanuit Nederlands perspectief; een analyse van fiscale regelgeving en jurisprudentie (diss. Groningen), Den Haag: Sdu Uitgevers 2010. In identieke zin de lezenswaardige conclusie van A-G Cruz Villalón in de strafzaak tegen R, 29 juni 2010, nr. C-285/09, V-N 2010/33.20. 
ontdekt echter de opzet, waarna Collée probeert de zaak terug te draaien en alsnog stelt dat hij intracommunautair heeft geleverd aan de Belgische afnemer. De Duitse Belastingdienst weigert echter de vrijstelling met recht op aftrek van voorbelasting (nultarief volgens de Nederlandse regeling) omdat Collée de voor het bewijs dienende bescheiden niet doorlopend en direct na de intracommunautaire levering in zijn boekhouding had opgenomen. Het Hof formuleert een belangrijk uitgangspunt gebaseerd op het evenredigheidsbeginsel:

"Wat (...) de vraag betreft of de belastingdienst mag weigeren een intracommunautaire levering vrij te stellen van de BTW, enkel omdat het boekhoudkundige bewijs van deze levering niet tijdig is geleverd, moet worden vastgesteld dat een nationale maatregel die het recht op vrijstelling van een intracommunautaire levering afhankelijk stelt van de naleving van formele verplichtingen, zonder rekening te houden met de materiële vereisten en, met name, zonder na te gaan of aan deze vereisten is voldaan, verder gaat dan noodzakelijk is ter waarborging van de juiste heffing van de belasting." (r.o. 29)

Formele bewijsvoorschriften die voorbijgaan aan de materiële werkelijkheid zijn dus niet toegestaan omdat zij verdergaan dan nodig is om een juiste heffing van BTW te bereiken. Strijd met het evenredigheidsbeginsel is dan aan de orde.

Vervolgens wijdt het Hof nog enkele overwegingen aan het achterhouden door Collée van het bewijs dat een intracommunautaire levering had plaatsgevonden om zo een hogere provisie te behalen. Het achterhouden van dergelijk bewijs kan volgens het Hof tot gevolg hebben dat de vrijstelling (nultarief volgens de Nederlandse regeling) niet van toepassing is als voor de betrokken lidstaat gevaar bestaat van verminderde belastinginkomsten (r.o. 34). Het is de taak van de nationale rechter om na te gaan of het achterhouden van een intracommunautaire handeling en de daaruit voortvloeiende vertraging bij de herziening van de bijbehorende opnamen in de boeken al dan niet zijn verricht in het kader van BTW-fraude. Het Hof beslist dat belastingplichtigen in geval van misbruik van recht (zie paragraaf 5.3) of fraude (zie paragraaf 6.3) geen beroep kunnen doen op het Unierecht. Het Hof voegt daar aan toe dat:

"In een situatie als in het hoofdgeding kan het feit dat een tussenpersoon werd ingeschakeld om de contractuele provisies te kunnen ontvangen, niet worden gelijkgesteld met een in het kader van BTW-fraude verrichte handeling, noch met een misbruik van gemeenschapsrecht, wanneer vaststaat dat een dergelijke handeling niet is verricht met het oog op het verkrijgen van een ongerechtvaardigd belastingvoordeel." (r.o. 39)

Deze overweging lijkt mij een belangrijke verfijning van het beginsel van het verbod van misbruik van recht. Het beginsel is dus toegesneden op enkel de Unieregeling die wordt misbruikt. De verfijning lijkt mij ook logisch, gezien het feit dat één van de voorwaarden voor toepassing van het verbod van misbruik van recht is de aanwezigheid van strijd met doel en strekking (zie uitgebreid 5.3). Per definitie moet dit gezocht worden in de misbruikte regeling - in casu de BTW-richtlijn.

Wat betreft de bewijslast bij intracommunautaire leveringen volgt het Hof kort weergegeven de lijn: in de BTW-richtlijn is de bewijslast niet geregeld. Wel kent het 
Unierecht de algemene rechtsbeginselen als maatstaf die men bij de vormgeving van de bewijslast moet aanleggen. Deze lijn staat niet op zichzelf maar keert steeds terug als het Hof constateert dat een bepaald veld niet is afgedekt door de BTW-richtlijn (Zie paragraaf 4.5.2.5). Het gevolg van deze benadering is dat de vrijheid die de BTWrichtlijn op bepaalde gebieden de lidstaten toekent niet leidt tot willekeur en, zoals boven gezien, tot een overdreven formalisme. 


\section{HOOFDSTUK 11}

\section{Recht op aftrek van voorbelasting}

\section{$11.1 \quad$ Inleiding}

De algemene rechtsbeginselen hebben ook hun invloed uitgeoefend op het recht op aftrek van voorbelasting. De toegang tot het recht op aftrek van voorbelasting wordt sinds het Seeling-arrest, ${ }^{1}$ dat gevolgd werd door een serie arresten op dit terrein, mede bepaald door het leerstuk inzake het keuzevermogen. Dit leerstuk komt, ook al is het nauw verweven met de aftrek van voorbelasting, bij de behandeling van het belastbaar feit in paragraaf 6.5 aan de orde. Verder komen de arresten die betrekking hebben op de voorwaarden en formaliteiten van het aftrekrecht aan de orde in paragraaf 12.3 .

Ter inleiding op het onderwerp beschrijf ik hierna eerst het raamwerk en de achtergrond van de regeling met betrekking tot het recht op aftrek van voorbelasting (paragraaf 11.2). Daarbij staat centraal het relevante deel van de BTW-richtlijn op dit terrein. Bij die regeling is de rechtspraak van het Hof bepaald niet onbelangrijk (paragraaf 11.3), omdat de uitleg van het Hof het doel van de regeling in de schijnwerpers zet. Wanneer een en ander in beeld is gebracht, behandelt de volgende paragraaf het gelijkheidsbeginsel (paragraaf 11.4) en de daarop volgende paragraaf het evenredigheidsbeginsel (paragraaf 11.5). Dit laatste rechtsbeginsel doet op twee velden zijn werking gevoelen. Ten eerste bij de beperking van de mogelijkheden van de machtiging (artikel 395, BTW-richtlijn; voorheen artikel 27, Zesde richtlijn) en ten tweede bij het verzoek tot belastingheffing (zogenoemd optieverzoek) (artikel 137, lid 1, sub d, BTW-richtlijn; voorheen artikel 13C, sub a, Zesde richtlijn).

Dit hoofdstuk behandelt niet het vertrouwens- en het rechtszekerheidsbeginsel, ofschoon de jurisprudentie, ${ }^{2}$ zie voor de behandeling van dit onderwerp hoofdstuk 5 ,

1. Hof 8 mei 2003, nr. C-269/00, W. Seeling, BNB 2004/1, V-N 2003/28.20. Een woon-bedrijfspand als zakelijk vermogen aangemerkt levert volledige aftrek van voorbelasting op.

2. Zie het Sudholz-arrest van 29 april 2004, nr. C-17/01, V-N 2004/24.16, NTFR 2004/674 waar het Hof heeft beslist dat maatregelen op basis van artikel 395, BTW-richtlijn geen terugwerkende kracht mogen hebben. Zie verder Hof 3 december 1998, nr. C-381/97, Belgocodex, BNB 1999/29, V-N 1999/ 14.25. Deze procedure besteedt aandacht aan de werking van het rechtszekerheidsbeginsel inzake de niet uitgewerkte keuze mogelijkheid door België in geval van belaste verhuur. Zie nader de arresten $\rightarrow$ 
laat zien dat het beginsel zich ook op het gebied van de aftrek van voorbelasting laat gelden. De jurisprudentie is aldaar ondergebracht, aangezien zij voornamelijk betrekking heeft op het rechtszekerheidsbeginsel in de relatie tussen belastingplichtige en overheid en speelt daarnaast ook een rol bij startende ondernemers die erkenning van hun status als belastingplichtige genoten (paragraaf 7.2.3) (algemene rechtsbeginselen van formeel recht). ${ }^{3}$

\subsection{Het raamwerk van de aftrekregeling}

De kern van het BTW-stelsel is te vinden in artikel 2, Eerste richtlijn ${ }^{4}$ (zie ook paragraaf 2.2), thans artikel 1, lid 2, BTW-richtlijn. Dit artikel vermeldt dat het BTWstelsel:

\footnotetext{
“(...) berust op het beginsel dat van goederen en diensten een algemene verbruiksbelasting wordt geheven welke strikt evenredig is aan de prijs van goederen en diensten, zulks ongeacht het aantal transacties welke tijdens het produktie- en distributieproces vóór de fase van heffing plaatsvonden. Bij elke transactie is de belasting over de toegevoegde waarde, berekend over de prijs van het goed of van de dienst volgens het tarief dat voor het goed of voor de dienst geldt, verschuldigd onder aftrek van het bedrag van de belasting over de toegevoegde waarde waarmede de onderscheidene elementen van de prijs rechtstreeks zijn belast. (...)"
}

Uit de Eerste richtlijn blijkt dat het recht op aftrek van voorbelasting een cruciaal onderdeel is van het stelsel (stelselbeginsel). Het is essentieel om te bereiken dat de BTW evenredig is aan de prijs van de goederen en diensten ongeacht het aantal transacties. De Eerste richtlijn kan dus gezien worden als het fundament van het recht op aftrek van voorbelasting. De regeling in de huidige richtlijn is nader uitgewerkt in de artikelen $167 \mathrm{t} / \mathrm{m} \mathrm{192, \text {BTW-richtlijn. } ^ { 5 }}$

In de Wet $\mathrm{OB}$ is het systeem van de aftrek van voorbelasting neergelegd in artikel 2. In deze bepaling vindt men dat op de belasting die verschuldigd is, ter zake van leveringen van goederen en diensten, in aftrek wordt gebracht de belasting ter zake van de aan de ondernemer verrichte leveringen van goederen en verleende diensten, ter zake van de door hem verrichte intracommunautaire verwervingen van goederen en ter zake van de invoer van voor hem bestemde goederen. De uitwerking is te vinden in de artikelen 15, 16 en 17 van de Wet OB en de artikelen 10 t/m 15 Uitv.

\footnotetext{
$\rightarrow$ Gemeente Leusden \& Holin Groep BV, 29 april 2004, nrs. C-487/01 en C-7/02, V-N 2004/24.17 en het arrest Stichting Goed Wonen II 26 april 2005, nr. C-376/02, V-N 2005/23.16. In deze laatste arresten gaat het echter ook om een wetswijziging tot BTW-vrijstelling. Zie de eindbeslissing van de HR inzake Stichting Goed Wonen II, 14 december 2007, nr. 34.514, V-N 2007/59.18, NTFR 2008/48.

3. Zie voor het onderscheid tussen algemene rechtsbeginselen als interpretatiebeginsel en als beginselen van formeel recht paragraaf 4.4.5.

4. Vastgesteld op 11 april 1967, zie Pb van 14 april 1967, nr. 71.

5. De BTW-richtlijn bevat ook nog een bijzondere bepaling betreffende de aftrek van voorbelasting namelijk de artikelen 354 en 355 (voor handelaren in beleggingsgoud).
} 
Besch. OB 1968. ${ }^{6}$ Gezien het gegeven dat dit werk de rechtspraak van het Hof ter hand neemt, neem ik de regelgeving in de BTW-richtlijn als uitgangspunt. ${ }^{7}$

Artikel 168, BTW-richtlijn (voorheen artikel 17, lid 2, Zesde richtlijn) kent enkel aftrekrecht toe aan belastingplichtigen die de goederen en diensten, waar de voorbelasting op drukt, gebruiken voor belaste handelingen. Een belastingplichtige heeft een onmiddellijk recht op aftrek van voorbelasting als aan de voorwaarden is voldaan. Ook als hij de goederen niet direct gebruikt in de hoedanigheid van belastingplichtige (blijven bijvoorbeeld een periode ongebruikt). De mate waarin bewijs moet worden geleverd is afhankelijk van de aard van het goed en de periode die ligt tussen aanschaf en gebruik. Worden de goederen aanvankelijk gebruikt als niet-belastingplichtige en na enige tijd alsnog in de onderneming gebruikt, dan kan de voorbelasting die drukt op de betreffende goederen niet alsnog in aftrek worden gebracht. Dit blijkt uit het Lennartz-arrest. ${ }^{8}$ In het arrest gaat het om een nieuw aangeschafte auto die aanvankelijk in privé werd gebruikt. ${ }^{9}$ Een jaar later begon

6. In de Wet $O B$ treft men op verscheidene plaatsen specifieke regelingen aan, namelijk artikel 25 (kleine-ondernemersregeling), artikel 27 (landbouwregeling), artikel 28 (tabaksproducten), artikel 28e (margeregeling), artikel 28m (beleggingsgoud), artikel 24, tweede lid (teruggaaf bij uitvoer door nietondernemers).

7. De regeling met betrekking tot het aftrekrecht zoals die is te vinden in de BTW-richtlijn verschilde tot 1 januari 2007 van hetgeen onze nationale Wet OB vermeldt. Kort weergegeven houdt het stelstel van de BTW-richtlijn in dat recht op aftrek van voorbelasting bestaat indien en voor zover de belastingplichtige de goederen en diensten waarop de voorbelasting drukt gebruikt voor belaste prestaties. Het uitgangspunt van de Wet OB was tot 1 januari 2007 dat de ondernemer recht op aftrek van voorbelasting had wanneer de goederen en diensten waarop de voorbelasting drukt werden gebezigd in het kader van de onderneming en in beginsel niet werden gebruikt voor vrijgestelde prestaties. Ook de wijze waarop de aftrek van voorbelasting werd behandeld bij privégebruik door de ondernemer week in de Wet OB (en het daarop gebaseerde BUA) af van de BTW-richtlijn. Zie in dit kader Hof 14 juli 2005, nr. C-434/03, Charles-Tijmens, BNB 2005/284, V-N 2005/35.18, NTFR 2005/965. Zie verder in de literatuur A. van Dongen \& H.W.M. van Kesteren, Verenigbaarheid BUA met de Zesde richtlijn, WFR 2005/786 en A. van Dongen, Heffing van BTW op privé-gebruik, WFR 2005/1393 en meer in algemene zin K.M. Braun, Aftrek van voorbelasting (diss. Leiden), Deventer: Kluwer 2002, blz. $80 \mathrm{t} / \mathrm{m}$ 82. Aan dit verschil in systeem wordt door mij slechts sporadisch aandacht besteed. Overigens is door de wetswijziging van 1 januari 2007 onze nationale Wet OB in overeenstemming gebracht met de BTW-richtlijn. Zie voor een uitgebreide behandeling van de gevolgen van de wetswijziging voor het recht op aftrek S.T.M. Beelen, Aftrek van btw als (belaste) omzet ontbreekt (diss. Rotterdam), Deventer: Kluwer 2010.

8. Hof 11 juli 1991, nr. C-97/90, Lennartz, V-N 1991/2402, FED 1991/647, r.o. 20. Zie ook A-G Jacobs in zijn conclusie bij het arrest in de pt. 41 en 42.

9. De auto werd aanvankelijk in geringe mate gebruikt in de onderneming, namelijk voor $8 \%$. Op grond van de toentertijd Duitse administratieve praktijk werd geen aftrek toegestaan voor bedrijfsgebruik van minder dan $10 \%$ van het totale gebruik. Aanvankelijk werd dan ook geen aftrek verricht. Het jaar daarop toen Lennartz zijn belaste activiteiten uitbreidde wilde hij alsnog herziening, overeenkomstig artikel 187, BTW-richtlijn (voorheen 20, lid 2, Zesde richtlijn), van de BTW die drukte op de aankoopprijs van de auto. Het Hof geeft onder meer aan (r.o. 26 en 29), dat gebruik voor het verrichten van belaste handelingen (hoe gering ook) recht op aftrek van voorbelasting verleent. Eventueel gevolgd door een dienst op grond van artikel 26, lid 1, sub a, BTW-richtlijn (voorheen artikel 6, lid 2, sub a, Zesde richtlijn) voor het privégebruik. Dit kan anders zijn als een lidstaat een machtiging tot afwijking van de Zesde richtlijn zou hebben verkregen op grond van artikel 395, BTW-richtlijn. 
belanghebbende zijn eigen adviespraktijk en gebruikte hij de auto voor belaste handelingen. Vervolgens wilde hij een deel van de voorbelasting die drukte op de auto in aftrek brengen, namelijk het deel dat was toe te rekenen aan de periode dat de auto werd gebruikt in de onderneming. Het Hof besliste dat de voorbelasting niet in aftrek kan worden gebracht indien de goederen aanvankelijk privé zijn gebruikt en op een later moment worden gebruikt voor belastingplichtige activiteiten.

Het recht op aftrek van voorbelasting dat is ontstaan op grond van artikel 168, BTWrichtlijn is niet altijd definitief. Herziening van het aftrekrecht is mogelijk op basis van artikel 187, BTW-richtlijn (voorheen artikel 20, lid 2, Zesde richtlijn). Artikel 187, BTW-richtlijn past het aftrekrecht aan en is niet zelfstandig een bepaling die recht op aftrek oplevert. Zoals uit het Lennartz-arrest blijkt, bestaat op grond van artikel 187, BTW-richtlijn geen recht op aftrek als niet aanvankelijk is gehandeld als belastingplichtige. Artikel 187, BTW-richtlijn kan enkel een aanpassing tot gevolg hebben van de aanvankelijk op basis van artikel 168, BTW-richtlijn toegekende recht op aftrek van voorbelasting. ${ }^{10}$ Het Hof duidt in het Lennartz-arrest artikel 187, BTW-richtlijn dan ook aan als een 'berekeningsmethode voor de herziening van de oorspronkelijke aftrek' (r.o. 12).

Artikel 187, BTW-richtlijn bepaalt dat herziening mogelijk is voor investeringsgoederen voor een periode van vijf jaar. Voor onroerende investeringsgoederen kan de herzieningsperiode tot maximaal 20 jaar worden verlengd.

De lidstaten hebben de vrijheid om de term 'investeringsgoederen' nader invulling te geven. Dat blijkt uit de tekst van artikel 189, sub a, BTW-richtlijn (voorheen 20, lid 4, Zesde richtlijn). In sub c van artikel 189, BTW-richtlijn is aangegeven, dat de lidstaten 'alle' passende maatregelen kunnen nemen om te verzekeren dat de herziening niet tot ongerechtvaardigde voordelen leidt.

Op dit moment is bij de Tweede Kamer een wetsvoorstel aanhangig dat het begrip 'investeringsbedrijfsmiddelen' introduceert. ${ }^{11}$ Daaronder worden niet enkel (on) roerende zaken begrepen, maar ook diensten waarvan de uitgaven voor de inkomsten- of vennootschapsbelasting moeten worden geactiveerd en waarop een ondernemer voor die belastingen kan afschrijven. De richtlijn kent echter de term 'investeringsgoederen'. De vraag is of daar ook economische goederen onder vallen, zoals diensten waarvan de uitgaven voor de inkomsten- of vennootschapsbelasting

10. Zie in dit kader ook het arrest Waterschap Zeeuws Vlaanderen, 2 juni 2005, nr. C-378/02, V-N 2005 | 30.17, NTFR 2005/896. In dit arrest is beslist dat deze benadering ook geldt voor een publiekrechtelijk lichaam dat op het tijdstip van aanschaf van het investeringsgoed als overheid handelde.

11. Kamerstukken II 2004/05, 30 061, nr. 2. De invoeringsdatum was aanvankelijk voorzien op 1 juli 2005. 
moeten worden geactiveerd. Volgens het VNO-arrest ${ }^{12}$ dient men onder 'investeringsgoederen' te verstaan: ${ }^{13}$

“(...) goederen die, gebruikt voor bedrijfsdoeleinden, zich onderscheiden door hun duurzame aard en hun waarde, en waarvan de aanschaffingskosten normaliter dan ook niet als lopende uitgaven worden geboekt, doch over meerdere jaren worden afgeschreven. (...)" (r.o. 18)

Hierbij zijn 'duurzaamheid' en 'waarde' niet in absolute zin op te vatten:

“(...) dat de lid-staten een zekere beoordelingsruimte genieten met betrekking tot de eisen waaraan op het punt van de duurzaamheid en waarde der goederen en van de toe te passen afschrijvingsregels moet zijn voldaan, al zullen zij het bestaan van een wezenlijk verschil tussen investeringsgoederen en de andere goederen die bij het beheer en de dagelijkse activiteit der ondernemingen worden gebruikt hebben te erkennen". (r.o. 18)

In het VNO-arrest geeft het Hof de lidstaten een zekere beoordelingsvrijheid. Men kan zich de vraag stellen of deze beoordelingsvrijheid zover gaat dat daar ook zogenoemde economische goederen onder vallen. Het Hof geeft ruimte wat betreft de 'waarde' en 'duurzaamheid' en van de toe te passen afschrijvingsregels en niet met betrekking tot interpretatie en kwalificatie van het begrip goederen. ${ }^{14}$ De beoordelingsruimte gaat niet zover dat de lidstaten op grond van artikel 189, sub a, BTW-richtlijn de ruimte hebben om in hun nationale regeling diensten, waarvan de uitgaven voor de inkomsten- of vennootschapsbelasting moeten worden geactiveerd, als investeringsgoederen aan te merken.

Artikel 173, BTW-richtlijn (voorheen artikel 17, lid 5, Zesde richtlijn) regelt het gemengd gebruik van goederen en diensten. De regeling houdt in dat aftrek slechts wordt toegestaan voor dat gedeelte van de BTW dat evenredig is aan het bedrag van de handelingen waarvoor recht op aftrek bestaat (de pro-rata methode). De wijze waarop vervolgens de verhoudingsgewijze toerekening (pro-rata) moet worden berekend is in artikel 174, BTW-richtlijn bepaald (voorheen artikel 19, lid 1, Zesde richtlijn).

Gezien de mogelijkheid dat een pro-rata berekening op basis van de verhouding van de vergoedingen een verstorend effect kan hebben, in die zin dat te veel of te weinig voorbelasting wordt verleend, staat artikel 173, lid 2, BTW-richtlijn (voorheen

12. Hof 1 februari 1977, nr. 51/76, VNO, BNB 1978/18

13. Daarbij dient men wel te bedenken dat dit arrest deze term uitlegt in de context van artikel 17 , Tweede richtlijn. Het Hof wijst er op in het Nordania Finans-arrest dat de definitie van het begrip 'investeringsgoederen' van artikel 19, lid 2, Zesde richtlijn niet noodzakelijk samen valt met de definitie die aan dit begrip is gegeven in het VNO-arrest. Zie nader Hof 6 maart 2008, nr. C-98/07, Nordania Finans A/S, V-N 2008/15.20, r.o. 29 en 30.

14. B.G van Zadelhoff is van mening dat de BTW-richtlijn geen ruimte biedt op dit vlak aan de lidstaten. Zie zijn column 'Doe maar normaal' in WFR 2005/619. Volgens mij kan dit anders zijn als een lidstaat beschikt over een machtiging (artikel 395, BTW-richtlijn) en deze voldoet aan het evenredigheidsbeginsel en de fiscale neutraliteit (zie nader 5.2, 9.2 en 11.5.1). 
artikel 15, lid 5, Zesde richtlijn) de lidstaten toe om andere methoden te gebruiken. Zoals een pro-rata per sector, of op basis van gebruik van de goederen en diensten.

Artikel 179, BTW-richtlijn (voorheen artikel 18, lid 2, Zesde richtlijn) behandelt het recht op onmiddellijke aftrek van voorbelasting. Artikel 372, BTW-richtlijn (voorheen artikel 28, lid 3, sub d, Zesde richtlijn) biedt de lidstaten de bewegingsvrijheid om daar onder bepaalde voorwaarden van af te wijken. Deze bepaling is enkel van toepassing op de lidstaten die een dergelijke regeling op 1 januari 1978 in hun nationale wet hadden opgenomen.

Artikel 183, BTW-richtlijn (voorheen artikel 18, lid 4, Zesde richtlijn) geeft de mogelijkheid om in een situatie dat het recht op teruggaaf de te betalen belasting overstijgt, het saldo door te schuiven naar de volgende periode. ${ }^{15}$

\subsection{De uitleg van de aftrekregeling door het Hof van Justitie EU}

Het Hof start in bijna elk arrest ${ }^{16}$ over de aftrekregeling met een verwijzing naar het doel van de regeling. In latere arresten over deze materie begint het Hof geregeld met het zinsdeel: 'Om te beginnen zij eraan herinnerd, dat (...)' om dan te vervolgen met een beschrijving van het doel van de aftrekregelgeving. ${ }^{17}$ Duidelijk is dat het doel van de regelgeving een constant baken is waarop het Hof koerst. De interpretatie van de aftrekregeling vertoont dus een sterk teleologisch karakter. Het doel van de aftrekregeling is in het eerder aangehaalde artikel 2, Eerste richtlijn verwoord. Het Hof overweegt daarover in het arrest Metropol Treuhand en Stadler: ${ }^{18}$

15. Het zal duidelijk zijn dat dergelijke regelingen die de onmiddellijke aftrek blokkeren op gespannen voet staan met de neutraliteit. Frankrijk had gebruik gemaakt van deze mogelijkheid die de BTWrichtlijn biedt en beëindigde deze regeling met een ruime overgangsregeling. Het Hof besliste dat deze overgangsregeling geoorloofd is. Hof 18 december 2007, nr. C-368/06, Cedilac SA, NTFR 2008/83. Zie ook Hof 10 juli 2008, nr. C-25/07, Alicja Sosnowska, V-N 2008/35.15. Het Hof besliste in dit arrest dat de Poolse regeling op basis van 183, BTW-richtlijn in strijd is met het evenredigheidsbeginsel. De Poolse regeling was enkel van toepassing bij startende ondernemers met de bedoeling om zo fraude tegen te gaan bij deze nieuwe onbekende groep van belastingplichtige. Met name het aspect dat de Poolse regeling niet de mogelijkheid bood om te bewijzen dat de starters onder de normale regeling vielen (ontbreken mogelijkheid van tegenbewijs), leverde strijd op met het evenredigheidsbeginsel (zie verder paragraaf 12.3.2.2).

16. Zie bijvoorbeeld Hof 22 juni 1993, nr. C-333/91, Sofitam SA, FED 1993/608, r.o. 10; Hof 1 april 2004, nr. C-90/02, G. Bockemühl, V-N 2004/20.18, r.o. 39.

17. Zie bijvoorbeeld Hof 22 februari 2001, nr. C-408/98, Abbey National, V-N 2001/15.26, r.o. 24; Hof 29 oktober 2009, nr. C-29/08, AB SKF, V-N 2009/56.13, r.o. 55; Hof 29 oktober 2009, nr. C-174/08, NCC Construction Danmark A/S, V-N 2009/56.14, r.o 40; Hof 6 maart 2008, nr. C-98/07, Nordania Finans A/S, V-N 2008/15.20, in r.o. 19. Zie voor variatie in de terminologie Hof 13 maart 2008, nr. C-437/06, Securenta, V-N 2008/14.20, in r.o. 24 komt de terminologie voor 'allereerst zij eraan herinnerd'; Hof 18 december 2008, nr. C-488/07, Royal Bank of Scotland Group Plc, V-N 2008/62.26, in r.o. 14 'vaste rechtspraak'.

18. Hof 8 januari 2002, nr. C-409/99, Metropol \& Stadler, V-N 2002/8.33, r.o. 42. In deze procedure oordeelde het Hof dat het in 1995 bestaand aftrekrecht in Oostenrijk met betrekking tot autokosten op minibussen niet verder kan worden beperkt gezien de strijd met de zogenoemde standstillbepaling van artikel 176, tweede alinea, BTW-richtlijn (voorheen artikel 17, lid 6, Zesde richtlijn). 
“(...) dat volgens het fundamentele beginsel van het BTW-stelsel, dat is neergelegd in artikel 2 van de Eerste en van de Zesde richtlijn, bij elke transactie inzake productie of distributie BTW verschuldigd is, onder aftrek van de BTW waarmee de verrichtingen in eerdere stadia rechtstreeks zijn belast. Volgens vaste rechtspraak maakt het recht op aftrek waarin de artikelen 17 en volgende van de Zesde richtlijn voorzien, integrerend deel uit van de BTW-regeling en kan het in beginsel niet worden beperkt. Dit recht wordt onmiddellijk uitgeoefend voor alle belasting die op de in de eerdere stadia verrichte handelingen is geheven. (...)"

In verscheidene arresten zijn overwegingen als hierboven geciteerd te vinden. ${ }^{19}$ Wel zijn er variaties in formulering. ${ }^{20}$ Zonder dat daar - voor zover ik kan zien betekenis aan moet worden toegekend. In het Ghent Coal-arrest wordt expliciet de fiscale neutraliteit als centraal ijkpunt ten tonele gevoerd: ${ }^{21}$

“(...), dat de aftrekregeling tot doel heeft, de ondernemer geheel te ontlasten van de in het kader van al zijn economische activiteiten verschuldigde of betaalde BTW. Het gemeenschappelijk stelsel van belasting over de toegevoegde waarde waarborgt derhalve een volstrekt neutrale fiscale belasting van alle economische activiteiten, ongeacht het oogmerk of het resultaat van die activiteiten, mits die activiteiten op zich aan de heffing van BTW zijn onderworpen (...)." (r.o. 15)

Hieruit blijkt overduidelijk dat het doel dat uiteindelijk wordt beoogd te bereiken met de aftrekregeling in de BTW-richtlijn is een 'volstrekt neutrale belasting van alle economische activiteiten'. ${ }^{22}$ Daarbij wordt door het Hof gelijk een inperking toegevoegd. Dit doel geldt enkel voor activiteiten die op zich aan de heffing van BTW zijn onderworpen. In geval van onderworpenheid aan de BTW-heffing wordt de fiscaal neutrale heffing gewaarborgd. De volgende paragraaf 11.4 gaat nader in op de relatie met de fiscale neutraliteit als uitdrukking van het gelijkheidsbeginsel.

Het Hof wijst er op dat de regels die het recht op aftrek van voorbelasting beheersen uniform zijn in de lidstaten en dat de uitzonderingen op het aftrekrecht beperkt zijn tot de gevallen die de BTW-richtlijn vermeldt. De inbreukprocedure tegen Spanje: ${ }^{23}$

19. Zie bijvoorbeeld Hof 8 juni 2000, nr. C-98/98, Midland Bank, BNB 2001/118, V-N 2000/44.20, FED 2000/645, NTFR 200/921, r.o. 29; Hof 19 september 200, nr. C-177/99, Ampafrance, V-N 2000/48.19, r.o. 34.

20. Zie bijvoorbeeld Hof 21 maart 2000, nr. C-110/98, Gabalfrisa SL e.a. nr. C-110/98, V-N 2000/22.12, r.o. 43 en 44.

21. Hof 15 januari 1998, nr. C-37/95, Ghent Coal Terminal, V-N 1998/29.14, r.o. 15.

22. Het element van de (volstrekt) 'neutrale fiscale belasting van alle economische activiteiten' is ondermeer te vinden in de arresten: Hof 1 april 2004, nr. C-90/02, Bockemühl, V-N 2004/20.18, NTFR 2004/513, r.o. 39; Hof 22 juni 1993, nr. C-333/91, Sofitam SA, FED 1993/608, r.o. 10; Hof 22 februari 2001, nr. C-408/98, Abbey National, V-N 2001/15.26, r.o. 24.

23. Hof 6 oktober 2005, nr. C-204/03, Commissie/Spanje, V-N 2005/51.21, r.o. 23. Het arrest heeft betrekking op de berekening van de pro-rata en de invloed van subsidies op het aftrekrecht. De aangehaalde rechtsoverweging 23 is één van de standaardoverwegingen die het Hof gebruikt bij de uitleg van het aftrekrecht. Praktisch identieke overwegingen zijn onder meer te vinden in de arresten: Hof 21 september 1988, nr. 50/87, Commissie/Frankrijk, BNB 1994/306, FED 1990/123, r.o. 17; Hof 6 juli 1995, BP Supergaz, nr. C-62/93, Jur. 1995, blz. I-1883, r.o. 18; Hof 15 januari 1998, nr. C-37/95, Ghent Coal Terminal, V-N 1998/29.14, slot van r.o. 16; Hof 8 januari 2002, nr. C-409/99, Metropol \& Stadler, V-N 2002/8.33, slot van r.o. 42. 
"Zoals het Hof herhaaldelijk heeft geoordeeld, heeft elke beperking van het recht op aftrek gevolgen voor de hoogte van de belastingdruk en moet deze in alle lidstaten op dezelfde wijze worden toegepast. Afwijkingen zijn dus slechts toegestaan in de gevallen die de Zesde richtlijn uitdrukkelijk vermeldt (...)" (r.o. 23)

Vergelijkbare overwegingen treft men aan in de jurisprudentie op het terrein van de vrijstellingen. ${ }^{24}$ Het Hof neemt als vertrekpunt dat de vrijstellingen autonome begrippen van gemeenschapsrecht zijn, die tot doel hebben verschillen in de toepassing van het BTW-stelsel tussen de lidstaten te voorkomen. Uit het SUFAarrest blijkt dat een uniforme uitleg van de vrijstellingen wordt gestuurd door het gegeven dat een deel van de eigen middelen van de Europese Unie wordt gefinancierd uit de opbrengst van de BTW. In de overwegingen van het Hof bij de uitleg van het recht op aftrek van voorbelasting is geen verwijzing te vinden naar de financiering van de eigen middelen. In de genoemde inbreukprocedure tegen Spanje wijst het Hof op de ernst van de consequentie van het niet genieten van de aftrek van voorbelasting, namelijk dat elke beperking van dit recht gevolgen heeft voor de hoogte van de belastingdruk en dat het aftrekrecht in alle lidstaten op dezelfde wijze moet worden toegepast. Met de verwijzing naar de gevolgen voor de belastingdruk kan bedoeld zijn de belastingdruk voor ondernemers en - voor zover ik kan zien niet zozeer de financiering van de eigen middelen van de Europese Unie. Duidelijk is dat, gezien het effect op de belastingdruk, de beperkingen op het recht op aftrek uitdrukkelijk in de BTW-richtlijn dienen te zijn vermeld en in de lidstaten uniform behoren te worden uitgelegd en toegepast.

\section{$11.4 \quad$ Het gelijkheidsbeginsel}

\subsubsection{Inleiding}

In de vorige paragraaf is aan de orde geweest dat het doel van de aftrekregeling is het bereiken van de neutraliteit zoals dat zijn grondslag vindt in artikel 2, Eerste richtlijn. Deze paragraaf gaat nader in op het gelijkheidsbeginsel op het terrein van het aftrekrecht. Zoals is uiteengezet in paragraaf 4.4.4 verwijst het Hof geregeld naar de fiscale neutraliteit als uitdrukking van het gelijkheidsbeginsel voor de BTW. ${ }^{25}$ Daarbij is van belang - zie paragraaf 3.5.2 - dat met een verwijzing naar de fiscale neutraliteit het Hof niet altijd het gelijkheidsbeginsel op het oog heeft. In de volgende paragrafen zal blijken dat het Hof op een aantal terreinen wel degelijk de fiscale neutraliteit als uitdrukking van het gelijkheidsbeginsel gebruikt ter onderbouwing van zijn beslissing. De eerste is de afbakening tussen handelingen die wel en die niet aan de BTW zijn onderworpen (paragrafen 11.4.2 en 11.4.3). De tweede situatie doet zich voor bij een beroep op het aftrekrecht in het kader van de Achtste richtlijn door een belastingplichtige die in een andere lidstaat is gevestigd (paragraaf 11.4.4). Verder speelt de fiscale neutraliteit als uitdrukking van het

24. Zie nader paragraaf 10.3 .

25. Zie bijvoorbeeld het arrest van 21 april 2005, nr. C-25/03, Hundt E\wein, V-N 2005/22.18. In r.o. 72 is te vinden dat het beginsel van de fiscale neutraliteit een uitvloeisel is van het gelijkheidsbeginsel. Zie verder de jurisprudentie die is aangehaald in paragraaf 4.4 .4 . 
gelijkheidsbeginsel op een bijzondere wijze een rol in het Eurodental-arrest (paragraaf 11.4.5).

\subsubsection{Eindverbruikers kennen geen fiscale neutraliteit}

De BTW-heffing richt zich tot, algemeen gezegd, ondernemers. Zij zijn belastingplichtig en dienen - met aftrek van de voorbelasting - de BTW af te wentelen tot deze afwenteling de consument, de eindverbruiker bereikt. De strikte scheidslijn tussen ondernemer en consument veroorzaakt niet enkel belastingdrukverschillen aan de omzetkant van de onderneming, maar ook aan de inkoopkant waar de al dan niet aftrek van voorbelasting de belastingdruk bepaalt. En die drukbepaling is soms kwestieus, zolang de positie van een organisatie die tussen ondernemer en consument 'zweeft' kwestieus is. Dat is soms het geval waar overheden jegens hun burgers/klanten voorziening verschaffen of goederen leveren. In paragraaf 7.4.6 is beschreven dat de belastingplicht van overheidslichamen onder omstandigheden afhangt van het optreden van een verstoring van de mededinging. In het arrest Waterschap Zeeuws Vlaanderen (WZV) ${ }^{26}$ onderbouwde belanghebbende het bestaan van een dergelijke verstoring door de situatie van een marktdeelnemer met die van een publiekrechtelijk lichaam te vergelijken, en betoogde vervolgens dat een marktdeelnemer in vergelijkbare omstandigheden de voorbelasting in aftrek kan brengen. Wat was er aan de hand in deze procedure? Het overheidslichaam WZV bouwde een rioolwaterzuiveringsinstallatie en verkocht na vijf jaar de installatie aan een stichting. Tegelijkertijd sloot WZV een huurovereenkomst met de stichting en opteerde zij voor belastingheffing voor de verhuur. WZV meende recht te hebben op teruggaaf van de nog op de installatie rustende herzienings-BTW.

Het Hof besliste op prejudiciële vragen van de Hoge Raad dat WZV niet voor teruggaaf van de herzienings-BTW in aanmerking komt. In dit arrest oordeelde het Hof dat een publiekrechtelijk lichaam dat als overheid in de zin van artikel 13, BTW-richtlijn en dus als niet-belastingplichtige, een investeringsgoed aanschaft en dit goed nadien als belastingplichtige verkoopt, in het kader van deze verkoop geen recht heeft op herziening op basis van artikel 187, BTW-richtlijn om de bij de aanschaf van dat goed voldane BTW in aftrek te brengen. ${ }^{27}$

Het WZV probeerde echter in deze procedure het recht op aftrek binnen te halen door naar voren te brengen, dat als de voorbelasting niet in aftrek zou kunnen worden gebracht, dit tot aanzienlijke concurrentievervalsing zou leiden (r.o. 42). Ter illustratie van het bestaan van concurrentievervalsing vergeleek het WZV de situatie van een marktdeelnemer met die van een publiekrechtelijk lichaam, en betoogde het

26. Hof 2 juni 2005, nr. C-378/02, Waterschap Zeeuws Vlaanderen (WZV), V-N 2005/30.17, NTFR $2005 / 896$

27. Zie tevens Hof 11 juli 1991, nr. C-97/90, Lennartz, V-N 1991/2402, FED 1991/647. In deze procedure besliste het Hof, dat als een auto aanvankelijk privé wordt gebruikt en in een later jaar zakelijk, niet leidt tot toepassing van de herzieningsregels en dan ook niet in een later jaar alsnog een deel van de voorbelasting kan terugvragen. 
dat de marktdeelnemer in vergelijkbare omstandigheden de als voorbelasting voldane BTW van de nadien ontvangen BTW kan aftrekken. Het WZV was dan ook van mening dat dit een rechtvaardiging vormde voor toepassing van de uitzondering van artikel 13, lid 1, tweede alinea, BTW-richtlijn, op grond waarvan publiekrechtelijke lichamen als belastingplichtigen moeten worden aangemerkt in geval van een verstoring van de mededinging van enige betekenis. ${ }^{28}$

Het Hof honoreerde dit argument niet.

“(...) De eventuele concurrentievervalsing, in omstandigheden zoals die van het hoofdgeding, vindt haar oorsprong immers eerder in de uitoefening door het publiekrechtelijke lichaam van het recht om voor belastingheffing over de verkoop of de verhuur van het betrokken onroerende goed te kiezen, dan in de toepassing van het stelsel volgens hetwelk publiekrechtelijke lichamen niet als belastingplichtigen worden aangemerkt voor de handelingen die zij als overheid verrichten. Zoals de advocaat-generaal in punt 38 van zijn conclusie heeft opgemerkt, kan dit stelsel op zich weliswaar tot op zekere hoogte de toepassing van de beginselen van neutraliteit en gelijke behandeling doorkruisen, doch is dit gevolg inherent aan het bestaan van uitzonderingen op het BTW-stelsel." (r.o. 43)

In de aangehaalde conclusie, punt 38, overweegt advocaat-generaal Jacobs:

"Het is inherent aan het bestaan van uitzonderingen op het BTW-stelsel dat zij de beginselen van neutraliteit en van gelijke behandeling tot op zekere hoogte zullen doorkruisen. Wat de merites van de beslissing om overheidslichamen als eindverbruikers te beschouwen ook mogen zijn, zij maakt integrerend deel uit van de richtlijn. In die en in vergelijkbare situaties zullen belastingplichtigen en personen die van het BTW-stelsel zijn uitgesloten, onvermijdelijk verschillend worden behandeld."

Verschillende behandeling van belastingplichtigen en eindverbruikers is inherent aan het systeem zoals dat is neergelegd in de BTW-richtlijn. Dit verschil in behandeling werkt door in de toekenning van het recht op aftrek van voorbelasting. In het Nordania Finans-arrest ${ }^{29}$ over de uitleg van de pro rata-regeling is het als volgt te vinden:

“(...) Het gemeenschappelijke BTW-stelsel waarborgt aldus de volkomen neutraliteit van de belastingdruk op alle economische activiteiten, mits deze activiteiten in beginsel zelf aan de heffing van btw zijn onderworpen (...). (cursief: AHB)" (r.o. 15)

Daargelaten de vraag of het verlenen van een optie tot belaste levering van de rioolwaterzuiveringsinstallatie passend is, was de gedachte van het Waterschap wel begrijpelijk om de niet geringe investering van BTW-druk te schonen, waar - zo voege ik er aan toe, bovendien wat verderop in het proces gezuiverd water bij ondernemers en consumenten uit de kraan komt. Hier zou zich een vergelijking kunnen opdringen met de in paragraaf 7.2.2. behandelde startende ondernemer, die zich van de BTW op de investering kon ontdoen, maar de vergelijking houdt hiermee

28. Zie ook paragraaf 7.4.6.

29. Hof 6 maart 2008, nr. C-98/07, Nordania Finans A/S, V-N 2008/15.20, r.o. 17. Een bijna identieke overweging is te vinden in Hof 18 december 2008, nr. C-488/07, Royal Bank of Scotland Group Plc, V-N 2008/62.26 waar tevens de berekening van de pro-rata aan de orde is. Zie in het bijzonder r.o. 15. 
meteen op, aangezien deze wel het BTW-land van de economische activiteiten en dus van de aftrek van voorbelasting kon binnengaan en het Waterschap daar niets te zoeken heeft. Het publiek rechtelijk lichaam opererend als overheid in de zin van artikel 13, lid 1, BTW-richtlijn staat buiten de BTW-regels, zoals de advocaatgeneraal verwoordt: zij 'als eindverbruiker is te beschouwen'. Zonder economische activiteiten op het moment van de investering kan men het veld van de voorbelasting niet binnentreden. En dat betekent dus dat men in een economisch gezien vergelijkbare situatie rechtens niet aan een vergelijking toekomt, dus bij voorbaat bot vangt met het doen van een beroep op de fiscale neutraliteit. Het interpretatiebeginsel reikt niet tot buiten de woorden van de BTW-richtlijn.

De BTW-richtlijn is niet ruimer dan zij is, hoe lovenswaardig het onder omstandigheden ook zou kunnen zijn het neutraliteitsbeginsel meer te dienen dan de richtlijn doet. Tot het afwijken van de BTW-richtlijn hebben de lidstaten geen bevoegdheid. Zie in dit verband de inbreukprocedure tegen Spanje $\mathrm{j}^{30}$ en Frankrijk ${ }^{31}$ over de opname van subsidies in de pro-rata berekening. De Spaanse regeling beperkte het aftrekrecht indien subsidies werden verleend voor de aanschaf van bepaalde goederen en diensten. Deze aftrekbeperking was zowel aan de orde bij belastingplichtigen die uitsluitend belaste prestaties verrichtten als bij belastingplichtigen die gedeeltelijk belaste en vrijgestelde prestaties verrichtten. Beide categorieën belastingplichtigen werden geconfronteerd met een aftrekbeperking indien een subsidie werd ontvangen. Het Hof besliste dat de nationale regeling in strijd is met de BTW-richtlijn. Subsidies kunnen enkel de pro-rata berekening van artikel 174, BTW-richtlijn (voorheen artikel 19, lid 1, Zesde richtlijn) beïnvloeden als er al een aftrekbeperking is op grond van 173, lid 1, BTW-richtlijn (voorheen artikel 17, lid 5, Zesde richtlijn), dus bij zogenoemde 'gemengde' belastingplichtigen. De Spaanse regering verdedigde de regeling met het argument dat deze de fiscale neutraliteit ten goede komt. Het Hof geeft echter aan dat de lidstaten niet de bevoegdheid hebben om imperfecties in het systeem in hun nationale regelgeving op te heffen. Ook al verbeteren deze maatregelen de fiscale neutraliteit van het systeem.

"Het betoog van de Spaanse regering dat door de uitlegging van artikel 19 van de Zesde richtlijn die zij voorstelt, het evenwicht op het gebied van de mededinging en derhalve het beginsel van neutraliteit van de BTW beter kunnen worden gewaarborgd, moet worden afgewezen. De lidstaten zijn immers verplicht de Zesde richtlijn toe te passen, zelfs wanneer zij deze voor verbetering vatbaar achten. Uit het arrest van 8 november 2001, Commissie/ Nederland, (C-338/98, Jurispr. blz. I-8265, punten 55 en 56), volgt immers dat de lidstaten niet mogen afwijken van de in de Zesde richtlijn uitdrukkelijk voorziene bepalingen door andere beperkingen van het recht op aftrek in te voeren dan die waarin de artikelen 17 en 19 van deze richtlijn voorzien, ook wanneer de door bepaalde lidstaten voorgestelde uitlegging beter strookt met bepaalde doelstellingen van de Zesde richtlijn, zoals de neutraliteit van de belasting." (r.o. 28)

30. Hof 6 oktober 2005, nr. C-204/03, Commissie/Spanje, V-N 2005/51.21, NTFR 2005/1624, in het bijzonder r.o. 28 .

31. In gelijke zin het arrest van eveneens 6 oktober 2005, nr. C-243/03, Commissie/Frankrijk, V-N 2005/ 51.22, NTFR 2005/1625, r.o. 35. 
Niet belastingplichtigen en belastingplichtigen met vrijgestelde prestaties kunnen dus niet met een beroep op de fiscale neutraliteit binnen het bereik van de aftrekregeling komen. Het Hof kan en hoeft daarom niet te onderzoeken of er daadwerkelijk sprake is van een schending van het beginsel.

\subsubsection{Het SKF-arrest en de gelijke behandeling van ongelijke gevallen}

SKF mengt zich in het beheer van haar dochtermaatschappijen en verricht tegen betaling diensten op het terrein van beheer, administratie en marketing. ${ }^{32}$ SKF is van plan de groep waartoe zij behoort te herstructureren en in dit kader wil zij alle aandelen verkopen van een $100 \%$ dochtermaatschappij. De opbrengst van deze aandelentransactie is SKF van plan te gebruiken voor het financieren van andere activiteiten van de groep. Diverse adviseurs staan SKF bij en brengen voor deze adviezen BTW in rekening. De vraag is of SKF deze BTW in aftrek kan brengen op haar aangifte.

Het Hof overweegt dat de verkoop van de aandelen een verlengstuk is van de economische activiteiten van SKF en dan ook binnen de werkingssfeer van de BTW valt (r.o. 33). De overdracht van de aandelen is vrijgesteld krachtens artikel 135, lid 1, sub f, BTW-richtlijn (voorheen artikel 13B, sub d, punt 5, Zesde richtlijn). De vraag is dan welke gevolgen deze transactie heeft voor het aftrekrecht. ${ }^{33}$ Wij komen hier op het terrein van, wat ook wel genoemd wordt, de leer van de algemene kosten. ${ }^{34}$ Het Hof hierover:

"Of er sprake is van recht op aftrek, hangt dus af van de handelingen in een later stadium ten behoeve waarvan de handelingen in een eerder stadium worden gebruikt. Zo bestaat dat recht wanneer de aan btw onderworpen handeling in een eerder stadium rechtstreeks en onmiddellijk verband houdt met een of meer in een later stadium verrichte handelingen waarvoor recht op aftrek bestaat. Indien dit niet het geval is, moet worden nagegaan of de kosten voor het betrekken van goederen en diensten in een eerder stadium deel uitmaken van de algemene kosten van de economische activiteit van de belastingplichtige in haar geheel. Voor het bestaan van een rechtstreeks en onmiddellijk verband moeten in beide gevallen de kosten van de diensten in een eerder stadium zijn opgenomen in de prijs van de bijzondere handelingen in een later stadium of in de prijs van de door de belastingplichtige in het kader van zijn economische activiteit geleverde goederen of verrichte diensten." (r.o. 60)

"In casu hebben de uitgaven voor de door SKF betrokken diensten volgens de beschrijving van de verwijzende rechter 'rechtstreeks betrekking' op de aandelenverkoop en maken zij deel uit van de algemene kosten van de economische activiteit van SKF in haar geheel." (r.o. 61)

32. Hof 29 oktober 2009, nr. C-29/08, AB SKF, V-N 2009/56.13, NTFR 2009/2421.

33. Meerdere aspecten komen rond het aftrekrecht aan bod, zoals de criteria wanneer aandelentransacties binnen het bereik van de BTW vallen en of er sprake is van een algemeenheid van goederen om er enkele te noemen. Ik laat dit buiten beschouwing omdat ik mij op deze plaats richt op de betekenis van de fiscale neutraliteit als uitdrukking van het gelijkheidsbeginsel. Voor de genoemde aspecten verwijs ik naar S.T.M. Beelen 2010, blz. 145 e.v.

34. Zie voor een behandeling van het recht op aftrek van de algemene kosten S.T.M. Beelen 2010, blz. $153 \mathrm{t} / \mathrm{m} 163$. 
“Dienaangaande kan uit het bij het Hof ingediende dossier niet worden opgemaakt of deze uitgaven rechtstreeks en onmiddellijk verband houden, (...), met de voorgenomen aandelenoverdrachten of met de economische activiteit van SKF in haar geheel, daar deze handelingen volgens de verwijzende rechter tot doel hadden andere activiteiten van de groep te financieren. Om een dergelijk rechtstreeks en onmiddellijk verband vast te stellen, is het namelijk van belang te weten of de gedane uitgaven kunnen worden opgenomen in de prijs van de aandelen die SKF wil overdragen, dan wel of zij uitsluitend deel uitmaken van de bestanddelen van de prijs van de producten van SKF." (r.o. 62)

Het Hof wijst er in rechtsoverweging 66 op dat:

"Wanneer het recht op aftrek van voorbelasting wordt geweigerd voor uitgaven voor adviesverlening over een aandelenoverdracht die is vrijgesteld wegens inmenging in het beheer van de vennootschap waarvan de aandelen worden overgedragen, en bij een overdracht die buiten de werkingssfeer van de btw valt, wordt aanvaard op grond dat zij algemene kosten van de belastingplichtige vormen, worden objectief soortgelijke handelingen in strijd met het beginsel van fiscale neutraliteit fiscaal verschillend behandeld."

Het Hof overweegt dus dat de fiscale neutraliteit zich er tegen verzet dat marktdeelnemers die dezelfde handelingen verrichten, ter zake van de aftrek van voorbelasting verschillend worden behandeld. In paragraaf 4.4.4.2 is uiteengezet dat de fiscale neutraliteit een uitdrukking is van het gelijkheidsbeginsel. Het Hof heeft dan een verschil in behandeling op het oog van de volgende soortgelijke handelingen: 1. Vrijgestelde handelingen inzake aandelen die binnen de reikwijdte van de BTW vallen.

2. Handelingen inzake aandelen die buiten het bereik van de BTW vallen.

Voorafgaand aan het SKF-arrest zijn er drie arresten gewezen die richtinggevend worden in het SKF-arrest. Het gaat om Abbey National I, ${ }^{35}$ Cibo Participation ${ }^{36}$ en Kretztechnik. ${ }^{37}$ Korts mogelijk weergegeven ging het in deze arresten om het volgende:

- Abbey National I : Bedrijfsoverdracht door middel van een activa/passiva transactie.

- Cibo Participation: De verwerving van deelnemingen en inmenging in het beheer van deze deelnemingen.

- Kretztechnik : Uitgifte van nieuwe aandelen.

Deze zaken hebben in elk geval gemeen dat men naar middelen zoekt om de continuïteit van het bedrijf in stand te houden en dat men daarvoor verschillende opties heeft, namelijk een bedrijfsoverdracht door middel van een activa/passiva transactie, verwerving van deelnemingen en een emissie van aandelen. De kosten die hiermee verband houden hoeven niet per se in de kostprijs van de actie zelf zijn terug te vinden, maar evenmin als kostprijselement in de prijzen van de belaste output. Het is tegen deze achtergrond dat het Hof een algemene route zoekt om de baan vrij te maken voor aftrek van voorbelasting. De bedrijfsoverdracht door middel

35. Hof 22 februari 2001, nr. C-408/98, Abbey National I, V-N 2001/15.26.

36. Hof 27 september 2001, nr. C-16/000, Cibo Participations Plc, V-N 2001/55.7.8

37. Hof 26 mei 2005, nr. C-465/03, Kretztechnik, BNB 2005/313 m.n.v Van Hilten. 
van een activa/passiva transactie, verwerving van een deelneming en de uitgifte van nieuwe aandelen vallen onder situatie 2 en het Hof heeft in dit kader beslist dat in situatie 2 de kosten voor advies gelden als een deel van de algemene kosten van de belastingplichtige en dan ook onder omstandigheden voor aftrek in aanmerking kunnen komen.

In de eerder geciteerde rechtsoverweging 66 overweegt het Hof aan het slot dat als situatie 1 anders wordt behandeld dan situatie 2:

“(...) objectief soortgelijke handelingen in strijd met het beginsel van fiscale neutraliteit $(\ldots) "$

worden behandeld. Op grond van de fiscale neutraliteit dient dus de behandeling wat betreft het recht op aftrek van voorbelasting gelijk te zijn. Het Hof gebruikt zoals in paragraaf 4.4.4.2 is uiteengezet - de term fiscale neutraliteit als uitdrukking van het gelijkheidsbeginsel. In de paragrafen 4.4.3.2 is uiteengezet dat het gelijkheidsbeginsel weliswaar richtinggevend is, maar nog een maatstaf, een criterium of een gemeenschappelijk punt ter vergelijking behoeft. En dit geeft dan aan waarin de soortgelijkheid gelegen is, hetgeen meestal wordt gevonden in de ratio van de bepaling. Dat is ook in het SKF-arrest het geval. Het Hof overweegt:

"Elke andere uitlegging zou de ondernemer bij het verrichten van zijn economische activiteit belasten met de kosten van BTW, zonder dat hij deze zou kunnen aftrekken (...)" (r.o. 70; met weglating van de verwijzingen)

Het Hof heeft hier het wezen van de BTW op het oog, namelijk de prijsevenredige heffing die met behulp van de essentiële aftrek van voorbelasting de belasting doorwentelt. Men ziet dus dat de maatstaf voor gelijktrekking van de gevallen volledig wordt gevonden in de ratio legis van de heffing zelf. Dat betekent dan dat de situaties 1 en 2 op grond van de fiscale neutraliteit tot een zelfde uitkomst moeten leiden wat betreft het recht op aftrek van voorbelasting. Zoals eerder naar voren is gebracht heeft het Hof beslist dat in situatie 2 aftrek van voorbelasting mogelijk is voor zover de kosten waar de BTW op drukt zijn versleuteld in de prijzen die worden berekend voor de belaste activiteiten. Ook in situatie 1 komt dan het recht op aftrek binnen bereik voor zover de input van de vrijgestelde transactie wordt doorberekend in de prijzen van de overige belaste activiteiten.

Het is te betwisten of wel sprake is van een objectieve gelijkheid van de handelingen. Het is binnen of buiten de scope van de BTW (zie vorige paragraaf 11.4.2) en is men binnen de scope dan presteert men hetzij belast of vrijgesteld. Het Hof neemt mee in de overwegingen het doel van de aftrekregeling. Daar is tegen in te brengen dat het juist bij een vrijstelling de bedoeling van de regelgeving is dat het recht op aftrek 
wordt geblokkeerd. De uitwerking van het arrest is voor de praktijk complex. ${ }^{38}$ Met Beelen ben ik het eens dat het een bijna onmogelijke taak is om uit te maken of de kosten zijn opgenomen in de prijs van de verkochte aandelen of deel uitmaken van de kostprijs van de overige handelingen die tot de economische activiteiten behoren. ${ }^{39}$ En dit is niet onbelangrijk gezien het feit dat de voorbelasting die drukt op kosten gemaakt om een aandelentransactie uit te voeren omvangrijk kunnen zijn.

\subsubsection{Teruggaven aan belastingplichtigen gevestigd in een andere lidstaat}

In de Debouche-case ${ }^{40}$ vraagt een Belgische advocaat - advocatenprestatie zijnde in België vrijgesteld - in Nederland voorbelasting terug die hem bij de huur van een personenauto in Nederland in rekening is gebracht. Deze auto gebruikte hij echter volledig voor zijn beroepsuitoefening in België. Debouche meende op grond van de Achtste richtlijn in Nederland voor het recht op aftrek van voorbelasting in aanmerking te komen gezien het feit dat advocaten in Nederland, in tegenstelling tot in België, niet zijn vrijgesteld.

Het Hof besliste echter dat Debouche geen recht heeft op teruggaaf van aan hem in rekening gebrachte BTW.

“(...) Indien dat verzoek werd ingewilligd, zou hij evenwel in een gunstiger positie komen te verkeren dan Nederlandse advocaten, die recht hebben op aftrek van voorbelasting omdat zij belaste handelingen verrichten, terwijl Debouche enkel vrijgestelde handelingen verricht." (r.o. 19)

Opvallend is dat het Hof Debouche vergelijkt met Nederlandse advocaten. Terwijl Debouche enkel werkzaamheden verricht in België. Vergelijking met Belgische advocaten zou dan ook meer voor de hand hebben gelegen. Niet dat een dergelijke vergelijking tot een ander resultaat zou leiden. Indien Debouche recht op teruggaaf van BTW zou hebben, dan zou hij in een gunstiger positie zijn gebracht ten opzichte van zijn Belgische concurrenten die geen recht op aftrek hebben.

Zoals in paragraaf 12.3.1.3 aan de orde is bij de behandeling van het Minerales-arrest, heeft het gelijkheidsbeginsel een sterke werking indien de posities van belastingplichtige in verschillende lidstaten met elkaar worden vergeleken. Dit is een logische uitwerking van het streven naar één interne markt waar, zoals in paragraaf 1.1 aan de orde is geweest, de BTW een uitwerking van is.

38. Zie J.J.M. Lamers \& M.M.W.D. Merkx, Btw, een kosten-batenanalyse, WFR 2010/907. Zij uiten kritiek op het feit dat de SKF-zaak, met zijn strikte formulering van de doorberekeninggedachte, met zich meebrengt dat als sprake is van een niet-kostendekkende exploitatie het recht op aftrek kan worden beperkt. Zij achten een dergelijke uitkomst in strijd met de fiscale neutraliteit.

39. S.T.M. Beelen 2010, blz. 152.

40. Hof 26 september 1996, nr. C-302/93, E, Debouche, BNB 1997/95, m.n.v. Van Hilten, V-N 1996/4058, pt. 17. Zie in dit kader ook Hof 13 juli 2000, nr. C-136/99, Monte Dei Paschi Di Sienna, V-N 2000/50.22, FED 2000/615 m.n.v. Swinkels. 


\subsubsection{Intracommunautaire en in de lidstaat vrijgestelde handelingen (Eurodental-arrest)}

Het Hof heeft in het Eurodental-arrest ${ }^{41}$ het recht op aftrek verduidelijkt voor intracommunautaire handelingen met betrekking tot tandprothesen. De Luxemburgse vennootschap Eurodental SARL legt zich toe op de vervaardiging en reparatie van tandprothesen in opdracht van in Duitsland gevestigde tandartsen. De binnenlandse levering van tandprothesen door tandartsen en tandtechnici is vrijgesteld op grond van artikel 132, lid 1, sub e, BTW-richtlijn (voorheen 13A, lid 1, sub e, Zesde richtlijn) en levert geen recht op aftrek van voorbelasting op. Daarentegen brengt de vrijstelling voor intracommunautaire leveringen van artikel 138, lid 1, BTW-richtlijn (voorheen artikel 28 quater, A, sub a, Zesde richtlijn) wel recht op aftrek van voorbelasting met zich mee voor de leverancier.

Het Hof onderzoekt in het Eurodental-arrest de verhouding tussen twee soorten vrijstellingen in de BTW-richtlijn: die van bepaalde binnenlandse activiteiten van algemeen belang, genoemd in artikel 132, lid 1, BTW-richtlijn, en die ten gunste van intracommunautaire transacties. Het geschil is gerezen omdat de bedrijfsmatige activiteit die in het hoofdgeding aan de orde is, onder het bereik van beide soorten vrijstellingen kan vallen, hetzij vanwege haar aard (levering van tandprothesen door tandtechnici), hetzij vanwege haar modaliteit (intracommunautair). De gevolgen zijn evenwel verschillend: valt zij onder de eerste categorie, dan bestaat geen recht op aftrek van voorbelasting, in het andere geval bestaat dat wel. ${ }^{42}$

Bijzonder in deze procedure is dat Duitsland ervoor heeft gekozen om op grond van de overgangsregeling van artikel 370, BTW-richtlijn (voorheen artikel 28, lid 3, sub a, Zesde richtlijn) handelingen met betrekking tot tandprothesen verricht door tandartsen en tandtechnici op haar grondgebied te belasten. Dit in tegenstelling tot Luxemburg.

Het Hof komt tot de beslissing dat de overeenkomstig artikel 132, lid 1, BTW-richtlijn vrijgestelde handelingen geen recht geven op aftrek van voorbelasting, zelfs niet wanneer deze handelingen een intracommunautair karakter hebben. Het Hof onderbouwt deze beslissing onder meer met een analyse van het leerstuk van de fiscale neutraliteit. Allereerst overweegt het Hof dat het beginsel van fiscale neutraliteit er zich onder meer tegen verzet dat soortgelijke diensten, die dus met elkaar in concurrentie staan, uit het oogpunt van de BTW verschillend worden behandeld (r.o. 46). Indien de handelingen die aan de orde zijn in deze procedure recht zouden geven op aftrek wanneer zij een intracommunautair karakter vertonen, zou de

41. Hof 7 december 2006, nr. C-240/05, Eurodental SARL, V-N 2007/2.17, NTFR 2007/157. In het arrest zijn zowel handelingen voor als na 1 januari 1993 verricht. Ik besteed in deze paragraaf enkel aandacht aan de BTW gevolgen van de handelingen die na 1 januari 1993 zijn verricht en dan ook onder het overgangsregime voor intracommunautaire transacties vallen.

42. Zie ook HR 3 april 2009, nr. 43.446, V-N 2009/16.17 en de conclusie in deze zaak van A-G Van Hilten van 10 december 2007, V-N 2008/5.18. De HR besliste dat verwerving van Zweedse tandprothesen vrijgesteld is van BTW. De levering in Zweden was belast met een zogenoemd nultarief. 
fiscale neutraliteit niet in acht worden genomen, aangezien dezelfde handelingen, wanneer zij binnen een lidstaat worden verricht, niet tot aftrek leiden. Bijgevolg zouden belastingplichtigen die een intracommunautaire handeling verrichten in een gunstiger positie komen te verkeren dan belastingplichtigen die een binnenlandse handeling verrichten (r.o. 47).

De Duitse regering bracht naar voren dat nu zij op grond van de overgangsregeling de in geding zijnde handelingen belast, dat er toe kan leiden dat dergelijke handelingen met een intracommunautair bereik voor de consument duurder zouden kunnen zijn, aangezien zij in Duitsland worden belast en aftrek van de in Luxemburg betaalde BTW niet is toegestaan. Daarentegen zouden dezelfde handelingen, die belastbaar zijn indien deze binnen Duitsland worden verricht, recht geven op aftrek. Daardoor zouden de in Duitsland gevestigde belastingplichtigen in een gunstiger positie komen te verkeren dan hun in Luxemburg gevestigde concurrenten.

Het Hof is niet gevoelig voor dit argument:

"In dat verband moet met name worden beklemtoond dat de omstandigheid dat de handhaving van de betrokken afwijkings- en overgangsregeling in bepaalde lidstaten in voorkomend geval zou kunnen leiden tot mededingingsverstoringen in Duitsland, deze lidstaat geenszins het recht geeft om zelf mededingingsverstoringen te veroorzaken ten nadele van de lidstaten die aan de bepalingen van de Zesde richtlijn uitvoering hebben gegeven. Dat zou in casu echter het geval zijn indien Eurodental de BTW in Luxemburg mocht aftrekken, omdat in dat geval de binnen deze lidstaat verrichte handelingen, die geen recht geven op aftrek van voorbelasting, zouden worden benadeeld ten opzichte van handelingen die vanuit die lidstaat worden verricht." (r.o. 56; met weglating van verwijzing naar jurisprudentie)

Het Hof voegt daar ogenblikkelijk aan toe (r.o. 57), dat wat de bijzondere situatie betreft waarop de Duitse regering zich beroept, het derhalve de taak van de gemeenschapswetgever is om alles in het werk te stellen om de definitieve gemeenschappelijke regeling voor BTW-vrijstellingen vast te stellen en aldus de geleidelijke harmonisatie van de nationale BTW-wetgevingen te verwezenlijken, aangezien alleen daardoor de mededingingsverstoringen die het gevolg zijn van de door de BTW-richtlijn toegestane afwijkings- en overgangsregelingen kunnen worden opgeheven. Een duidelijke boodschap aan de gemeenschapswetgever.

Het Hof vergelijkt belastingplichtigen die een binnenlandse handeling verrichten met belastingplichtigen die een intracommunautaire transactie verrichten (r.o. 56). En - zoals hierboven beschreven - heeft de fiscale neutraliteit dan tot gevolg dat Eurodental geen recht op aftrek van voorbelasting heeft.

Toch is deze toepassing van de fiscale neutraliteit niet geheel bevredigend. De opvatting van het Hof zal tot gevolg hebben dat ondernemers in Luxemburg uit de markt worden geprijsd. Zij hebben namelijk geen recht op aftrek van voorbelasting voor de intracommunautaire transactie terwijl hun afnemer wel BTW moet betalen in Duitsland. Het Hof kiest er echter niet voor bij de toepassing van de fiscale neutraliteit om handelingen verricht door tandtechnici in Luxemburg te vergelijken 
met dezelfde handelingen verricht door tandtechnici in Duitsland. Een dergelijke verstoring van de concurrentieverhoudingen veroorzaakt door overgangsregelingen moeten in de visie van het Hof worden opgelost door de gemeenschapswetgever en niet door toepassing van het leerstuk van de fiscale neutraliteit. ${ }^{43}$ Dit kan wel eens lastig blijken te zijn. Tandtechnici in Duitsland hebben een concurrentievoordeel ten opzichte van hun concurrenten gevestigd in lidstaten die geen gebruik maken van de overgangsregeling. Het is de vraag of de Duitse regering snel een dergelijk voordeel zal beëindigen.

Verder springt een opvallend aspect in het oog bij vergelijking van het Eurodentalarrest met het in de vorige paragraaf behandelde Debouche-arrest. In beide arresten rust de beslissing op de fiscale neutraliteit. Zowel in de Eurodental-case, als in het Debouche-arrest worden concurrentieverhoudingen in de overwegingen betrokken. Alleen in het Debouche-arrest vergelijkt het Hof Belgische advocaten met Nederlandse advocaten en in het Eurodental-arrest worden Luxemburgse tandtechnici die binnenlandse prestaties verrichten vergeleken met Luxemburgse tandtechnici die intracommunautaire transacties verrichten. In dit laatste arrest wijst het Hof expliciet een vergelijking van Luxemburgse tandtechnici met Duitse tandtechnici af. Men ziet dat in de casus Eurodental het gegeven een rol speelt dat sprake is van een overgangsregeling en het Hof expliciet aangeeft dat een dergelijke overgangsregeling een lidstaat niet het recht geeft om mededingingsverstoringen te veroorzaken ten nadele van lidstaten die aan de bepalingen van de BTW-richtlijn uitvoering hebben gegeven.

\section{$11.5 \quad$ Het evenredigheidsbeginsel}

\subsubsection{Beperking recht op aftrek op grond van een machtiging}

\subsubsection{Inleiding}

Artikel 395, BTW-richtlijn (voorheen artikel 27, Zesde richtlijn) biedt de lidstaten de mogelijkheid om in hun nationale BTW-wetgeving bepalingen op te nemen die afwijken van de BTW-richtlijn. Het artikel vermeldt dat de Raad op voorstel van de Commissie met eenparigheid van stemmen elke lidstaat kan machtigen, bijzondere, van de BTW-richtlijn afwijkende maatregelen te treffen teneinde de belastinginning te vereenvoudigen of bepaalde vormen van belastingfraude of -ontwijking te voorkomen. ${ }^{44}$ Een dergelijke maatregel moet dus duidelijk gericht zijn op, of het voorkomen van belastingfraude of -ontwijking, dan wel de belastingheffing te

43. Zie nader M.W.C. Soltysik, Overgangsbepalingen in de Europese BTW, WFR 2007/303. Soltysik behandelt een aantal arresten waaruit blijkt dat het Hof niet in alle situaties schadelijke effecten van de overgangsbepalingen kan voorkomen.

44. Artikel 27, Zesde richtlijn vermeldt in plaats van 'belastinginning' de term 'belastingheffing'. Volgens mij wordt met deze wijziging in terminologie geen verandering in betekenis beoogd. Door mij zal verder de term 'belastingheffing worden gebruikt. Dit gezien het feit dat de behandelde jurisprudentie betrekking heeft op de heffing en niet op de inning van belasting. 
vereenvoudigen. Indien de maatregel gericht is op de vereenvoudiging van de belastingheffing wordt een extra eis gesteld, namelijk dat de maatregel geen noemenswaardige invloed mag hebben op het belastingbedrag dat verschuldigd is in het stadium van het eindverbruik. Deze voorwaarde is gesteld omdat men wil voorkomen dat er een effect van de maatregel uitgaat op het bedrag dat een lidstaat bijdraagt aan de eigen middelen van de Europese Unie. Deze eis wordt uiteraard niet gesteld indien het gaat om maatregelen die gericht zijn op het voorkomen van belastingfraude of -ontwijking.

Uit de jurisprudentie van het Hof blijkt dat de mogelijkheden om af te wijken van de BTW-richtlijn niet onbegrensd zijn. In verschillende arresten heeft het Hof de kaders aangegeven. Zie bijvoorbeeld de inbreukprocedure tegen België. ${ }^{45}$ Zie verder ook het Skripalle-arrest ${ }^{46}$ en het K-Line-arrest. ${ }^{47}$ Deze arresten liggen alle op het terrein van de maatstaf van heffing en zijn besproken in paragraaf 9.2.1.

Op het terrein van het recht op aftrek is de mogelijkheid om af te mogen wijken van de BTW-richtlijn aan de orde geweest in een tweetal arresten, namelijk het Ampafrance-arrest ${ }^{48}$ en het Sudholz-arrest. ${ }^{49}$ In beide arresten is het evenredigheidsbeginsel aan de orde, evenwel met een verschillende uitkomst als resultaat. Interessant dus om na te gaan welke feiten en/of juridische argumenten de verschillende uitkomst tot gevolg hebben.

In dit verband zij kort aan de hoofdlijn bij de toepassing van het evenredigheidsbeginsel herinnerd. ${ }^{50}$ Samenvattend is de lijn die het Hof volgt toetsing van de geschiktheid, de noodzakelijkheid en de evenwichtigheid. Hierbij zij opgemerkt dat de drie stappen niet in elk arrest expliciet worden afgewikkeld. Zoals zal blijken is dat ook in het Ampafrance-arrest en het Sudholz-arrest niet het geval. Allereerst zal ik aandacht besteden aan het Ampafrance-arrest en vervolgens aan het Sudholz-arrest.

\subsubsection{Ampafrance-arrest}

Dit arrest is gewezen naar aanleiding van prejudiciële vragen van de Franse rechter over de geldigheid van beschikking 89/487/EEG. ${ }^{51}$ Deze beschikking was gebaseerd

45. In deze procedure besliste het Hof dat een nationale regeling die bepaald dat de catalogusprijs de minimum maatstaf van heffing is bij de levering van nieuwe personenauto's ontoelaatbaar is. Ook al heeft de desbetreffende lidstaat een machtiging op grond van artikel 395, BTW-richtlijn. Hof 10 april 1984, nr. 324/82, Commissie/België, Jur. 1984, blz. 1861.

46. Hof 29 mei 1997, nr. C-63/96, W. Skripalle, V-N 1998/627. In dit arrest besliste het Hof dat afwijkingen van de maatstaf van heffing enkel zijn toegestaan indien deze absoluut nodig zijn voor het te bereiken doel.

47. Hof 9 juli 1992, nr. C-131/91, K-Line, Jur. 1992, blz. 4513. In deze procedure besliste het Hof dat een minimum prijs in geval van levering van tweedehandse auto's niet is toegestaan.

48. Hof 19 september 2000, nr. C-177/99 en C-181/99, Ampafrance SA, e.a., V-N 200/48.19, NTFR 2000/ 1407.

49. Hof 29 april 2004, nr. C-17/01, W. Sudholz, V-N 2004/24.16, NTFR 2004/674.

50. In paragraaf 3.4.2.2 ga ik er uitgebreider op in.

51. Pb van 16 augustus 1989, L 239, blz. 21. 
op het hierboven beschreven artikel 395, BTW-richtlijn. De beschikking beoogde de uitsluiting van aftrek voor uitgaven van verblijf, ontvangsten, spijzen, drank en ontspanning. De Franse wetgeving voorzag op het moment van inwerkingtreding van de richtlijn niet in een dergelijke uitsluiting van het aftrekrecht. In feite kwam de beschikking dan ook neer op een machtiging om af te mogen wijken van artikel 176, tweede alinea, BTW-richtlijn (voorheen artikel 17, lid 6, tweede alinea, Zesde richtlijn). Deze bepaling in de BTW-richtlijn geeft aan dat de lidstaten, totdat door de Raad een nieuwe regeling is vastgesteld voor uitgaven waarvoor geen recht op aftrek van voorbelasting bestaat, elke uitsluiting kunnen handhaven waarin hun wetgeving op 1 januari 1979 (datum inwerkingtreding Zesde Richtlijn) dan wel, voor de lidstaten die na die datum tot de Europese Unie zijn toegetreden, op de datum van hun toetreding voorzag. Het gevolg is dat een lidstaat niet de beperkingen van het aftrekrecht mag uitbreiden en zijn nationale regelgeving zo minder in overeenstemming brengt met de doelstellingen van de richtlijn. Het is een lidstaat wel toegestaan om de uitsluitingen van het aftrekrecht te beperken en zo zijn regelgeving meer in overeenstemming te brengen met de doelstellingen van de richtlijn. ${ }^{52}$ Deze bepaling wordt dan ook wel een standstillbepaling genoemd.

Het Hof gaat eerst na wat precies de inhoud is van beschikking 89/487/EEG. Vervolgens toetst hij de beschikking aan het evenredigheidsbeginsel.

De toetsing aan het evenredigheidsbeginsel houdt allereerst in dat wordt nagegaan of de maatregel geschikt is om het doel dat wordt beoogd te bereiken. Deze stap vindt men in het arrest niet expliciet terug. Wel gaat het Hof uitgebreid in op de tweede stap, de vraag of de maatregel noodzakelijk is (rechtsoverwegingen $56 \mathrm{t} / \mathrm{m}$ 61); dat om het doel te bereiken geen even doelmatige alternatieven voorhanden zijn die minder belastend zijn.

\footnotetext{
"Anderzijds moeten de bepalingen van een communautair besluit betreffende het BTWsysteem noodzakelijk zijn ter verwezenlijking van het ermee nagestreefde specifieke doel en zo weinig mogelijk afbreuk doen aan de doeleinden en beginselen van de Zesde richtlijn, wil dit besluit in overeenstemming zijn met het evenredigheidsbeginsel." (r.o. 59)
}

Met de verwijzing naar de doeleinden van de BTW-richtlijn heeft het Hof op het oog (r.o. 34) dat het een fundamenteel uitgangspunt is van het BTW-stelsel dat bij elke transactie inzake productie of distributie BTW is verschuldigd onder aftrek van de BTW waarmee de verrichtingen in eerdere handelsfasen rechtstreeks waren belast. Afwijkingen van dit uitgangspunt zijn dus slechts toegestaan in de gevallen waarin de richtlijn uitdrukkelijk voorziet. Vervolgens oordeelt het Hof over de noodzakelijkheid van de maatregel:

"Welnu, een maatregel waarbij alle uitgaven voor verblijf, ontvangsten, spijzen of dranken en ontspanning in beginsel zijn uitgesloten van het recht op BTW-aftrek, dat een fundamenteel beginsel is van het met de Zesde richtlijn ingevoerde BTW-stelsel, terwijl passende middelen die minder afbreuk doen aan dit beginsel dan een uitsluiting van het recht op 
aftrek voor bepaalde uitgaven, mogelijk zijn of in de nationale rechtsorde reeds bestaan, is niet kennelijk noodzakelijk ter bestrijding van belastingfraude en -ontwijking." (r.o. 61)

Daarbij heeft het Hof op het oog dat het risico van belastingfraude of -ontwijking niet geldt voor uitgaven die een strikt beroepsmatige doeleinden hebben gediend en dit blijkt uit objectieve gegevens (r.o. 56). De beschikking sluit ook de BTW die drukt op deze uitgaven uit van het recht op aftrek van voorbelasting.

In rechtsoverweging 59 heeft het Hof aangeven, dat de beschikking 89/487 EEG niet vermeldt waarom de afwijkende maatregel waarvoor de Franse regering toestemming had gevraagd noodzakelijk was ter voorkoming van bepaalde vormen van fraude. Mogelijk dat dit ook een rol heeft gespeeld bij het oordeel van het Hof. Ook al lijkt het mij dat in het bijzonder de overkill die de Franse regeling bevat fataal is voor de geldigheid van de beschikking.

De redactie van $\mathrm{V}-\mathrm{N}$ heeft kritiek op de toepassing van het evenredigheidsbeginsel door het Hof in het Ampafrance-arrest. De redactie van Vakstudie Nieuws meent dat het Hof zich moeizaam door de problematiek heenslaat:

“(...), met als enig instrument een handvol fundamentele beginselen, en lijkt met zijn overwegingen het spoor enigszins bijster te raken."

Het Ampafrance-arrest lezend kan inderdaad niet aan de indruk worden ontkomen dat het Hof moeite heeft het evenredigheidsbeginsel in te vullen. Zo is niet duidelijk welke 'passende middelen' het Hof op het oog heeft die minder afbreuk doen aan het recht op aftrek van voorbelasting. In ieder geval is duidelijk dat beschikkingen van de Raad die zijn gebaseerd op artikel 395, BTW-richtlijn getoetst worden aan het evenredigheidsbeginsel. Dat betekent dat lidstaten niet zondermeer kunnen vertrouwen op toestemming om af te mogen wijken van de BTW-richtlijn. Verder kan in deze procedure een rol hebben gespeeld dat het een beschikking betreft om af te mogen wijken van artikel 176, BTW-richtlijn. Deze bepaling kan gezien worden als een tijdelijke maatregel, voorafgaand aan een definitief stelsel waarin het recht op aftrek van voorbelasting voor bepaalde uitgaven wordt uitgesloten. Mogelijk dat het Hof daarbij strenger te werk gaat dan bij de overige bepalingen van de BTW-richtlijn. Welbeschouwd worden veel problemen op het terrein van artikel 176, BTW-richtlijn door de lidstaten over zich zelf afgeroepen door het gebrek aan voortgang op het terrein van een definitieve regeling voor privégebruik. Deze bepaling kan dan ook om meerdere redenen een 'standstillbepaling' worden genoemd.

\subsubsection{Sudholz-arrest}

Het Hof oordeelde in het Sudholz-arrest ${ }^{53}$ wederom over de geldigheid van een inperking van het recht op aftrek gebaseerd op een machtiging op grond van artikel 395, BTW-richtlijn. In dit arrest spelen ook de geldigheid van de terugwerkende 
kracht en enkele andere formele onderwerpen die van belang kunnen zijn bij het afgeven van een machtiging. ${ }^{54}$ Hierop ga ik niet in.

In het Sudholz-arrest staat centraal de geldigheid van beschikking 2000/186. ${ }^{55}$ Deze beschikking van de Raad machtigt Duitsland de aftrek van omzetbelasting die drukt op voertuigen die door ondernemers mede voor privédoeleinden worden gebruikt, tot $50 \%$ te beperken.

De Sudholz-zaak verschilt op een aantal punten van het Ampafrance-arrest. De beschikking die centraal staat in het Ampafrance-arrest heeft betrekking op een volledige uitsluiting van het recht op aftrek van voorbelasting en niet een forfaitaire beperking van dat recht tot $50 \%$. Verder had de beschikking enkel als doel het tegengaan van belastingfraude of -ontwijking. De beschikking die aan de orde is in het Sudholz-arrest beoogde daarnaast ook een vereenvoudiging van de heffing. Verder blijkt ook uit het Ampafrance-arrest dat de betrokken uitgaven in het kader van de inkomsten- of vennootschapsbelasting aan een effectief systeem van controle waren onderworpen. In het Sudholz-arrest wordt van een dergelijke controle mogelijkheid geen melding gemaakt. Verder kan van belang zijn dat de machtiging in het Ampafrance-arrest aangeeft dat wordt afgeweken van artikel 176, BTWrichtlijn (de zogenoemde standstillbepaling). Terwijl de tekst van de beschikking die getoetst wordt in het Sudholz-arrest aangeeft dat wordt afgeweken van de algemene aftrekregeling die is te vinden in artikel 168, sub a, BTW-richtlijn (voorheen artikel 17, lid 2, Zesde richtlijn). Het vertrekpunt voor Frankrijk in het Ampafrance-arrest kan dan ook lastiger zijn geweest, gezien het feit dat Frankrijk probeerde via de machtigingsprocedure alsnog onder het bereik van de standstillbepaling te komen.

Vervolgens gaat het Hof na of een forfaitaire beperking van het aftrekrecht geldig is. In het bijzonder het gegeven dat het niet eenvoudig is om vooraf het privé gebruik vast te stellen en de moeilijkheid om met behulp van controles achteraf onregelmatigheden op te sporen, is voor het Hof voldoende om een forfaitaire regeling op zich aanvaardbaar te vinden. ${ }^{56}$

54. In het arrest geeft het Hof verder aan dat publicatie van de machtiging niet verplicht is. Bijzonder in deze procedure is het procesverloop. De hoofdregel is dat de mondelinge behandeling eindigt op het moment dat de advocaat-generaal concludeert. In dit geval verscheen de conclusie van A-G Geelhoed op 24 oktober 2002. Gezien het gegeven dat het Hof nog een verduidelijking wilde hebben over de invloed van de maatregel op het uiteindelijke belastingbedrag dat uiteindelijk verschuldigd is in het stadium van het eindverbruik, werd de mondelinge behandeling heropend en verscheen een tweede conclusie van de A-G. Zie voor een toelichting op het procesverloop R. Barents, Procedures en procesvoering voor het Hof en het Gerecht van eerste aanleg van de EG, Deventer: Kluwer 2005, blz. 500. Zie ook de encyclopedie NDFR Omzetbelasting, Sdu Uitgevers, Europees rechtelijk kader, paragraaf 3.4. In ieder geval is heropening van de mondelinge behandeling uitzonderlijk.

55. Beschikking 2000/186/EEG van de Raad van 28 februari 2000, Pb L 59, blz. 12.

56. A-G Cosmos wijst echter in zijn conclusie van 23 maart 2000 bij het in paragraaf 11.5.1.2 behandelde Ampafrance-arrest een forfaitaire regeling af. Dit gezien het ontbreken van de mogelijkheid van tegenbewijs. 
$\mathrm{Na}$ dit te hebben vastgesteld gaat het Hof over tot de beoordeling of een drempel van $50 \%$ evenredig is met het nagestreefde doel. Hierbij lijkt vooral te overtuigen, dat het percentage kennelijk is gebaseerd op een gemiddeld privégebruik van de betrokken voertuigen en dat de regeling een bepaling kent die bij zeer laag privé gebruik (minder dan 5\%) het recht op aftrek niet beperkt. Dat de maatregel dan mogelijk te ruw uitwerkt voor belastingplichtigen die de betrokken voertuigen voor meer dan 50\% (maar voor minder dan 95\%) voor zakelijke doeleinden willen gebruiken, moet volgens het Hof als inherent worden aangemerkt van een maatregel ter vereenvoudiging. De beschikking die Duitsland toestaat het aftrekrecht te beperken is dan ook in overeenstemming met de doelstellingen van de BTW-richtlijn en het evenredigheidsbeginsel.

\subsubsection{Tussenconclusies}

Het Hof beschermt het - voor de BTW zo wezenlijke - recht op aftrek van voorbelasting. Het gaat om een fundamenteel beginsel van de BTW en daaraan wil het Hof anders dan bij hoge uitzondering binnen het raam van de evenredigheid - niet tornen. Met het woord beginsel doelt mijns inziens het Hof overigens niet op het begrip beginsel in de door mij bedoelde zin van algemeen rechtsbeginsel, maar op fundamenteel uitgangspunt van de BTW. Het recht op aftrek van voorbelasting is wel een uitwerking van het neutraliteitsbeginsel in de zin van 'klassiek BTW-beginsel' dat de goederen en diensten in elke schakel van het voortbrengingsproces wil bevrijden (stelselbeginsel) (zie paragraaf 3.5.2). In die zin beschermt het evenredigheidsbeginsel dus dit BTW-beginsel.

Het verschil in resultaat tussen beide arresten is dat in het Ampafrance-arrest de machtiging in strijd is met het evenredigheidsbeginsel, terwijl in het Sudholz-arrest de toetsing wordt doorstaan. Volgens mij is dit verschil in resultaat te verklaren door het gegeven dat de beschikking in het Sudholz-arrest geen volledige uitsluiting van het aftrekrecht kent. En voorts gaf Duitsland aan dat dit percentage niet zomaar was geprikt, maar was gebaseerd op een gemiddeld gebruik van de betrokken voertuigen. Kortom, de Duitse regeling was zo veel als mogelijk toegesneden op het beoogde doel. En dat is waar het uiteindelijk bij het evenredigheidsbeginsel om gaat. Het Ampafrance-arrest en het Sudholz-arrest bevatten dan ook aanwijzingen voor de lidstaten, Commissie en Raad voor het ontwikkelen van regelgeving die haar basis vindt in artikel 295, BTW-richtlijn. Zoals het Sudholz-arrest laat zien, is van belang dat een lidstaat kan onderbouwen dat de maatregel geschikt is om het nagestreefde doel te bereiken. Tevens is van belang dat de maatregel geen overkill tot gevolg heeft. In het Sudholz-arrest voorkomt de Duitse regering dat door de reikwijdte van de maatregel te beperken (in casu geen beperking van aftrek bij een zeer laag privégebruik).

\subsubsection{Optieverzoek}

Belastingplichtigen die vrijgestelde prestaties verrichten hebben in beginsel geen recht op aftrek van voorbelasting. Het is duidelijk dat de vrijstellingen in het (voor 
het overige belaste) ondernemerscircuit de neutraliteit verstoren (in de betekenis van het bevrijden van de voordruk). Degene die namelijk vrijgesteld presteert zal de BTW die hij in rekening krijgt gebracht (lock-in BTW) verdisconteren in de vergoedingen die hij aan zijn afnemers berekent. De afnemer kan deze lock-in BTW niet in aftrek brengen. Ook al verricht hij zelf met BTW belaste prestaties. De kern van het probleem is dus dat de uitgaande vrijgestelde handelingen aan de 'inkoopzijde' van de onderneming in beginsel geen recht op aftrek van voorbelasting kennen. Artikel 137 BTW-richtlijn (voorheen artikel 13C, Zesde richtlijn) kent echter voor bepaalde financiële en onroerend-goedprestaties een mogelijkheid om dit probleem op te lossen. ${ }^{57}$ De lidstaten moeten de belastingplichtigen alsdan de mogelijkheid bieden te kiezen voor belastingheffing. Daarbij is van belang dat de belastingplichtige zelf kiest of hij in de belastingheffing wil worden betrokken. Indien eenmaal is gekozen voor belastingheffing dan komt ook het aftrekrecht binnen bereik.

Artikel 137, lid 2, BTW-richtlijn vermeldt dat de lidstaten de bepalingen voor de uitoefening van het keuzerecht kunnen vaststellen. De vraag die dan opkomt, is of de lidstaten de mogelijkheid hebben om voorwaarden te stellen aan een dergelijke keuze-regeling en of ze de regeling zonder meer in de loop van de tijd kunnen wijzigen.

In het arrest Objekt Kirchberg ${ }^{58}$ was aan de orde de vraag of het aftrekrecht kan worden geweigerd indien bepaalde vooraf gestelde voorwaarden niet zijn vervuld. In dit arrest staat centraal de invulling door het Groothertogdom Luxemburg van het keuzerecht. Het Groothertogdom Luxemburg heeft het keuzerecht beperkt tot het geval waarin de huurder van een onroerend goed zelf een belastingplichtige is die recht heeft op aftrek, en de uitoefening van dit recht aan een voorafgaande goedkeuringsprocedure onderworpen. In het Objekt Kirchberg-arrest heeft belanghebbende te laat het verzoek tot belaste verhuur ingediend.

Het Hof overweegt dat de lidstaten de mogelijkheid hebben om aan het keuzerecht voorwaarden te verbinden en dat een voorafgaande goedkeuringsprocedure de lidstaten de mogelijkheid geeft van te voren na te gaan of deze voorwaarden zijn vervuld. Vervolgens besliste het Hof dat het ontbreken van een terugwerkende kracht niet tot gevolg heeft dat een dergelijke regeling in strijd is met het evenredigheidsbeginsel (r.o. 29). Cruciaal lijkt mij's Hofs overweging dat de goedkeuringsprocedure niet tot gevolg mag hebben dat afbreuk wordt gedaan aan het aftrekrecht. ${ }^{59}$ Verder overweegt het Hof dat het ontbreken van terugwerkende

57. Het recht om voor belastingheffing te kiezen is enkel mogelijk voor de in artikel 137, BTW-richtlijn genoemde handelingen. Het betreft bepaalde financiële handelingen, levering van een (gedeelte) van een gebouw en van het bijbehorende terrein (met uitzondering van de levering voor de eerste ingebruikname), levering van onbebouwde onroerende goederen (met uitzondering van bouwterreinen), verhuur en verpachting van onroerende goederen.

58. Hof 9 september 2004, nr. C-269/03, Objekt Kirchberg, V-N 2004/48.9, NTFR 2004/1515.

59. Zie verder Hof 30 maart 2006, nr. C-184/04, Uudenkaupungin Kaupunki, V-N 2006/18.25. In deze procedure besliste het Hof dat een lidstaat die aan belastingplichtigen het recht verleent om te $\rightarrow$ 
kracht van de goedkeuringsprocedure een nuttig effect kan hebben. Het is namelijk niet uitgesloten dat het ontbreken van terugwerkende kracht de verhuurders aanspoort om op tijd hun verzoek in te dienen. ${ }^{60}$

\subsection{Conclusies}

Het Hof heeft in het Ghent Coal-arrest ${ }^{61}$ overwogen dat het doel van de aftrekregeling is:

"de ondernemer in het geheel te ontlasten van de in het kader van al zijn economische activiteiten verschuldigde of betaalde BTW".

Het uitgangspunt is dan ook een volstrekte neutrale belasting van alle economische activiteiten (zie paragraaf 11.3 ). ${ }^{62}$

De fiscale neutraliteit strekt zich niet uit tot personen die niet aan de BTW-richtlijn zijn onderworpen, maar dit misschien wel profijtelijk zouden vinden omdat daarmee de concurrentiepositie meer gelijk zou zijn dan in een situatie dat men erbuiten staat (zie paragraaf 11.4.2). Net als bij belastingplicht (zie paragraaf 7.3.4) zien wij ook bij de uitleg van de regels op het terrein van het aftrekrecht dat de werking van het beginsel niet almachtig is en uiteraard niet buiten de oevers van de regels kan treden. Zonder economische activiteiten op het moment van de investering kan men het veld van de voorbelasting niet binnentreden. En dat betekent dus dat men in een economisch gezien vergelijkbare situatie rechtens niet aan een vergelijking toekomt, dus bij voorbaat bot vangt met het doen van een beroep op de fiscale neutraliteit. Het interpretatiebeginsel reikt niet tot buiten de woorden van de BTW-richtlijn.

Het evenredigheidsbeginsel laat zich gelden bij de invulling door de lidstaten van artikel 395, BTW-richtlijn. De machtiging om af te mogen wijken van de BTWrichtlijn wordt beperkt door het evenredigheidsbeginsel. In het Ampafrance-arrest sneuvelt de Franse regeling bij de toets aan het evenredigheidsbeginsel. De Duitse

$\rightarrow$ kiezen voor belastingheffing over de verhuur van een onroerend goed, op grond van artikel 137, BTW-richtlijn de aftrek die vóór de uitoefening van die keuzerecht zijn gedaan, niet mag uitsluiten wanneer het verzoek met betrekking tot de uitoefening van dit keuzerecht niet is ingediend binnen zes maanden na ingebruikname van het onroerend goed. Dit gezien het feit dat de desbetreffende nationale regeling niet zozeer de omvang van het keuzerecht betreft maar de gevolgen van de uitoefening van dit recht. Artikel 137, BTW-richtlijn machtigt de lidstaten niet om de herziening van de aftrek artikel 187, BTW-richtlijn te beperken.

60. zie ook Hof 19 januari 1982, nr. 8/81, U. Becker, Jur. 1982, blz. 53 en Hof 3 december 1998, nr. C-381/ 97, Belgocodex, BNB 1999/29, V-N 1999/14.25, Jur. 1998, blz. I-8153.

61. Hof 15 januari 1998, nr. C-37/95, Ghent Coal Terminal, V-N 1998/29.14, r.o. 15.

62. Het element van de (volstrekt) 'neutrale fiscale belasting van alle economische activiteiten' is onder meer te vinden in de arresten: HvJ EU 1 april 2004, nr. C-90/02, Bockemühl, V-N 2004/20.18, NTFR 2004/513, r.o. 39; HvJ EU 22 juni 1993, nr. C-333/91, Sofitam SA, FED 1993/608, r.o. 10; HvJ EU 22 februari 2001, nr. C-408/98, Abbey National, V-N 2001/15.26, r.o. 24. 
regeling echter doorstaat in het Sudholz-arrest de test aan het evenredigheidsbeginsel. Beslissend daarbij is dat de Duitse regeling meer is toegespitst op het doel dat wordt beoogd.

Bij de mogelijkheid om te kiezen voor belaste heffing op grond van artikel 137, BTWrichtlijn toetst het Hof aan het evenredigheidsbeginsel. Daarbij is van belang dat geen afbreuk wordt gedaan aan het recht op aftrek van voorbelasting. 


\section{Administratieve verplichtingen in het binnenlandsverkeer}

\subsection{Algemeen kader}

De BTW-richtlijn regelt uitgebreid de administratieve verplichtingen in het binnenlands verkeer (artikelen $193 \mathrm{t} / \mathrm{m}$ 273, BTW-richtlijn). ${ }^{1}$ Het is dus duidelijk dat de regelgever meent dat het materiële BTW-bouwwerk stevig op administratieve verplichtingen gefundeerd dient te zijn. In de voorloper van de BTW-richtlijn zijn de verplichtingen te vinden in artikel 22, Zesde richtlijn. ${ }^{2}$ Dat in de Zesde richtlijn de materie in 'slechts' éen artikel is geregeld in tegenstelling tot de meer dan 80 artikelen in de BTW-richtlijn duidt niet op een toegenomen belang in de communautaire regelgeving. ${ }^{3}$ Artikel 22, Zesde richtlijn beslaat namelijk in de gangbare belastingpocket 10 pagina's kleine druk aan tekst.

Een bepaald niet onbelangrijk deel van de administratieve verplichtingen gaat over de factuur, centraal document in de BTW. De Raad heeft recentelijk een richtlijn aangenomen tot wijziging van de BTW-richtlijn. ${ }^{4}$ De aanpassing beoogt de regels verder te harmoniseren door de lidstaten minder mogelijkheden te geven om af te wijken van de BTW-richtlijn. Daarbij is in het bijzonder een wijziging van de regels met betrekking tot het elektronisch factureren van belang. De wijziging is erop gericht de administratieve lasten te verlichten door de regels voor de inhoud, uitgifte en bewaring van de facturen te vereenvoudigen.

\footnotetext{
1. Voor de verplichtingen van bepaalde invoer- en uitvoerhandelingen zie de artikelen $274 \mathrm{t} / \mathrm{m} \mathrm{280}$, BTW-richtlijn.

2. Gedoeld wordt op artikel 28 nonies, Zesde richtlijn, dat artikel 22 van dezelfde richtlijn heeft gewijzigd. In het vervolg van mijn onderzoek zal ik het desbetreffende artikel aanduiden als artikel 22, Zesde richtlijn.

3. Wel is het zo dat de huidige BTW-richtlijn diverse artikelen bevat over elektronisch factureren. Een fenomeen dat in de begintijd van de BTW niet aan de orde was.

4. Bij Richtlijn 2010/45 EU van 13 juli 2010, Pb EU 2010 L 189 is de BTW-richtlijn gewijzigd. De lidstaten moeten uiterlijk 31 december 2012 hun wettelijke bepalingen hebben aangepast. De wettelijke bepalingen dienen op 1 januari 2013 in te gaan.
} 
De BTW-richtlijn beoogt de verplichtingen te harmoniseren. De considerans vermeldt:

"De verplichtingen van de belastingplichtigen moeten zoveel mogelijk worden geharmoniseerd teneinde de nodige waarborgen te verkrijgen met betrekking tot de gelijkheid van de belastingheffing in alle lidstaten." (r.o. 45)

De verplichtingen moeten dus zo veel als mogelijk worden geharmoniseerd om een gelijke belastingheffing te bereiken. ${ }^{5}$ De Considerans laat de harmonisatie voor wat het is bij afwijkende maatregelen voor bepaalde doeleinden:

"De lidstaten moeten, met inachtneming van bepaalde beperkingen en voorwaarden, bijzondere van deze richtlijn afwijkende maatregelen kunnen treffen of handhaven, teneinde de belastingheffing te vereenvoudigen of bepaalde vormen van belastingfraude of belastingontwijking te voorkomen." (r.o. 59)

Te oordelen naar de tekst, zie hierna, hebben de lidstaten een zekere vrijheid bij het opleggen van verplichtingen aan belastingplichtigen. Zoals in het vervolg van deze paragraaf zal blijken speelt deze bewegingsvrijheid een rol in de jurisprudentie van het Hof. ${ }^{6}$ Behalve dat de harmonisatie door de lidstatelijke bevoegdheid tot afwijkingen wordt doorkruist, heeft zij ook te lijden van zogenoemde 'kan-bepalingen' in dit veld. Telkens wanneer daarvan sprake is, luidt de aanvangszin van de bepaling: 'De lidstaten kunnen ...(...)....7 De lidstaten zijn dan niet verplicht om het betreffende onderdeel in hun nationale regelgeving in te voeren. Het facultatieve karakter van bepaalde onderdelen van de verplichtingen wordt nog eens versterkt door artikel 272, BTW-richtlijn (voorheen artikel 22, lid 9, Zesde richtlijn). In dit artikel is namelijk bepaald dat de lidstaten bepaalde belastingplichtigen kunnen ontheffen van de verplichtingen.

Duidelijk is dus dat de lidstaten een zekere vrijheid hebben bij het implementeren van verscheidene onderdelen van de administratieve verplichtingen. Daar staat echter tegenover dat bepaalde onderdelen van de BTW-richtlijn beginnen met: 'De lidstaten treffen de mogelijke maatregelen om te verzekeren dat ...(...).' Deze onderdelen hebben dus een dwingend karakter, zijn imperatief van aard.

Ten slotte hebben de lidstaten de mogelijkheid om verdergaande eisen aan belastingplichtigen te stellen dan de richtlijn doet. Artikel 273, BTW-richtlijn, onder

5. In praktisch identieke zin overweging 14 van de considerans van de Zesde richtlijn. Deze overweging verwijst ook naar de noodzaak om de verplichtingen te harmoniseren gezien de controle op de grondslag van de eigen middelen. Dit aspect is weggelaten in de considerans van de BTW-richtlijn.

6. Deze overweging is ook te vinden in de Zesde richtlijn (overweging 17) en speelt dan ook een rol in de jurisprudentie van het Hof waar de corresponderende bepalingen in de Zesde richtlijn worden uitgelegd.

7. Zie in dit kader, zonder uitputtend te zijn, artikel 22, lid 6, Zesde richtlijn wat betreft de verplichting tot het indienen van een jaaraangifte.

8. Zie in dit kader onder meer artikel 214, BTW-richtlijn (voorheen artikel 22, lid 1, sub c, Zesde richtlijn) waarin is bepaald dat de lidstaten de noodzakelijke maatregelen dienen te treffen voor de identificatie onder een individueel nummer van bepaalde belastingplichtigen. 
meer (voorheen artikel 22, lid 8, Zesde richtlijn), bepaalt dat de lidstaten onder voorbehoud van gelijke behandeling andere verplichtingen kunnen voorschrijven die zij noodzakelijk achten. Deze maatregelen moeten dan dienen ter waarborging van de juiste heffing van de BTW en ter voorkoming van fraude. Daarbij gelden de voorwaarden dat deze verplichtingen in het handelsverkeer tussen de lidstaten geen aanleiding mogen geven tot formaliteiten bij grensoverschrijding en zij niet mogen worden benut voor het opleggen van extra factureringsverplichtingen.

Het Eerste verslag van de Commissie aan de Raad over de werking van het gemeenschappelijk BTW-stelsel brengt naar voren over de bevoegdheid tot verdergaande verplichtingen dat artikel 22, lid 8, Zesde richtlijn (thans artikel 273, BTW-richtlijn) moet worden gezien in de stand van het harmonisatieproces. ${ }^{9}$ Hoofdstuk VI van het verslag schrijft over deze bepaling (thans 273, BTW-richtlijn):

"In de Zesde richtlijn komt belastingontduiking en -ontwijking slechts ter sprake om de bijzondere maatregelen die de Lid-Staten op nationaal vlak hebben getroffen, te rechtvaardigen: het gaat hierbij hetzij om maatregelen die door de richtlijn bewust buiten het harmonisatieproces werden gelaten, hetzij om maatregelen die daar wel betrekking op hebben maar van de een of andere bepaling van de richtlijn afwijken. Onder de eerste categorie vallen de maatregelen betreffende de toepassingsvoorwaarden van de vrijstellingen van de artikelen 13, 14 en 15, alsmede de in het kader van artikel 22, lid 8, getroffen maatregelen betreffende de verplichtingen van de belastingplichtigen. Onder de tweede categorie vallen de op grond van artikel 27 getroffen vereenvoudigingsmaatregelen. Hieruit kan slechts één conclusie worden getrokken, namelijk dat de bestrijding van belastingontduiking en -ontwijking in de eerste plaats tot de taak van de nationale autoriteiten wordt gerekend."

De Commissie geeft in haar verslag dus aan dat volgens haar, maatregelen die onder het bereik van artikel 22, lid 8, Zesde richtlijn (huidig artikel 273, BTW-richtlijn) vallen, bewust buiten het harmonisatie proces zijn gelaten. ${ }^{10}$ De lidstaten hebben dus kennelijk een ruime bevoegdheid om hun nationale regelgeving op dit terrein aan te vullen. ${ }^{11}$

Uit het bovenstaande kan samenvattend worden gesteld, dat bepaalde onderdelen van de BTW-richtlijn verplicht zijn om te implementeren, andere onderdelen zijn

9. Eerste verslag van de Commissie aan de Raad over de werking van het gemeenschappelijk stelsel van belasting over de toegevoegde waarde, ingediend op grond van artikel 34, Zesde richtlijn (77/388/EEG) van 17 mei 1977, Com(83) 426 def., 14 september 1983.

10. Overigens is duidelijk dat de Commissie na het verschijnen van de Zesde richtlijn wel degelijk op communautair vlak een rol ziet in de fraude bestrijding. Zie in dit kader de diverse initiatieven op het terrein van de bestrijding van de carrouselfraude, Com (2007) 758 def. en Com (2008) 147 def. Verder is van belang in het kader van de administratieve verplichtingen dat de Commissie in een later stadium is gekomen met de zogenoemde factureringsrichtlijn. Deze richtlijn heeft als doel de factuurvereisten te harmoniseren en heeft geleid tot aanpassing van de Zesde richtlijn. Zie richtlijn 2001/115/EG van 20 december 2001, Pb 2002 L 15/24. Zie ook A. van Dongen, De harmonisatie van de BTW, Amersfoort: Sdu Uitgevers 2007, blz. 117 en blz. 301 t/m 303. Zie ook E.C.M. van der Hel - van Dijk, Aanpassing verordening (EG) nr. 1798/2003: efficiënte bestrijding BTW-fraude?, WFR 2010/525.

11. Zie in dit kader het slot van paragraaf 12.4.1.3 waar ik aandacht besteed aan het Jeunehommearrest. 
facultatief, sommige onderdelen mogen worden versoepeld en de regelgeving bevat ook de mogelijkheid om verdergaande verplichtingen dan genoemd in de BTWrichtlijn te introduceren. Te verwachten is dat de algemene rechtsbeginselen zich in een dergelijke omgeving thuis voelen. De mogelijkheid om op grond van de letterlijke tekst van de BTW-richtlijn verdergaande verplichtingen op te leggen kan worden begrensd door het overige Unierecht en dan meer in het bijzonder de algemene rechtsbeginselen. Wij komen deze dan ook hierna in de rechtspraak van het Hof op het terrein van de artikelen 193 t/m 273, BTW-richtlijn tegen.

Paragraaf 12.2 besteedt aandacht aan de verschuldigdheid van BTW en in paragraaf 12.3 gaat het in het bijzonder over het bewijs dat noodzakelijk is om in aanmerking te komen voor het recht op aftrek van voorbelasting, zoals het factuurvereiste. Het hoofdstuk sluit af met een conclusie.

\subsection{Verschuldigdheid van BTW}

\subsubsection{Creditfacturen (Langhorst-arrest)}

In het handelsverkeer komt het geregeld voor dat afnemers van prestaties facturen opmaken in plaats van de leveranciers (zogenoemde creditfacturen dan wel selfbilling), hetgeen in kan houden dat misslagen op die facturen repercussies kunnen hebben voor de leveranciers. Beïnvloeden die misslagen de fiscale positie van de leverancier? In het Langhorst-arrest ${ }^{12}$ is van zo'n situatie sprake. In deze procedure had de Duitse landbouwer Langhorst geopteerd voor een heffing van $7 \%$ in plaats van 13\%. Zijn afnemer maakte altijd de facturen op voor een tarief van 13\%. De afnemer bleef $13 \%$ op de creditfacturen vermelden. Langhorst makte geen bezwaar tegen de onjuiste vermelding van het tarief op de facturen maar meende wel slechts 7\% BTW verschuldigd te zijn.

De Duitse rechter stelde onder meer de prejudiciële vraag of ingevolge artikel 21, lid 1, sub c, Zesde richtlijn (huidig artikel 203, BTW-richtlijn) door de ontvanger van de goederen of diensten uitgereikte creditnota door de lidstaten kan worden geacht dienst te doen als factuur.

Volgens artikel 22, lid 3, sub a, Zesde richtlijn (huidig artikel 220, BTW-richtlijn) is iedere belastingplichtige verplicht een factuur uit te reiken voor goederenleveringen of diensten die hij verricht aan een andere belastingplichtige of een niet-belastingplichtige rechtspersoon. Het Hof overweegt dat in het toen van kracht zijnde artikel 22, lid 3, sub b, Zesde richtlijn (huidig artikel 226, BTW-richtlijn) de minimumvoorwaarden zijn vastgesteld die verplicht op de factuur moeten worden vermeld, namelijk: de prijs exclusief belasting, de belasting volgens elk afzonderlijk 
tarief, alsook in voorkomend geval, de vrijstelling. ${ }^{13}$ Na de opsomming van deze drie punten geeft sub c, van lid 3 vervolgens aan de lidstaten de vrijheid om zelf criteria vast te stellen om het document als factuur te kunnen laten functioneren. Volgens het arrest moeten de lidstaten bij die bevoegdheid wel rekening houden met één van de doelstellingen die de BTW-richtlijn nastreeft en dat is de inning van BTW en de controle daarop. ${ }^{14}$ Deze doelstelling komt terug in rechtsoverweging 20 van het arrest. Het Hof onderzoekt namelijk of de Duitse regeling voldoet aan die doelstelling van inning en controle. Het Hof overweegt over de uitleg van artikel 22, lid 3, sub a, Zesde richtlijn:

“Aangezien deze bepaling, (...), de juiste inning van de belasting dient te waarborgen en fraude moet voorkomen, staat evenwel niets eraan in de weg, dat de betrokken document door de ontvanger van de goederen of de diensten wordt opgesteld, mits het de voor de factuur voorgeschreven vermeldingen bevat en de belastingplichtige die de goederen levert of de diensten verricht, in voorkomend geval, de gelegenheid heeft gehad om te verzoeken dat de inhoud wordt gecorrigeerd."

Door het vereiste dat de prestatieverrichter de gelegenheid moet hebben gehad de factuur te kunnen corrigeren knoopt het Hof aan bij het civielrechtelijke element van de factuur. Als een partij de factuur opmaakt en een ander deze accordeert, dan bevestigt dit de rechtsrelatie: wat partijen over en weer van elkaar weten en te verwachten hebben in financiële zin.

Het Hof onderbouwt de beslissing verder door erop te wijzen dat de afnemer in veel gevallen het beste in staat is om de juistheid van de creditfactuur na te gaan en dat een dergelijke creditfactuur dezelfde inlichtingen bevat als de gebruikelijke factuur (rechtsoverwegingen 21 en 22). Ook bij de normale gang van zaken, dat de uitreiking van een factuur door de verrichter van de prestatie plaatsvindt, is er een mogelijkheid van instemming met de factuur van de ander en keurt de ontvanger deze goed door betaling van de vergoeding. Vandaar dat het Hof dit element ook laat terugkomen bij de creditfactuur. Het is logisch om de verrichter van de prestatie ook de mogelijkheid te geven de inhoud van deze creditfactuur goed te keuren.

Het Hof besliste vervolgens dat een door een afnemer opgemaakte factuur kan worden aangemerkt als een 'factuur' in de zin van de BTW-richtlijn, wanneer aan de volgende drie voorwaarden is voldaan:

1. deze nota bevat de vermeldingen die in de BTW-richtlijn zijn voorgeschreven voor facturen; en

13. De Langhorst-procedure heeft betrekking op een andere tekst van artikel 22, Zesde richtlijn. De richtlijn 2001/115/EG van 20 december 2001, zogenoemde factureringsrichtlijn (Pb EG 2002 L 15/24). Dat neemt niet weg dat de uitgangspunten die de Langhorst-procedure blootlegt nog steeds relevant zijn.

14. Zie in dit kader ook de arresten van het Hof 14 juli 1998, nrs. 123/87 en 330/87, Jeunehomme en EGI, Jur. 1988, blz. 4517, r.o. 16 en 17 en het arrest van 5 december 1996, nr. C-85/95, Reisdorf, Jur. 1996, blz. I-6257, r.o. 24. Zie verder ook de zeventiende Considerans van de Zesde richtlijn. 
2. de creditfactuur wordt opgesteld met instemming van de belastingplichtige die de goederen levert of de diensten verricht, hetgeen impliceert dat

3. de belastingplichtige die de prestatie verricht bezwaar kan maken tegen het op de creditfactuur vermelde BTW-bedrag bij de opsteller van de factuur/de afnemer. ${ }^{15}$

Het Hof geeft ook aan, dat de belastingplichtige die geen bezwaar heeft gemaakt tegen het feit dat op de factuur dienst doende creditnota een BTW-bedrag is vermeld dat hoger is dan het bedrag dat over de belastbare omzet verschuldigd is, kan worden beschouwd als degene die dit bedrag heeft vermeld en derhalve het aangegeven bedrag verschuldigd is in de zin van artikel 21, lid 1, sub c, Zesde richtlijn (thans artikel 203, BTW-richtlijn). ${ }^{16}$

"Anders zou namelijk een deel van de BTW die voorkomt op het als factuur dienst doende document, niet door de belastingplichtige behoeven te worden betaald, zelfs indien deze BTW door de ontvanger van de goederen of diensten (...) volledig had kunnen worden afgetrokken, wat een eventuele fraude of collusie, die in strijd zijn met de goede werking van het bij de Zesde richtlijn ingevoerde gemeenschappelijke BTW-stelsel en met het daarbij nagestreefde doel de inning van de BTW en de controle daarvan door de belastingadministratie te verzekeren, in de hand zou werken." (r.o. 28)

In deze overweging komt de doelstelling van de regels omtrent de factuurvereiste duidelijk naar voren, namelijk het voorkomen van fraude door de controle te verzekeren. Het Hof neemt ook het middel, namelijk verschuldigdheid in geval van uitreiking creditfactuur, mee in de beschouwing en komt tot een afweging tussen het doel van de regels en de wijze waarop dit is uitgewerkt in de bepaling. Verder gaat het Hof ook na of de maatregel noodzakelijk is om het doel te bereiken. Het Hof overweegt dat als een hoger BTW bedrag wordt vermeld op de creditfactuur dan datgene dat volgens de regelgeving verschuldigd is, deze toch op aangifte moet worden voldaan omdat anders een deel van de BTW die voorkomt op de factuur niet door de belastingplichtige behoeft te worden betaald. In paragraaf 3.4.2.2 is naar

15. Zie ook de redactie van V-N, die van mening is dat de essentiële elementen uit het Langhorst-arrest zijn de verplichte vermeldingen uit de BTW-richtlijn en het bezwaar kunnen maken tegen het op de creditfactuur vermelde bedrag. De redactie van $\mathrm{V}-\mathrm{N}$ is van mening dat het Hof in het Langhorst-arrest niet een voor alle gevallen geldende uitleg van de BTW-richtlijn geeft in geval van uitreiking van credit-facturen. Indien een andere nationale regeling aan het Hof wordt voorgelegd zal deze opnieuw bezien en beoordeeld worden. In het Langhorst-arrest betreft het specifieke uitgangspunten die in het Duitse systeem zijn te vinden.

16. Bij de introductie van de BTW was in Nederland al een regeling gegeven voor de gevallen waarin het gebruikelijk was dat de afnemer de factuur opmaakt, zoals bij veilingen (Bijlage I bij het Besluit van 29 oktober 1968, nr. 120 (OB-BTW-14)). Naar aanleiding van het Langhorst-arrest is een algemene regeling gegeven waarin ondermeer is aangegeven, dat de afnemer in de gelegenheid wordt gesteld bezwaar te maken tegen de op de creditnota vermelde gegevens (zoals het omzetbelasting bedrag). Ingeval bezwaar wordt gemaakt, verliest de creditnota haar werking als factuur en dient de ondernemer die de prestatie verricht alsnog zelf een factuur uit te reiken (Besluit van 12 februari 2009, nr. CPP2009/263M, paragraaf 3.2.3, V-N 2009/11.21). De strekking van het nieuwe Besluit lijkt mij in overeenstemming met het Langhorst-arrest en de toetsing aan de algemene rechtsbeginselen te kunnen doorstaan. Of zoals de redactie van V-N het uitdrukt: "Door gebruik te maken van de criteria uit de Duitse zaak wordt een 'EG-proof' situatie bereikt.” 
voren gebracht dat als het Hof het evenredigheidsbeginsel in stelling brengt, regelmatig de noodzakelijkheid van de maatregel wordt onderzocht. Het Hof gebruikt in het arrest Langhorst niet expliciet de term evenredigheidsbeginsel, echter neemt wel mee in de overwegingen een doel-middelafweging en de noodzakelijkheid van de maatregel.

\subsubsection{Correctie van de verschuldigdheid (Schmeink E' Strobel, Stadeco)}

Artikel 203, BTW-richtlijn luidt als volgt:

"De BTW is verschuldigd door eenieder die deze belasting op een factuur vermeldt."

Deze bepaling vervangt artikel 21, lid 1, sub c, Zesde richtlijn (tekst 1996). ${ }^{17}$ Het gebruik van de term 'ieder' doet vermoeden dat ook niet belastingplichtigen BTW verschuldigd kunnen zijn. Het Hof heeft in het arrest Maria Karageorgou ${ }^{18}$ bepaald dat, in de omstandigheden van het geval, vermelding van BTW op een factuur geen 'BTW' is. Het betrof een vertaalster die in een relatie van ondergeschiktheid stond met het Griekse Ministerie van Buitenlandse Zaken waarvoor zij vertaalwerk verrichtte. Zij was voor de BTW niet belastingplichtig, maar had toch een factuur uitgeschreven met vermelding van BTW. Het Hof besliste dat wanneer deze vertalers bij vergissing een BTW-bedrag vermelden op facturen voor dergelijke diensten, dan kan dat bedrag niet als BTW worden aangemerkt (r.o. 41). ${ }^{19}$ Men kan dus de conclusie trekken dat, als een particulier een 'factuur' uitreikt met de vermelding van een bedrag aan 'BTW' dit niet onder het bereik van artikel 203, BTW-richtlijn valt. ${ }^{20}$

17. Artikel 21, lid 1, letter c, Zesde richtlijn luidt voor zover van belang: "In het binnenlands verkeer is de belasting over de toegevoegde waarde verschuldigd:

(...)

c. Door eenieder die de belasting over de toegevoegde waarde vermeldt op een factuur of een als zodanig dienstdoend document."

De tekst in de Zesde richtlijn is een aantal keren gewijzigd en ook de hier geciteerde versie wijkt iets af van het huidige artikel 203, BTW-richtlijn. Opvallend is dat het zinsdeel 'in het binnenlands verkeer' niet is terug te vinden in het huidig artikel 203, BTW-richtlijn. Zie hierover A-G De Wit in zijn conclusie bij HR 30 november 2007, nr. 41.179, BNB 2008/131, V-N 2007/48.17. Artikel 203, BTW-richtlijn is geïmplementeerd in artikel 37 Wet $\mathrm{OB}$.

18. Hof 6 november 2003, nrs. C-78/02 t/m C-80/02, Karageorgou e.a., V-N 2003/58.17, FED 2004/134. 19. Zie tevens HR van 14 december 2007 (nr. 37.748, BNB 2008/123, V-N 2007/59.17). In deze procedure vermelde belanghebbende een bedrag aan BTW op de facturen ter zake van de bemiddeling bij kinderopvang, terwijl deze diensten vallen onder de vrijstelling van 132, lid 1, sub g, BTW-richtlijn. De HR overweegt in r.o. 3.2.5: “(...) dat indien op een aan een particulier-eindverbruiker uitgereikte factuur 'omzetbelasting' of 'BTW' wordt vermeld, dit een vermelding is die plaatsvindt buiten het systeem van de omzetbelasting, waaraan met oog op de heffing geen zelfstandige betekenis kan worden toegekend. Die vermelding kan daarom niet het gevolg oproepen dat artikel 37 van de Wet verbindt aan het vermelden van omzetbelasting op een factuur". Uit deze rechtsoverweging blijkt dat de HR het ook relevant vindt dat de factuur is uitgereikt aan een particulier-eindverbruiker. Zie verder HR van 14 november 2008, nr. 42.312, V-N 2008/55.22.

20. Zie voor een kritische beschouwing over deze problematiek J.J.M. Lamers, Verschuldigdheid van BTW, NTFR-B 2008/22. Zie tevens J.J.P. Swinkels in zijn noot bij het arrest van de HR van 14 december 2007, BNB 2008/123. 
Indien echter een belastingplichtige een BTW-bedrag vermeldt op een factuur, dan is de enkele vermelding van de BTW in principe genoeg om de belasting verschuldigd te doen zijn. In de Engelse literatuur wordt artikel 21, lid 1, letter c, Zesde richtlijn (thans artikel 203, BTW-richtlijn) dan ook aangeduid als een catch-all provision. ${ }^{21}$ De bepaling is zo ruim geformuleerd dat zij ook kan raken regulier opererende ondernemers, die een vergissing maken en het vaak in hun macht hebben hun vergissing - al dan niet met behulp van hun afnemer - te herstellen. Moet ongelimiteerde toepassing van de catch-all plaatsvinden; hoe dan ook? De vraag is vooral relevant in kwesties waarin de afnemer van de foutenmaker een aftrekgerechtigde ondernemer is. ${ }^{22}$ Dit houdt in dat de vraag rijst, of er niet nog een correctiemogelijkheid tegen de ieder rakende bepaling is op te werpen? En nu deze mogelijkheid niet in de tekst voorhanden zijnde, hier niet ook algemene rechtsbeginselen de helpende hand zouden kunnen bieden? Een situatie als deze vinden wij in het arrest Schmeink \& Strobel. ${ }^{23}$ Hieraan besteed ik aandacht gezien het feit dat de problematiek van artikel 203, BTW-richtlijn nauw verweven is met de factureringsverplichtingen zoals deze zijn neergelegd in de artikelen $217 \mathrm{t} / \mathrm{m} \mathrm{240,}$ BTW-richtlijn (voorheen artikel 22, Zesde richtlijn).

Het Schmeink en Strobel-arrest bestaat uit twee zaken. Deze twee zaken zijn door de Duitse rechter gevoegd en vervolgens werden er een aantal prejudiciële vragen gesteld over de uitleg van het artikel 203, BTW-richtlijn (voorheen artikel 21, lid 1, letter c, Zesde richtlijn) De Duitse rechter wilde onder meer weten of het bereik van de catch-all bepaling zich ook uitstrekt tot gevallen waarin de opsteller van de factuur te goeder trouw is. Voorts wilde hij weten of in dat geval herziening van de in rekening gebrachte BTW mogelijk is en de verschuldigdheid van de ten onrechte gefactureerde BTW zich derhalve niet voordoet.

Het Hof antwoordt:

“(...), dat de Zesde richtlijn geen enkele bepaling bevat over de herziening van ten onrechte gefactureerde BTW door de opsteller van de factuur. In artikel 20 van de Zesde richtlijn wordt alleen bepaald, onder welke voorwaarden de aftrek van de voorbelasting kan worden herzien bij degenen aan wie de goederen zijn geleverd of voor wie de diensten zijn verricht." (r.o. 48)

Het Hof geeft met zo veel woorden dus aan dat het antwoord op grond van de letterlijke tekst van de BTW-richtlijn duidelijk is. Namelijk in beginsel een onbeperkte werking van de catch-all bepaling. ${ }^{24}$ Toch blijkt uit het vervolg dat de algemene rechtsbeginselen de werking intomen. Het loslaten van de letterlijke tekst en vervolgens algemene rechtsbeginselen een rol toe te kennen heeft tot gevolg dat

21. P. Farmer \& R. Lyal, EC Tax Law, Oxford: Claradon Press 1994, onder meer blz. 206.

22. Paragraaf 12.4.1.2 behandelt het recht op aftrek in geval van BTW die ten onrechte op een factuur is vermeld.

23. Hof 19 september 2000, nr. C-454/98, Schmeink \& Cofreth \& Co KG en M. Strobel, BNB 2000/167, V-N 2000/47.16.

24. Zie ook Hof 6 november 2003, nrs. C-78/02 t/m C-80/02, Karageorgou e.a., V-N 2003/58.17, FED 2004/134, r.o. 49. 
de uitleg van de catch-all bepaling redelijker wordt, maar tevens dat voor de praktijk een grotere onzekerheid ontstaat over de precieze werking van de bepaling.

Het Hof overweegt dat Schmeink en Strobel het gevaar voor verlies van belastinginkomsten tijdig en volledig hadden uitgeschakeld doordat de opsteller van de factuur deze opnieuw in handen kreeg en vernietigde vóór de ontvanger haar had gebruikt, of doordat de opsteller van de factuur, die was gebruikt, het op de factuur afzonderlijk vermelde bedrag heeft voldaan.

Het Hof is van mening, dat indien de opsteller van de factuur het gevaar voor verlies van belastinginkomsten tijdig en volledig heeft uitgeschakeld, het beginsel van de neutraliteit van de BTW (in de betekenis van het bevrijden van de economische activiteiten van de voordruk, zie hieronder) verlangt, dat de ten onrechte gefactureerde BTW kan worden herzien zonder dat de lidstaten deze herziening afhankelijk mogen stellen van de goede trouw van de opsteller van de factuur. ${ }^{25}$ Het Hof hamert er nog eens op:

“(...), dat de maatregelen die de lidstaten krachtens artikel 22, lid 8, van de Zesde richtlijn ter waarborging van de juiste heffing van de belasting en ter voorkoming van fraude kunnen nemen, niet verder mogen gaan dan ter bereiking van die doelstelling noodzakelijk is (...). Zij mogen dus niet op zodanige wijze worden aangewend, dat zij afbreuk doen aan de neutraliteit van de BTW, een basisbeginsel van het bij de desbetreffende gemeenschapsregeling ingevoerde gemeenschappelijke BTW-stelsel." (r.o. 59)

Indien vervolgens vaststaat dat de opsteller van de factuur maatregelen heeft genomen die het gevaar voor het weglekken van de belastingopbrengst tijdig en volledig uitschakelen, het niet meer noodzakelijk is dat hij zijn goede trouw aantoont. Het Hof volgt dus de gebruikelijke afweging tussen doel en middel. Het doel is al bereikt, namelijk het voorkomen van het gevaar van verloren gaan van belastingopbrengst. Waarom dan nog een middel gebruiken dat de neutraliteit verstoort? Een logische benadering lijkt mij, op één aspect na. Een belastingplichtige die maatregelen neemt welke ertoe leiden dat de door hem onjuist met BTW opgestelde factuur, niet tot aftrek van voorbelasting bij de afnemer komt, toont toch ook zijn goede trouw aan? Oftewel, het nemen van maatregelen dat geen BTW weglekt ondersteunt toch het feit dat belanghebbende uit goede trouw handelt? ${ }^{26}$ In ieder geval is duidelijk dat het nemen van dergelijke maatregelen door een belanghebbende de werking van de catch-all bepaling beperkt.

Het voorgaande houdt in dat als verlies van belastinginkomsten niet volledig is uitgeschakeld de lidstaten wel degelijk de eis kunnen stellen dat de opsteller van de factuur zijn goede trouw aantoont. Zie dan ook:

25. In identieke zin het eerder aangehaalde Karageorgou-arrest in r.o. 50.

26. In de jurisprudentie van het Hof komen regelmatig termen voor als 'fraude' en 'goede trouw'. Denkbaar is dat in de diverse lidstaten deze begrippen verschillend worden ingevuld. Mogelijk dat in bepaalde lidstaten sneller sprake is van de kwalificatie 'fraude' dan in Nederland. 
“(...) Indien blijkt dat een aan de ontvanger van de factuur verleende aftrek niet meer ongedaan kan worden gemaakt, kan de opsteller van de factuur die niet te goede trouw is, immers om de belastingneutraliteit te garanderen aansprakelijk worden gesteld voor het tekort aan belastinginkomsten, (...)." (r.o. 61)

Het Hof gebruikt op deze plaats het argument van de belastingneutraliteit om te ondersteunen dat de catch-all bepaling in een dergelijk geval moet werken. Het arrest heeft betrekking op twee in de bedrijfskolom opvolgende partijen en dus gaat het hier niet over de neutraliteit in de zin van hetgeen in paragraaf 4.4.4 wordt aangeduid als 'uitdrukking van het gelijkheidsbeginsel voor de BTW', maar in de betekenis van het bevrijden van economische activiteiten van voordruk (stelselbeginsel). Dit blijkt ook met zo veel woorden uit de eerder aangehaalde rechtsoverweging 59 waar het Hof spreekt van de neutraliteit als basisbeginsel van het BTWstelsel.

De Hoge Raad heeft op 30 november 2007 prejudiciële vragen gesteld in de zaak Stadeco BV over artikel 203, BTW-richtlijn. ${ }^{27}$ De Hoge Raad vraagt onder andere of in een situatie waarin een factuur is uitgereikt als bedoeld in artikel 203, BTW-richtlijn aan een ontvanger die geen recht op aftrek van BTW heeft (waardoor geen gevaar van verlies aan belastinginkomsten bestaat), de lidstaten aan herziening van de bij vergissing gefactureerde en mitsdien ingevolge artikel 203, BTW-richtlijn verschuldigde BTW de voorwaarden mogen verbinden dat de belastingplichtige aan zijn afnemer alsnog een herstelfactuur uitreikt waarop geen BTW-bedrag is vermeld. Het Nederlandse Besluit Administratieve en factureringsverplichtingen van 12 februari 2009 stelt deze eis nadrukkelijk wel. ${ }^{28}$ Tevens stelt het Besluit de eis dat terugbetaling aan de afnemer van de gefactureerde omzetbelasting plaats moet vinden. ${ }^{29}$

Op 12 maart 2009 is de conclusie van advocaat-generaal Kokott verschenen waarin zij aangeeft dat het Unierecht de lidstaten niet verbiedt om herziening van de bij vergissing in rekening gebrachte (en dus overeenkomstig artikel 203, BTW-richtlijn

27. HR 30 november 2007, BNB 2008/131, V-N 2007/57.18).

28. Paragraaf 3.6.1 van het Besluit van 12 februari 2009, nr. CPP2009/263M, V-N 2009/11.21.

29. Deze eis raakt het beginsel van de ongerechtvaardigde verrijking zoals dat in diverse arresten is te vinden. Zie Hof 9 november 1983, nr. 199/82, Spa San Giorgio, Jur. 1983, blz. 3595; Hof 24 maart 1988, nr. 104/86, Commissie/Italië, Jur. 1988, blz. 1799; Hof 9 december 2003, nr. C-129/00, Commissie/Italië, Jur. 2003, blz. I-4637 en meer recent Hof 10 april 2008, nr. C-309/06, Marks \& Spencer, V-N 2008/21.22. In het Marks \& Spencer-arrest is aan de orde een situatie dat de Engelse Belastingdienst vaststelt een vergissing te hebben begaan nu een bepaald product in aanmerking had moeten komen voor het zogenoemde nultarief. Het Hof geeft aan dat het Unierecht zich er niet tegen verzet dat onder een nationaal rechtstelsel de teruggaaf van de ten onrechte geheven belasting wordt geweigerd in omstandigheden waarin dit uitloopt op een ongerechtvaardigde verrijking. Dit gezien het feit dat de BTW is afgewenteld in de prijzen op de afnemers. Het Hof stelt wel voorwaarden, namelijk - gestileerd weergegeven - dat het niet afgewentelde bedrag wordt terugbetaald (vastgesteld na een economische analyse); gelijke behandeling van belastingplichtigen die soortgelijke goederen verkopen; gelijke behandeling van belastingplichtigen ongeacht of zij concurrenten van elkaar zijn als zij zich in een vergelijkbare situatie bevinden. 
verschuldigde belasting) afhankelijk te maken van de voorwaarde dat de belastingplichtige alsnog een herstelfactuur uitreikt aan zijn afnemer. ${ }^{30}$ Dit geldt volgens haar tevens wanneer de ontvanger van de factuur geen recht op aftrek van voorbelasting heeft.

Het Stadeco-arrest ${ }^{31}$ leert dat de BTW-richtlijn geen uitdrukkelijke bepaling bevat voor het geval dat de BTW bij vergissing op een factuur is vermeld en niet op grond van een aan deze belasting onderworpen handeling verschuldigd is. Zolang de Uniewetgever deze lacune niet verhelpt, zijn de lidstaten vrij om de voorwaarden te stellen. Wel voegt het Hof daar ogenblikkelijk aan toe dat de voorwaarden die de lidstaten kunnen nemen ter waarborging van de juiste heffing van de belasting en ter voorkoming van fraude, niet verder mogen gaan dan ter bereiking van die doelstellingen noodzakelijk is. Zij mogen dus niet op zodanige wijze worden aangewend dat zij afbreuk doen aan de neutraliteit van de BTW, een basisbeginsel van het BTW-stelsel (r.o. 39). Vervolgens gaat het Hof na of de Nederlandse regeling niet verder gaat dan vereist is om het doel te bereiken. Bijzonder is dat de afnemer van Stadeco een publiekrechtelijk lichaam is zonder aftrekrecht. Dit staat de eis van een herstel factuur niet in de weg want het:

“(...), kan niet algemeen worden uitgesloten dat complexe omstandigheden en rechtsbetrekkingen eraan in de weg staan dat de belastingadministratie tijdig vaststelt dat andere overwegingen zich tegen de uitoefening van het recht op aftrek verzetten". (r.o. 46)

Het ontbreken van recht op aftrek bij de afnemer betekent dus niet dat automatisch het gevaar van het verlies aan belastinginkomsten is uitgeschakeld. De Belastingdienst kan namelijk te laat deze omstandigheid ontdekken. Ook de eis dat aan herziening van de BTW mede de voorwaarde is verbonden dat de opsteller van de factuur de ontvanger van de verrichte diensten de ten onrechte betaalde BTW vergoedt, is in overeenstemming met het Unierecht.

Allereerst constateert het Hof dat de BTW-richtlijn teruggave van ten onrechte in rekening gebrachte BTW niet regelt. Dat het op grond van de neutraliteit past dat de lidstaten zorgen voor een regeling. Daarbij zijn de lidstaten vrij in het stellen van de voorwaarden, maar deze voorwaarden moeten voldoen aan een doel - middel afweging. Ze mogen niet zo ver gaan dat de teruggave onmogelijk of uiterst moeilijk wordt. Tevens gaat het Hof na of de maatregel geschikt is. Dit blijkt uit de overwegingen waarin het Hof vermeldt dat ook al heeft de afnemer geen recht op aftrek, de eis van herstel facturen toch zinvol is. Kortom, het Hof loopt de aspecten van het evenredigheidsbeginsel langs.

30. De conclusie is opgenomen in V-N 2009/15.20.

31. Hof 18 juni 2009, nr. C-566/07, Stadeco BV, V-N 2009/31.14. 
Het Hof heeft in een aantal arresten ${ }^{32}$ verduidelijkt dat als een bepaald terrein niet is geregeld in de BTW-richtlijn, dat dan de lidstaten vrij zijn in de vormgeving en het stellen van voorwaarden. Uit de in paragraaf 4.5.2.5 behandelde jurisprudentie blijkt dat de lidstaten daarbij wel de algemene rechtsbeginselen in acht moeten nemen en niet in strijd mogen komen met het rechtskarakter van de BTW. Het Stadeco-arrest past in deze lijn, althans wat de toets aan het evenredigheidsbeginsel betreft.

\subsubsection{Overige verplichtingen (Eismann-arrest)}

Eismann verkocht levensmiddelen aan huis in Italië. Daarvoor schakelde hij verkopers in die met vrachtauto's, geladen met de voor de verkoop bestemde goederen, de huizen van potentiële particuliere kopers langsgingen. De Italiaanse Belastingdienst legde geldboetes op aan Eisman omdat hij de begeleidende documenten voor goederen die binnen Italiaans grondgebied zijn vervoerd, niet of verkeerd had opgesteld. Bijzonder is dat de Italiaanse regeling niet van toepassing was op grensoverschrijdend goederenvervoer. ${ }^{33}$

In het Eisman-arrest ${ }^{34}$ staat de uitleg van het in paragraaf 12.1 kort geduide artikel 22, lid 8, Zesde richtlijn (huidig artikel 273, BTW-richtlijn) centraal. ${ }^{35}$

“De Lid-Staten kunnen, onder voorbehoud van gelijke behandeling van de door belastingplichtigen verrichte binnenlandse handelingen en handelingen tussen de lidstaten, andere verplichtingen voorschrijven die zij noodzakelijk achten ter waarborging van de juiste heffing van de belasting en ter voorkoming van fraude mits deze verplichtingen in het handelsverkeer tussen de Lid-Staten geen aanleiding geven tot formaliteiten in verband met het overschrijden van een grens. (...)"

32. Zie Hof 3 maart 2004, nr. C-395/02, Transport Service NV, V-N 2004/18.18. Toegespitst op de voorwaarden van de inning, zie r.o. 27 e.v. Hof 14 september 2006, nr. C-72/05, Wollny, V-N 2006/ 50.13. In dit arrest geeft het Hof aan dat de maatstaf van privégebruik conform herzieningsregeling is toegestaan. Hof 13 maart 2008, nr. C-437/06, Securenta, V-N 2008/14.20. In deze procedure is onder meer beslist dat de verdeelsleutel voor niet aftrekbare voorbelasting bij niet economische activiteiten door de lidstaten mag worden bepaald. Toegespitst op de problematiek die aan de orde is in deze paragraaf formuleert het Hof het als volgt in het Reemtsma-arrest: "Voorst is het vaste rechtspraak dat bij het ontbreken van een gemeenschapsregeling ter zake, de procedurevoorschriften ter verzekering van de bescherming van de rechten welke de justitiabelen aan het gemeenschapsrecht ontlenen, op grond van het beginsel van procesautonomie van de lidstaten een aangelegenheid van de interne rechtsorde van elke lidstaat zijn (...)", Hof 15 maart 2007, Reemtsma Cigarettenfabriken GmbH, ne. C-35/05, V-N 2007/15.10, r.o. 40.

33. Zie in dit kader ook D.B. Bijl, M.E. van Hilten, D.G. van Vliet, Europese BTW en Nederlandse omzetbelasting, Deventer: Kluwer 2001, blz. 425. Deze schrijvers menen, dat ook van belang was in deze procedure dat de desbetreffende verplichting zowel voor binnenlandse als voor buitenlandse ondernemers gold. Zie in dit kader ook de in het Eisman-arrest aangehaalde Italiaanse circulaire.

34. Hof 24 oktober 1996, nr. C-217/94, Eismann Alto Adigo Srl, Jur. 1996, blz. I-5287.

35. Artikel 22, lid 8, Zesde richtlijn is praktisch identiek aan artikel 273, BTW-richtlijn. Wel vermeldt de BTW-richtlijn 'inning' in plaats van 'heffing'. Nationaal hebben deze termen een verschillende betekenis. In de BTW-richtlijn wordt echter geen andere betekenis beoogd. 
Zoals ook aan de orde zal komen in paragraaf 12.3.1.2 bij de behandeling van het Jeunehomme-arrest geeft deze bepaling de lidstaten een zekere vrijheid om, afgezien van de verplichtingen zoals deze zijn neergelegd in de BTW-richtlijn, extra verplichtingen op te leggen. ${ }^{36}$

Deze vrijheid is echter wel beperkt door de werking van het primaire Unierecht en dan in het bijzonder de bepalingen van het Werkingsverdrag en de algemene rechtsbeginselen. Uit de letterlijke tekst van de bepaling blijkt dat het gelijkheidsbeginsel zich laat gelden. Gelijke behandeling van de door belastingplichtigen verrichte binnenlandse handelingen en handelingen tussen de lidstaten dient gewaarborgd te zijn. Twee aspecten zijn in dit kader van belang. Het gaat om gelijke behandeling van gelijksoortige transacties en niet over gelijke behandeling van personen. Ten tweede kan men zich afvragen welke transacties gelijk behandeld dienen te worden. Transacties die enkel in het binnenland worden verricht? Of enkel de grens passeren? Of dienen transacties die in het binnenland worden verricht gelijk te worden behandeld met transacties die de grens passeren? Op deze laatste invulling van het gelijkheidsbeginsel spitste de prejudiciële vraag van de Italiaanse rechter zich toe. Daarbij speelde dat de overgangsregeling met het oog op de afschaffing van de fiscale grenzen mede een rol. $^{37}$ De Italiaanse rechter wenste te vernemen of het gelijkheidsbeginsel zoals dat onder meer is neergelegd in artikel 22, lid 8, Zesde richtlijn (huidig artikel 273, BTW-richtlijn), aldus moet worden uitgelegd, dat het zich verzet tegen een nationaal voorschrift op grond waarvan begeleidende documenten moeten worden opgesteld voor goederen die uitsluitend binnen de betrokken lidstaat worden vervoerd, wanneer een dergelijke verplichting niet bestaat voor het handelsverkeer tussen de lidstaten. Kortom, mag een lidstaat binnenlandse transacties omgeven met zwaardere administratieve eisen in vergelijking met intracommunautaire transacties?

Bij de beantwoording van de vraag overweegt het Hof dat bij de uitleg van een gemeenschapsrechtelijke bepaling niet alleen dient te worden gekeken naar de gebruikte bewoordingen, maar dat men ook te rade dient te gaan bij de context van de bepaling en de doelstellingen van de regeling waarin zij is neergelegd. ${ }^{38}$ Bij de vaststelling van de context en de doelstellingen van artikel 22, lid 8, Zesde richtlijn (huidig artikel 273, BTW-richtlijn) is van belang dat deze bepaling deel uitmaakt van Hoofdstuk XVI bis van de richtlijn, ingevoegd bij richtlijn 91/680/EEG. ${ }^{39}$ De bepaling

36. Zie ook Hof 15 januari 2009, nr. C-502/07, K-1, NTFR 2009/269. In deze procedure heeft het Hof beslist dat het beginsel van een gemeenschappelijk BTW-stelsel zich er niet tegen verzet dat de lidstaten maatregelen invoeren die voorzien in sancties voor onregelmatigheden bij de aangifte van het bedrag van de verschuldigde BTW. Integendeel, artikel 22, lid 8, Zesde richtlijn bepaalt dat de lidstaten andere verplichtingen kunnen voorschrijven die zij noodzakelijk achten ter waarborging van de juiste heffing van de belasting.

37. Richtlijn 91/680 (Pb 1991, L 376, p.1).

38. Zie in dit kader paragraaf 4.4.2.5.

39. Richtlijn 91/680/EEG van de Raad van 16 december 1991 tot aanvulling van het gemeenschappelijk stelsel van belasting over de toegevoegde waarde en tot wijziging, met het oog op de afschaffing van de fiscale grenzen, van Richtlijn 77/388/EEG. De richtlijn 91/680/EEG is gepubliceerd in Pb 2001 L 376, blz. 1. 
van dit hoofdstuk betreft de overgangsregeling voor de belastingheffing in het handelsverkeer tussen de lidstaten en beogen voornamelijk het handelsverkeer tussen de lidstaten te regelen en niet dat van het binnenland van één lidstaat. De richtlijn 91/680/EEG is in hoofdzaak gericht op de totstandkoming van de interne markt, de opheffing van de belastinggrenzen tussen de lidstaten en de afschaffing van de controles voor fiscale doeleinden aan de binnengrenzen voor elke handeling tussen de lidstaten. Het Hof overweegt vervolgens dat richtlijn 91/680/EEG niet tot doel heeft, de formaliteiten in verband met zuiver binnenlandse handelingen te harmoniseren of te vereenvoudigen.

“(...), dat de communautaire wetgever tot op heden de volledige en uitputtende harmonisatie van de formaliteiten die de lidstaten voor binnenlandse handelingen kunnen opleggen teneinde de juiste heffing van BTW te waarborgen en fraude te voorkomen, niet heeft verwezenlijkt". (r.o. 19)

En vervolgt over artikel 22, lid 8, Zesde richtlijn (huidig artikel 273, BTW-richtlijn).

“(...) Dit artikel verzet zich er bijgevolg niet tegen, dat een lidstaat voor binnenlandse handelingen in die staat zwaardere formaliteiten oplegt dan voor het intracommunautaire handelsverkeer." (r.o. 20)

Het Hof verwees vervolgens naar Peurex-arrest ${ }^{40}$ waarin is beslist dat het Werkingsverdrag een lidstaat niet het recht ontzegt, nationale producten zwaarder te belasten dan ingevoerde producten, en dat dergelijke ongelijkheden het gevolg zijn van nietgeharmoniseerde wetgevingen op gebieden die onder de bevoegdheid van de lidstaten vallen. Het Hof besliste dan ook dat het Unierecht zich er niet tegen verzet indien een lidstaat op grond van artikel 22, lid 8, Zesde richtlijn (huidig artikel 273, BTW-richtlijn) vereist dat begeleidende documenten worden opgesteld voor goederen die uitsluitend binnen één lidstaat worden vervoerd.

\subsubsection{Tijdstip van verschuldigdheid}

Het Hof heeft in twee arresten het tijdstip van verschuldigdheid verduidelijkt. Het eerste arrest, de zaak Balocchi, ${ }^{41}$ gaat over de regeling op grond waarvan de lidstaten

40. Hof 13 maart 1979, nr. 86/78, Peureux, Jur. 1979, blz. 897. Het Hof geeft aan in r.o. 32: "In artikel 95 (huidig artikel 110 VwEU: toevoeging AHB) wordt weliswaar aan elke Lid-Staat het recht ontzegd, op producten van de overige Lid-Staten hogere belastingen te heffen dan op nationale producten, maar niet om nationale producten zwaarder te belasten dan ingevoerde producten. Dergelijke ongelijkheden vallen niet binnen de werkingssfeer van artikel 95, maar zijn het gevolg van de bijzonderheden van de niet-geharmoniseerde nationale wetgeving op gebieden die onder de bevoegdheid van de Lid-Staten vallen." Zie in dit kader ook A.W. van der Woude, Belastingen begrensd, Delft: Eburon 2000, blz. 124 waar een viertal gebieden worden beschreven waar geen sprake is van een door artikel 110 VwEU verboden discriminatie. Onder meer wordt behandeld de in deze subparagraaf door mij beschreven situatie dat nationale producten worden benadeeld ten opzichte van de producten uit andere lidstaten. 41. Hof 20 oktober 1993, nr. C-10/92, Balocchi, Jur. 1993, blz. I-5105. 
een vooruitbetaling op de verschuldigde belasting mogen invoeren ${ }^{42}$, mits, zo besliste het Hof, de nationale regeling bij de te schatten vooruitbetaling haar belastingplichtigen maar niet overvraagt, hetgeen het geval is als men geschatte vooruitbetalingen moet doen die de werkelijk verschuldigde belasting danig overtreffen. Een verdere onderbouwing van de beslissing - die overigens hooguit impliciet, een verwijzing naar een toepassing van het evenredigheidsbeginsel in zich draagt - geeft het Hof niet.

In het tweede arrest, het Italitica-arrest, ${ }^{43}$ handelend over een typische Italiaanse verleggingregeling, zou men een toepassing van het evenredigheidsbeginsel kunnen verwachten, maar men treft het niet aan. Om die reden besteed ik er kort aandacht aan. Het gaat om een verleggingsregeling die inhoudt dat op de afnemer van een dienst de verplichting rust om de BTW aan de Belastingdienst te betalen indien een onregelmatige factuur is uitgereikt door de presterende ondernemer zonder vermelding van BTW. Het is de vraag of de Italiaanse regeling inzake de verlegging van de verschuldigdheid in overeenstemming is met de bepalingen van de Zesde richtlijn. De belangrijkste vraag is of artikel 10, lid 2, Zesde richtlijn (thans artikelen $63 \mathrm{t} / \mathrm{m} 66$, BTW-richtlijn) toestaat te bepalen dat voor alle dienstverrichtingen de ontvangst van de prijs wordt aangemerkt als het feit waardoor de belasting verschuldigd wordt. De tweede prejudiciële vraag gaat over de termijn waarbinnen de factuur moet worden uitgereikt, ook al heeft de ontvangst van de vergoeding nog niet plaatsgevonden. ${ }^{44}$

42. Artikel 206, BTW-richtlijn (voorheen artikel 22, lid 5, Zesde richtlijn) bepaalt dat iedere belastingplichtige het nettobedrag van de BTW (verschuldigde BTW min de voorbelasting) bij de indiening van de periodieke aangifte moet voldoen. Tevens geeft het artikel de lidstaten de mogelijkheid een ander tijdstip voor de betaling van dit bedrag vast te stellen of te bepalen dat voorlopige vooruitbetalingen moeten worden gedaan. De achtergrond van de introductie van de 'voorlopige vooruitbetalingen' is het voorkomen dat bij belastingplichtigen (die in feite belastingontvangers zijn voor rekening van de staat) zich grote sommen van overheidsgeld ophopen. Omdat op het tijdstip van de voldoening van de vooruitbetaling de boekhouding over de betrokken periode in de regel nog niet is afgesloten, mogen de lidstaten voorschrijven dat daarbij moet worden uitgegaan van de omzet die is behaald in dezelfde periode van het voorgaande jaar. De lidstaten kunnen dan toestaan dat de belastingplichtigen de vooruitbetaling bepalen aan de hand van de omzet die zij volgens hun schatting aan het einde van de periode daadwerkelijk zullen hebben gehaald.

43. Hof 26 oktober 1995, nr. C-144/94, Italiticca, Jur. 1995, blz. I-3653.

44. De derde prejudiciële vraag houdt in de kwestie, of de lidstaten die gebruik maken van de 'afwijking' van het algemene stelsel, verplicht zijn bepalingen vast te stellen volgens welke van de verrichte dienst bewijsstukken en aantekeningen opgesteld moeten worden, wanneer de factuur niet is uitgereikt of de ontvangst van de prijs niet heeft plaatsgevonden. Het Hof verduidelijkt, onder verwijzing naar artikel 22, lid 2 en 8, Zesde richtlijn (thans artikelen 242 en 273, BTW-richtlijn), dat de lidstaten op dit terrein een ruime beoordelingsvrijheid hebben. Tevens merkt het Hof op dat voor de uitleg een 'rechtvaardiging' is te vinden in het gegeven dat de Lidstaten rekening moeten kunnen houden met de omvang van de ondernemingen en de soort van activiteiten, alsmede met de vereisten die voortvloeien uit andere wettelijke regelingen. Het Hof besliste vervolgens, dat de lidstaat die van de eerder vermelde afwijking gebruik maakt, niet gehouden is bepalingen vast te stellen volgens welke van de voltooide dienst en de daarvoor verschuldigde prijs bewijsstukken of aantekeningen opgesteld moeten worden wanneer de factuur of het als zodanig dienst doende document niet is uitgereikt of de ontvangst van de prijs niet heeft plaatsgevonden. 
De antwoorden op de deze vragen moeten gelezen worden, tegen de achtergrond van de Italiaanse verlegging van de verschuldigdheid bij onregelmatige facturen.

De Italiaanse regeling is bedoeld om fraude en misbruik te voorkomen en te bestrijden. De eerste indruk is dat de Italiaanse regeling ongekend ver gaat. Zo is de regeling van toepassing op alle diensten. Duidelijk is ook dat de gevolgen voor afnemers vergaand kunnen zijn. Zij kunnen immers getroffen worden door naheffingsaanslagen indien de presterende ondernemer onzorgvuldig te werk gaat. Verder maak ik uit de feiten, zoals deze zijn weergegeven in de conclusie en het arrest, op dat de afnemer ook getroffen kan worden door een boete.

Artikel 10, lid 2, Zesde richtlijn (thans artikel 63, BTW-richtlijn) bepaalt het volgende:

"Het belastbare feit vindt plaats en de belasting wordt verschuldigd op het tijdstip waarop de goederen worden geleverd of de diensten worden verricht."

De derde alinea van dit lid (huidig artikel 66, BTW-richtlijn) luidt onder meer als volgt:

"In afwijking van het voorgaande kunnen de Lid-Staten bepalen dat de belasting voor bepaalde handelingen of bepaalde categorieën belastingplichtigen verschuldigd wordt: (...) wanneer de factuur of het als zodanig dienst doende document niet of niet tijdig wordt uitgereikt, binnen een bepaalde termijn te rekenen vanaf de datum van het belastbare feit."

De verwijzende rechter merkt op dat afwijkingen slechts mogelijk zijn voor 'bepaalde handelingen' of 'bepaalde categorieën belastingplichtigen'. De nationale rechter vraagt zich af of de richtlijn de Lidstaten toestaat te bepalen dat voor alle dienstverrichtingen de 'ontvangst van de prijs' wordt aangemerkt als het feit waardoor de belasting 'verschuldigd' wordt. Bij de beantwoording van deze vraag zou een doel - middel afweging verwacht kunnen worden, namelijk tussen voorkoming en bestrijding van fraude en de - alsdan, te - ruime Italiaanse regeling. Het Hof kent echter betekenis toe aan de voorgeschiedenis van de Zesde richtlijn. Artikel 6, lid 4 van de Tweede richtlijn, alsmede het voorstel van de Commissie voor de Zesde richtlijn voorzagen in enkele uitzonderingen op de regel dat de belasting verschuldigd wordt op het moment waarop de dienst wordt verricht. Het gegeven dat in de definitieve tekst het aantal uitzonderingen aanzienlijk is uitgebreid, doet vermoeden dat de communautaire wetgever de lidstaten een ruime beoordelingsbevoegdheid heeft willen geven bij het inrichten van de bepalingen inzake de verschuldigdheid. ${ }^{45}$ Het Hof besliste dan ook dat artikel 10, lid 2, derde alinea van de Zesde richtlijn de lidstaten toestaat te bepalen, dat voor alle dienstverrichtingen de ontvangst van de prijs het feit is waardoor de belasting verschuldigd wordt. Artikel 22, lid 3, sub a, 
Zesde richtlijn, waarin is bepaald dat de belastingplichtige een factuur dient uit te reiken, verzet zich niet tegen deze uitleg volgens het Hof. ${ }^{46}$

\subsection{Het recht op aftrek van voorbelasting}

\subsubsection{De factuur}

Volgens artikel 220, BTW-richtlijn (artikel 22, lid 3, sub a, Zesde richtlijn) moet een belastingplichtige een factuur uitreiken voor het leveren van goederen en het verrichten van diensten aan andere belastingplichtigen. Lidstaten mogen om een juiste heffing veilig te stellen of fraude te voorkomen andere verplichtingen voorschrijven (artikel 273, BTW-richtlijn, voorheen artikel 22, lid 8, Zesde richtlijn). Dit is de heffingskant. Ten behoeve van de aftrekkant bepaalt artikel 178, lid 1, sub a, BTWrichtlijn (voorheen artikel 18, lid 1, sub a, Zesde richtlijn) dat een belastingplichtige moet beschikken over een factuur om het aftrekrecht te kunnen uitoefenen. Hieruit volgt tegelijkertijd dat het bezit of de afgifte van een factuur niet onder alle omstandigheden verplicht is. Vooral in de relatie tussen de belastingplichtigen en de eindverbruiker bestaat geen factuurplicht. ${ }^{47}$ De factuur is dus vooral van belang in het economisch verkeer tussen belastingplichtigen. Zij speelt, zoals ook uit de hierna te behandelen rechtspraak blijkt, een voorname rol in het stelsel van het recht op aftrek van voorbelasting. Daarover en over het effectueren van dit recht handelen de volgende paragrafen, aangezien daarbij ook algemene rechtsbeginselen aan de orde komen.

46. Het Hof besloot verder dat een lidstaat die van de in artikel 10, lid 2, derde alinea, Zesde richtlijn (huidig artikel 66, BTW-richtlijn) bedoelde afwijking gebruik maakt, niet gehouden is tot vaststelling van 'een bepaalde termijn te rekenen vanaf de datum van het belastbaar feit', als termijn waarbinnen de factuur of het als zodanig dienst doende document moet worden uitgereikt, ook al heeft de ontvangst van de prijs nog niet plaatsgevonden. A-G Jacobs (conclusie van 13 juli 1995, pt. 35 t/m 37) is van mening dat de richtlijn niet het precieze moment aangeeft waarop een factuur moet worden uitgereikt. Artikel 22, lid 3, Zesde richtlijn bepaalt enkel dat een belastingplichtige een factuur moet uitreiken voor verrichte diensten en geleverde goederen aan andere belastingplichtigen. Het ontbreken van iedere aanwijzing over het moment waarop een factuur moet worden uitgereikt geeft aan, dat dit volgens het stelsel van ondergeschikt belang is. De lidstaten hebben dus een zekere vrijheid op dit gebied, mits zij maar voldoen aan hun algemene verplichting om de juiste toepassing van de belastingbepalingen te verzekeren. Het Hof en de A-G zien dus geen bezwaren tegen de Italiaanse uitwerking op deze onderdelen van de BTW-richtlijn.

47. Zie het Careda-arrest (Hof 26 juni 1997, nrs. C-370/95, C-371/95 en C-372/95, Jur. 1997, blz. I-3721), welk arrest niet over de factuurvereisten handelt, maar over de toepasselijkheid van artikel 401, BTWrichtlijn op grond waarvan het, kort gezegd, de lidstaten niet is toegestaan belastingen in te voeren die het karakter van een omzetbelasting hebben. De vraag van de Spaanse rechter spitste zich toe op het probleem of de factuur - naast de andere elementen - mede een element is dat bepaalt of een heffing het karakter van een omzetbelasting en of artikel 401, BTW-richtlijn aldus moet worden uitgelegd, dat - wil een heffing het karakter van een omzetbelasting bezitten - het noodzakelijk is dat de heffing door middel van een factuur wordt afgewenteld. Het Hof besliste dat de afgifte en het bezit van de factuur niet een wezenlijk kenmerk van de omzetbelasting zijn. Zie ook paragraaf 2.2 waar ik het arrest behandel in het licht van het verbruiksbeginsel. 
Het Reisdorf-arrest ${ }^{48}$ maakt onderscheid tussen de bepalingen die het recht op aftrek betreffen, en die welke betrekking hebben op het bewijs van dit recht. Over de bewijslevering bevat artikel 22, Zesde richtlijn geen bepaling. De lidstaten kunnen volgens het Reisdorf-arrest regels stellen voor de controle op de uitoefening van het recht en met name voor de manier waarop belastingplichtigen dit recht moeten bewijzen. ${ }^{49}$ Het Hof verstaat daaronder ook de bevoegdheid om het origineel van de factuur te verlangen, alsook om de belastingplichtige - die niet meer in het bezit is van de factuur - met andere afdoende middelen de aftrek te laten bewijzen. ${ }^{50}$

\subsubsection{Genius-arrest}

Genius Holding BV (verder: Genius), actief in montage- en fabricagewerkzaamheden, makkte ter uitvoering van haar opdrachten gebruik van onderaannemers. Een tweetal onderaannemers brachten BTW aan Genius in rekening welke Genius in aftrek bracht op haar aangifte. Aftrek van voorbelasting is echter slechts toegestaan indien de op de factuur vermelde BTW ook daadwerkelijk verschuldigd is. In overeenstemming met de zogeheten verleggingregeling ${ }^{51}$ en van toepassing is op de activiteiten van Genius, is de onderaannemer geen BTW verschuldigd. De regeling werkt zo dat Genius op aangifte BTW dient te voldoen over de bedragen die door de onderaannemers aan haar in rekening worden gebracht. Genius kan dan de BTW direct weer in dezelfde, eigen, aangifte in aftrek brengen. Per saldo hoeft zij dan geen BTW op aangifte te voldoen. In deze casus werd door de onderaannemers de verleggingsregeling echter niet toegepast en zij brachten dan ook ten onrechte BTW aan Genius in rekening. Het gevolg hiervan is dat Genius deze BTW in principe niet in aftrek kan brengen gezien het gegeven dat zij niet beschikt over een factuur die voldoet aan de eisen van de Wet OB.

De Hoge Raad ${ }^{52}$ stelde prejudiciële vragen, waarin centraal stond het element dat de BTW die de onderaannemer in rekening bracht slechts verschuldigd is - niet op grond van de materiële wetsbepalingen, maar - op de enkele grond van het vermeld zijn daarvan op de facturen. Genius meende, dat deze BTW die aan haar ten onrechte in rekening was gebracht, voor aftrek in aanmerking kwam. De prejudiciële vraag houdt dan ook in, of de slechts formeel verschuldigde BTW in aftrek kan worden gebracht.

48. Hof 5 december 1996, nr. C-85/95, Reisdorf, V-N 1997/402.

49. Curieus in de Reisdorf-procedure was, dat belanghebbende wel degelijk over de originele facturen beschikte maar om onduidelijke redenen niet wilde overleggen (zie r.o. 10 in het Reisdorf-arrest). 50. De redactie van V-N trekt uit het Reisdorf-arrest de conclusie dat de lidstaten een zekere vrijheid hebben bij de invulling van het begrip 'factuur'. Dat neemt niet weg dat de door het Hof gebruikte bewoordingen een nogal zware, maar wel in het systeem passende, bewijslast aangeven (V-N 1997/402). 51. Die op grond van de in artikel 395, BTW-richtlijn (voorheen 27, Zesde richtlijn) vermelde machtigingsprocedure tot stand is gebracht.

52. Hof 13 december 1989, nr. 342/87, Genius Holding, BNB 1990/237, V-N 19990/42 pt. 14, FED $1990 / 123$ 
De Commissie en Genius brachten naar voren dat het in strijd met het doel van de aftrekregeling zou zijn, indien enkel aftrek mogelijk is van ter zake van leveringen of diensten verschuldigde belasting en niet die van ten onrechte op een factuur vermelde BTW. Zij verwezen naar het gegeven dat de aftrekregeling een volstrekt neutrale fiscale belasting van alle economische activiteiten dient te waarborgen, mits zij op zich aan de heffing van BTW zijn onderworpen. Verder bepleitte Genius dat, een dergelijke inperking van het recht op aftrek van voorbelasting tot gevolg zou hebben dat belastingplichtigen verplicht zouden zijn te controleren of aan hen gefactureerde BTW ook wettelijk verschuldigd is, en daarvoor is een beoordeling van de gekozen tariefindeling en bekendheid met de toegekende vrijstellingen noodzakelijk. Dit zou niet bevorderlijk zijn voor een goed verloop van de handelsbetrekkingen.

Het Hof blijkt weinig op te hebben met het standpunt van Genius en de Commissie en beslist op rechtstheoretische gronden. Bij de analyse van de Zesde richtlijn start het Hof met te overwegen dat bij de formulering van de regeling van artikel 17, lid 2, sub a, Zesde richtlijn (thans artikel 168, sub a, BTW-richtlijn) zowel is afgeweken van de formulering van artikel 11, lid 1, sub a van de Tweede richtlijn als van die van artikel 17, lid 2, sub a van het voorstel van de Commissie voor de Zesde richtlijn. Volgens die twee bepalingen mocht de belastingplichtige immers alle belasting aftrekken die aan hem was gefactureerd voor de aan hem geleverde goederen en voor de te zijnen behoeve verrichte diensten, zulks ongeacht of deze BTW daadwerkelijk verschuldigd is. Het Hof concludeerde uit de wijzigingen die zijn aangebracht ten opzichte van de Tweede richtlijn en ten opzichte van het voorstel voor de Zesde richtlijn, dat enkel recht op aftrek van voorbelasting bestaat voor belasting die verschuldigd is - dat wil zeggen belasting ter zake van een aan de BTW onderworpen handeling - of die is voldaan voor zover zij verschuldigd was.

De bovenstaande uitleg van artikel 17, lid 2, sub a, Zesde richtlijn (huidig artikel 168, sub a, BTW-richtlijn) wordt volgens het Hof bevestigd in andere bepalingen van de Zesde richtlijn ${ }^{53}$ en is volgens het Hof de beste, ook wanneer het erom gaat, belastingfraude tegen te gaan.

Het argument van de Commissie en Genius met betrekking tot de neutraliteitsverstoring, ziet in het bijzonder op de betekenis dat op de economische activiteiten geen BTW mag blijven drukken (zie paragraaf 11.2). Met het argument dat een dergelijke strikte uitleg de neutraliteit kan verstoren maakt het Hof zich eenvoudig af, door te overwegen dat het aan de lidstaten is om in hun nationale recht de mogelijkheid op te nemen om, wanneer de opsteller van de factuur te goeder trouw

53. Uit artikel 18, lid 1, sub a, Zesde richtlijn (thans artikel 178, sub a, BTW-richtlijn) blijkt dat voor het uit kunnen oefenen van het recht op aftrek een factuur vereist is die voldoet aan artikel 22, lid 3, sub b, Zesde richtlijn (huidig artikel 220 t/m 236 en 238 t/m 240, BTW-richtlijn). Volgens de genoemde bepalingen is het recht op aftrek dus afhankelijk van de voorwaarde, dat op de factuur de belasting wordt vermeld die ter zake van de geleverde goederen en de verrichte diensten verschuldigd is. Het recht op aftrek van voorbelasting bestaat dus niet voor belasting, die niet aan een bepaalde handeling is gerelateerd omdat de betrokken handeling niet aan de BTW is onderworpen. 
blijkt te zijn, alle ten onrechte gefactureerde belasting te herzien. Volgens deze benadering vindt de correctie dan niet plaats bij degene die factureert maar wordt het recht op aftrek geblokkeerd bij de afnemer (zie ook paragraaf 12.2.2). ${ }^{54}$

Het Hof komt in dit arrest tot een vrij strakke uitleg van het recht op aftrek van voorbelasting en dan in het bijzonder wat de vereisten van de factuur betreft. Vermeldt de factuur BTW die niet verschuldigd is door degene die de prestatie verricht, dan kan de afnemer deze BTW niet in aftrek brengen. Het lijkt erop dat verstoring van de neutraliteit (in de betekenis dat op de economische activiteiten geen BTW mag blijven drukken) in stand wordt gelaten in het voordeel van een vrij strakke uitleg van de vereisten die gesteld worden aan facturen. De letterlijke tekst en het gevaar voor fraude winnen het van de neutraliteit. Paragraaf 12.3.1.3 zal een voorbeeld van een andere uitslag laten zien.

\subsubsection{Jeunehomme-arrest}

Een belastingplichtige kan, aldus artikel 178, sub a, BTW-richtlijn (voorheen artikel 18, lid 1, letter a, Zesde richtlijn) enkel de voorbelasting in aftrek brengen indien hij in het bezit is van een factuur die voldoet aan de eisen van de artikelen $220 \mathrm{t} / \mathrm{m} 236$ en 238 t/m 240, BTW-richtlijn (voorheen artikel 22, lid 3, Zesde richtlijn).

Artikel 226, BTW-richtlijn stelt een scala van vermeldingen verplicht op de factuur, onder meer: de prijs exclusief belasting, de belasting volgens elk afzonderlijk tarief, alsook, in voorkomend geval, de vrijstelling. In de voorloper van de BTWrichtlijn (en voor de aanpassing van de Zesde richtlijn aan de factureringsrichtlijn) stelde artikel 22, lid 3, sub c, Zesde richtlijn: "De lidstaten stellen de criteria vast volgens welke een document kan worden geacht dienst te doen als factuur." In het Jeunehomme-arrest ${ }^{55}$ van 14 juli 1988 gaat het om deze bepaling.

54. De Belastingdienst heeft nu twee mogelijkheden om tot heffing te komen in geval van ten onrecht gefactureerde BTW. Namelijk door toepassing van artikel 37 Wet OB (artikel 203, BTW-richtlijn) bij de opsteller van de factuur of de weigering van de aftrek van voorbelasting op grond van het Geniusarrest bij de afnemer. Op grond van het Besluit van 12 februari 2009 (nr. CPP2009/263M, paragraaf 3.6.2., V-N 2009/11.21) past de Belastingdienst slechts één van deze mogelijkheden toe door een keuze te maken tussen de leverancier en de afnemer. De inspecteur zal zich in het algemeen eerst wenden tot degene die de factuur heeft uitgereikt en laat de aftrek van voorbelasting bij de afnemer in stand. Dat is dus een ander uitgangspunt dan is te vinden in de jurisprudentie van het Hof waarbij de aftrek wordt geweigerd bij de afnemer en slechts herziening van de ten onrechte gefactureerde BTW wordt toegestaan indien het verlies van belastinginkomsten tijdig en volledig is uitgeschakeld. A-G Sharpton besteedt in haar conclusie (punten $47 \mathrm{t} / \mathrm{m} \mathrm{51}$ ) bij het Reemtsma-arrest aandacht aan beide scenario's en wijst er op dat ook het alternatieve systeem (m.a.w. de Nederlandse praktijk) te verkiezen is op grond van de eenvoud. Toch pleit zij niet voor herziening van de lijn die is ingezet met het Geniusarrest. Gezien het feit dat het arrest is gebaseerd op aanvaarde uitleggingbeginselen en al meer dan vijftien jaar vaste rechtspraak is. Indien het Hof om zou gaan, “(...) zou zulks waarschijnlijk té veel opschudding veroorzaken in de BTW-praktijk in de lidstaten". A-G Sharpton conclusie van 8 juni 2006 bij het arrest van 15 maart 2007, nr. C-35/05, Reemtsma Cigarettenfabriken GmbH, V-N 2007/15.10. 55. Hof 14 juli 1988, gevoegde zaken nrs. 123 en 330/87, L. Jeunehomme en EGI, Jur. 1988, blz. 4517. 
België maakte gebruik van letter c van lid 3. Bij de levering van personen auto's moest de factuur tevens vermelden: het merk, het model, het jaartal, de cilinderinhoud, de motorsterkte, het carrosseriemodel, alsmede het chassisnummer en het jaar waarin de geleverde personenauto voor het eerst in het verkeer werd gebracht. De Belgische rechter stelde de prejudiciële vraag of de Belgische regeling voldoet aan de Zesde richtlijn indien (enigszins gestileerd weergegeven) naast de vermeldingen van artikel 22, lid 3, sub b, Zesde richtlijn een aantal andere vermeldingen is vereist. In deze procedure ging het om het recht op aftrek van voorbelasting. De Belgische Belastingdienst blokkeerde de aftrek omdat de facturen niet voldeden aan de uitputtende omschrijving.

\section{Het Hof beslist:}

"Voor de uitoefening van het recht op aftrek mag evenwel slechts worden vereist dat de factuur nog andere vermeldingen bevat dan die welke in artikel 22, lid 3, sub b, van de richtlijn zijn genoemd, voor zover die bijkomende vermeldingen noodzakelijk zijn om de inning van de belasting over de toegevoegde waarde en de controle daarvan door de belastingadministratie te verzekeren. Bovendien mogen die vermeldingen niet zo talrijk zijn, dat zij de uitoefening van het recht op aftrek nagenoeg onmogelijk of overdreven moeilijk maken." (r.o. 17)

Uit de rechtsoverweging blijkt dus dat de aanvullende eisen die een lidstaat mag stellen in verhouding moeten staan met het doel, namelijk om de inning en de controle van de BTW te verzekeren. Uit de laatste zin van de rechtsoverweging blijkt dat ook al zijn aanvullende vereisten noodzakelijk om het doel te bereiken, dan nog een beperking geldt, namelijk dat de uitoefening van het recht op aftrek niet al te zeer bemoeilijkt mag worden. ${ }^{56}$

Ondanks de bevoegdheid om aanvullende eisen te mogen stellen, zoals deze was te vinden in de letterlijke tekst van toen van kracht zijnde artikel 22, lid 3, sub c, Zesde richtlijn, wordt de vrijheid van de lidstaten begrensd door de werking van het evenredigheidsbeginsel. ${ }^{57}$

56. Naast artikel 22, lid 3, speelde ook artikel 22, lid 8, Zesde richtlijn (thans artikel 273, BTW-richtlijn) een rol. Ten aanzien daarvan oordeelde het Hof dat deze bepaling een bijzondere is die buiten de machtigingsprocedure om gaat en enkel betrekking heeft op de mogelijkheid voor de lidstaten om andere verplichtingen voor te schrijven dan die welke in de richtlijn zijn voorzien (r.o. 15).

57. Het Hof liet de beoordeling of de door de Belgische regeling verlangde vermeldingen aan het genoemde criteria voldoet over aan de nationale rechter. Zie verder Zie in dit verband ook Hof 15 juli 2010, nr. C-368/09, Pannon Gép Centrum kft, V-N 2010/37.24. In deze procedure is een nationale regeling waarbij onjuiste vermelding op een factuur (onjuiste datum voltooiing dienst en geen doorlopende nummering) leidt tot verval van recht op aftrek niet toegestaan. Zie tevens Hof 30 september 2010, nr. C-392/09, Uszodaépítö kft, NTFR 2010/2318. In deze proceure wijst het Hof erop dat het recht op aftrek dient te worden gehonoreerd als aan de materiële voorwaarden is voldaan; ook als aan bepaalde formele voowaarden niet wordt voldaan. 


\subsubsection{Minerales-arrest (SGGSEMF)}

Het Franse Minerales kreeg Duitse BTW in rekening gebracht en verzocht de Duitse Belastingdienst op grond van de Achtste richtlijn om teruggaaf van deze BTW. ${ }^{58}$ Een probleem was dat Minerales de originele facturen was kwijt geraakt en het verzoek daarom ondersteunde met duplicaten van de facturen. Deze duplicaten waren de Franse Minerales verstrekt door Duitse dienstverrichters. De Duitse Belastingdienst weigerde de teruggaaf omdat geen originele facturen werden overgelegd. Het Finanzgericht stelde twee prejudiciële vragen. In de eerste plaatst, wilde het Finanzgericht weten of de Achtste richtlijn eraan in de weg staat als het interne recht van een lidstaat toestaat het recht op teruggaaf te bewijzen door overlegging van een duplicaat van de factuur. Als het antwoord op deze vraag ontkennend luidt, dan wilde het Finanzgericht in de tweede plaats weten of uit het gemeenschapsrechtelijke discriminatieverbod en het beginsel van de neutraliteit ${ }^{59}$ van de BTW volgt, dat een belastingplichtige zijn recht op teruggaaf kan bewijzen door overlegging van een duplicaat van de factuur.

In het Minerales-arrest ${ }^{60}$ is de verplichting aan de orde voor de niet in het binnenland gevestigde belastingplichtigen om bij het verzoek tot teruggaaf van belasting de originelen van de facturen of invoerdocumenten bij te voegen (zie artikel 3, sub a, Achtste richtlijn). Het Hof constateert dat de verplichting in de Achtste richtlijn, die tot 1 januari 2010 van kracht was voor teruggaaf van voorbelasting aan in een andere lidstaat gevestigde ondernemers, in formulering verschilt van de corresponderende bepalingen in de Zesde richtlijn. In de artikelen 18 , lid 1 , sub a, en 22 , lid 3, Zesde richtlijn is het recht op aftrek van voorbelasting normaliter afhankelijk van het bezit van het origineel van de factuur of van het document dat, volgens de door de betrokken lidstaat vastgestelde criteria, kan worden geacht als zodanig dienst te doen (huidig artikel 178, sub a, BTW-richtlijn en de artikelen 220 t/m 236 en 238 t/m 240, BTW-richtlijn). Daarentegen eist artikel 3, sub a, Achtste richtlijn ondubbelzinnig een originele factuur om voor een teruggaaf in aanmerking te komen. Deze eis kan volgens het Hof in overeenstemming zijn met het oogmerk van de Achtste richtlijn zoals blijkt uit de zesde overweging van de considerans; daarin staat namelijk de gerichtheid van de Achtste richtlijn op het bestrijden van 'bepaalde vormen van belastingfraude of belastingontwijking' en dan ook het voorkomen dat een niet in de betrokken lidstaat gevestigde ondernemer de factuur nogmaals kan gebruiken voor andere verzoeken om teruggaaf.

58. Per 1 januari 2010 is de Achtste richtlijn vervangen door richtlijn 2008/9/EG. Belastingplichtigen kunnen de 'buitenlandse BTW' vanaf die datum centraal terugvragen bij de Belastingdienst van de lidstaat waar zij hun zetel van bedrijfsuitoefening hebben. De Achtste richtlijn-procedure is dus komen te vervallen.

59. Uit de prejudiciële vraag blijkt niet of de Duitse rechter doelt op de fiscale neutraliteit als interpretatiebeginsel dan wel op neutraliteit als stelselbeginsel in de zin van het bevrijden van de voordruk. Zie voor dit onderscheid de paragrafen 3.5.2 en 4.4.4.2.

60. Hof 11 juni 1998, nr. C-361/96, SGGSEMF (Minerales), Jur. 1998, blz. I-3495. 
Het Hof meent echter dat de Achtste richtlijn niet in die zin kan worden uitgelegd, dat het uitsluit dat een lidstaat een verzoek om teruggaaf kan inwilligen in het bijzondere geval waarin de transactie naar aanleiding waarvan een verzoek om teruggaaf wordt verzocht, zonder twijfel plaats heeft gehad en vaststaat dat er, gelet op de omstandigheden, geen risico van verdere verzoeken om teruggaaf bestaat.

"Uit de rechtspraak van het Hof volgt immers, dat het afgeleide recht de algemene rechtsbeginselen en met name het evenredigheidsbeginsel in acht moet nemen (...). De uitsluiting van die mogelijkheid nu is in dit geval niet noodzakelijk om belastingfraude of -ontwijking te voorkomen." (r.o. 30)

Uit de toets aan de noodzakelijkheid van de maatregel blijkt de werking van het evenredigheidsbeginsel. Een maatregel is niet noodzakelijk indien een lidstaat het doel kan bereiken met een minder verdergaande maatregel (zie paragraaf 3.4.2). In rechtsoverweging 30 is het Hof snel klaar. De maatregel is namelijk niet noodzakelijk om belastingfraude of -ontwijking te voorkomen.

Het Hof komt dan ook tot het oordeel dat de Achtste richtlijn er niet aan in de weg staat, dat een lidstaat in zijn interne recht een niet in deze lidstaat gevestigde belastingplichtige de mogelijkheid biedt om, ingeval een factuur buiten zijn schuld is zoekgeraakt, zijn recht op teruggaaf te bewijzen door overlegging van een duplicaat van de factuur, wanneer de transactie heeft plaatsgehad en geen risico bestaat van verdere verzoeken om teruggaaf.

Na dit te hebben beslist, komt het Hof toe aan de tweede prejudiciële vraag, namelijk of uit het gemeenschapsrechtelijke discriminatieverbod en uit het beginsel van neutraliteit van de omzetbelasting volgt, dat een in een andere lidstaat gevestigde belastingplichtige, ingeval de factuur buiten zijn schuld is zoekgeraakt, zijn recht op teruggaaf kan bewijzen door overlegging van een duplicaat van de factuur. De Duitse rechter verwijst in zijn tweede prejudiciële vraag naar het discriminatieverbod, omdat een in Duitsland gevestigde belastingplichtige - als hij de originele factuur is kwijtgeraakt - op grond van een billijkheidsregeling de voorbelasting in aftrek kan brengen als hij kan overleggen een duplicaat van de factuur. ${ }^{61}$ Indien deze mogelijkheid zou worden onthouden aan belastingplichtigen in andere lidstaten dan dringt de vraag naar de werking van het discriminatieverbod zich op de voorgrond.

Het Hof beantwoordt de prejudiciële vraag met een verwijzing naar het nondiscriminatiebeginsel in artikel 18 VwEU. Dit artikel verbiedt elke discriminatie op grond van nationaliteit:

"Overeenkomstig het in artikel 6 van het Verdrag (huidig artikel 18 VwEU: toevoeging AHB) neergelegde non-discriminatiebeginsel wordt er in de vijfde overweging van de considerans van de Achtste richtlijn uitdrukkelijk aan herinnerd, dat die richtlijn 'er niet toe mag leiden dat belastingplichtigen verschillend worden behandeld naar gelang van de lidstaat waar zij zijn gevestigd', Volgens vaste rechtspraak is er evenwel slechts sprake van discriminatie, 
wanneer verschillende regels worden toegepast op vergelijkbare situaties dan wel dezelfde regel op verschillende situaties (...)."62 (r.o. 34)

De Duitse regering bracht naar voren, dat de onmogelijkheid om af te wijken van de verplichting het originele stuk bij te voegen, haar rechtvaardiging vindt in het risico van misbruik van niet originele stukken bij verzoeken om teruggaaf door niet in de lidstaat gevestigde belastingplichtigen. In tegenstelling van de in het binnenland gevestigde belastingplichtigen kan namelijk de boekhouding niet door de nationale Belastingdienst worden onderzocht en omdat de afhandeling van verzoeken om administratieve bijstand tussen de lidstaten over het algemeen veel tijd vergt en weinig doeltreffend is. De Duitse regering probeerde dus een rechtvaardigingsgrond voor de discriminatoire behandeling naar voren te brengen: gezien de verschillende controlemogelijkheden zijn het geen vergelijkbare gevallen. Het Hof vindt echter, onder een aantal voorwaarden, het gebrek aan controlemogelijkheden geen rechtvaardiging. ${ }^{63}$ De voorwaarden die het Hof stelt zijn, dat de transactie waarvan om teruggaaf wordt verzocht heeft plaatsgehad, de factuur of invoerdocument buiten de schuld van de belastingplichtige is zoekgeraakt en er geen risico van verdere verzoeken om teruggaaf bestaat. Is aan deze voorwaarden voldaan dan moet het verzoek om teruggaaf worden gehonoreerd.

\title{
Vervolgens voegt het Hof toe:
}

\begin{abstract}
"Aangezien het non-discriminatiebeginsel in een dergelijke situatie verlangt, dat een niet in de betrokken lidstaat gevestigde belastingplichtige zijn recht op BTW-teruggaaf kan bewijzen door overlegging van een duplicaat of fotokopie van de factuur onder dezelfde voorwaarden als een aldaar gevestigde belastingplichtige, behoeft de tweede vraag niet vanuit het oogpunt van het beginsel van neutraliteit van de BTW te worden onderzocht." (r.o. 37)
\end{abstract}

In het Minerales-arrest laten twee algemene rechtsbeginselen zich gelden. Namelijk het evenredigheidsbeginsel en het non-discriminatiebeginsel (artikel 18 VwEU). In Duitsland gevestigde belastingplichtigen kunnen op grond van een nationale regeling op basis van een fotokopie dan wel een duplicaat, onder bepaalde voorwaarden, op grond van een billijkheidsregeling het recht op aftrek van voorbelasting uitoefenen. Deze mogelijkheid mag een in een andere lidstaat gevestigde belastingplichtige niet worden onthouden.

62. Art 18 VwEU luidt: "Binnen de werkingsfeer van de Verdragen en onverminderd de bijzondere bepalingen, daarin gesteld, is elke discriminatie op grond van nationaliteit verboden. (...)" 63. Een recente voorbeeld waar dit argument wel doel trof is het arrest Schmelz (26 oktober 2010, nr. C-97/09, V-N 2010/58.20, NTFR 2010/2576). In deze procedure ligt de vraag voor of de zogenoemde kleine ondernemersregeling in overeenstemming is met de artikelen 18 VWEU, 43 EG en 49 EG, voor zover de lidstaten deze faciliteit toepassen op belastingplichtigen op hun grondgebied gevestigd, maar de mogelijkheid uitsluiten voor in andere lidstaten gevestigde kleine ondernemers. Het Hof ziet een rechtvaardiging in de beperking gezien de noodzaak om de doeltreffendheid van de fiscale controles te waarborgen. Hierbij speelt een rol dat internationale gegevensuitwisseling tussen de lidstaten niet mogelijk is, omdat geen gegevensuitwisseling plaatsvindt inzake de kleine ondernemers nu zij gezien hun geringe omzetten onder de uitwisselingsgrens blijven. In deze procedure is een gebrekkige controle mogelijkheid een rechtvaardiging om in te breken op het non-discriminatiebeginsel. 
Het non-discriminatiebeginsel heeft een ruimere werking dan het begrip fiscale neutraliteit. Dit blijkt uit het in paragraaf 4.4.4.2 behandelde Marks \& Spencerarrest $^{64}$ waarin het Hof overweegt dat van schending van de fiscale neutraliteit slechts sprake kan zijn tussen concurrerende handelaren, terwijl schending van het algemene gelijkheidsbeginsel ${ }^{65}$ in belastingzaken de vorm kan aannemen van andere soorten van discriminatie jegens handelaren die niet noodzakelijk concurrenten zijn, maar zich in andere opzichten in vergelijkbare situaties bevinden. ${ }^{66}$ In dit geval ligt een toets aan het algemene non-discriminatiebeginsel voor de hand gezien het verschil van behandeling tussen in het binnenland gevestigde belastingplichtigen en die gevestigd zijn in een andere lidstaat. De oorzaak van de ongelijke behandeling is namelijk gelegen in het feit dat gelijke gevallen onder verschillende regels vallen (gevestigd eigen lidstaat 'soepele' BTW-richtlijn/gevestigd andere lidstaat 'zwaardere' Achtste richtlijn). Deze ongelijkheid kan bij de materieel met elkaar botsende regels van gelijke rang niet met het interpretatiebeginsel fiscale neutraliteit worden opgeheven. De ongelijkheid die door het verschil in voorwaarden wordt opgeroepen lost het Hof op met hulp van het algemene non-discriminatiebeginsel in het Werkingsverdrag. Een fraai staaltje bescherming door gelijkheid op primair niveau waar de bescherming daarvan op secundair niveau tekstueel in gebreke blijft. In de geharmoniseerde BTW komt men dit weinig tegen. ${ }^{67}$ De redactie van Vakstudie Nieuws vraagt zich af, of dit niet tot ongelijkheid leidt indien bepaalde lidstaten niet een dergelijke nationale regeling bezitten. ${ }^{68}$ Een en ander heeft dan, volgens de redactie van Vakstudie Nieuws, tot gevolg dat afhankelijk van de regeling in diverse lidstaten belastingplichtigen verschillend worden behandeld.

Ten slotte kan men zich ook afvragen hoe het Minerales-arrest uitwerkt voor de Dertiende richtlijn. Deze richtlijn verschaft het recht op teruggaaf van voorbelasting aan buiten de Europese Unie gevestigde ondernemers. Geldt artikel 18 VwEU (voorheen artikel $12 \mathrm{EG}$ ) ook voor de gelijkheid tussen belastingplichtigen die gevestigd zijn buiten en binnen de Europese Unie? Volgens de tekst van artikel 18 VwEU geldt het in dit artikel neergelegde discriminatieverbod enkel binnen het toepassingsbereik van de Europese Verdragen. Een dergelijke ongelijke behandeling kan onder het bereik van de WTO vallen. In paragraaf 2.3.2.1 is behandeld dat een internationale overeenkomst invloed kan uitoefenen op de uitleg van een bepaling van afgeleid Unierecht. Denkbaar is dat het risico van fraude en misbruik wat betreft de toepassing van Dertiende richtlijn wel degelijk relevant is bij de beoordeling of

64. Hof 10 april 2008, nr. C-309/06, Marks \& Spencer, V-N 2008/21.22. Zie in dit kader in het bijzonder r.o. 49.

65. Zie paragraaf 3.4.1.2 waar ik op basis van rechtspraak en literatuur de stelling aanneem, dat geen onderscheid is toe te kennen aan het discriminatieverbod zoals dat in het Werkingsverdrag is te vinden en het Europeesrechtelijke gelijkheidsbeginsel.

66. Zie voor een uitgebreide behandeling van het onderscheid tussen fiscale neutraliteit en het gelijkheidsbeginsel paragraaf 4.4.4.2.

67. Zie paragraaf 1.2 waar door mij naar voren is gebracht dat in de BTW jurisprudentie nauwelijks meer bepalingen van het werkingsverdrag aan de orde zijn, dit in vergelijking met de VPB. De jurisprudentie van het Hof heeft met name betrekking op de uitleg van het secundaire Unierecht. 68. V-N 1998/39.42, blz. 3343. 
een verschil in behandeling is geoorloofd. Het onderscheid is dan dat binnen de Europese Unie een verordening de uitwisseling van gegevens regelt. ${ }^{69}$ Met belastingautoriteiten buiten de Europese Unie bestaat deze controle mogelijkheid slechts in beperkte vorm.

\subsubsection{Aanvullende voorwaarden recht op aftrek voorbelasting}

\subsubsection{Gabalfrisa-arrest}

De Spaanse Belastingdienst weigerde de startende ondernemer Gabalfrisa recht op aftrek van voorbelasting te verlenen met betrekking tot vóor de aanvang van haar activiteit verrichte handelingen. ${ }^{70}$ Hoofdstuk 7 behandelt de belastingplicht en daarmee ook de beginnende belastingplicht. Hierop ga ik nu niet in. In deze paragraaf zal ik voornamelijk aandacht besteden aan de uitleg van artikel 22, lid 1, juncto lid 8, Zesde richtlijn (thans artikel 213 juncto artikel 273, BTW-richtlijn). ${ }^{71}$

In het Gabalfrisa-arrest stelde de Spaanse regering, dat krachtens artikel 22, lid 1, juncto lid 8, Zesde richtlijn de uitoefening van het aftrekrecht afhankelijk kan worden gesteld van bepaalde voorwaarden, zoals de indiening van een uitdrukkelijk verzoek of inachtneming van een termijn van een jaar tussen dat verzoek en de daadwerkelijke aanvang van de belaste handelingen. Met deze vereisten worden volgens de Spaanse regering dezelfde controledoeleinden nagestreefd als met artikel 22, lid 1, Zesde richtlijn bedoelde opgave van het begin of de beëindiging van de activiteit. Tevens bracht de Spaanse regering naar voren dat de lidstaten krachtens artikel 22, lid 8, Zesde richtlijn de bevoegdheid hebben om andere dan in de richtlijn genoemde verplichtingen voor te schrijven ter waarborging van de juiste heffing van belasting en ter voorkoming van fraude. De Spaanse regering had vooral op het oog de bevoegdheid om de uitoefening van het recht op aftrek afhankelijk te stellen van de indiening van een uitdrukkelijk verzoek en de inachtneming van een termijn van een jaar tussen dat verzoek en de daadwerkelijke aanvang van de belaste handelingen.

Artikel 22, lid 1, Zesde richtlijn (huidig artikel 213, BTW-richtlijn) schrijft voor, dat de belastingplichtige opgave moet doen van het begin, de wijziging en de beëindiging

69. Verordening nr. 1798/2003 van de Raad van 7 oktober 2003 betreffende de administratieve samenwerking op het gebied van de belasting over de toegevoegde waarde, Pb L 264 van 15 oktober 2003, blz. 1-11.

70. Hof 21 maart 2000, gevoegde zaken nrs. C-110/98 t/m C-147/98, Gabalfrisa SL e.a., V-N 2000/22.12. 71. Artikel 273, BTW richtlijn vermeldt: “De lidstaten kunnen, onder voorbehoud van gelijke behandeling van door belastingplichtigen verrichte binnenlandse handelingen en handelingen tussen de lidstaten, andere verplichtingen voorschrijven die zij noodzakelijk achten ter waarborging van de juiste inning van de BTW en ter voorkoming van fraude, mits deze verplichtingen in het handelsverkeer tussen de lidstaten geen aanleiding geven tot formaliteiten in verband met een grensoverschrijding.

De in de eerste alinea geboden mogelijkheid mag niet worden benut voor het opleggen van extra verplichtingen naast de in hoofdstuk 3 vastgestelde verplichtingen inzake facturering." Het artikel is praktisch identiek aan artikel 22, lid 8, Zesde richtlijn. Wel vermeldt de Zesde richtlijn 'heffing' in plaats van 'inning'. Ook al hebben deze termen in Nederland een verschillende betekenis lijkt mij dat in de BTWrichtlijn geen wijziging wordt beoogd. 
van zijn activiteit. Deze bepaling geeft volgens het Hof de lidstaten echter niet de bevoegdheid om, zolang geen opgave wordt gedaan, de uitoefening van het recht op aftrek op te schorten tot de daadwerkelijke aanvang van de belaste handelingen, dan wel de belastingplichtige de uitoefening van dat recht te ontzeggen (r.o. 51).

Verder is de uitleg van artikel 22, lid 8, Zesde richtlijn (thans artikel 273, BTWrichtlijn) van belang. Het bepaalt dat de lidstaten - onder voorwaarden - andere verplichtingen kunnen voorschrijven die zij noodzakelijk achten ter waarborging van de juiste heffing en ter voorkoming van fraude. Het Hof daarover:

"Bovendien mogen de maatregelen die de lidstaten krachtens artikel 22, lid 8, van de Zesde richtlijn nemen ter waarborging van de juiste heffing van de belasting en ter voorkoming van fraude, niet verder gaan dan ter bereiking van die doelstelling noodzakelijk is. Zij mogen dus niet op zodanige wijze worden aangewend, dat zij een systematische belemmering voor het recht op BTW-aftrek opleveren, welk recht een basisbeginsel is van het bij de desbetreffende gemeenschapsregeling ingevoerde gemeenschappelijke BTW-stelsel (...)" (r.o. 52).

Uit de rechtsoverweging blijkt dus dat de maatregel (het middel) niet verder mag gaan dan noodzakelijk is ter bereiking van de juiste heffing en het voorkomen van fraude (doel). De maatregel mag niet het recht op aftrek van voorbelasting systematisch belemmeren. De juiste verhouding tussen middel en doel is niet aanwezig als de uitoefening van het basisbeginsel (recht op aftrek van voorbelasting) systematisch wordt belemmerd. ${ }^{72}$

In de Spaanse nationale regeling werd het recht op aftrek van voorbelasting niet alleen afhankelijk gesteld van de indiening van een uitdrukkelijk verzoek en de inachtneming van een termijn van een jaar tussen dat verzoek en de daadwerkelijke aanvang van de belaste handelingen, maar werd het recht op aftrek van voorbelasting systematisch geschorst tot de daadwerkelijke aanvang van de belaste handelingen. Het recht op aftrek kon zelfs vervallen indien geen begin werd gemaakt met de belaste handelingen. Het Hof besliste dan ook:

"Een dergelijke regeling gaat derhalve verder dan noodzakelijk is ter waarborging van de juiste heffing van de belasting en de voorkoming van fraude" (r.o. 54).

De Spaanse regeling doorstaat de doel - middel afweging niet.

“(...) artikel 17 van de Zesde richtlijn zich verzet tegen een nationale regeling die de uitoefening van het recht op aftrek van BTW (...), afhankelijk stelt van de vervulling van bepaalde voorwaarden, (...), bij gebreke waarvan het recht op aftrek komt te vervallen, of althans pas kan worden uitgeoefend vanaf de daadwerkelijke aanvang van de normale verrichtingen van de belaste handelingen" (r.o. 55).

Opvallend is dat het Hof verwijst naar artikel 17 (huidig artikelen 167 t/m 172, BTW-richtlijn) - het artikel dat het recht op aftrek van voorbelasting bepaalt - en niet naar artikel 22, lid 8, Zesde richtlijn (huidig artikel 273, BTW-richtlijn). De 
reden hiervoor kan zijn dat de Spaanse rechter in de prejudiciële vraag uitleg vraagt over artikel 17, Zesde richtlijn. Artikel 22, lid 8, Zesde richtlijn wordt ter verdediging naar voren gebracht door de Spaanse regering. Een andere reden kan een meer systematische zijn. Zoals ik in hoofdstuk 11 naar voren heb gebracht geeft artikel 17, Zesde richtlijn de ruime regeling weer van het recht op aftrek van voorbelasting voor zover er belaste handelingen worden verricht. Artikel 22, lid 8, Zesde richtlijn kan het recht op aftrek van voorbelasting niet zonder meer inperken. Zoals blijkt uit het Gabalfrisa-arrest beperkt het evenredigheidsbeginsel de reikwijdte van artikel 22, lid 8, Zesde richtlijn.

\subsubsection{Sosnowska-arrest}

De Poolse Belastingdienst weigerde Sosnowska teruggaaf van de aan haar in rekening gebrachte BTW. Dit op grond van een voor startende ondernemers specifieke Poolse regeling. Kort weergegeven kwam deze regeling hierop neer, dat een startende ondernemer de eerste zestig dagen van zijn bestaan een BTW-teruggaaf niet krijgt uitbetaald. Deze teruggaaf wordt doorgeschoven naar de toekomst. Overigens kan de termijn van zestig dagen op grond van allerlei redenen worden verlengd. Uitbetaling is wel mogelijk als de startende ondernemer een zekerheid stelt. Sosnowska had - als startende ondernemer - niet een dergelijke zekerheid gesteld, met als gevolg dat het teruggaaf verzoek niet werd uitbetaald maar doorgeschoven naar de toekomst.

De Sosnowska-case ${ }^{73}$ lijkt sterk op het in de vorige paragraaf behandelde Gabalfrisaarrest. In die zaak weigerde de Spaanse Belastingdienst een startende ondernemer recht op aftrek van voorbelasting met betrekking tot vóór de aanvang van haar activiteit verrichte handelingen. Er zijn echter een aantal belangrijke verschillen. Zo wordt in de Sosnowska-procedure niet het recht op aftrek van voorbelasting geweigerd, maar wordt de uitbetaling van de teruggaaf doorgeschoven naar de toekomst. De procedure draait dan ook niet - zoals in de vorige paragraaf - om de uitleg van artikel 22 , lid 1 , juncto lid 8 , Zesde richtlijn waar is bepaald dat de uitoefening van het aftrekrecht afhankelijk kan worden gesteld van bepaalde voorwaarden, maar om de uitleg van artikel 18, lid 4, Zesde richtlijn (thans artikel 183, BTW-richtlijn):

"indien voor een bepaalde aangifteperiode het bedrag van de toegestane aftrek groter is dan dat van de verschuldigde belasting, kunnen de lidstaten hetzij het overschot doen overbrengen naar de volgende periode, hetzij het overschot teruggeven overeenkomstig de door hen vastgestelde regeling. (...)"

Het Hof verwijst naar de inbreukprocedure tegen Italië waar is beslist dat de lidstaten bij de vaststelling van de regeling voor de teruggaaf van het BTW-overschot een zekere bewegingsvrijheid hebben. ${ }^{74}$ Tevens is in dat geval beslist dat de regeling geen afbreuk mag doen aan het beginsel van neutraliteit van het BTW-stelsel door de belastingplichtige geheel of gedeeltelijk de last van de BTW te doen dragen. Een 
dergelijke regeling moet met name de belastingplichtige in staat stellen, op passende wijze de gehele uit het BTW-overschot voortvloeiende schuldvordering te innen, waarbij de teruggaaf binnen een redelijke termijn moet geschieden door een betaling in gereed geld of op een gelijkwaardige wijze en de wijze van teruggaaf in elk geval voor de belastingplichtige geen enkel financieel risico mag meebrengen.

Volgens de Poolse regering is de regeling gerechtvaardigd doordat het gaat om nieuwe belastingplichtigen die de belastingadministratie niet kent en dat veelal uitgebreide controles moeten worden verricht teneinde elke mogelijke vorm van belastingfraude en -ontwijking te voorkomen.

Het Hof heeft in de bekende arresten Teleos ${ }^{75}$ en Garage Molenheide ${ }^{76}$ erkend dat het rechtmatig is als de lidstaten passende maatregelen nemen om hun financiële belangen te beschermen. Daarbij moet wel het evenredigheidsbeginsel in acht worden genomen. Daar voegt het Hof ogenblikkelijk aan toe dat:

“(...) een nationale wettelijke regeling tot vaststelling van de nadere regels voor de teruggaaf van het BTW-overschot die voor een categorie van belastingplichtigen wegens een vermoeden van belastingfraude bezwarender is, zonder dat de belastingplichtige, om toch onder minder beperkende voorwaarden te vallen, over de mogelijkheid beschikt het bewijs te leveren dat er geen sprake is van belastingfraude of -ontwijking, geen evenredig middel is ter bestrijding van belastingfraude en -ontwijking en op buitensporige wijze afbreuk doet aan de doelstellingen en de beginselen van de Zesde btw-richtlijn (...)" (r.o. 24).

De Poolse regeling kent niet een regeling om tegenbewijs te leveren en doorstaat dan ook niet de toetsing aan het evenredigheidsbeginsel. Bovendien is het Hof van mening dat de Poolse teruggaaf regeling niet voldoet aan een redelijke teruggaaf termijn vooral als deze termijn vergeleken wordt met belastingplichtigen die al langer zijn opgenomen bij de belastingadministratie. De Poolse autoriteiten hebben geen argumenten aangevoerd die kunnen verklaren waarom het noodzakelijk was een dergelijk groot verschil in behandeling in te voeren teneinde belastingfraude en -ontwijking te bestrijden. De mogelijkheid om zekerheid te stellen veranderd hier niets aan. Deze mogelijkheid kan namelijk juist bij startende ondernemers - die gewoonlijk niet over aanzienlijke middelen beschikken - onoverkomelijk zijn. De verplichting tot deze zekerheidstelling teneinde op de normale termijn aanspraak te kunnen maken heeft in werkelijkheid alleen tot gevolg dat de financiële last als gevolg van de niet-beschikbaarheid van het bedrag van het BTW-overschot wordt vervangen door de financiële last als gevolg van de niet-beschikbaarheid van het bedrag van de zekerheid.

$\rightarrow$ richtlijn. Zie tevens Hof 28 juli 2011, nr. C-274/10, Commissie/Hongarije, V-N 2011/39.18, NTFR 2011/ 2083. In deze procedure loopt de Hongaarse teruggaafregeling tegen de grenzen die een lidstaat heeft om de regeling vorm te geven, gezien het feit dat de regeling tot gevolg kan hebben dat de belastingplichtige de BTW-druk moet dragen.

75. Hof 27 september 2007, nr. C-409/04, Teleos Plc, BNB 2008/11, V-N 2007/47.19, r.o. 52 en 53.

76. Hof 18 december 1997, nrs. C-286/94, C-340/95, C-41/95, C-47/96 Garage Molenheide e.a., V-N 1998/6.29, r.o. 46 en 47. 
De Poolse regeling die bij de uitbetalingsregels onderscheid maakt tussen starters en 'bestaande' ondernemers sneuvelt dus. De rechtvaardigingsgrond - fraude bestrijding - zou op zich kunnen voldoen. Echter het ontbreken van een tegenbewijsregeling, de lange teruggaaf periode en de zekerheidsstelling maken de regeling onevenredig.

\subsection{Conclusies}

In dit hoofdstuk zijn op het terrein van de administratieve verplichtingen in het binnenlandse verkeer, in het bijzonder die met betrekking tot de factuurvereisten, de arresten onderzocht op het voorkomen van algemene rechtsbeginselen en de toepassing daarvan. Het gaat om het verplicht in te voeren administratieve regels en de bevoegdheid van de lidstaten om aanvullende regelingen te treffen. Uit de jurisprudentie blijkt dat ook op het terrein dat niet is geharmoniseerd de algemene rechtsbeginselen zich laten gelden. Vooreerst leert het Jeunehomme-arrest, dat de bevoegdheid om in verband met inning en fraude andere verplichtingen op te leggen is begrensd door het evenredigheidsbeginsel.

In het Reisdorf-arrest is onder meer beslist dat de lidstaten mogen eisen dat het origineel wordt overgelegd om in aanmerking te komen voor het recht op aftrek van voorbelasting. In het Minerales-arrest wordt daarentegen aangegeven dat een belastingplichtige ook op een andere wijze dan door middel van een originele factuur het recht op aftrek van voorbelasting mag onderbouwen. Het lijkt er dus op dat in het Reisdorf-arrest de lidstaten meer ruimte wordt gegeven voor het verzwaren van de vereisten. In het Reisdorf-arrest wordt in het bijzonder veel betekenis toegekend aan de eerder genoemde veertiende en zeventiende overwegingen in de Considerans die in het bijzonder gericht zijn op het voorkomen van belastingontwijking of belastingfraude. Daar staat tegenover dat in het Minerales-arrest vooral het evenredigheidsbeginsel en het discriminatiebeginsel van artikel 18 VwEU een rol spelen bij de uitleg van het begrip 'factuur' in de context van de Achtste richtlijn. De vraag doet zich nu voor waardoor in een bepaald geval een algemeen rechtsbeginsel zich laat gelden, terwijl bij de beantwoording van een praktisch identieke prejudiciële vraag de werking van de algemene rechtsbeginselen afwezig is. Beide zaken lijken ogenschijnlijk op elkaar omdat in beide gevallen sprake was van een factuur die valide moet zijn. En daarom is het op het eerste gezicht aardig te zien, dat in het ene geval de algemene rechtsbeginselen een rol spelen en het andere niet. De vraag stellen is haar beantwoorden. De gevallen zijn immers noch naar feiten noch naar rechtsvraag, noch begripsmatig aan elkaar gelijk. Het verschil van kracht van de algemene rechtsbeginselen kan worden veroorzaakt door het gegeven dat de prejudiciële vragen net wat anders zijn geformuleerd. Ook de context van de regelgeving die het Hof verduidelijkt speelt een rol. In het Minerales-arrest was sprake van een belastingplichtige die in een andere lidstaat was gevestigd en dan ook strijd met het non-discriminatiebeginsel van artikel 18 VwEU aan de orde was.

Uit het Eismann-arrest blijkt dat de eis van gelijke behandeling, zoals die in artikel 22, lid 8, Zesde richtlijn (huidig artikel 273, BTW-richtlijn) is te vinden, geldt 
voor gelijke transacties die in één lidstaat worden verricht. Ook mogen grensoverschrijdende transacties niet door formaliteiten worden belemmerd. Echter binnenlandse transacties mogen wel met zwaardere formaliteiten worden omgeven in vergelijking met intracommunautaire transacties.

In het Minerales-arrest is een situatie aan de orde waarin belastingplichtigen die zijn gevestigd in het binnenland voorbelasting kunnen terugvragen aan de hand van een duplicaat van de factuur, terwijl daarentegen in een andere lidstaat gevestigde belastingplichtigen enkel op grond van de originele factuur een teruggaaf verzoek kunnen staven. Een dergelijk verschil in behandeling acht het Hof in strijd met het non-discriminatiebeginsel van artikel $18 \mathrm{VwEU}$. In de Minerales-case ligt een toets aan het Werkingsverdrag voor de hand. De oorzaak van de ongelijke behandeling is namelijk gelegen in het feit dat gelijke gevallen onder verschillende regels vallen (gevestigd eigen lidstaat 'soepele' BTW-richtlijn/gevestigd andere lidstaat 'zwaardere' Achtste richtlijn). Deze ongelijkheid kan bij de materieel met elkaar botsende regels van gelijke rang niet met het interpretatiebeginsel fiscale neutraliteit worden opgeheven. De ongelijkheid die door het verschil in voorwaarden wordt opgeroepen lost het Hof op met hulp van het algemene non-discriminatiebeginsel in het Werkingsverdrag. Een fraai staaltje bescherming door gelijkheid op primair niveau waar de bescherming daarvan op secundair niveau tekstueel in gebreke blijft. In de geharmoniseerde BTW komt men dit weinig tegen.

Sinds het verschijnen van het Langhorst-arrest, veertien jaar geleden, zien wij dat het Hof ook op het gebied van de uitleg van bepalingen over de administratieve verplichtingen algemene rechtsbeginselen een rol laat spelen. In die zin is de redactie van Vakstudie Nieuws op haar wenken bediend. De redactie daarvan schreef in 1997:

"Het zou de uitvoering in de diverse lidstaten ten goede komen als de Luxemburgse rechter bij zijn harmoniserende rechtsvinding iets meer ruimte zou nemen."77

In de arresten Jeunehomme, Langhorst, Minerales, Gabalfrisa, Schmeink \& Strobel, Stadeco en Sosnowska speelt het evenredigheidsbeginsel een rol. In deze arresten gaat het om het bijstellen van de administratieve verplichtingen tot rechtens meer adequate in gevallen dat de lidstaten eisen stellen aan het realiseren van het recht op aftrek van voorbelasting (arresten Gabalfrisa en Sosnowska) of om factuurvereisten (Jeunehomme-arrest) tot en met het opzij zetten van de letterlijke, harde formele eisen van de factuur (Minerales-arrest) en op het terrein van de verschuldigdheid van de BTW (arresten Langhorst en Stadeco). In de arresten Jeunehomme, Langhorst, Gabalfrisa, Schmeink \& Strobel is een duidelijke doel - middel afweging te vinden. In de arresten Langhorst en Minerales onderzoekt het Hof de noodzaak van de maatregel. 



\section{Slotbeschouwing en conclusies}

\subsection{Inleiding}

Om inzichtelijk te krijgen en te ordenen wat wij onder ons onderwerp algemene rechtsbeginselen moeten of kunnen verstaan en de plaats aan te geven waarin deze beginselen hun werking hebben, heb ik een voor dit onderzoek hanteerbare definitie van algemene rechtsbeginselen uitgewerkt (paragraaf 3.2.3). Voorts heb ik een aanvankelijk grove onderscheiding gemaakt tussen de beginselen die - naar de onderzochte literatuur algemeen aanvaard - eigen zijn aan de BTW enerzijds en algemene rechtsbeginselen anderzijds. Zonder de BTW eigen beginselen achter de concepten, wetsopbouw en wetsbegrippen functioneert de BTW niet. Wij spreken over het verbruiksbeginsel (paragraaf 2.2), het neutraliteitsbeginsel (paragraaf 2.4), en het beginsel van territorialiteit (paragraaf 2.3.1), bestemming of oorsprong (paragraaf 2.3.2).

De algemene rechtsbeginselen die in dit onderzoek aan de orde zijn betreffen het gelijkheidsbeginsel, het evenredigheidsbeginsel en het rechtszekerheidsbeginsel. Bij het bespreken van de rol en de toepassing van deze 'grote' beginselen is het interessant en nuttig te onderscheiden tussen het materiële rechtsterrein en het formele rechtsterrein (paragraaf 3.3.1). Op het gebied van de inhoud van de regels die de belastingplicht, het belastbaar feit, de aftrek van voorbelasting, enz., enz., bepalen, het gebied dat men in het algemeen het materiële recht noemt, werken de algemene rechtsbeginselen als interpretatiebeginsel, als ware het interpretatieregels' bij de uitleg door het Hof van het richtlijnenrecht. In dit toepassingsveld hebben de algemene rechtsbeginselen raakvlakken met de uitleg naar de ratio van een bepaling en soms de analogie argumentatie (paragraaf 4.4). Bij nagenoeg alle kernpunten van het materiële recht spelen de 'grote' algemene rechtsbeginselen op deze wijze een rol (hoofdstukken $6 \mathrm{t} / \mathrm{m} \mathrm{12}$ ). Dezelfde beginselen opereren ook op het terrein van de formele rechtsverhoudingen tussen overheid en particulier, als norm waaraan het overheidsoptreden moet voldoen. Hoofdstuk 5 heeft daarop in het bijzonder betrekking en paragraaf 7.2 speelt het een rol bij de startende ondernemer. De algemene rechtsbeginselen vervullen die rol dan naast, kortst gezegd, andere beginselen van behoorlijk bestuur, die overigens in dit onderzoek uiteraard niet aan de orde komen. Het onderzoek naar het voorkomen, het identificeren en de werking van de algemene rechtsbeginselen is tenslotte juridisch ingekaderd door, algemeen 
gezegd, het Unierecht, meer in het bijzonder door het zogenoemde secundaire Unierecht, met name richtlijnen, de taak van het Hof, zijn leerstukken en interpretatiemethoden (hoofdstuk 4).

Uit het onderzoek blijkt dat de invloed van de algemene rechtsbeginselen op het BTW-recht onmiskenbaar is. Dit hoofdstuk zal het materiaal uit de vorige hoofdstukken ordenen en zo inzichtelijk maken de wijze waarop de algemene rechtsbeginselen het BTW-recht beïnvloeden.

\subsection{Gelijkheidsbeginsel en fiscale neutraliteit}

\subsubsection{Gelijkheidsbeginsel}

De term fiscale neutraliteit zijn wij in het onderzoek in twee betekenissen tegengekomen (paragraaf 2.4). In de eerste plaats in de betekenis van gelijkheid in fiscale verhoudingen en in de tweede plaats in de zin van het bevrijden van voorbelasting (stelselbeginsel). In de eerste betekenis is de fiscale neutraliteit een uitdrukking van het gelijkheidsbeginsel zoals het zich laat gelden bij de uitleg van de BTW-richtlijn (paragraaf 4.4.4.2). In deze zin blijkt het beginsel een rol te spelen bij:

- De belastingplichtige; in het bijzonder de reikwijdte van het begrip belastingplichtige - economische activiteit - waar het gaat om de startende ondernemer; zie paragraaf 7.2 en de daar behandelde arresten. En zie de belastingplicht van publiek rechtelijke lichamen in paragraaf 7.4.

- De maatstaf van heffing; in het bijzonder bij het splitsten van vergoedingen; zie paragraaf 9.4 en de daar behandelde jurisprudentie.

- De vrijstellingen; zie paragraaf 10.4 en de aldaar behandelende arresten.

- Het recht op aftrek van voorbelasting: NCC-arrest (zie hieronder en in paragraaf 4.4.4.2)

Het beginsel verzet zich dan tegen een ongelijke BTW-behandeling van soortgelijke goederen en diensten die met elkaar concurreren. Het Marks \& Spencer III-arrest zie voor de gelijke bewoordingen de arresten Morgan Flemming, Ampliscientifica en NCC - vertolkt het beginsel als volgt:

"In de eerste plaats verzet het beginsel van fiscale neutraliteit, dat een basisbeginsel van het gemeenschappelijke BTW-stelsel vormt (...), zich er met name tegen dat soortgelijke goederen, die dus met elkaar concurreren, uit het oogpunt van de btw ongelijk worden behandeld (...)." (r.o. 47)

Vervolgens preciseert het Hof het onderscheid met het gelijkheidsbeginsel:

"In de tweede plaats komt het gelijkheidsbeginsel ter zake van btw tot uitdrukking in het beginsel van fiscale neutraliteit (...). Van schending van het beginsel van fiscale neutraliteit kan evenwel slechts sprake zijn tussen concurrerende handelaars, zoals in punt 47 van het onderhavige arrest is aangegeven, terwijl schending van het algemene gelijkheidsbeginsel in belastingzaken de vorm kan aannemen van andere soorten van discriminatie jegens handelaars die niet noodzakelijk concurrenten zijn, maar zich in andere opzichten in een vergelijkbare situatie bevinden." (r.o. 49) 
Het Marks \& Spencer-arrest wijst erop dat het gelijkheidsbeginsel 'tot uitdrukking' komt in het beginsel van fiscale neutraliteit. Tevens indiceert het Hof dat het algemene gelijkheidsbeginsel ruimer is, doordat het niet enkel gericht is op gelijkheid van goederen en diensten (handelaren) die met elkaar in concurrentie staan (zie paragraaf 4.4.4.2). Vervolgens is daar in het NCC-arrest aan toe gevoegd:

"Met dit beginsel van fiscale neutraliteit heeft de gemeenschapswetgever ter zake van btw uitdrukking gegeven aan het algemene beginsel van gelijke behandeling." (r.o. 41)

“Terwijl laatstgenoemd beginsel, net als andere algemene beginselen van gemeenschapsrecht, een grondwettelijk karakter heeft, dient het beginsel van fiscale neutraliteit echter in wetgeving te worden uitgewerkt, hetgeen enkel kan geschieden door een besluit van afgeleid gemeenschapsrecht (...)." (r.o. 42)

In de laatste aangehaalde rechtsoverweging wijst het Hof erop dat het secundaire Unierecht (in casu de BTW-richtlijn) de fiscale neutraliteit dient uit te werken. Dit in tegenstelling tot het gelijkheidsbeginsel als algemeen rechtsbeginsel. Deze overwegingen lijken erop te duiden dat de fiscale neutraliteit geen algemeen rechtsbeginsel is nu het Hof erop wijst dat het een beginsel is dat opgenomen dient te worden in het secundaire Unierecht voordat het werkingskracht heeft. Dit is niet het geval. Het Hof geeft namelijk tevens aan dat de fiscale neutraliteit 'een uitdrukking' is van het gelijkheidsbeginsel, namelijk in de zin van gelijke behandeling van goederen en diensten die met elkaar concurreren. Gezien deze verwevenheid met het gelijkheidsbeginsel als algemeen rechtsbeginsel is fiscale neutraliteit in deze betekenis een algemeen rechtsbeginsel. Niet goed valt in te zien, dat als de fiscale neutraliteit niet zou zijn verwerkt in de structuur en de tekst van de BTW-richtijn, het Hof op grond van het Unierecht een ongelijke behandeling van goederen en diensten die met elkaar in concurrentie staan zou tolereren. Het gelijkheidsbeginsel maakt namelijk onderdeel uit van het primaire Unierecht en de BTW-richtlijn dient uitgelegd te worden in het licht van het primaire Unierecht (paragraaf 4.5.1).

Het interpretatiebeginsel fiscale neutraliteit is gereserveerd voor de BTW en belastingplichtigen die met elkaar in concurrentie treden (Marks \& Spencer III, Morgan Flemming, Ampliscientifica, NCC). Een enkele maal ziet men dan ook dat, wanneer de actieradius van de fiscale neutraliteit een bepaalde ongelijkheid niet kan treffen, de rol door het algemene gelijkheidsbeginsel of het non-discriminatiebeginsel in het Werkingsverdrag wordt overgenomen.

In het Minerales-arrest is een situatie aan de orde waarin belastingplichtigen die zijn gevestigd in het binnenland voorbelasting kunnen terugvragen aan de hand van een duplicaat van de factuur, terwijl daarentegen in een andere lidstaat gevestigde belastingplichtigen enkel op grond van de originele factuur een teruggaaf verzoek kunnen staven. Een dergelijk verschil in behandeling acht het Hof in strijd met het non-discriminatiebeginsel van artikel $18 \mathrm{VwEU}$. In de Minerales-case ligt een toets aan het Werkingsverdrag voor de hand. De oorzaak van de ongelijke behandeling is namelijk gelegen in het feit dat gelijke gevallen onder verschillende regels vallen (gevestigd eigen lidstaat 'soepele' BTW-richtlijn/gevestigd andere lidstaat 
'zwaardere' Achtste richtlijn). Deze ongelijkheid kan bij de materieel met elkaar botsende regels van gelijke rang niet met het interpretatiebeginsel fiscale neutraliteit worden opgeheven. De ongelijkheid die door het verschil in voorwaarden wordt opgeroepen lost het Hof op met hulp van het algemene non-discriminatiebeginsel in het Werkingsverdrag.

In het Puffer-arrest toetst het Hof aan het algemene gelijkheidsbeginsel en niet aan de fiscale neutraliteit. In het Puffer-arrest is geen vergelijking aan de orde van belastingplichtigen gevestigd in verschillende lidstaten zoals in het Minerales-arrest, zodat het Hof niet de hulp in kan roepen van het non-discriminatiebeginsel in artikel $18 \mathrm{VwEU}$, maar een beroep doet op het algemene gelijkheidsbeginsel (zie paragraaf 3.4.1.2). Het Hof komt in het Puffer-arrest tot de slotsom dat de toepassing van het leerstuk van het keuzevermogen bij belastingplichtigen die belaste handelingen verrichten niet in strijd is met het algemene gelijkheidsbeginsel omdat de situatie van belastingplichtigen verschilt van niet-belastingplichtigen en dat een eventueel verschil in behandeling het gevolg is van de toepassing van verschillende regels op verschillende situaties. In de arresten Minerales en Puffer-arrest acteert niet de voor de BTW gereserveerde fiscale neutraliteit, maar komt het Hof tot een oplossing met behulp van het algemene gelijkheidsbeginsel of het non-discriminatiebeginsel in het Werkingsverdrag.

Het beginsel van de fiscale neutraliteit is leidend bij de uitleg van de BTW-richtlijn. Daarbij is wel van belang de constatering dat het beginsel van de fiscale neutraliteit (als uitdrukking van het gelijkheidsbeginsel) op de vraag stuit: wanneer zijn handelingen vergelijkbaar? Het vaststellen of handelingen wel of niet gelijk zijn, hangt af van het criterium dat wordt gekozen om de gevallen te vergelijken. Er is altijd een richtsnoer nodig om vast te stellen of de gevallen (handelingen) gelijk zijn. Voor het beantwoorden van deze vraag speelt doorgaans de ratio van een bepaling een rol (paragraaf 4.4.4.3).

Fiscale neutraliteit als uitdrukking van het gelijkheidsbeginsel treedt enkel op als interpretatiebeginsel en uiteraard niet, zoals het gelijkheidsbeginsel als zodanig kan doen, als een norm waar de overheid zich in zijn verhouding tot de burger/belastingplichtige aan moet houden. De fiscale neutraliteit als interpretatiebeginsel zien wij, in het onderzoek, bij de startende ondernemer (paragraaf 7.2.2), bij publiekrechtelijke lichamen (paragraaf 7.4), het splitsen van vergoedingen (paragraaf 9.4) en de vrijstellingen (v10.4).

Paragraaf 13.2.3 gaat nader in op de wijze waarop dit interpretatiebeginsel het BTWrecht uitlegt.

\subsubsection{Fiscale neutraliteit als stelselbeginsel}

Het begrip fiscale neutraliteit komt in de jurisprudentie niet alleen voor als uitdrukking van het gelijkheidsbeginsel, maar ook in een betekenis die weinig met een algemeen rechtsbeginsel als zodanig heeft te maken en ligt op het terrein van de 
BTW als stelsel van belasting (economische activiteiten bevrijden van de voorbelasting, zie paragrafen 2.2 en 2.4). De term fiscale neutraliteit in de betekenis dat economische activiteiten van voordruk moeten worden bevrijd komen wij tegen bij de arresten:

- die betrekking hebben op de aanvang van de belastingplicht (Rompelman, Ghent Coal, Gabalfrisa, zie paragraaf 7.2); en

- die betrekking hebben op de nationale administratieve verplichtingen (Schmeink \& Strobel, Stadeco, zie de paragrafen 12.2.2 en 12.3.2.1).

In deze arresten overweegt het Hof, dat de aftrekregeling tot doel heeft, de ondernemer geheel te ontlasten van de in het kader van al zijn economische activiteiten verschuldigde of betaalde BTW, en spreekt het van basisbeginsel van het BTWstelsel. Het communautaire BTW-stelsel waarborgt derhalve een volstrekt neutrale belasting van alle economische activiteiten, ongeacht het oogmerk of het resultaat van die activiteiten, mits die activiteiten op zich aan de heffing van BTW zijn onderworpen (paragrafen 7.2 en 12.2.2). Overwegingen in deze woorden of strekking van het Hof richten zich derhalve op de BTW als stelsel van belasting. Zoals in paragrafen 2.4 en 11.3 naar voren komt is het bevrijden van belastingplichtigen van voordruk één van de kenmerken van de BTW als belasting en wat naar mijns inziens neerkomt op de BTW als verbruiksbelasting.

\subsubsection{Fiscale neutraliteit, analoge toepassing en de ratio van de bepaling}

De analogieredenering heeft betrekking op gevallen die niet met zo veel woorden in de regelgeving worden genoemd, maar een sterke gelijkenis vertonen met gevallen die wel in de regelgeving worden genoemd (paragraaf 4.4.3.2). Gebleken is dat het Hof de fiscale neutraliteit ziet als een uitdrukking van het gelijkheidsbeginsel (paragraaf 4.4.4.2). Het streven het gelijke gelijk te behandelen hebben de analogieredenering en de fiscale neutraliteit gemeen. In paragraaf 4.4.3.2 is naar voren gebracht dat het gelijkheidsbeginsel steun nodig heeft van een richtsnoer dat bepaalt of de gevallen vergelijkbaar zijn.

In paragraaf 4.4.3.2 is verduidelijkt dat een analoge toepassing van een regel veelal gebaseerd is op de ratio van de bepaling. Uit de ratio van de analoog toe te passen regel is dan af te leiden of sprake is van gelijke gevallen. In essentie gaat het om de vraag of het te beoordelen geval gelijk is aan de gevallen uit de analoog toe te passen regel. De gelijkheid moet dus in verband staan met de inhoud van de regel. In de betekenis van de regel zijn dan dienovereenkomstig de argumenten te vinden om de regel toe te passen. Het Hof gebruikt interpretatieve argumenten - zoals een onderzoek naar de ratio van een bepaling - om een analoge toepassing van een regel te onderbouwen.

Ook bij toepassing van het fiscale neutraliteitsbeginsel als interpretatiebeginsel, kan de ratio van een bepaling worden gebruikt om te beoordelen of sprake is van soortgelijkheid van goederen of diensten. Bij de fiscale neutraliteit gaat het veelal om de vraag of de gevallen (handelingen) gelijk zijn. Deze gelijkheid van de gevallen 
moet in verband staan met de inhoud van een regel. In de ratio van een regel zijn dan de argumenten te vinden om de gevallen (handelingen) gelijk te schakelen. Gebleken is dat het Hof de ratio van een bepaling gebruikt om de fiscale neutraliteit betekenis te geven en zo naar een oplossing stuurt. In het Rompelman-arrest (paragraaf 7.2) beschrijft het Hof allereerst de ratio (r.o. 19), namelijk dat de aftrekregeling tot doel heeft, de ondernemer geheel te ontlasten van de in het kader van al zijn economische activiteiten verschuldigde of betaalde BTW. Het BTW-stelsel waarborgt derhalve een volstrekt neutrale fiscale belasting van alle economische activiteiten, ongeacht het oogmerk of het resultaat van die activiteiten mits die activiteiten op zich aan de heffing van BTW worden onderworpen. Na het weergeven van de ratio vervolgt het Hof (r.o. 23) dat, het beginsel van fiscale neutraliteit van de BTW ten aanzien van de belasting van de ondernemer vereist, dat de eerste investeringsuitgaven die worden gedaan ten behoeve en ter verwezenlijking van een onderneming, als economische activiteiten worden aangemerkt. Het zou in strijd zijn met dat beginsel, indien die activiteiten worden geacht eerst een aanvang te nemen op het tijdstip waarop een onroerend goed daadwerkelijk wordt geëxploiteerd, dat wil zeggen wanneer de belastbare inkomsten ontstaan. Iedere andere uitlegging van artikel 9, BTW-richtlijn zou de ondernemer bij het verrichten van zijn economische activiteit belasten met de kosten van BTW, zonder dat hij die zou kunnen aftrekken, en zou neerkomen op een willekeurig onderscheid tussen investeringsuitgaven voor en tijdens de daadwerkelijke exploitatie van een onroerend goed. Een ieder die investeringshandelingen verricht, welke ten nauwste verband houden met en noodzakelijk zijn voor de toekomstige exploitatie van een onroerend goed, is derhalve te beschouwen als belastingplichtige in de zin van artikel 9, BTW-richtlijn. Uit het Rompelman-arrest blijkt dat het Hof de gelijkheid zoekt in de ratio van de regel (in casu het doel van het aftrekrecht, namelijk het bevrijden van voorbelasting). Dezelfde structuur en redenering volgt het Hof in de eerder genoemde arresten: Ghent Coal, Inzo en Gabalfrisa, dan wel verwijst het naar het Rompelman-arrest.

Bijzonder aan deze constatering is dat de ratio van een regeling een rol speelt bij de toepassing van de fiscale neutraliteit. Of - in deze betekenis - bij de toepassing van het gelijkheidsbeginsel. In paragraaf 2.2 is het verbruiksbeginsel neergezet als onderdeel van het rechtskarakter en in hoofdstuk 3 zijn de algemene rechtsbeginselen beschreven. Wat betreft de fiscale neutraliteit als uitdrukking van het gelijkheidsbeginsel is er daarentegen een relatie. Er is niet zozeer sprake van een botsing van het rechtskarakter met het gelijkheidsbeginsel. Eerder is het zo dat het gelijkheidsbeginsel als interpretatiebeginsel een bondgenoot vindt in het rechtskarakter van de BTW. In het Rompelman-arrest is dat het doel van de regeling in geschil, namelijk het bevrijden van voorbelasting. Het Hof gebruikt in het Rompelman-arrest het doel van de regeling om de gelijkheid van de handelingen te onderbouwen. De relatie tussen ratio - fiscale neutraliteit - gelijkheidsbeginsel is niet zonder betekenis. Het belang van de ratio van de regeling bij het bepalen van de gelijkheid, betekent namelijk dat als de context/ratio is te onderscheiden, dat dan ook geen verstoring van de fiscale neutraliteit aan de orde is. Uit de ratio van de bepaling blijkt dan dat de gevallen verschillend zijn en niet onder de (zelfde) regel vallen. 
Het Hof verwijst in het bijzonder in de arresten over het recht op aftrek van voorbelasting en de vrijstellingen naar het doel van de regeling. Zie de arresten over de uitleg van het recht op aftrek (zonder uitputtend te zijn): Cibo (r.o. 29), Kretztechnik (r.o. 34), Midland Bank (r.o. 19), Abbey National I (r.o. 24), I/S Fini (r.o. 25). Het Hof verwijst in deze arresten naar het doel van het recht op aftrek van voorbelasting, namelijk het bevrijden van de economische activiteiten van voorbelasting. Voor de arresten op het terrein van de vrijstellingen zie onder meer: de arresten Ygeia (r.o. 23), Kügler (r.o. 29), Dornier (r.o. 43), waar het Hof overweegt dat het doel van de medische vrijstelling is het voorkomen dat de dienst ontoegankelijk is vanwege verhoogde kosten. Zie over de uitleg van de postvrijstelling het TNTarrest (r.o. 32 en 33) waar het Hof overweegt dat het doel van vrijstellingen is het begunstigen van bepaalde activiteiten van algemeen belang. Zie over het doel van de kostenreductie bij de financiële vrijstellingen de arresten: Velvet Steel (r.o. 24), Swiss RE (r.o. 49) en SEB (r.o. 21). Ook betrekt het Hof geregeld het rechtskarakter (zie paragraaf 2.2 voor het verbruiksbeginsel en voor de neutraliteit als stelselbeginsel paragraaf 2.4) in de overwegingen, zie in dit kader de arresten: Hong Kong (r.o. 9), Mohr (r.o. 22) en het systeem van de BTW (de afwenteling op de eindverbruiker) in de arresten: Careda (r.o. 14 en 15), Gibbs (r.o. 19).

Komt de fiscale neutraliteit - als uitdrukking voor de BTW van het gelijkheidsbeginsel - in een arrest voor, dan is in het zelfde arrest ook veelal de ratio van een bepaling te vinden. Zie onder meer de arresten Kügler (r.o. 20), Ygeia (r.o. 32 en 33) en TNT (r.o. 33).

Uit het voorgaande blijkt dat als de fiscale neutraliteit een rol speelt bij de uitleg van de BTW-richtlijn, de gelijkheid van de gevallen kan worden gevonden in de ratio van de bepaling. In het Wellcome-arrest gebruikt het Hof echter niet expliciet de ratio om de gelijkheid te bepalen, maar vindt er een directe vergelijking plaats (paragraaf 7.3.2). Een belangrijke overweging bij de behandeling van de rechtsvraag van de belastingplicht betrof de vergelijking met de positie van de particulier. In deze procedure is een steunoverweging bij de vaststelling dat men niet belastingplichtig is, dat de aandelentransacties van Wellcome vergelijkbaar zijn met die van een particulier. De ratio van een bepaling speelt een rol bij het ondersteunen van de gelijkheid van de gevallen, niettemin blijkt uit het Wellcome-arrest dat er een enkele keer een rechtstreekse vergelijking plaatsvindt zonder steun van de ratio van een bepaling.

\subsection{Rechtszekerheids- en vertrouwensbeginsel}

\subsubsection{Objectieve uitleg}

In paragraaf 10.5 zijn behandeld - aan de hand van het BLP-arrest, Cantor-arrest en het MKG-arrest - situaties waarin belanghebbenden een beroep doen op een vrijstelling terwijl de vrijstelling volgens de letterlijke tekst van de bepaling niet op hen van toepassing is, met als argument dat men voor een naastliggende, alsdan 
vrijgestelde, vorm zou hebben kunnen kiezen. Daartoe leent het rechtszekerheidsbeginsel zich niet. Men kan daaronder geen bescherming krijgen wanneer men de belaste, 'richtlijnduidelijke', vorm heeft gekozen. Niet van belang is dat belanghebbende een keuze heeft gehad om zijn handelingen anders vorm te geven, om een zelfde economisch resultaat te bereiken. Het interessante van deze gevallen, waarin het rechtszekerheidsbeginsel juist geen bescherming kan geven, is mijns inziens dat het zich leent voor bredere toepassing dan enkel op het terrein van de vrijstellingen. Ofschoon rechtens (grondwettelijk; legaliteit) vanzelfsprekend, is het interessante voor de rechtspraktijk, waarin men na gedane zaken vaak een beroep doet op 'ik had het ook anders kunnen doen', dat het rechtszekerheidsbeginsel geen bescherming biedt en dit zich ook uitstrekt tot een bredere toepassing, waarin men eenmaal de vormen gekozen heeft met betrekking tot bijvoorbeeld belastingplicht, tarief en recht op aftrek van voorbelasting.

Het is aan belanghebbende om vooraf de voor- en nadelen af te wegen. Indien eenmaal een keuze is gemaakt, dan stuurt het rechtszekerheidsbeginsel als interpretatiebeginsel (zie paragraaf 10.5) naar een stelsel waar uit de objectieve handelingen de BTW-gevolgen blijken. Zie ook hierna, waar het rechtszekerheidsbeginsel stand houdt tot het moment van fraude of misbruik.

\subsubsection{Geen bescherming in geval van fraude of misbruik}

Het Hof heeft beslist - Halifax (r.o. 68), I/S Fini (r.o. 32), Kittel (r.o. 54), Kefalas (r.o. 20), Diamantis (r.o. 33), Paletta (r.o. 25), zie de paragrafen 5.3, 6.3 en 10.7 - dat het Unierecht geen bescherming biedt in geval van fraude of misbruik van het recht. Dit uitgangspunt geldt in het gehele Unierecht.

In geval van misbruik van recht is de gekozen juridische opzet van de handelingen door belanghebbenden gecreëerd met het oog op de fiscale gevolgen. In dat geval is veelal sprake van een bewuste risico aanvaarding die in geval van strijd met het doel van de regels, een doorbreking van de rechtszekerheid kan rechtvaardigen. Ik heb mij in paragraaf 5.3 afgevraagd of bij toepassing van het beginsel van het verbod van misbruik van recht wel sprake is van een conflict met het rechtszekerheidsbeginsel. Het is namelijk één van de voorwaarden om het verbod van misbruik van recht in stelling te kunnen brengen dat er strijd is met het doel van de regels. Het doel van de regels zal veelal kenbaar zijn bij belanghebbende. Dit blijkt namelijk uit het feit dat belanghebbende kiest voor een gekunstelde opzet. Op deze wijze probeert hij namelijk onder het doel dat de regels beogen te bereiken uit te komen. Door te pogen met een juridische opzet het doel van de regels te frustreren, geeft belanghebbende aan het doel dat de regels proberen te bereiken maar al te goed te kennen. Strijd met het rechtszekerheidsbeginsel lijkt mij dan ook niet aan de orde.

\subsubsection{Rechtszekerheidsbeginsel in de uitvoeringssfeer}

Hoofdstuk 5 beschrijft een drietal terreinen waar de rechtszekerheid als algemeen rechtsbeginsel van formeel recht aan de orde is (de formele rechtskracht van 
besluiten, de terugwerkende kracht van regels en uitgestelde werking van arresten). Het gaat dan om de formele relatie overheid - belastingplichtige, primair niet om interpretaties van een materieel rechtelijke bepaling in de BTW-richtlijn.

Het Hof neemt als uitgangspunt in de arresten Rewe en Comet, dat de vaststelling en toepassing door een lidstaat van een redelijke beroepstermijn voldoet aan het doeltreffendheidbeginsel en dan ook in beginsel is toegestaan. Wel blijkt uit deze arresten dat een lidstaat een tweetal voorwaarden in acht moet nemen. Allereerst mogen de procesregels voor rechten gebaseerd op het Unierecht niet ongunstiger zijn dan voor soortgelijke nationale vorderingen (non-discriminatiebeginsel). Ten tweede mag het niet zo zijn dat het uiterst moeilijk is om rechten gebaseerd op het Unierecht te realiseren (doeltreffendheidbeginsel). De toepassing van fatale beroepstermijnen is te zien als een uitwerking van het rechtszekerheidsbeginsel en een goede proceseconomie.

Op de formele rechtskracht (paragraaf 5.4) staat het Hof inbreuken toe. Deze inbreuken zijn uiteengezet in een serie van arresten. Met als beginpunt het Emmot-arrest en voorlopig eindpunt de zaak Kühne \& Heitz (zie paragraaf 5.4 voor de tussenliggende arresten). In het laatstgenoemde arrest komt naar voren dat doorbreking van de formele rechtskracht - dan wel de rechtszekerheid voor de lidstaat - enkel in bijzondere situaties het geval kan zijn. Voldaan moet dan zijn aan een viertal voorwaarden:

- Het bestuursorgaan is naar nationaal recht bevoegd om op het besluit terug te komen.

- Het in geding zijnde besluit definitief is geworden ten gevolge van een uitspraak van de hoogste nationale rechter.

- Uit latere rechtspraak van het Hof blijkt dat deze uitspraak berust op een onjuiste uitleg van het Unierecht, zonder dat een prejudiciële vraag is gesteld.

- Belanghebbende heeft zich onmiddellijk tot het bestuursorgaan gewend na kennis te hebben genomen van die rechtspraak van het Hof.

De voorwaarde dat het moet gaan om een belanghebbende die in eerste instantie door de rechter in het ongelijk is gesteld, beperkt in belangrijke mate de groep van belastingplichtigen bij wie de doorbreking van de formele rechtskracht aan de orde kan zijn.

Zagen wij hiervoor dat de fatale beroepstermijn - uitwerking van het rechtszekerheidsbeginsel - de overheid bescherming biedt, in het navolgende onderwerp zien wij een tegenhanger hiervan. Bij het verbod op wetswijzigingen met terugwerkende kracht mag immers niet met terugwerkende kracht belastingplichtigen rechten worden ontnomen (paragraaf 5.5). Het is dan namelijk zo dat het rechtszekerheidsbeginsel belastingplichtigen beschermt tegen claims die zijn ontstaan in verstreken tijdvakken (arresten Belgodex en Schlosstrasse).

Uit het arrest Goed Wonen II blijkt dat terugwerkende kracht van wetgeving is toegestaan als aan een tweetal voorwaarden is voldaan: 
1. indien dit voor een doel van algemeen belang noodzakelijk is; en

2. het rechtmatig vertrouwen van betrokkenen naar behoren in acht wordt genomen.

Wat de eerste voorwaarde betreft kan de vrees voor constructies die worden opgezet tussen het tijdstip van bekendmaken van de wetswijziging en het in werking treden van de wet een doel van algemeen belang zijn dat de terugwerkende kracht rechtvaardigt. Wat de tweede voorwaarde betreft moeten de informatiemethoden voldoende duidelijk zijn voor de betrokkenen om de gevolgen van de wetswijziging te begrijpen.

Het Hof kan in bijzondere situaties een arrest een uitgestelde werking geven (paragraaf 5.6). Daar bedoel ik mee dat de gevolgen niet onmiddellijk intreden maar na een bepaalde periode zodat een lidstaat (of een andere procespartij) een zekere periode heeft om zich in te stellen op de gevolgen. Het is evident dat het leerstuk is ontwikkeld onder invloed van het rechtszekerheidsbeginsel. Het beginsel beschermt partijen tegen onverwachte schokken/gevolgen in de jurisprudentie (Defrene II-arrest). Ingeval een arrest uitgestelde werking heeft dan vindt het Hof een evenwicht tussen een juiste en uniforme uitleg van het Unierecht en dat van de rechtszekerheid in de rechtsbetrekkingen die, hoewel op basis van een onjuiste uitleg, te goede trouw zijn aangegaan. Het uitgangspunt is een werking ex tunc (arrest My Travel), echter als cumulatief voldaan is aan de volgende twee voorwaarden is een werking ex nunc aan de orde:

1. Particulieren of lidstaten zijn tot een met de strekking van een communautaire bepaling strijdig gedrag gebracht op grond van een objectieve, grote onzekerheid over de strekking van de communautaire bepalingen, aan welke onzekerheid het gedrag van andere lidstaten of van de Commissie eventueel heeft bijgedragen (arresten Defrene II, EKW, Bosman en Legros).

2. De beslissing van het Hof heeft ernstige economische gevolgen voor een lidstaat (arresten EKW en Grezelcyk).

Kortom, van belang is onzekerheid over de strekking van een Unieregeling en het gevaar van ernstige economische verstoring, waarbij van belang is dat onder dit laatste niet is te verstaan een omvangrijke derving van belastingopbrengst. In paragraaf 5.6 zijn de bovenstaande voorwaarden toegelicht. Tevens bleek dat de lidstaten zich geregeld beroepen op een uitgestelde werking, echter dit zelden goed onderbouwen (arresten Uudenkaupungin Kaupunki, Linneweber en Grzelczyk). Beperkte toepassing van het leerstuk lijkt mij gewenst om zo te zorgen dat de lidstaten richtlijnen correct implementeren in hun nationale regels.

In het Unierecht kan het gaan om de 'gezagsrelatie' tussen Uniewetgever en de lidstaat als implementator. Het rechtszekerheidsbeginsel biedt dan bescherming aan de lidstaten (formele rechtskracht en uitgestelde werking van arresten). In de 'gezagsrelatie' tussen nationale wetgever en belastingplichtige biedt het rechtszekerheidsbeginsel bescherming aan de belastingplichtige (in beginsel geen terugwerkende kracht regelgeving). 


\subsubsection{Rechtszekerheid en de uitleg naar doel en strekking}

Een uitleg naar doel en strekking van de regelgeving kan op gespannen voet staan met het rechtszekerheidsbeginsel. Vooral als het Hof kiest voor een uitleg in het nadeel van een belastingplichtige met voorbijgaan aan de duidelijke woorden van de tekst kan deze spanning aan de orde zijn (paragraaf 4.4.3.4). In paragraaf 3.4.3.1 is naar voren gebracht dat de berekenbaarheid van het recht van belang is en dit laat zich bepaald niet minder gelden in het belastingrecht. In paragraaf 5.3 zijn arresten aan de orde geweest waarin het Hof het BTW-recht uitlegt in het nadeel van belanghebbende. Dit is in het bijzonder het geval als belanghebbende kiest voor een gekunstelde opzet om zo de BTW-druk te mitigeren. In het DFDS-arrest (inzake vaste inrichting/vertegenwoordiger), Levob-arrest (inzake combinatie prestaties tot dienst), RAL-arrest (inzake begrip vermakelijkheidsdienst), BUPA-arrest (inzake vooruitbetaling op nog niet vaststaande leveringen) en het Centralan-arrest heeft het Hof constructies 'getackeld' met voorbijgaan aan het bijzondere beginsel van het verbod van misbruik van recht. Een opvallend arrest in deze lijn is het Centralanarrest. Naar mijn mening een bijzonder arrest omdat het Hof expliciet vermeldt dat de gekozen uitleg niet in de regels is te vinden. De BTW-richtlijn voorziet niet in regels voor het geval aan de orde in het arrest. Het Hof kiest voor een uitleg die in overeenstemming is met het doel van de regels. Zoals in paragraaf 5.3 verduidelijkt, verijdelt het Hof de constructie met een analogieargumentatie die haar oorsprong vindt in de ratio van de bepaling. Bijzonder is - naar mijn mening - dat belanghebbende naar alle waarschijnlijkheid deze analoge toepassing niet zag aankomen.

In de Nederlandse literatuur is gediscussieerd over de wijze waarop een analogieargumentatie zich verhoudt tot een bijzonder leerstuk als fraus legis. De literatuur is overwegend van mening dat veelal - op grond van het rechtszekerheidsbeginsel de extra eisen van het bijzondere leerstuk noodzakelijk zijn en dat voor een analogieargumentatie geen plaats is als de norm voor belanghebbende niet kenbaar is.

In het Centralan-arrest geeft het Hof expliciet aan dat men afwijkt van de regels in de BTW-richtlijn omdat het doel van de regels daarmee is gediend. Naar mijn mening staat een dergelijke interpretatietechniek op gespannen voet met het rechtszekerheidsbeginsel nu belanghebbende een dergelijke uitleg niet had kunnen voorzien en dient de voorkeur - uit oogpunt van rechtszekerheid - constructies te toetsen aan de eisen van het verbod van misbruik van recht. Een ontwikkeld beginsel van verbod van misbruik van recht waarborgt dat de uitleg van de regels niet op gespannen voet komt te staan met het rechtszekerheidsbeginsel, in het bijzonder de eis dat uit het geheel van objectieve factoren moet blijken dat het wezenlijke doel van de betrokken transacties erin bestaat een belastingvoordeel te verkrijgen vormt zo'n waarborg. Uit deze gerichtheid van de opzet van de betrokken transacties, blijkt namelijk dat belanghebbende de ratio van de bepaling kent. Deze probeert hij weloverwogen te ontgaan. 


\subsection{Evenredigheidsbeginsel}

\subsubsection{Algemeen rechtsbeginsel van formeel recht}

De toetsing aan het evenredigheidsbeginsel komt (Fedesa-arrest) - samengevat neer op de volgende aspecten (3.4.2.2):

1. Geschiktheid.

2. Noodzakelijkheid.

3. Evenwichtigheid van de maatregel.

Niet in alle arresten waar het beginsel een rol speelt zijn de bovenstaande drie aspecten even duidelijk te onderscheiden. Het evenredigheidsbeginsel laat zich dan ook in de wisselende krachten van de elementen gelden (de arresten Ampafrance, aspecten 2 en 3; Commissie/België (nr. 324/82) 1 en 2; Skripalle enkel 2; voor hetzelfde verschijnsel als interpretatiebeginsel zie bijvoorbeeld: Minerales enkel 2; Langhorst 2 en 3, Sosnowska 2 en 3). De precisie van de onderlinge verhoudingen daarvan in de arresten heb ik niet geanalyseerd. Wel valt op dat de noodzakelijkheid van de maatregel prominent in de jurisprudentie aanwezig is.

Het evenredigheidsbeginsel laat zich gelden bij het inkaderen van de machtiging voor een maatregel ter vereenvoudiging en voorkoming van misbruik (artikel 395, BTW-richtlijn). Op een aantal plaatsen is aan deze machtiging aandacht besteed, namelijk bij:

- Maatregelen ter voorkoming van misbruik (paragraaf 5.2; arresten Commissie/ België (nr. 324/82), BATI).

- Minimum maatstaf van heffing (paragraaf 9.2.1; arresten Direct Cosmetics, Commissie/Frankrijk, K-line, Skripalle).

- Beperking van het recht op aftrek (paragraaf 11.5.1; arresten Ampafrance, Sudholz).

Het Hof heeft in het Ampafrance-arrest expliciet beslist dat een maatregel op grond van artikel 395, BTW-richtlijn ter vereenvoudiging en voorkoming van misbruik dient te voldoen aan het evenredigheidsbeginsel.

Er kan worden vastgesteld dat het Hof, afgezien van het feit dat de rechtspraak op het terrein van de minimum maatstaf de eerdere rechtspraak inzake de criteria van het evenredigheidsbeginsel bevestigt, onder omstandigheden forfaitaire regelingen op dit terrein accepteert. Ook is duidelijk dat gelieerde verhoudingen aanleiding kunnen zijn om een minimum maatstaf van heffing ter voorkoming van misbruik te introduceren. Daarbij moet wel in het oog worden gehouden, dat dergelijke maatregelen niet verder mogen gaan dan strikt noodzakelijk is om het beoogde doel te bereiken. Dit betekent onder meer dat de fictieve maatstaf niet hoger mag zijn dan de normale marktprijs (paragraaf 9.2; arrest Skripalle).

De lidstaten hebben verscheidene pogingen gedaan om het aftrekrecht in te perken daarbij steunend op een machtiging op grond van artikel 395, BTW-richtlijn. Uit de arresten Ampafrance (paragraaf 11.5.1.2) en Sudholz (paragraaf 11.5.1.3) blijkt, dat het 
evenredigheidsbeginsel het neutraliteitsbeginsel beschermt. Ik doel dan niet op het neutraliteitsbeginsel als uitdrukking van het gelijkheidsbeginsel, maar als stelselbeginsel dat probeert te bereiken dat goederen en diensten worden bevrijd van de voorbelasting (zie paragraaf 3.5.2).

De beide arresten kennen een verschillend resultaat. In het Ampafrance-arrest is de machtiging in strijd met het evenredigheidsbeginsel, terwijl in het Sudholz-arrest de test wordt doorstaan. Volgens mij is dit verschil in resultaat te verklaren door het gegeven dat de beschikking in het Sudholz-arrest geen volledige uitsluiting van het aftrekrecht kent. En voorts gaf Duitsland in deze procedure aan, dat dit percentage niet zomaar was geprikt, maar is gebaseerd op een gemiddeld gebruik van de betrokken voertuigen. Kortom, de Duitse regeling was zo veel als mogelijk toegesneden op het beoogde doel. En dat is waar het uiteindelijk bij het evenredigheidsbeginsel om gaat. Het Ampafrance-arrest en het Sudholz-arrest bevatten dan ook aanwijzingen voor de lidstaten, Commissie en Raad voor het ontwikkelen van regels die hun basis vinden in artikel 395, BTW-richtlijn. Zoals het Sudholz-arrest laat zien, is van belang dat een lidstaat kan onderbouwen dat de maatregel geschikt is om het nagestreefde doel te bereiken en tevens is van belang dat de maatregel geen overkill tot gevolg heeft. In het Sudholz-arrest voorkomt de Duitse regering dit door de reikwijdte van de maatregel te beperken (in casu geen beperking van de aftrek bij een zeer laag privégebruik).

Het Hof brengt in de beschikking Transport Service NV het evenredigheidsbeginsel in het spel om daarmee de grenzen van de werking van het Unierecht - d.w.z. de grenzen tot waar men positiefrechtelijk kan gaan - aan te geven. De lijn is deze: de BTW-richtlijn kent geen bepaling die de inning van BTW regelt. Daaruit volgt dat de lidstaten in beginsel volledige vrijheid hebben om de wijze van heffen (en naheffen) te regelen. Maar daarbij moet wel het overige Unierecht (buiten de BTW-richtlijn) in acht worden genomen. Het Hof heeft daarbij de algemene rechtsbeginselen op het oog die deel uitmaken van het primaire Unierecht. In het bijzonder het evenredigheidsbeginsel: de maatregelen mogen niet verder gaan dan ter bereiking van het doel noodzakelijk is. Uit de beslissing inzake Transport Service NV blijkt dus, dat als het secundaire Unierecht (in casu de BTW-richtlijn) geen regeling bevat die de materie regelt, dit voor het Hof aanleiding is te toetsen aan de algemene rechtsbeginselen, in casu het evenredigheidsbeginsel (zie paragraaf 4.5.2.5 en de daar behandelde jurisprudentie).

\subsubsection{Het evenredigheidsbeginsel als interpretatiebeginsel}

Het evenredigheidsbeginsel als interpretatiebeginsel komen wij in het onderzoek tegen bij de navolgende onderwerpen: de vrijstellingen met aftrek van voorbelasting, meer in het bijzonder in geval van intracommunautaire leveringen (paragraaf 10.7), bij de risicoverdeling van fraudegevolgen (paragrafen 5.2, 6.3, 10.7), voorts bij bewijsvoorschriften (paragrafen 6.3, 12.3), verder bij de administratieve verplichtingen (paragrafen 12.2 en 12.3 ) en ten slotte bij de machtiging tot afwijking (paragrafen 5.2, 9.2, 11.5.1). 
Het eerste terrein waarop het evenredigheidsbeginsel een rol speelt is dat van de rechtspraak inzake de vrijstelling met aftrek van voorbelasting in geval van intracommunautaire leveringen. In de in paragrafen 10.6 en 10.7 behandelde arresten Teleos en Colleé, waarin ook het rechtszekerheidsbeginsel een rol speelde, blijkt dat het evenredigheidsbeginsel bij de uitleg van de regelgeving op het terrein van de intracommunautaire leveringen betekenis heeft. De lidstaten moeten niet alleen in overeenstemming met het evenredigheidsbeginsel middelen aanwenden waarmee het door het nationale recht nagestreefde doel weliswaar doeltreffend kan worden bereikt, maar ook de doelstellingen en beginselen van de betrokken Unieregeling zo min mogelijk aantasten. Zo mogen de door de lidstaten vastgestelde maatregelen weliswaar de rechten van de schatkist zo doelmatig mogelijk proberen te beschermen, maar zij mogen niet verder gaan dan voor dit doel noodzakelijk is.

Het Hof wijst erop dat het doel belastingfraude te voorkomen rechtvaardigt dat de leveranciers soms zware verplichtingen worden opgelegd. De verdeling van de risico's tussen de leverancier en de belastingautoriteiten, naar aanleiding van fraude door een derde, moet evenwel verenigbaar zijn met het evenredigheidsbeginsel. In het Teleos-arrest wijst het Hof erop, dat een regeling waarbij de verantwoordelijkheid voor de betaling van de BTW volledig bij de leverancier komt te liggen, ongeacht of hij al dan niet bij de fraude betrokken is, het geharmoniseerde BTWstelsel niet noodzakelijk beschermt tegen fraude en misbruik door de afnemer. Kortom, het middel van de volledige afwenteling van de risico's op de leverancier is niet geschikt om het doel te bereiken.

In het Collée-arrest wijst het Hof formele bewijsvoorschriften die voorbijgaan aan de materiële werkelijkheid af, omdat zij verdergaan dan nodig is om de juiste heffing van BTW te bereiken. Strijd met het evenredigheidsbeginsel is dan aan de orde.

Op het terrein van de administratieve verplichtingen in het binnenlandsverkeer is het evenredigheidsbeginsel van belang bij de interpretatie van de bepalingen in de BTW-richtlijn. Het evenredigheidsbeginsel laat zich gelden in het: Jeunehommearrest (vermeldingen op factuur, paragraaf 12.4.1.3), Langhorst-arrest (creditfactuur, paragraaf 12.2.1), Minerales-arrest (duplicaat factuur, paragraaf 12.4.1.5), Gabalfrisaarrest (aanvullende voorwaarden aftrek, paragraaf 12.4.2.1), Stadeco-arrest (correctie verschuldigdheid, paragraaf 12.2.2), Schmeink \& Strobel-arrest (correctie verschuldigdheid, paragraaf 12.2.2) en het Sosnowska-arrest (doorschuiven teruggaaf, paragraaf 12.4.2.2). Het Hof hanteert een duidelijk doel - middel afweging om overmatige administratieve eisen aan banden te leggen. In de arresten Langhorst en Minerales onderzoekt het Hof ook de noodzakelijkheid van de maatregel.

Bij de toepassing van het evenredigheidsbeginsel speelt een rol het doel dat de bepaling beoogt te bereiken. Het Hof weegt het doel dat de regeling beoogt te bereiken af tegen het middel dat een lidstaat kiest om het doel te bereiken. Op het terrein van de vrijstellingen of de machtigingen om af te mogen wijken van de BTW-richtlijn is het doel dat wordt beoogd het bevrijden van de transactie van de BTW-druk (arresten 
Ampafrance en Sudholz). Wat wij bij de toepassing van het gelijkheidsbeginsel zien steun bij de ratio van een bepaling -, zien wij dan ook bij het evenredigheidsbeginsel.

Het evenredigheidsbeginsel heeft zonder meer een invloed op de vorming van het BTW-recht. En wel in twee toepassingsvelden, namelijk als algemeen rechtsbeginsel van formeel recht (relatie overheid-particulier) en als interpretatiebeginsel (uitleg bepaling in de BTW-richtlijn).

\subsection{Relatie tussen algemene rechtsbeginselen en klassieke BTW-beginselen}

Het gelijkheidsbeginsel, evenredigheidsbeginsel en het rechtszekerheidsbeginsel zijn nadrukkelijk aanwezig in de jurisprudentie van het Hof, gewezen op het gebied van, kort gezegd, de BTW-richtlijnen. Het beginsel van de fiscale neutraliteit, eveneens als interpretatiebeginsel functionerend, is een uitdrukking van het gelijkheidsbeginsel specifiek voor de BTW. Het opereert beperkter in tweeledige zin: naar het toepassingsgebied gemeten, slechts in de beschouwing nemend de handelingen die met elkaar in concurrentie treden. Een enkele maal ziet men dan ook dat, wanneer de actieradius van de fiscale neutraliteit een bepaalde ongelijkheid niet kan treffen, de rol door het algemene gelijkheidsbeginsel of het non-discriminatiebeginsel in het Werkingsverdrag wordt overgenomen.

De fiscale neutraliteit komt in de jurisprudentie ook voor niet als algemeen rechtsbeginsel, maar in de betekenis van het bevrijden van voorbelasting van economische activiteiten (stelselbeginsel). Het gelijkheidsbeginsel als interpretatiebeginsel heeft een criterium nodig om te bepalen dat de gevallen gelijk zijn (paragraaf 4.4.4). Het criterium is veelal te vinden in de ratio van een bepaling. De ratio van een bepaling geeft dan aan of gevallen gelijk zijn en dan ook wel of niet onder dezelfde regel dienen te vallen. Het onderscheid tussen fiscale neutraliteit als uitdrukking van het gelijkheidsbeginsel voor de BTW en fiscale neutraliteit als stelselbeginsel is niet absoluut. Toepassing van de fiscale neutraliteit (als uitdrukking van het gelijkheidsbeginsel) vindt - waar, anders dan bijvoorbeeld bij vrijstellingen, de focus van een rechtsvraag op de voorbelasting komt te liggen - steun/legitimiteit in het doel dat de bepaling nastreeft te bereiken, namelijk het bevrijden van voordruk in geval van economische activiteiten. Het Hof verwijst in bijna elk arrest op het terrein van de BTW naar het doel van de bepaling (paragraaf 13.2.3). Komt de fiscale neutraliteit als uitdrukking van het gelijkheidsbeginsel - in een arrest voor, dan is in hetzelfde arrest veelal ook de ratio van een bepaling te vinden.

Het doel dat de regels beogen te bereiken speelt ook een rol bij het evenredigheidsbeginsel. Het Hof kijkt naar de ratio van de regels om een doel-middelafweging uit te voeren. Het middel dat een lidstaat kiest moet in verhouding staan met het doel dat de regeling beoogt te bereiken. Kortom, ook hier blijkt - zoals bij de toepassing van de fiscale neutraliteit als uitdrukking van het gelijkheidsbeginsel - steun van het klassieke BTW-beginsel (neutraliteit als stelselbeginsel). 
In de hoofdstukken 1 en 2 heb ik mij afgevraagd wat de werking en invloed is van de klassieke BTW-beginselen en of zij bruikbaar zijn bij de uitleg van het recht. Het evenredigheidsbeginsel en de fiscale neutraliteit, als uitdrukking van het gelijkheidsbeginsel, steunen veelal op de ratio van een bepaling. En deze is weer vaak terug te voeren tot het doel van de BTW, namelijk het verbruik van de consument te treffen (paragraaf 2.2 verbruiksbeginsel) en daarmee samenhangend het stelselbeginsel neutraliteit (paragraaf 2.4), welke ik aangeduid heb als klassieke BTWbeginselen. De twee algemene rechtsbeginselen kunnen niet optimaal functioneren bij de uitleg van de BTW-bepalingen zonder de klassieke BTW-beginselen. Het evenredigheidsbeginsel en de fiscale neutraliteit als uitdrukking van het gelijkheidsbeginsel hebben dan de ratio nodig van het verbruiksbeginsel en de neutraliteit als stelselbeginsel. Bij de behandeling van het verbruiksbeginsel (paragraaf 2.2) en de neutraliteit als stelselbeginsel (paragraaf 2.4) hebben wij gezien dat deze klassieke BTW-beginselen het rechtskarakter van de BTW-vormen.

Het rechtszekerheidsbeginsel biedt bescherming aan de lidstaten (formele rechtskracht en uitgestelde werking van arresten) maar uiteraard ook aan belastingplichtigen (in beginsel geen terugwerkende kracht van regelgeving). In deze leerstukken is te zien hoe het beginsel opereert in de formele relatie overheid belastingplichtige. Daarnaast acteert het als interpretatiebeginsel van de bepalingen in de BTW-richtlijn (paragraaf 13.3.1). In de volgorde van de interpretatiemethoden (paragraaf 4.4.2) staat de taalkundige op de eerste plaats, de teleologische verderop en aan het slot misbruik van recht. Een relatie tussen het rechtszekerheidsbeginsel en de klassieke BTW-beginselen komt in de jurisprudentie niet voor, omdat primair de woorden de zekerheid geven en doorgaans geacht kunnen worden het primaire doel van de regeling te verwoorden. 


\section{SUMMARY}

Application and role of general principles of law within VAT as interpreted by the European Court of Justice of the EU

\section{Introduction}

The present study investigates the influence of the general principles of law on the VAT-Directive. In particular, I focus on the following principles: equality, proportionality and legal certainty.

The subject of this research is to explore and analyse the place of the aforementioned principles in European case-law, their scope of application, their comparative effects and impacts on each other as well as their possible relationship with and influence on other aspects of VAT law. In this study I restrict my analysis by the case-law of the European Court of Justice of the EU (Court) concerning the VAT-Directive.

As it becomes evident from the VAT literature and case-law, the VAT system cannot function without its own inherent principles. In the second chapter I give their description and henceforth specify them as classic VAT principles. Here I make an analytical review of the following principles: consumption (paragraph 2.2), neutrality (paragraph 2.4), territoriality (paragraph 2.3.1) and destination or origin (paragraph 2.3.2).

To assure the proper insight into the subject of my study, I went first to analyze the general principles of law. In the third chapter I worked out their definition, as well as their place of application in the EU law. General principles of law are: prominently evident and conventionally accepted as judicially valid. The principles of equality, proportionality and legal certainty fully qualify to this definition. It's obvious that these three principals are not only universally acknowledged, but also have enough weight to exercise the influence on the whole legislative system. Classic VAT principles (principles of consumption, territoriality and destination or origin) do not meet the above-mentioned requirements and therefore cannot be defined as general principles of law. Thus, the coverage area of principle of consumption is restricted to VAT itself; principle of destination or origin is applied exclusively in order to avoid conflicts of jurisdictions; and the role of the principle of territoriality is being undermined as it becomes more difficult for a single Member State to preserve its own independent tax system. Fiscal neutrality has two possible applications. First it can operate as a systemic VAT principle (relief of a taxable person of the burden of input VAT). In this sense it is exclusively applicable within the boundaries of VAT itself and therefore does not qualify as general principle of law either. Nonetheless, it can actually fall under the category of general principles whenever, in matters relating to VAT, it expresses the principle of equality. 
The principle of prohibiting of abuse of rights is also a general principle of law considering its indisputable place in the EU juridical system as a whole. Ban on abusive practices is supported by the universal foundation of the law. This principle comes into action in situations when the interpretation of the law differs from the literal meaning of a certain provision, but nonetheless stays in conformity with its spirit and purpose, which this very provision targets to achieve (paragraph 5.3).

I differentiate between a substantive law and a so-called procedural law which defines a formal procedural relationship between a public authority (e.g. Tax Administration) and a taxable person (paragraph 3.3.1). With respect to the tax legislation which defines a taxable person, tax obligations, deduction of input VAT, taxable transactions, etc., in other words, the aspects which belong to the substantive law, the general law principles act as principles of interpretation. In this scope of application general principles of law are especially of use in interpreting or explaining the underlying purpose of the provision and, whenever appropriate, in justifying the appliance of analogical argumentation. These very principles also operate in the area of legal relationships between a public authority and a taxable person, acting as a standard to which performance of the public authority is bound to adhere. Thus, in this study I make the following distinction in the application of the general principles of law:

- within the spectrum of the formal relationship between a public authority and a taxable person;

- as a principle of interpretation of VAT law.

Furthermore, I use the definition of restrictive and extending working of the general principles of law on the VAT rules. Herewith I mean that the Court can broaden the interpretation of a VAT rule with the result that a taxable person would either benefit from a certain deduction or exemption or, on the contrary, would not be able to make use of it. The extent of this stretch can vary. It's not exceptional for the Court to extend application of the rule beyond the boundaries which have already been established by the previous juridical practice. Naturally, it can also be the case, that the Court chooses not to apply a certain obligation which would mean that a VAT rule has been interpreted in a more narrow or restricted perspective. Consequentially, in cases when these two working mechanisms result in the disadvantage for a taxable person, it can potentially lead to an inherent conflict with the principle of legal certainty (analogical argumentation, paragraph 4.4.3.4, the principle of prohibition of abuse of rights, paragraph 5.3).

A term, which falls under 'independent European Union law concept', is generally used in its autonomous sense, often apart from its meanings in the national legislative systems. The primary goal of this concept is to prevent divergencies in the interpretation of VAT rules among different Member States (paragraph 4.3).

The Court expects the interpretation of the national law to be made in a manner compatible with the VAT-Directive. This requirement becomes explicitly clear if the Court indicates a certain term as having an independent community meaning. Under 
this condition Member States cannot deviate from it and the National Legislator is bound to assure that the National Law uses this term in conformity with the designated meaning. It is a settled case-law of the Court to interpret VAT-Directive in conformity with the general principles of law. The National Court, in turn, has an obligation to make an interpretation in compliance with the Directive as well as with general principles of law (paragraph 4.7).

\section{Principle of Equality}

The term 'fiscal neutrality' can have two meanings. On the one hand it can mean the equality in fiscal relationships and, on the other hand, it stands for a relief of the taxable person of the burden of input VAT. The former is a reflection, in matters relating to VAT, of the principle of equality (4.4.2). In this meaning it is applicable by the defining of the following:

- taxable person (especially concerning a starting enterprise (paragraph 7.2.2) and public bodies (paragraph 7.4));

- taxable amount (paragraph 9.4);

- exemptions (paragraph 10.4);

- deduction of input VAT (paragraphs 4.4.4.2, 13.2.1).

Therefore, in its first meaning, principle of fiscal neutrality operates as a fundamental principle of equality for the common system of VAT which precludes treating similar goods and services, which are in competition with each other, differently for VAT purposes. Naturally, the general principle of equality has a broader application scope. Thus, in matters relating to tax, it also can be employed against other kinds of discriminations which affect traders who are not necessarily in competition with other, but who are nevertheless in similar situation in other respects. In some cases when a matter of dispute cannot be covered by the principle of fiscal neutrality it however can be addressed by the general principle of equality (paragraph 6.5) or by the principle of non-discrimination in the Treaty of the Functioning of the EU (paragraph 12.3.1.3).

Principle of fiscal neutrality has a leading role by the interpretation of VAT-Directive. Here it's of importance to mention that fiscal neutrality, as an expression of the principle of equality, imposes a question: when can activities be considered as having a similar nature? The answer to this question depends on the criteria which have been chosen to compare the cases. It almost always requires to have a guideline to make a proper judgment. The purpose of the provision plays here a prominent role.

The analogical argumentation is applicable for cases which are not literally described in the legislation, but essentially exhibit a strong similarity with cases which have been documented there (paragraph 4.4.3.2). Both the analogical argumentation and principle of fiscal neutrality aim to handle similar cases in a similar manner and both are often based upon the purpose of the provision. 
Therefore, fiscal neutrality operates as principle of interpretation only when, in matters related to VAT, it reflects the principle of equality. Whereas the latter has a broader application and also acts as a standard to which public authorities are to comply in their formal relationships with taxable persons.

As I stated earlier the principle of fiscal neutrality, apart from being an expression of principle of equality, is also used in case-law in a meaning which has little to do with general principles of law, but operates exclusively within the system of VAT (to relieve the trader of the burden of input VAT, paragraphs 2.2 and 2.4). Thus, Community VAT system guarantees completely neutral taxation of all economic activities provided these activities are VAT liable (paragraphs 7.2, 11.4 and 12.2.2).

\section{Principle of legal certainty}

The principle of legal certainty is a fundamental principle of EU law which requires the rules to be clear and precise, so that individuals may ascertain unequivocally what their rights and obligations are and may act accordingly. The principle of legitimate expectations is being seen as a subpart of the principle of legal certainty and implies that a public authority respects the expectations it has elicited by a taxable person.

The Court permits a certain extent of freedom in exercising the principle of legal certainty on the national level. At the same time it also imposes a restrictive condition implying that the effectiveness of the EU law cannot be compromised.

In the fifth chapter I make an overview of three areas of application where principle of legal certainty plays a role in a formal relationship between a taxable person and a public authority:

- formal legal force;

- ban on retroactive application of legislation;

- delayed validity of the Court's decisions.

Interpretation of a substantive law is not a concern of this overview.

In the 'hierarchical' relationship between EU legislator and the implementing Member State, the principle of legal certainty gives protection to the Member State (formal legal force and delayed validity of the Court decisions). Time-limits for bringing legal proceedings can be seen as a product of the legal certainty and goodworking procedural economy.

It's evident that the principle of legal certainty plays a predominant role in the area of delayed validity of the Court decisions (paragraph 5.6). Also here the principle protects Member States against unexpected developments within EU law. It's of importance to note that whenever a judicial decision acts with the delayed validity a proper balance should be sought between the correct interpretation of the EU law and the principle of legal certainty, especially wherever legal relationships (between 
a public authority and a taxable person) established in good faith are threatened to be compromised.

In 'hierarchal' relationship between a national legislator and a taxable person the principle of legal certainty protects the latter (ban on retroactive application of legislation). The Court's decision precludes national laws, which fall under EU law, from taking effect from a point in time before its publication. The exceptions however can be made where the purpose to be achieved so demands and where the legitimate expectations of those concerned are duly respected.

It's up to the individual concerned to weigh carefully and beforehand the practical consequences of a certain handling. Once the choice is made the principle of legal certainty starts to operate as a principle of interpretation (paragraph 10.0) wherefrom its effect on VAT becomes clear.

According to the Court's decision, EU law precludes from giving protection in cases of abuse of rights (paragraph 5.3) or pursuit of fraudulent ends (paragraph 6.3). This starting point applies for the whole EU law. In case of abuse of rights the choice of handling of the individual concerned is made in pursuit of certain beneficial ends. In this situation it is often the case that the concerned party accepts the risks it undertakes with regard to the discrepancy between the chosen handling and the purpose of the rules. In other words, the party concerned is often well aware that the chosen tactic calls into question its justification from the perspective of legal certainty. Nonetheless, in the court proceedings, it can be a challenge to avoid a conflict with the principle of legal certainty in cases of abuse of rights. One of the necessary conditions in order to ascertain the case as an abusive practice is to determine that the handling in question is in contradiction with the very purpose of the provision the latter aims to achieve. That the purpose of the provision is known to the individual concerned is often apparent from the artificial nature of the chosen transactions. An attempt to frustrate the purpose of the rules in such a deliberate manner exposes the fact that the party concerned is well aware of this very purpose what makes the conflict with the principle of legal certainty non-existent.

The case-law concerning carousel fraud demonstrates that two forces are to be balanced against each other in this case. On the one hand there is a principle of legal certainty, which supports an objective approach and turns a blind eye to the purpose of the chosen handling. On the other hand it's the decision of the Court which prohibits a taxable person from making an appeal to the EU law in case of abuse of rights and fraud. As it becomes apparent from Kittel-doctrine that whenever these two forces are in stride with each other the principle of legal certainty has to give way.

The interpretation directed at the purpose of the provision can cause some tension with the principle of legal certainty. It's especially the case when the Court makes an interpretation to the disadvantage of a taxable person (DFDS, Levob, RAL, BUPA and Centralan) (paragraphs 4.4.3.4 and 5.3). In these cases the party concerned resorts to an artificial nature of the transactions in order to reduce the tax burden. Here in its 
decision making process the Court applies reasoning which are not based on general principle of abuse of rights. Centralan-case is most outstanding in this respect because the Court explicitly mentions that the chosen interpretation is not to be found in VAT-Directive. In this case the Court frustrates the applied construction with the analogical argumentation which finds its origin in the purpose of the provision. In my opinion, the chosen manner of analogical interpretation is in conflict with the principle of legal certainty as it's logical to suggest that a taxable person could not possibly predict this way of approach. Thus, from the perspective of legal certainty such artificial constructions should be challenged by means of applying the principle of prohibiting abusive practices which would guarantee avoidance of a conflict between the chosen manner of interpretation and the principle of legal certainty. It's especially true in order to meet the requirement that it should become obvious on the basis of objective factors that the essential aim of the transaction is to obtain a tax advantage.

Principle of proportionality

Principle of proportionality rests upon three following pillars:

- appropriateness;

- necessity;

- counterbalance.

Not in all cases, where this principle comes into action, all three of the aforementioned aspects can be clearly distinguished. The principle of proportionality can utilize them in variable proportions.

The Court employs the principle of proportionality in order to confine the borders of application of EU law (paragraph 4.5.2.5). In the absence of rules (VAT-Directive does not have a clause which covers this area) it is for the legal systems of the Member States to determine its own working boundaries of VAT, provided it stays within the limits of the whole EU law and gives a duly respect to the general principles of law and, in particular, to the principle of proportionality.

The restrictive role of principle of proportionality can be of importance during authorization of measures designed to simplify the procedure for charging the tax or for prevention of certain types of tax evasion and avoidance. In my study I have paid a more detailed attention to the authorization of the following derogative provisions:

- legal measures to prevent tax evasion and avoidance in general (paragraph 5.2);

- minimum basis for charging VAT (paragraph 9.2.1);

- limitation of the right for deduction (paragraph 11.5.1).

As it becomes obvious from Sudholz-case, it's essential that Member States provide enough support to demonstrate that the proposed measures are adequate and sufficient for the purpose of achieving the desired goal without being excessive or leading to unwonted results. 
With regard to the principle of proportionality in its interpretational role I address the following subjects:

- exemption with the right of deduction of input VAT, in particular concerning delivery of goods and services within the EU (paragraph 10.2);

- risk distribution of consequences of fraud (paragraphs 5.2, 6.3, 10.7);

- evidentiary rules (paragraphs 6.3, 12.3).

The Member States should not only employ means with which the desirable target can be achieved, but also to make an effort to keep the objectives and principles of the affected EU law intact. Similar with the principle of equality, the purpose of the provision plays a role by applying the principle of proportionality. To find the balance the Court is to weigh the desired goal against the chosen means to achieve it.

Thus, the principle of proportionality exercises its influence from a double perspective: acting within the spectrum of procedural law (relationship between a public authority and a taxable person) and as a principle of interpretation of VAT-Directive.

Relationship between general principles of law and classic principles of VAT

Both principle of proportionality and fiscal neutrality (as an expression of principle of equality) rely upon the purpose of the provision. In turn, the purpose of the provision can be traced back to the primary goal of VAT - to target the consumption (principle of consumption), and through it to come back to fiscal neutrality (as a systemic VAT principle) which is also one of classic principles of VAT. As this research demonstrates classic VAT principles establish the legal nature of VAT. In fact, the two aforementioned general principles of law cannot guarantee ideal interpretation of VAT law without being supported by classic VAT principles. Therefore, both the principle of proportionality and the principle of fiscal neutrality (as an expression of principle of equality) need to have the purpose of the provision which, at the endpoint, depends upon the principle of consumption and coherent to it fiscal neutrality (as a systemic VAT principle).

Principle of legal certainty offers protection not only to the Member States (formal legal force and delayed validity of the Court's decisions), but also to a taxable person (ban on retroactive application of rules). These doctrines also demonstrate how this principle functions with respect to formal relationship between a public authority and a taxable person. Additionally, the principle of legal certainty acts as a principle of interpretation of VAT-Directive. Among different methods of interpretation the literal method takes the first place, it is followed by the teleological method and finally by prohibition of abuse of rights. We do not see jurisprudential examples of relationship between principle of legal certainty and classic principles of VAT. The reason for that can be found in a simple fact that it is primarily words and their plain meaning which are meant to give certainty and therefore should be respected and relied upon for the best clarification of the primary goal of the rules. 



\section{LIJST VAN AANGEHAALDE LITERATUUR}

\begin{tabular}{ll}
\hline Auteur & Beschrijving \\
\hline ABC-rapport & Algemeen rapport van de subgroepen A,B en C, \\
& ingesteld ter bestudering van de verschillende \\
& mogelijkheden tot harmonisatie van de omzet- \\
& belasting, Commissie van EEG, Directoraat Ge- \\
& neraal van de Concurrentie, Directie \\
& belastingvraagstukken, januari 1962
\end{tabular}

Arnull 1990

Aristoteles 1999

Barents 1996

Barents, Brinkhorst 2003

Barents 2005

Beelen 2010

Bijl 1988

Bijl 1990

Bijl 1991

Bijl, Hilten Van, Vliet Van 2001
A. Arnull, The General Principle of EEC Law and the Individual, New York: St. Martin's Press 1990

Aristoteles, Ethica Nicomachea, Groningen: Historische Uitgeverij 1999

R. Barents, The principle of Subsidiarity and the Court of Justice, in: de Efs bundel Neutrality and Subsidiarity in Taxation, London/The Hague/Boston: Kluwer Law International 1996

R. Barents \& L.J. Brinkhorst, Grondlijnen van Europees recht, Deventer: Kluwer 2003

R. Barents, Procedures en procesvoering voor het Hof van Justitie EG en het Gerecht van eerste aanleg van de EG, Deventer: Kluwer 2005

S.T.M. Beelen, Aftrek van btw als (belaste) omzet ontbreekt (diss. Rotterdam), Deventer: Kluwer 2010

D.B. Bijl, Derde-generatie-BTW, WFR 1988/183

D.B. Bijl, De heffing van omzetbelasting ten aanzien van onroerend goed (diss. Tilburg), Deventer: Kluwer 1990

D.B. Bijl, De houdstermaatschappij in de omzetbelasting, WFR 1991/5977, blz. 1301-1309

D.B. Bijl, M.E. van Hilten \& D.G. van Vliet, Europese BTW en Nederlandse omzetbelasting, Deventer: Kluwer 2001 


\begin{tabular}{ll}
\hline Auteur & Beschrijving \\
\hline Bijl, Anten 2006 & $\begin{array}{l}\text { J.B.O. Bijl \& T.H. Anten, De BTW-heffing bij ge- } \\
\text { bruik voor privé- of andere dan bedrijfsdoelein- } \\
\text { den van bedrijfsmiddelen en diensten - een } \\
\text { voorstel, WFR 2006/581 }\end{array}$
\end{tabular}

Bijl 2010

Bijl, Wolvers, Wassenaar

Blank, Ziepzeerder 2001

Bomer, Kesteren Van 1999

Bomer 2001

Braakman, Kesteren Van 1998

Braun 2002

Brederode Van 1993

Brederode Van 1996

Brederode Van 1998

Brown \& Kennedy 2000
J.B.O. Bijl, Aftrek van BTW op kosten en investeringen met betrekking tot bedrijfsmiddelen, WFR 2010/872

B. Bijl, H. Wolvers \& M. Wassenaar, Het BTWCompensatiefonds, Den Haag: Sdu Uitgevers

A.J. Blank \& M.J. Ziepzeerder, Gevolgen van het arrest Fischer en Brandenstein, WFR 2001/1249

A.H. Bomer \& H. W.M. van Kesteren, De houdstermaatschappij: Geknipt voor de BTW, WFR 1999/6329, blz. 264

A.H. Bomer, Kleurveranderingen bij holdings en de rechtszekerheid, BTW Bulletin, november 2001, nr. 11

T. Braakman \& H.W.M. van Kesteren, De BTWpositie van de moeiende houdstermaatschappij, WFR 1998/6281, blz. 323 e.v.

K.M. Braun, Aftrek van voorbelasting in de BTW (diss. Leiden), Deventer: Kluwer 2002

R.F.W. van Brederode, De bijzondere positie van de landbouwer in de omzetbelasting (diss. Amsterdam UvA), Deventer: Kluwer 1993

R.F.W. van Brederode, Ethiek van het omzetbelastingrecht (oratie Rotterdam), Deventer: Kluwer 1996

R.F.W. van Brederode, De scheidslijn tussen consumptie en productie in de BTW, WFR 1998/1577

L.N. Brown \& T. Kennedy, The court of Justice of the European Communities, London: Sweet \& Maxwell 2000 


\begin{tabular}{|c|c|}
\hline Auteur & Beschrijving \\
\hline Burg 2000 & $\begin{array}{l}\text { E. Burg, Rationaliteit in de toepassing van con- } \\
\text { flicterende beginselen: het optimaliseringsver- } \\
\text { eiste, Blz. 55, in: E.T. Feteris, H. Kloosterhuis, } \\
\text { H.J. Plug, J.A. Pontier (red.), Met recht en Reden, } \\
\text { Bijdragen aan het Derde Symposium Juridische } \\
\text { Argumentatie Rotterdam } 18 \text { juni 1999, } \\
\text { Nijmegen: Ars Aequi Libri } 2000\end{array}$ \\
\hline Cnossen 1996 & $\begin{array}{l}\text { S. Cnossen, Om de toekomst van de vennoot- } \\
\text { schapsbelasting in de Europese Unie, } \\
\text { WFR 1996/871 }\end{array}$ \\
\hline Commissie 1977 & $\begin{array}{l}\text { Eerste verslag van de Commissie aan de Raad } \\
\text { over de werking van het gemeenschappelijk } \\
\text { stelsel van belasting over de toegevoegde } \\
\text { waarde, } 17 \text { mei } 1977, \operatorname{COM}(84) 426 \text { def }\end{array}$ \\
\hline Commissie 1994 & $\begin{array}{l}\text { Verslag over de werking van de overgangsrege- } \\
\text { ling van de Commissie, } 23 \text { november 1994, } \\
\text { COM (94) } 515 \text { def }\end{array}$ \\
\hline Corput Van der 2010 & $\begin{array}{l}\text { W. van der Corput, New EU VAT Rules Applicable } \\
\text { from } 1 \text { january } 2010 \text { (2), International VAT } \\
\text { Monitor, January/February 2010, blz. } 9\end{array}$ \\
\hline Dale Van 1992 & $\begin{array}{l}\text { Van Dale, Groot Woordenboek der Nederlandse } \\
\text { Taal } 1992\end{array}$ \\
\hline Daniels 1998 & $\begin{array}{l}\text { A.H.M. Daniels, Soevereine zaken (oratie: } \\
\text { Maastricht), Deventer: Kluwer } 1998\end{array}$ \\
\hline Debaedts 1991 & $\begin{array}{l}\text { F. Debaedts, De algemene rechtsbeginselen in het } \\
\text { administratief recht, in: M. van Hoecke (red.), } \\
\text { Algemene rechtsbeginselen, Antwerpen: Kluwer } \\
\text { rechtswetenschappen 1991, blz. } 268\end{array}$ \\
\hline
\end{tabular}

Denie 1987

A.H.R.M. Denie, De overheid in de omzetbelasting (diss. Leiden), Deventer: Kluwer 1987

Denie 1994

A.H.R.M. Denie, Minder muziek bij het jubileum van de BTW?, WFR 1994/27

Denie 1995a

A.H.R.M. Denie, Het intraverkeer: definitief met problemen, in: Belastingen in België, Duitsland en Nederland, Euregiobundel, Arnhem: 1995 Gouda Quint, blz. 197 e.v.

Denie 1995b

A.H.R.M. Denie, Tussen toen en toekomst, WFR 1995/1569 


\begin{tabular}{ll}
\hline Auteur & Beschrijving \\
\hline Denie 2001 & $\begin{array}{l}\text { A.H.R.M. Denie, De komst van het BTW-com- } \\
\text { pensatiefonds, in: BTW in Utopia, opstellen aan- } \\
\text { geboden aan D.B. Bijl, Deventer: Kluwer } 2001\end{array}$
\end{tabular}

Denie 2008a

Denie 2008b

Denie 2009

Dongen Van, Kesteren Van 2005

Dongen, Van 2005

Dongen, Van 2007a

Dongen, Van 2007b

Doesum, Van 2009

Doesum Van, Kesteren, Norden Van 2008

Dragtenstein 2009

Dworkin 1994

Eijsbouts, Jans, Prechal, Senden 2010
A.H.R.M. Denie, De kansspelbelasting op speelautomaten EU-bestendig?, MBB 2008, nr. 7/8

A.H.R.M. Denie, Liever BUA dan Europa, Forfaitair 2008/183

A.H.R.M. Denie, Moet de directeur-grootaandeelhouder, zonder BTW-status in de EU, managen? In: DGA en Fiscus: de stand van zaken, Maastrichtse fiscale symposia, nr. 18, Deventer: Kluwer 2009, blz. $3 \mathrm{t} / \mathrm{m} 18$

A. van Dongen \& H.W.M. van Kesteren, Verenigbaarheid BUA met de Zesde richtlijn, WFR 2005/786

A. van Dongen, Heffing van BTW op privé-gebruik, WFR 2005/1393

A. van Dongen, De harmonisatie van de BTW (diss. Tilburg), Amersfoort: Sdu Uitgevers 2007

A. van Dongen, De algemene beginselen bestaan niet, NTFR 2007/164

A.J. van Doesum, Contractuele samenwerkingsverbanden in de BTW (diss. Tilburg), Deventer: Kluwer 2009

A.J. van Doesum, H.W.M. van Kesteren, G.J. van Norden en I.H.T. Reiniers, De nieuwe regels voor de plaats van dienst in de BTW, WFR 2008/279

H.A.S. Dragtenstein, Vermogensetikettering van diensten, een brug te ver?, BTW-Brief 2009, nr. 3, blz. 6

R. Dworkin, Taking Rights Seriously, London: Duckworth 1994

W.T. Eijsbouts, J.H. Jans, A. Prechal en L.A.J. Senden, Europees recht, Algemeen deel, Sinds het Verdrag van Lissabon, Groningen: Europa Law Publishing 2010 


\begin{tabular}{|c|c|}
\hline Auteur & Beschrijving \\
\hline Europese Commissie 2007 & $\begin{array}{l}\text { International VAT Association van maart } 2007 \\
\text { getiteld, Combatting VAT Fraud in the EU, The } \\
\text { Way Forward }\end{array}$ \\
\hline Famer, Lyal 1994 & $\begin{array}{l}\text { P. Farmer \& R. Lyal, EC Tax Law, Oxford: } \\
\text { Clarendon Press } 1994\end{array}$ \\
\hline Farmer 1996 & $\begin{array}{l}\text { Paul Farmer, Taxable persons and the 'private life' } \\
\text { of companies, The EC Tax Journal, Volume 2, } \\
\text { 1996/97, Issue 1, blz. } 41\end{array}$ \\
\hline Geppaart 1965 & $\begin{array}{l}\text { Ch.P.A. Geppaart, Fiscale rechtsvinding, een on- } \\
\text { derzoek naar de rechtsvinding door de rechter in } \\
\text { belastingzaken in het bijzonder aan de hand van } \\
\text { de rechtspraak in de periode } 1 \text { maart } 1957-1 \\
\text { maart 1965, Amsterdam: NV uitgeverij FED } 1965\end{array}$ \\
\hline Geppaart 1996 & $\begin{array}{l}\text { Ch.P.A. Geppaart, Fiscale rechtsvinding in het } \\
\text { kader van de Europese Unie (afscheidsrede } \\
\text { Tilburg), Deventer: Kluwer } 1996\end{array}$ \\
\hline
\end{tabular}

Gerards $2002 \quad$ J.H. Gerards, Rechtelijke toetsing aan het gelijkheids-beginsel (diss. Maastricht), Nijmegen: Sdu Uitgevers 2002

Gijssels 1991

J. Gijssels, Rechtsbeginselen zijn nog geen recht, in: M. van Hoecke (red.), Algemene rechtsbeginselen, Antwerpen: Kluwer rechtswetenschappen 1991, blz. 38

Gorissen 2008

N.H.A. Gorissen, Gewekt vertrouwen in Europees perspectief. Een rechtsvergelijkend onderzoek naar de rol van het vertrouwensbeginsel in het Nederlandse, Belgische, Duitse en Europees (belasting)recht (diss. Maastricht), Amersfoort: Sdu Uitgevers 2008

Gribnau 1998

J.L.M. Gribnau, Rechtsbetrekking en rechtsbeginselen in het belastingrecht (diss. Rotterdam), Rotterdam: Sanders Instituut \& Gouda Quint 1998

Gribnau 2000a

J.L.M. Gribnau, Perspectieven op het gelijkheidsbeginsel, WFR 2000/6391, blz. 902 
Lijst van aangehaalde literatuur

\begin{tabular}{|c|c|}
\hline Auteur & Beschrijving \\
\hline Gribnau 2000b & $\begin{array}{l}\text { J.L.M. Gribnau, des Pudels Kern? Rechtsbeginse- } \\
\text { len als fundamentele rechtsbron, blz. 197, in: } \\
\text { E.T Feteris, H. Kloosterhuis, H.J. Plug, J.A. Pontier, } \\
\text { (red.), Met Recht en Reden, Bijdragen aan het } \\
\text { Derde Symposium Juridische Argumentatie } \\
\text { Rotterdam } 18 \text { juni 1999, Nijmegen: } \\
\text { Ars Aequi Libri } 2000\end{array}$ \\
\hline Gribnau 2009 & $\begin{array}{l}\text { J.L.M. Gribnau, Soevereiniteit en legitimiteit: } \\
\text { grenzen aan (fiscale) regelgeving (oratie Leiden), } \\
\text { Amersfoort: Sdu Uitgevers } 2009\end{array}$ \\
\hline Groenewegen 2006 & $\begin{array}{l}\text { F.T. Groenewegen, Wetsinterpretatie en } \\
\text { rechtsvorming (diss. Amsterdam UvA), } \\
\text { Boom Juridische Uitgevers } 2006\end{array}$ \\
\hline Groenewegen 2007 & $\begin{array}{l}\text { F.T. Groenewegen, Wetsinterpretatie en rechts- } \\
\text { vorming, Ars Aequi, } 56 \text { (2007) 1, blz. } 91\end{array}$ \\
\hline Gulik 2005 & $\begin{array}{l}\text { R. van Gulik, Klokken van Kao-Yang, Amsterdam: } \\
\text { De Boekerij } 2005\end{array}$ \\
\hline Happé 1996 & $\begin{array}{l}\text { R.H. Happé, Drie beginselen van fiscale rechts- } \\
\text { bescherming (diss. Leiden), Deventer: Kluwer } \\
1996\end{array}$ \\
\hline
\end{tabular}

Happé 2011

R.H. Happé, Belastingethiek: een kwestie van fair share, Geschriften van de Vereniging voor Belastingwetenschap, no. 243, Deventer: Kluwer 2011

Hel - van Dijk Van der 2010 E.C.M. van der Hel-van Dijk, Aanpassing verordening (EG) nr. 1798/2003: efficiënte bestrijding BTW-fraude?, WFR 2010/525

Hoecke Van 1991

M. van Hoecke, De algemene rechtsbeginselen als rechtsbron: een inleiding, in: M. van Hoecke (red.), Algemene rechtsbeginselen, Antwerpen: Kluwer rechtswetenschappen 1991

Hilten Van 1992

M.E. van Hilten, Bancaire en financiële prestaties in de Europese BTW (diss. Leiden), Deventer: Kluwer 1992

Hilten Van 1994a

M.E. van Hilten, Het bakje van de orgelman, BTW-Brief 1994, nr. 3, blz. 2

Hilten Van 1994b

M.E. van Hilten, Gedachten over de grenzen van de belastingplicht in de omzetbelasting, WFR 1994/15 
Lijst van aangehaalde literatuur

\begin{tabular}{ll}
\hline Auteur & Beschrijving \\
\hline Hilten Van 1995 & M.E. van Hilten, Neutraliteit anno nu, \\
WFR 1995/1579 \\
Hilten Van 1997a & $\begin{array}{l}\text { M.E. van Hilten, Over recht en onrecht, } \\
\text { WFR 1997/1011 }\end{array}$ \\
Hilten Van 1997b & $\begin{array}{l}\text { M.E. Van Hilten, Vaste inrichting en BTW: (on) } \\
\text { zelfstandig en niet onafhankelijk, }\end{array}$ \\
WFR 1997/1369 \\
Hilten Van 1998 & $\begin{array}{l}\text { M.E. van Hilten, De Europese Dimensie van door } \\
\text { de fiscus opgewekt vertrouwen in de BTW en het } \\
\text { douanerecht (oratie Leiden), Leiden: Rijks } \\
\text { Universiteit Leiden 1998 }\end{array}$
\end{tabular}

Hilten Van 2009

M.E. van Hilten, Vrijstellingen: hoe eng is strikt?, WFR 2009/1328

Hilten Van, Kesteren

Van 2007

M.E. van Hilten \& H.W.M. van Kesteren, Omzetbelasting, Deventer: Kluwer 2007

Hilten Van, Kesteren

Van 2010

Hilten Van 2010

M.E. van Hilten \& H.W.M. van Kesteren, Omzetbelasting, Deventer: Kluwer 2010

M.E. van Hilten, Over de neutraliteit van de omzetbelasting en het hellend vlak van de uitzonderingen (oratie Amsterdam VU), Deventer: Kluwer 2010

Hilten Van, Boender 2010

M.E. van Hilten \& J.B.J. Boender, BTW-pakket 2010, Plaats van dienst, teruggaaf en antifraudemaatregelen in de btw vanaf 2010, Deventer: Kluwer 2010

Hinssen 2009

N. Hinssen, Athesia Druck, reparatie IJsland-route mislukt?!, BTW-Bulletin, Juni 2009,

nr. 6 , blz. 1

House of Lords 2007

European Union Committee van het House of Lords van 25 mei 2007 over the missing trader. Het rapport is verkrijgbaar via Internet. www.publications.parliament.uk/pa/ld200607/ ldselect/ldeucom/ldeucom.htm

Hsu, Anen, Quartz 2008

M. Hsu, C. Anen, SR. Quartz, The Right and the Good: Distributive Justice and Neural Encoding of Equity and Efficiency, Science 23 May 2008, Vol. 320, no. 5879, p. 1092-1095. In paragraaf 3.2.1 


\begin{tabular}{ll}
\hline Auteur & Beschrijving \\
\hline IJzerman 1991 & $\begin{array}{l}\text { R.L.H. IJzerman, Het leerstuk van de wetsontdui- } \\
\text { king in het belastingrecht (diss. Amsterdam } \\
\text { UvA), Deventer: Kluwer 1991 }\end{array}$ \\
Jackson 1999 & $\begin{array}{l}\text { J.H. Jackson, The World Trade Organisation, Con- } \\
\text { stitution and Jurisprudence, London: The Royal } \\
\text { Institute of International Affairs 1999 }\end{array}$ \\
Jansen, Lange De, Prechal, & $\begin{array}{l}\text { J.H. Jansen, R. de Lange, S. Prechal \& R.J.G.M } \\
\text { Widdershoven, Inleiding tot het Europees be- } \\
\text { stuursrecht, Nijmegen: Ars Aequi Libri 2002 }\end{array}$ \\
Jansen 2003 & $\begin{array}{l}\text { H. Jansen, Van omgekeerde strekking, Een } \\
\text { pragma-dialectische reconstructie van a contra- } \\
\text { rio-argumentatie in het recht (diss. Amsterdam } \\
\text { UvA) 2003 }\end{array}$ \\
Jong De 2004 & $\begin{array}{l}\text { M. de Jong, Kühne \& Heitz: formele rechtskracht } \\
\text { onder omstandigheden 'doorbroken', } \\
\text { TFB 2004/04 }\end{array}$
\end{tabular}

Kamminga 2005

J.A. Kamminga, De rechtszekerheid van de terugwerkende kracht van BTW-anticonstructiewetgeving, WFR 2005/360

Kapteyn, VerLoren van

Themaat 2003

Kesteren Van 1994

Kesteren Van 2004

Kesteren Van, Bijl 2006a

P.J.G. Kapteyn \& P. VerLoren van Themaat, Het recht van de Europese Unie en van de Europese Gemeenschappen, Deventer: Kluwer 2003

H.W.M. van Kesteren, Fiscale rechtswil (diss. Leiden), Arnhem: Gouda Quint 1994

H.W.M. van Kesteren, misbruik van recht in de omzetbelasting (oratie Tilburg), Deventer: Kluwer 2004

H.W.M. van Kesteren \& J.B.O. Bijl, Aftrek en handelingen die buiten het bereik van de BTW blijven, WFR 2006/1379

Kesteren Van, Bijl 2006b

H.W.M. van Kesteren \& J.B.O. Bijl, BTW en onzakelijk gebruik of privégebruik, NTFR 2006/1591

Kesteren Van, Soltysik 2007

H.W.M. van Kesteren en M.W.C. Soltysik, Misbruik en onvoltooide harmonisatie, WFR 2007/481 
Lijst van aangehaalde literatuur

\begin{tabular}{|c|c|}
\hline Auteur & Beschrijving \\
\hline Kesteren Van, Vervloed 2009 & $\begin{array}{l}\text { H.W.M. van Kesteren \& J.L.M.J. Vervloed, Recla- } \\
\text { mediensten en werkelijk gebruik, BTW-brief } \\
\text { 2009, nr. 5, blz. } 3\end{array}$ \\
\hline Kloosterhuis 2002 & $\begin{array}{l}\text { H. Kloosterhuis, Van overeenkomstige toepas- } \\
\text { sing, de pragmadialectische reconstructie van } \\
\text { analogie-argumentatie in rechtelijke uitspraken } \\
\text { (diss. Amsterdam UvA) } 2002\end{array}$ \\
\hline Kooijmans 2008 & $\begin{array}{l}\text { P.H. Kooijmans, Internationaal publiekrecht, } \\
\text { Deventer: Kluwer } 2008\end{array}$ \\
\hline Koopmans 1991 & $\begin{array}{l}\text { T. Koopmans, Rechtsbeginselen in het Europees } \\
\text { Gemeenschapsrecht, Ars Aequi 1991, blz. } 927\end{array}$ \\
\hline Korf 2009 & $\begin{array}{l}\text { R. Korf, The General Agreement on Trade in } \\
\text { Services and Its Impact on European Taxation, in: } \\
\text { M. Lang, P. Melz, E. Kristoffersson (red.), Value } \\
\text { Added Tax and Direct Taxation, Similarities and } \\
\text { Differences, Amsterdam: IBFD } 2009\end{array}$ \\
\hline
\end{tabular}

Kortenaar 2012

G.G.M. Kortenaar, Gebruik uitvoeringsverordening als instrument in de Europese BTW, WFR 2012/98

Kogels 1988

H.A. Kogels, BTW zonder grenzen (II), MBB, januari 1988, blz. 5

Kogels 2008

H.A. Kogels, Modernisering van de BTW, MBB 2008/03

Kuile, Ter 1995

Hoe helder moet zonneklaar zijn? Arnhem: Gouda Quint 1995

Lamers 2006

J.J.M. Lamers, Etikettering, aftrek en heffing volgens Johan Cruijff, WFR 2006/159

Lamers 2008

J.J.M. Lamers, Verschuldigdheid van BTW, NTFR-B 2008/22

Lamers 2009

J.J.M. Lamers, Omtrent onttrekkingen, NTFR Beschouwingen 2009/39

Lamers 2010

J.J.M. Lamers \& M.M.W.D. Merkx, Btw, een kosten-batenanalyse, WFR 2010/907

Lantman, Kasmer 2010

R.J.M.C. Lantman \& M. Kasmer, Vermogensetiketering: enkel een privéaangelegenheid?, MBB $2010 / 3$ 


\begin{tabular}{ll}
\hline Auteur & Beschrijving \\
\hline Lang 2007 & M. Lang, Limitations of the Temporal Effects of \\
& Judgements of the ECJ, Intertax 2007 Volume 35,
\end{tabular}
Issue 4, blz. 230

Lang, Melz, Kristoffersson 2009 M. Lang, P. Melz, E. Kristoffersson, Value Added Tax and Direct Taxation, Similarities and Diferences, Amsterdam: IBFD 2009

Lejeune, Cortvriend, Accorsi 2011

I. Lejeune, E. Cortvriend en D. Accorsi, Implementing Measures Relating to EU Place-of-Supply Rules: Are Business Issues Solved and Is Certainty Provided?, International VAT Monitor May/June 2011, blz. 144.

Lenaerts, Nuffel Van 1999

K. Lenaerts \& P. van Nuffel, Europees recht in hoofdlijnen, Antwerpen/Apeldoorn: Maklu Uitgevers 1999

Linssen 2009

J.P.M. Linssen, VNLTO: geen aftrek van BTW ter zake van algemene belangenbehartiging, BTW-brief 2009, nr. 11, blz. 15

Lissenberg et al 1996

E. Lissenberg, P.W. Brouwer, F. Jacobs, E. Poortinga, De actualiteit van Paul Scholten, Nijmegen: Ars Aequi Libri 1996, blz. 91 e.v.

Loenen 1998

T. Loenen, Rechtstheorie, Het gelijkheidsbeginsel, Nijmegen: Ars Aequi Libri 1998

Merkx 2011

M.WM.W.D. Merkx, De woon- en vestigingsplaats in de btw (diss. Tilburg), Deventer: Kluwer 2011

Merkx 2011

M.M.W.D. Merkx, Btw-uitvoeringsverordening uitvoerbaar?, WFR 2011/1308

Mertens de Wilmars 1991

J. Mertens de Wilmars, Algemene rechtsbeginselen in het Europees recht, in: M. van Hoecke (red.), Algemene rechtsbeginselen, Antwerpen: Kluwer rechtswetenschappen 1991

Messere 1994

Ken Messere, Consumption Tax Rules, International Bureau of Fiscal Documentation, Bulletin December 1994, blz. 665 
Lijst van aangehaalde literatuur

\begin{tabular}{ll}
\hline Auteur & Beschrijving \\
\hline Moons 1991 & D. Moons, De toepassing van algemene rechts- \\
beginselen in het strafrecht in de verschillende \\
fasen van de rechtspleging, in: van Hoecke (red.) \\
Algemene rechtsbeginselen Antwerpen: Kluwer \\
rechtswetenschappen 1991
\end{tabular}

Moor- van Vugt De 1995

De Moor-van Vugt, Maten en gewichten, Het evenredigheidsbeginsel in Europees perspectief (diss. Tilburg), Zwolle: W.E.J. Tjeenk Willink 1995

Moor De 1996

A.E. De Moor, Waarom niet conform? Afscheidscollege, Deventer: Kluwer 1996

Mortelmans, Van Ooik, Prechal K.J.M. Mortelmans, R.H. van Ooik \& S. Prechal, 2004 Europees recht en de Nederlandse rechter, Deventer: Kluwer 2004

Muntjewerff 1996

A. Muntjewerff, ROSA een model gebaseerd computerprogramma voor het (leren) oplossen van juridische casus, in: E. Lissenberg, P.W. Brouwer, F. Jacobs, E. Poortinga, De actualiteit van Paul Scholten, Nijmegen: Ars Aequi Libri 1996

Nanetti, Mazotti 2006

F. Nanetti and G. Mazotti, The (un)lawfulness of IRAP in the European Legal system: the European Court of Justice's potential new trends with regard to temporal limitation of its interpretative decision, EC Tax Review 2006/3

Niessen 2010

R.E.C.M. Niessen, Inleiding tot het Nederlands belastingrecht, Deventer: Kluwer 2010

Neumark-Rapport

Commissie van de EEG, Rapport van het fiscaal en financieel Comité 1962

Nieuwenhuis 1979

Nieuwenhuizen 1993

Nieuwenhuizen 1994

J.H. Nieuwenhuis, Drie beginselen van contractenrecht (diss. Leiden), Deventer: Kluwer 1979

W.A.P. Nieuwenhuizen, Ondernemer in de omzetbelasting: een beetje zwanger is mogelijk!, WFR 1993/6080, blz. 1772

W.A.P. Nieuwenhuizen, Tolsma en het gelijk van het Hof van Justitie, WFR 1994/252

Nieuwenhuizen 1997a

W.A.P. Nieuwenhuizen, De Régie van de BTW, WFR $1997 / 54$ 


\begin{tabular}{ll}
\hline Auteur & Beschrijving \\
\hline Nieuwenhuizen 1997b & $\begin{array}{l}\text { W.A.P. Nieuwenhuizen, Holdingproblemen: drie } \\
\text { keer is scheepsrecht, BTW Bulletin 1997, nr. 10, } \\
\text { blz. } 1 \text {-5 }\end{array}$ \\
Nieuwenhuizen 2003 & $\begin{array}{l}\text { J.H.M. Nieuwenhuizen, Fraus legis (misbruik van } \\
\text { recht) en fiscaal-rechtelijke kwalificatie in de } \\
\text { BTW, WFR 2003/6557 }\end{array}$ \\
Nieuwenhuizen 2010 & $\begin{array}{l}\text { W.A.P. Nieuwenhuizen, BTW Jurisprudentie van } \\
\text { het Hof van Justitie 2010/2011, Deventer: Kluwer } \\
\text { 2010 }\end{array}$
\end{tabular}

Nieuwenhuizen 2010

J.H.M. Nieuwenhuizen, Rechtsvinding en fiscale werkelijkheid (diss. Tilburg), Deventer: Kluwer 2010

Norden Van 2002

G.J. van Norden, Fiscale eenheid voor de BTW uitgebreid, WFR 2002/6502, blz. 1541

Norden Van 2007

G.J. van Norden, Het concern in de BTW (diss. Tilburg), Deventer: Kluwer 2007

Offermans 1996

R.H.M.J. Offermanns, Het ondernemerbegrip in Europees perspectief (diss. Tilburg) 1996

Oranje 1986

C.J. Oranje, analogie en fraus legis, in Leids fiscaal jaarboek 1986, Arnhem: Gouda Quint BV 1986

Orshoven Van 1991

P. van Orshoven, Non scripta, sed nata lex - Over het begrip en de plaats in de normenhiërarchie van de algemene rechtsbeginselen, in: M. van Hoecke (red.), Algemene rechtsbeginselen, Antwerpen: Kluwer rechtswetenschappen 1991, blz. 73

Ortlep, Verhoeven 2008

R. Ortlep \& M.J.M. Verhoeven, De voorrangsregel versus het beginsel van nationale procedurele autonomie, SEW, nr. 12, december 2008, blz. 207 e.v.

Otto, Vrouwenvelder 2002 W.P Otto \& E.M. Vrouwenvelder, Het grenzeloze gemak van de fiscale eenheid, BTW-brief nr. 8/9 2002

Paardt Van der 1992

R.N.G. van der Paardt, Holdings en BTW, MBB 1992/7-8, blz. 209-215

Paardt Van der 2000

R.N.G. van der Paardt, Subsidies en BTW in de Europese Unie (diss. Groningen), Deventer: Kluwer 2000 
Lijst van aangehaalde literatuur

\begin{tabular}{ll}
\hline Auteur & Beschrijving \\
\hline Pauwels 2009 & $\begin{array}{l}\text { M.R.T. Pauwels, Terugwerkende kracht van } \\
\text { belastingwetgeving: gewikt en gewogen (diss. } \\
\text { Tilburg), Amersfoort: Sdu Uitgevers } 2009\end{array}$ \\
Pijnacker Hordijk, Snoep 1996 & $\begin{array}{l}\text { E.P.H. Pijnacker Hordijk \& T.M. Snoep, NJB 14 juni } \\
\text { 1996, blz. 923 }\end{array}$ \\
Pistone 1999 & $\begin{array}{l}\text { Pasquale Pistone, Fixed Establisment and } \\
\text { Permanent Establishment, VAT Monitor 1999, } \\
\text { nr. 3, blz. 101 t/m 106 }\end{array}$ \\
Ploeger 1972a & $\begin{array}{l}\text { L.F. Ploeger, Het verbruik in de omzetbelasting (I), } \\
\text { WFR 1972/969 }\end{array}$ \\
Ploeger 1972b & $\begin{array}{l}\text { L.F. Ploeger, Het verbruik in de } \\
\text { omzetbelasting (II), WFR 1972/989 }\end{array}$ \\
Prechal, Heukers 1986 & $\begin{array}{l}\text { S. Prechal \& T. Heukers, Algemene beginselen in } \\
\text { het Nederlandse recht en het Europese recht: } \\
\text { rechtsvergelijking en interactie, Nederlands } \\
\text { rapport ten behoeve van het FIDE-congres 1986, } \\
\text { SEW, 1986, mei, blz. 287 }\end{array}$
\end{tabular}

Prechal 1991

S. Prechal, Richtlijnconforme interpretatie: Alice in wonderland, WFR, 199/596

Prechal 2005

S. Prechal, Directives in EC Law, Oxford: University Press 2005

Prinssen 2004

J.M. Prinssen, Doorwerking van Europees recht, De verhouding tussen directe werking, conforme interpretatie en overheidsaansprakelijkheid (diss. Amsterdam UvA 2004). Deventer: Kluwer 2004

Raad Van 2008

C. van Raad, Cursus belastingrecht (internationaal belastingrecht), Deventer: Kluwer (losbl.)

Rawls 2006

J. Rawls, Een theorie van rechtvaardigheid, Rotterdam: Lemniscaat 2006, blz. 364 t/m 369

Reugebrink 1965

J. Reugebrink, Enkele beschouwingen over de neutraliteit van de omzetbelasting (openbare les Leiden), Deventer: Kluwer 1965

Reugebrink 1994

J. Reugebrink, Een dubbel jubileum van de omzetbelasting, WFR 1994/3

Reugebrink 1995

J. Reugebrink, De zomer was groots, WFR 1995/1792 


\begin{tabular}{l}
\hline Auteur \\
Reugebrink, Hilten Van 1997
\end{tabular}

Rozemond 2000

Ruppe 1983

Russel 1997

Sanders 1995

Sanders 2007

Sanders 2008

Sanders 2011

Schermers 1983

Scholten 1974

Schoordijk 1997

Schuver-Bravenboer 2009

Simons 1994a

Simons 1994b
Beschrijving

J. Reugebrink \& M.E. van Hilten, Omzetbelasting, Deventer: Kluwer 1997

K. Rozemond, Vierentwintig varianten van de one right answer thesis, blz. 65, in: E.T Feteris, H. Kloosterhuis, H.J. Plug, J.A. Pontier, (red.), Met Recht en Reden, Bijdragen aan het Derde Symposium Juridische Argumentatie Rotterdam 18 juni 1999, Nijmegen: Ars Aequi Libri 2000

H.G. Ruppe, General Report, Cahier de droit fiscal international, XXXVII Congres, Deventer: Kluwer 1983

B. Russell, Geschiedenis van de westerse filosofie, Katwijk: Servire Uitgevers 1997

J.T. Sanders, Over BTW en aandelen en BTW over aandelen (I), BTW-brief 1995, nr. 6/7, blz. 3

J.T. Sanders, Rechtstreeks beroep op richtlijn bepalingen in de BTW, BTW-brief nr. 6/7 2007, blz. 8

J.T. Sanders, Zijn we Safe?, BTW-Brief nr. 4 2008, blz. 3

J.T. Sanders, Le droit de rêver (diss. Groningen), Amersfoort: Sdu Uitgevers 2011

H.G. Schermers, Algemene rechtsbeginselen als bron van gemeenschapsrecht, SEW 9 (1983), blz. 514

P. Scholten, Asser-Scholten (Algemeen deel), Zwolle: E.E.J.Tjeenk Willink 1974

H.C.F. Schoordijk, Enige aspecten van privaat- en fiscaalrechtelijke rechtsvinding, WFR 1997/6251

M. Schuver-Bravenboer, Fiscaal overgangsbeleid. Een raamwerk voor het vormgeven en beoordelen van het overgangsbeleid van de fiscale wetgever (diss. Leiden), Deventer: Kluwer 2009

A.L.C. Simons, Terug naar de basis van de BTW: het maatschappelijk verkeer!, WFR 1994/5

A.L.C. Simons, Neutrality in VAT and the OrganGrinder, EC-Tax Review 1994/2, blz. 44 


\begin{tabular}{ll}
\hline Auteur & Beschrijving \\
\hline Simons 1995a & $\begin{array}{l}\text { A.L.C. Simons, De nieuwe rechtstheorie getrig- } \\
\text { gerd door BTW constructies, WFR 1995/469 }\end{array}$ \\
Simons 1995b & $\begin{array}{l}\text { A.L.C. Simons, Open brief aan } \\
\text { prof. mr. J. Reugebrink, WFR 1995/1587 }\end{array}$ \\
Simons 1999 & $\begin{array}{l}\text { A.L.C. Simons, Foute rechtsontwikkeling van de } \\
\text { prestatie in de omzetbelasting, WFR 1999/743 }\end{array}$
\end{tabular}

Skaar 1991

A. Skaar, Permanent Establishment, Erosion of a Tax Treaty Priciple, Deventer/Boston: Kluwer Law and Taxation Publishers 1991

Slooten Van 2005

G.J. van Slooten, Het arrest Charles-Tijmens en teruggaaf van voorbelasting achteraf: formele rechtskracht, maar pas na een redelijke termijn, BTW-brief, nr. 8/9 2005

Slooten Van 2012

G.J. van Slooten, De BTW-Verordening: mogen wijzigingen vermomd gaan als 'verduidelijking'?, WFR 2012/86

Smith 1996

S. Smith, Subsidiarity and Neutrality in European Tax Policy: Economic Consideration, in de EFS uitgave Neutrality and Subsidiarity in Taxation, London/The Hague/Boston,: Kluwer Law International 1996

Soetaert 1991

R. Soetaert, Algemene rechtsbeginselen in Cassatie, in: M. van Hoecke (red.), Algemene rechtsbeginselen,

Antwerpen: Kluwer rechtswetenschappen 1991, blz. 94

Soeteman 1991

A. Soeteman, Hercules aan het werk. Over de rol van rechtsbeginselen in het recht. Ars Aequi 1991, blz. 744

Soltysik 2007

M.W.C. Soltysik, Overgangsbepalingen in de Europese BTW, WFR 2007/303

Soltysik 2010

M.W.C. Soltysik, Het arrest VNLTO: alweer? Ja alweer, maar dan anders!, MBB 2010/06

Spaak rapport

Rapport van de Chefs der delegaties van de Ministers van Buitenlandse zaken, Brussel 21 april 1956

Stevens 2000

D.M.P.M. Stevens, Het verrichten van diensten onder bezwarende titel als belastbaar feit in de omzetbelasting (diss. Maastricht) 2000 


\begin{tabular}{ll}
\hline Auteur & Beschrijving \\
\hline Stevens 2003 & $\begin{array}{l}\text { S.A. Stevens, De belaste overheid (diss. Tilburg), } \\
\text { Deventer: Kluwer 2003, blz. } 399\end{array}$ \\
Storme 1991 & $\begin{array}{l}\text { M. Storme, Algemene beginselen van behoorlijke } \\
\text { procesvoering, in: M. van Hoecke (red.) Alge- } \\
\text { mene rechtsbeginselen, Antwerpen: Kluwer } \\
\text { rechtswetenschappen 1991, blz. } 168\end{array}$
\end{tabular}

Swinkels 2000

Swinkels 2004

Swinkels 2009

Terra 1984

Terra 1988

Terra 1989

Terra 1998

Terra 2001

Terra, Wattel 2005

Terra, Kajus 2006

Terra, Wattel 2008

Thomas 2004
J.J.P. Swinkels, De Belastingplichtige in de Europese BTW (diss Amsterdam UvA) 2000

J.J.P. Swinkels, Europese ontwikkelingen omtrent onjuiste rechtspraak van de hoogste nationale rechter, Belasting Brief 2004/04

J.J.P. Swinkels, BTW-actualiteiten betreffende verhuur van onroerende zaken, WFR 2009/1344

B.J.M. Terra, Omzetbelasting bij grensoverschrijdend verkeer (diss. Leiden), Deventer: FED 1984

B.J.M. Terra, Sales Taxation, The case of value added tax in the European Community, Deventer-Boston: Kluwer Law and taxation Publishers 1988

B.J.M. Terra, De plaats van de prestatie (oratie: Amsterdam UvA), Deventer: Kluwer 1989

B.J.M. Terra, The Place of Supply in European VAT, Dordrecht: Kluwer Law International 1998

B.J.M. Terra, Europees indirect belastingrecht, Nijmegen: Ars Aequi Libri 2001

B.J.M. Terra, P.J. Wattel, European Tax Law, Fed Fiscale Studieserie, Deventer: Kluwer 2005, blz. $178 \mathrm{t} / \mathrm{m} 184$

B. Terra \& J. Kajus, A Guide to the European VAT Directives, Volume 1, Introduction to European VAT and other Indirect Taxes, Amsterdam: IBFD (losbladig)

B.J.M. Terra \& P.J. Wattel, European Tax Law, Deventer: Kluwer 2008

E. Thomas, Formele rechtskracht en de terugbetaling van in strijd met Europees recht geheven belasting, MBB 2004/09 


\begin{tabular}{ll}
\hline Auteur & Beschrijving \\
\hline Tridimas 2006 & $\begin{array}{l}\text { T. Tridimas, The General Priciples of EU Law, } \\
\text { Oxford: Oxford University Press } 2006\end{array}$ \\
Tromp 1991 & $\begin{array}{l}\text { U. Tromp, Nieuws over holdings, BTW-brief 1991, } \\
\text { nr } 5 \text { (50) }\end{array}$ \\
Tromp 1991 & $\begin{array}{l}\text { U. Tromp, Hof van Justitie EG over holdings, } \\
\text { BTW-brief 1991, nr. } 5 \text { (50) }\end{array}$
\end{tabular}

Tromp 1995

Utz 1993

Vanistendael 1991

Verheij 2005

Verhoeven 2008

Vervloed 1990

Vervloed 1997

Vervloed 2007

Verweij 2008

Vliet Van 2007

Voyez 2001

Vroon 2011
U.E. Tromp, Hof van Justitie over kinderopvang, BTW-brief 1995/10, blz. 7

S.G. Utz, Tax Policy, An Introduction and Survey of the Principles Debates, St. Paul: West publishing Co 1993

F. Vanistendael, Algemene rechtsbeginselen in het belastingrecht, in: M. van Hoecke (red.), Algemene rechtsbeginselen, Antwerpen: Kluwer rechtswetenschappen 1991

N. Verheij, Relatief onaantastbaar? Over formele rechtskracht van besluiten (oratie Maastricht) 2005

M. Verhoeven, De rechtstreekse werking van de communautaire beschikking, Ars Aequi, maart 2008

J.L.M.J. Vervloed, Optreden als overheid, BTW-brief 1990, nr. 5, blz. 1

J.L.M.J. Vervloed, IJsland ijlt na, BTW-Brief 1997/4, blz. 9 -11

J.L.M.J. Vervloed, Eén betaling voor diverse prestaties, BTW-brief, nr.4 2007, blz. 5 e.v.

C. Verweij, Brengt de zaak-NLTO wel helder licht in de vermogensetikettering voor de BTW, WFR $2008 / 660$

D.G. van Vliet, Selectief beroep op richtlijnregelingen mogelijk?, NTFR Beschouwingen 2007/20

J. Voyez, Changing face of Article 9, Taxation“ 6 december 2001, blz. 246

T. Vroon, Vreemd is niet gek, BTW-brief 2011/29 


\begin{tabular}{l}
\hline Auteur \\
\hline Wal Van der, Hartendorf 2004
\end{tabular}

Wattel 1992

Weber, Davids 2008a

Weber, Davids 2008b

Wiarda 1999

Widdershoven, Ortlep 2004

Wolf 2010

Woude Van der 1991

Woude Van der 2000

Zadelhoff Van 1992

Zadelhoff, Van 2005

Zadelhoff Van 2008

Zijlstra 2011
Beschrijving

E.R. van der Wal \& M.S. Hartendorf, En spelletje monopoly: over concurrentievervalsing bij gelegenheid geven tot parkeren door gemeenten, BTW-brief nr. 6/7 2004, blz. 12 e.v.

P.J. Wattel, De fiscale behandeling van het wederrechtelijke (diss. Amsterdam UvA), Deventer: Kluwer 1992

D.M. Weber \& F.H.I.J. Davids, De acte éclaire en acte clair-leer in het belastingrecht - algemeen (deel I), TFB 2008/2

D.M. Weber \& F.H.I.J. Davids, De acte éclaire en acte clair-leer - de praktische toepassing (deel II), TFB 2008/3

G.J. Wiarda, Drie typen van rechtsvinding, bewerkt en van een nabeschouwing voorzien door T. Koopmans. Deventer: W.E.J. Tjeenk Willink 1999

R.J.G.M. Widdershoven \& R. Ortlep, Schendingen van EG-recht door rechters, NJ 2004/125

R.A. Wolf, Carrouselfraude (diss. Groningen), Den Haag: Sdu Uitgevers 2010

A.W. van der Woude, Nogmaals richtlijnconforme uitleg van de Wet, WFR 1991/853

A.W. van der Woude, Belastingen begrensd (diss. Rotterdam), Delft: Eburon 2000

B.G. van Zadelhoff, Onroerende goederen en belasting over de toegevoegde waarde (diss. Amsterdam Uva), Deventer: Uitgeverij FED 1992

B.G van Zadelhof, Column 'Doe maar normaal' in WFR 2005/619

B.G. van Zadelhoff, Belastingplichtige in de BTW, Deventer: Fed Fiscale Brochure 2008

P.F. Zijlstra, Belastingplanning en rechtsmisbruik in de omzetbelasting, WFR 2011/167 


\section{LIJST VAN AANGEHAALDE JURISPRUDENTIE}

\section{Hof van Justitie van de Europese Unie}

\section{6}

Hof 16 juli 1956 en 29 november 1956, nr. 8/55, Belgische Steenkool Federatie (Fédéchar), Jur. 1956, blz. 309

\section{8}

Hof 13 juni 1958, nr. 9/56, Meroni \& C. e.a., Jur. 1958, blz. 11

1962

Hof 14 december 1962, nrs 16/62 en 17/62, Fruit en Groente e.a., Jur. 1962, blz. 575

\section{3}

Hof 5 februari 1963, nr. 26/62, Van Gend en Loos, Jur. 1963, blz. 3

Hof 17 juli 1963, nr. 13/63, Commissie/Italië, Jur. 1963, blz. 351

\section{4}

Hof 14 januari 1964, nr. 6/64, Costa Enel, Jur. 1964, blz. 1203

Hof 13 november 1964, nr. 90/63 en 91/63, Commissie/Luxemburg en Commissie/ België, Jur. 1964, blz. 1279

\section{0}

Hof 6 oktober 1970, nr. 9/70, Grad, Jur. 1970, blz. 825

\section{4}

Hof 12 februari 1974, nr. 152/73, Sotgiu, Jur. 1974, blz. 153

Hof 3 december 1974, nr. 33/74, Binsbergen, Jur. 1974, blz. 1299

Hof 4 december 1974, nr. 41/74, Van Duyn, Jur. 1974, blz. 1337

\section{5}

Hof 19 maart 1975, nr. 28/74, Gillet, Jur. 1975, blz. 533

\section{6}

Hof 8 april 1976, nr. 43/75, Defrenne II, Jur. 1976, blz. 455 Hof 8 april 1976, nr. 48/75, Royer, Jur. 1976, blz. 497

Hof 16 december 1976, nr. 33/76, Rewe, Jur. 1976, blz. 1989

Hof 16 december 1976, nr. 45/76, Comet, Jur. 1979, blz. 2043 
1977

Hof 1 februari 1977, nr. 51/76, VNO, BNB 1978/18

Hof 3 maart 1977, nr. 80/76, North Kerry Milk Products Ltd, Jur. 1977, blz. 425

Hof 5 juli 1977, nr. 114/76, Bela Mühle, Jur. 1977, blz. 1211

Hof 19 oktober 1977, nrs. 117/76 en 16/77, Ruckdeschel e.a., Jur. 1977, blz. 1753

Hof 19 oktober 1977, nrs. 124/76 en 20/77 Moulins Pont-à-Mousson e.a., Jur. 1977, blz. 1795

1978

Hof 16 februari 1978, nr. 61/77, Commissie/lerland, Jur. 1978, blz. 417

Hof 25 oktober 1978, nr. 125/77, KSH, Jur. 1978, blz. 1991

\section{9}

Hof 25 januari 1979, nr. 98/78, Racke, Jur. 1979, blz. 69 Hof 25 januari 1979, nr. 99/78, Decker, Jur. 1979, blz. 101 Hof 13 maart 1979, nr. 86/78, Peureux, Jur. 1979, blz. 897 Hof 8 april 1976, nr. 43/75, Defrenne II, Jur. 1976, blz. 455

Hof 12 juni 1979, nrs. 181/78 en 229/78, Ketelhandel P. Van Paassen, BNB 1980/44 Hof 12 juni 1979, nr. 126/78, NV Nederlandse Spoorwegen, BNB 1980/2

\section{0}

Hof 5 maart 1980, nr. 265/78, Ferwerda, Jur. 1980, blz. 617

Hof 27 maart 1980, nrs. 66/79, 127/79 en 128/79, Salumi, Jur. 1980, blz. 1237

Hof 17 december 1980, nr. 149/79, Commissie/België, Jur. 1980, blz. 3881

1981

Hof 5 februari 1981, nr. 154/80, Coöperatieve Aardappelenbewaarplaats GA, BNB 1981/232

Hof 5 februari 1981, nr. 50/80, J. Horvath, Jur. 1981, blz. 385

1982

Hof 19 januari 1982, nr. 8/81, Ursula Becker, Jur. 1982, blz. 52

Hof 1 april 1982, nr. 89/81, Hong Kong Trade Development Council, BNB 1982/311, FED 1983/25

Hof 5 mei 1982, nr. 15/81, Gaston Schul I, BNB 1982/225

Hof 6 mei 1982, nr. 54/81, Fromme, Jur. 1982, blz. 1449

Hof 10 juni 1982, nr. 255/81, Grendel, Jur. 1982, blz. 2301

Hof 1 juli 1982, nr. 222/81, BAZ Bausystem AG, Jur. 1982, blz. 2527

Hof 15 juli 1982, nr. 270/81, Felicitas, Jur. 1982, blz. 2771

Hof 6 oktober 1982, nr 283/81, Cilfit, Jur. 1982, blz. 3415

Hof 26 oktober 1982, nr. 221/81, W. Wolf, Jur. 1982, blz. 3681

Hof 26 oktober 1982, nr. 240/81, S. Einberger, Jur. 1982, blz. 3699 


\section{3}

Hof 21 september 1983, gevoegde zaken nrs. 205-215/82, Deutsche Milchkontor I, Jur. 1983, blz. 2633

Hof 9 november 1983, nr. 199/82, Spa San Giorgio, Jur. 1983, blz. 3595

\section{4}

Hof 22 februari 1984, nr. 70/83, Kloppenburg, Jur. 1984, blz. 1075

Hof 28 februari 1984, nr. 294/82, S. Einberger, BNB 1987/6, FED 1985/541

Hof 10 april 1984, nr. 14/83, Von Colson en Kamann, Jur. 1984, blz. 1891

Hof 10 april 1984, nr. 324/82, Commissie/België, Jur. 1984, blz. 1861

\section{5}

Hof 30 januari 1985, nr. 143/83, Commissie/Denemarken, Jur. 1985, blz. 427

Hof 13 februari 1985, nr. 5/84, Direct Cosmetics I, Jur. 1985, blz. 617

Hof 14 februari 1985, nr. 268/83, Rompelman c.s., BNB 1985/315

Hof 4 juli 1985, nr. 168/84, Günter Berkholz, Jur. 1985, blz. 2251

Hof 10 juli 1985, nr. 16/84, Commissie/Nederland, FED 1985/509

Hof 11 juli 1985, nr. 107/84, Commissie/Bondsrepubliek Duitsland, Jur. 1985, blz. 2663

\section{6}

Hof 15 januari 1986, nr. 41/84, Pinna, Jur. 1986, blz. 1

Hof 23 januari 1986, nr. 283/84, Trans Tirreno Express Spa, Jur. 1986, blz. 231

Hof 26 februari 1986, nr. 152/84, Marshall I, Jur. 1986, blz. 723

Hof 8 juli 1986, nr. 73/85, Kerrutt, Jur. 1986, blz. 2219

Hof 25 november 1986, nrs. 201/85 en 202/85, M. Klensch e.a., Jur. 1986, blz. 3477

Hof 4 december 1986, nr. 205/84, Commissie/Duitsland, Jur. 1986, blz. 3755

\section{7}

Hof 26 maart 1987, nr. 231/87 en nr. 129/88, Carpaneto Piacentino, FED 1990/312

Hof 26 maart 1987, nr. 235/85, Commissie/Nederland, FED 1987/341

Hof 21 mei 1987, nr. 249/85, Albako, Jur. 1987, blz. 2345

Hof 1 oktober 1987, nr. 311/85, Vereniging voor Vlaamse reisbureaus, Jur. 1987, blz. 3801

Hof 8 oktober 1987, nr. 80/86, Kolpinghuis, Jur. 1987, blz. 3969

Hof 22 oktober 1987, nr. 314/85, Foto Frost, Jur. 1987, blz. 4199

Hof 24 november 1987, nr. 125/86, Commissie/Italië, Jur. 1987, blz. 4669

\section{8}

Hof 2 februari 1988, nr. 24/86, Blaizot, Jur. 1988, blz. 379

Hof 4 februari 1988, nr. 391/85, Commissie/België, Jur. 1988, blz. 579

Hof 23 februari 1988, nr. 353/85, Commissie/Verenigd Koninkrijk, Jur. 1988, blz. 817 Hof 3 maart 1988, nr. 252/86, G. Bergandi, Jur. 1988, blz. 1343

Hof 8 maart 1988, nr. 102/86, Apple and Pear Development Council, Jur. 1988, blz. 1443

Hof 24 maart 1988, nr. 104/86, Commissie/Italië, Jur. 1988, blz. 1799

Hof 26 april 1988, nr. 316/86, Krücken, Jur. 1988, blz. 2213

Hof 5 juli 1988, nr. 269/86, W.J.R. Mol, BNB 1988/303, FED 1988/495 
Hof 5 juli 1988, nr. 289/86, Vereniging Happy Family Rustenburgerstraat, FED 1988/496 Hof 12 juli 1988, nrs. 138 en 139/86, Direct Cosmetics II, Jur. 1988, blz. 3937 Hof 14 juli 1988, nr. 207/87, Weissgerber, Jur. 1988, blz. 4433 Hof 14 juli 1988, nrs. 123 en 330/87, L. Jeunehomme en EGI, Jur. 1988, blz. 4517 Hof 21 september 1988, nr. 50/87, Commissie/Frankrijk, BNB 1994/306, FED 1991/203 Hof, 23 november 1988, nr. 230/87, Naturally yours Cosmetics Ltd, Jur. 1988, blz. 6365

1989

Hof 15 maart 1989, nr. 51/88, Hamann, FED 1990/91

Hof 15 juni 1989, nr. 348/87, SUFA, FED 1989/559

Hof 27 juni 1989, nr. 50/88, H. Kühne, FED 1990/739

Hof 13 juli 1989, nr. 173/88, M. Henriksen, FED 1990/72

Hof 17 oktober 1989, nrs. 231/87 en 129/88, Carpaneto Piacentino I, FED 1990/313

Hof 13 december 1989, nr. 342/87, Genius Holding, BNB 1990/237, V-N 1990/42, pt. 14, FED 1990/123

\section{0}

Hof 8 februari 1990, nr. C-320/88, Safe Rekencentrum BV, BNB 1990/271, V-N 1990/ 2122, pt. 24, FED 1990/330

Hof 13 maart 1990, nr. C-30/89, Commissie/Frankrijk, Jur. 1990, blz. 691

Hof 17 mei 1990, nr. 262/88, D.H. Barber, Jur. 1990, blz. I-1889

Hof 13 november 1990, nr. C-106/89, Marleasing, Jur. 1990, blz. I-4135

Hof 13 november 1990, nr. C-331/88, Fedesa e.a., Jur. 1990, blz. I-4023

Hof 6 december 1990, nr. C-343/89, M. Witzemann, BNB 1991/190, V-N 1991/2268, pt. 17, FED 1991/354

\section{1}

Hof 21 februari 1991, nrs. C-143/88 en C-92/89, Süderdithmarschen, Jur. 1991,

blz. 415

Hof 28 februari 1991, nr. C-360/87, Commissie/Italië (Grondwater I), Jur. 1991, blz. 791

Hof 30 mei 1991, nr. C-361/88, Commissie/Duitsland, Jur. 1991, blz. I-2567

Hof 11 juni 1991, nr. C-300/89, Commissie/Raad, Jur. 1991, blz. 2867

Hof 20 juni 1991, nr. C-60/90, Polysar Investment Netherlands BV, V-N 1991/2140, pt 35, FED 1991/633

Hof 10 juli 1991, nr. C-90/90, Neu e.a., Jur. 1991, blz. I-3617

Hof 11 juli 1991, nr. C-97/90, Lennartz, V-N 1991/2402, FED 1991/647

Hof 25 juli 1991, nr. C-208/90, Emmott, Jur. 1991, blz. I-4269

Hof 25 juli 1991, nr. C-202/90, Ayuntamiento de Sevilla/Spaanse ontvangers, V-N 1991/2162, punt 45, Jur. 1991, blz. 4247, V-N 1991/2162, pt. 45

Hof 25 juli 1991, nr. C-221/89, Factortame e.a., Jur. 1991, blz. I-3956

Hof 19 november 1991, nrs. C-6/90 en C-9/90, Francovich en Bonifaci, Jur. 91, blz. I-5357 


\section{2}

Hof 31 maart 1992, nr. C-200/90, Dansk Denkavit APS en P. Poulsen Trading APS, V-N 1992/1463, pt. 17

Hof 6 mei 1992, nr. C-20/91, P. de Jong, BNB 1992/377, V-N 1992/2794 pt. 17, FED 1992/636

Hof 9 juli 1992, nr. C-131/91, K-Line Air Services Europe BV, Jur. 1992, blz. 4513

Hof 16 juli 1992, nr. C-163/90, Legros, Jur. 1992, blz. I-4625

Hof 14 oktober 1992, Commissie/Italië, Jur. 1992, blz. I-5269

\section{3}

Hof 19 januari 1993, nr. C-101/91, Commissie/Italië, Jur. 1993, blz. 191

Hof 3 maart 1993, nr. C-8/92, General Milk Products, Jur. 1993, blz. I-779

Hof 25 mei 1993, nr. C-193/91, G. Mohsche, FED 1995/550

Hof 22 juni 1993, nr. C-333/91, Sofitam SA, FED 1993/608

Hof 2 augustus 1993, nr. C-111/92, W. Lange, Jur. 1993, blz. I-4677

Hof 20 oktober 1993, nr. C-10/92, Balocchi, Jur. 1993, blz. I-5105

Hof 27 oktober 1993, nr. C-338/91, Steenhorst-Neerings Jur. 1993, blz. I-5435

Hof 27 oktober 1993, nr. C-281/91, Muys en De Winter, BNB 1994/95, V-N 1993/4006,

pt. 47

Hof 17 november 1993, nr. C-68/92, Commissie/Frankrijk, V-N 1994/592 pt. 36 Hof 17 november 1993, nr. C-69/92, Commissie/Luxemburg, Jur. 1993, blz. I-5907, Hof 17 november 1993, nr. C-73/92, Commissie/Spanje, Jur. 1993, blz. I-5997

Hof 1 december 1993, nr. C-234/91, Commissie/Denemarken, Jur. 1993, blz. I-6273

Hof 15 december 1993, nr. C-63/92, Lubbock fine \& Co, FED 1994/155, BNB 1999/193 Hof 16 december 1993, nr. C-334/92, Wagner Miret, Jur. 1993, blz. I-06911

\section{4}

Hof 27 januari 1994, nr. C-98/91, Herbrink, Jur. 1994, blz. I-223

Hof 23 februari 1994, nr. C-236/92, Camitato, Jur. 1994, blz. I-483

Hof 3 maart 1994, nr. C-16/93, Tolsma, BNB 1994/271, V-N 1994/1069, pt 25, FED $1994 / 348$

Hof 2 juni 1994, nr. C-33/93, Empire Stores Ltd, V-N 1995/3109, pt 21

Hof 14 juli 1994, nr. C-91/92, Faccini Dori, Jur. 1994, blz. I-3325

Hof 28 september 1994, nr. C-128/93, Fisscher, Jur. 1994, blz. 4583

Hof 5 oktober 1994, nr. C-151/93, Voogd Vleesimport en -export, Jur. 1994,

blz. I-4915

Hof 6 december 1994, nr. C-410/92, Johnson, Jur. 1994, blz. I-5483

\section{5}

HvJ 14 februari 1995, nr. C-279/93, Schumacker, Jur. 1995, blz. I-225

Hof 6 april 1995, nr. C-4/94, BLP, V-N 1995/3030, pt. 27, FED 1995/495

Hof 6 juli 1995, nr. C-62/93, BP Soupergaz, Jur. 1995, blz. I-1883

Hof 11 augustus 1995, nr. C-453/93, Bulthuis-Griffioen, V-N 1995/2932, pt. 32,

FED 1995/703

Hof 11 augustus 1995, nrs. C-367/93 t/m C-377/93, Roders e.a., Jur. 1995, blz. I-2229

Hof 4 oktober 1995, nr. C-291/92, D. Armbrecht, BNB 1996/62, V-N 1995/3902 pt 33 
Hof van 24 oktober 1995, nr. C-266/93, Volkswagen en VAG Leasing, Jur. 1995, blz. I-3479

Hof 26 oktober 1995, nr. C-144/94, Italiticca SpA, Jur. 1995, blz. I-3653

Hof 23 november 1995, nr. C-394/93, Alonso-Pérez, Jur. 1995, blz. I-4101

Hof 15 december 1995, nr. C-415/93, Bosman, Jur. 1995, blz. I-4921

1996

Hof 29 februari 1996, nr. C-215/94, J. Mohr, BNB 1997/32

Hof 29 februari 1996, nr. C-110/94, INZO, V-N 1996/1396, pt. 27

Hof 5 maart 1996, nrs. C-46/93 en C-48/93, Brasserie du Pêcheur, Jur. 1996, blz. I-1029

Hof 7 maart 1996, nr. C-192/94, El Corte Inglés, Jur. 1996, blz. I-1281

Hof 28 maart 1996, nr. C-468/93, Gemeente Emmen, V-N 1996/1545, pt 24,

FED 1996/690

Hof 2 mei 1996, nr. C-206/94, Paletta, Jur. 1996, blz. I-2357

Hof 2 mei 1996, nr. C-231/94, Faaborg-Gelting-Linien A/S, V-N 1996/2120, pt. 22

Hof 23 mei 1996, nr. C-331/94, Commissie/Griekenland, Jur. 1996, blz. I-2675

Hof 20 juni 1996, nr. C-155/94, Wellcome Trust, V-N 1997/1034, pt 17, FED 1996/577

Hof 27 juni 1996, nr. C-107/94, Asscher, Jur. 1996, blz. I-3089

Hof 11 juli 1996, nr. C-306/94, Régie Dauphinoise, BNB 1997/38

Hof 26 september 1996, nr. C-230/94, R. Enkler, V-N 1997/653, pt. 22

Hof 26 september 1996, nr. C-327/94, J. Dudda, V-N 1997/1225

Hof 26 september 1996, nr. C-302/93, E, Debouche, BNB 1997/95, V-N 1996/4058, pt. 17

Hof 24 oktober 1996, nr. C-317/94, Elida Gibbs Ltd, V-N 1996/4573, pt. 25

Hof 24 oktober 1996, nr. C-435/93, Dietz, Jur. 1996, blz. I-5223

Hof 26 oktober 1996, nr. C-327/94, Jürgen Dudda, V-N 1997/1225, pt. 18

Hof 24 oktober 1996, nr. C-217/94, Eismann Alto Adigo Srl, Jur. 1996, blz. I-5287

Hof 5 december 1996, nr. C-85/95, Reisdorf, V-N 1997/402

\section{7}

Hof 6 februari 1997, nr. C-247/95, Marktgemeinde Welden, V-N 1997/1659, pt. 16 Hof 6 februari 1997, nr. C-80/90, Harnas \& Helm, BNB 1997/386, V-N 1997/1031, FED 1997/158

Hof 20 februari 1997, nr. C-260/95, DFDS A/S, V-N 1997/1662, pt. 17

Hof 6 maart 1997, nr. C-167/95, Maatschap Linthorst, Pouwels \& Scheres c.s., V-N $1997 / 1400$, pt. 31

Hof 29 mei 1997, nr. C-63/96, Skripalle, V-N 1998/627

Hof 25 juni 1997, nr. C-114/96, R. Kieffer en R. Thill, Jur. 1997, blz. I-3629

HvJ 26 juni 1997, nrs. C-370/95 en C-371/95, C-372/95, Careda Sa, Femara, Facomare, V-N 1997/3631, pt 45

Hof 3 juli 1997, nr. C-330/95, Goldsmith, V-N 1997/2988, pt. 18

Hof 17 juli 1997, nr. C-190/95, ARO Lease BV, V-N 1997/2933, pt. 7

Hof 16 september 1997, nr. C-145/96, B. von Hoffmann, V-N 1997/3865, pt. 25

Hof 16 oktober 1997, nr. C-258/95, Fillibeck, V-N 1998/2.35

Hof 17 september 1997, nr. C-141/96, Langhorst, V-N 1997/3932, pt 12

Hof 6 november 1997, nr. C-116/96, Reisbüro Binder GmbH, V-N 1998/4.13 
Hof 2 december 1997, nr. C-188/95, Fantask, Jur. 1997, blz. I-6783

Hof 4 december 1997, nr. C-253-258/96, Kampelmann e.a., Jur. 1997, blz. I-6907 Hof 18 december 1997, nr. C-384/95, Landboden-Agrardiensten GmbH, V-N 1998/ 5.17, FED 1998/141

Hof 18 december 1997, nrs. C-286/94, C-340/95, C-401/95 en C-47/96, Garage Molenheide BVBA e.a., V-N 1998/6.29

\section{8}

Hof 15 januari 1998, nr. C-37/95, Ghent Coal Terminal NV, V-N 1998/29.14 Hof 7 mei 1998, nr. C-390/96, Lease Plan Luxembourg, V-N 1998/57.19

Hof 12 mei 1998, nr. C-367/96, Kefalas e.a., Jur. 1998, blz. I-2843

Hof 28 mei 1998, nr. C-3/97, Goodwin \& Unstead, V-N 1998/57.17

Hof 4 juli 1998, nr. 168/84, G. Berkholz, Jur. 1985, blz. 2251

Hof 11 juni 1998, nr. C-361/96, SGGSEMF (Minerales), V-N 1998/39.42

Hof 11 juni 1998, nr. C-283/95, K. Fischer, V-N 1998/39.43

Hof 14 juli 1998, nrs. 123/87 en 330/87, Jeunehomme en EGI, Jur. 1988, blz. 4517

Hof 16 juli 1998, nr. C-355/96, Silhouette, Jur. 1988, blz. I-4799

Hof 15 september 1998, nr. C-231/96, Edis, Jur. 1998, blz. I-4951

Hof 19 september 1998, Liïkenne, nr. C-412/96, Jur. 1998, blz. I-5141

Hof 22 oktober 1998, nr. C-308/96, Madgett \& Baldwin, V-N 1998/59.20

Hof 12 november 1998, nr. C-149/97, Motor Industry, V-N 1997/3098, pt. 28

Hof 17 november 1998, nr. C-228/96, Aprile, Jur. 1998, blz. I-7141

Hof 3 december 1998, nr. C-381/97, Belgocodex, BNB 1999/29, V-N 1999/14.25

\section{9}

Hof 25 februari 1999, nr. C-349/96, Card Protection Plan, BNB 1999/224, V-N 1999/15.28 Hof 9 maart 1999, nr. C-212/97, Centros, Jur. 1999, blz. I-1459

Hof 27 april 1999, nr. C-48/97, Kuwait Petroleum (GB) Ltd, V-N 1999/27.15

Hof 4 mei 1999, nr. C-262/96, S. Sürül, Jur. 1999, blz. I-2685

Hof 11 juni 2009, nr. C-572/07, RLRE Tellmer Property sro, V-N 2009/29.17, NTFR 2009/1441

Hof 29 juni 1999, nr. C-158/98, VOF Coffeeshop Siberië, BNB 2000/178,

V-N 1999/36.17, FED 1999/619

Hof 7 september 1999, nr. C-216/97, Gregg \& Gregg, BNB 1999/395, V-N 1999/47.21

Hof 14 september 1999, nr. C-310/97, AssiDomän Kraft Products, Jur. 1999, blz. I-5363

Hof 23 november 1999, nr. C-149/96, Portugal/Raad, Jur. 1999, blz. I-8395

\section{0}

Hof 9 maart 2000, nr. C-437/97, EKW/Wein \& Co, Jur. 2000, blz. I-1157

Hof 21 maart 2000, nr. C-110 t/m C-147/98, Gabalfrisa SL e.a. V-N 2000/22.12

Hof 23 maart 2000, nr. C-373/97, Diamantis, Jur. 2000, blz. I-1705

Hof 8 juni 2000, nr. C-396/98, Schlosstrasse, NTFR 2000/922, V-N 2000/44.21

Hof 8 juni 2000, nr. C-400/98, Breitsohl, V-N 2000/43.19

Hof 8 juni 2000, nr. C-98/98, Midland Bank, BNB 2001/118, V-N 2000/44.20,

FED 2000/645, NTFR 200/921 
Hof 13 juli 2000, nr. C-136/99, Monte Dei Paschi di Siena, V-N 2000/50.22, FED 2000/615

Hof 13 juli 2000, nr. C-36/99, Idéal Tourisme, NTFR 2000/1068

Hof 15 juni 2000, nr. C-365/98, Brinkmann, NTFR 2000/1074

Hof 29 juni 2000, nr. C-455/98, Salumets e.a., Jur. 2000, blz. I-4993

Hof 12 september 2000, nr. C-408/97, Commissie/Nederland, V-N 2000/41.19

Hof 12 september 2000 nr. C-276/97, Commissie/Frankrijk, Jur. 2000, blz. I-6251;

Hof 12 september 2000, nr. C-359/97, Commissie/Verenigd Koninkrijk, Jur. 2000, blz. I-6355

Hof 12 september 2000, nr. C-358/97, Commissie/Ierland, Jur. 2000, blz. I-6301 Hof 12 september 2000, nr. C-260/98, Commissie/Griekenland, BNB 2000/377, V-N 2000/41.19

Hof 12 september 2000, nr. C-408/97, Commissie/Nederland, BNB 2000/377, V-N 2000/41.19

Hof 19 september 2000, nrs. C-177/99 en C-181/99, Ampafrance, V-N 2000/48.19, NTFR 2000/1407

Hof 19 september 2000, nr. C-454/98, Schmeink \& Cofreth \& Co KG en M. Strobel, BNB 2000/167, V-N 2000/47.16

Hof 14 november 2000, nr. C-142/99, Floridienne \& Berginvest, V-N 2000/53.17

Hof 14 december 2000, nr. C-110/99, Emsland-Stärcke, Jur. 2000, blz. I-1569

Hof 14 december 2000, nr. C-446/98, Câmara Municipal do Porto, V-N 2001/3.20

\section{1}

Hof 18 januari 2001, nr. C-150/99, Stockholm Lindöpark, V-N 2001/11.21

Hof 25 januari 2001, nr. C-429/97, Commissie/Frankrijk, Jur. 2001, blz. 637

Hof 22 februari 2001, nr. C-408/98, Abbey National, V-N 2001/15.26

Hof 8 maart 2001, nr. C-240/99, Skandia, V-N 2001/22.19

Hof 8 maart 2001, nrs. C-397/98 en C-410/98, Metallgesellschaft e.a., Jur. 2001,

blz. I 1727

Hof 8 maart 2001, L. Bakcsi, nr. C-415/98, BNB 2001/200, V-N 2001/18.30

Hof 15 maart 2001, nr. C-108/00, SPI, V-N 2001/22.16

Hof 3 mei 2001, nr. C-481/98, Commissie/Frankrijk, V-N 2001/42.18

Hof 15 mei 2001, nr. C-34/99, Primback, V-N 2001/32.20

Hof 17 mei 2001, nrs. C-322/99 en C-323/99, Fischer \& Brandenstein, V-N 2001/32.27

Hof 29 mei 2001, nr. C-86/99, Freemans, V-N 2001/35.27

Hof 3 juli 2001, nr. C-380/99, Bertelsmann AG, V-N 2001/39.21

Hof 12 juli 2001, C-102/00, Welthgrove BV, BNB 2002/182, V-N 2001/42.14, FED 2001/541

Hof 25 juli 1991, nr. C-221/89, Factortame e.a. Jur. 1991, blz. I-3956

Hof 20 september 2001, nr. C-184/99, Grzelczyk, Jur. 2001, blz. I-6193

Hof 27 september 2001, nr. C-16/00, Cibo Participations SA, V-N 2001/55.7, FED 2002/31

Hof 4 oktober 2001, nr. C-326/99, Stichting Goed Wonen I, V-N 2001/56.25

Hof 9 oktober 2001, nr. C-108/99, Cantor Fitzgerald International, V-N 2001/58.20, NTFR 2001/1488

Hof 25 oktober 2001, nr. C-78/00, Commissie/Italië, Jur. 2001, blz. I-8195 
Hof 8 november 2001, nr. C-338/98, Commissie/Nederland, BNB 2002/149, NTFR 2001/1570

Hof 13 december 2001, nr. C-235/00, CSC Financial Services, V-N 2002/5.26

\section{2}

Hof 8 januari 2002, nr. C-409/99, Metropol \& Stadler, V-N 2002/8.33, NTFR 2002/05

Hof 27 februari 2002, nr. C-302/00, Commissie/Frankrijk, Jur. 2002, blz. I-2055

Hof 21 maart 2002, Kennemer Golf \& Counttry Club, nr. C-174/00, BNB 2003/30,

V-N 2002/20.13, FED 2002/249

Hof 20 juni 2002, nr. C-287/00, Commissie/Duitsland, V-N 2002/34.17, FED 2002/535

Hof 11 juli 2002, nr. C-62/00, Marks \& Spencer, V-N 2002/49.28, NTFR 2002/1014

Hof 10 september 2002, nr. C-141/00, Ambulanter Pflegedienst Kügler, FED 2003/55, NTFR 2002/1390

Hof 17 september 2002, nr. C-498/99, Town \& County Factors, V-N 2002/50.21, NTFR 2002/1391

Hof van 15 oktober 2002, nr. C-427/98, Commissie/Duitsland, V-N 2002/54.22

Hof 12 december 2002, nr. C-324/00, Lankhorst-Hohorst GmbH, Jur. 2002, blz. I-9977

\section{3}

Hof 6 februari 2003, nr. C-45/01, Dornier, V-N 2003/58.18, FED 2004/195, NTFR 2003/1905

Hof 3 april 2003, nr. C-144/00, M. Hoffmann, BNB 2003/196, V-N 2003/20.12, NTFR 2003/631

Hof 8 mei 2003, nr. C-269/00, W. Seeling, BNB 2004/1, V-N 2003/28.20

Hof 8 mei 2003, nr. C-384/01, Commissie/Frankrijk, V-N 2003/29.22

Hof 13 mei 2003, C-463/00, Commissie/Spanje, Jur. 2003, blz. I-4581

Hof 26 juni 2003, nr. C-305/01, MKG-Kraftfahrzeuge, V-N 2003/34.13, FED 2003/513, NTFR 2003/1144

Hof 11 september 2003, nr. C-445/00, Oostenrijk/Raad, Jur. 2003, blz. I-8549 Hof 30 september 2003, nr. C-224/01, Köbler, BNB 2004/151, NTFR 2003/2125 Hof 6 november 2003, nr. C-101/01, Lindqvist, Jur. 2003, blz. I-12971 Hof 6 november 2003, nr. C-45/01, Dornier, V-N 2003/58.18, FED 2004/195, NTFR 2003/1905

Hof 6 november 2003, nrs. C-78/02 t/m C-80/02, Karageorgou e.a., V-N 2003/58.17, FED 2004/134

Hof 20 november 2003, nr. C-307/01, P. d'Ambrumenil, V-N 2003/61.19, NTFR 2003/1974

Hof 20 november 2003, nr. C-212/01, M. Unterpertinger, V-N 2003/61.19,

FED 2004/70, NTFR 2003/1973

Hof 20 november 2003, nr. C-8/01, Taksatoringen, V-N 2003/13.18, FED 2004/259, NTFR 2003/1975

Hof 9 december 2003, nr. C-129/00, Commissie/Italië, Jur. 2003, blz. I-4637

\section{4}

Hof 13 januari 2004, nr. C-453/00, Kühne \& Heitz NV, NJ 2004/125, V-N 2004/8.3, NTFR 2004/116 
Hof 3 maart 2004, nr. C-395/02, Transport Services NV, NTFR 2004/399

Hof 1 april 2004, nr. C-90/02, Bockemühl, V-N 2004/20.18, NTFR 2004/513

Hof 29 april 2004, nr. C-17/01, W. Sudholz, V-N 2004/24.16, NTFR 2004/674, 10.5.1.3

Hof 29 april 2004, nrs. C-487/01 en C-7/02, Gemeente Leusden en Holin Groep BV, V-N 2004/24.17, NTFR 2004/670

Hof 9 september 2004, nr. C-269/03, Objekt Kirchberg, V-N 2004/48.9, NTFR 2004/1515

Hof 18 november 2004, nr. C-284/03, Temco Europe, V-N 2005/21.22,

NTFR 2004/1739

\section{5}

Hof 20 januari 2005, nr. C-412/03, Hotel Scandic Gåsabäck, V-N 2005/8.22

Hof 17 februari 2005, nrs. C-453/02 en C-462/02, Linneweber \& Akriditis,

V-N 2005/13.14, NTFR 2005/302

Hof 3 maart 2005, nr. C-32/03, I/S Fini H, V-N 2005/15.8, NTFR 2005/322

Hof 3 maart 2005, nr. C-428/02, FML, V-N 2005/15.10, NTFR 2005/357

Hof 15 maart 2005, nr. C-209/03, D. Bidar, Jur. 2005, blz. I-2119

Hof 21 april 2005, nr. C-25/03, Hundt Eßwein, BNB 2005/229, V-N 2005/22.18

Hof 26 april 2005, nr. C-376/02, Stichting Goed Wonen II, V-N 2005/23.16, NTFR 2005/600

Hof 12 mei 2005, nr. C-452/03, RAL, V-N 2005/32.26, NTFR 2005/728

Hof 26 mei 2005, nr. C-465/03, Kretztechnik, BNB 2005/313

Hof 26 mei 2005, nr. C-498/03, Kingscrest, V-N 2005/29.19

Hof 2 juni 2005, nr. C-378/02, Waterschap Zeeuws Vlaanderen (WZV),

V-N 2005/30.17, NTFR 2005/896

Hof 14 juli 2005, nr. C-434/03, Charles en Charles-Tijmens, BNB 2005/284,

V-N 2005/35.18

Hof 14 juli 2005, nr. C-435/03, BATI, V-N 2005/37.21, NTFR 2005/1019

Hof 21 juli 2005, nr. C-349/03, Commissie/Verenigd Koninkrijk

Hof 15 september 2005, nr. C-58/04, A. Köhler, V-N 2005/47.24

Hof 6 oktober 2005, nr. C-291/03, MyTravel Plc, V-N 2005/58.23, NTFR 2005/1423

Hof 6 oktober 2005, nr. C-204/03, Commissie/Spanje, V-N 2005/51.21, NTFR 2005/1624

Hof 6 oktober 2005, nr. C-243/03, Commissie/Frankrijk, V-N 2005/51.22,

NTFR 2005/1625

Hof 27 oktober 2005, nr. C-41/04, Levob, NTFR 2005/1497

Hof 1 december 2005, nrs. C-394/04 en C-395/04, Ygeia e.a., V-N 2005/60.23, NTFR 2005/1724

Hof 15 december 2005, nr. C-63/04, Centralan Property Ltd., V-N 2005/61.19, NTFR 2006/90

\section{6}

Hof 10 januari 2006, nr. C-178/03, Commissie/Parlement, Jur. 2006, blz. I-107 Hof 12 januari 2006, nr. C-354/03, nr. C-355/03, nr. C-484/03, Optigen, Fulcrum Electronics, Bond House Systems, V-N 2006/7.20, NTFR 2006/979

Hof 9 februari 2006, nr. C-415/04, Stichting Kinderopvang Enschede, BNB 2006/154, V-N 2006/11.25, NTFR 2006/430 
Hof 21 februari 2006, nr. C-419/02, BUPA Hospitals Ltd., BNB 2006/172, NTFR 2006/467 Hof 21 februari 2006, nr. C-255/02, Halifax, BNB 2006/170, V-N 2006/13.20, NTFR 2006/359 Hof 7 maart 2006, nr. C-166/05, Heger, V-N 2006/47.14 Hof 9 maart 2006, nr. C-114/05, Gillan Beach Ltd, V-N 2006/46.15 Hof 16 maart 2006, nr. C-234/04, R. Kapferer, SEW 2006/57 Hof 23 maart 2006, nr. C-210/04, FCE Bank Plc, BNB 2006/184, V-N 2006/18.24 Hof 30 maart 2006, nr. C-184/04, Uudenkaupungin Kaupanki, V-N 2006/18.25 Hof 6 april 2006, nr. C-245/04, EMAG, V-N 2006/21.18, NTFR 2006/526 Hof 27 april 2006, nrs. C-443/04 en C-444/04, Solleveld \& Van den Hout-Van Eijnsbergen, BNB 2006/256

Hof 4 mei 2006, nr. C-169/04, Abbey National II, NTFR 2006/687

Hof 11 mei 2006, nr. C-384/04, Federation of Technological Industries e.a., V-N 2006/27.14

Hof 8 juni 2006, nr. C-430/04, Halle, V-N 2006/46.14, NTFR 2006/938

Hof 8 juni 2006, nr. C-106/05, L.u.P. GmbH, V-N 2006/33.17

Hof 6 juli 2006, nrs. C-439/04 en C-440/04, A. Kittel en Recolta Recycling, V-N 2006/42.13

Hof 6 juli 2006, nr. C-251/05, Talacre Beach Caravan Sales, V-N 2006/41.16, NTFR 2006/1021

Hof 12 september 2006, nr. C-196/04, Cadbury Schweppes, NTFR 2006/1406 Hof 14 september 2006, nr. C-228/05, Stradasfalti, V-N 2006/47.15, NTFR 2006/1554 Hof 14 september 2006, nr. C-72/05, Wollny, V-N 2006/50.13

Hof 14 september 2006, nrs. C-181/04 t/m C-183/04, Elmeka NE, V-N 2006/49.19 Het Hof 19 september 2006, EG i-21 Germany GmbH \& Arcor AG van nrs. C-392/04 en C-422/04, Jur. 2006, blz. I-8559

Hof 3 oktober 2006, nr. C-475/03, Banca Popolare, V-N 2006/52.20, NTFR 2006/1578 Hof 7 december 2006, nr. C-240/05, Eurodental SARL, V-N 2007/2.17, NTFR 2007/157 Hof 12 december 2006, nr. C-446/04, Test Claiments, BNB 2007/130, V-N 2007/5.9, NTFR 2007/5.9

Hof 14 december 2006, nr. C-401/05, VDP Dental Laboratory, BNB 2007/94, V-N 2007/6.21, NTFR 2007/158

Hof 14 december 2006, nr. C-228/05, Stradasfalti, V-N 2006/47.15, NTFR 2006/1554

2007

Hof 6 maart 2007, nr. C-292/04, Meilicke, V-N 2007/14.3, NTFR 2007/523

Hof 15 maart 2007, Reemtsma Cigarettenfabriken GmbH, nr. C-35/05,

V-N 2007/15.10

Hof 29 maart 2007, nr. C-111/05, Aktiebolaget NN, V-N 2007/18.22

Hof 17 april 2007, nr. C-470/03, AGM-COS.MET, Pb EG C 96 van 28 april 2007, blz. 2 Hof 19 april 2007, nr. C-445/05, Velvet Steel Immobilien, V-N 2007/21.18

Hof 5 juni 2007, nr. C-2/95, SDC, V-N 1997/206

Hof 7 juni 2007, nr. C-80/06, Carp, Pb EG C 170/7

Hof 7 juni 2007, nr. C-335/05, RLP, V-N 2007/28.20

Hof 14 juni 2007, nr. C-434/05, Horizon College, BNB 2006/238, V-N 2008/100, NTFR 2007/1088 
Hof, 21 juni 2007, nr. C-453/05, L. Volker, NTFR 2007/1202

Hof 21 juni 2007, nr. C-453/05, V. Ludwig, V-N 2007/31.23, blz. I-5083

Hof 26 juni 2007, nr. C-305/05, Ordre des barreaux francophones en germanophone Hof 26 juni 2007, nr. C-305/05, Orde van Franstalige en Duitstalige Balies e.a., Jur. 2007, blz. I-5305

Hof 28 juni 2007, C-363/05, J.P. Morgan Flemming Claverhouse Investement trust Plc, V-N 2007/36.25

Hof 28 juni 2007, nr. C-73/06, Planzer Luxembourg Sàrl, V-N 2007/36.23

Hof 5 juli 2007, nr. 321/05, Kofoed, V-N 2007/34.12

Hof 18 juli 2007, nr. C-277/05, Sociéte Thermale d'Eugénie-les Bains, V-N 2007/34.25, NTFR 2007/1413

Hof 27 september 2007, nr. C-409/04, Teleos Plc., BNB 2008/11, V-N 2007/47.19

Hof 27 september 2007, nr. C-146/05, Collée, BNB 2008/12, V-N 2007/47.20

Hof 27 september 2007, nr. C-184/05, Twoh International, BNB 2008/13, V-N 2007/47.21

Hof 11 oktober 2007, nr. C-283/06 en C-312/06, Kögáz e.a., V-N 2007/48.18

Hof 18 oktober 2007, nr. C-355/06, J.A. van der Steen, V-N 2007/48.19

EG 18 oktober 2007, nr. C-97/06, Navicon SA, V-N 2007/49.21

Hof 25 oktober 2007, nr. C-174/06, Co.Ge.P. Srl, V-N 2007/49.17

Hof 6 december 2007, nr. C-401/06, Commissie/Duitsland, V-N 2007/59.15

Hof 13 december 2007, nr. C-408/06, F. Götz, V-N 2008/3.21

Hof 18 december 2007, nr. C-368/06, Cedilac SA, NTFR 2008/83

\section{8}

Hof 17 januari 2008, nr. C-105/07, Lammers \& Van Cleeff, Jur. 2008, blz. I-173

Hof 12 februari 2008, nr. C-2/06, W. Kempter KG, SEW 2008/199, NTFR 2008/1872

Hof 21 februari 2008, nr. C-425/06, Part Service SRL, V-N 2008/11.17

Hof 21 februari 2008, nr. C-271/06, Netto Supermarkt GmbH \& co, V-N 2008/11.16, NTFR 2008/405

Hof 6 maart 2008, nr. C-98/07, Nordania Finans A/S, V-N 2008/15.20

Hof 13 maart 2008, nr. C-437/06, Securenta, V-N 2008/14.20

Hof 3 april 2008, nr. C-124/07, J.C.M. Beheer BV, V-N 2008/17.16

Hof 3 april 2008, nr. C-442/05, Zweckverband, V-N 2008/20.17

Hof 10 april 2008, nr. C-309/06, Marks \& Spencer, V-N 2008/21.22

Hof 22 mei 2008, nr. C-162/07, Ampliscientifica Srl en Amplifin, V-N 2008/25.20

Hof 3 juni 2008, nr. C-308/06, Intertanko e.a. Jur. 2008, blz. I-4057

Hof 12 juni 2008, nr. C-462/05, Commissie/Portugal, V-N 2008/29.20

Hof 10 juli 2008, nr. C-25/07, Alicja Sosnowska, V-N 2008/35.15

Hof 10 juli 2008, nr. C-484/06, FE Koninklijke Ahold NV, V-N 2008/41.23

Hof 17 juli 2008, nr. C-132/06, Commissie/Italië, NTFR 2008/1604

Hof 9 september 2008, nrs. C-120/06p en C-121/06p, FIAMM en Fedon, SEW 2009/150

Hof 16 september 2008, nr. C-288/07, Isle of Wight, V-N 2008/47.21

Hof 16 oktober 2008, nr. C-253/07, Canterburry Hockey Club, V-N 2008/49.18

Hof 6 november 2008, nr. C-291/07, TRR, V-N 2008/55.20

Hof 20 november 2008, nr. C-18/08, Foselev Sud-Ouest SarL, Jur. 2008, blz. I-8745

Hof 11 december 2008, nr. C-371/07, Danfoss A/S en AstraZenica A/S, V-N 2009/3.24,

NTFR 2008/2508 
Hof 11 december 2008, nr. C-407/07, Stichting CBIT, V-N 2008/60.20, NTFR 2008/2507 Hof 18 december 2008, nr. C-488/07, Royal Bank of Scotland Group Plc, V-N 2008/62.26 Hof 22 december 2008, nr. C-414/07, Magoora, V-N 2009/3.25

\section{9}

Hof 15 januari 2009, nr. C-502/07, K-1, NTFR 2009/269

Hof 12 februari 2009, nr. C-515/07, Vereniging Noordelijke Land en Tuinbouworganisatie, BNB 2009/202, V-N 2009/9.27, NTFR 2009/475

(VNLTO), BNB 2009/202, V-N 2009/9.27, NTFR 2009/475

Hof 19 februari 2009, nr. C-1/08, Athesia Druck Srl, V-N 2009/11.19, NTFR 2009/476

Hof 24 maart 2009, nr. C-445/06, nr. C-445/06, Danske Slagterier, FED 2009/45

Hof 23 april 2009, nr. C-460/07, Sandra Puffer, V-N 2009/25.17, NTFR 2009/1030

Hof 23 april 2009, nr. C-357/07, TNT Post UK Ltd., V-N 2009/21.16

Hof 4 juni 2009, nr. C-102/08, Salix, V-N 2009/28.13, NTFR 2009/1384

Hof 11 juni 2009, nr. C-572/07, RLRE Tellmer Propertt sro, V-N 2009/29.17,

NTFR 2009/1441

Hof 18 juni 2009, nr. C-566/07, Stadeco BV, V-N 2009/31.14

Hof 22 oktober 2009, nr. C-242/08, Swiss RE Germany Holding GmbH, V-N 2009/53.21

Hof 29 oktober 2009, nr. C-29/08, AB SKF, V-N 2009/56.13, NTFR 2009/2421

Hof 29 oktober 2009, nr. C-174/08, NCC Construction Danmark A/S, V-N 2009/56.14, NTFR 2009/2422

Hof 19 november 2009, nr. C-461/08, Don Bosco, V-N 2009/59.17

Hof 3 september 2009, nr. C-37/08, RCI Europe, V-N 2009/47.23

\section{0}

Hof 21 januari 2010, nr. C-472/08, Alstom Power Hydro, V-N 2010/11.22

Hof 11 februari 2010, nr. C-88/09, Graphic Procédé, V-N 2010/11.23

Hof 25 maart 2010, nr. C-79/09, Commissie/Nederland, NTFR 2010/849

Hof 15 april 2010, nrs. C-538/08, C-33-09, X Holding \& Oracle, V-N 2010/19.22

Hof 3 juni 2010, nr. C-237/09, N. De Fruytier, V-N 2010/30.13

Hof 15 juli 2010, nr. C-582/08, Commissie/Verenigd Koninkrijk, V-N 2010/37.25

Hof 15 juli 2010, nr. C-368/09, Pannon Gép Centrum kft, V-N 2010/37.24

Hof 29 juli 2010, nr. C-40/09, Astra Zeneca UK Ltd, V-N 2010/41.12

Hof 30 september 2010, nr. C-392/09, Uszodaépítö kft, NTFR 2010/2318

Hof 7 oktober 2010, nr. C-53/09 en C-55/09, LMUK en Baxi, V-N 2010/55.21,

NTFR 2010/2378

Hof 26 oktober 2010, nr. C-97/09, I. Schmelz, V-N 2010/58.20, NTFR 2010/2576

Hof 28 oktober 2010, nr. C-175/09, AXA UK Plc, NTFR 2010/2509

Hof 18 november 2010, nr. C-84/09, X, V-N 2010/62.20, NTFR 2010/2841

Hof 7 december 2010, nr. C-285/09, R., V-N 2011/2.11, NTFR 2010/2842

Hof 22 december 2010, nr. C-103/09, Weald Leasing Ltd, V-N 2011/8.18, NTFR 2011/81

Hof 22 december 2010, nr. C-277/09, RBSD, V-N 2011/8.19, NTFR 2011/82

\section{1}

Hof 10 maart 2011, nr. C-540/09, SEB, NTFR 2011/640

Hof 12 mei 2011, nr. C-107/10, ENEL, V-N 2011/27.6, NTFR 2011/1274 
Hof 28 juli 2011, nr. C-274/10, Commissie/Hongarije, V-N 2011/39.18, NTFR 2011/2083 Hof 6 oktober 2011, nr. C-421/10, Stoppelkamp, V-N 2011/50.20, NTFR 2011/2519 Hof 27 oktober 2011, nr. C-504/10, Tanoarch, V-N 2011/57.20, NTFR 2011/2572 Hof 10 november 2011, nrs. C-259/10, C-260/10, Rank Group Plc, V-N 2011/62.20, NTFR 2011/2930

Hof 15 december 2011, nr. C-427/10, BAPV, V-N 2012/4.25, NTFR 2012/37

Hof 21 december 2011, nr. C-499/10, VOM, V-N 2012/8.24, NTFR 2012/174

\section{Hoge Raad der Nederlanden}

HR 12 april 1978, nr. 18 452, BNB 1978/135 HR 12 april 1978, nr. 18 464, BNB 1978/136 HR 12 april 1978, nr. 18 495, BNB 1978/137 HR 6 juni 1979, nr. 19290, BNB 1979/211 HR 5 januari 1983, nr. 20 941, BNB 1983/104 HR 2 mei 1984, nr. 22 153, BNB 1984/295 HR 16 mei 1984, nr. 22 246, BNB 1984/212 HR 14 september 1988, nr. 25 005, BNB 1989/213 HR 5 september 1990, nr. 26 721, BNB 1990/305 HR 21 november 1990, nr. 26 362, BNB 1991/19 HR 19 december 1990, nr. 26 144, BNB 1991/40 HR 19 december 1990, 26 764, BNB 1991/41 HR 18 september 1991, nr. 27 127, BNB 1992/182 HR 24 april 1991, nr. 26 878, BNB 1991/206 HR 17 juni 1992, nr. 26 777, BNB 1992/294 HR 17 juni 1992, nr. 27 048, BNB 1992/295 HR 7 december 1994, nr. 29 153, BNB 1995/87 HR 8 juli 1996, nr. 30 318, V-N 1996/2906 HR 4 september 1996, nr. 31 456, BNB 1997/43 HR 26 augustus 1998, nr. 33 518, BNB 1998/372 HR 26 augustus 1998, nr. 33 625, BNB 1999/50 HR 26 augustus 1998, nr. 33 662, BNB 1999, blz. 384; FED 1999, blz. 224, V-N 1998, blz. 4398

HR 26 augustus 1998, nr. 33.690, V-N 1998/46.26

HR 5 januari 2000, nr. 32 957, BNB 2000/130

HR 6 december 2000, nr. 35.704, NTFR 2000/1886

HR 21 maart 2001, nr. C01/321, NTFR 2001/495

HR 22 maart 2002, nr. 33 562, BNB 2002/183

HR 26 april 2002, nr. 35 775, NTFR 2002/630

HR 26 april 2002, nr. 36 802, BNB 2002/192c, V-N 2002/23.22

HR van 14 juni 2002, nr. 35 976, V-N 2002/32.20

HR 24 januari 2003, NTFR 2003/326

HR 18 februari 2005, nr. 37 690, NTFR 2005/273

HR 2 mei 2005, nr. 36.277, NTFR 2005/690

HR 12 augustus 2005, nr. 36.924, NTFR 2005/1074

HR 12 augustus 2005, nr. 35.977, NTFR 2005/1072 
HR 12 augustus 2005, nr. 36.923, NTFR 2005/1073

HR 23 februari 2007, nr. 42 387, V-N 2007/12.20

HR 10 augustus 2007, nr. 43169, V-N 2007/40.27, NTFR 2007/1513

HR 5 oktober 2007, nr. 43.268, V-N 2007/47.2, NTFR 2007/1829

HR 2 november 2007, nr. 42.415, BNB 2008/53

HR 30 november 2007, nr. 41.179, BNB 2008/131, V-N 2007/48.17

HR 14 december 2007, nr. 34.514, V-N 2007/59.18, NTFR 2008/48

HR 14 december 2007, nr. 37.748, BNB 2008/123, V-N 2007/59.17

HR 14 november 2008, nr. 43.185, V-N 2008/11.23

HR 14 november 2008, nr. 42.312, V-N 2008/55.22

HR 3 april 2009, nr. 43.446, V-N 2009/16.17

HR 12 maart 2010, nr. 08/00309, V-N 2010/15.4, NTFR 2010/1026

HR 11 juni 2010, nr. 07/12617, V-N 2010/30.12

HR 10 februari 2012, nr. 08/05317, V-N 2012/13.20, NTFR 2012/639

HR 30 maart 2012, nr. 09/03079, nog niet gepubliceerd

\section{Gerechtshoven}

Gerechtshof Amsterdam

12 november 1986, nr. 4565/86, BNB 1988/84

16 juni 1987, nr. 4565/86, BNB 1989/93

19 januari 2009, nrs. P07/00782, 07/00783, V-N 2009/16.16

26 november 2009, nr. P08/01220, V-N 2010/12.21

Gerechtshof 's-Gravenhage

27 maart 1991, nr. 638/90, V-N 1991, blz. 2332

11 december 1996, nr. 95/2558, FED 1997/174

17 juni 1998, nr. BK-96/02279, FED 1998/624

Gerechtshof Leeuwarden

16 januari 1987, nr. 1995/82, BNB 1988/64 



\section{TREFWOORDENREGISTER}

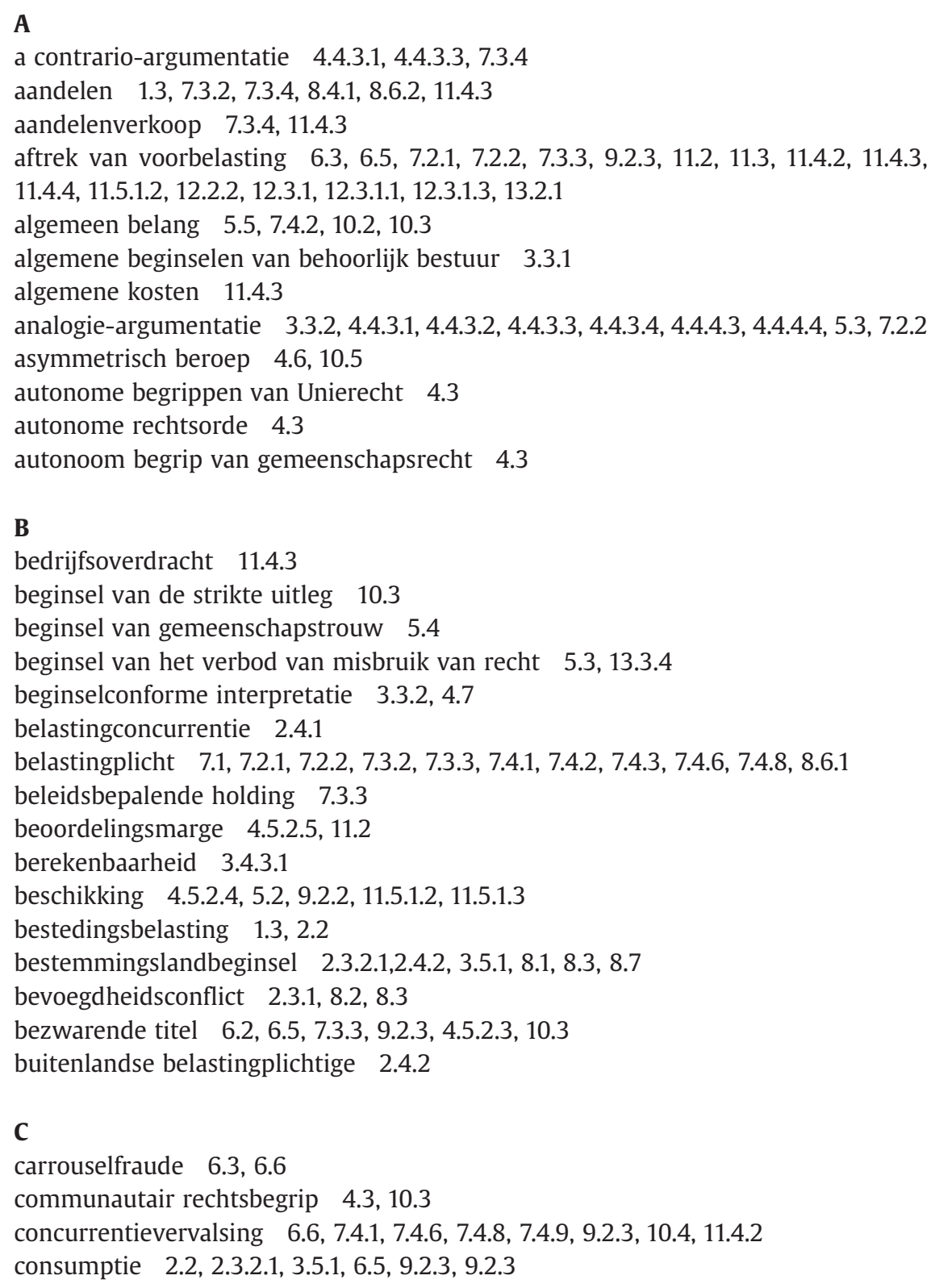


consumptiebelasting $\quad 2.2,2.4 .2$

contextuele interpretatiemethode 4.4.2.4

creditfacturen $\quad 12.2 .1$

\section{D}

diensten $\quad 6.1,6.3,6.5,8.1,8.3,8.6 .2,9.3 .2$

directeur-grootaandeelhouder 1.3

discriminatieverbod $\quad 3.4 .1 .2$

dividend $7.3 .2,7.3 .3$

doel en strekking $4.4 .3 .4,10.3,10.7,13.3 .4$

doelstellingen van de EU 1.1

doeltreffendheidsbeginsel $\quad 5.4,5.5$

drugs 6.4

E

economische realiteit $8.4 .1,8.4 .2$

eenheid van prestatie 9.1, 9.3.1

eindverbruiker $\quad 2.2,2.4 .1,7.2 .1$

elektronisch factureren 12.1

evenredigheidsbeginsel $\quad 2.4 .2,3.2 .3,3.4 .1 .2,3.4 .2 .1,3.4 .2 .2,5.2,5.3,7.4 .5,7.4 .9,9.2 .1$ $9.2 .2,9.2 .3,10.7,11.5 .1 .1,11.5 .1 .2,11.5 .1 .3,12.2 .1,12.2 .2,12.2 .4,12.3 .1 .2,12.3 .1 .3,12.3 .2 .2$ evenwichtigheid $3.4 .2 .2,11.5 .1 .1,13.4 .1$

externe neutraliteit $\quad 2.4 .1,2.4 .2$

$\mathbf{F}$

factuur $12.1,12.2 .1,12.2 .2,12.2 .4,12.3 .1,12.3 .1 .2,12.3 .1 .3,13.2 .1$

fictieve dienst 6.1

fictieve heffingen 6.5

fictieve levering $6.1,6.5,9.2 .3$

fictieve prestatie $6.5,9.2 .3$

financiële vrijstellingen $10.3,10.4$

fiscale neutraliteit $\quad 4.4 .4 .2,4.4 .4 .3,4.5 .2 .3,4.8,6.3,6.4,6.5,7.2 .1,7.2 .2$,

7.3.4, 7.4.2,7.4.5, 7.4.6, 7.4.9, 8.2, 9.2.2, 9.3.2, 10.3, 10.4, 11.4.2, 11.4.3, 11.4.5,

12.3.1.3, 3.2.1, 13.2.2

formele rechtskracht 5.4

fraude 6.3

\section{G}

gelijkheidsbeginsel $2.4 .1,3.2 .3,3.3 .1,3.4 .1 .1,3.4 .1 .2,3.4 .2 .2,3.5 .2,4.4 .3 .1,4.4 .3 .2$, 4.4.3.4, 4.4.4.2, 4.4.4.3, 4.7, 5.3, 6.4, 6.5, 7.2.2, 7.4.2, 7.4.5, 7.4.8, 7.4.9, 9.2.2, 10.4, 10.5, $11.3,11.4 .3,12.2 .2,12.2 .3,13.2 .1$

gelijksoortigheid $\quad 4.4 .4 .2$

gemiddelde consument $\quad 9.3 .2$

geschiktheid $\quad 3.4 .2 .2,9.2 .1,11.5 .1 .1,13.4 .1$ 
gezondheidskundige verzorging 10.4

goede trouw $7.2 .3,12.2 .2$

grammaticale interpretatie 4.4 .2 .1

\section{$\mathbf{H}$}

heffingsconflict 2.3.1, 2.3.2.1, 8.1

historische interpretatiemethode 4.4 .2 .2

holding 7.3.3, 8.6.1

hoofdhuis $8.1,8.4 .1$

horizontale directe werking 4.6

houdstermaatschappij 7.3 .4

I

implementatieproces $\quad 4.5 .2 .3$

inkoop-vi $8.3,8.7$

inmenging in het beheer $7.3 .3,11.4 .3$

Internationaal Gerechtshof 4.4 .1

interne markt $1.1,2.3 .2 .2,3.4 .3 .3,5.2,7.4 .6,8.2,8.7,11.4 .4,12.2 .3$

interne neutraliteit $\quad 2.4 .1$

interpretatiebeginsel $\quad 3.3 .1,3.3 .2,3.3 .3,4.4 .4 .2,5.3,7.2 .2,7.4 .9,11.4 .2,12.3 .1 .3,13.2 .1$, 13.4.2, 13.5

interpretatiemethoden $\quad 3.3 .3$

interpretatietechniek $\quad 3.3 .3,13.3 .4$

intracommunautaire levering $\quad 2.3 .2 .2,10.7,11.4 .5$

intracommunautaire transactie $\quad 2.3 .2 .2,11.4 .5,12.2 .3$

intracommunautaire verwerving $2.3 .2 .2,6.1,10.7$

investeringsbedrijfsmiddelen 11.2

investeringsgoederen $6.5,11.2$

invoer $1.5,2.3 .2 .2,6.1,6.4$

\section{K}

kan-bepaling $\quad 2.4 .2,4.5 .2 .3,4.5 .2 .5,7.4 .5,8.6 .1,9.2 .2,10.4,12.1$

kenbaarheid 3.4.3.2, 4.4.3.4

klassieke BTW-beginselen 2.1, 13.5

L

leemteprobleem $\quad 4.4 .3 .1$

legaliteitsbeginsel $\quad 4.4 .3 .1,4.4 .3 .4$

levering 6.1

\section{M}

maatregelen ter vereenvoudiging $\quad$ 4.5.2.4

maatschappelijk verkeer 3.2 .1

machtiging $\quad 5.2,5.6 .2,9.2 .1,9.2 .3,11.5 .1 .2,11.5 .1 .3,13.4 .1$

management $7.3 .3,7.3 .4$ 
medische vrijstellingen $\quad 10.3$

methode van rechtsvinding $3.3 .3,4.4 .2 .3,7.2 .2$

misbruik van recht $3.3 .2,4.4 .2 .5,5.3,6.3,10.7,13.3 .2$

misleidend gedrag 5.4

modale consument $\quad 9.3 .2$

$\mathbf{N}$

neutraliteitsbeginsel $\quad 3.5 .2,7.2 .2$

non-discriminatiebeginsel $4.4 .4 .2,5.4,12.3 .1 .3,13.2 .1$

noodzakelijkheid $\quad 3.4 .2 .2,9.2 .1,11.5 .1 .1,11.5 .1 .2,12.2 .1,12.3 .1 .3,13.4 .1,13.4 .2$

normale waarde 9.2 .2

nuttig effect $3.4 .2 .2,3.4 .3 .2,6.2$

$\mathbf{0}$

OECD 2.3.2.1

ondernemingsvermogen 6.5

oorsprongslandbeginsel $\quad 2.3 .2 .1,2.3 .2 .2,2.4 .2,3.5 .1$

organisatorische verwevenheid 7.4 .4

particuliere belegger 7.3 .4

postvrijstelling 10.3

primaire Unierecht $1.1,2.3 .1,3.3 .1,3.4 .2 .2,4.5 .1,4.6,8.2,8.7,12.2 .3$

primaire vestigingsplaats 8.3

privégebruik 6.5

proceseconomie 5.4

$\mathbf{R}$

ratio $4.4 .2 .5,4.4 .3 .2,4.4 .3 .3,4.4 .4 .3,7.2 .2$

rationele afbakening $8.2,8.3$

rechtsbeginselen $\quad 2.3 .1,3.2 .1,3.2 .2,3.2 .3,3.3 .1,3.3 .2,3.3 .3,3.4 .2 .2,3.5 .1,4.2,4.4 .1$, 4.4.2.3, 4.5.1, 4.6, 5.3, 7.4.5, 8.2, 8.7, 9.2.3, 9.3.2, 10.7, 12.2.3, 12.3.1.3

rechtsbeginsel van formeel recht $3.3 .1,3.3 .2,7.2 .3,13.3 .3,13.4 .2$

rechtsbewustzijn $\quad 3.2 .1,3.2 .2,3.2 .3,3.4 .1 .2$

rechtskarakter $2.2,3.5 .1$

rechtsnormen 3.2 .2

rechtsregels $3.2 .2,3.2 .3,3.3 .3,5.3$

rechtstreeks verband $6.2,6.5,7.3 .3$

rechtstreekse werking 4.6

rechtsverfijning $\quad 3.3 .3$

rechtsvergelijkende interpretatiemethode 4.4 .2 .3

rechtszekerheidsbeginsel $3.2 .3,3.3 .2,3.4 .3 .2,4.5 .2 .3,4.7,5.3,5.4,5.6 .2,5.6 .4,6.3$, 6.6, 7.2.1, 7.2.3, 7.4.6, 8.2, 10.5, 10.7

richtlijnconforme interpretatie $4.6,4.7$ 
S

secundaire Unierecht $1.1,1.2,2.3 .1,3.3 .1,3.4 .2 .2,4.4 .4 .2,4.5 .1,4.5 .2 .4,4.6,4.7$

secundaire vestigingsplaats 8.3

self-billing $\quad 12.2 .1$

softdrugs 6.4

splitsen van vergoeding 9.3

stelselbeginsel 2.4.1, 3.5.2, 9.1, 11.5.1.4, 13.2.1

subsidiariteitsbeginsel $2.4 .2,3.4 .2 .2$

symbolische vergoeding $\quad 9.2 .3$

systematische interpretatiemethode $\quad 4.4 .2 .4$

$\mathbf{T}$

tarief $2.3 .2 .1,2.4 .2,4.7,9.3 .2,12.2 .1$

teleologische interpretatiemethode 4.4 .2 .5

territorialiteitsbeginsel $\quad 2.3 .1,3.5 .1,8.2,8.7$

terugwerkende kracht $3.3 .1,3.4 .3 .2,5.2,5.4,5.5,7.2 .1,7.2 .3,11.5 .2$

$\mathbf{U}$

uitgestelde werking 5.6.1, 5.6.2, 5.6.4

uitgifte van nieuwe aandelen 11.4 .3

V

vaste inrichting $\quad 2.4 .2,4.3,5.3,8.1,8.3,8.4 .1,8.5$

verbod van misbruik $5.3,8.2,13.3 .2,13.3 .4$

verbruiksbeginsel $\quad 2.2,3.5 .1,8.3$

verbruiksbelasting $\quad 2.2,2.3 .2 .1,2.4 .1$

Verdrag van Lissabon 1.6

vergelijkbare producten 2.4 .2

vergelijkingsmethode $4.4 .3 .2,7.2 .2$

verhuur $1.3,5.5,7.4 .5,8.1,9.3 .2,10.3,10.4,10.5,11.4 .2$

verlengstuk 11.4 .3

vermogensetikettering 6.5

verticale rechtstreekse werking 4.6

verticale werking $\quad 4.5 .2 .4$

vertrouwensbeginsel $3.3 .2,3.4 .3 .1,3.4 .3 .2,3.4 .3 .3,5.5$

verwerving van deelnemingen 11.4 .3

vestigingsplaats $2.4 .2,8.5$

voorbereidende handelingen $7.2 .2,7.2 .3$

voorkoming van misbruik 9.2.1, 13.4.1

vrijheid van rechtsvormkeuze 10.4 
W

wederkerigheid 2.4 .2

werkelijk gebruik $\quad 8.6 .1,8.6 .2$

wilsverklaring $\quad 7.2 .3$

woonplaats 8.5

WTO 2.3.2.1

Z

zelfstandigheid $\quad 7.4 .4,8.4 .1$ 


\section{CURRICULUM VITAE}

Albert Bomer is op 9 februari 1963 geboren te Utrecht. Na het behalen van zijn Atheneum-B diploma aan het Niels Stensen College te Utrecht is hij economische wetenschappen gaan studeren aan de Erasmus Universiteit Rotterdam. In 1988 studeerde hij af in de fiscale-economie.

In januari 1990 trad de heer Bomer in dienst bij het Ministerie van Financiën en heeft hij de postdoctorale opleiding tot inspecteur der omzetbelasting aan het Opleidinginstituut Financiën gevolgd. Vervolgens volgde hij in 1996 de postdoctorale opleiding Europese Fiscale Studies aan de Erasmus Universiteit. Hij is sinds 1 oktober 2008 lid van de Ius Commune Research School.

De heer Bomer was werkzaam als BTW-specialist bij de inspecties Den Bosch en Amersfoort. Vervolgens Ondernemingen Utrecht en Grote Ondernemingen Rotterdam. Sinds november 2004 is de heer Bomer Landelijk Vaktechnisch Coördinator Omzetbelasting en vanaf januari 2011 werkzaam bij het Landelijk Kantoor Belastingregio's te 's-Gravenhage. Hij houdt zich bezig met alle vraagstukken op het gebied van de BTW, maar is vooral gespecialiseerd in de Europeesrechtelijke aspecten.

De heer Bomer verzorgt het commentaar in het naslagwerk NDFR voor de onderdelen Europeesrechtelijke leerstukken, het Hof van Justitie EU, de Europese BTW en bij de artikelen 1,2 en 2a Wet OB. Ook heeft hij regelmatig in het Weekblad Fiscaal Recht gepubliceerd. Verder is hij geregeld spreker op seminars over actuele BTWonderwerpen. 
